Prepared for the U.S. Department of Energy under Contract DE-AC05-76RL01830

\title{
Characterization of Vadose Zone Sediments Below the C Tank Farm: Borehole C4297 and RCRA Borehole 299-E27-22
}

\begin{abstract}
CF Brown
RJ Serne

BN Bjornstad

DG Horton

DC Lanigan

RE Clayton

MM Valenta
\end{abstract}

September 2008
TS Vickerman

IV Kutnyakov

KN Geiszler

SR Baum

KE Parker

MJ Lindberg

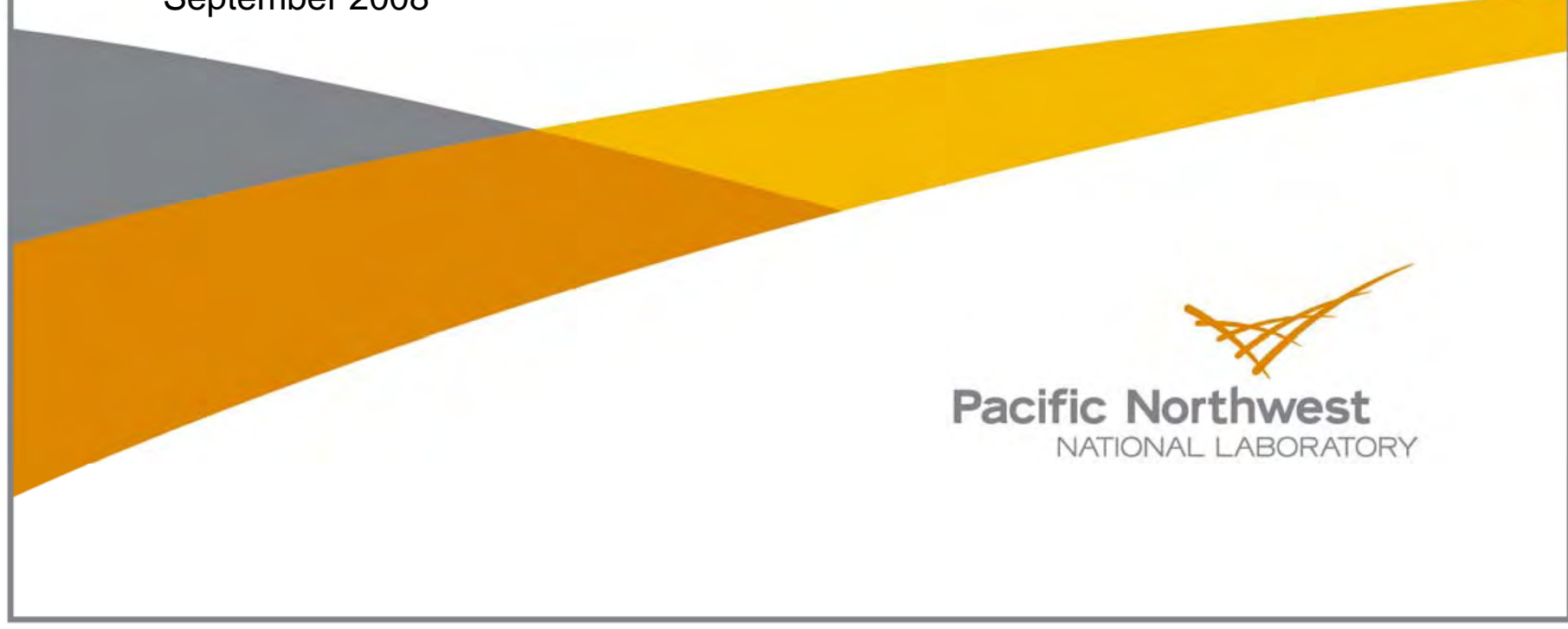




\title{
DISCLAIMER
}

This report was prepared as an account of work sponsored by an agency of the United States Government. Neither the United States Government nor any agency thereof, nor Battelle Memorial Institute, nor any of their employees, makes any warranty, express or implied, or assumes any legal liability or responsibility for the accuracy, completeness, or usefulness of any information, apparatus, product, or process disclosed, or represents that its use would not infringe privately owned rights. Reference herein to any specific commercial product, process, or service by trade name, trademark, manufacturer, or otherwise does not necessarily constitute or imply its endorsement, recommendation, or favoring by the United States Government or any agency thereof, or Battelle Memorial Institute. The views and opinions of authors expressed herein do not necessarily state or reflect those of the United States Government or any agency thereof.

\author{
PACIFIC NORTHWEST NATIONAL LABORATORY \\ operated by \\ BATTELLE \\ for the \\ UNITED STATES DEPARTMENT OF ENERGY \\ under Contract DE-AC05-76RL01830
}

\author{
Printed in the United States of America \\ Available to DOE and DOE contractors from the \\ Office of Scientific and Technical Information, \\ P.O. Box 62, Oak Ridge, TN 37831-0062; \\ ph: (865) 576-8401 \\ fax: (865) 576-5728 \\ email: reports@adonis.osti.gov

\footnotetext{
Available to the public from the National Technical Information Service, ph: (800) 553-6847

fax: (703) 605-6900

email: orders@ntis.fedworld.gov

online ordering: http://www.ntis.gov/ordering.htm
} \\ U.S. Department of Commerce, 5285 Port Royal Rd., Springfield, VA 22161
}

$\checkmark s$ This document was printed on recycled paper. 


\section{Characterization of Vadose Zone Sediments Below the C Tank Farm: Borehole C4297 and RCRA Borehole 299-E27-22}
C. F. Brown
T. S. Vickerman
R. J. Serne
I. V. Kutnyakov
B. N. Bjornstad
K. N. Geiszler
D. G. Horton
S. R. Baum
D. C. Lanigan
K. E. Parker
R. E. Clayton
M. J. Lindberg
M. M. Valenta

September 2008

Prepared for CH2M HILL Hanford Group, Inc. and the U.S. Department of Energy under Contract DE-AC05-76RL01830

Pacific Northwest National Laboratory

Richland, Washington 99352 


\section{Executive Summary}

This report was revised in September 2008 to remove acid-extractable sodium data from Tables 4.7 and 4.25. The sodium data was removed due to potential contamination introduced during the acid extraction process. The rest of the text remains unchanged from the original report issued in September 2006.

The overall goal of the Tank Farm Vadose Zone Project, led by CH2M HILL Hanford Group, Inc., is to define risks from past and future single-shell tank farm activities at the Hanford Site. To meet this goal, CH2M HILL Hanford Group, Inc. tasked scientists from Pacific Northwest National Laboratory (PNNL) to perform detailed analyses on vadose zone sediments from within Waste Management Area (WMA) C. This report is the first of two reports written to present the results of these analyses. Specifically, this report contains all the geologic, geochemical, and selected physiochemical characterization data collected on vadose zone sediment recovered from borehole C4297, installed adjacent to tank C-105, and from borehole 299-E27-22, installed directly north of the C Tank Farm. This report also presents the interpretation of data in the context of sediment types, the vertical extent of contamination, the migration potential of the contaminants, and the likely source of the contamination in the vadose zone below the C Tank Farm. The information presented in this report supports the WMA A-AX, C, and U field investigation report in preparation by CH2M HILL Hanford Group, Inc.

Sediments from borehole 299-E27-22 were characterized for their potential to be used as background (i.e., uncontaminated) sediments against which to compare contaminated sediments during the C Tank Farm characterization effort. Upon analysis of sediment samples from borehole 299-E27-22, elevated concentrations of chloride, nitrate, sulfate, phosphate, magnesium, calcium, strontium, and sodium were encountered at various depths within the borehole. Although no known spills have been recorded at the location where borehole 299E27-22 was emplaced, the data strongly suggest the sediment has been contacted by a non-radiological waste stream. While the data from borehole 299-E27-22 are presented within this report, it is not recommended that the data be used holistically as background or baseline values for uncontaminated sediment. Instead, data from a companion report (Lindenmeier et al. 2002), which was an investigation of samples from borehole 299-E33-338, should be used for baseline comparisons.

A core log was generated for both boreholes and a geologic evaluation of all core samples was performed at the time of opening. Aliquots of sediment from the borehole core samples were analyzed and characterized in the laboratory for the following parameters: moisture content, gamma-emitting radionuclides, one-to-one sediment:water extracts (which provide soil $\mathrm{pH}$, electrical conductivity, cation, trace metal, and anion data), total carbon and inorganic carbon content, and $8 \mathrm{M}$ nitric acid extracts (which provide a measure of the total leachable contaminant content from the sediment). Two key radioactive contaminants, technetium-99 and uranium-238, along with other trace metals were determined in acid and water extracts using inductively coupled plasma-mass spectrometry (ICP-MS). The laboratory tests provided the following conclusions regarding contamination at the C Tank Farm:

1. Heterogeneities, including fine-grained thin lenses in the Hanford formation $\mathrm{H} 1$ and $\mathrm{H} 2$ units, likely cause anisotropy in water flow. Increased moisture was found to correlate with each of the fine-grained thin lenses intercepted by the coring. Average moisture contents for the Hanford formation $\mathrm{H} 1$ and $\mathrm{H} 2$ units in borehole 299-E27-22 were approximately the same as the moisture contents from the same units in borehole 299-E33-338, as well as in the contaminated borehole (C4297). This is likely an indication that any leak that has occurred in the vicinity of borehole C4297 was either small in total volume and/or occurred sufficiently long ago that residual vadose zone moisture has returned to background or "natural" conditions. 
2. The $\mathrm{pH}$ profile for sediments from borehole $\mathrm{C} 4297$ showed elevated soil $\mathrm{pH}$ values (up to 9.53 vs. less than 8.0 for the remainder of the borehole) from 40.8 to $51.3 \mathrm{ft}$ below ground surface (bgs), which were indicative of alkaline tank fluid interactions. The first sample with a measurably elevated soil $\mathrm{pH}$, via 1:1 sediment:water extraction, was collected at a depth that coincided with the bottom of tank C 105. However, based on observations at other tank farms ( $\mathrm{SX}$ and $\mathrm{BX}$ ) where it is certain that caustic wastes are in the vadose zone, yet water extract $\mathrm{pH}$ values never exceed 10, this study concluded that $\mathrm{pH}$ is not a very sensitive parameter to use for evaluating the extent of plume migration in the vadose zone. However, the elevated $\mathrm{pH}$ zone is considered to be a good indicator of the initial tank waste contact zone.

3. The average porewater corrected electrical conductivity (EC) from borehole 299-E27-22, at $8.68 \mathrm{mS} / \mathrm{cm}$, was more than a factor of three times greater than the average EC from borehole 299-E33-338 (2.63 mS/cm); further highlighting the fact that sediments from this borehole have been compromised by a waste spill or leak. The EC depth profile for borehole C4297 showed elevated EC in the Hanford formation $\mathrm{H} 1$ unit over the same depth range that exhibited elevated soil $\mathrm{pH}$ (40.8 to $51.3 \mathrm{ft}$ bgs). The peak pore-water-corrected EC value measured in sediments from borehole C4297 occurred at $45 \mathrm{ft}$ bgs with a concentration of $20.5 \mathrm{mS} / \mathrm{cm}$. Although measurably elevated, this value was approximately four times more dilute as that measured in sediments collected near tank BX-102, and was more than eighty times as dilute as the peak value in contaminated sediment collected near tank SX-108 (slant borehole).

4. Elevated sodium was measured in C4297 borehole sediments beginning at approximately $7 \mathrm{ft}$ bgs and extending to a depth of $71 \mathrm{ft}$ bgs. Speculation is that these trends indicate some chemical reaction between alkaline tank fluids and native sediments that formed a cation exchange front, whereby sodium replaced calcium and magnesium in the sediments as the dominant exchangeable cation.

5. In the core and grab samples from borehole C4297, there was a bimodal uranium concentration profile as a function of depth. A relatively small extractable uranium peak was measured in the 1:1 sediment:water extracts from 7 to $22 \mathrm{ft}$ bgs. The uranium present at this depth was likely associated with the cesium-137 activity measured shallow in the borehole ( 2.5 to $12 \mathrm{ft}$ bgs). The second peak of water-extractable uranium was observed at a depth corresponding to the bottom of tank C-105 (40 ft bgs) and extended to a total depth of $60 \mathrm{ft}$ bgs. However, due to the high dissolved (bi)carbonate concentration in this zone, some of the water-extractable uranium was likely naturally present labile uranium released as a function of uranyl-carbonate complexation. The maximum water extractable uranium concentration over this depth occurred at $57.2 \mathrm{ft}$ bgs with a peak value $2.17 \mathrm{E}-2 \mu \mathrm{g} / \mathrm{g}$. These samples were scanned using inductively coupled plasma mass spectrometry for the presence of uranium-236, which was not observed; therefore, it is unlikely that the majority of the uranium present over this zone resulted from Hanford processing activities.

6. The nitrate water extract values for borehole C4297 were elevated beginning at a depth that corresponded to the bottom of tank C-105 (40 ft bgs) to as deep as $160 \mathrm{ft}$ bgs. Additionally, there were several anomalously high nitrate samples collected throughout the soil profile that could be lithology related. Nitrate migration in the subsurface is considered to be entirely conservative; in other words, it will move freely with the infiltrating water. Thus, nitrate concentration can be used to estimate the total vertical extent of a contaminant plume. Based on data from borehole 
C4297, it appears that a multi-modal, at least bimodal, waste signature is present. Based on the dilute nitrate profile, it appears that the maximum penetration of the "first" or "primary" plume is currently at a depth of approximately $160 \mathrm{ft}$ bgs. The peak maximum of the "second" plume occurred as deep as $114 \mathrm{ft}$ bgs and appeared to be less concentrated than the "primary" plume.

7. The first observance of technetium-99 in sediment samples from borehole C4297 occurred at $40.8 \mathrm{ft}$ bgs, a depth that corresponded closely to the bottom of tank C-105. Technetium-99, like nitrate, is considered to be completely conservative in mobility. Therefore, it is not surprising that technetium-99 exhibited a similar concentration profile to nitrate. Some differences were observed between the technetium-99 and nitrate profiles. As with nitrate, a bimodal concentration profile of technetium-99 contamination was present in C4297 borehole samples, with the primary technetium 99 peak occurring between 105 and $160 \mathrm{ft}$ bgs, and a smaller secondary peak present between 40 and $66 \mathrm{ft}$ bgs. Similar to the nitrate, the peak technetium-99 concentration present in these sediment samples was measured in the sample collected from approximately $137 \mathrm{ft}$ bgs.

8. Molybdenum, which is a fission product generated during the operation of nuclear reactors, can sometimes be used to delineate the profile of waste plumes in the subsurface. In the case of samples from borehole C4297, fission-produced molybdenum was clearly present between 26 and $64 \mathrm{ft}$ bgs. The primary zone of fission-produced molybdenum occurred between 55 and $64 \mathrm{ft}$ bgs; however, unlike the technetium-99 and nitrate contamination, it appears that all the fissionproduced molybdenum in this borehole form a contiguous plume that is the result of a single contamination event. Therefore, the bimodal technetium-99 contamination profiles versus a single contaminant plume for molybdenum supports a two source contamination model.

Based on evaluating all these measurements, this study concluded that the C4297 borehole data establishes the vertical extent of tank contamination at this location. Tank waste-related contaminants were observed from just below ground surface ( $2.5 \mathrm{ft}$ bgs) to a total depth of approximately $160 \mathrm{ft}$ bgs. Six of the eight parameters measured ( $\mathrm{pH}, \mathrm{EC}$, sodium, nitrate, technetium-99, and molybdenum) exhibited distinct contaminant profiles as a function of depth. Additionally, two of the contaminants (nitrate and technetium-99) could be further characterized as having bi- or multimodal profiles, indicated at least two distinct waste sources have contributed to the contamination present in this borehole.

Selected concentration ratios of mobile contaminants in (a) the vadose zone sediments sampled from borehole C4297, (b) the WMA C groundwater contaminant plumes, and (c) specific single-shell tanks at the time of suspected leaks were used to assess whether there were indications that the groundwater contamination present at WMA C is related to current vadose zone contamination. Comparisons of contaminant ratios from all available data sets, as well as those measured in samples from borehole C4297, were performed. Initial attempts to relate the groundwater and pore water compositions used the ratios of the concentrations of various contaminants (technetium-99, fluoride, sulfate, sodium, and nitrate) to one another. The agreement between the vadose zone pore water and contaminated groundwater data sets was not good. The technetium-99/nitrate ratios for samples from the contaminated zones in borehole C4297 were generally greater than about $0.2 \mathrm{pCi} / \mu \mathrm{g}$. Such values are greater than the technetium99/nitrate ratios in all of the groundwater wells except well 299-E27-4. However, the agreement for the other ratios between groundwater from well 299-E27-4 and pore water from borehole C4297 was not good, although there is certain to be some fractionation between technetium-99 and the other constituents, especially sodium. 
In summary, there is no current similarity between the present or past groundwater contamination and current pore water compositions from the contaminated borehole sediments. Therefore, the contaminants in the groundwater cannot be linked, currently or during the era of contaminant introduction in the vadose zone, to the pore water currently in the borehole sediments, which are believed to be derived from the liquids that leaked or spilled from tank C-105. 


\section{Acknowledgments}

This work was conducted as part of the Tank Farm Vadose Zone Project led by CH2M HILL Hanford Group, Inc. in support of the U.S. Department of Energy, Office of River Protection. The authors wish to thank Frank J. Anderson, Fredrick M. Mann, David A. Myers, Thomas E. Jones, and Harold A. Sydnor with CH2M HILL Hanford Group, Inc. for their support of this work; and Marcus I. Wood with Fluor Hanford, Inc., and Bill Deutsch and Wooyong Um, both with Pacific Northwest National Laboratory (PNNL), for their technical review. We would also like to express our gratitude to Robert Lober with the U.S. Department of Energy, Office of River Protection.

We would especially like to thank Kent D. Reynolds (Duratek Federal Services, Inc.) for his efforts in selecting depths to sample and executing the field work that obtained the sample. 


\section{Acronyms and Abbreviations}

\begin{tabular}{|c|c|}
\hline amsl & above mean sea level \\
\hline ASA & American Society of Agronomy \\
\hline ASTM & American Society for Testing and Materials \\
\hline bgs & below ground surface \\
\hline CCU & Cold Creek unit \\
\hline $\mathrm{CCU} / \mathrm{R}$ & Cold Creek unit and/or Ringold \\
\hline CCUl & Cold Creek unit, lower subunit; also referred to as Cold Creek caliche subunit \\
\hline CCUu & Cold Creek unit, upper subunit \\
\hline DOE & U.S. Department of Energy \\
\hline EC & electrical conductivity \\
\hline EPA & U.S. Environmental Protection Agency \\
\hline GEA & gamma energy analysis \\
\hline H1 & Hanford formation - H1 unit \\
\hline $\mathrm{H} 2$ & Hanford formation - H2 unit \\
\hline H3 & Hanford formation - H3 unit \\
\hline $\mathrm{HCl}$ & hydrochloric acid \\
\hline HPGe & high-purity germanium \\
\hline IC & ion chromatography or ion chromatograph \\
\hline ICP & $\begin{array}{l}\text { inductively coupled plasma (also called inductively coupled plasma - optical emission } \\
\text { spectroscopy }\end{array}$ \\
\hline ICP-MS & inductively coupled plasma-mass spectrometer \\
\hline ICP-OES & inductively coupled plasma-optical emission spectroscopy \\
\hline $\mathrm{KCl}$ & potassium chloride \\
\hline $\mathrm{K}_{\mathrm{d}}$ & distribution coefficient, or sorption partition coefficient, in units of $\mathrm{mL} / \mathrm{g}$ \\
\hline KUT & potassium, uranium, and thorium \\
\hline MC & moisture content \\
\hline NDIR & non-dispersive infrared \\
\hline NIST & National Institute of Standards and Technology \\
\hline ORNL & Oak Ridge National Laboratory \\
\hline PNNL & Pacific Northwest National Laboratory \\
\hline $\mathrm{PPg}$ & Plio-Pleistocene gravel \\
\hline PUREX & Plutonium Uranium Extraction (Plant) \\
\hline RCRA & Resource Conservation and Recovery Act of 1976 \\
\hline REDOX & $\begin{array}{l}\text { Reduction Oxidation Process (the second fuel reprocessing process used at the Hanford Site } \\
\text { to extract plutonium) }\end{array}$ \\
\hline UFA & unsaturated flow apparatus (ultracentrifuge for squeezing pore water out of sediment) \\
\hline USGS & U.S. Geological Survey \\
\hline WMA & waste management area \\
\hline $\mathrm{XRF}$ & x-ray fluorescence (a technique to measure total element mass in solids) \\
\hline
\end{tabular}




\section{Units of Measure}

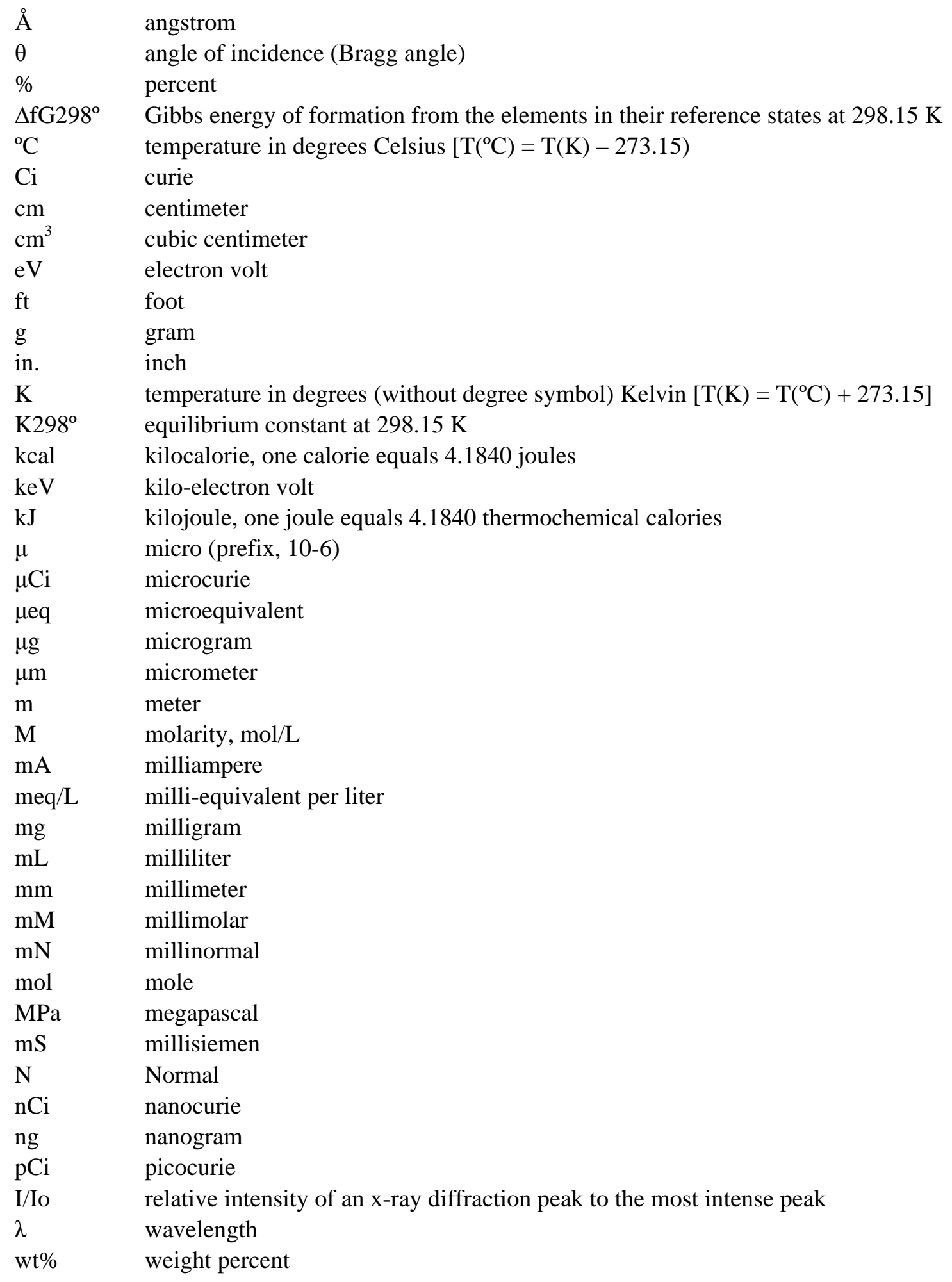




\section{Contents}

Executive Summary ......................................................................................................

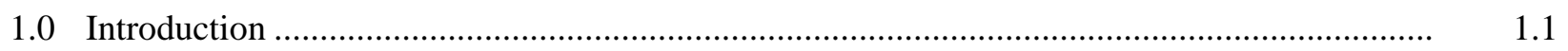

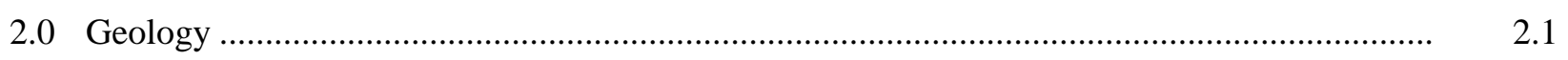

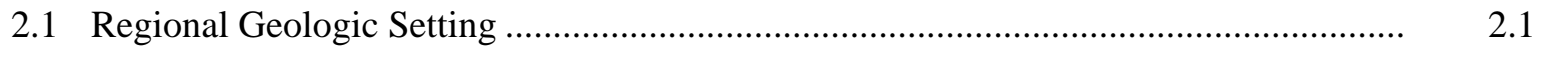

2.1.1 Ringold Formation ............................................................................ 2.2

2.1.2 Cold Creek Unit ........................................................................... 2.2

2.1.3 Hanford formation ..................................................................................... 2.2

2.2 Geologic Setting of the C Tank Farm ..................................................................... 2.5

2.2.1 Stratigraphy and Lithology ................................................................ 2.7

2.2.2 Clastic Dikes ..................................................................................... 2.11

2.3 Summary of Recent Characterization Activities at C Tank Farm ................................ 2.11

2.3.1 Hydrogeologic Characterization..................................................................... 2.13

2.3.2 Hydrogeology of Borehole 299-E27-22 (Background Well) .......................... 2.16

2.3.3 Borehole C4297................................................................................ 2.25

2.3.4 Discussion of Increased-Moisture Zones .................................................... $\quad 2.30$

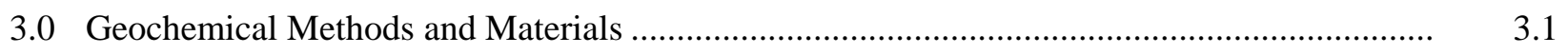

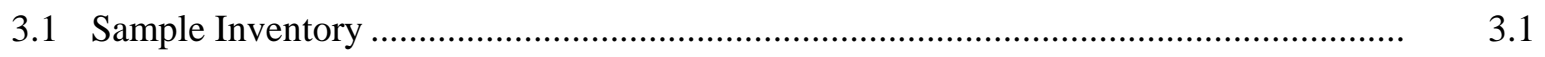

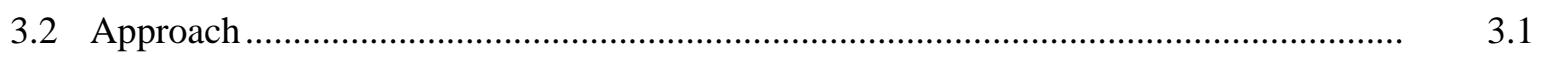

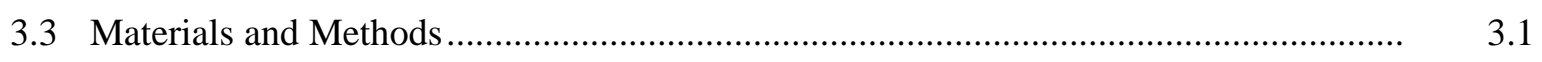

3.3.1 Moisture Content ...................................................................................... $\quad 3.2$

3.3.2 1:1 Sediment:Water Extracts..................................................................... 3.2

3.3.3 8 M Nitric Acid Extract........................................................................... 3.3

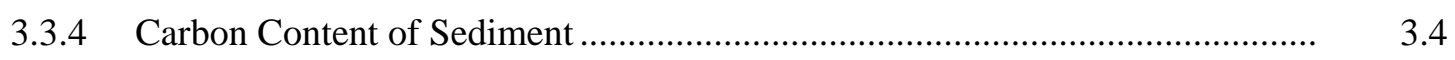

3.3.5 Elemental Analysis.................................................................................... 3.4

3.3.6 Particle-Size Distribution ....................................................................... 3.5

3.3.7 Particle Density .................................................................................... 3.5

3.3.8 Water Potential (Suction) Measurements ....................................................... 3.5

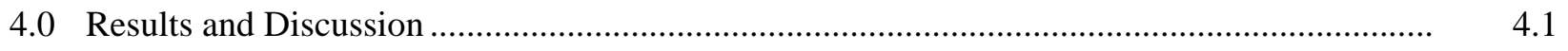

4.1 Vadose Zone Sediment from Borehole 299-E27-22 ................................................

4.1.1 Moisture Content ........................................................................................ 4.1

4.1.2 1:1 Sediment:Water Extracts for Borehole 299-E27-22 ................................... 4.4

4.1.3 8 M Nitric Acid-Extractable Amounts of Selected Elements........................... 4.11

4.1.4 Bulk Chemical Composition of Sediment from 299-E27-22 ........................... 4.14

4.1.5 Radionuclide Content in Vadose Zone Sediment from 299-E27-22 ................ 4.15

4.1.6 Total Carbon, Calcium Carbonate, and Organic Carbon Content of Vadose Zone Sediment from Borehole 299-E27-22 ........................................................... 4.22 
4.1.7 Particle Size Measurements on Vadose Zone Sediment …............................... $\quad 4.23$

4.1.8 Matric Suction Potential Measurements........................................................... $\quad 4.24$

4.2 Vadose Zone Sediment from Borehole C4297 ............................................................ 4.31

4.2.1 Moisture Content ............................................................................................. 4.31

4.2.2 1:1 Sediment:Water Extracts and Pore Water Samples for Borehole C4297.... 4.36

4.2.3 Vadose Zone Pore water Chemical Composition............................................. 4.56

4.2.4 8 M Nitric Acid-Extractable Amounts of Selected Elements in Borehole C4297 Sediments ........................................................................................ 4.59

4.2.5 Radionuclide Content in Vadose Zone Sediment from Borehole C4297 .......... 4.86

4.2.6 Total Carbon, Calcium Carbonate, and Organic Carbon Content of Vadose Zone Sediment from Borehole C4297 ..................................................................... 4.90

4.2.7 Matric Potential of Borehole C4297 Vadose Zone Sediments......................... 4.90

5.0 Groundwater Status Below the C Tank Farm .....................................................................

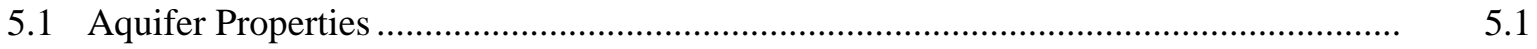

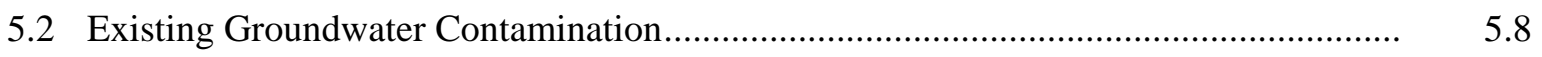

5.2.1 Extent of Contamination - Depth Distribution ............................................. 5.8

5.2.2 Extent of Contamination - Geographic Distribution..................................... $\quad 5.10$

5.3 Comparison of Groundwater, Vadose Zone Pore Water, and Tank Leak Chemical

Compositions ......................................................................................................... 5.19

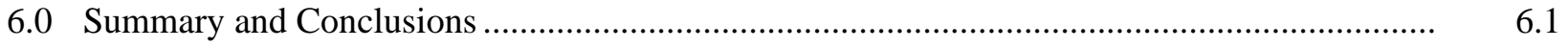

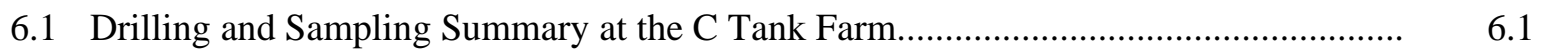

6.2 Physical Model for C Tank Farm Geology ................................................................

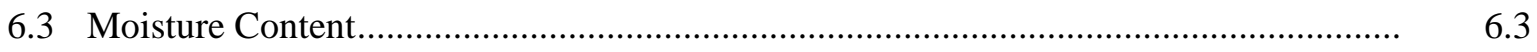

6.4 Vertical Extent of Contamination in Borehole C4297 _..................................................

6.5 Detailed Characterization to Elucidate Controlling Geochemical Processes.................. 6.5

6.6 Estimates of Contaminant Inventory and Sorption-Desorption Values ........................... 6.7

6.7 Other Geochemical Characterization Observations .................................................... 6.10

6.8 Description of Waste Management Area C Upper Unconfined Aquifer ....................... 6.13

6.9 Existing Groundwater Contamination......................................................................... 6.14

6.10 Complexities in Groundwater Data (Vertical and Temporal Variations) ...................... $\quad 6.15$

6.11 Vadose Zone Pore Water and Groundwater Chemical Ratio Comparisons.................... 6.15

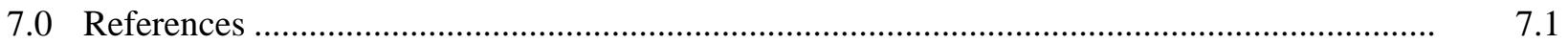

Appendix A. Core Photographs ....................................................................................... A.1

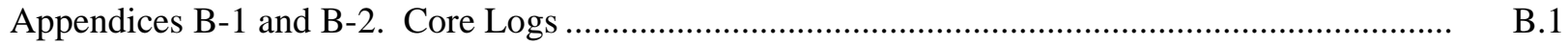




\section{Figures}

2.1. Thickness and Distribution of Cataclysmic Flood Deposits within the Central Pasco Basin...

2.2. Generalized Stratigraphy for the Late-Cenozoic Sediments at the C Tank Farm .....................

2.3. Selected Borehole Location Map for the C Tank Farm.

2.6

2.4. East-West Hydrogeologic Cross Section A-A' Across the $C$ Tank Farm

2.8

2.5. North-South Hydrogeologic Cross Section B-B' Across the C Tank Farm

2.9

2.6. Sediment Textural Classification

2.15

2.7. Summary Geohydrologic Log for Background Borehole 299-E27-22.

2.18

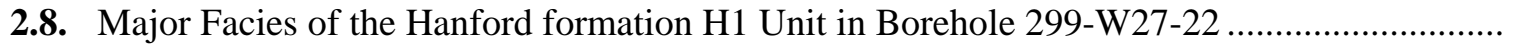

2.19

2.9. Minor Facies of the Hanford formation H1 Unit in Borehole 299-W27-22

2.20

2.10. Sand Facies of the Hanford formation H2 Unit in Borehole 299-E27-22

2.20

2.11. Pebbly Sand Facies of the Hanford formation H2 Unit in Borehole 299-E27-22

2.21

2.12. Gravels of the CCU/R Unit in Borehole 299-E27-22

2.25

2.13. Summary Hydrogeologic Log for Borehole C4297.

2.28

2.14. Typical Backfill from Borehole C4297.

2.29

2.15. Hanford formation H1 Unit in Borehole C4297

2.29

2.16. Hanford formation $\mathrm{H} 2$ Unit in Borehole C4297.

2.30

4.1. Gravimetric Moisture Content, $\mathrm{pH}$, and Electrical Conductivity Calculated from Sediment:Water Extracts for Borehole 299-E27-22

4.2. Water-Extractable Major Anions in Borehole 299-E27-22 Sediments.

4.3. Cations in 1:1 Sediment:Water Extracts for Borehole 299-E27-22.

4.4. Trace Metals in 1:1 Sediment:Water Extracts Borehole 299-E27-22.

4.5. Acid-Extractable Concentrations of Major Cations in Borehole 299-E27-22 Sediment ...

4.6. Acid-Extractable Concentrations of Aluminum, Iron, Manganese, Silicon, and Zinc from Borehole 299-E27-22 Sediments .

4.7. Concentration of Uranium-238, Chromium, and Molybdenum in Borehole 299-E27-22 Sediment that is Acid-Extractable.

4.8. Comparison between Acid-and Water-Extractable Sulfate and Phosphate in Vadose Zone Sediments from Borehole 299-E27-22

4.9. Particle-Size Distribution of Hanford formation H1 Unit Sub-Samples from Borehole 299-E27-22

4.10. Particle-Size Distribution of Hanford formation H2 Unit Sub-Samples from Borehole 299-E27-22.

4.11. Matric Water Potential Measured by Filter Paper Technique on Core Samples from Borehole 299-E27-22.

4.12. Borehole C4297 Sediment:Water Extract pH, Actual, and Calculated Pore Water Electrical Conductivity

4.13. Borehole C4297 Water-Extractable Anions ( $\mu \mathrm{g} / \mathrm{g}$ dry sediment)...

4.14. Water-Extractable Cations in C4297 Vadose Zone Sediments.

4.15. Water-Extractable Metals in C4297 Vadose Sediments 
4.17. Distribution of Mobile Metals in Water Extracts of C4297 Vadose Zone Sediments .............

4.18. Distribution of Mobile Metals in Water Extracts of C4297 Vadose Zone Sediments

4.19. Derived Pore Water Composition of Major Cations in C4297 Vadose Zone Sediments .........

4.20. Derived Pore Water Anion Composition in C4297 Vadose Zone Sediments

4.21. Derived Pore Water Composition for Selected Metals in C4297 Vadose Zone Sediments.....

4.22. Derived Pore Water Composition for Selected Metals in C4297 Vadose Zone Sediments.....

4.71

4.23. Derived Pore Water Composition of Mobile Metals in C4297 Vadose Zone Sediments........

4.72

4.24. Derived Pore Water Composition of Mobile Metals in C4297 Vadose Zone Sediments

4.73

4.25. Acid-Extractable Cations in C4297 Vadose Zone Sediments

4.80

4.26. Acid-Extractable Major Metals in C4297 Vadose Zone Sediments

4.81

4.27. Acid-Extractable Trace Metals in C4297 Vadose Zone Sediments

4.82

4.28. Acid-Extractable Trace Metals in C4297 Vadose Zone Sediments.

4.83

4.29. Acid-Extractable Mobile Metals in C4297 Vadose Zone Sediments

4.84

4.30. Acid-Extractable Mobile Metals in C4297 Vadose Zone Sediments

4.85

4.31. Matric Potential for Borehole C4297 Samples

4.95

5.1. Well Location Map for Waste Management Area $C$

5.2. Discharge History for the 216-B Pond and the Gable Mountain Pond through 1993.

5.3

5.3. Hydrographs from Selected Wells around Waste Management Area C, 200 East Area

5.4. Groundwater Flow Directions in the Vicinity of the C Tank Farm (A) 1958 to 1994, Wells 299-E26-1, 299-E26-4, and 299-E27-1, 45 Measurements; and (B) 1990 to 2003, Wells 299-E27-12, 299-E27-14, and 299-E27-7, 24 Measurements

5.5. July 2004 Water Table Map for the 200 East Area (from Hartman et al. 2005).

5.6. Historic Water Table Elevations in Selected Wells at Waste Management Area C .....

5.7. Specific Conductance and Concentrations of Nitrate and Technetium-99 versus Depth below the Water Table in Well 299-E27-22.

5.8. Tritium Concentration in the Area of WMA C and WMA A-AX. Top of the Aquifer, Fiscal Year 2005

5.9. Iodine-129 Concentration in the Area of WMA C and WMA A-AX. Top of the Aquifer, Fiscal Year 2005.

5.10. Nitrate Concentrations in the Area of WMA C and WMA A-AX. Top of the Aquifer, Fiscal Year 2005.

5.11. Nitrate, Sulfate, and Technetium-99 Concentrations in Upgradient Well 299-W27-7 at WMA C.

5.12. Sulfate, Nitrate, and Technetium-99 Concentrations in Selected Downgradient Wells at WMA C

5.13. Plume Map for Technetium-99 in the Area of WMA C. Top of the Aquifer, Fiscal Year 2005

5.14. Technetium-99/Nitrate and Technetium-99/Sulfate Relationships for Selected Wells at WMA C.

5.15. Cyanide Concentration in Wells at WMA C.

5.16. Selected Compositional Relationships between Groundwater Samples from Wells at WMA C and C4297 Pore Water. 


\section{Tables}

2.1. Two Borings Used for Recent Geochemical Characterization in the Vicinity of the

C Tank Farm

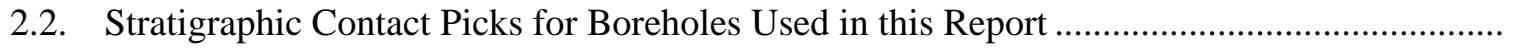

2.3. Paleo-Magnetic Samples from Borehole 299-E27-22 .

2.16

2.4. Splitspoon Samples Selected for Physical and Chemical Characterization from the Vadose Zone in 299-E27-22

2.5. Gravimetric Moisture Content Measured in Core and Grab Samples................................... 2.25

2.6. Splitspoon Core Samples from C4297............................................................................. 2.27

4.1. Gravimetric Moisture Content of Core Samples Obtained from Borehole 299-E27-22......... $\quad 4.2$

4.2. $\mathrm{pH}$ and Electric Conductivity Values for 1:1 Sediment:Water Extracts and UFA Squeezings from Borehole 299-E27-22 ............................................................................

4.3. Anion Composition of Water Extracts of 299-E27-22 Sediment .........................................

4.4. Water-Extractable Cations in Borehole 299-E27-22 Sediments ............................................ 4.10

4.5. Other Water-Extractable Species in Borehole 299-E27-22 Sediments................................. 4.11

4.6. Water-Extractable Mobile Trace Contaminants in Borehole 299-E27-22 Sediments ............. 4.12

4.7. Acid-Extractable Major Cations in Borehole 299-E27-22 Sediments ...................................

4.8. Acid-Extractable Content for Major Constituents in Borehole 299-E27-22 Sediments .......... $\quad 4.16$

4.9. Acid-Extractable Mobile Trace Metals in Borehole 299-E27-22 Sediments......................... 4.17

4.10. Total Chemical Composition of Borehole 299-E27-22 Sediments........................................ 4.22

4.11. Total, Inorganic, and Organic Carbon Content of Vadose Zone Sediments from Borehole 299-E27-22

4.12. Wet Sieve Particle Size Results for Borehole 299-E27-22 Sediments

4.13. Particle Size Data for Borehole 299-E27-22 Sediments Using Two Techniques Reported as Cumulative Percent Finer Than .

4.14. Matric Potential as Measured by Filter Paper Method for Borehole 299-E27-22 Core Sediments ....

4.15. Moisture Content for Borehole C4297 Core and Grab Samples.

4.16. $\mathrm{pH}$ and Pore Water Corrected Electrical Conductivity Data for Sediment:Water Extracts from Borehole C429.

4.17. Water-Extractable Anions in Borehole C4297 Vadose Zone Sediments.

4.18. Water-Extractable Concentrations of Other Metals in C4297 Vadose Zone Sediments..

4.19. Water-Extractable Cations in C4297 Vadose Zone Sediments.

4.20. Water-Extractable Concentrations of Mobile Metals in C4297 Vadose Sediments

4.21. Calculated Pore water Anion Concentrations in C4297 Vadose Zone Sediments.....

4.22. Calculated Pore Water Cation Concentrations in C4297 Vadose Zone Sediments

4.23. Calculated Pore Water Concentrations of Selected Constituents in C4297 Vadose Zone Sediments.

4.24. Calculated Pore Water Concentrations of Potentially Mobile Constituents in C4297 Vadose Sediments. 
4.26. Acid-Extractable Constituents in C4297 Vadose Zone Sediments

4.27. Acid-Extractable Trace Metals in C4297 Vadose Zone Sediments.

4.28. Acid-Extractable Mobile Metals in C4297 Vadose Zone Sediments

4.29. Gamma Emitting Radionuclides in Borehole C4297 Vadose Zone Sediments .

4.30. Total Alpha, Beta, and Actinides in Borehole C4297 Vadose Zone Sediments

4.31. Carbon Contents of Vadose Zone Sediments in Borehole C4297

4.32. Matric Potential of Vadose Zone Sediments in Borehole C4297

5.1. Thickness of the Unconfined Aquifer beneath Waste Management Area $C$

5.2. Results of Slug Testing in Well 299-E27-22 at Waste Management Area C

5.3. Results of 1989 Slug Testing at Three Wells at Waste Management Area C

5.4. Depth-Discrete Water Sample Results from Well 299-E27-22

5.5. Average Concentration of Mobile Contaminants in Groundwater in the Vicinity of Waste Management Area C for Fiscal Year 2005

5.6. Estimated Concentration Ratios for Selected Constituents in Tank Leaks from WMA C and in Groundwater beneath WMA C

5.7. Estimated Concentration Ratios for Selected Constituents in Tank Leaks from WMA C and in Pore Water from Borehole C4297...

6.1. Stratigraphic Units and Contacts.

6.2. Maximum Pore Water Concentrations in Sediments from Hanford formation Unit

6.3. Estimated Inventory of Contaminants in Borehole C4297

6.4. Desorption $\mathrm{K}_{\mathrm{d}}$ Values for Potential Contaminants of Concern 


\subsection{Introduction}

The overall goals of the Tank Farm Vadose Zone Project, led by CH2M HILL Hanford Group, Inc., are to: (1) define risks from past and future single-shell tank farm activities, (2) identify and evaluate the efficacy of interim measures, and (3) aid, via collection of geotechnical information and data, the future decisions that must be made by the U.S. Department of Energy (DOE) regarding the near-term operations, future waste retrieval, and final closure activities for the single-shell tank waste management areas (WMA). For a more complete discussion of the goals of the Tank Farm Vadose Zone Project, see the overall work plan, Phase 1 RCRA Facility Investigation/Corrective Measures Study Work Plan for the Single-Shell Tank Waste Management Areas (DOE 1999). Specific details on the rationale for activities performed at WMA C are found in Crumpler (2003). To meet these goals, CH2M HILL Hanford Group, Inc. asked scientists from Pacific Northwest National Laboratory (PNNL) to perform detailed analyses of vadose zone sediment, both uncontaminated and contaminated, in the vicinity of WMA C.

Specifically, this report contains all the geologic, geochemical, and selected physical characterization data collected on vadose zone sediment recovered from two sources: (1) a new RCRA monitoring well, 299-E27-22, located just outside the WMA fence line to the northeastern quadrant of the C Tank Farm, and (2) a borehole collected within the C Tank Farm (near tank C-105) that extended from ground surface down to approximately $200 \mathrm{ft}$ below ground surface (bgs). The location of the contaminated borehole was chosen because of: (1) an ambiguous liquid level drop (evaporation or leak) that occurred in tank C-105 between 1963 and 1967 and (2) vadose zone monitoring data (spectral gamma data from drywell 30-05-07) that indicate two high cesium-137 zones located near and just below the bottom of tank C-105 (Wood et al. 2003). Location maps are presented in Section 2. Although tanks C-101, C-110, C-111, C-201, C-202, C-203, and C-204 are all assumed to have leaked, tank C-105 is the only tank in the C Tank Farm with spectral gamma data supporting a potential leak.

Tank C-105 was placed into service during 1946 and actively received waste until 1978. Over its years of service, numerous waste types were stored in the tank, including metal waste, uranium recovery waste, coating waste from the Plutonium-Uranium Extraction (PUREX) Plant, low-level waste and strontium sludge from B Plant, and supernatants from the Reduction Oxidation (REDOX) Plant going to B Plant for cesium-137 recovery. Tank C-105 was interim stabilized in October 1995 and currently contains 132.000 gallons of sludge. The sludge is estimated to contain 33,000 gallons of drainable interstitial liquids and 2,000 gallons of supernatant.

Contamination was first detected in the vicinity of tank C-105 in March 1974, when gross gamma logs of borehole 30-04-02 showed a zone of high activity at a depth of approximately $40 \mathrm{ft}$ bgs. The anomalous contamination precipitated the installation of four new boreholes (30-05-05, 30-05-06, 30-05-08, and 30-05-09). Investigations ultimately concluded the contamination was the result of a tank overfill at C-105 and leakage from subsurface pipeline connections in the area; although the exact date of the overfill event is not known.

Brodeur (1993) identified two other zones of subsurface contamination in the vicinity of tank C-105. The first of these was located between tanks C-104 and C-105 and was attributed to a cascade line leak. The second zone was located at approximately $27 \mathrm{ft}$ bgs between tanks C-103 and C-105. The occurrence of this contamination was attributed to a subsurface pipeline leak or leaks from either tank C 103 or C-106, although there is no direct documentation that a leak occurred at either tank. 
A total of ten vadose zone monitoring boreholes, which were all emplaced in the 1970s, surround tank C-105. Successive logging of the boreholes 4 years apart has shown that the contaminants are stable and that changes in their concentration profiles can be attributed to radioactive decay. DOE (1998b), using gamma logging results from these boreholes, has performed visualizations of the cesium-137 and cobalt-60 contamination in vadose zone sediments surrounding tank C-105. The visualizations show that both contaminants originated between tanks C-104 and C-105. Based on Kos' contaminant visualizations (DOE 1998b), the cesium-137 and cobalt-60 plumes appear to have migrated to a depth of $120 \mathrm{ft}$ bgs and $80 \mathrm{ft}$ bgs, respectively. Generally, cesium-137 is much less mobile than cobalt-60 (see other tank farm borehole reports such as Serne et al. 2002a, 2002b, 2002c, 2002d, 2002e, 2002f, and 2004 and distribution coefficient $\left(\mathrm{K}_{\mathrm{d}}\right)$ data compilations by EPA 1999 and Cantrell et al. 2003) so the DOE (1998b) data and interpretation are unique.

This report is divided into sections that describe the geology, geochemical characterization methods employed, geochemical results for borehole C4297, comparison between contaminant distributions for boreholes C4297 and 299-E27-22, and the correlation between the existing vadose zone pore water with current and past groundwater contamination characteristics. Also provided is the interpretation of the data in the context of determining the appropriate hydrogeologic model, the vertical extent of contamination, the migration potential of the contaminants that still reside in the vadose zone, and the correspondence of the contaminant distribution in the borehole sediment to groundwater plumes in the aquifer proximate and downgradient from the $\mathrm{C}$ Tank Farm. In addition, appendices with additional geology details and sediment photographs are provided.

English units are used in this report for descriptions and discussions of drilling activities and samples because that is the system of units used by drillers to measure and report depths and well construction details. To convert feet to meters, multiply by 0.3048 ; to convert inches to centimeters, multiply by 2.54 . The metric system is used in this report for all other purposes. 


\subsection{Geology}

The discussion of the geology of C Tank Farm, presented in this report, focuses on the results of two new boreholes drilled in the vicinity of C Tank Farm. One of the boreholes was drilled within the C Tank Farm (between tanks 241-C-104 and -105). A second hole was sampled from an "uncontaminated" Resource Conservation and Recovery Act of 1976 (RCRA) borehole (299-E27-22) drilled just north of the $\mathrm{C}$ Tank Farm. The second hole was drilled to provide background data on the chemical and radiological characteristics of the vadose zone sediments, from which to compare potentially contaminated sediments within the tank farm. However, as will be demonstrated in the following sections, borehole 299-E27-22 has been compromised by a non-radiological waste stream.

The geology of the vadose zone underlying the C Tank Farm forms the framework through which contaminants that leaked from single-shell tanks or their ancillary piping and junction boxes move and is fundamental to the understanding of migration and distribution of the contamination in the vadose zone. Of particular interest are the interrelationships between the coarser and finer-grained facies, and the degree of contrast in their physical, chemical, and radiological properties.

This section presents a discussion of the regional geologic setting and the geology of the C Tank Farm, followed by a discussion of the geohydrologic characterization methods and background information on the two new boreholes sampled for physical, chemical, and radiological characterization.

\subsection{Regional Geologic Setting}

The Hanford Site is located within the Columbia Plateau of southeastern Washington State. This broad plain, situated between the Cascade Mountains to the west and the Rocky Mountains to the east, is underlain by a thick sequence of Miocene-age tholeiitic basalt flows (the Columbia River Basalt Group). The Columbia River Basalt Group is more than 3,000 m (9,843 ft) thick and forms the bedrock beneath southeastern Washington. Sedimentary interbeds are sandwiched between the basalt flows, particularly in the uppermost Saddle Mountains Basalt. These interbeds, along with the porous basalt flow tops and flow bottoms, form confined aquifers that extend across the Pasco Basin (DOE 1988).

The basalt flows have been folded and faulted creating broad structural and topographic basins, separated by asymmetric anticlinal ridges. Sediments of late Miocene, Pliocene, and Pleistocene age have accumulated up to $520 \mathrm{~m}$ (1,700 ft) thick in some of these basins. The Hanford Site lies within the Pasco Basin, one of the larger basins. The Pasco Basin is partially bisected by the Umtanum-Gable Mountain anticline creating two subordinate synclinal basins. The largest of these is the Cold Creek syncline, which is further subdivided into two sub-basins, the Wye Barricade depression and the Cold Creek depression. The Cold Creek depression underlies the principal waste management areas (200 East and 200 West Areas) of the Hanford Site, including the C Tank Farm.

The generalized stratigraphy beneath the Hanford Site consists of, in ascending order, the Columbia River Basalt Group, the Ringold Formation, the Cold Creek unit (CCU; formerly named the Plio-Pleistocene unit), and the Hanford formation. The CCU and Hanford formation are both informal designations. Thin veneers of Holocene alluvium, colluvium, and/or eolian sediments discontinuously overlie these principal geologic units. The regional suprabasalt stratigraphy is described in more detail elsewhere (Lindsey 1995; DOE 1988, 2002). 


\subsubsection{Ringold Formation}

The Ringold Formation records fluvial-lacustrine deposition associated with the ancestral Columbia River drainage system, following the last eruption of basalt at the Hanford Site about 10.5 million years ago (Tallman et al. 1981; DOE 1988; Lindsey et al. 1994a; Lindsey 1995). Deformation of the Yakima folds, which began in the middle Miocene Epoch, concurrent with the Columbia River basalt volcanism, continued into Ringold time so the centers of down-warped basins received more sediments than the margins. The Ringold Formation is up to $185 \mathrm{~m}$ (600 ft) thick in the center of the basin and pinches out against the basin-bounding basalt ridges.

The Ringold Formation consists of semi-indurated clay, silt, fine- to coarse-grained sand, and variably cemented granule to cobble gravel. Ringold Formation sediments have been classified into five sediment facies associations: (1) fluvial gravel, (2) fluvial sand, (3) overbank deposits, (4) lacustrine deposits, and (5) alluvial fan deposits. See Lindsey $(1995,1996)$ and Lindsey et al. (2001) for more detailed descriptions of these facies.

\subsubsection{Cold Creek Unit}

After a period of post-Ringold incision, the eroded surface of the Ringold Formation was locally weathered and/or covered with accretionary deposits of the CCU. These deposits consist of fluvial, eolian and/or colluvial sediment, often pedogenically altered (DOE 2002). The CCU includes those deposits formerly referred to as the "Plio-Pleistocene unit" and "pre Missoula Gravels," as well as the "early Palouse soil" and "caliche layer" within the 200 West Area. The new name, CCU, was given to these deposits because recent studies suggest this unit is all of late Pliocene age. The CCU is a more appropriate name choice because it is independent of age and geographically better describes the unit, which is generally confined to the boundaries of the Cold Creek syncline within the west-central Pasco Basin (DOE 2002).

Five different facies of the CCU have been differentiated based on grain size, sedimentary structure, sorting, roundness, fabric, and mineralogic composition (DOE 2002). These facies include:

(1) fluvial-overbank and/or eolian, (2) calcic paleosol, (3) mainstream alluvium, (4) colluvium, and

(5) sidestream alluvium. The multi-lithic, sandy gravel (mainstream alluvial) facies may lie beneath the basaltic sand and gravels of the Hanford formation within the C Tank Farm.

\subsubsection{Hanford formation}

The Hanford formation is an informal name used within the Pasco Basin to describe Pleistocene cataclysmic flood deposits (Tallman et al. 1979, 1981; DOE 1988, 2002). Ice-Age floods originated from outbursts of glacial Lake Missoula, as well as other ice-dammed lakes (Baker and Bunker 1985), pluvial lake Bonneville (O’Connor 1993), or possible sub-glacial floods (Shaw et al. 1999) associated with the Cordilleran Ice Sheet. The Hanford formation may include some minor fluvial, colluvial, and/or eolian deposits interbedded with flood deposits.

As mentioned in the preceding paragraph, the Hanford formation consists predominantly of unconsolidated sediments that cover a wide range in grain size, from boulder-size gravel to sand, silty sand, and silt. The sorting ranges from poorly sorted (for gravel facies) to well sorted (for fine sand to silt facies). Traditionally, the Hanford formation has been subdivided into three lithofacies (gravel 
dominated, sand dominated, and interbedded sand and silt-dominated), which grade into one another, both vertically and laterally (DOE 2002). These lithofacies may interfinger with or grade from gravel-dominated to sand-dominated facies, or sand-dominated to silt-dominated facies, but rarely from gravel-dominated to silt-dominated facies.

Ice-age floods created Cold Creek bar (Figure 2.1), a giant, streamlined deposit of gravel, sand, and silt that extends for 12 miles downstream of Umtanum Ridge. Gravel-dominated deposits, laid down under the strongest flood currents, are generally restricted to the north side of the bar. At the south end of the bar, where flood currents were gentler, interbedded sand and silt deposits were laid down. In between these two areas, deposits of predominantly sand accumulated, which includes the area beneath C Tank Farm.

The interbedded sand- and silt-dominated facies (DOE 2002) is stratigraphically equivalent to Touchet Beds (Flint 1938). In the late 1980s, these deposits began to be called by a variety of other informal names, including "slackwater facies” (Moody 1987; Lindsey et al. 1992b; Connelly et al. 1992a; Last et al. 1989; Smith 1993), "silt-dominated facies” (Lindsey et al. 1992a, 1994b; Connelly et al. 1992b), "silty facies” (Lindsey et al. 1994a), and "rhythmite facies” (Baker et al. 1991). Interbedded sand- and silt-dominated facies occur as sequences of rhythmic, graded beds that range from 0.1 to $1 \mathrm{~m}$ ) ( 0.3 to $3.3 \mathrm{ft}$ ) in thickness and are characterized by loose, horizontal- to ripple-laminated, grayish, coarse to medium sand, grading up into brownish, cohesive, fine sand to silt.

Sand-dominated facies of the Hanford formation (Lindsey et al. 1992a, 1992b, 1994a, 1994b; Connelly et al. 1992a, 1992b) consist of relatively thick ( $\leq 21 \mathrm{~m}[3.3 \mathrm{ft}]$ ), predominantly horizontally laminated, loose, basalt-rich, fine- to coarse-grained sand, sometimes grading upward into a thinner sequence of ripple-laminated fine sand to silt. The sand-dominated facies have also been referred to as the "transitional sand facies" (Reidel et al. 1992; Fecht and Weekes 1996) and the "plane-laminated sand facies” (Baker et al. 1991). Typically, sand-dominated facies contain approximately equal amounts of quartz-feldspar and mafic (i.e., basalt) grains (Tallman et al. 1979). This composition gives the Hanford formation its characteristic "salt and pepper" appearance that is frequently noted in drillers' and geologists' logs.

The gravel-dominated facies (Lindsey et al. 1992a, 1992b, 1994b; Connelly et al. 1992a, 1992b) of the Hanford formation have been variously named "Pasco gravels" (Brown 1970; Myers and Price 1979; Tallman et al. 1979, 1981: DOE 1984), "Missoula flood gravels” (Webster and Crosby 1982), “coarse-grained main-channel facies” (DOE 1988; Last et al. 1989), and "coarse-grained flood gravels” (Moody 1987; Baker et al. 1991). Gravel-dominated facies consist of loose, massive to horizontal and large-scale, planar-tabular cross-bedded, poorly sorted mixtures of gravel, sand, and silt. Gravel clasts in flood gravels generally consist of 50\% to $75 \%$ subangular to subrounded basalt (DOE 2002). Rounded rip-up clasts of caliche and/or semi-indurated silt and clay are common in the gravel-dominated facies.

Below an elevation of approximately $300 \mathrm{~m}$ (1,000 ft) within the central Pasco Basin, the Hanford formation unconformably overlies the CCU and, where the CCU is eroded, lies directly on the Ringold Formation or Columbia River basalt. Within the central Pasco Basin, up to $100 \mathrm{~m}$ (328 ft) of flood deposits accumulated along Priest Rapids, Cold Creek, and Gable Mountain flood bars, which developed as the floods temporarily expanded into the Pasco Basin (Figure 2.1). The bulk of the vadose zone at the Hanford Site lies within sediments of the Hanford formation. 


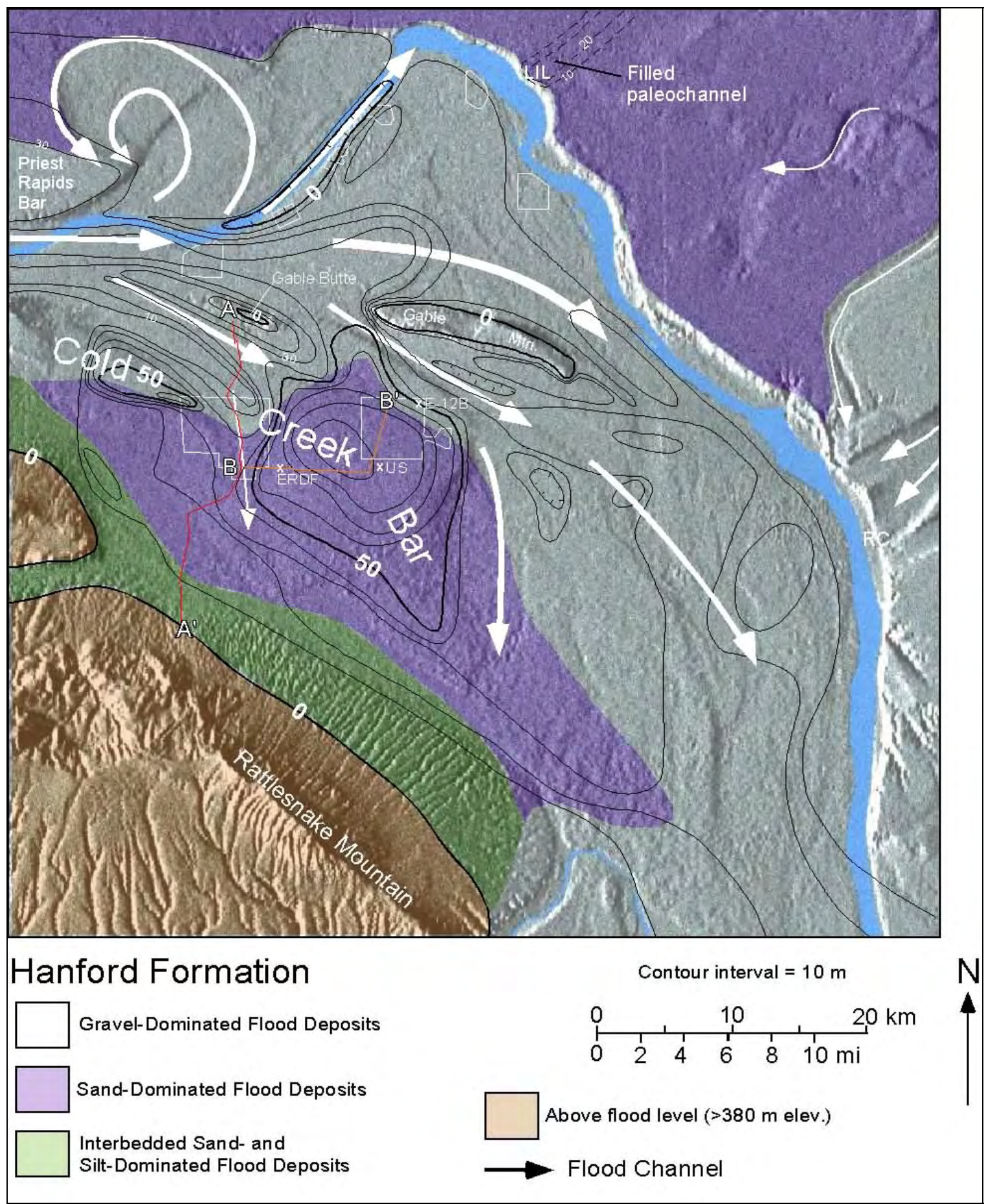

Figure 2.1. Thickness and Distribution of Cataclysmic Flood Deposits (i.e., Hanford formation) within the Central Pasco Basin 


\subsection{Geologic Setting of the C Tank Farm}

The geology in the vicinity of the C Tank Farm has been described in numerous reports (Price and Fecht 1976; Tallman et al. 1979; Last et al. 1989; Lindsey et al. 1992a, Connelly et al. 1992b; DOE 1998a; Horton and Narbutovskih 2001; Wood et al. 2003; Lindsey et al. 2004). A generalized stratigraphic column for the C Tank Farm is illustrated in Figure 2.2.

This report follows the standardized stratigraphic nomenclature recommended in DOE (2002); therefore, the names for post-Ringold Formation stratigraphic units may differ from the terminology used in previous reports.

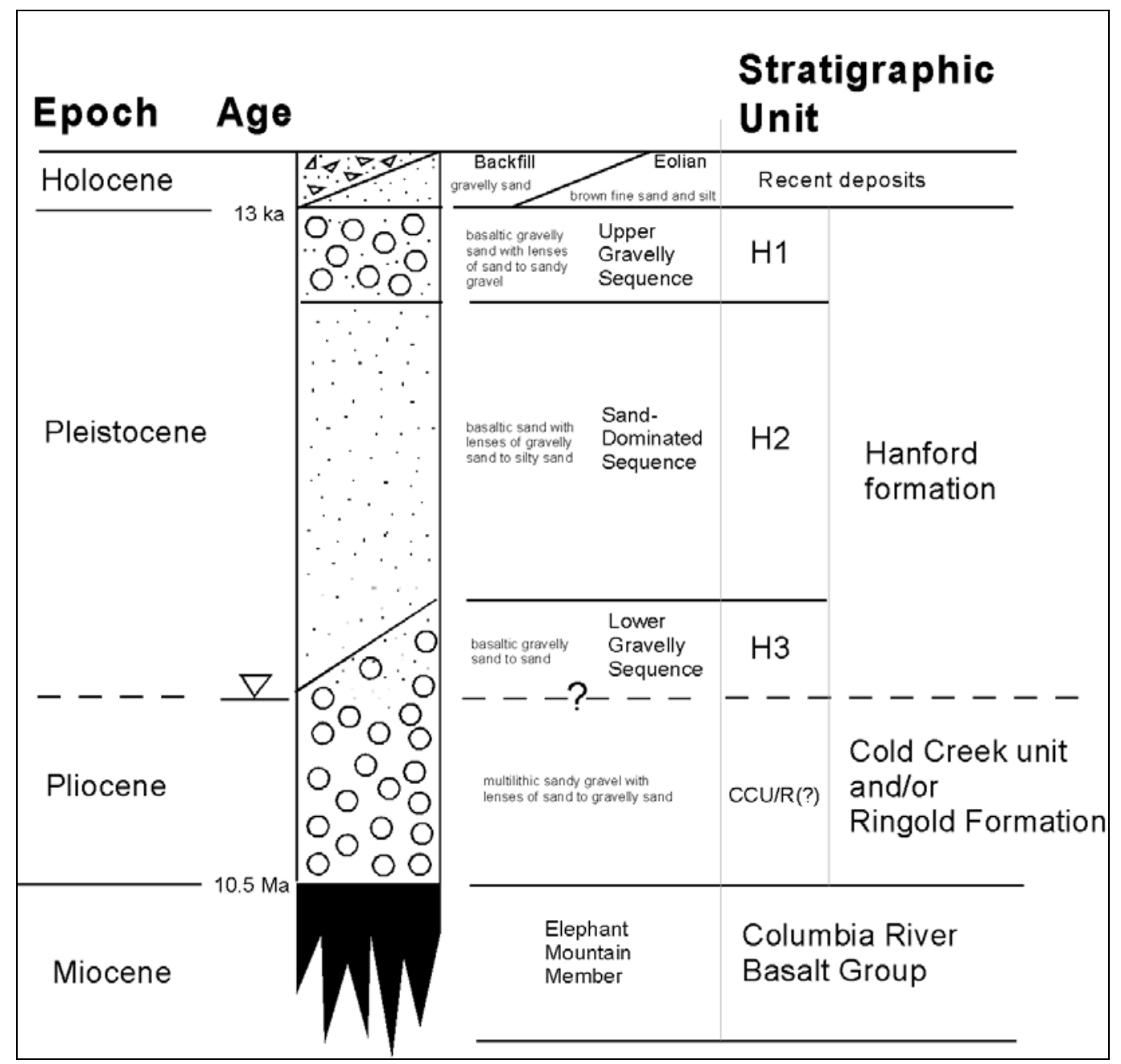

Figure 2.2. Generalized Stratigraphy for the Late-Cenozoic Sediments at the C Tank Farm

The subsurface geology of the C Tank Farm is interpreted from dozens of boreholes drilled in the area. A total of 670 dry wells were constructed between 1944 and 1978 to monitor for leaks from twelve 530,000-gallon and four smaller 55,000-gallon single-shell tanks within the C Tank Farm (DOE 1998a). Three of the twelve larger tanks and all four of the smaller tanks are designated assumed leakers; the remaining tanks within C Tank Farm are classified as sound. The dry wells have served as 
primary and secondary leak-detection devices. Most of the dry wells extend to depths of between 100 and $150 \mathrm{ft}$ bgs, while the groundwater is approximately $250 \mathrm{ft}$ bgs (DOE 1998a). While no wells extend to the uppermost aquifer within C Tank Farm, 10 groundwater monitoring wells are located around its perimeter. Locations of the monitoring wells in the vicinity of the C Tank Farm, and other key boreholes used in this report, are shown in Figure 2.3.

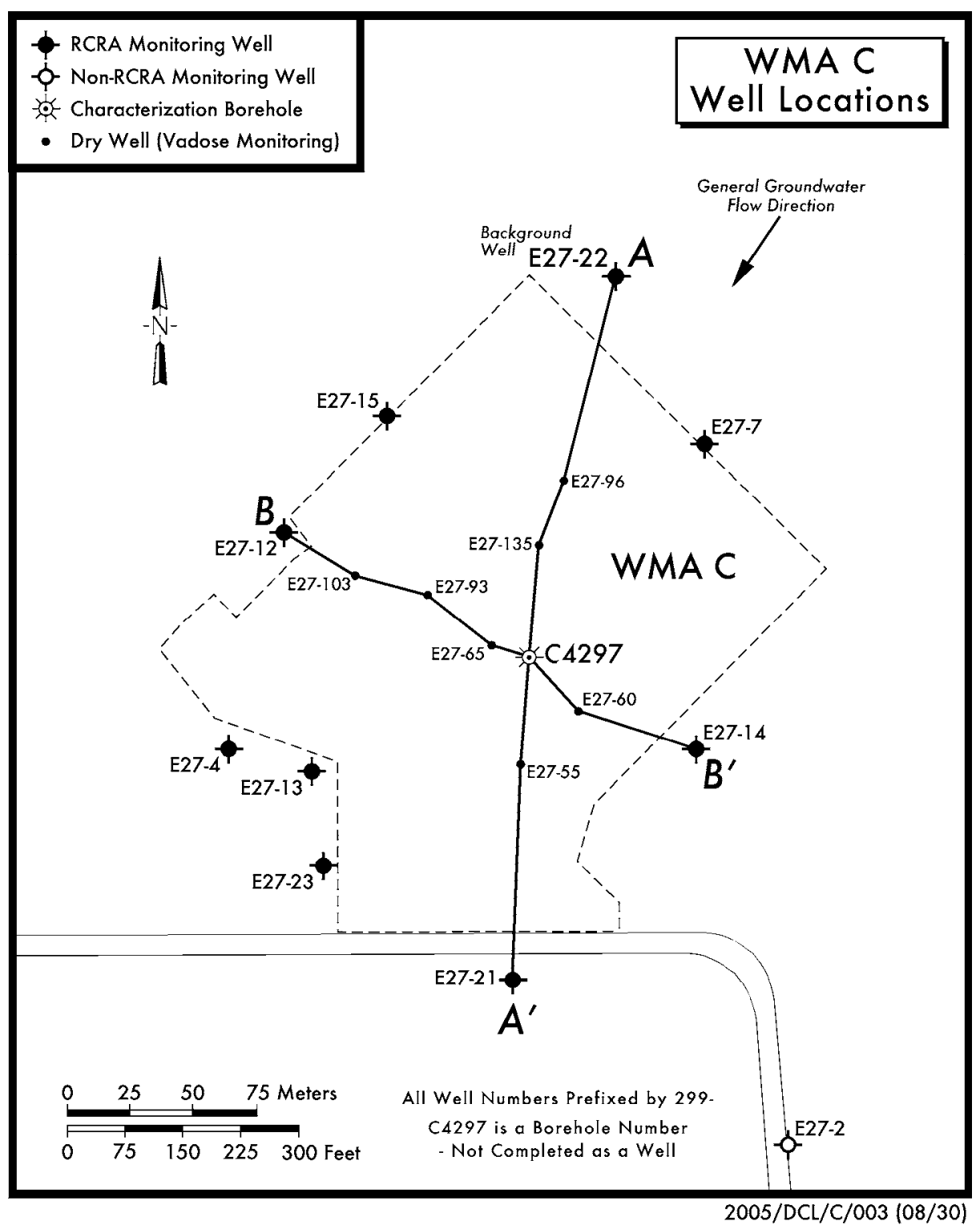

Figure 2.3. Selected Borehole Location Map for the C Tank Farm. Cross sections A-A' and B-B' are shown in Figures 2.4 and 2.5, respectively. 


\subsubsection{Stratigraphy and Lithology}

The tank farm was excavated into the Pleistocene-age Hanford formation and Holocene eolian deposits that mantle the central portion of the Cold Creek flood bar. The depth to groundwater in the vicinity of the C Tank Farm is about $250 \mathrm{ft}$. Post-basalt strata beneath the tank farm include (in descending order): (1) recent deposits, (2) Hanford formation, and (3) CCU and/or Ringold Formation.

Two geologic cross sections (Figures 2.4 and 2.5) are presented for the $C$ Tank Farm. The most recent and comprehensive investigations on the interpreted geology of $C$ Tank Farm include those reported in Wood et al. (2003) and Lindsey et al. (2004).

Holocene Deposits. Holocene deposits within the C Tank Farm consist of backfill material emplaced around the tanks during their construction in 1943 to 1944 . This backfill material is composed of mostly sandy, matrix-supported gravelly deposits of the Hanford formation H1 unit (H1). Some of the surficial eolian sand may also be mixed with the backfill material. Prior to construction of the C Tank Farm, up to $5 \mathrm{ft}$ of windblown sand and silt blanketed the area.

Bottoms of the larger single-shell tanks within the C Tank Farm were placed at a depth of 40 to $42 \mathrm{ft}$ bgs. During tank installation, the Hanford formation (mostly H1 unit) was removed to this depth and stockpiled for later placement around and over the underground storage tanks. The backfill consists of a mostly a loose, gravelly, medium to coarse sand mixed with variable amounts of finer sand and silt.

Hanford formation. The Hanford formation, which comprises most of the vadose zone in the C Tank Farm, consists of two informal subunits: the $\mathrm{H} 1$ and $\mathrm{H} 2$ units. The $\mathrm{H} 2$ unit, a sand-dominated sequence, underlies a coarser (i.e., more gravelly) H1 unit. Locally, another gravelly sequence (H3 unit) sometimes lies at the base of the Hanford formation. During excavation of the C Tank Farm, most of the Hanford formation $\mathrm{H} 1$ unit was removed, so that the $\mathrm{H} 2$ unit is the predominant unit beneath the backfill emplaced around the tanks (Figures 2.4 and 2.5).

Gravel-Dominated Sequence (H1 Unit). The H1 unit is present around the perimeter of the C Tank Farm and locally beneath the backfill within the tank farm (Figures 2.4 and 2.5). Most of the material used for backfill around the tanks is from the gravels and sands of the Hanford formation H1 unit, which was removed during tank installation.

Sand-Dominated Sequence (H2 Unit). The H2 unit consists of predominantly sand-dominated facies of the Hanford formation. Cementation is very minor or absent, and total $\mathrm{CaCO}_{3}$ content is generally only a few weight percent or less. Within the H2 unit may be thin lenses of fine sand and silt, or beds of matrix-supported pebbly sand.

Lindsey et al. (2004) and Williams and Narbutovskih (2004) identified a third unit (H3) of the Hanford formation, which is usually reserved for a clast-supported, gravel-dominated facies at the base of the Hanford formation (DOE 2002). However, at C Tank Farm, the overall texture of this unit is still predominantly sand, with only a minor component of pebbly to slightly pebbly sand. The H3 unit of Lindsey et al. (2004) and Williams and Narbutovskih (2004) does not contain appreciably more gravel than the $\mathrm{H} 2$ unit. Therefore, for this evaluation, only the $\mathrm{H} 1$ and $\mathrm{H} 2$ units of the Hanford formation are differentiated within the C Tank Farm. 


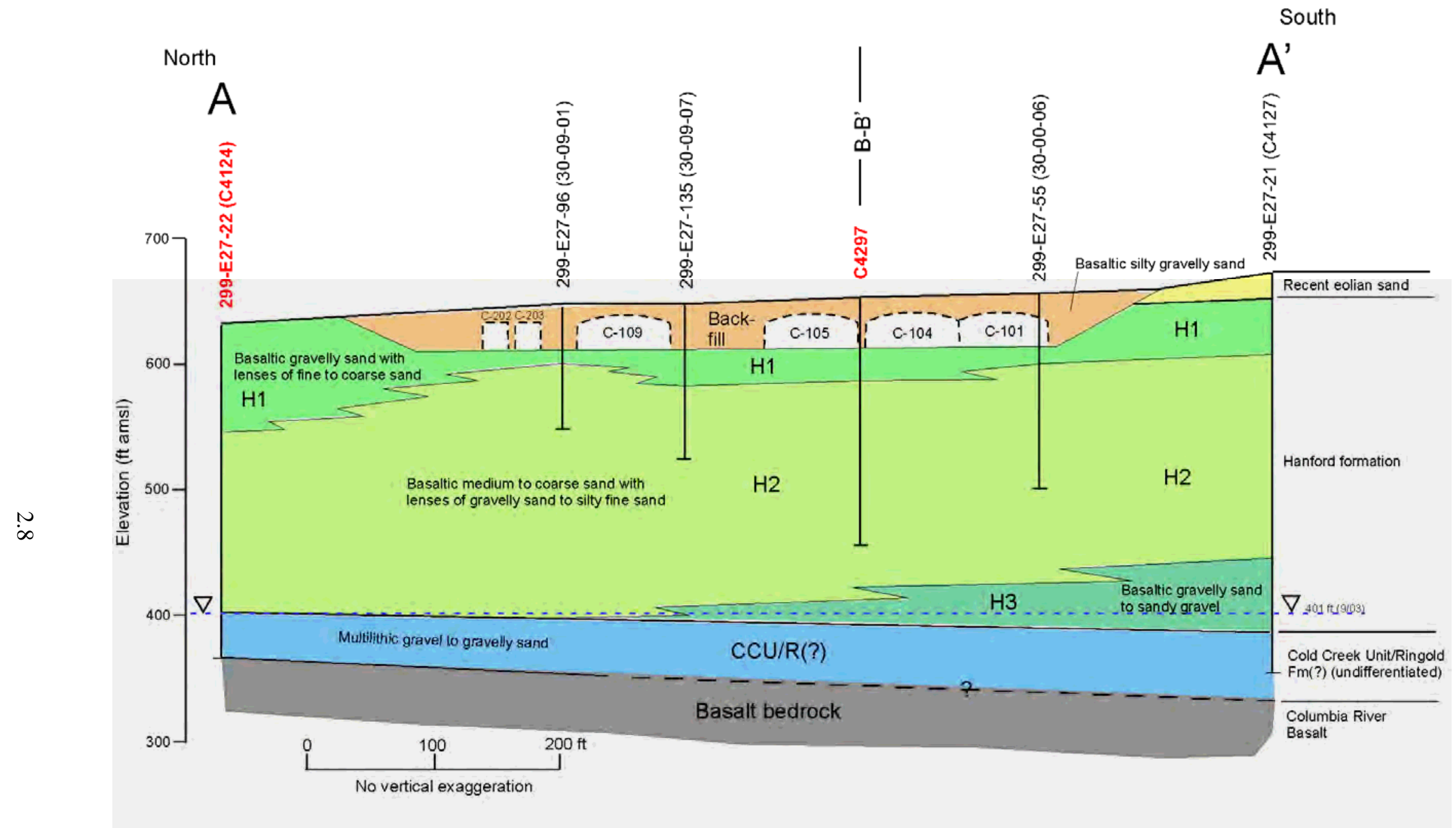

Figure 2.4. East-West Hydrogeologic Cross Section A-A’ Across the C Tank Farm (located in Figure 2.3) 

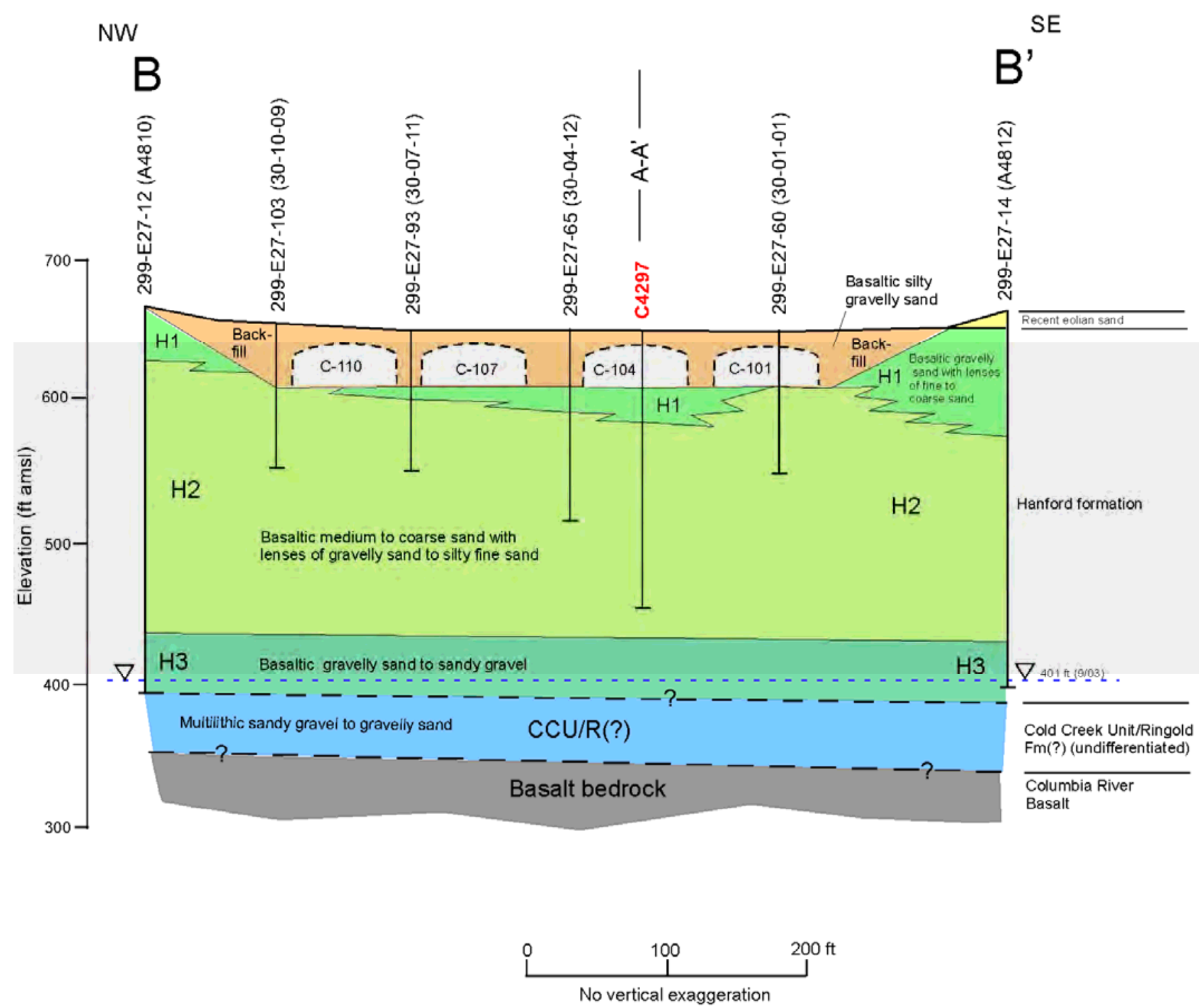

Figure 2.5. North-South Hydrogeologic Cross Section B-B' Across the C Tank Farm (located in Figure 2.3) 
Pre-Hanford formation Strata. Beneath the Hanford formation $\mathrm{H} 2$ unit, starting at about the 230-ft depth in C Tank Farm, is a layer up to $40 \mathrm{ft}$ thick of multi-lithic, gravel-dominated sediments. At present, there is considerable disagreement on how to classify this sequence. The unconfined aquifer is fully contained in this gravelly sequence so it is important to determine its origin, since origin can affect hydraulic conductivity and the rate at which water is transmitted through the unit. Possible associations for the gravel-dominated sequence, which extends up to an elevation of $420 \mathrm{ft}$ (230 ft depth), include: (1) a lowermost gravel sequence of the Hanford formation (H3 unit), (2) mainstream alluvial facies of the CCU (formerly called Pre-Missoula Gravels, or Plio-Pleistocene gravels [PPg]), (3) Wooded Island Member (Unit A) of the Ringold Formation, or (4) a combination of these units.

Most earlier reports identified this sequence as Hanford formation H3 unit. More recently, a report by Williams and Narbutovskih (2004) classified the sequence as a combination of H3/CCU based on a few measurements of high in-situ hydraulic conductivity derived from pump tests in well 299-E27-22 (C4124). However, the hydraulic conductivity measurements in this gravel-dominated sequence ranged from 0.13 to $>22,000 \mathrm{ft} /$ day, which covers the entire range of $\mathrm{K}_{\mathrm{sat}}$ for most sedimentary units at the Hanford Site. In another recently published report, Lindsey et al. (2004) identified this lower gravel sequence as strictly Ringold Formation (Unit A) based on the presence of iron-oxide staining, more induration, and its composition, which includes many clasts besides basalt (i.e., multi-lithic).

At the A-AX Tank Farm, just a few hundred feet south of the C Tank Farm, overlying the gravel sequence at about the same 420 -ft elevation, is a fine-grained layer of predominantly silt and clay lying 90 to $100 \mathrm{ft}$ above the top of basalt. The color of this fine-grained unit, which is up to $30 \mathrm{ft}$ thick, shows shades of blue, green, brown, olive, and gray (Wood et al. 2003). Neither clay-rich zones nor blue, green, or olive colors occur in the Hanford formation (DOE 2002). These colors are generally only found in older, fine-grained facies of the Ringold Formation (e.g., Lower Mud unit) at the Hanford Site. It follows that if the fine-grained layer at the 420 -ft elevation is Ringold, then the underlying gravel-dominated sequence must also be Ringold Formation.

On the opposite side of C Tank Farm, at B Tank Farm located 4,000 ft to the northwest, is another thick (up to $35 \mathrm{ft}$ ), fine-grained stratum, 50 to $60 \mathrm{ft}$ above basalt. Wood et al. (2000) classified this layer as the $\mathrm{Hf} / \mathrm{PPu}$ (?). However, the silt layer appears to be too thick to be part of the Hanford formation and not like the color normally observed for Hanford formation materials. Wood et al. (2000) most strongly believed this unit represented a silt-dominated, fluvial-eolian facies of the Plio-Pleistocene unit, more recently classified as the laminated to massive lithofacies of the CCU (DOE 2002).

In any case, since the $C$ Tank Farm appears surrounded with deposits of either the Ringold and/or CCU that extend from 50 to $100 \mathrm{ft}$ above basalt, it is reasonable to assume these deposits underlie the C Tank Farm as well. However, no fine-grained strata are present in C Tank Farm, like those at A, AX or B Tank Farms; therefore, it is difficult to pick the contact between Hanford formation and pre-Hanford formation units.

The composition of the lower gravel sequence beneath C Tank Farm appears to be multi-lithic, unlike Hanford formation gravels, which are concentrated in basalt (DOE 2002). Since the lithology of the unit is inconsistent with that of the Hanford formation, we conclude that the lower gravel sequence beneath C Tank Farm is composed of Ringold Formation Unit A, perhaps overlain with some mainstream-alluvial facies of the CCU, which is also multi-lithic. Thus, in this report we designate this unit as CCU/R. Clearly more work needs to be done to establish the physical and mineralogical characteristics of the 
different coarse-grained facies of the Hanford formation, CCU, and Ringold Formation, in order to establish the true nature of the sediments in stratigraphically ambiguous areas such as C Tank Farm.

\subsubsection{Clastic Dikes}

Clastic dikes are vertical to sub-vertical sedimentary structures that crosscut normal sedimentary layering that are common to ice-age flood deposits, especially in the sand- and silt-dominated facies of the Hanford formation (Black 1979; Fecht and Weekes 1996; Fecht et al. 1999). Some clastic dikes were noted during excavation of the C Tank Farm (Price and Fecht 1976) but none have yet to be reported in boreholes from C Tank Farm. However, very little core has been collected beneath the C Tank Farm from which to evaluate the presence of dikes in the subsurface.

Where clastic dikes intersect the ground surface, and are not covered with younger deposits, a feature known as "patterned ground" can be observed (Fecht et al. 1999). Within the 200 East Area, however, "patterned ground" has not been observed due to the many manmade surface disturbances and/or because it is buried under a cover of recent eolian sand.

Clastic dikes occur in swarms and form four types of networks: (1) regular-shaped polygonal patterns, (2) irregular-shaped, polygonal-patterns, (3) pre-existing fissure fillings, and (4) random occurrences. Regular polygonal networks resemble 4- to 8-sided polygons and typically range from $3 \mathrm{~cm}$ (1.18 in.) to $1 \mathrm{~m}(3.28 \mathrm{ft})$ in width, from $2 \mathrm{~m}(6.56 \mathrm{ft})$ to greater than $20 \mathrm{~m}(65.6 \mathrm{ft})$ in depth and from 1.5 to $100 \mathrm{~m}$ (4.92 to $328.08 \mathrm{ft}$ ) along strike. Smaller dikelets, sills, and small-scale faults and shears are commonly associated with master dikes that form the polygons.

\subsection{Summary of Recent Characterization Activities at C Tank Farm}

Two boreholes were recently drilled and sampled in the immediate vicinity of C Tank Farm. One of these holes (C4297) was drilled via the cable-tool method within an area of expected contamination between tanks 241-C-104 and -105. Splitspoon core samples were collected at ten irregular intervals, between 24 and $126 \mathrm{ft}$ bgs for physical and chemical characterization and extent of radiological contamination in an area of suspected contamination.

Samples were also collected from a second borehole, 299-E27-22 (C4124), located just north and a bit east of C Tank Farm northern fence line (Figure 2.3). This borehole was completed as a RCRA ground-monitoring well, and as such represents a "clean” borehole that can be compared against C4297 for background levels of chemical and radiological constituents. Continuous, 2.5-ft long by 4-in. diameter, splitspoon cores were collected from 299-E27-22 between the 19 and $111 \mathrm{ft}$ depths bgs. Below this, from $111 \mathrm{ft}$ to $230 \mathrm{ft}$ bgs, one 2.5 -ft core sample was collected every $5 \mathrm{ft}$. Key information on each of these two boreholes is presented in Table 2.1. Contact picks for the different stratigraphic units within these boreholes is presented in Table 2.2. 
Table 2.1. Two Borings Used for Recent Geochemical Characterization in the Vicinity of the C Tank Farm

\begin{tabular}{|c|c|c|c|c|c|c|c|c|c|c|c|c|}
\hline $\begin{array}{c}\text { Hanford } \\
\text { ID }\end{array}$ & \begin{tabular}{|c|} 
Borehole \\
Number \\
\end{tabular} & Northing & Easting & $\begin{array}{c}\text { Total } \\
\text { Depth } \\
\text { (ft bgs) }\end{array}$ & $\begin{array}{l}\text { Primary } \\
\text { Purpose }\end{array}$ & $\begin{array}{c}\text { Drill } \\
\text { Method }\end{array}$ & \begin{tabular}{|c|}
$\begin{array}{c}\text { Surface } \\
\text { Elevation } \\
\text { (ft) }\end{array}$ \\
\end{tabular} & \begin{tabular}{|c|} 
Length// \\
ID of \\
Splitspoon
\end{tabular} & $\begin{array}{c}\text { Date Cores } \\
\text { Collected } \\
\end{array}$ & $\begin{array}{c}\text { Date Cores } \\
\text { Logged/ } \\
\text { Sampled in Lab } \\
\end{array}$ & $\begin{array}{c}\text { Percent of } \\
\text { Hole Cored } \\
\end{array}$ & $\begin{array}{c}\text { Core Logged } \\
\text { By }\end{array}$ \\
\hline & C4297 & 136534.78 & 575151.18 & 126.6 & \begin{tabular}{|l|} 
Vadose Zone \\
Characterization
\end{tabular} & $\begin{array}{l}\text { Cable tool/ } \\
\text { splitspoon }\end{array}$ & - & $2.5 \mathrm{ft} / 4 \mathrm{in}$. & \begin{tabular}{|l|}
$02 / 17 / 2004$ to \\
$02 / 26 / 2004$
\end{tabular} & $04 / 1 / 2004$ & 13.8 & $\begin{array}{l}\text { Bruce Bjornstad } \\
\text { (PNNL) }\end{array}$ \\
\hline 299-E27-22 & C4124 & 136685.33 & 575185.10 & 268 & $\begin{array}{l}\text { RCRA } \\
\text { Groundwater } \\
\text { Monitoring }\end{array}$ & $\begin{array}{l}\text { Becker } \\
\text { hammer }\end{array}$ & 631.9 & $2.5 \mathrm{ft} / 4 \mathrm{in}$. & $\begin{array}{l}\text { 08/21/2003 to } \\
09 / 02 / 2003\end{array}$ & \begin{tabular}{|l}
$10 / 28 / 2003$ to \\
$10 / 30 / 2003$
\end{tabular} & 41 & $\begin{array}{l}\text { Bruce Bjornstad } \\
\text { (PNNL) }\end{array}$ \\
\hline
\end{tabular}


Table 2.2. Stratigraphic Contact Picks for Boreholes Used in this Report

\begin{tabular}{|c|c|c|c|}
\hline & & 299-E27-22 & $\mathbf{C 4 2 9 7}$ \\
\hline & Surface elevation ft (amsl) & 632 & $*$ \\
\hline \multirow{5}{*}{ 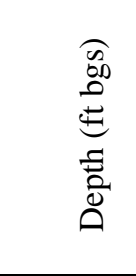 } & Eolian/Backfill & 0 & 0 \\
\hline & H1 & 5 & 39.8 \\
\hline & $\mathrm{H} 2$ & 82 & 65 \\
\hline & $\mathrm{CCU} / \mathrm{R}$ & 228 & NR \\
\hline & Top of basalt & 268 & NR \\
\hline \multirow{4}{*}{ 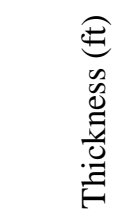 } & Eolian/Backfill & 5 & 39.8 \\
\hline & H1 & 77 & 25.2 \\
\hline & $\mathrm{H} 2$ & 146 & NR \\
\hline & $\mathrm{CCU} / \mathrm{R}$ & 40 & NR \\
\hline \multirow{5}{*}{ 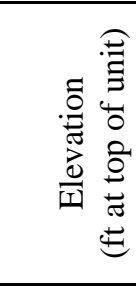 } & Eolian/Backfill & 632 & $*$ \\
\hline & H1 & 627 & $*$ \\
\hline & $\mathrm{H} 2$ & 550 & $*$ \\
\hline & CCU/R & 404 & NR \\
\hline & Top of basalt & 364 & NR \\
\hline \multicolumn{4}{|c|}{$=$ Below ground surface. } \\
\hline CCU & \multicolumn{3}{|c|}{ = Cold Creek unit. } \\
\hline H1 & \multicolumn{3}{|c|}{$=$ Hanford formation unit 1.} \\
\hline $\mathrm{H} 2$ & \multicolumn{3}{|c|}{$=$ Hanford formation unit 2.} \\
\hline NR & \multicolumn{3}{|c|}{ = Not reached. } \\
\hline$*$ & \multicolumn{3}{|c|}{$=$ No surface elevation is available. } \\
\hline
\end{tabular}

\subsubsection{Hydrogeologic Characterization}

Geophysical logs are available and used in the interpretation of both boreholes. Other hydrogeologic characterization information, performed in the laboratory, included geologic logging and photography. Information on moisture content was available from two independent sources: (1) the downhole neutron-moisture geophysical log collected in the field (C4297 only), as well as (2) gravimetric moisture content of core samples collected in the laboratory.

\subsubsection{Geophysical Logging}

Geophysical logs have been used extensively within C Tank Farm to evaluate the subsurface distribution and migration of gamma-emitting radionuclides over time (DOE 1998a). Because radiological contamination masks the natural gamma response within the tank farms, potassium, uranium, and thorium (KUT) logs are better for interpreting lithology and picking stratigraphic contacts. One limitation of the geophysical logs, which collect data every half foot, is that they generally cannot detect strata less than $2 \mathrm{ft}$ in thickness. Therefore, thin, lower-permeability, fine-grained layers, such as those that sometimes cap sand sequences within the Hanford formation H2 unit and may result in the lateral spreading of moisture and contaminants, may not show up on geophysical logs. 
Geophysical logging was performed on both boreholes, reported herein, using a high-purity germanium (HPGe) spectral-gamma detector. Processing of the spectral-gamma log data allows the identification of gamma-emitting man-made radionuclides (if present) and the background levels of radiogenic KUT that are naturally present in earth materials. As expected, some manmade radiological contaminants were detected in C4297, within the C Tank Farm, while no manmade radiological contaminants were detected in borehole 299-E27-22, outside the tank farm.

A neutron-moisture geophysical log was obtained for only one of the two holes (C4297). The neutron-moisture log is generally used to depict the relative moisture content within a 20 to $30 \mathrm{~cm}$ radius around the borehole. However, the neutron-moisture logging tool was not calibrated for the casing conditions; therefore, absolute moisture values cannot be obtained directly from the neutron-moisture log. Generally, where there is no radiological contamination, the total gamma count rate increases in finer grained sediments with corresponding increase in moisture content due to the moisture-retaining properties of these sediments.

\subsubsection{Sample Handling}

Because there was no manmade radiological contamination in 299-E27-22, sample handling was slightly different for this clean hole compared to C4297, which was sampled within the C Tank Farm. Cores from 299-E27-22 were processed in the PNNL Sigma V Building. In this hole, two, 4-in.-diameter, 1-ft-long Lexan ${ }^{1}$-lined core samples were recovered from each 2.5-ft splitspoon. Upon recovery, any open spaces in the ends of the liners were stuffed with aluminum foil in the field and plastic end caps secured with duct tape. The outside of the liner was labeled with borehole number, depth interval, and an "up" arrow. In the laboratory, Lexan liners were cut and opened lengthwise with a saw before being logged, photographed, and sampled.

Alternatively, potentially contaminated core samples from C4297 were processed at the PNNL 325 Building. Splitspoon cores were collected and transferred to the laboratory in four, 4.0-in.-diameter, 0.5-ft-long stainless steel liners. Liners were sealed with plastic end caps and the outsides labeled with chain-of-custody number, up arrow, and the letter "A", "B”, "C", or "D." The letter "A" was assigned to the deepest of the four cores, and the letter " $\mathrm{D}$ " assigned to the shallowest 0.5 -ft core in the 2-ft run. Once received at the PNNL 325 Building, C4297 samples were stored in a refrigerator to maintain the sample temperatures between $2^{\circ} \mathrm{C}$ and $4^{\circ} \mathrm{C}$.

Because of the potential for radiological contamination, more precautions were taken while processing the $\mathrm{C} 4297$ cores from within the C Tank Farm. Soon after receiving the cores, the end cap at the bottom of each "A" liner was removed and a small filter paper was placed into the soil to measure matric potential. After imbedding the filter paper into the soil, the end cap was replaced and samples were returned to cold storage for several weeks. Over this period of time, the filter paper should have absorbed an amount of moisture that was in equilibrium with the ambient moisture of the soil.

After filter-paper equilibration, the core samples were sequentially taken to a fume hood in a radiologically controlled laboratory for sample processing. Liner end caps and filter paper were removed and sediment within the sample liners was extracted using either a hammer by tapping on the stainless

\footnotetext{
${ }^{1}$ Lexan is a registered trademark of the General Electric Company, Schenectady, New York.
} 
steel liner or a specially constructed hydraulic "extruder." The contents of the stainless steel liner were placed in a plastic tray - one plastic tray per 0.5-ft liner. A geologic description was performed while the material in the tray was sampled and photographed. A complete set of core photographs for C4297, as well as the background hole (299-E27-22), are presented in Appendix A. Efforts were made to keep the sample materials as intact as possible, at least until a photograph was taken. However, in the coarser-grained sediments, the internal structures could generally not be preserved because of the unconsolidated, friable nature of those materials.

\subsubsection{Sub-Sampling and Geologic Description}

Cores from 299-E27-22 were opened in late October 2003 and C4297 on April 1, 2004. The same geologist (B.N. Bjornstad) was present to log both holes; core logs are presented in Appendix B. The geologist also sampled finer grained beds for paleo-magnetism from one of the boreholes (299-E27-22). Immediately upon extracting material from a core liner from the two holes, moisture samples were collected. An attempt was made to sample the finer grained and/or wetter materials as well as any distinct hydrogeologic units, while at the same time trying to avoid slough and/or other unrepresentative portions. A visual geologic evaluation of cores from the C Tank Farm probe holes was conducted in accordance with the following procedures: ASTM D 2488 (ASTM 1993) and PNNL (1999).

Throughout the sub-sampling and geologic evaluation activities, the PNNL geologist made visual observations regarding the mineralogy, structure, grain-size distribution (and sorting), maximum particle size, grain-shape (e.g., roundness), color, moisture, consolidation, and reaction to dilute hydrochloric acid ( $\mathrm{HCl}$ ) (used to test for the presence of calcium carbonate). Particular attention was given to estimate the percentage (by weight) of gravel, sand, and mud (silt+clay), and to classify the samples based on the modified Folk (1968)-Wentworth (1922) classification scheme historically used at the Hanford Site. This sediment classification scheme uses a ternary diagram to categorize the sediment into 1 of 19 textural classes based on the relative proportions of gravel, sand, and mud (Figure 2.6).

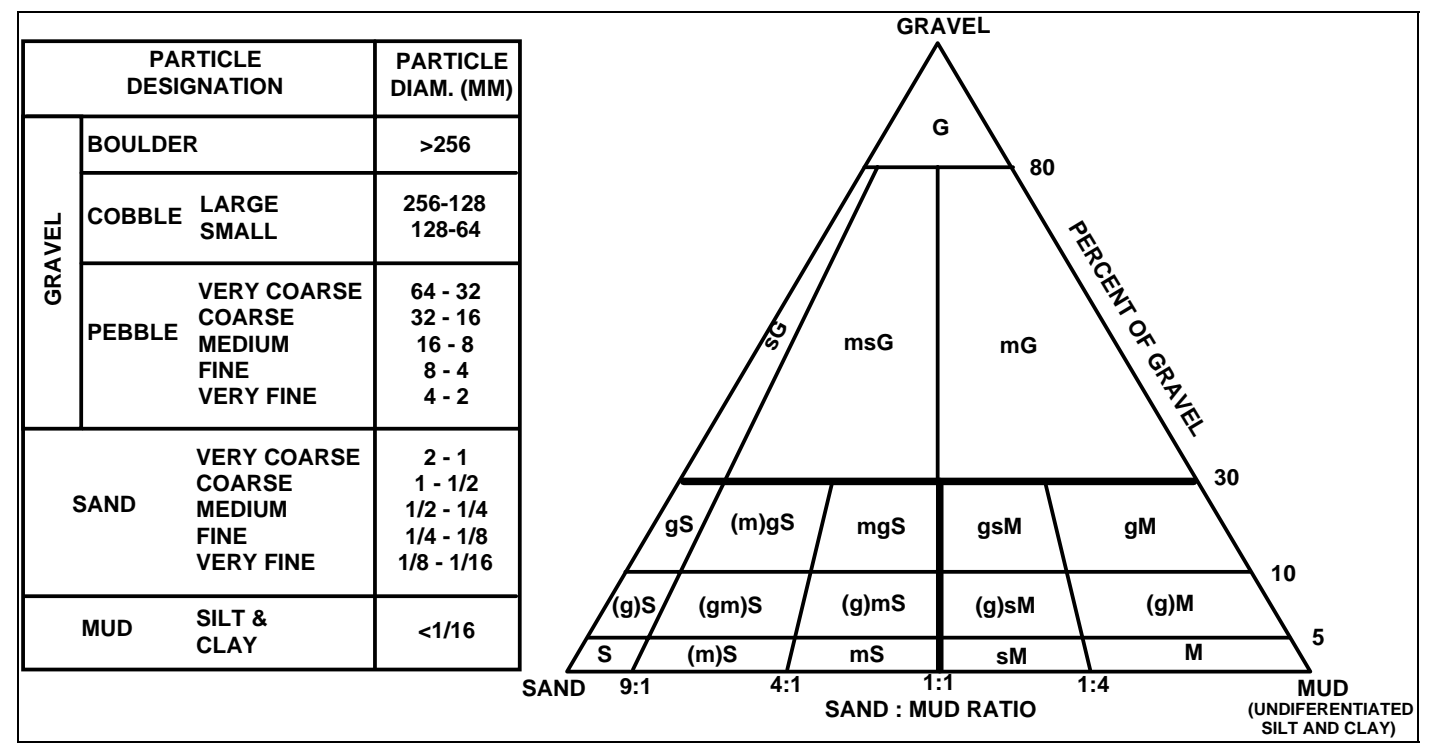

Figure 2.6. Sediment Textural Classification (modified after Folk 1968 and Wentworth 1922) 
The tops of many of the cores contained several inches or more of sloughed material in the core liners. Slough is recognizable by its darker, more massive and poorly sorted nature and, if present, is always at the top of the core. The sloughed material represents sediment that fell back into the hole or wasn't completely removed between core runs. Re-coring of sloughed materials was more common in coarser and looser sediments found in the backfill and the Hanford formations; it was generally not found in the finer-grained and/or higher moisture intervals, which are more cohesive and hold together better between core runs. Whenever possible, sampling of sloughed material was intentionally avoided during the collection of physical- and chemical-characterization samples within the laboratory.

\subsubsection{Hydrogeology of Borehole 299-E27-22 (Background Well)}

Borehole 299-E27-22 (C2124) was drilled using the Becker Hammer method between August 21 and September 3, 2003, and completed as a RCRA groundwater monitoring well on September 10, 2003. The borehole is located just north of the C Tank Farm (Figure 2.3). Total depth of the borehole is $268 \mathrm{ft}$ $(81.7 \mathrm{~m})$ bgs; the hole terminated at the top of basalt, which was about $37.5 \mathrm{ft}(11.4 \mathrm{~m})$ below the groundwater table.

Continuous, 2.5-ft-long by 4-in.-diameter, splitspoon cores were collected between 19 and $111 \mathrm{ft}$ bgs. Below this, from $111 \mathrm{ft}$ to $230 \mathrm{ft}$ bgs, one 2.5-ft core sample was collected every $5 \mathrm{ft}$. Two 1.0-ft long plastic (i.e., Lexan) core liners were collected for each 2.5 - $\mathrm{ft}$ core run. The extra $0.5 \mathrm{ft}$ collected in the shoe of the splitspoon was used for geologic description in the field geologist's log. Generally, after performing a geologic description, the core material in the shoe was discarded. No core samples were collected between the ground surface and $19 \mathrm{ft}$, or between 230 to $268 \mathrm{ft}$ bgs. In all, a total of the $41 \%$ of the hole was cored (Table 2.1).

Geologic logging and sampling for gravimetric moisture occurred after each core segment was cut and split open, logged, and photographed. During logging, PNNL staff also collected six samples for paleo-magnetic analysis (Table 2.3). Additional samples were collected across a suspected paleosol at $45 \mathrm{ft}$ bgs for cosmogenic-isotope burial dating. Core photos taken during logging of this hole are presented in Appendix A of this report. After geologic logging, photographing, and sampling, the plastic-lined cores were resealed with duct tape and placed into cold storage for archival purposes.

Table 2.3. Paleo-Magnetic Samples from Borehole 299-E27-22

\begin{tabular}{||l|l|c|}
\hline \multicolumn{1}{|c|}{$\begin{array}{c}\text { Depth } \\
\text { (ft bgs) }\end{array}$} & \multicolumn{1}{c|}{ Lithology } & $\begin{array}{c}\text { Stratigraphic Unit } \\
\text { (Hanford formation) }\end{array}$ \\
\hline \hline 35.7 & Fine to medium sand & H1 \\
\hline 39.3 & Fine to medium sand & H1 \\
\hline 43.3 & Medium sand & $\mathrm{H} 1$ \\
\hline 48.2 & Silty fine sand & H1 \\
\hline 82.6 & Fine sand & H2 \\
\hline 88.2 & Medium to coarse sand & H2 \\
\hline
\end{tabular}


Figure 2.7 presents a summary geologic log for borehole 299-E27-22 based on a compilation of the field-geologist's log (http://172.17.20.14/eis/hwisapp), geological log of opened cores (Appendix B), the total-gamma geophysical log, gravimetric-moisture measurements, and core photographs (Appendix A of this report). Four primary stratigraphic units were encountered in this borehole: (1) eolian sand, (2) the Hanford formation H1 unit, (3) the Hanford formation H2 unit, and (4) the undifferentiated Cold Creek unit and/or Ringold Formation (CCU/R)]. A brief description of the sampled materials from each of these major stratigraphic units is presented in the following paragraphs.

Based on the results of geophysical logging, no radioactive contaminants were detected in borehole 299-E27-22. Major changes in lithology, especially within the Hanford formation H1 unit, are visible as sudden shifts in total-gamma activity at approximately $49 \mathrm{ft}$ bgs (Figure 2.7). Within the Hanford formation $\mathrm{H} 2$ unit, on the other hand, the total gamma activity is relatively high and then decreases steadily to the base of the Hanford formation. The steady decrease is probably due to a slight increase in the gravel content with depth. The total gamma drops sharply at the contact with the water table at $230 \mathrm{ft}$ bgs, a result of the gamma-ray attenuation by the water-filled pores.

Several spikes in moisture content occurred within the vadose zone (Figure 2.7). These appear to be associated with two thin ( $1 \mathrm{ft}$ or less), fine-grained, silty layers at about the 49 and $99 \mathrm{ft}$ depths. A third spike occurred at a sharp interface at $83 \mathrm{ft}$ between beds of pebbly sand and fine sand. 


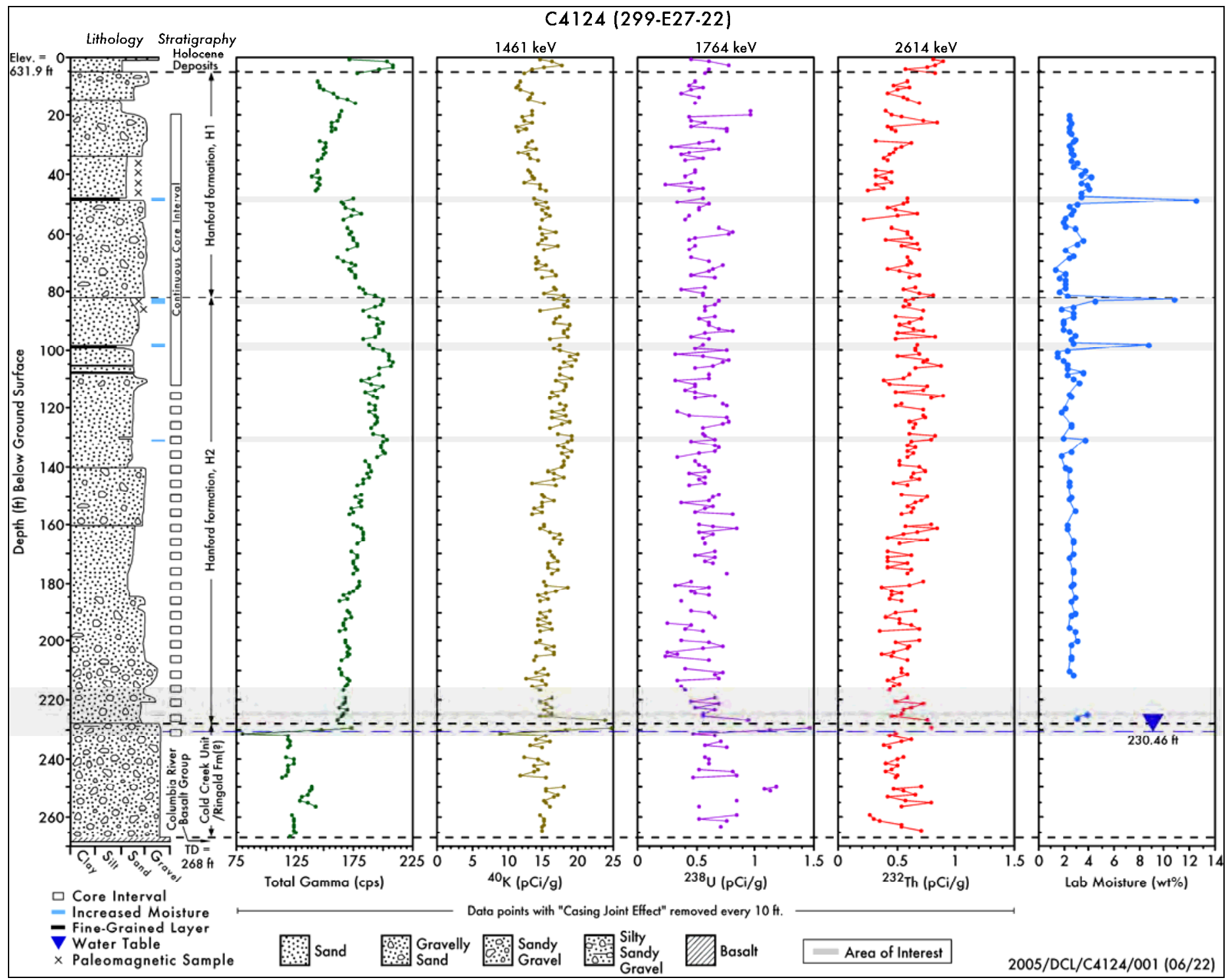

Figure 2.7. Summary Geohydrologic Log for Background Borehole 299-E27-22 


\subsubsection{Recent Materials}

About $5 \mathrm{ft}$ of recent materials lie at the top of borehole 299-E27-22. This includes $1 \mathrm{ft}$ of manmade crushed gravel placed atop $4 \mathrm{ft}$ of windblown sand.

\subsubsection{Hanford formation}

Pleistocene cataclysmic flood deposits of the Hanford formation underlie recent sediments to a depth of $228 \mathrm{ft}$ in borehole 299-E27-22. Two units of the Hanford formation are represented; these include a coarser pebbly sand sequence with up $20 \%$ pebbles (H1 unit) and an underlying sand-dominated sequence (H2 unit).

Hanford formation $\mathrm{H1}$ Unit. The $\mathrm{H} 1$ unit, which extends from 5 to $82 \mathrm{ft}$ bgs, consists of mostly loose, pebbly fine- to coarse-grained sand (Figure 2.8). Lesser amounts of pure sand to silty fine sand are also present (Figure 2.9). A total of 45 samples, ranging from pebbly sand to silty fine sand, were collected for physical and chemical characterization from the Hanford formation H1 unit. The average moisture content for the $\mathrm{H} 1$ unit in 299-E27-22 was $2.8 \pm 1.6 \mathrm{wt} \%$ water.

Hanford formation $\mathrm{H} 2$ Unit. The H2 unit is predominantly medium-to-coarse-grained sand at shallow depths (Figure 2.10), grading down into more pebbly sand (Figure 2.11) to a depth of $228 \mathrm{ft}$ bgs. The term "salt and pepper" is often used to describe sands of the H2 unit on geologic logs due to the roughly equal amounts of light- (quartz and feldspar) and dark-colored (basaltic) grains. These beds show occasional weak horizontal laminations and are generally non-calcareous to weakly calcareous. A few, relatively thin layers of fine sand to silty-fine sand lie within the upper part of the H2 unit (Figure 2.7).

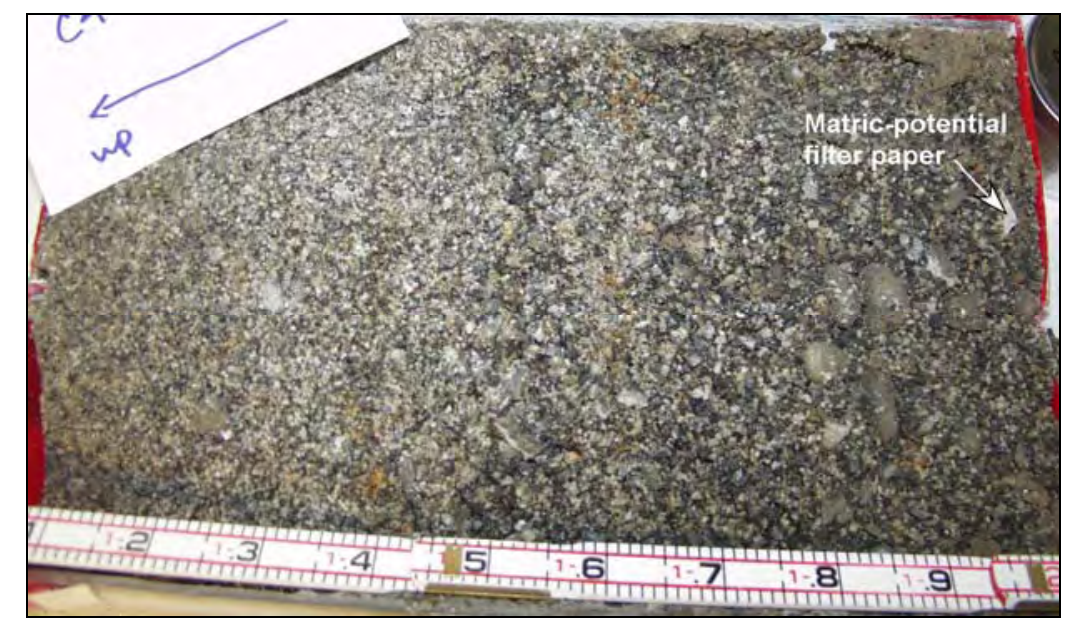

Figure 2.8. Major Facies of the Hanford formation H1 Unit in Borehole 299-W27-22 (weakly laminated, basaltic, slightly moist, pebbly coarse sand; top of the 1-ft-long core is to the left; 20 to $21 \mathrm{ft}$ depth) 


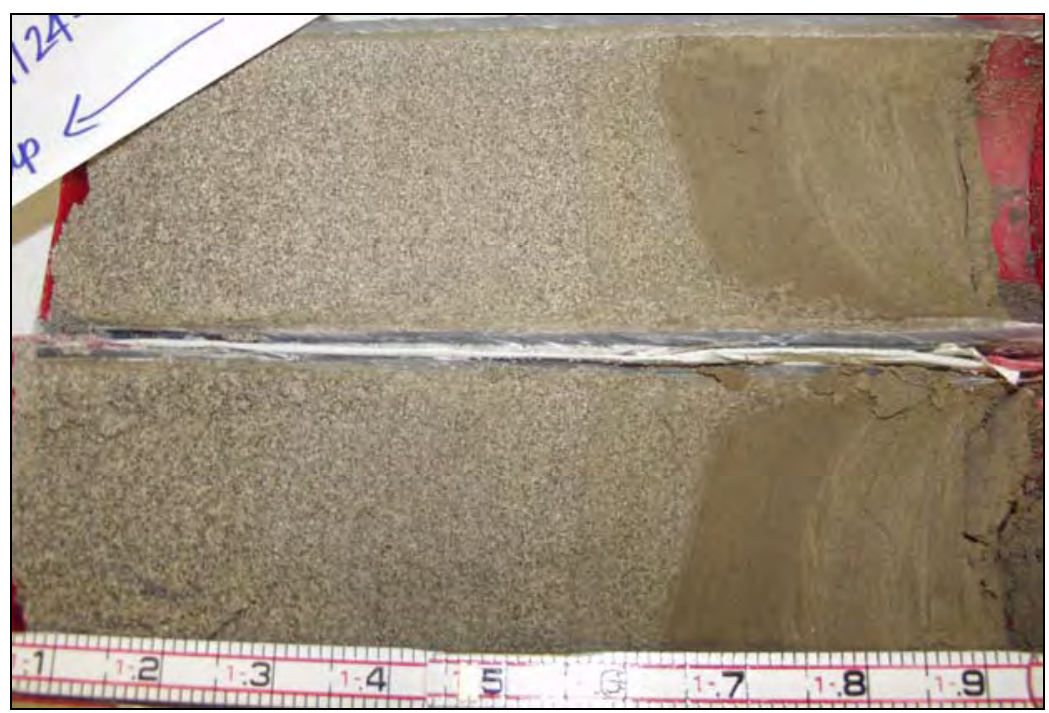

Figure 2.9. Minor Facies of the Hanford formation H1 Unit in Borehole 299-W27-22 (gray, well-laminated fine to medium sand in sharp contact with brown, moist, silty fine sand; top of the 1-ft long core is to the left; 47.5 to $48.5 \mathrm{ft}$ depth)

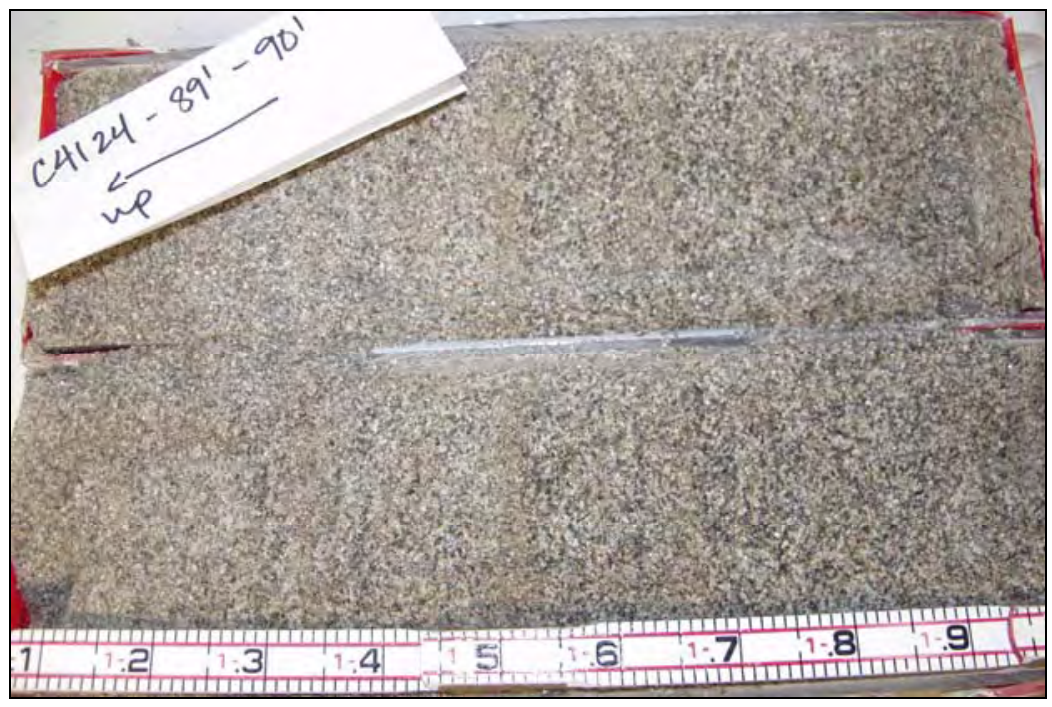

Figure 2.10. Sand Facies of the Hanford formation H2 Unit in Borehole 299-E27-22 (predominantly horizontally laminated coarse sand; top of the 1-ft-long core is to the left; 89 to $90 \mathrm{ft}$ depth) 


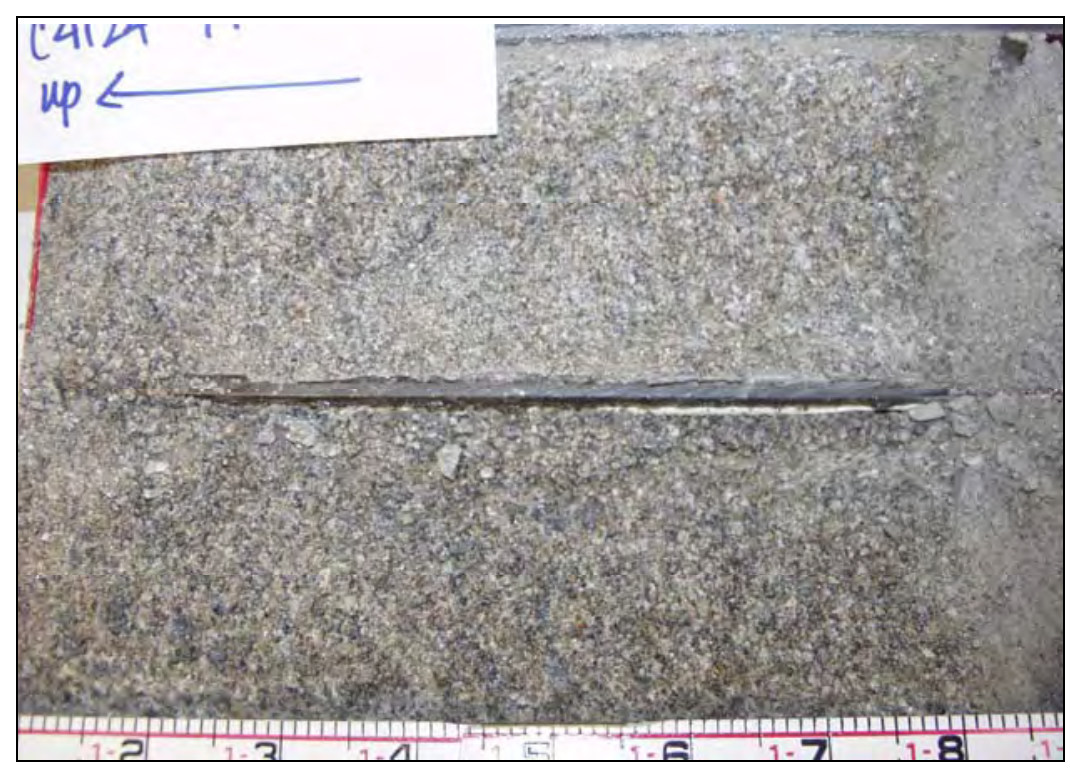

Figure 2.11. Pebbly Sand Facies of the Hanford formation H2 Unit in Borehole 299-E27-22 (top of the 1-ft long core is to the left; 195 to $196 \mathrm{ft}$ depth)

A total of 65 characterization samples were collected from the Hanford formation H2 unit (Table 2.4). Two 1-ft core segments ( 97.5 to $98.5 \mathrm{ft}$ and 165 to $166 \mathrm{ft}$ ) from the Hanford formation $\mathrm{H} 2$ unit were left intact and sent to Melanie Mayes, Oak Ridge National Laboratory (ORNL), for special geohydrologic characterization. In these two cores, the only analysis performed by PNNL was on matric-potential filter paper samples collected from the bottom ends of these cores. The average moisture content for the H2 unit (2.7 $\pm 1.4 \mathrm{wt} \%$ ) was about the same as the H1 unit (Table 2.5).

Table 2.4. Splitspoon Samples Selected for Physical and Chemical Characterization from the Vadose Zone in 299-E27-22 (one characterization sample was collected from each of the depths indicated)

\begin{tabular}{|c|c|c|c|}
\hline Sample Number & $\begin{array}{l}\text { Depth } \\
\text { (ft bgs) }\end{array}$ & Lithology & $\begin{array}{c}\text { Stratigraphic Unit } \\
\text { (Hanford formation) }\end{array}$ \\
\hline C4124-20 & $19-20$ & Pebbly coarse sand & $\mathrm{H} 1$ \\
\hline C4124-21 & $20-21$ & Pebbly coarse sand & $\mathrm{H} 1$ \\
\hline C4124-22.5 & $21.5-22.5$ & Medium-coarse sand & $\mathrm{H} 1$ \\
\hline C4124-23.5 & $22.5-23.5$ & Medium-coarse sand & H1 \\
\hline C4124-25 & $24-25$ & Pebbly coarse sand & H1 \\
\hline C4124-26 & $25-26$ & Pebbly coarse sand & H1 \\
\hline C4124-27.5 & $26.5-27.5$ & Pebbly sand & H1 \\
\hline C4124-28.5 & $27.5-28.5$ & Pebbly sand & H1 \\
\hline C4124-30 & $29-30$ & Pebbly sand & H1 \\
\hline C4124-31 & $30-31$ & Pebbly sand & H1 \\
\hline C4124-32.5 & $31.5-32.5$ & Slightly pebbly sand & $\mathrm{H} 1$ \\
\hline
\end{tabular}


Table 2.4. (contd)

\begin{tabular}{|c|c|c|c|}
\hline Sample Number & $\begin{array}{c}\text { Depth } \\
\text { (ft bgs) }\end{array}$ & Lithology & $\begin{array}{l}\text { Stratigraphic Unit } \\
\text { (Hanford formation) }\end{array}$ \\
\hline C4124-33.5 & $32.5-33.5$ & Slightly pebbly sand & H1 \\
\hline C4124-35 & $34-35$ & Fine-medium sand & H1 \\
\hline C4124-36 & $35-36$ & Fine-medium sand & $\mathrm{H} 1$ \\
\hline C4124-37.5 & $36.5-37.5$ & Fine-medium sand & $\mathrm{H} 1$ \\
\hline C4124-38.5 & 37.5-38.5 & Fine-medium sand & $\mathrm{H} 1$ \\
\hline C4124-40 & $39-40$ & Fine-medium sand & H1 \\
\hline C4124-41 & $40-41$ & Fine-medium sand & $\mathrm{H} 1$ \\
\hline C4124-42.5 & $41.5-42.5$ & Fine-medium sand & $\mathrm{H} 1$ \\
\hline C4124-43.5 & $42.5-43.5$ & Fine-medium sand & $\mathrm{H} 1$ \\
\hline C4124-45 & $44-45$ & Silty fine sand to fn-medium sand & $\mathrm{H} 1$ \\
\hline C4124-46 & $45-46$ & Fine-medium sand & H1 \\
\hline C4124-47.5 & $46.5-47.5$ & Fine-medium sand & H1 \\
\hline C4124-48.5 & 47.5-48.5 & Fine-medium sand to silty fine sand & $\mathrm{H} 1$ \\
\hline C4124-50 & $49-50$ & Pebbly coarse sand & H1 \\
\hline C4124-51 & $50-51$ & Pebbly coarse sand & H1 \\
\hline C4124-52.5 & $51.5-52.5$ & Pebbly silty sand & H1 \\
\hline C4124-53.5 & $52.5-53.5$ & Pebbly sand & $\mathrm{H} 1$ \\
\hline C4124-55 & $54-55$ & Pebbly coarse sand & $\mathrm{H} 1$ \\
\hline C4124-56 & $55-56$ & Pebbly coarse sand & H1 \\
\hline C4124-57.5 & $56.5-57.5$ & Coarse sand & $\mathrm{H} 1$ \\
\hline C4124-58.5 & 57.5-58.5 & Coarse sand & $\mathrm{H} 1$ \\
\hline C4124-62.5 & $61.5-62.5$ & Pebbly sand & $\mathrm{H} 1$ \\
\hline C4124-63.5 & 62.5-63.5 & Pebbly sand & $\mathrm{H} 1$ \\
\hline C4124-66 & $65-66$ & Gravel and sand & $\mathrm{H} 1$ \\
\hline C4124-67.5 & 66.5-67.5 & Pebbly sand & $\mathrm{H} 1$ \\
\hline C4124-68.5 & 67.5-68.5 & Pebbly sand & $\mathrm{H} 1$ \\
\hline C4124-72.5 & 71.5-72.5 & Pebbly sand & $\mathrm{H} 1$ \\
\hline C4124-73.5 & 72.5-73.5 & Slightly pebbly sand & $\mathrm{H} 1$ \\
\hline C4124-75 & $74-75$ & Slightly pebbly sand & H1 \\
\hline C4124-76 & $75-76$ & Slightly pebbly sand & $\mathrm{H} 1$ \\
\hline C4124-77.5 & 76.5-77.5 & Slightly pebbly sand & $\mathrm{H} 1$ \\
\hline C4124-78.5 & 77.5-78.5 & Slightly pebbly sand & $\mathrm{H} 1$ \\
\hline C4124-80 & $79-80$ & Slightly pebbly sand & H1 \\
\hline C4124-81 & 80-81 & Slightly pebbly sand & $\mathrm{H} 1$ \\
\hline C4124-82.5 & $81.5-82.5$ & Fine-medium sand & H2 \\
\hline
\end{tabular}


Table 2.4. (contd)

\begin{tabular}{|c|c|c|c|}
\hline Sample Number & $\begin{array}{c}\text { Depth } \\
\text { (ft bgs) }\end{array}$ & Lithology & $\begin{array}{c}\text { Stratigraphic Unit } \\
\text { (Hanford formation) }\end{array}$ \\
\hline C4124-83.5 & $82.5-83.5$ & Coarse sand & $\mathrm{H} 2$ \\
\hline C4124-85 & 84-85 & Fine-coarse sand & $\mathrm{H} 2$ \\
\hline C4124-86 & $85-86$ & Fine-medium sand & $\mathrm{H} 2$ \\
\hline C4124-87.5 & $86.5-87.5$ & Medium-coarse sand & $\mathrm{H} 2$ \\
\hline C4124-88.5 & $87.5-88.5$ & Medium-coarse sand & $\mathrm{H} 2$ \\
\hline C4124-90 & $89-90$ & Fine-coarse sand & $\mathrm{H} 2$ \\
\hline C4124-91 & $90-91$ & Fine-coarse sand & $\mathrm{H} 2$ \\
\hline C4124-92.5 & $91.5-92.5$ & Medium-coarse sand & $\mathrm{H} 2$ \\
\hline C4124-93.5 & $92.5-93.5$ & Medium-coarse sand & $\mathrm{H} 2$ \\
\hline C4124-95 & $94-95$ & Medium-coarse sand & $\mathrm{H} 2$ \\
\hline C4124-96 & $95-96$ & Medium-coarse s sand & $\mathrm{H} 2$ \\
\hline C4124-97.5 & $96.5-97.5$ & Medium-coarse sand & $\mathrm{H} 2$ \\
\hline C4124-98.5 & 97.5-98.5 & Fine-coarse sand & $\mathrm{H} 2$ \\
\hline C4124-100 & $99-100$ & Fine-coarse sand & $\mathrm{H} 2$ \\
\hline C4124-101 & $100-101$ & Fine-coarse sand & $\mathrm{H} 2$ \\
\hline C4124-102.5 & $101.5-102.5$ & Fine-coarse sand & $\mathrm{H} 2$ \\
\hline C4124-103.5 & $102.5-103.5$ & Fine-coarse sand & $\mathrm{H} 2$ \\
\hline C4124-105 & 104-105 & Fine-coarse sand & $\mathrm{H} 2$ \\
\hline C4124-106 & 105-106 & Fine-coarse sand w/silty sand lens & $\mathrm{H} 2$ \\
\hline C4124-107.5 & $106.5-107.5$ & Fine-coarse sand w/silty sand lens & $\mathrm{H} 2$ \\
\hline C4124-108.5 & $107.5-108.5$ & Fine-coarse sand & $\mathrm{H} 2$ \\
\hline C4124-110 & 109-110 & Pebbly coarse sand & $\mathrm{H} 2$ \\
\hline C4124-111 & $110-111$ & Slightly pebbly sand & $\mathrm{H} 2$ \\
\hline C4124-115 & $114-115$ & Medium-coarse sand & $\mathrm{H} 2$ \\
\hline C4124-116 & $115-116$ & Fine-coarse sand & $\mathrm{H} 2$ \\
\hline C4124-120 & $119-120$ & Fine-coarse sand & $\mathrm{H} 2$ \\
\hline C4124-121 & $120-121$ & Fine-coarse sand & $\mathrm{H} 2$ \\
\hline C4124-125 & $124-125$ & Medium-coarse sand & $\mathrm{H} 2$ \\
\hline C4124-126 & $125-126$ & Medium-coarse sand & $\mathrm{H} 2$ \\
\hline C4124-130 & 129-130 & Fine-coarse sand & $\mathrm{H} 2$ \\
\hline C4124-131 & $130-131$ & Fine sand & $\mathrm{H} 2$ \\
\hline C4124-135 & 134-135 & Fine-coarse sand & $\mathrm{H} 2$ \\
\hline C4124-136 & $135-136$ & Fine-coarse sand & $\mathrm{H} 2$ \\
\hline C4124-140 & $139-140$ & Fine-coarse sand & $\mathrm{H} 2$ \\
\hline
\end{tabular}


Table 2.4. (contd)

\begin{tabular}{|c|c|c|c|}
\hline Sample Number & $\begin{array}{c}\text { Depth } \\
\text { (ft bgs) }\end{array}$ & Lithology & $\begin{array}{c}\text { Stratigraphic Unit } \\
\text { (Hanford formation) }\end{array}$ \\
\hline C4124-141 & $140-141$ & Fine-medium sand & $\mathrm{H} 2$ \\
\hline C4124-145 & $144-145$ & Pebbly sand & $\mathrm{H} 2$ \\
\hline C4124-146 & $145-146$ & Pebbly sand & $\mathrm{H} 2$ \\
\hline C4124-150 & $149-150$ & Pebbly sand to sandy pebble gravel & $\mathrm{H} 2$ \\
\hline C4124-151 & 150-151 & Pebbly sand & $\mathrm{H} 2$ \\
\hline C4124-155 & 154-155 & Silty pebbly gravel & $\mathrm{H} 2$ \\
\hline C4124-160 & 159-160 & Pebbly sand & $\mathrm{H} 2$ \\
\hline C4124-161 & 160-161 & Pebbly sand & $\mathrm{H} 2$ \\
\hline C4124-165 & 164-165 & Fine-coarse sand & $\mathrm{H} 2$ \\
\hline C4124-166 & 165-166 & Fine-coarse sand & $\mathrm{H} 2$ \\
\hline C4124-170 & $169-170$ & Fine-coarse sand & $\mathrm{H} 2$ \\
\hline C4124-171 & $170-171$ & Fine-coarse sand & $\mathrm{H} 2$ \\
\hline C4124-175 & 174-175 & Medium-coarse sand & $\mathrm{H} 2$ \\
\hline C4124-176 & $175-176$ & Medium-coarse sand & $\mathrm{H} 2$ \\
\hline C4124-180 & 179-180 & Fine-medium sand & $\mathrm{H} 2$ \\
\hline C4124-181 & $180-181$ & Fine-medium sand & $\mathrm{H} 2$ \\
\hline C4124-185 & 184-185 & Pebble gravel & $\mathrm{H} 2$ \\
\hline C4124-186 & 185-186 & Fine-coarse sand & $\mathrm{H} 2$ \\
\hline C4124-190 & 189-190 & Fine-coarse sand & $\mathrm{H} 2$ \\
\hline C4124-191 & 190-191 & Fine-coarse sand & $\mathrm{H} 2$ \\
\hline C4124-195 & 194-195 & Pebbly sand & $\mathrm{H} 2$ \\
\hline C4124-196 & 195-196 & Pebbly sand & $\mathrm{H} 2$ \\
\hline C4124-200 & 199-200 & Silty pebbly sand & $\mathrm{H} 2$ \\
\hline C4124-201 & $200-201$ & Silty pebbly sand & $\mathrm{H} 2$ \\
\hline C4124-205 & 204-205 & Pebbly sand & $\mathrm{H} 2$ \\
\hline C4124-206 & 205-206 & Pebbly sand & $\mathrm{H} 2$ \\
\hline C4124-210A & 209-210 & Gravel and sand & $\mathrm{H} 2$ \\
\hline C4124-210B & 209-210 & Gravel & $\mathrm{H} 2$ \\
\hline C4124-211A & $210-211$ & Pebbly silty sand & $\mathrm{H} 2$ \\
\hline C4124-211B & $210-211$ & Silty pebbly sand & $\mathrm{H} 2$ \\
\hline C4124-220 & $219-220$ & Gravel & $\mathrm{H} 2$ \\
\hline C4124-225 & $224-225$ & Silty pebbly sand & $\mathrm{H} 2$ \\
\hline C4124-226 & $225-226$ & Silty pebbly sand & $\mathrm{H} 2$ \\
\hline C4124-230 & $229-230$ & Gravel & CCU/R \\
\hline
\end{tabular}


Table 2.5. Gravimetric Moisture Content Measured in Core and Grab Samples (units are wt\% water)

\begin{tabular}{|c|c|c|c|c|c|c|c|c|c|c|}
\hline \multirow[b]{2}{*}{$\begin{array}{c}\text { Stratigraphic } \\
\text { Unit }\end{array}$} & \multicolumn{5}{|c|}{ 299-E27-22 (C4124)* } & \multicolumn{5}{|c|}{ C4297 } \\
\hline & $\begin{array}{c}\text { Number of } \\
\text { Samples }\end{array}$ & Mean & Min. & Max. & $\begin{array}{l}\text { Std. } \\
\text { Dev. }\end{array}$ & $\begin{array}{l}\text { Number of } \\
\text { Samples }\end{array}$ & Mean & Min & Max & $\begin{array}{l}\text { Std. } \\
\text { Dev. }\end{array}$ \\
\hline Backfill & 0 & NA & NA & NA & NA & 28 & 5.24 & 3.43 & 9.39 & 1.26 \\
\hline $\mathrm{H}_{1}$ & 45 & 2.84 & 1.22 & 12.46 & 1.60 & 23 & 3.24 & 2.25 & 4.10 & 0.50 \\
\hline $\mathrm{H}_{2}$ & 65 & 2.73 & 1.38 & 10.72 & 1.35 & 93 & 3.39 & 2.29 & 8.23 & 0.80 \\
\hline CCU/R & 0 & NA & NA & NA & NA & 0 & NA & NA & NA & NA \\
\hline
\end{tabular}

\subsubsection{Cold Creek Unit and/or Ringold Formation (CCU/R)}

Only a single sample was collected from the CCU/R from borehole 299-E27-22. This sample consisted of rounded to angular, multi-lithic gravel with little or no matrix present (Figure 2.12). Most of the fines within the matrix probably shook out of the sample as the splitspoon was driven into this coarsegrained formation. The gravel is multi-lithic, with relatively few basalt clasts compared to what is normally observed for the Hanford formation. The base of the CCU/R unit occurs at $268 \mathrm{ft}$ where the top of the Columbia River basalt was encountered.

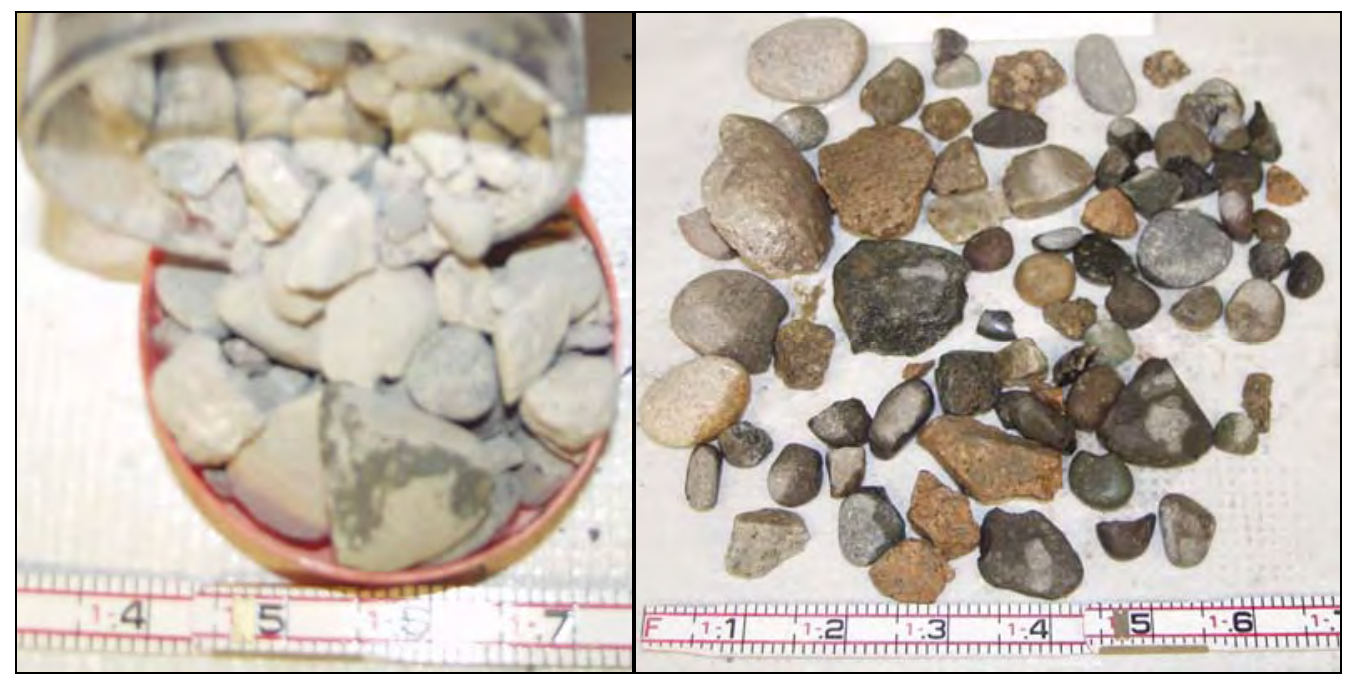

Figure 2.12. Gravels of the CCU/R Unit in Borehole 299-E27-22 (left - silt coatings cover most clasts, making identification of gravel composition difficult; right - silt coatings washed off revealing the multi-lithic nature of the gravel; 230-ft depth)

\subsubsection{Borehole C4297}

Borehole C4297 was drilled and sampled using a cable-tool, splitspoon technique between February 17 and March 17, 2004 (Table 2.1). The borehole lies about equidistant between single-shell tanks 241-C-104 and C-105 (Figure 2.3). Total depth of the borehole was $196.5 \mathrm{ft}$ (59.9 m) bgs; the hole 
was terminated within pebbly sands of the Hanford formation H2 unit. Surface elevation of the boring was never measured but the geographic coordinates were N136534.78 and E575151.18.

During drilling, a total of eleven 2.5-ft long, 4-in. diameter splitspoon core samples were collected intermittently starting at a depth of $24 \mathrm{ft}$ bgs on April 1, 2004. Four 0.5-ft-long stainless steel core liners were collected within the splitspoon during each core run. The extra $0.5 \mathrm{ft}$ collected in the shoe of the splitspoon was used for geologic description in the field geologist's log. Generally, after performing a geologic description, the core material in the shoe was either discarded or saved into a 1-liter polypropylene bottle.

A separate sample was collected in the laboratory from each of the $0.5 \mathrm{ft}$ liners for physical, chemical, and radiological characterization, making a total of 35 characterization samples collected from this hole (Table 2.6). In all, about $17.5 \mathrm{ft}$ of core was obtained from C4297, or about $14 \%$ of the total length of the hole (Table 2.1). In between splitspoons, grab samples were collected in 1-liter polypropylene bottles every 1 to $3 \mathrm{ft}$. These samples were later measured for gravimetric-moisture content, which are included in the moisture profile presented in Figure 2.13.

All cores were opened, observed, and sampled within a radiologically controlled PNNL laboratory on April 1, 2004. Geologic logging occurred after the contents of each 0.5-ft stainless steel core liner was emptied into an open plastic container, followed by photographing and sub-sampling for physical, chemical, and radiological characterization. Upon completion of these activities, the contents in the plastic containers were sealed shut and placed into cold storage for archival purposes. Core photos and geologic logs of the material within the core liners are presented in Appendix B.

Figure 2.13 presents a summary log for C4297 based on core descriptions, the field-geologist log, core photographs, geophysical logs, and laboratory-derived gravimetric moisture. The hydrogeology between core runs is an interpretation based on field-geologist's logs, geophysical logging and laboratory moisture. Three primary stratigraphic units were encountered by this borehole: (1) recent backfill material, (2) the Hanford formation H1 unit, and (3) the Hanford formation H2 unit. A brief description of the sampled materials from each of these major stratigraphic units is presented below.

\subsubsection{Backfill}

The backfill in C4297 extended from the ground surface to a depth of $12.3 \mathrm{~m}$ (39.8 ft) where it was in contact with the Hanford formation (Figure 2.13). A total of 11 physical, chemical, and radiological characterization samples were collected from three splitspooned intervals within backfill material (Table 2.6). Backfill material consisted of moderately sorted, matrix-supported, pebbly sand to siltypebbly sand (Figure 2.14). The color was most often grayish brown. Most gravel clasts and sand grains were composed of basalt. Backfill materials were weakly consolidated and only slightly calcareous (see Appendix B for more detailed descriptions). Overall, the moisture content for backfill materials was slightly higher (averaging $5.2 \pm 1.3 \mathrm{wt} \%$ ) compared to the underlying Hanford formation (Table 2.5). This was also indicated on the neutron-moisture log.

This unit appears to be rather homogeneous and lacks lithologic variation, except near the base, where a moisture spike may indicate the presence of a thin silty layer. Gamma-emitting radionuclides appear to extend from the surface to a depth of about $20 \mathrm{ft}$ (Figure 2.13). 
Table 2.6. Splitspoon Core Samples from C4297. Four characterization samples, labeled "A" through " $D$ " were collected from most of the cores for a total of 35 samples.

\begin{tabular}{|c|c|c|c|c|}
\hline $\begin{array}{l}\text { Chain of } \\
\text { Custody ID }\end{array}$ & $\begin{array}{c}\text { Depth Range } \\
\text { (ft) }\end{array}$ & $\begin{array}{l}\text { Mid Depth } \\
\text { (ft) }\end{array}$ & Lithology & $\begin{array}{c}\text { Stratigraphic Unit } \\
\text { (Hanford formation) }\end{array}$ \\
\hline S04028-12D & $24.0-24.5$ & 24.25 & Pebbly sand & Backfill \\
\hline S04028-12C & $24.5-25.0$ & 24.75 & Pebbly sand & Backfill \\
\hline S04028-12B & $25.0-25.5$ & 25.25 & Pebbly sand & Backfill \\
\hline S04028-12A & $25.5-26.0$ & 25.75 & Pebbly sand & Backfill \\
\hline S04028-15D & $29.25-29.75$ & 29.50 & Pebbly sand & Backfill \\
\hline S04028-15C & $29.75-30.25$ & 30.00 & Silty gravelly sand & Backfill \\
\hline S04028-15B & $30.25-30.75$ & 30.50 & Pebbly sand & Backfill \\
\hline S04028-15A & $30.75-31.25$ & 31.00 & Pebbly sand & Backfill \\
\hline S04028-21B & $36.4-36.9$ & 36.65 & Silty gravelly sand & Backfill \\
\hline S04028-21A & $36.9-37.4$ & 37.15 & Medium-coarse sand & Backfill \\
\hline S04028-24D & 39.05-39.55 & 39.30 & Gravelly sand & Backfill \\
\hline S04028-24C & $39.55-40.05$ & 39.80 & Coarse sand & $\mathrm{H} 1$ \\
\hline S04028-24B & $40.05-40.55$ & 40.30 & Coarse sand & H1 \\
\hline S04028-24A & $40.55-41.05$ & 40.80 & Coarse sand & H1 \\
\hline S04028-27C & $44.2-44.7$ & 44.45 & Coarse sand & H1 \\
\hline S04028-27B & $44.7-45.2$ & 44.95 & Coarse sand & $\mathrm{H} 1$ \\
\hline S04028-27A & $45.2-45.7$ & 45.45 & Coarse sand & $\mathrm{H} 1$ \\
\hline S04028-37B & $61.75-62.25$ & 62.00 & Pebbly sand & $\mathrm{H} 1$ \\
\hline S04028-37A & $62.25-62.75$ & 62.50 & Pebbly sand & $\mathrm{H} 1$ \\
\hline S04028-44D & $69.5-70.0$ & 69.75 & Medium-coarse sand & $\mathrm{H} 2$ \\
\hline S04028-44C & $70.0-70.5$ & 70.25 & Coarse sand & $\mathrm{H} 2$ \\
\hline S04028-44B & $70.5-71.0$ & 70.75 & Coarse sand & H2 \\
\hline S04028-44A & $71.0-71.5$ & 71.25 & Coarse sand & $\mathrm{H} 2$ \\
\hline S04028-49D & $77.8-78.3$ & 78.05 & Slightly pebbly sand & $\mathrm{H} 2$ \\
\hline S04028-49C & $78.3-78.8$ & 78.55 & Slightly pebbly sand & $\mathrm{H} 2$ \\
\hline S04028-49B & 78.8-79.3 & 79.05 & Coarse sand & $\mathrm{H} 2$ \\
\hline S04028-49A & 79.3-79.8 & 79.55 & Coarse sand & $\mathrm{H} 2$ \\
\hline S04028-66D & $104.3-104.8$ & 104.55 & Coarse sand & $\mathrm{H} 2$ \\
\hline S04028-66C & $104.8-105.3$ & 105.05 & Coarse sand & $\mathrm{H} 2$ \\
\hline S04028-66B & $105.3-105.8$ & 105.55 & Coarse sand & $\mathrm{H} 2$ \\
\hline S04028-66A & $105.8-106.3$ & 106.05 & Coarse sand & $\mathrm{H} 2$ \\
\hline S04028-78D & $124.6-125.1$ & 124.85 & Coarse sand & $\mathrm{H} 2$ \\
\hline S04028-78C & $125.1-125.6$ & 125.35 & Slightly pebbly sand & $\mathrm{H} 2$ \\
\hline S04028-78B & $125.6-126.1$ & 125.85 & Slightly pebbly sand & $\mathrm{H} 2$ \\
\hline S04028-78A & $126.1-126.6$ & 126.35 & Pebbly sand & $\mathrm{H} 2$ \\
\hline
\end{tabular}




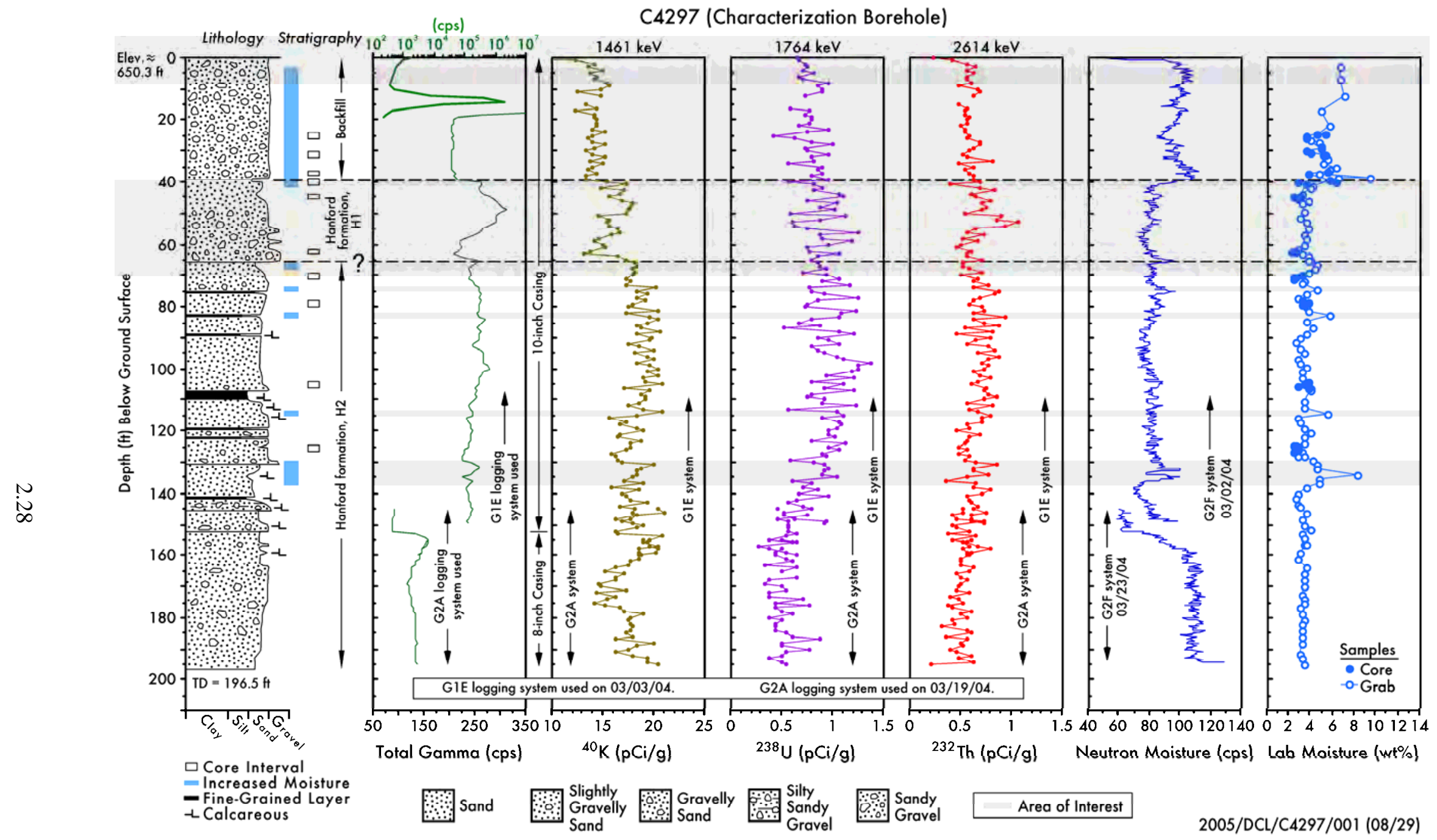

Figure 2.13. Summary Hydrogeologic Log for Borehole C4297. Zones of increased moisture are well illustrated on Lab Moisture column. Fine-grained layers are defined as those consisting predominantly of particles $<0.25 \mathrm{~mm}$ in diameter (i.e., fine sand and smaller). 


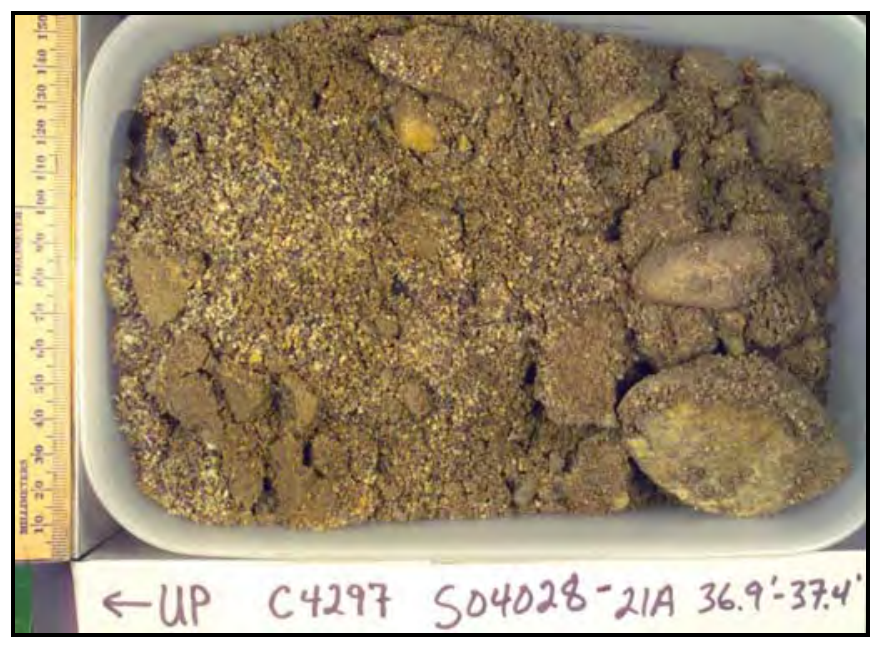

Figure 2.14. Typical Backfill from Borehole C4297. Described as a moist, dark grayish brown, poorly sorted, silty gravelly sand.

\subsubsection{Hanford formation}

Pleistocene cataclysmic flood deposits of the Hanford formation underlie backfill materials to the bottom of the hole at $196.5 \mathrm{ft}$. Other units, including the CCU/R were probably present at depth, but were not penetrated by the relatively shallow depth of this hole. The Hanford formation at C4297 was all sand dominated. There were no clast-supported, gravel-dominated facies in this hole, which are often observed toward the top of the Hanford formation; these have been classified as the $\mathrm{H} 1$ unit. However, there was a 15 -ft thick pebbly sand zone between 50 to $65 \mathrm{ft}$ bgs, which could be equivalent to the gravel-dominated facies of the $\mathrm{H} 1$ unit. Below that was a thick sequence of the sand-dominated $\mathrm{H} 2$ unit.

Hanford formation H1 Unit. The Hanford formation H1 unit may be present between 40 to $65 \mathrm{ft}$ bgs. A coarser 15-ft thick layer of moderately sorted, basaltic, pebbly sand between 50 to $65 \mathrm{ft}$ bgs was interpreted as H1 unit (Figure 2.15). Small pebbles, mostly of sub-angular to sub-rounded basalt, made up about $30 \%$ of the total volume. Above the pebbly sand and below the backfill was $10 \mathrm{ft}$ of medium- to coarse-grained, "salt and pepper" sand, which is included with the H1 unit.

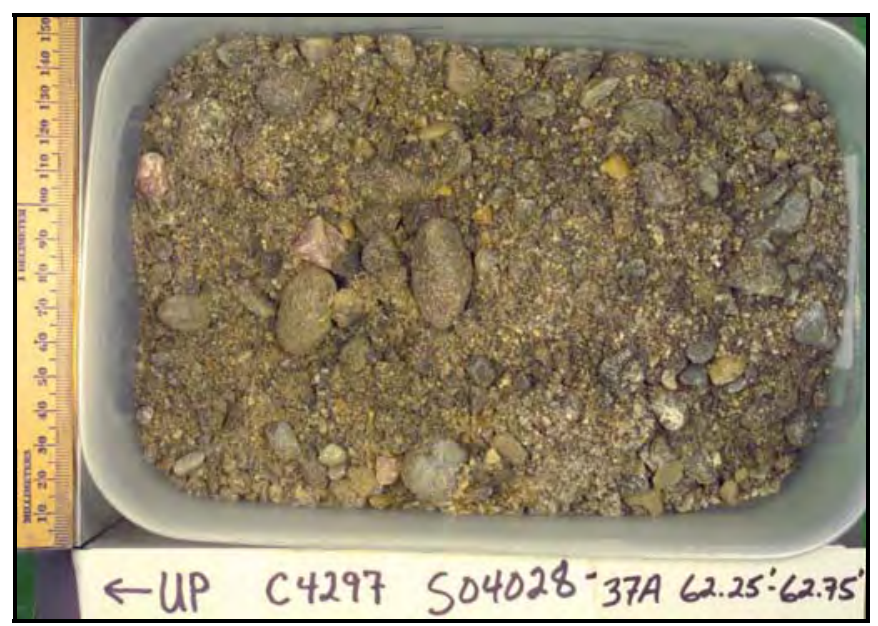

Figure 2.15. Hanford formation H1 Unit in Borehole C4297. This core was described as a slightly moist, loose, moderately sorted, grayish brown, pebbly sand. 
A total of eight characterization samples were obtained from the Hanford formation H1 unit from C4297 (Table 2.6). Two of these samples were from the pebbly sand; the remaining six were of coarse sand. The average moisture content for the $\mathrm{H} 1$ unit in $\mathrm{C} 4297$ was $3.2 \pm 0.5 \%$.

Hanford formation $\mathbf{H} 2$ Unit. The Hanford formation H2 unit consisted of grayish brown, loose, moderately- to well-sorted, medium- to coarse-grained sand (Figure 2.16) to slightly pebbly sand. It appears identical to the $\mathrm{H} 1$ unit (Figure 2.15), with the exception of having less gravel-sized sediment present. The salt-and-pepper-like sand consisted of $20 \%$ to $40 \%$ basalt rock fragments. A total of 16 characterization samples were collected from the H2 unit (Table 2.6). The average moisture content was $3.4 \pm 0.8 \%$, about the same as the $\mathrm{H} 1$ unit (Table 2.5 ).

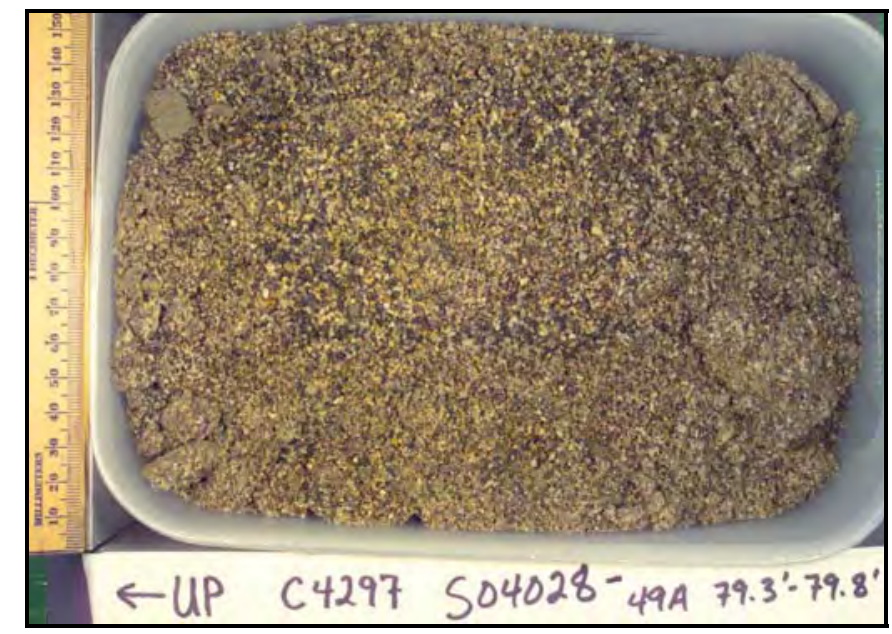

Figure 2.16. Hanford formation $\mathrm{H} 2$ Unit in Borehole C4297. This core consisted of a loose, moderately sorted, grayish brown, coarse to very coarse sand. The sample is non-calcareous and about $30 \%$ to $40 \%$ of the sand grains are composed of basalt rock fragments; the remainder is mostly quartz and feldspar.

\subsubsection{Discussion of Increased-Moisture Zones}

The distribution of moisture in the vadose zone at C Tank Farm was determined by gravimetric moisture measured directly from core samples in the laboratory (Figures 2.7 and 2.13). Neutron-moisture $\log$ data is only available for one of the two holes (C4297) reported herein, and these data appear to corroborate the lab-moisture results (Figure 2.13). However, several pronounced spikes that appear on the laboratory-moisture plot do not appear in the neutron-moisture log. This is likely the result of a number of thin (few inches or less) fine-grained layers that were preferentially sampled during core processing. These thin layers are not visible on the geophysical log because the neutron flux is averaged over a larger area beyond the limits of the fine-grained layer, including adjacent relatively dry layers. Thus, the resulting field logging signal is dampened. In general, the neutron-moisture log appears to accurately reflect the relative bulk moisture content, and can confidently be used as a substitute to estimate bulk moisture conditions when core samples are unavailable. However, most thin ( $<6$ in.) moist zones will go undetected on neutron-moisture logs. 
The moisture distributions for the two new boreholes are shown in Figures 2.7 and 2.13. Zones with relatively high moisture are illustrated via a light blue bar immediately to the right of the lithologic log in these diagrams. In general, the highest concentrations of moisture in the vadose zone at $\mathrm{C}$ Tank Farm are associated with fine-grained lenses of fine sand and/or silt. Most of these occur within the Hanford formation $\mathrm{H} 2$ unit, although there is also one at the base of the backfill in C4297, and within the H1 unit in 299-E27-22.

Moisture can also concentrate wherever there is a sudden, large contrast in grain size. This is illustrated at the 82-ft depth in 299-E27-22 (Figure 2.7) where there is a sharp contact between gravelly sand overlying fine to coarse sand. Moisture may also move vertically along discordant clastic dikes, which are known to occur, especially within the Hanford formation (Fecht et al. 1999). During high-recharge events, moisture may move preferentially within the coarser-grained vadose zone strata in contrast to fine-grained layers which transmit relatively more moisture under a low flux rate. No clastic dikes were observed in the core collected from either 299-E27-22 or C4297. 


\subsection{Geochemical Methods and Materials}

This chapter discusses the methods and philosophy used to determine which C4297 borehole samples would be characterized and the parameters that would be measured and analyzed in the laboratory. It also describes the materials and methods used to conduct analyses of the physical, geochemical, and radio-analytical properties of the sediments, and the water potential (suction) measurements of the core liners in each sequential splitspoon sample from borehole 299-E27-22 (RCRA monitoring well).

\subsection{Sample Inventory}

Samples were identified using a project-specific prefix, in this case S04028 for C4297 borehole samples and C4124 for 299-E27-22 borehole samples followed by a specific sample identification suffix, such as -01. As noted in Section 2.3, the cores contained four liners identified by the letters A, B, C, and $\mathrm{D}$, where the A Liner was always in the deeper position closest to the drive shoe (i.e., the protective end attached to the bottom of the drive casing). All spilt-spoon samples can be delineated from grab samples by the additional A, B, C, or D nomenclature following the sample identification suffix, such as S04028 12A.

\subsection{Approach}

During a past investigation at WMA SX, a significant finding was that changes in sediment type and contaminant concentrations occurred within a distance of a few inches within a given liner. It was concluded that a more methodical scoping approach would be necessary to provide the technical justification for selecting samples for detailed characterization as defined in the data quality objectives process (DOE 1999). Subsequently, a method was developed that considered depth, geology (e.g., lithology, grain-size composition, and carbonate content), individual liner contaminant concentration (e.g., radionuclides, nitrate), moisture content, and overall sample quality. Analyses and certain key parameters (i.e., moisture content, gamma energy analysis) were performed on sediment from each liner. Grab samples were also utilized as part of this study, particularly from depths that were not well represented by the core samples. More complicated analyses were performed on sediment from selected depths.

The objective of this WMA C characterization study was to quantify the extent of penetration of mobile contaminants into the vadose zone sediment from a suspected leak event from or near tank C-105. Because of the potential for slough material in the upper liner, only the sediment from the A liner was analyzed for most constituents except moisture and gamma energy. During geologic examination, the liner contents were sub-sampled for moisture content, gamma-emission radiocounting, 1:1 water extracts (which provide soil $\mathrm{pH}, \mathrm{EC}$, cation, and anion data), total carbon and inorganic carbon content, and $8 \mathrm{M}$ nitric acid extracts (which provide a measure of the total-leachable sediment content of contaminants). The remaining sediment from each liner was then sealed and placed in cold storage.

\subsection{Materials and Methods}

During sub-sampling of the selected core liner, every effort was made to minimize moisture loss and prevent cross contamination between samples. Depending on the sample matrix, very coarse pebbles and 
larger material (i.e., >32 mm) were avoided during sub-sampling. Larger substrate was excluded to provide moisture content representative of counting and 1:1 sediment:water extract samples. Therefore, the results from the sub-sample measurements may contain a possible bias toward higher concentrations for some analytes that would be preferentially associated with the smaller sized sediment fractions.

Procedures ASTM D2488-93 (1993) and PNL-MA-567-DO-1 (PNL 1990a) were followed for visual descriptions and geologic description of all splitspoon samples. The sediment classification scheme used for geologic identification of the sediment types (used solely for graphing purposes in this report) was based on the modified Folk/Wentworth classification scheme (1968).

\subsubsection{Moisture Content}

Gravimetric water contents of the sediment samples from each liner were determined using PNNL procedure PNNL-AGG-WC-001 (PNNL 2005). This procedure is based on the American Society for Testing and Materials procedure “Test Method for Laboratory Determination of Water (Moisture) Content of Soil and Rock by Mass” (ASTM D2216-98 [ASTM 1998]). One representative sub-sample of at least 15 to $70 \mathrm{~g}$ was taken from each liner. Sediment samples were placed in tared containers, weighed, and dried in an oven at $105{ }^{\circ} \mathrm{C}$ until constant weight was achieved, which took at least 24 hours.

The containers were removed from the oven, sealed, cooled, and weighed. At least two weighings, each after a 24-hour heating, were performed to ensure that all moisture was removed. All weighings were performed using a calibrated balance. A calibrated weight set was used to verify balance performance before weighing samples. The gravimetric water content was computed as the percentage change in soil weight before and after oven drying.

\subsubsection{1:1 Sediment:Water Extracts}

The water-soluble inorganic constituents were determined using a 1:1 sediment:de-ionized-water extract method. This method was chosen because the sediment was too dry to easily extract vadose zone pore water. The extracts were prepared by adding an exact weight of de-ionized water to approximately 60 to $80 \mathrm{~g}$ of sediment sub-sampled from each liner. The weight of de-ionized water needed was calculated based on the weight of the field-moist samples and their previously determined moisture contents. The sum of the existing moisture (pore water) and the de-ionized water was fixed at the mass of the dry sediment. An appropriate amount of de-ionized water was added to screw cap jars containing the sediment samples. The jars were sealed and briefly shaken by hand, then placed on a mechanical orbital shaker for one hour. The samples were allowed to settle until the supernatant liquid was fairly clear. The supernatant was carefully decanted and separated into unfiltered aliquots for conductivity and $\mathrm{pH}$ determinations, and filtered aliquots (passed through $0.45 \mu \mathrm{m}$ membranes) for anion, cation, alkalinity, and radionuclide analyses. More details can be found in Rhoades (1996) and within Methods of Soils Analysis - Part 3 (ASA 1996).

\subsubsection{1 pH and Conductivity}

Two, approximately 3-mL aliquots of the unfiltered 1:1 sediment:water extract supernatants were used for $\mathrm{pH}$ and conductivity measurements. The $\mathrm{pH}$ of the extracts was measured with a solid-state $\mathrm{pH}$ electrode and a pH meter calibrated with buffers 4, 7, and 10. Electrical conductivity was measured and compared to potassium chloride standards with a range of $0.001 \mathrm{M}$ to $1.0 \mathrm{M}$. 


\subsubsection{Anions}

The 1:1 sediment:water extracts were analyzed for anions using ion chromatography (IC). Fluoride, chloride, nitrite, bromide, nitrate, carbonate, phosphate, and sulfate were separated on a Dionex AS17 column with a gradient elution of $1 \mathrm{mM}$ to $35 \mathrm{mM}$ sodium hydroxide and measured using a conductivity detector. This methodology is based on U.S. Environmental Protection Agency (EPA) Method 300.0A (EPA 1984) with the exception of using the gradient elution of sodium hydroxide. Water extract chromatograms were visually scanned to assure there were no unidentified peaks caused by other constituents. No unexpected peaks were found in the water extracts from the RCRA borehole or C4297 sediments.

\subsubsection{Cations and Trace Metals}

Major cation analysis was performed using an inductively coupled plasma-optical emission spectroscopy (ICP-OES) unit using high-purity calibration standards to generate calibration curves and verify continuing calibration during the analysis run. Dilutions of 100x, 50x, 10x, and 5x were made of each 1:1 water extract for analysis to investigate and correct for matrix interferences. Details of this method are found in EPA Method 6010B (EPA 2000b). The second instrument used to analyze trace metals, including technetium-99, neptunium-237, uranium-238, plutonium-239, and americium-241 was an inductively coupled plasma-mass spectrometer (ICP-MS) using PNNL-AGG-415 method (PNNL 1998). This method is quite similar to EPA Method 6020 (EPA 2000c).

\subsubsection{Alkalinity}

The alkalinity and inorganic/organic carbon content of several of the 1:1 sediment:water extracts were measured using standard titration with acid and a carbon analyzer, respectively. The alkalinity procedure is equivalent to the U.S. Geological Survey (USGS) National Field Manual (USGS 2001) method.

\subsubsection{M Nitric Acid Extract}

Approximately $20 \mathrm{~g}$ of oven-dried sediment was contacted with $8 \mathrm{M}$ nitric acid at a ratio of approximately 5 parts acid to one part sediment. The slurries were heated to about $80{ }^{\circ} \mathrm{C}$ for several hours and then the fluid was separated by centrifugation and filtration through $0.2 \mu \mathrm{m}$ membranes. The acid extracts were analyzed for major cations and trace metals using ICP-OES and ICP-MS techniques, respectively. The acid digestion procedure is based on EPA SW-846 Method 3050B (EPA 2000a).

\subsubsection{Gamma Energy Analysis}

Gamma energy analysis (GEA) was performed on sediment from either the A or the B core liners for contaminated sediments from borehole C4297. All samples for GEA were analyzed using 60\%-efficient intrinsic germanium gamma detectors. All germanium counters were efficiency calibrated for distinct geometries using mixed gamma standards traceable to the National Institute of Standards and Technology (NIST). Field-moist samples were placed in $150-\mathrm{cm}^{3}$ counting containers and analyzed for 100 minutes in a fixed geometry. All spectra were background-subtracted. Spectral analysis was conducted using libraries containing most mixed fission products, activation products, and natural decay products. Control samples were run throughout the analysis to ensure correct operation of the detectors.

The controls contained isotopes with photo peaks spanning the full detector range and were monitored for 
peak position, counting rate, and full-width half-maximum. Details are found in Gamma Energy Analysis, Operation, and Instrument Verification using Genie2000 ${ }^{\mathrm{TM}}$ Support Software (PNNL 1997).

\subsubsection{Total Beta and Total Alpha Measurements on Water and Acid Extracts}

Gross alpha and beta measurement were made on both the water and acid extracts. For each extract, approximately $1 \mathrm{~mL}$ of sample was placed in a 20 -mL tared liquid scintillation vial and weighed. Fifteen $\mathrm{mL}$ of scintillation cocktail were then added and the samples were mixed and counted on a Wallac Model 1415 Liquid Scintillation Counter as prescribed in procedure AGG-RRL-002, Liquid Scintillation Counting and Instrument Verification Using the 1400 DSA $^{\text {TM }}$ Support Software (PNNL 2000). Results were converted to picocuries per gram (pCi/g) of dry sediment by using the known solution-tosolid ratios used to extract aliquots of the sediment.

\subsubsection{Carbon Content of Sediment}

The total carbon concentration in each core sample was measured with a Shimadzu TOC-V CSN instrument with a SSM-5000A Total Organic Carbon Analyzer by combustion at approximately $900^{\circ} \mathrm{C}$ based on ASTM Method, Standard Test Methods for Analysis of Metal Bearing Ores and Related Materials by Combustion Infrared Absorption Spectrometry (ASTM E1915-01). Samples were placed into pre-combusted, tared, ceramic combustion sample holders and weighed on a calibrated balance. After the combustion sample holders were placed into the furnace introduction tube, approximately 2 minutes waiting period was allowed for the ultra-pure oxygen carrier gas to remove any carbon dioxide introduced to the system from the atmosphere during sample placement. After this sparging process, the sample was moved into the combustion furnace and the combustion was begun. The carrier gas then delivered the sample combustion products to the cell of a non-dispersive infrared (NDIR) gas analyzer where the carbon dioxide was detected and measured. The amount of $\mathrm{CO}_{2}$ measured is proportional the total carbon content of the sample. Adequate system performance was confirmed by analyzing known quantities of a calcium carbonate standard.

Sediment/solid samples were analyzed for inorganic carbon content by placing a sediment aliquot into a ceramic combustion boat. The combustion boat was placed into the ion chromatograph (IC) introduction tube where it was sparged with ultra-pure oxygen for two minutes to remove atmospheric carbon dioxide. A small amount (usually $0.6 \mathrm{ml}$ ) of $3 \mathrm{M}$ phosphoric acid was then added to the sample in the combustion boat. The boat was moved into IC combustion furnace where it was heated to $200^{\circ} \mathrm{C}$. Samples were completely covered by the acid to allow full reaction to occur. Ultra-pure oxygen swept the resulting carbon dioxide through a dehumidifier and scrubber into the cell of a NDIR gas analyzer where the carbon dioxide was detected and measured. The amount of $\mathrm{CO}_{2}$ measured is proportional the inorganic carbon content of the sample.

Organic carbon content was determined by the difference between the inorganic carbon and total carbon concentration.

\subsubsection{Elemental Analysis}

The elemental composition of the bulk sediment from five liners from the RCRA borehole, 299-E27-22, was determined via x-ray fluorescence (XRF). The samples were prepared by placing $10 \mathrm{~g}$ of sediment in a tungsten carbide grinding vessel, which was ground twice for 30 seconds (total of 
60 seconds) using a Herzog HSM-100/H Semi-Automatic Pulverizer. After the second grinding, $1 \mathrm{~g}$ of Chemplex SpectroBlend briquetting additive was added to the grinding vessel and the mixture was ground for 10 seconds. Two $38 \mathrm{~mm}$ Spex XRF pellet caps were prepared for each sample by adding approximately $4 \mathrm{~g}$ of boric acid to each cap. The boric acid was spread evenly across the bottom of the cap and gently compressed. Next, 5 g of blended sample was added to each cap, and the cap was placed into a pellet die. The pellet die was compressed to 35,000 psi using a Carver Press and held for 3 minutes. The pressure was then released and the pellet was placed in a S4 Pioneer wave length dispersive XRF instrument from Bruker AXS (Madison WI). Using an analysis model that was developed for these samples, the amount of nineteen elements (i.e., sodium through phosphorous, potassium, calcium, titanium, chromium through iron, nickel through zinc, rubidium through zirconium, and barium) were analyzed on each sample. Six geologic material standards/reference materials that represent a wide range of geologic materials were run along with the unknown sediments. Results for each element for the five standards were reported along with the certified values from NIST, USGS, and other institutions that provide certified standards. The accuracy of the results was satisfactory for the standards; also, the total oxide composition of the sediments from borehole 299-E27-22 summed to close to $100 \%$, suggesting that the results were acceptable.

No elemental analyses were performed on the contaminated $C$ borehole sediments because the XRF instrument was not set up to test radioactive samples at the time this report was generated. Also, the bulk elemental analysis of moderately radionuclide-contaminated sediments, such as the three TX borehole sediments, did not vary significantly from uncontaminated samples (Serne et al. 2004a).

\subsubsection{Particle-Size Distribution}

The wet sieving/hydrometer method was used to determine the particle size distribution of selected samples from the background borehole, 299-E27-22. No particle size measurements were made on samples from C4297. The hydrometer technique is described in ASA (1986a), Part 1, Method 15-5, "Hydrometer Method"; it concentrates on quantifying the relative amounts of silt and clay. The silt and clay separates were saved for later mineralogical analyses. Samples from the borehole that were used for the hydrometer method were never air or oven dried to minimize the effects of particle aggregation that can affect the separation of clay grains from the coarser material.

\subsubsection{Particle Density}

The particle density of bulk grains from the background borehole are usually determined using pychnometers as described in ASA (1986b) Part 1, Method 14-3, "Pychnometer Method,” and oven-dried material. The particle density is an input needed to determine the particle size when using the hydrometer method. However, no direct particle density measurements were made for the sediments from borehole 299-E27-22. The particle size data reported in this document used the quartz default value of $2.65 \mathrm{~g} / \mathrm{cm}^{3}$ to calculate the particle size distribution. The error in using this simplifying assumption is not significant since most of the samples consisted of fine to medium-grained sand.

\subsubsection{Water Potential (Suction) Measurements}

Suction measurements (using the filter paper method PNL-MA-567-SFA-2 [PNL 1990b], which is essentially the same as ASTM [2002]), were made on the core liners in each splitspoon sampler from borehole 299-E27-22 and on the disturbed, unused sediment after geologic characterization and 
sub-sampling had been performed on C4297 samples. This method relies on three filter papers folded together into a small sandwich that rapidly equilibrates with the sediment sample. The middle filter paper does not contact sediment that might stick to the paper and bias the mass measurements. At equilibrium, the matric suction in the filter paper is the same as the matric suction of the sediment sample. The dry filter paper sandwiches were placed in the borehole 299-E27-22 liners and the C4297 air-tight storage containers while still filled with the sediment and remained there for 3 weeks to allow sufficient time for the matric suction in the sediment to equilibrate with the matric suction in the filter paper. The mass of the wetted middle filter paper that had no direct contact with the sediment was subsequently determined, and the suction of the sediment was determined from a calibration relationship between filter paper water content and matric suction. The filter paper method provides a good estimate of water potentials over the range from -0.01 to -2 MPa (1 to $200 \mathrm{~m}$ [3.3 to $656 \mathrm{ft}$ ] suction head) (Deka et al. 1995).

The relationships used for converting the water content of filter paper to matric suction for Whatman \#42 filter paper have been determined by Deka et al. (1995) and can be expressed as:

$$
\begin{aligned}
& \mathrm{Sm}=10^{(5.144-6.699 \mathrm{w})} / 10 \text { for } \mathrm{w}<0.5 \\
& \mathrm{Sm}=10^{(2.383-1.309 \mathrm{w})} / 10 \text { for } \mathrm{w}>0.5
\end{aligned}
$$

where: $\mathrm{Sm}=$ matric suction $(\mathrm{m})$

$\mathrm{w}=$ gravimetric water content of the filter paper $(\mathrm{g} / \mathrm{g})$.

Soil matric suction analysis was conducted on 111 core liner samples from borehole 299-E27-22. The matric potential samples covered the borehole profile from 20 to $230 \mathrm{ft}$ bgs in 0.5 to $5 \mathrm{ft}$ increments. At C4297, each of the 10 A liner sediments were analyzed for soil matric suction after some exposure to air (potentially drying) during geologic characterization of the samples. The filter paper sandwich could not be inserted in the C4297 core liners prior to characterization, as was possible for samples from borehole 299-E27-22, due to the configuration of the stainless steel liners. 


\subsection{Results and Discussion}

This section presents the geochemical and physical characterization data collected on sediment from the RCRA borehole, 299-E27-22, and borehole C4297, which was emplaced near tank C-105. The results for 299-E27-22 are presented in Section 4.1, and those for C4297 are given in Section 4.2.

The first characterization activities emphasized tests that were key to determining the vertical distribution and maximum vertical extent of mobile contaminants in the vadose zone sediments. Such information on the borehole sediments included moisture content and total and inorganic carbon content, and the $\mathrm{pH}, \mathrm{EC}$, measurements of major cations, anions, and trace metals (including technetium-99 and uranium-238) in 1:1 sediment:water- and $8 \mathrm{M}$ nitric acid-extracts. A GEA of the sediments was also performed to search for any detectable manmade gamma emitting radionuclides. The particle size, bulk chemical composition, and alpha- and beta-emitting radionuclides of selected sediment samples were measured in the second characterization phase. The determination of particle size and bulk chemical composition aided in defining contacts between major geologic units. These parameters also helped to better define the background composition of the "uncontaminated" sediments for determining the vertical extent of mobile contaminants in the contaminated borehole. The measurement of beta- and alphaemitting radionuclides (i.e., strontium-90 and transuranics, respectively) allows direct measurement of the vertical migration potential of these potentially risky contaminants.

\subsection{Vadose Zone Sediment from Borehole 299-E27-22}

\subsubsection{Moisture Content}

The moisture content of the sediment from the liners of borehole 299-E27-22 that was continuously cored (19 to $111 \mathrm{ft}$ bgs) and selectively cored (111 to $230 \mathrm{ft} \mathrm{bgs)} \mathrm{is} \mathrm{listed} \mathrm{in} \mathrm{Table} 4.1$ and presented as a graph (Figure 2.7) in Chapter 2. Figure 2.7 shows the gravimetric moisture content of small aliquots of sediment taken during the geologic description activities. The moisture content profile correlates with the lithology described in Section 2.3.2 and shown in Figure 2.7. The only region with elevated moisture in the Hanford formation H1 unit, and was a thin, fine-medium sand to silty fine-sand lens at $\sim 48 \mathrm{ft}$ bgs. The rest of the Hanford formation $\mathrm{H} 1$ unit was rather dry, with a mean gravimetric moisture content of $2.6 \mathrm{wt} \%$. The next zone of elevated moisture was found at the contact of the Hanford formation H1 and $\mathrm{H} 2$ units at $\sim 82 \mathrm{ft}$ bgs, with a gravimetric moisture content of $12.5 \mathrm{wt} \%$. The final zone of elevated moisture was in the Hanford formation $\mathrm{H} 2$ unit at $\sim 98 \mathrm{ft}$ bgs and corresponded to a thin, fine to coarse sand contact. The rest of the Hanford formation $\mathrm{H} 2$ unit was relatively dry, with a mean gravimetric moisture content of $2.5 \mathrm{wt} \%$. Below the Hanford formation strata, the Cold Creek upper sub-unit (CCUu) is believed to have been penetrated by the final splitspoon core sample collected. The sample was composed of gravel and was quite dry. No core samples were obtained from borehole 299-E27-22 in the lower Cold Creek sub-unit or the Ringold units. 
Table 4.1. Gravimetric Moisture Content of Core Samples Obtained from Borehole 299-E27-22

\begin{tabular}{|c|c|c|c|c|c|}
\hline $\begin{array}{l}\text { Depth } \\
\text { (ft bgs) }\end{array}$ & $\begin{array}{l}\text { Stratigraphic Unit } \\
\text { (Hanford formation) }\end{array}$ & $\begin{array}{c}\text { Moisture } \\
\text { Content } \\
\% \mathrm{Wt}\end{array}$ & $\begin{array}{l}\text { Depth } \\
\text { (ft bgs) }\end{array}$ & $\begin{array}{l}\text { Stratigraphic Unit } \\
\text { (Hanford formation) }\end{array}$ & $\begin{array}{c}\text { Moisture } \\
\text { Content } \\
\% \mathrm{Wt}\end{array}$ \\
\hline 19.5 & $\mathrm{H} 1$ & $2.38 \%$ & 52.0 & H1 & $2.69 \%$ \\
\hline 20.5 & H1 & $2.30 \%$ & 53.0 & $\mathrm{H} 1$ & $2.53 \%$ \\
\hline 22.0 & $\mathrm{H} 1$ & $2.48 \%$ & 54.5 & $\mathrm{H} 1$ & $2.12 \%$ \\
\hline 23.0 & $\mathrm{H} 1$ & $2.38 \%$ & 55.5 & $\mathrm{H} 1$ & $1.97 \%$ \\
\hline 24.5 & $\mathrm{H} 1$ & $2.45 \%$ & 57.0 & $\mathrm{H} 1$ & $2.01 \%$ \\
\hline 25.5 & H1 & $2.47 \%$ & 58.0 & H1 & $2.85 \%$ \\
\hline 27.0 & H1 & $2.80 \%$ & 62.0 & $\mathrm{H} 1$ & $3.45 \%$ \\
\hline 28.0 & H1 & $2.68 \%$ & 63.0 & H1 & $2.99 \%$ \\
\hline 29.5 & $\mathrm{H} 1$ & $2.43 \%$ & 65.5 & H1 & $2.08 \%$ \\
\hline 30.5 & $\mathrm{H} 1$ & $2.56 \%$ & 67.0 & $\mathrm{H} 1$ & $2.68 \%$ \\
\hline 32.0 & $\mathrm{H} 1$ & $2.47 \%$ & 68.0 & $\mathrm{H} 1$ & $2.41 \%$ \\
\hline 33.0 & H1 & $2.68 \%$ & 72.0 & H1 & $1.22 \%$ \\
\hline 34.5 & H1 & $2.55 \%$ & 73.0 & H1 & $2.09 \%$ \\
\hline 35.5 & H1 & $3.07 \%$ & 74.5 & H1 & $1.59 \%$ \\
\hline 37.0 & H1 & $2.69 \%$ & 75.5 & $\mathrm{H} 1$ & $1.99 \%$ \\
\hline 38.0 & H1 & $3.65 \%$ & 77.0 & $\mathrm{H} 1$ & $2.06 \%$ \\
\hline 39.5 & H1 & $3.28 \%$ & 78.0 & H1 & $2.04 \%$ \\
\hline 40.5 & H1 & $4.15 \%$ & 79.5 & H1 & $1.54 \%$ \\
\hline 42.0 & H1 & $3.26 \%$ & 80.5 & $\mathrm{H} 1$ & $2.26 \%$ \\
\hline 43.0 & H1 & $3.83 \%$ & 82.0 & $\mathrm{H} 2$ & $10.72 \%$ \\
\hline 44.5 & H1 & $4.00 \%$ & 83.0 & $\mathrm{H} 2$ & $4.44 \%$ \\
\hline 45.5 & $\mathrm{H} 1$ & $3.34 \%$ & 84.5 & $\mathrm{H} 2$ & $2.63 \%$ \\
\hline 47.0 & H1 & $3.32 \%$ & 85.5 & $\mathrm{H} 2$ & $1.79 \%$ \\
\hline 48.0 & H1 & $12.46 \%$ & 87.0 & $\mathrm{H} 2$ & $2.75 \%$ \\
\hline 49.5 & $\mathrm{H} 1$ & $2.99 \%$ & 88.0 & $\mathrm{H} 2$ & $2.75 \%$ \\
\hline 50.5 & H1 & $2.39 \%$ & 89.5 & H2 & $1.90 \%$ \\
\hline 90.5 & H2 & $1.95 \%$ & 145.5 & H2 & $2.42 \%$ \\
\hline 92.0 & H2 & $1.89 \%$ & 149.5 & H2 & $2.61 \%$ \\
\hline 93.0 & $\mathrm{H} 2$ & $2.35 \%$ & 150.5 & $\mathrm{H} 2$ & $2.39 \%$ \\
\hline
\end{tabular}


Table 4.1. (contd)

\begin{tabular}{|c|c|c|c|c|c|}
\hline $\begin{array}{l}\text { Depth } \\
\text { (ft bgs) }\end{array}$ & $\begin{array}{l}\text { Stratigraphic Unit } \\
\text { (Hanford formation) }\end{array}$ & $\begin{array}{c}\text { Moisture } \\
\text { Content } \\
\% \text { Wt }\end{array}$ & $\begin{array}{l}\text { Depth } \\
\text { (ft bgs) }\end{array}$ & $\begin{array}{c}\text { Stratigraphic Unit } \\
\text { (Hanford formation) }\end{array}$ & $\begin{array}{c}\text { Moisture } \\
\text { Content } \\
\% \mathrm{Wt}\end{array}$ \\
\hline 94.5 & H2 & $2.84 \%$ & 154.5 & $\mathrm{H} 2$ & $2.79 \%$ \\
\hline 95.5 & H2 & $2.52 \%$ & 159.5 & H2 & $2.29 \%$ \\
\hline 97.0 & $\mathrm{H} 2$ & $2.73 \%$ & 160.5 & $\mathrm{H} 2$ & $2.20 \%$ \\
\hline 98.0 & H2 & $8.74 \%$ & 164.5 & $\mathrm{H} 2$ & $2.73 \%$ \\
\hline 99.5 & $\mathrm{H} 2$ & $2.14 \%$ & 165.5 & $\mathrm{H} 2$ & $2.75 \%$ \\
\hline 100.5 & H2 & $1.48 \%$ & 169.5 & $\mathrm{H} 2$ & $2.69 \%$ \\
\hline 102.0 & H2 & $1.38 \%$ & 170.5 & H2 & $2.38 \%$ \\
\hline 103.0 & $\mathrm{H} 2$ & $1.96 \%$ & 174.5 & $\mathrm{H} 2$ & $2.68 \%$ \\
\hline 104.5 & $\mathrm{H} 2$ & $2.25 \%$ & 175.5 & $\mathrm{H} 2$ & $2.70 \%$ \\
\hline 105.5 & $\mathrm{H} 2$ & $2.15 \%$ & 179.5 & $\mathrm{H} 2$ & $2.73 \%$ \\
\hline 107.0 & H2 & $3.50 \%$ & 180.5 & H2 & $2.58 \%$ \\
\hline 108.0 & H2 & $2.16 \%$ & 184.5 & H2 & $2.91 \%$ \\
\hline 109.5 & $\mathrm{H} 2$ & $2.68 \%$ & 185.5 & $\mathrm{H} 2$ & $2.48 \%$ \\
\hline 110.5 & H2 & $3.09 \%$ & 189.5 & H2 & $2.88 \%$ \\
\hline 114.5 & $\mathrm{H} 2$ & $2.31 \%$ & 190.5 & $\mathrm{H} 2$ & $2.57 \%$ \\
\hline 115.5 & $\mathrm{H} 2$ & $2.53 \%$ & 194.5 & H2 & $2.43 \%$ \\
\hline 119.5 & H2 & $2.12 \%$ & 195.5 & $\mathrm{H} 2$ & $2.77 \%$ \\
\hline 120.5 & $\mathrm{H} 2$ & $1.79 \%$ & 199.5 & $\mathrm{H} 2$ & $2.99 \%$ \\
\hline 124.5 & $\mathrm{H} 2$ & $2.49 \%$ & 200.5 & $\mathrm{H} 2$ & $2.55 \%$ \\
\hline 125.5 & $\mathrm{H} 2$ & $2.49 \%$ & 204.5 & $\mathrm{H} 2$ & $2.53 \%$ \\
\hline 129.5 & $\mathrm{H} 2$ & $1.97 \%$ & 205.5 & $\mathrm{H} 2$ & $2.48 \%$ \\
\hline 130.5 & H2 & $3.61 \%$ & 209.5 & H2 & $2.37 \%$ \\
\hline 135.5 & $\mathrm{H} 2$ & $1.67 \%$ & 210.5 & $\mathrm{H} 2$ & $2.53 \%$ \\
\hline 139.5 & $\mathrm{H} 2$ & $2.10 \%$ & 224.5 & $\mathrm{H} 2$ & $3.72 \%$ \\
\hline 140.5 & $\mathrm{H} 2$ & $2.44 \%$ & 225.5 & $\mathrm{H} 2$ & $3.08 \%$ \\
\hline 144.5 & $\mathrm{H} 2$ & $2.37 \%$ & 229.5 & CCU & NA \\
\hline \multicolumn{6}{|c|}{$\begin{array}{l}\text { CCU }=\text { Cold Creek unit } \\
\text { NA }=\text { not analyzed }\end{array}$} \\
\hline
\end{tabular}




\subsubsection{1:1 Sediment:Water Extracts for Borehole 299-E27-22}

A subset of samples from the 299-E27-22 splitspoon cores were characterized by performing 1:1 sediment:water extracts. The following tables present the mass of a given constituent leached per gram of sediment as measured in the water extracts. Other figures show dilution-corrected values that represent concentrations in vadose zone pore water. As discussed in several other Vadose Zone Characterization Project reports, the dilution-corrected 1:1 sediment:water extracts are a reasonable estimate of the actual vadose zone pore water (Serne et al. 2002a, 2002b, 2002c, 2002e, 2002f).

\subsubsection{1 $\mathrm{pH}$ and Electrical Conductivity}

The water extracts' $\mathrm{pH}$ and electrical conductivity (EC) for select 299-E27-22 cores are shown in Table 4.2 and Figure 4.1. The $\mathrm{pH}$ is plotted as measured in the 1:1 sediment:water extracts but the EC is corrected for dilution and plotted as if it was actual pore water. The $\mathrm{pH}$ profile is constant with all values between 7.4 and 7.6. The pore water corrected EC data are more variable, with a range of 4.39 to $20.1 \mathrm{mS} / \mathrm{cm}$ in the Hanford formation $\mathrm{H} 1$ unit and a range of 4.30 to $12.9 \mathrm{mS} / \mathrm{cm}$ in the Hanford formation $\mathrm{H} 2$ unit. Overall, the calculated pore water conductivities were elevated when compared to the RCRA borehole (299-E33-338) emplaced near the B-BX-BY Waste Management Area (Lindenmeier et al. 2002). The seven samples tested from the Hanford formation $\mathrm{H} 1$ unit (six samples plus one duplicate) had an average pore water corrected EC of $9.08 \mathrm{mS} / \mathrm{cm}$, which was elevated by more than a factor of three when compared to the average EC from borehole 299-E33-338. The thirteen samples tested from the Hanford formation $\mathrm{H} 2$ unit (twelve samples plus one duplicate) had an average pore water EC of $8.47 \mathrm{mS} / \mathrm{cm}$, which again were in excess of three times higher than the average measured EC in borehole 299-E33-338.

Table 4.2 also contains data for the two samples from borehole 299-E27-22 that were unsaturated flow apparatus (UFA) "squeezed" to collect actual undiluted pore water. Comparison of the actual UFA pore water EC to the dilution corrected pore water EC for the same samples (from 48.0 and $82.0 \mathrm{ft}$ bgs) indicated that the dilution corrected values are biased high by as much as $40 \%$. This indicates that the $1: 1$ water:sediment extract technique employed to release the entrained pore water from the samples likely dissolved/leached small amounts of salts from the sediment, which resulted in a slightly elevated pore water corrected EC value. Similar trends have been observed in background characterization boreholes collected near the B-BX and SX Tank Farms and are documented in Serne et al. (2002a, 2002b, 2002c, 2002d, and 2002e). Interpretation of the $\mathrm{pH}$ and EC data for samples from 299-E27-22 revealed that $\mathrm{pH}$ was within the range measured in other 200 Area sediments (Serne et al. 2004a, 2004b, but that EC was significantly elevated with respect values observed in the 200 Area (Lindenmeier et al., 2002), indicating the presence of a higher salinity fluid at this location.

\subsubsection{Water Extract Composition of the 1:1 Sediment:Water Extract for Borehole 299-E27-22}

The 1:1sediment:water extract anion composition from 299-E27-22 samples, in units of $\mu$ g per gram of dry sediment, is shown in Table 4.3 and Figure 4.2. Values in Table 4.3 that appear to be elevated compared to the others are shown in bold type while values that appear to be lower than others are shown in italics. A comparison of the masses of water-extractable anions per gram of sediment from the background sediments from the Hanford formation H1 and H2 units in 299-E27-22 showed that there is some variability in anion composition between the two formations. The largest variability measured amongst the 20 samples tested (18 samples plus two duplicates) occurred at the depths associated with 
lenses of finer-grained material. The two samples composed of finer grained materials (samples 48.0 and 82.0) both contained significantly more chloride, nitrate, and sulfate than most of the remaining sediment samples, which could be a result of residual moisture from the undocumented "release" remaining in these zones of lower hydraulic conductivity. Overall, the elevated water extractable chloride, nitrate, sulfate, and phosphate concentrations in these samples, when accompanied by the EC data presented earlier, indicate that this borehole was not a good candidate for determining the background or natural conditions in the vadose zone at C Tank Farm.

Table 4.2. $\quad \mathrm{pH}$ and Electric Conductivity Values for 1:1 Sediment:Water

Extracts and UFA Squeezings from Borehole 299-E27-22

\begin{tabular}{|l|c|l|l||}
\hline $\begin{array}{c}\text { Depth } \\
\text { (ft bgs) }\end{array}$ & $\begin{array}{c}\text { Stratigraphic Unit } \\
\text { (Hanford formation) }\end{array}$ & pH & $\begin{array}{c}\text { Conductivity } \\
\text { (mS/cm) }\end{array}$ \\
\hline 28.0 & H1 & 7.55 & 20.1 \\
\hline 40.5 & H1 & 7.43 & 7.95 \\
\hline 45.5 & H1 & 7.51 & 8.42 \\
\hline 48.0 & H1 & 7.50 & 4.39 \\
\hline 48.0 Dup & H1 & 7.49 & 4.44 \\
\hline 48.0 UFA & H1 & 7.18 & 2.96 \\
\hline 50.5 & H1 & 7.53 & 6.88 \\
\hline 78.0 & H1 & 7.55 & 11.4 \\
\hline 82.0 & H2 & 7.43 & 4.31 \\
\hline 82.0 Dup & H2 & 7.48 & 4.30 \\
\hline 82.0 UFA & H2 & 6.93 & 3.22 \\
\hline 85.5 & H2 & 7.47 & 7.64 \\
\hline 95.5 & H2 & 7.60 & 7.73 \\
\hline 100.5 & H2 & 7.60 & 10.9 \\
\hline 139.5 & H2 & 7.43 & 12.9 \\
\hline 145.5 & H2 & 7.55 & 9.87 \\
\hline 160.5 & H2 & 7.52 & 10.8 \\
\hline 164.5 & H2 & 7.44 & 8.51 \\
\hline 185.5 & H2 & 7.57 & 10.8 \\
\hline 200.5 & H2 & 7.48 & 8.32 \\
\hline 210.5 & H2 & 7.54 & 8.24 \\
\hline 225.5 & 7.51 & 5.74 \\
\hline Dup = Duplicate sample & & \\
\hline UFA = Unsaturated flow apparatus & & \\
\hline
\end{tabular}


C4124 (299-E27-22)

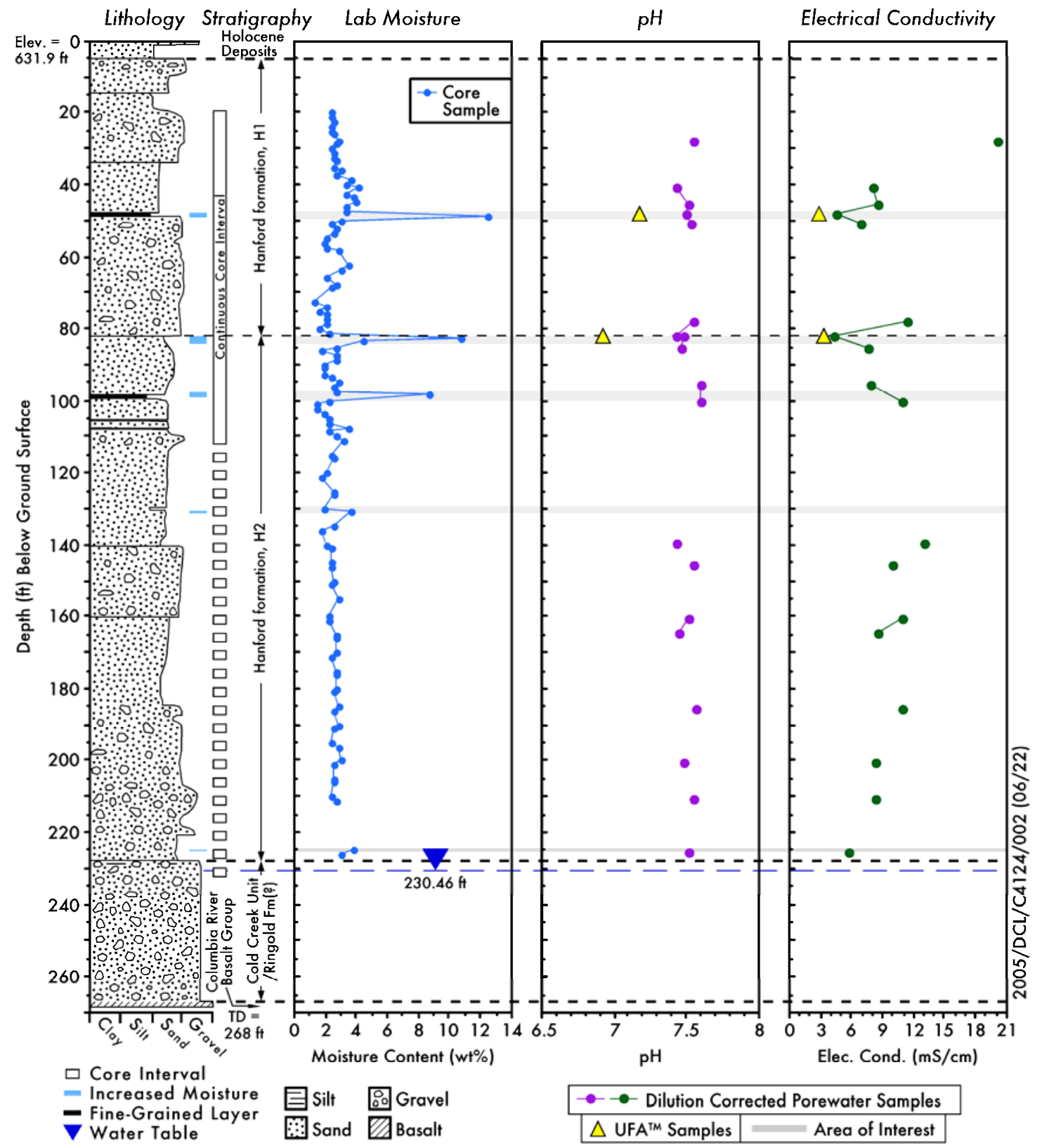

Figure 4.1. Gravimetric Moisture Content, $\mathrm{pH}$, and Electrical Conductivity Calculated from Sediment:Water Extracts for Borehole 299-E27-22

Table 4.4 shows the water-leachable concentrations of divalent and monovalent cations, in units of microgram per gram $(\mu \mathrm{g} / \mathrm{g})$ of dry sediment, for the RCRA borehole 299-E27-22. Table 4.5 shows the water-leachable concentrations of aluminum, silicon, iron, manganese, zinc, phosphorous, and sulfur. The latter two were converted to their respective anions, phosphate and sulfate, and the data are plotted to compare with the IC measured anion data in Figure 4.2; the comparison for sulfate is quite good. The distributions of water leachable masses of several of the major cations versus depth are shown in Figure 4.3. The depth profiles for the divalent alkaline earth cations calcium, magnesium, and strontium show higher values leached from the two samples composed of finer-grained materials. These results are 
consistent with the anion data, and confirm the presence of a waste source signature in the vadose zone at this location. None of the 299-E27-22 sediment:water extracts contained measurable amounts of aluminum, iron, manganese, or zinc. These results indicate that the sample material is oxidized and not highly weathered.

Tables 4.6 and 4.7 and Figure 4.4 show the water-leachable concentrations of some metals that are present in tank leak fluids. None of the samples tested contained quantifiable water-extractable concentrations of either technetium-99 or chromium. All but one of the samples contained trace amounts of water-extractable molybdenum, and all of the samples tested contained trace amounts of water extractable uranium. The lack of quantifiable concentrations of water-extractable technetium and chromium, combined with the presence of only trace water-extractable molybdenum and uranium, indicates that the waste source impacting the vadose zone at this location was at most, distantly associated with tank waste producing processes.

The values presented in Tables 4.2 through 4.7 were compared to similar data for the C Tank Farm borehole, C4297, to evaluate whether significantly different values are found in any samples. The occurrence of elevated concentrations of water-extractable sodium and technetium-99 would suggest that tank fluids percolated into the vadose zone where borehole C4297 was pushed. Relatively high uranium was also measured in some C4297 samples but appears to be the result of natural variation rather than a tank waste source. 
Table 4.3. Anion Composition of Water Extracts of 299-E27-22 Sediment (units $\mu \mathrm{g} / \mathrm{g}$ dry sediment)

\begin{tabular}{|c|c|c|c|c|c|c|c|c|c|}
\hline $\begin{array}{l}\text { Depth } \\
\text { (ft bgs) }\end{array}$ & $\begin{array}{l}\text { Stratigraphic Unit } \\
\text { (Hanford formation) }\end{array}$ & Fluoride & Chloride & Nitrate & $\begin{array}{l}\text { Alkalinity } \\
\text { as } \mathrm{CO}_{3}\end{array}$ & Sulfate & Phosphate & Nitrite & Bromide \\
\hline 28.0 & $\mathrm{H} 1$ & 0.38 & 0.48 & 0.99 & 36.1 & 88.6 & ND & ND & ND \\
\hline 40.5 & H1 & 0.47 & 1.01 & 7.80 & 39.6 & 111 & 2.07 & ND & ND \\
\hline 45.5 & $\mathrm{H} 1$ & 0.43 & 0.95 & 5.20 & 36.1 & 99.3 & ND & ND & ND \\
\hline 48.0 & H1 & 0.42 & 26.5 & 19.4 & 37.4 & 182 & ND & ND & ND \\
\hline 48.0 Dup & H1 & 0.43 & 27.8 & 19.9 & 35.4 & 191 & ND & ND & ND \\
\hline 50.5 & H1 & 0.33 & 4.42 & 1.92 & 37.7 & 24.5 & ND & ND & ND \\
\hline 78.0 & H1 & 0.37 & 3.22 & $N D$ & 40.8 & 55.8 & ND & ND & ND \\
\hline 82.0 & $\mathrm{H} 2$ & 0.35 & 21.0 & 19.6 & 32.0 & 138 & ND & ND & ND \\
\hline 82.0 Dup & $\mathrm{H} 2$ & 0.33 & 20.4 & 19.5 & 36.1 & 132 & ND & ND & ND \\
\hline 85.5 & $\mathrm{H} 2$ & 0.31 & 6.06 & 5.47 & 33.4 & 37.3 & ND & ND & ND \\
\hline 95.5 & $\mathrm{H} 2$ & 0.36 & 3.67 & 6.87 & 38.8 & 35.0 & ND & ND & ND \\
\hline 100.5 & $\mathrm{H} 2$ & 0.32 & 2.61 & 5.21 & 39.5 & 20.5 & ND & ND & ND \\
\hline 139.5 & $\mathrm{H} 2$ & 0.33 & 6.62 & 5.15 & 30.0 & 72.7 & ND & ND & ND \\
\hline 145.5 & $\mathrm{H} 2$ & 0.35 & 4.12 & 2.82 & 36.8 & 61.5 & ND & ND & ND \\
\hline 160.5 & $\mathrm{H} 2$ & 0.40 & 3.16 & 7.51 & 35.4 & 56.7 & ND & ND & ND \\
\hline 164.5 & $\mathrm{H} 2$ & 0.26 & 2.95 & 8.37 & 32.7 & 58.8 & ND & ND & ND \\
\hline 185.5 & $\mathrm{H} 2$ & 0.58 & 2.91 & 7.32 & 42.2 & 66.4 & ND & ND & ND \\
\hline 200.5 & $\mathrm{H} 2$ & 0.38 & \begin{tabular}{|l}
1.89 \\
\end{tabular} & 6.97 & 31.3 & 48.1 & ND & ND & ND \\
\hline 210.5 & $\mathrm{H} 2$ & 0.50 & 1.85 & $N D$ & 38.8 & 54.5 & ND & ND & ND \\
\hline 225.5 & $\mathrm{H} 2$ & 0.35 & 1.24 & $N D$ & 36.5 & 36.0 & ND & ND & ND \\
\hline \multicolumn{10}{|c|}{$\begin{array}{l}\text { Bold values are higher than others for given constituent. } \\
\text { Italicized values are lower than others for a given constituent. } \\
\text { Dup = Duplicate sample. } \\
\text { ND = Analyte was not detected in the sample. }\end{array}$} \\
\hline
\end{tabular}




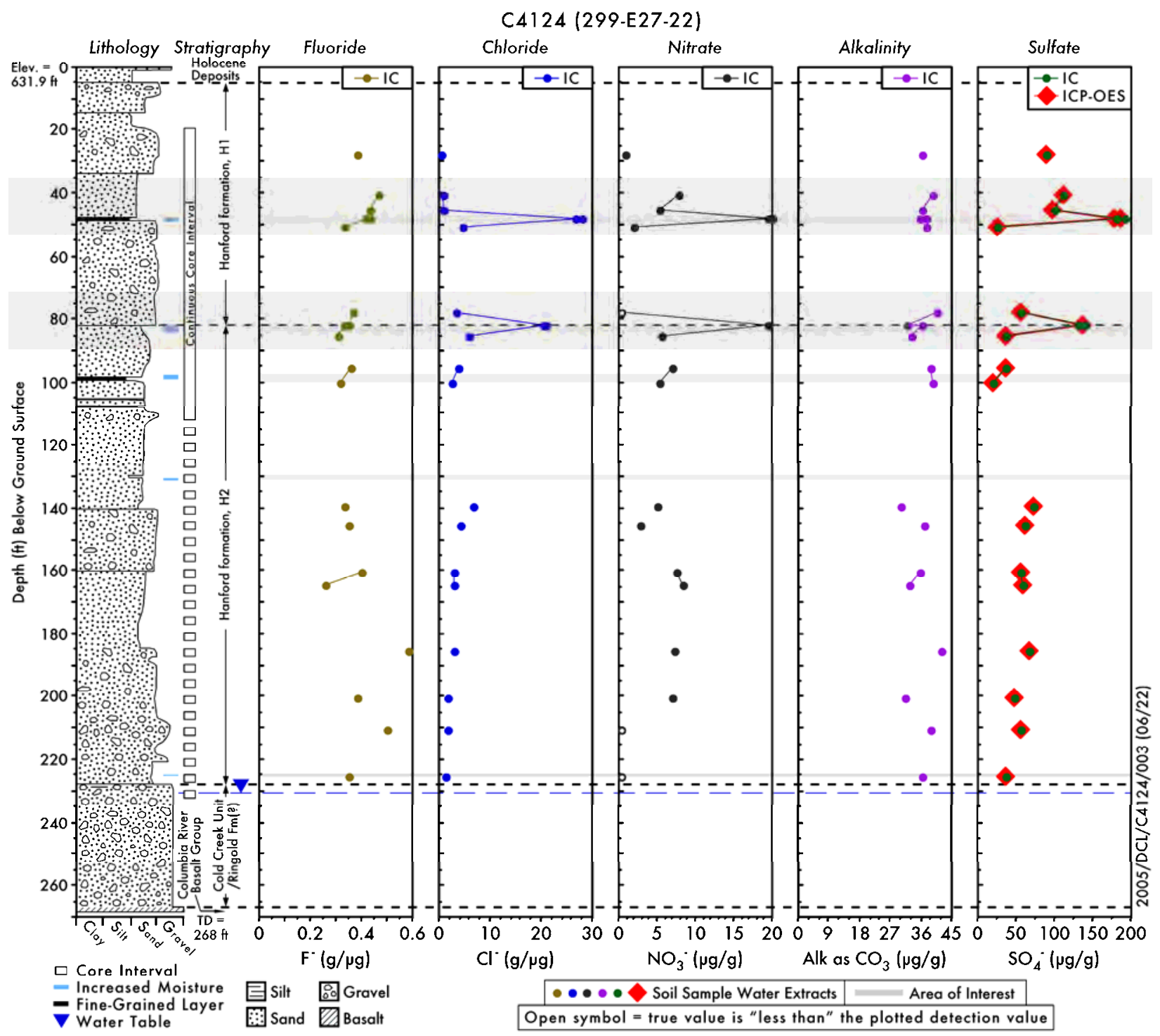

Figure 4.2. Water-Extractable Major Anions in Borehole 299-E27-22 Sediments ( $\mu \mathrm{g} / \mathrm{g}$ dry sediment) 
Table 4.4. Water-Extractable Cations in Borehole 299-E27-22 Sediments ( $\mu \mathrm{g} / \mathrm{g}$ dry soil)

\begin{tabular}{|c|c|c|c|c|c|c|c|}
\hline $\begin{array}{l}\text { Depth } \\
\text { (ft bgs) }\end{array}$ & $\begin{array}{l}\text { Stratigraphic Unit } \\
\text { (Hanford formation) }\end{array}$ & Magnesium & Calcium & Strontium & Barium & Sodium & Potassium \\
\hline 28.0 & H1 & $5.6 \mathrm{E}+00$ & $2.5 \mathrm{E}+01$ & 1.1E-01 & (3.0E-02) & $1.4 \mathrm{E}+01$ & $(4.9 \mathrm{E}+00)$ \\
\hline 40.5 & H1 & $6.9 \mathrm{E}+00$ & $3.2 \mathrm{E}+01$ & 1.3E-01 & $(2.2 \mathrm{E}-02)$ & $1.8 \mathrm{E}+01$ & $(4.5 \mathrm{E}+00)$ \\
\hline 45.5 & $\mathrm{H} 1$ & $6.0 \mathrm{E}+00$ & $2.7 \mathrm{E}+01$ & 1.1E-01 & $(2.6 \mathrm{E}-02)$ & $1.8 \mathrm{E}+01$ & $(4.2 \mathrm{E}+00)$ \\
\hline 48.0 & $\mathrm{H} 1$ & $1.3 \mathrm{E}+01$ & $5.6 \mathrm{E}+01$ & 2.1E-01 & $(1.9 \mathrm{E}-02)$ & $2.7 \mathrm{E}+01$ & $6.5 \mathrm{E}+00$ \\
\hline 48.0 Dup & $\mathrm{H} 1$ & $1.3 \mathrm{E}+01$ & $5.9 \mathrm{E}+01$ & 2.2E-01 & $(1.4 \mathrm{E}-02)$ & $2.8 \mathrm{E}+01$ & $6.5 \mathrm{E}+00$ \\
\hline 50.5 & $\mathrm{H} 1$ & $2.6 E+00$ & $9.8 E+00$ & 5.0E-02 & $(3.5 \mathrm{E}-02)$ & $1.1 \mathrm{E}+01$ & $(3.5 \mathrm{E}+00)$ \\
\hline 78.0 & $\mathrm{H} 1$ & $5.1 \mathrm{E}+00$ & $1.6 \mathrm{E}+01$ & 8.7E-02 & (3.0E-02) & $1.4 \mathrm{E}+01$ & $6.6 \mathrm{E}+00$ \\
\hline 82.0 & $\mathrm{H} 2$ & $1.4 \mathrm{E}+01$ & $4.1 \mathrm{E}+01$ & 1.8E-01 & $(2.1 \mathrm{E}-02)$ & $1.8 \mathrm{E}+01$ & $7.7 \mathrm{E}+00$ \\
\hline 82.0 Dup & $\mathrm{H} 2$ & $1.4 \mathrm{E}+01$ & $4.1 \mathrm{E}+01$ & 1.8E-01 & $(2.2 \mathrm{E}-02)$ & $1.8 \mathrm{E}+01$ & $7.7 \mathrm{E}+00$ \\
\hline 85.5 & $\mathrm{H} 2$ & $4.2 \mathrm{E}+00$ & $1.3 \mathrm{E}+01$ & 7.2E-02 & (3.3E-02) & $1.1 \mathrm{E}+01$ & $(5.7 \mathrm{E}+00)$ \\
\hline 95.5 & $\mathrm{H} 2$ & $4.1 \mathrm{E}+00$ & $1.1 \mathrm{E}+01$ & 6.2E-02 & $(3.7 \mathrm{E}-02)$ & $1.3 \mathrm{E}+01$ & $(5.4 \mathrm{E}+00)$ \\
\hline 100.5 & $\mathrm{H} 2$ & $3.0 \mathrm{E}+00$ & $7.5 E+00$ & 4.2E-02 & (3.0E-02) & $1.1 \mathrm{E}+01$ & $(4.8 \mathrm{E}+00)$ \\
\hline 139.5 & $\mathrm{H} 2$ & $6.3 \mathrm{E}+00$ & $1.6 \mathrm{E}+01$ & 9.7E-02 & $(3.5 \mathrm{E}-02)$ & $1.7 \mathrm{E}+01$ & $6.5 \mathrm{E}+00$ \\
\hline 145.5 & $\mathrm{H} 2$ & $4.5 \mathrm{E}+00$ & $1.3 \mathrm{E}+01$ & 7.4E-02 & $(4.8 \mathrm{E}-02)$ & $1.8 \mathrm{E}+01$ & $6.4 \mathrm{E}+00$ \\
\hline 160.5 & $\mathrm{H} 2$ & $4.4 \mathrm{E}+00$ & $1.4 \mathrm{E}+01$ & 7.5E-02 & $(4.2 \mathrm{E}-02)$ & $1.7 \mathrm{E}+01$ & $(6.2 \mathrm{E}+00)$ \\
\hline 164.5 & $\mathrm{H} 2$ & $4.5 \mathrm{E}+00$ & $1.6 \mathrm{E}+01$ & 7.7E-02 & $(2.4 \mathrm{E}-02)$ & $1.4 \mathrm{E}+01$ & $5.3 \mathrm{E}+00$ \\
\hline 185.5 & $\mathrm{H} 2$ & $4.2 \mathrm{E}+00$ & $1.5 \mathrm{E}+01$ & 9.2E-02 & $(3.6 \mathrm{E}-02)$ & 2.3E+01 & $6.4 \mathrm{E}+00$ \\
\hline 200.5 & $\mathrm{H} 2$ & $3.5 \mathrm{E}+00$ & $1.3 \mathrm{E}+01$ & 7.0E-02 & (5.3E-02) & $1.5 \mathrm{E}+01$ & $(4.7 \mathrm{E}+00)$ \\
\hline 210.5 & $\mathrm{H} 2$ & $3.7 \mathrm{E}+00$ & $1.4 \mathrm{E}+01$ & 7.4E-02 & $(2.5 \mathrm{E}-02)$ & $1.8 \mathrm{E}+01$ & $(5.0 \mathrm{E}+00)$ \\
\hline 225.5 & $\mathrm{H} 2$ & $3.3 \mathrm{E}+00$ & $1.3 \mathrm{E}+01$ & 7.6E-02 & $(4.2 \mathrm{E}-02)$ & $1.0 \mathrm{E}+01$ & $(4.6 \mathrm{E}+00)$ \\
\hline \multicolumn{8}{|c|}{$\begin{array}{l}\text { Bold values are higher than others for given constituent. } \\
\text { Italicized values are lower than others for a given constituent. }\end{array}$} \\
\hline
\end{tabular}


Table 4.5. Other Water-Extractable Species in Borehole 299-E27-22 Sediments ( $\mu \mathrm{g} / \mathrm{g}$ dry soil)

\begin{tabular}{|c|c|c|c|c|c|c|c|c|}
\hline $\begin{array}{c}\text { Depth } \\
\text { (ft bgs) }\end{array}$ & $\begin{array}{c}\text { Stratigraphic Unit } \\
\text { (Hanford formation) }\end{array}$ & Aluminum & Silicon & Iron & Manganese & Zinc & $\begin{array}{c}\text { Phosphorous } \\
\text { as } \mathrm{PO}_{4}\end{array}$ & $\begin{array}{l}\text { Sulfur } \\
\text { as } \mathrm{SO}_{4}\end{array}$ \\
\hline 28.0 & H1 & $\mathrm{ND}^{\mathrm{c}}$ & $1.0 \mathrm{E}+01$ & $(2.4 \mathrm{E}-02)$ & ND & $(1.1 \mathrm{E}-01)$ & (1.5E-01) & $8.92 \mathrm{E}+01$ \\
\hline 40.5 & $\mathrm{H} 1$ & ND & $1.2 \mathrm{E}+01$ & (9.6E-03) & ND & (6.8E-02) & (1.8E-01) & $1.10 \mathrm{E}+02$ \\
\hline 45.5 & H1 & ND & $1.2 \mathrm{E}+01$ & (9.2E-03) & ND & (7.5E-02) & (1.2E-01) & $9.85 \mathrm{E}+01$ \\
\hline 48.0 & H1 & ND & $1.7 \mathrm{E}+01$ & $(1.2 \mathrm{E}-02)$ & ND & $(5.2 \mathrm{E}-02)$ & (1.5E-01) & $1.79 E+02$ \\
\hline 48.0 Dup & H1 & ND & $1.7 \mathrm{E}+01$ & (6.7E-03) & ND & $(4.0 \mathrm{E}-02)$ & (9.8E-02) & $1.86 \mathrm{E}+02$ \\
\hline 50.5 & H1 & $(6.9 \mathrm{E}-04)$ & $8.5 \mathrm{E}+00$ & (1.6E-02) & ND & $(5.3 \mathrm{E}-02)$ & $(1.1 \mathrm{E}-01)$ & $2.46 \mathrm{E}+01$ \\
\hline 78.0 & H1 & ND & $8.5 \mathrm{E}+00$ & $(1.2 \mathrm{E}-02)$ & $(1.9 \mathrm{E}-03)$ & $(3.4 \mathrm{E}-02)$ & (8.8E-02) & $5.53 \mathrm{E}+01$ \\
\hline 82.0 & $\mathrm{H} 2$ & ND & $1.3 E+01$ & (1.8E-02) & $(9.9 \mathrm{E}-04)$ & (8.5E-02) & (7.9E-02) & $1.36 \mathrm{E}+02$ \\
\hline 82.0 Dup & $\mathrm{H} 2$ & ND & $1.4 \mathrm{E}+01$ & (1.2E-02) & ND & $(7.6 \mathrm{E}-02)$ & (9.3E-02) & $1.35 E+02$ \\
\hline 85.5 & $\mathrm{H} 2$ & (4.6E-03) & $8.0 \mathrm{E}+00$ & (1.0E-02) & $(5.1 \mathrm{E}-04)$ & $(5.8 \mathrm{E}-02)$ & $(1.9 \mathrm{E}-02)$ & $3.76 \mathrm{E}+01$ \\
\hline 95.5 & $\mathrm{H} 2$ & (7.5E-03) & $8.2 \mathrm{E}+00$ & (1.2E-02) & ND & $(1.5 \mathrm{E}-02)$ & (7.4E-02) & $3.50 \mathrm{E}+01$ \\
\hline 100.5 & $\mathrm{H} 2$ & (1.4E-02) & $7.6 \mathrm{E}+00$ & (1.5E-02) & ND & (1.2E-03) & (6.3E-02) & $2.04 \mathrm{E}+01$ \\
\hline 139.5 & $\mathrm{H} 2$ & ND & $8.4 \mathrm{E}+00$ & (1.3E-02) & ND & (2.6E-03) & (1.2E-02) & 7.22E +01 \\
\hline 145.5 & $\mathrm{H} 2$ & $(2.3 \mathrm{E}-03)$ & $8.6 \mathrm{E}+00$ & $(2.0 \mathrm{E}-02)$ & (7.1E-04) & (8.6E-03) & (1.3E-01) & $6.07 \mathrm{E}+01$ \\
\hline 160.5 & $\mathrm{H} 2$ & (2.4E-03) & $8.6 \mathrm{E}+00$ & (1.4E-02) & (8.8E-04) & (8.9E-03) & (3.9E-02) & $5.63 \mathrm{E}+01$ \\
\hline 164.5 & $\mathrm{H} 2$ & ND & $9.1 \mathrm{E}+00$ & (1.1E-02) & ND & ND & (5.6E-02) & $5.83 \mathrm{E}+01$ \\
\hline 185.5 & $\mathrm{H} 2$ & ND & $9.9 \mathrm{E}+00$ & (9.8E-03) & (1.5E-03) & (2.8E-03) & (8.9E-02) & $6.63 \mathrm{E}+01$ \\
\hline 200.5 & $\mathrm{H} 2$ & (5.2E-03) & $8.7 \mathrm{E}+00$ & (1.4E-02) & $(1.5 \mathrm{E}-03)$ & $(1.7 \mathrm{E}-02)$ & (1.8E-01) & $4.80 \mathrm{E}+01$ \\
\hline 210.5 & $\mathrm{H} 2$ & \begin{tabular}{|c|}
$(6.8 \mathrm{E}-03)$ \\
\end{tabular} & $9.8 \mathrm{E}+00$ & (2.0E-02) & (3.1E-03) & ND & (3.6E-02) & $5.45 \mathrm{E}+01$ \\
\hline 225.5 & $\mathrm{H} 2$ & (1.3E-03) & $1.0 \mathrm{E}+01$ & (3.1E-02) & $(2.5 E-03)$ & ND & (4.7E-02) & $3.64 \mathrm{E}+01$ \\
\hline
\end{tabular}

Bold values are higher than others for given constituent.

Parentheses signify reported values are below level of quantitation.

$\mathrm{ND}=$ Analyte was not detected in the sample

\subsection{3 $8 \mathrm{M}$ Nitric Acid-Extractable Amounts of Selected Elements}

The amount of material that could be extracted from the vadose zone sediment by $8 \mathrm{M}$ nitric acid is shown in Tables 4.7 through 4.9 and Figures 4.5 through 4.7. The $8 \mathrm{M}$ nitric acid extraction is a protocol used by EPA to estimate the maximum concentrations of regulated metals in contaminated sediment that would be biologically available. Aliquots of sediment from borehole 299-E27-22 were subjected to acid extraction to establish baseline values to compare with acid extracts of potentially contaminated sediments from borehole C4297.

The acid extract data showed high values for aluminum, calcium, iron, potassium, magnesium, and zinc in the fine-grained sample from the Hanford formation H1 unit (sample 48.0). The fine-grained sample from the Hanford formation H2 unit (sample 82.0) was elevated in aluminum, calcium, and potassium. The remaining samples contained consistent quantities of all the elements measured. A 
comparison of the water-leachable and acid-leachable contents of the sediments from borehole 299-E2722 (see data shown in Tables 4.4 to 4.6 versus Tables 4.7 to 4.9 ) showed that less than $0.1 \%$ of the acidextractable quantities of the following elements were water leachable: aluminum, barium, iron, manganese, chromium, and phosphorous as phosphate. Less than $1 \%$ of the acid-extractable quantities of the following elements were water leachable: calcium, potassium, magnesium, strontium, zinc, and uranium. Less than $10 \%$ of the acid-extractable sodium and molybdenum were water soluble and less than $40 \%$ of the acid-extractable sulfur as sulfate was water extractable. Comparisons of the water- to acid-soluble sulfur and phosphorous are shown in Figure 4.8.

Table 4.6. Water-Extractable Mobile Trace Contaminants in Borehole 299-E27-22 Sediments ( $\mu$ g per gram dry soil)

\begin{tabular}{|c|c|c|c|c|c|c|}
\hline $\begin{array}{l}\text { Depth } \\
\text { (ft bgs) }\end{array}$ & $\begin{array}{c}\text { Stratigraphic Unit } \\
\text { (Hanford formation) }\end{array}$ & Technetium-99 & Uranium-238 & Chromium & $\begin{array}{c}\text { Molybdenum } \\
\text { (ICP-MS) }\end{array}$ & $\begin{array}{l}\text { Molybdenum } \\
\text { (ICP) }\end{array}$ \\
\hline 28.0 & H1 & (5.00E-07) & 3.28E-04 & (4.30E-05) & 3.82E-03 & (3.0E-03) \\
\hline 40.5 & $\mathrm{H} 1$ & $(2.01 E-06)$ & 5.31E-04 & $(1.44 \mathrm{E}-04)$ & 5.34E-03 & (6.7E-03) \\
\hline 45.5 & $\mathrm{H} 1$ & $(1.00 \mathrm{E}-06)$ & 4.57E-04 & $(1.25 \mathrm{E}-04)$ & 3.81E-03 & $(2.0 \mathrm{E}-03)$ \\
\hline 48.0 & H1 & $(2.50 \mathrm{E}-06)$ & 7.54E-04 & $(1.28 \mathrm{E}-03)$ & 4.69E-03 & $(2.2 \mathrm{E}-03)$ \\
\hline 48.0 Dup & H1 & $(2.50 \mathrm{E}-06)$ & $7.78 \mathrm{E}-04$ & (1.43E-03) & $4.70 \mathrm{E}-03$ & $(2.9 \mathrm{E}-03)$ \\
\hline 50.5 & $\mathrm{H} 1$ & $(0.00 \mathrm{E}+00)$ & $1.84 \mathrm{E}-04$ & $(2.88 \mathrm{E}-04)$ & $5.34 \mathrm{E}-03$ & $(2.6 \mathrm{E}-03)$ \\
\hline \begin{tabular}{|l|}
78.0 \\
\end{tabular} & $\mathrm{H} 1$ & $(1.00 \mathrm{E}-06)$ & $3.86 \mathrm{E}-04$ & (1.94E-04) & 7.99E-03 & $(5.8 \mathrm{E}-03)$ \\
\hline 82.0 & $\mathrm{H} 2$ & $(4.10 \mathrm{E}-06)$ & $6.48 \mathrm{E}-04$ & $(1.04 \mathrm{E}-03)$ & 7.29E-03 & $(1.2 \mathrm{E}-02)$ \\
\hline 82.0 Dup & $\mathrm{H} 2$ & (3.58E-06) & 6.47E-04 & (1.01E-03) & 6.50E-03 & (8.9E-03) \\
\hline 85.5 & $\mathrm{H} 2$ & (3.00E-06) & $2.20 \mathrm{E}-04$ & (3.36E-04) & $6.33 \mathrm{E}-03$ & $(1.1 \mathrm{E}-02)$ \\
\hline 95.5 & $\mathrm{H} 2$ & $(2.50 \mathrm{E}-06)$ & $2.41 \mathrm{E}-04$ & $(2.47 \mathrm{E}-04)$ & 6.99E-03 & $(5.2 \mathrm{E}-03)$ \\
\hline 100.5 & $\mathrm{H} 2$ & (3.51E-06) & 3.61E-04 & $(1.80 \mathrm{E}-04)$ & 7.23E-03 & $(4.3 \mathrm{E}-03)$ \\
\hline 139.5 & $\mathrm{H} 2$ & $(5.01 E-07)$ & $6.49 \mathrm{E}-04$ & $(1.75 \mathrm{E}-03)$ & $6.89 \mathrm{E}-03$ & $(9.4 \mathrm{E}-04)$ \\
\hline 145.5 & $\mathrm{H} 2$ & ND & 6.34E-04 & (6.57E-04) & 5.56E-03 & $(1.7 \mathrm{E}-03)$ \\
\hline 160.5 & $\mathrm{H} 2$ & ND & $2.20 \mathrm{E}-04$ & (1.96E-04) & 7.11E-03 & (6.9E-03) \\
\hline 164.5 & $\mathrm{H} 2$ & ND & 2.41E-04 & (3.08E-04) & 5.70E-03 & $(1.8 \mathrm{E}-03)$ \\
\hline 185.5 & $\mathrm{H} 2$ & ND & 3.60E-04 & $(2.23 \mathrm{E}-04)$ & 7.45E-03 & (3.4E-03) \\
\hline 200.5 & $\mathrm{H} 2$ & (5.00E-07) & 2.83E-04 & (1.39E-04) & 4.10E-03 & $(1.1 \mathrm{E}-02)$ \\
\hline 210.5 & $\mathrm{H} 2$ & ND & $1.90 \mathrm{E}-04$ & $(1.04 \mathrm{E}-04)$ & $4.68 \mathrm{E}-03$ & $(6.6 \mathrm{E}-03)$ \\
\hline 225.5 & $\mathrm{H} 2$ & ND & 1.53E-04 & (1.12E-04) & (1.49E-03) & ND \\
\hline \multicolumn{7}{|c|}{$\begin{array}{l}\text { Parentheses signify values below level of quantitation. } \\
\text { Dup = Duplicate sample } \\
\text { ND = Analyte was not detected in the sample } \\
\end{array}$} \\
\hline
\end{tabular}




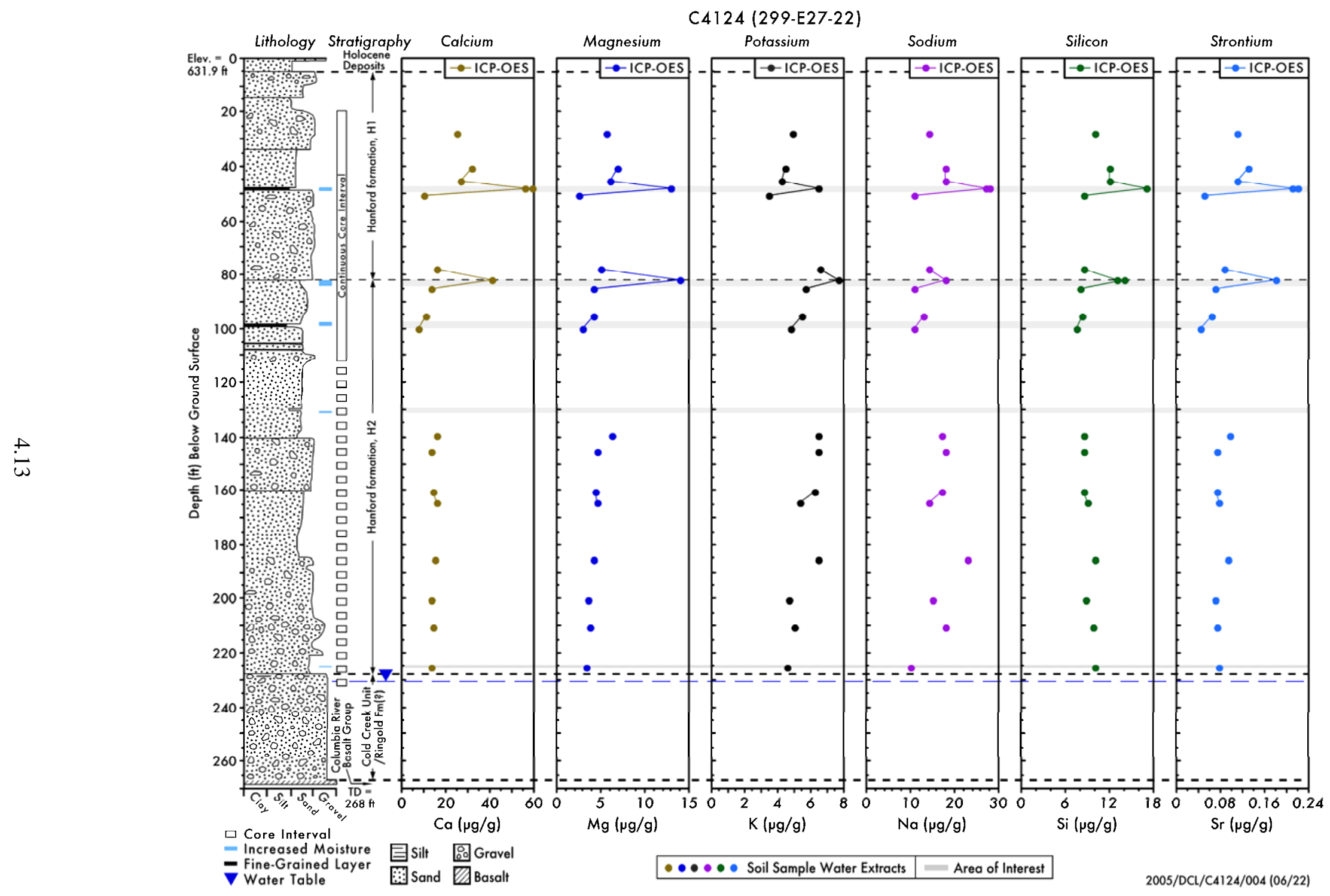

Figure 4.3. Cations in 1:1 Sediment:Water Extracts for Borehole 299-E27-22 
Table 4.7. Acid-Extractable Major Cations in Borehole 299-E27-22 Sediments ( $\mu \mathrm{g} / \mathrm{g}$ dry sediment)

\begin{tabular}{|c|c|c|c|c|c|c|c|}
\hline $\begin{array}{c}\text { Depth } \\
\text { (ft bgs) }\end{array}$ & $\begin{array}{l}\text { Stratigraphic Unit } \\
\text { (Hanford formation) }\end{array}$ & Barium & Calcium & Potassium & Manganese & Strontium & Sodium \\
\hline 28.0 & H1 & $(6.8 \mathrm{E}+01)$ & $6.8 \mathrm{E}+03$ & $6.5 \mathrm{E}+02$ & $3.8 \mathrm{E}+03$ & $3.1 \mathrm{E}+01$ & $-\quad-$ \\
\hline 40.5 & H1 & $(1.0 \mathrm{E}+02)$ & $8.9 \mathrm{E}+03$ & $1.4 \mathrm{E}+03$ & $5.4 \mathrm{E}+03$ & $4.9 \mathrm{E}+01$ & $-\quad-\quad-$ \\
\hline 45.5 & H1 & $(7.7 \mathrm{E}+01)$ & $7.7 \mathrm{E}+03$ & $1.1 \mathrm{E}+03$ & $4.9 \mathrm{E}+03$ & $4.0 \mathrm{E}+01$ & $-\quad-$ \\
\hline 48.0 & H1 & $(9.4 \mathrm{E}+01)$ & $1.1 \mathrm{E}+04$ & $2.1 \mathrm{E}+03$ & $7.0 \mathrm{E}+03$ & $4.5 \mathrm{E}+01$ & $-\quad-$ \\
\hline 48.0 Dup & H1 & $(9.3 \mathrm{E}+01)$ & $1.1 \mathrm{E}+04$ & $2.0 \mathrm{E}+03$ & $6.9 \mathrm{E}+03$ & $4.7 \mathrm{E}+01$ & $-\quad-$ \\
\hline 50.5 & H1 & $(6.3 \mathrm{E}+01)$ & $7.7 \mathrm{E}+03$ & $7.8 \mathrm{E}+02$ & $4.1 \mathrm{E}+03$ & $2.7 \mathrm{E}+01$ & $-\quad-$ \\
\hline 78.0 & H1 & $(5.2 \mathrm{E}+01)$ & $7.1 \mathrm{E}+03$ & $7.2 \mathrm{E}+02$ & $4.1 \mathrm{E}+03$ & $2.7 \mathrm{E}+01$ & $-\quad-$ \\
\hline 82.0 & $\mathrm{H} 2$ & $(9.2 \mathrm{E}+01)$ & $9.2 \mathrm{E}+03$ & $1.6 \mathrm{E}+03$ & $5.6 \mathrm{E}+03$ & $3.8 \mathrm{E}+01$ & $-\quad-$ \\
\hline 82.0 Dup & H2 & $(8.5 E+01)$ & $9.2 \mathrm{E}+03$ & $1.6 \mathrm{E}+03$ & $5.7 \mathrm{E}+03$ & $3.9 \mathrm{E}+01$ & $-\quad-$ \\
\hline 85.5 & $\mathrm{H} 2$ & $(5.1 \mathrm{E}+01)$ & $7.7 \mathrm{E}+03$ & $7.8 \mathrm{E}+02$ & $4.0 \mathrm{E}+03$ & $2.5 \mathrm{E}+01$ & $-\quad-$ \\
\hline 95.5 & $\mathrm{H} 2$ & $(5.2 \mathrm{E}+01)$ & $8.1 \mathrm{E}+03$ & $8.8 \mathrm{E}+02$ & $4.5 \mathrm{E}+03$ & $2.8 \mathrm{E}+01$ & $-\quad-$ \\
\hline 100.5 & $\mathrm{H} 2$ & $(5.9 \mathrm{E}+01)$ & $9.2 \mathrm{E}+03$ & $1.0 \mathrm{E}+03$ & $5.1 \mathrm{E}+03$ & $3.2 \mathrm{E}+01$ & $-\quad-$ \\
\hline 139.5 & $\mathrm{H} 2$ & $(6.2 \mathrm{E}+01)$ & $8.8 \mathrm{E}+03$ & $1.1 \mathrm{E}+03$ & $4.8 \mathrm{E}+03$ & $3.7 \mathrm{E}+01$ & $-\quad-$ \\
\hline 145.5 & H2 & $(6.1 \mathrm{E}+01)$ & $6.5 \mathrm{E}+03$ & $8.7 \mathrm{E}+02$ & $4.5 \mathrm{E}+03$ & $2.5 \mathrm{E}+01$ & $-\quad-$ \\
\hline 160.5 & $\mathrm{H} 2$ & $(7.0 \mathrm{E}+01)$ & $7.5 \mathrm{E}+03$ & $1.0 \mathrm{E}+03$ & $5.2 \mathrm{E}+03$ & $3.2 \mathrm{E}+01$ & $-\quad-\quad$ \\
\hline 164.5 & H2 & $(5.8 \mathrm{E}+01)$ & $7.0 \mathrm{E}+03$ & $1.1 \mathrm{E}+03$ & $5.3 \mathrm{E}+03$ & $3.1 \mathrm{E}+01$ & $-\quad-$ \\
\hline 185.5 & $\mathrm{H} 2$ & $(7.3 \mathrm{E}+01)$ & $6.5 \mathrm{E}+03$ & $9.8 \mathrm{E}+02$ & $4.7 \mathrm{E}+03$ & $3.0 \mathrm{E}+01$ & $-\quad-$ \\
\hline 200.5 & $\mathrm{H} 2$ & $(6.6 \mathrm{E}+01)$ & $6.5 \mathrm{E}+03$ & $8.9 \mathrm{E}+02$ & $4.7 \mathrm{E}+03$ & $3.1 \mathrm{E}+01$ & $-\quad-$ \\
\hline 210.5 & $\mathrm{H} 2$ & $(6.4 \mathrm{E}+01)$ & $5.8 \mathrm{E}+03$ & $8.9 \mathrm{E}+02$ & $4.4 \mathrm{E}+03$ & $3.1 \mathrm{E}+01$ & $-\quad-$ \\
\hline 225.5 & H2 & $(5.8 \mathrm{E}+01)$ & $5.5 \mathrm{E}+03$ & $7.5 \mathrm{E}+02$ & $3.8 \mathrm{E}+03$ & $2.7 \mathrm{E}+01$ & $-\quad-$ \\
\hline \multicolumn{8}{|c|}{$\begin{array}{l}\text { Bold values are higher than others for given constituent. } \\
\text { Parentheses signify values below level of quantitation. } \\
\text { Dup = Duplicate sample }\end{array}$} \\
\hline
\end{tabular}

\subsubsection{Bulk Chemical Composition of Sediment from 299-E27-22}

Five core samples were selected from this borehole and analyzed for bulk chemical composition using XRF. The total chemical composition of the samples is shown in Table 4.10. As found for most Hanford Site sediments, the bulk chemistry is dominated by silicon and aluminum oxides, with iron and calcium being next in abundance. There was also several (1 to 4) percent of sodium, potassium, and magnesium present in all the sediments. For the RCRA borehole sediments at the C Tank Farm, the major metal data do not show striking differences in elemental concentrations with lithology. 


\subsubsection{Radionuclide Content in Vadose Zone Sediment from 299-E27-22}

The sediment cores from borehole 299-E27-22 did not contain any manmade gamma radioactivity. The radioanalytical analyses performed on the sediment included direct gamma energy analysis and technetium-99 and uranium-238 analysis of the 1:1 sediment:water extracts and the sediment:acid extracts. The uranium and technetium water-extractable contents of the background sediments that were characterized are shown in Table 4.6 and the acid-extractable amounts are shown in Table 4.9. Both data sets indicated no elevated amounts are present. The GEA data were not reported because there was nothing significant to report.

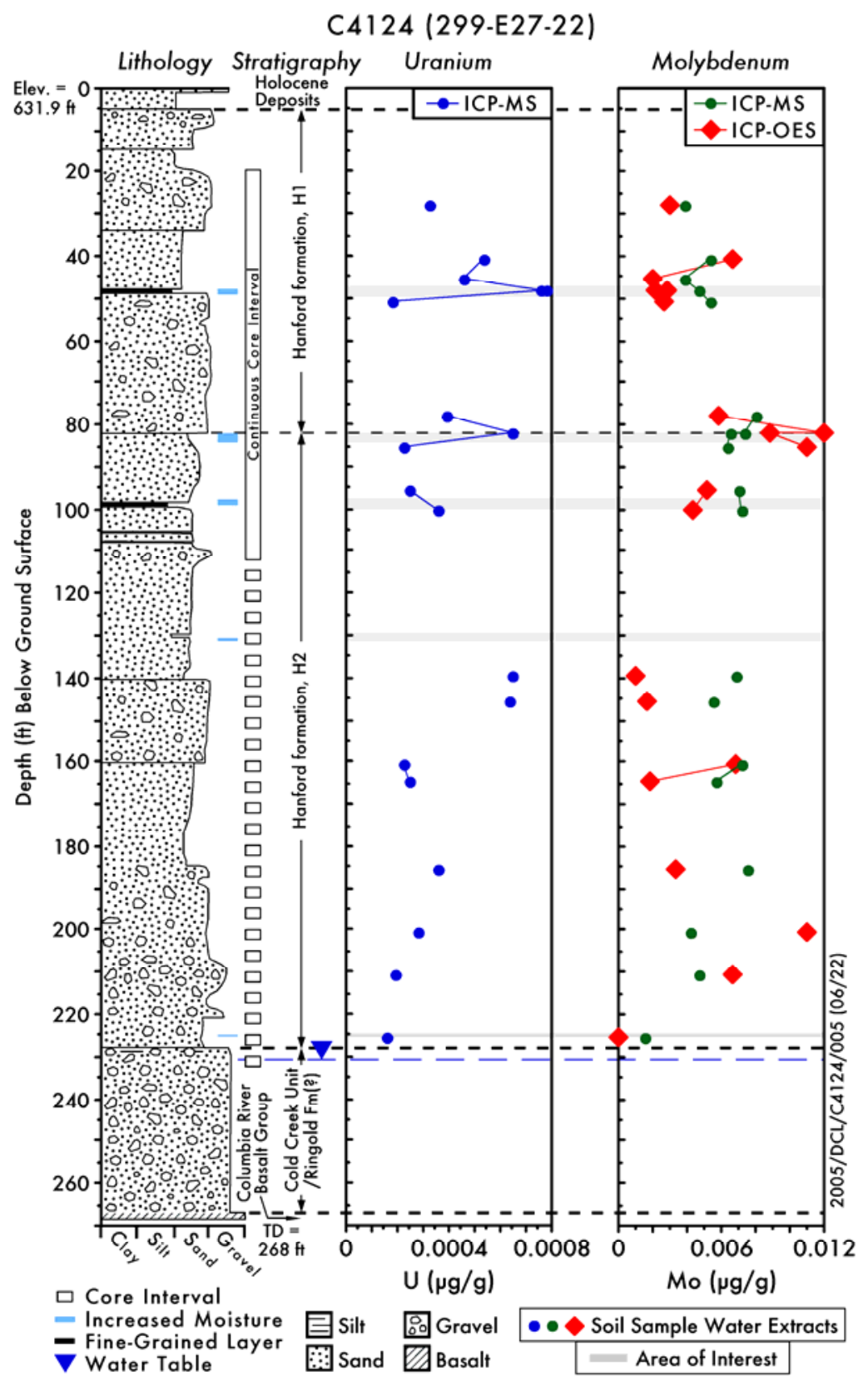

Figure 4.4. Trace Metals in 1:1 Sediment:Water Extracts Borehole 299-E27-22 
Table 4.8. Acid-Extractable Content for Major Constituents in Borehole 299-E27-22 Sediments ( $\mu \mathrm{g} / \mathrm{g}$ dry sediment)

\begin{tabular}{|c|c|c|c|c|c|c|c|c|}
\hline $\begin{array}{l}\text { Depth } \\
\text { (ft bgs) }\end{array}$ & $\begin{array}{l}\text { Stratigraphic Unit } \\
\text { (Hanford formation) }\end{array}$ & Aluminum & Iron & Manganese & Silicon & Potassium, & Sulfur & Zinc \\
\hline 28.0 & H1 & $4.8 \mathrm{E}+03$ & $1.5 \mathrm{E}+04$ & $2.1 \mathrm{E}+02$ & $(7.4 \mathrm{E}+01)$ & $9.2 \mathrm{E}+02$ & $1.2 \mathrm{E}+02$ & $2.6 \mathrm{E}+01$ \\
\hline 40.5 & H1 & $9.6 \mathrm{E}+03$ & $1.8 \mathrm{E}+04$ & $3.6 \mathrm{E}+02$ & $(1.9 \mathrm{E}+01)$ & $4.8 \mathrm{E}+02$ & $1.2 \mathrm{E}+02$ & $3.7 \mathrm{E}+01$ \\
\hline 45.5 & $\mathrm{H} 1$ & $7.7 \mathrm{E}+03$ & $1.5 \mathrm{E}+04$ & $3.1 \mathrm{E}+02$ & $(1.8 \mathrm{E}+01)$ & $4.8 \mathrm{E}+02$ & $1.1 \mathrm{E}+02$ & $3.3 \mathrm{E}+01$ \\
\hline 48.0 & $\mathrm{H} 1$ & $1.2 \mathrm{E}+04$ & $2.1 \mathrm{E}+04$ & $3.6 \mathrm{E}+02$ & $(6.9 \mathrm{E}+01)$ & $7.2 \mathrm{E}+02$ & $1.5 \mathrm{E}+02$ & $4.5 \mathrm{E}+01$ \\
\hline 48.0 Dup & $\mathrm{H} 1$ & $1.3 E+04$ & $2.2 E+04$ & $3.5 \mathrm{E}+02$ & $(4.0 \mathrm{E}+01)$ & $7.3 \mathrm{E}+02$ & $2.1 \mathrm{E}+02$ & $4.5 \mathrm{E}+01$ \\
\hline 50.5 & H1 & $5.4 \mathrm{E}+03$ & $1.4 \mathrm{E}+04$ & $2.7 \mathrm{E}+02$ & $(9.4 \mathrm{E}+01)$ & $7.3 \mathrm{E}+02$ & $1.0 \mathrm{E}+02$ & $2.8 \mathrm{E}+01$ \\
\hline 78.0 & $\mathrm{H} 1$ & $4.8 \mathrm{E}+03$ & $1.2 \mathrm{E}+04$ & $2.1 \mathrm{E}+02$ & $(6.1 \mathrm{E}+01)$ & $6.8 \mathrm{E}+02$ & $1.1 \mathrm{E}+02$ & $2.4 \mathrm{E}+01$ \\
\hline 82.0 & $\mathrm{H} 2$ & $8.1 \mathrm{E}+03$ & $1.6 \mathrm{E}+04$ & $3.5 \mathrm{E}+02$ & $(6.7 \mathrm{E}+01)$ & $5.5 \mathrm{E}+02$ & $1.3 \mathrm{E}+02$ & $3.7 \mathrm{E}+01$ \\
\hline 82.0 Dup & $\mathrm{H} 2$ & $8.1 \mathrm{E}+03$ & $1.6 \mathrm{E}+04$ & $3.4 \mathrm{E}+02$ & $(1.3 E+02)$ & $5.5 \mathrm{E}+02$ & $1.3 \mathrm{E}+02$ & $3.8 \mathrm{E}+01$ \\
\hline 85.5 & $\mathrm{H} 2$ & $4.6 \mathrm{E}+03$ & $1.1 \mathrm{E}+04$ & $2.2 \mathrm{E}+02$ & $(1.3 \mathrm{E}+02)$ & $5.1 \mathrm{E}+02$ & $1.1 \mathrm{E}+02$ & $2.4 \mathrm{E}+01$ \\
\hline 95.5 & $\mathrm{H} 2$ & $5.4 \mathrm{E}+03$ & $1.2 \mathrm{E}+04$ & $2.3 \mathrm{E}+02$ & $2.0 \mathrm{E}+02$ & $4.9 \mathrm{E}+02$ & $1.0 \mathrm{E}+02$ & $2.6 \mathrm{E}+01$ \\
\hline 100.5 & $\mathrm{H} 2$ & $6.9 \mathrm{E}+03$ & $1.5 \mathrm{E}+04$ & $2.8 \mathrm{E}+02$ & $(6.2 \mathrm{E}+01)$ & $5.1 \mathrm{E}+02$ & $1.0 \mathrm{E}+02$ & $3.0 \mathrm{E}+01$ \\
\hline 139.5 & $\mathrm{H} 2$ & $6.6 \mathrm{E}+03$ & $1.3 \mathrm{E}+04$ & $2.5 \mathrm{E}+02$ & $(6.6 \mathrm{E}+01)$ & $4.6 \mathrm{E}+02$ & $1.2 \mathrm{E}+02$ & $2.9 \mathrm{E}+01$ \\
\hline 145.5 & $\mathrm{H} 2$ & $6.0 \mathrm{E}+03$ & $1.5 \mathrm{E}+04$ & $2.4 \mathrm{E}+02$ & $(3.4 \mathrm{E}+01)$ & $7.4 \mathrm{E}+02$ & $1.1 \mathrm{E}+02$ & $2.8 \mathrm{E}+01$ \\
\hline 160.5 & $\mathrm{H} 2$ & $7.2 \mathrm{E}+03$ & $1.8 \mathrm{E}+04$ & $2.8 \mathrm{E}+02$ & $(1.5 \mathrm{E}+01)$ & $7.3 \mathrm{E}+02$ & $1.1 \mathrm{E}+02$ & $3.3 \mathrm{E}+01$ \\
\hline 164.5 & $\mathrm{H} 2$ & $7.5 \mathrm{E}+03$ & $1.6 \mathrm{E}+04$ & $2.7 \mathrm{E}+02$ & $(4.4 \mathrm{E}+01)$ & $5.8 \mathrm{E}+02$ & $1.0 \mathrm{E}+02$ & $3.1 \mathrm{E}+01$ \\
\hline 185.5 & $\mathrm{H} 2$ & $6.4 \mathrm{E}+03$ & $1.6 \mathrm{E}+04$ & $2.6 \mathrm{E}+02$ & $(2.7 \mathrm{E}+01)$ & $7.7 \mathrm{E}+02$ & $1.2 \mathrm{E}+02$ & $3.0 \mathrm{E}+01$ \\
\hline 200.5 & $\mathrm{H} 2$ & $6.4 \mathrm{E}+03$ & $1.6 \mathrm{E}+04$ & $2.6 \mathrm{E}+02$ & $(4.4 \mathrm{E}+01)$ & $7.2 \mathrm{E}+02$ & $1.1 \mathrm{E}+02$ & $3.0 \mathrm{E}+01$ \\
\hline 210.5 & $\mathrm{H} 2$ & $6.0 \mathrm{E}+03$ & $1.5 \mathrm{E}+04$ & $2.3 \mathrm{E}+02$ & $(2.9 \mathrm{E}+01)$ & $6.9 \mathrm{E}+02$ & $9.5 \mathrm{E}+01$ & $2.8 \mathrm{E}+01$ \\
\hline 225.5 & $\mathrm{H} 2$ & $5.2 \mathrm{E}+03$ & $1.2 \mathrm{E}+04$ & $2.3 \mathrm{E}+02$ & $(5.2 E+01)$ & $6.5 \mathrm{E}+02$ & 8.3E+01 & $2.4 \mathrm{E}+01$ \\
\hline
\end{tabular}

Bold values are higher than others for given constituent.

Parentheses signify values are below level of quantitation.

Dup = Duplicate sample 
Table 4.9. Acid-Extractable Mobile Trace Metals in Borehole 299-E27-22 Sediments ( $\mu$ g per gram dry sediment)

\begin{tabular}{|c|c|c|c|c|c|c|}
\hline $\begin{array}{l}\text { Depth } \\
\text { (ft bgs) }\end{array}$ & $\begin{array}{l}\text { Stratigraphic Unit } \\
\text { (Hanford formation) }\end{array}$ & Technetium-99 & Uranium-238 & $\begin{array}{l}\text { Chromium } \\
\text { (ICP-MS) }\end{array}$ & $\begin{array}{l}\text { Chromium } \\
\text { (ICP) }\end{array}$ & $\begin{array}{l}\text { Molybdenum } \\
\text { (ICP-MS) }\end{array}$ \\
\hline 28.0 & H1 & (8.03E-05) & $3.26 \mathrm{E}-01$ & $6.41 \mathrm{E}+00$ & $6.2 \mathrm{E}+00$ & $1.58 \mathrm{E}-01$ \\
\hline 40.5 & H1 & (1.07E-04) & 3.39E-01 & $1.16 E+01$ & $1.1 E+01$ & $1.50 \mathrm{E}-01$ \\
\hline 45.5 & $\mathrm{H} 1$ & $(8.75 \mathrm{E}-05)$ & 3.02E-01 & $1.04 \mathrm{E}+01$ & $1.0 \mathrm{E}+01$ & $(1.39 \mathrm{E}-01)$ \\
\hline 48.0 & H1 & (1.35E-04) & 4.60E-01 & $1.75 E+01$ & $1.7 E+01$ & $1.54 \mathrm{E}-01$ \\
\hline 48.0 Dup & H1 & $(1.49 \mathrm{E}-04)$ & $5.65 \mathrm{E}-01$ & $1.89 \mathrm{E}+01$ & $1.8 \mathrm{E}+01$ & $1.79 \mathrm{E}-01$ \\
\hline 50.5 & H1 & (8.10E-05) & 3.61E-01 & $7.78 \mathrm{E}+00$ & $7.0 \mathrm{E}+00$ & $1.86 \mathrm{E}-01$ \\
\hline 78.0 & $\mathrm{H} 1$ & $(8.08 \mathrm{E}-05)$ & 3.84E-01 & $6.40 \mathrm{E}+00$ & $6.0 \mathrm{E}+00$ & $(1.28 \mathrm{E}-01)$ \\
\hline 82.0 & $\mathrm{H} 2$ & $(9.36 \mathrm{E}-05)$ & 3.72E-01 & $1.12 \mathrm{E}+01$ & $1.1 \mathrm{E}+01$ & $1.60 \mathrm{E}-01$ \\
\hline 82.0 Dup & $\mathrm{H} 2$ & $(1.21 \mathrm{E}-04)$ & 3.83E-01 & $1.15 \mathrm{E}+01$ & $1.2 \mathrm{E}+01$ & $2.14 \mathrm{E}-01$ \\
\hline 85.5 & $\mathrm{H} 2$ & (8.36E-05) & 3.68E-01 & $7.41 \mathrm{E}+00$ & $6.8 \mathrm{E}+00$ & $(1.14 \mathrm{E}-01)$ \\
\hline 95.5 & $\mathrm{H} 2$ & $(1.16 \mathrm{E}-04)$ & $3.60 \mathrm{E}-01$ & $8.05 \mathrm{E}+00$ & $8.3 \mathrm{E}+00$ & $(1.25 \mathrm{E}-01)$ \\
\hline 100.5 & $\mathrm{H} 2$ & $(1.08 \mathrm{E}-04)$ & 4.30E-01 & $8.94 \mathrm{E}+00$ & $9.4 \mathrm{E}+00$ & $1.98 \mathrm{E}-01$ \\
\hline 139.5 & $\mathrm{H} 2$ & (8.66E-05) & $4.10 \mathrm{E}-01$ & $9.94 \mathrm{E}+00$ & $8.9 \mathrm{E}+00$ & $1.95 \mathrm{E}-01$ \\
\hline 145.5 & $\mathrm{H} 2$ & (7.97E-05) & $3.80 \mathrm{E}-01$ & $8.59 \mathrm{E}+00$ & $8.6 \mathrm{E}+00$ & 1.72E-01 \\
\hline 160.5 & $\mathrm{H} 2$ & $(1.04 \mathrm{E}-04)$ & 4.57E-01 & $1.15 \mathrm{E}+01$ & $1.0 \mathrm{E}+01$ & 2.57E-01 \\
\hline 164.5 & $\mathrm{H} 2$ & $(1.17 \mathrm{E}-04)$ & 4.05E-01 & $1.35 \mathrm{E}+01$ & $1.3 \mathrm{E}+01$ & $2.16 \mathrm{E}-01$ \\
\hline 185.5 & $\mathrm{H} 2$ & $(1.20 \mathrm{E}-04)$ & 4.01E-01 & $1.02 \mathrm{E}+01$ & $1.0 \mathrm{E}+01$ & 2.22E-01 \\
\hline 200.5 & $\mathrm{H} 2$ & $(1.04 \mathrm{E}-04)$ & 4.66E-01 & $1.12 \mathrm{E}+01$ & $1.1 \mathrm{E}+01$ & $2.28 \mathrm{E}-01$ \\
\hline 210.5 & $\mathrm{H} 2$ & (1.33E-04) & 3.46E-01 & $9.23 \mathrm{E}+00$ & $9.5 \mathrm{E}+00$ & $1.81 \mathrm{E}-01$ \\
\hline 225.5 & $\mathrm{H} 2$ & $(1.34 \mathrm{E}-04)$ & $3.15 \mathrm{E}-01$ & $8.23 \mathrm{E}+00$ & $7.7 \mathrm{E}+00$ & $(1.25 \mathrm{E}-01)$ \\
\hline \multicolumn{7}{|c|}{$\begin{array}{l}\text { Bold values are higher than others for given constituent. } \\
\text { Parentheses signify values are below level of quantitation. } \\
\text { Dup = duplicate sample }\end{array}$} \\
\hline
\end{tabular}


C4124 (299-E27-22)

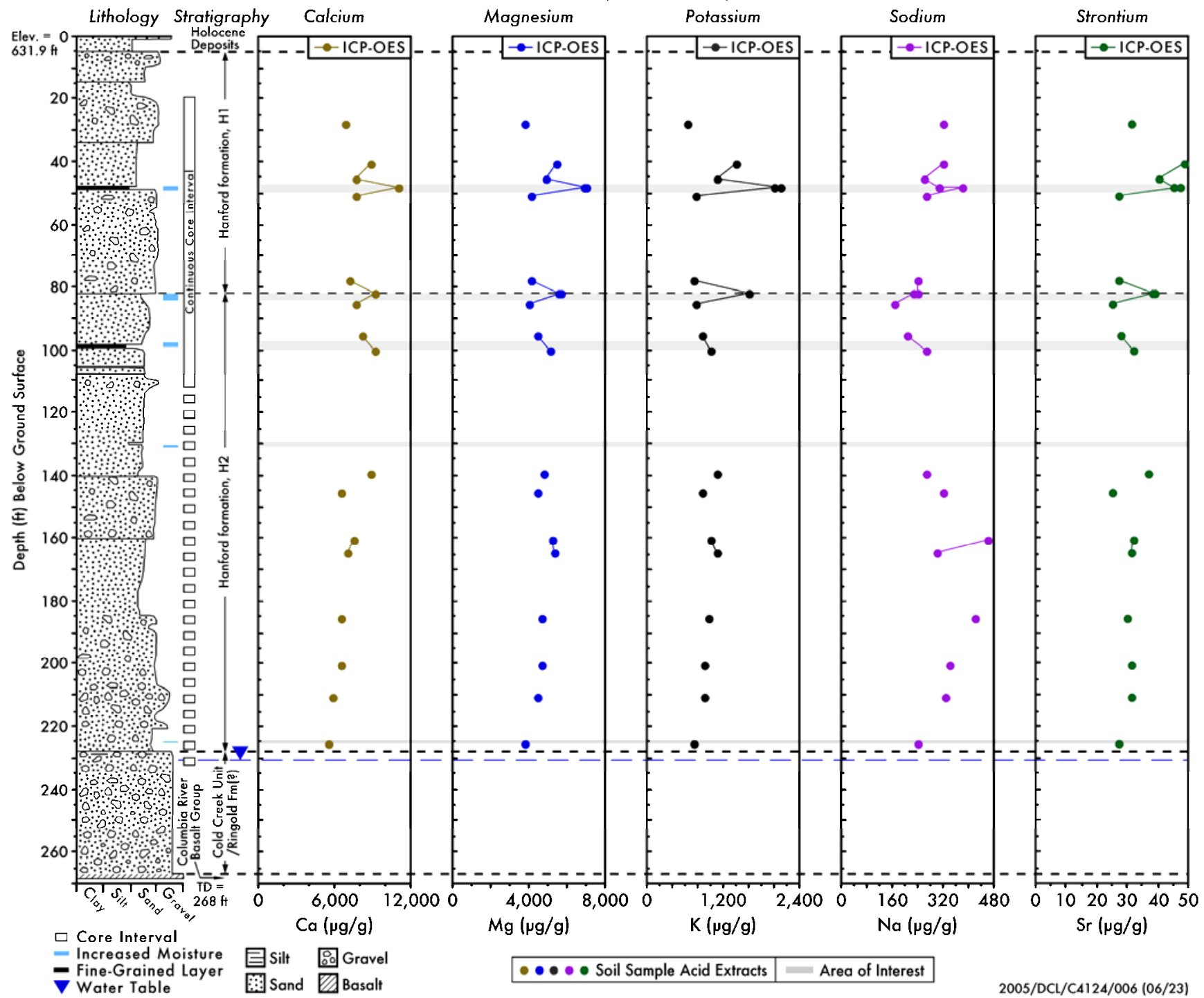

Figure 4.5. Acid-Extractable Concentrations of Major Cations in Borehole 299-E27-22 Sediment 


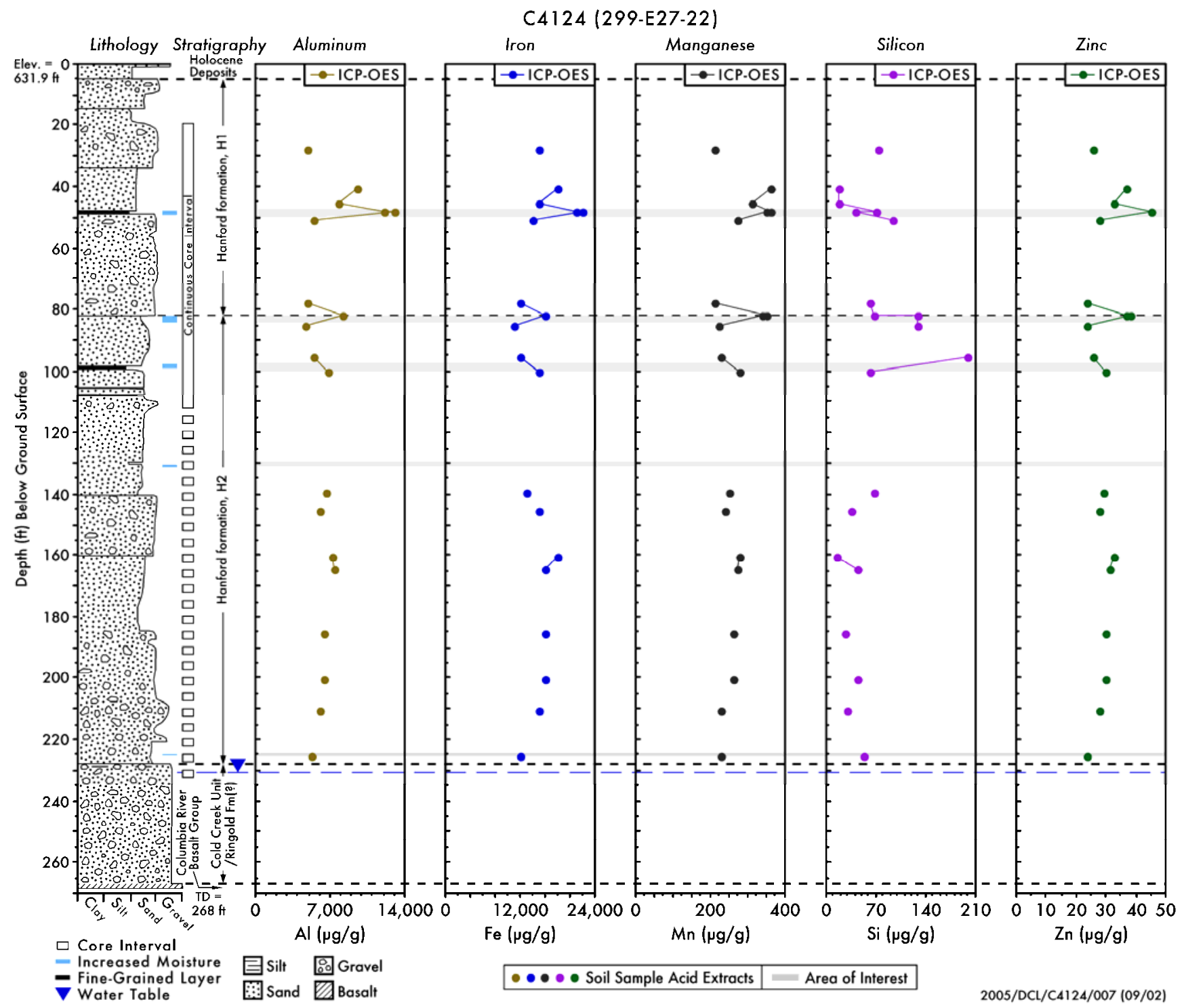

Figure 4.6. Acid-Extractable Concentrations of Aluminum, Iron, Manganese, Silicon, and Zinc from Borehole 299-E27-22 Sediments 
C4124 (299-E27-22)

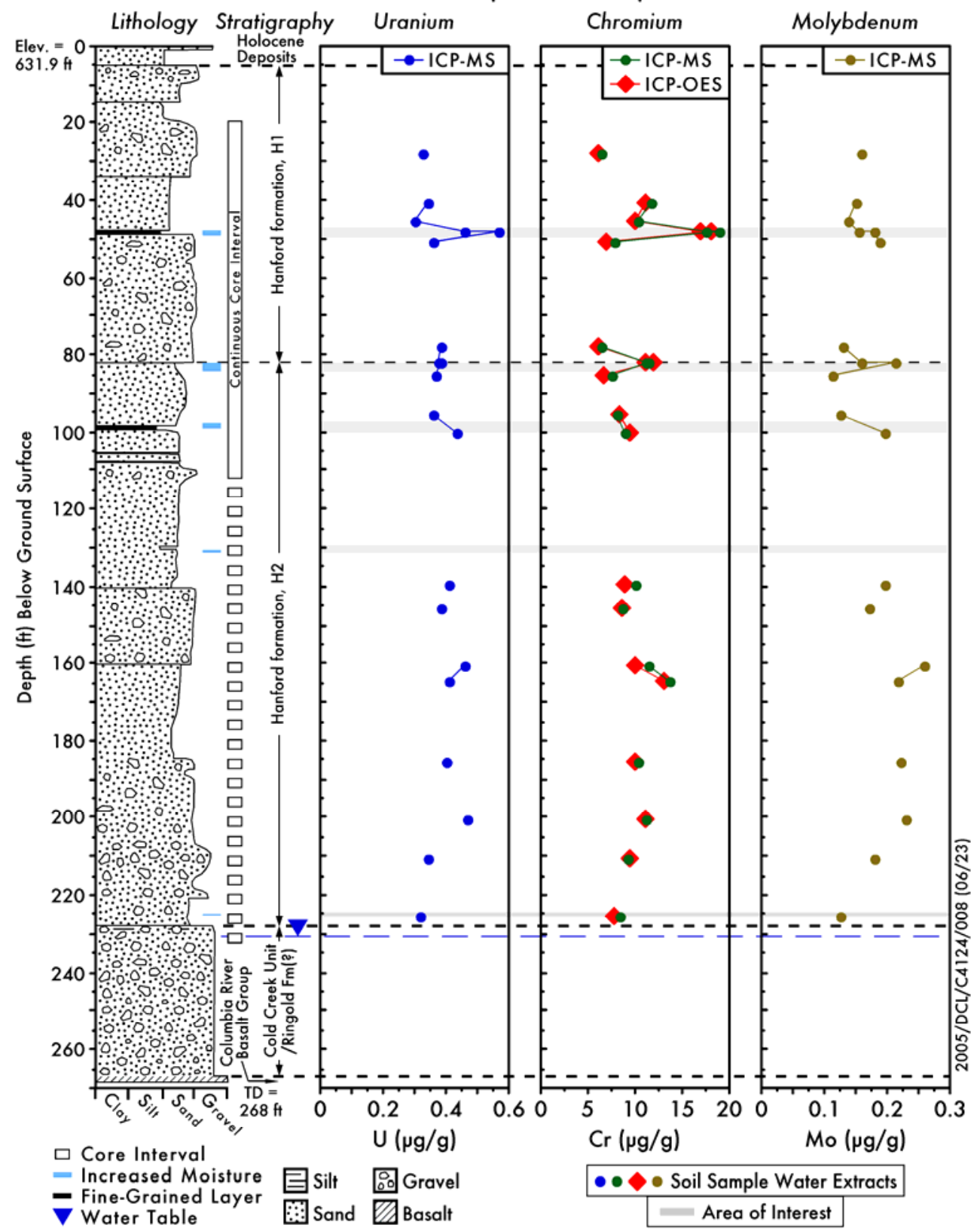

Figure 4.7. Concentration of Uranium-238, Chromium, and Molybdenum in Borehole 299-E27-22 Sediment that is Acid-Extractable. (Technetium-99 and ruthenium were not detected in clean sediments; thus, they are not plotted.) 


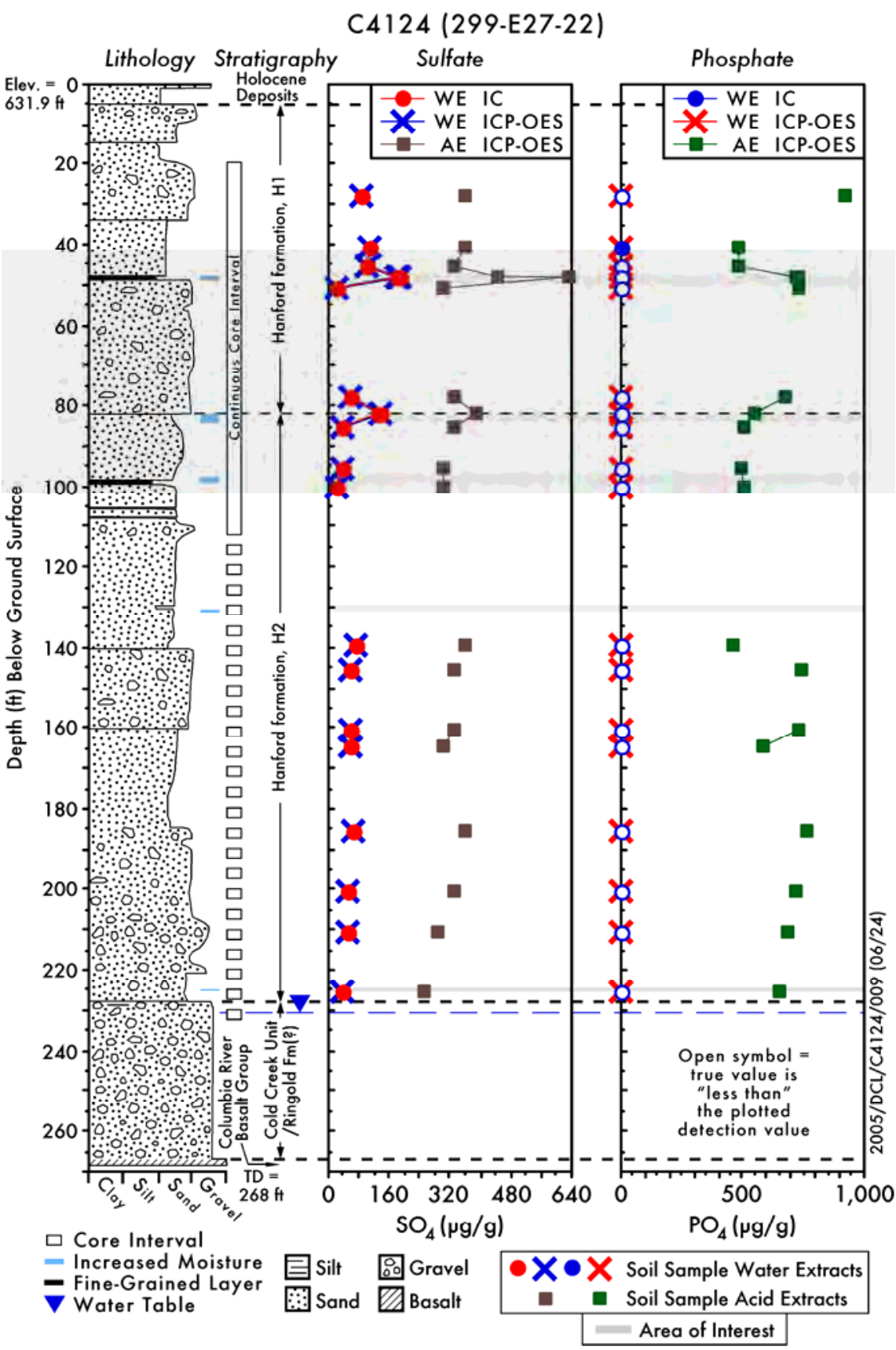

Figure 4.8. Comparison between Acid-and Water-Extractable Sulfate and Phosphate in Vadose Zone Sediments from Borehole 299-E27-22 
Table 4.10. Total Chemical Composition of Borehole 299-E27-22 Sediments (as Weight \% Oxides)

\begin{tabular}{|c|c|c|c|c|c|}
\hline Depth (ft bgs) & 24.5 & 47.0 & 89.5 & 129.5 & 225.5 \\
\hline $\begin{array}{l}\text { Stratigraphic Unit } \\
\text { (Hanford formation) }\end{array}$ & H1 & H1 & H2 & H2 & H2 \\
\hline $\mathrm{Na}_{2} \mathrm{O}$ & $3.35 \mathrm{E}+00$ & $3.05 \mathrm{E}+00$ & $2.78 \mathrm{E}+00$ & $2.77 \mathrm{E}+00$ & $3.12 \mathrm{E}+00$ \\
\hline $\mathrm{MgO}$ & $2.06 \mathrm{E}+00$ & $1.24 \mathrm{E}+00$ & $1.31 \mathrm{E}+00$ & $1.18 \mathrm{E}+00$ & $1.61 \mathrm{E}+00$ \\
\hline $\mathrm{Al}_{2} \mathrm{O}_{3}$ & $1.38 \mathrm{E}+01$ & $1.27 \mathrm{E}+01$ & $1.23 \mathrm{E}+01$ & $1.24 \mathrm{E}+01$ & $1.31 \mathrm{E}+01$ \\
\hline $\mathrm{SiO}_{2}$ & $6.34 \mathrm{E}+01$ & $7.13 \mathrm{E}+01$ & $7.20 \mathrm{E}+01$ & $7.28 \mathrm{E}+01$ & $6.81 \mathrm{E}+01$ \\
\hline $\mathrm{P}_{2} \mathrm{O}_{5}$ & 2.12E-01 & $1.20 \mathrm{E}-01$ & 1.31E-01 & 1.19E-01 & 1.71E-01 \\
\hline $\mathrm{K}_{2} \mathrm{O}$ & $1.59 \mathrm{E}+00$ & $1.93 \mathrm{E}+00$ & $2.29 \mathrm{E}+00$ & $2.42 \mathrm{E}+00$ & $1.92 \mathrm{E}+00$ \\
\hline $\mathrm{CaO}$ & $5.93 \mathrm{E}+00$ & $3.82 \mathrm{E}+00$ & $3.69 \mathrm{E}+00$ & $3.48 \mathrm{E}+00$ & $4.45 \mathrm{E}+00$ \\
\hline $\mathrm{TiO}_{2}$ & $1.32 \mathrm{E}+00$ & 6.89E-01 & 6.66E-01 & 5.65E-01 & 9.81E-01 \\
\hline $\mathrm{MnO}$ & 1.26E-01 & 8.56E-02 & 7.09E-02 & 6.03E-02 & 9.82E-02 \\
\hline $\mathrm{Fe}_{2} \mathrm{O}_{3}$ & $7.96 \mathrm{E}+00$ & $4.63 \mathrm{E}+00$ & $4.36 \mathrm{E}+00$ & $3.77 \mathrm{E}+00$ & $6.15 \mathrm{E}+00$ \\
\hline $\mathrm{Cr}_{2} \mathrm{O}_{3}$ & 3.46E-03 & 3.55E-03 & 2.37E-03 & 2.81E-03 & 3.30E-03 \\
\hline $\mathrm{NiO}$ & 3.60E-03 & 2.90E-03 & 2.35E-03 & ND & 2.49E-03 \\
\hline $\mathrm{CuO}$ & $2.04 \mathrm{E}-03$ & $1.94 \mathrm{E}-03$ & $1.89 \mathrm{E}-03$ & 1.79E-03 & 2.04E-03 \\
\hline $\mathrm{ZnO}$ & 4.69E-03 & 3.58E-03 & 3.32E-03 & 3.11E-03 & 3.90E-03 \\
\hline $\mathrm{Rb}_{2} \mathrm{O}$ & 3.98E-03 & 5.40E-03 & 7.46E-03 & 8.05E-03 & 5.20E-03 \\
\hline $\mathrm{SrO}$ & 3.94E-02 & 4.63E-02 & 4.00E-02 & 4.09E-02 & 3.72E-02 \\
\hline $\mathrm{ZrO}_{2}$ & $1.41 \mathrm{E}-02$ & 1.17E-02 & $1.42 \mathrm{E}-02$ & $1.20 \mathrm{E}-02$ & 1.18E-02 \\
\hline $\mathrm{BaO}$ & 7.37E-02 & 7.90E-02 & 8.04E-02 & 9.15E-02 & 7.79E-02 \\
\hline $\mathrm{YO}_{2}$ & $(2.30 \mathrm{E}-03)$ & $(2.20 \mathrm{E}-03)$ & $(1.90 \mathrm{E}-03)$ & (1.80E-03) & (2.60E-03) \\
\hline $\mathrm{LOI}^{\mathrm{c}}$ & 1.05E-01 & 2.08E-01 & 2.70E-01 & 2.75E-01 & 1.51E-01 \\
\hline Total (no LOI) & 99.99 & 99.72 & 99.75 & 99.73 & 99.84 \\
\hline Total (with LOI) & 100.00 & 99.93 & 100.02 & 100.00 & 100.00 \\
\hline \multicolumn{6}{|c|}{$\begin{array}{l}\text { Parentheses signify values below level of quantitation. } \\
\mathrm{ND}=\text { Analyte was not detected in the sample } \\
\text { LOI = Loss on ignition }\end{array}$} \\
\hline
\end{tabular}

\subsubsection{Total Carbon, Calcium Carbonate, and Organic Carbon Content of Vadose Zone Sediment from Borehole 299-E27-22}

Table 4.11 shows the total carbon, inorganic carbon, and organic carbon contents of the vadose zone sediment collected from borehole 299-E27-22. The inorganic carbon was also converted to the equivalent calcium-carbonate content. The sediment in the Hanford formation H1 and H2 units was relatively low in calcium carbonate ( $<3 \mathrm{wt} \%$ ), with little to no organic carbon. These values are quite typical and compare well with other RCRA borehole samples collected from other locations around the Hanford site (Serne et al. 2004b for WMA T and Brown et al. 2005 for WMA A-AX). 
Table 4.11. Total, Inorganic, and Organic Carbon Content of Vadose Zone Sediments from Borehole 299-E27-22

\begin{tabular}{|l|l|l|l|l|l||}
\hline $\begin{array}{c}\text { Depth } \\
\text { (ft) }\end{array}$ & $\begin{array}{c}\text { Stratigraphic Unit } \\
\text { (Hanford formation) }\end{array}$ & $\begin{array}{c}\text { Total } \\
\text { Carbon } \\
(\%)\end{array}$ & $\begin{array}{c}\text { Inorganic } \\
\text { Carbon } \\
(\%)\end{array}$ & $\begin{array}{c}\text { Inorganic Carbon } \\
\text { as CaCO } \\
\text { (\%) }\end{array}$ & $\begin{array}{c}\text { Organic } \\
\text { Carbon } \\
\text { (by difference) }\end{array}$ \\
\hline 28.0 & H1 & 0.12 & 0.09 & 0.76 & 0.03 \\
\hline 40.5 & H1 & 0.23 & 0.17 & 1.43 & 0.05 \\
\hline 45.5 & H1 & 0.18 & 0.16 & 1.37 & 0.01 \\
\hline 48.0 & H1 & 0.32 & 0.27 & 2.22 & 0.05 \\
\hline 48.0 Dup & H1 & 0.31 & 0.29 & 2.40 & 0.02 \\
\hline 50.5 & H1 & 0.30 & 0.17 & 1.41 & 0.13 \\
\hline 78.0 & H1 & 0.22 & 0.20 & 1.65 & 0.02 \\
\hline 82.0 & H2 & 0.27 & 0.24 & 1.96 & 0.03 \\
\hline 82.0 Dup & H2 & 0.29 & 0.28 & 2.34 & 0.01 \\
\hline 85.5 & H2 & 0.29 & 0.28 & 2.35 & 0.01 \\
\hline 95.5 & H2 & 0.24 & 0.24 & 1.97 & 0.00 \\
\hline 100.5 & H2 & 0.27 & 0.28 & 2.31 & 0.00 \\
\hline 139.5 & H2 & 0.28 & 0.27 & 2.24 & 0.01 \\
\hline 145.5 & H2 & 0.16 & 0.13 & 1.12 & 0.03 \\
\hline 160.5 & H2 & 0.17 & 0.13 & 1.12 & 0.03 \\
\hline 164.5 & H2 & 0.18 & 0.14 & 1.18 & 0.04 \\
\hline 185.5 & H2 & 0.14 & 0.11 & 0.89 & 0.04 \\
\hline 200.5 & H2 & 0.16 & 0.17 & 1.41 & 0.00 \\
\hline 210.5 & H2 & 0.17 & 0.15 & 1.26 & 0.02 \\
\hline 225.5 & & 0.17 & 0.13 & 1.06 & 0.04 \\
\hline Dup & & & & & \\
\hline
\end{tabular}

\subsubsection{Particle Size Measurements on Vadose Zone Sediment}

Both the hydrometer and wet sieving methods were used to determine the particle-size distributions of samples from borehole 299-E27-22. Wet sieving results are shown in Table 4.12 and the particle-size distribution data from the wet sieving and hydrometer analyses are shown in Table 4.13 and Figures 4.9 and 4.10 as plots of "cumulative percent finer than" versus "particle size in microns". Although all of the samples were selected for geochemical characterization, the aliquots of material chosen for characterization from each sample were biased in favor of the fine-grained strata since these tend to contain more moisture and are more likely to have contaminants associated with them. Therefore, the values in Table 4.13 should not be considered fully representative of the bulk of the Hanford formation $\mathrm{H} 1$ and $\mathrm{H} 2$ units. The $\mathrm{H} 1$ sample at $48 \mathrm{ft}$ bgs, with a median grain size of $\sim 74$ microns, was the finest grained sediment of the eighteen samples characterized (6 H1 samples and $12 \mathrm{H} 2$ samples). Based on the six $\mathrm{H} 1$ samples characterized, it appears that the fine-grained lens in this formation was isolated between 45 and $48 \mathrm{ft}$ bgs. The two samples collected at 40.5 and $45.5 \mathrm{ft}$ bgs both had median grain sizes of $\sim 250$ microns, compared to median grain sizes of 1,000 microns for the remaining samples from the 
Hanford formation H1 unit. The twelve samples from the H2 unit indicated that a similar percentage of silt/clay material was present in all of the samples. With the exception of two samples (82.0 and $139.5 \mathrm{ft}$ bgs), all of the samples from the Hanford formation $\mathrm{H} 2$ unit had median grain sizes between 500 to 1,000 microns. Significant differences were reported in the gravel component of the $12 \mathrm{H} 2$ unit samples $(0.2 \%$ to $25 \%)$, but as mentioned previously, this characterization effort focused on the finest-grained material present in each splitspoon core.

Table 4.12. Wet Sieve Particle Size Results for Borehole 299-E27-22 Sediments

\begin{tabular}{|c|c|c|c|c|}
\hline \multirow{2}{*}{$\begin{array}{l}\text { Depth } \\
\text { (ft bgs) }\end{array}$} & \multirow{2}{*}{$\begin{array}{l}\text { Stratigraphic Unit } \\
\text { (Hanford formation) }\end{array}$} & \multicolumn{3}{|c|}{ Weight Percent } \\
\hline & & Gravel & Sand & Silt/Clay \\
\hline 28.0 & H1 & 28.2 & 62.9 & 8.78 \\
\hline 40.5 & $\mathrm{H} 1$ & 0.104 & 85.1 & 14.3 \\
\hline 45.5 & $\mathrm{H} 1$ & 0.136 & 88.9 & 10.5 \\
\hline 48.0 & H1 & 0 & 61.6 & 36.3 \\
\hline 50.5 & H1 & 22.1 & 72.3 & 5.58 \\
\hline 78.0 & H1 & 11.0 & 77.6 & 11.2 \\
\hline 82.0 & $\mathrm{H} 2$ & 0.165 & 87.5 & 11.9 \\
\hline 85.5 & $\mathrm{H} 2$ & 1.74 & 89.6 & 8.61 \\
\hline 95.5 & $\mathrm{H} 2$ & 1.10 & \begin{tabular}{|l|}
88.4 \\
\end{tabular} & 10.4 \\
\hline 100.5 & $\mathrm{H} 2$ & 0.424 & 90.8 & 8.62 \\
\hline 139.5 & $\mathrm{H} 2$ & 0.112 & 88.4 & 11.0 \\
\hline 145.5 & $\mathrm{H} 2$ & 24.7 & 66.1 & 9.09 \\
\hline 160.5 & $\mathrm{H} 2$ & 15.9 & 68.8 & 15.2 \\
\hline 164.5 & $\mathrm{H} 2$ & 3.21 & 89.1 & 7.53 \\
\hline 185.5 & $\mathrm{H} 2$ & 18.9 & 60.9 & 20.0 \\
\hline 200.5 & $\mathrm{H} 2$ & 17.3 & 73.5 & 9.12 \\
\hline 210.5 & $\mathrm{H} 2$ & 17.1 & 68.5 & 14.2 \\
\hline 225.5 & $\mathrm{H} 2$ & 11.7 & 76.2 & 11.9 \\
\hline
\end{tabular}

\subsubsection{Matric Suction Potential Measurements}

Water potential measurements have been included in the Hanford Tank Farm Vadose Zone Characterization Program to document the energy state of pore waters in the tank farm sediments. At the tank farms, vegetation is absent, surface soils are coarse-textured, and the potential for drainage (recharge) is high (Gee 1987; Gee et al. 1992). However, actual drainage rates are generally unknown. Attempts are currently being made to status the soil water matrix potential and use the analysis to confirm the occurrence of recharge within the Hanford Site tank farms. 
Table 4.13. Particle Size Data for Borehole 299-E27-22 Sediments Using Two Techniques Reported as Cumulative Percent Finer Than

\begin{tabular}{|c|c|c|c|c|c|c|c|c|c|c|c|c|}
\hline $\begin{array}{c}\text { Stratigraphic Unit } \\
\text { (Hanford formation) }\end{array}$ & \multicolumn{2}{|c|}{ H1 } & \multicolumn{2}{|c|}{ H1 } & \multicolumn{2}{|c|}{ H1 } & \multicolumn{2}{|c|}{ H1 } & \multicolumn{2}{|c|}{ H1 } & \multicolumn{2}{|c|}{ H1 } \\
\hline $\begin{array}{c}\text { Sample depth } \\
\text { (ft bgs) }\end{array}$ & \multicolumn{2}{|c|}{28.0} & \multicolumn{2}{|c|}{40.5} & \multicolumn{2}{|c|}{45.5} & \multicolumn{2}{|c|}{48.0} & \multicolumn{2}{|c|}{50.5} & \multicolumn{2}{|c|}{78.0} \\
\hline & $\begin{array}{c}\text { Diameter } \\
(\mu \mathrm{m})\end{array}$ & $\begin{array}{c}\% \\
\text { finer than }\end{array}$ & $\begin{array}{c}\text { Diameter } \\
(\mu \mathrm{m})\end{array}$ & $\begin{array}{c}\% \\
\text { finer than }\end{array}$ & $\begin{array}{c}\text { Diameter } \\
(\mu \mathrm{m})\end{array}$ & $\begin{array}{c}\% \\
\text { finer than }\end{array}$ & $\begin{array}{c}\text { Diameter } \\
(\mu \mathrm{m})\end{array}$ & $\begin{array}{c}\% \\
\text { finer than }\end{array}$ & $\begin{array}{c}\text { Diameter } \\
(\mu \mathrm{m})\end{array}$ & $\begin{array}{c}\% \\
\text { finer than }\end{array}$ & $\begin{array}{c}\text { Diameter } \\
(\mu \mathrm{m})\end{array}$ & $\begin{array}{c}\% \\
\text { finer than }\end{array}$ \\
\hline & \multicolumn{12}{|c|}{ Wet Sieve } \\
\hline & 2,000 & 71.8 & 2,000 & 99.9 & |2,000 & 99.9 & |2,000 & 100 & 2,000 & 77.9 & 2,000 & 89.0 \\
\hline & 1,000 & 45.5 & 1,000 & 99.5 & 1,000 & 97.7 & 1,000 & 100 & 1,000 & 43.9 & 1,000 & 58.0 \\
\hline & 500 & 28.7 & 500 & 91.0 & 500 & 88.6 & 500 & 99.9 & 500 & 20.4 & 500 & 32.6 \\
\hline & 250 & 18.9 & 250 & 48.2 & 250 & 42.1 & 250 & 99.8 & 250 & 12.9 & 250 & 23.5 \\
\hline & 105 & 12.2 & 105 & 22.3 & 105 & 17.4 & 105 & 77.4 & 105 & 7.43 & 105 & 15.1 \\
\hline & 74 & 10.3 & 74 & 17.9 & 74 & 14.0 & 74 & 57.4 & 74 & 6.48 & 74 & 13.3 \\
\hline & 53 & 9.02 & 53 & 15.0 & 53 & 10.9 & 53 & 38.9 & 53 & 5.66 & 53 & 11.6 \\
\hline & \multicolumn{12}{|c|}{ Hydrometer } \\
\hline & 81.17 & 10.8 & 82.98 & 16.8 & 81.71 & 13.0 & 89.02 & 50.9 & 79.88 & 6.43 & 81.17 & 12.8 \\
\hline & 57.13 & 9.45 & 58.29 & 14.9 & 57.26 & 10.2 & 60.54 & 34.2 & 56.35 & 5.72 & 57.26 & 12.1 \\
\hline & 32.76 & 7.43 & 33.21 & 11.0 & 32.76 & 7.51 & 33.66 & 19.2 & 32.46 & 5.00 & 32.91 & 10.6 \\
\hline & 17.86 & 6.08 & 18.03 & 8.41 & 17.86 & 6.14 & 18.27 & 15.9 & 17.78 & 5.00 & 17.90 & 8.30 \\
\hline & 10.29 & 5.40 & 10.36 & 7.12 & 10.31 & 6.14 & 10.43 & 11.7 & 10.26 & 5.00 & 10.31 & 7.54 \\
\hline & 7.26 & 4.73 & 7.33 & 7.12 & 7.26 & 4.78 & 7.34 & 10.0 & 7.22 & 3.57 & 7.26 & 6.04 \\
\hline & 5.93 & 4.73 & 5.95 & 5.83 & 5.93 & 4.78 & 5.98 & 9.18 & 5.90 & 3.57 & 5.93 & 6.04 \\
\hline & 5.13 & 4.73 & 5.16 & 5.83 & 5.13 & 4.78 & $\mid 5.17$ & 8.35 & 5.11 & 3.57 & 5.13 & 6.04 \\
\hline & 1.47 & 4.05 & $\mid$\begin{tabular}{||l}
$\mid c$ \\
1.48
\end{tabular} & 5.18 & $\mid 1.47$ & 4.09 & $\mid 1.48$ & 6.68 & 1.47 & 4.29 & 1.47 & 4.53 \\
\hline
\end{tabular}


Table 4.13. (contd)

\begin{tabular}{|c|c|c|c|c|c|c|c|c|c|c|c|c|}
\hline $\begin{array}{c}\text { Stratigraphic Unit } \\
\text { (Hanford formation) }\end{array}$ & \multicolumn{2}{|c|}{ H2 } & \multicolumn{2}{|c|}{ H2 } & \multicolumn{2}{|c|}{ H2 } & \multicolumn{2}{|c|}{ H2 } & \multicolumn{2}{|c|}{ H2 } & \multicolumn{2}{|c|}{ H2 } \\
\hline $\begin{array}{l}\text { Sample depth } \\
\text { (ft bgs) }\end{array}$ & \multicolumn{2}{|c|}{82.0} & \multicolumn{2}{|c|}{85.5} & \multicolumn{2}{|c|}{95.5} & \multicolumn{2}{|c|}{100.5} & \multicolumn{2}{|c|}{139.5} & \multicolumn{2}{|c|}{145.5} \\
\hline & $\begin{array}{c}\text { Diameter } \\
(\mu \mathrm{m})\end{array}$ & $\begin{array}{c}\% \\
\text { finer than }\end{array}$ & $\begin{array}{c}\text { Diameter } \\
(\mu \mathrm{m})\end{array}$ & $\begin{array}{c}\% \\
\text { finer than }\end{array}$ & \begin{tabular}{|c} 
Diameter \\
$(\mu \mathrm{m})$
\end{tabular} & $\begin{array}{c}\% \\
\text { finer than }\end{array}$ & \begin{tabular}{|c} 
Diameter \\
$(\mu \mathrm{m})$
\end{tabular} & $\begin{array}{c}\% \\
\text { finer than }\end{array}$ & $\begin{array}{c}\text { Diameter } \\
(\mu \mathrm{m})\end{array}$ & $\begin{array}{c}\% \\
\text { finer than }\end{array}$ & $\begin{array}{c}\text { Diameter } \\
(\mu \mathrm{m})\end{array}$ & $\begin{array}{c}\% \\
\text { finer than }\end{array}$ \\
\hline & \multicolumn{12}{|c|}{ Wet Sieve } \\
\hline & 2,000 & 99.8 & 2, 2,000 & 98.3 & || 2,000 & 98.9 & || 2,000 & 99.6 & 2,000 & 99.9 & 2,000 & 75.3 \\
\hline & 1,000 & 98.6 & $\mid 1,000$ & 72.9 & $\mid 1,000$ & 74.0 & $\mid 1,000$ & 75.6 & 1,000 & 93.2 & $\mid 1,000$ & 47.2 \\
\hline & 500 & 94.1 & 500 & 31.6 & $\mid 500$ & 40.6 & | 500 & 31.4 & 500 & 60.2 & 500 & 25.9 \\
\hline & 250 & 70.6 & $\mid 250$ & 21.0 & $\mid 250$ & 23.9 & $\mid 250$ & 19.8 & 250 & 32.3 & 250 & 18.5 \\
\hline & 105 & 23.4 & $\mid 05$ & 12.0 & $\mid 105$ & 14.6 & $\mid 105$ & 12.0 & 105 & 16.5 & 105 & 12.1 \\
\hline & 74 & 17.5 & 74 & 10.3 & 74 & 12.1 & 74 & 10.2 & 74 & 14.0 & 74 & 10.7 \\
\hline & 53 & 12.6 & 53 & 8.81 & | 53 & 10.5 & | 53 & 8.75 & 53 & 11.7 & 53 & 9.32 \\
\hline & \multicolumn{12}{|c|}{ Hydrometer } \\
\hline & 82.08 & 16.5 & 80.43 & 10.5 & 80.62 & 10.6 & 81.35 & 8.49 & 82.08 & 11.2 & 81.71 & 10.8 \\
\hline & 57.52 & 13.5 & 56.74 & 9.65 & $\mid 56.87$ & 9.80 & $\mid 57.39$ & 7.88 & 57.78 & 9.94 & 57.52 & 9.45 \\
\hline & 32.91 & 10.5 & || $\mid 32.61$ & 8.04 & || 32.69 & 8.29 & ||33.06 & 7.27 & 33.06 & 7.46 & 33.06 & 8.10 \\
\hline & $\mid$\begin{tabular}{||l|}
17.90 \\
\end{tabular} & 8.25 & | 17.82 & 7.24 & $\mid$\begin{tabular}{||l}
17.86 \\
\end{tabular} & 7.54 & | 18.03 & 6.06 & $\mid 18.11$ & 7.46 & 18.07 & 7.43 \\
\hline & 10.31 & 7.50 & || 10.26 & 6.43 & $\mid 10.29$ & 6.78 & $\mid 10.41$ & 6.06 & 10.41 & 6.21 & 10.41 & 6.75 \\
\hline & 7.26 & 6.00 & | 7.26 & 6.43 & $\mid 7.26$ & 6.03 & $\mid 7.36$ & 6.06 & 7.36 & 6.21 & 7.36 & 6.75 \\
\hline & 5.93 & 6.00 & $\mid$\begin{tabular}{||l}
$\mid$ \\
5.91
\end{tabular} & 5.63 & ||$-9.93$ & 6.03 & $\mid$\begin{tabular}{||c}
$\mid$ \\
$\mid$
\end{tabular} & 6.06 & 6.00 & 5.59 & 6.01 & 6.75 \\
\hline & 5.13 & 6.00 & 5.12 & 5.63 & 5.13 & 6.03 & 5.18 & 4.85 & 5.18 & 4.97 & 5.18 & 5.40 \\
\hline & 1.47 & 4.50 & $\mid$\begin{tabular}{||l}
$\mid$ \\
$\mid$
\end{tabular} & 5.63 & $\mid$\begin{tabular}{||l}
$\mid c$ \\
1.48
\end{tabular} & 5.28 & $\mid$\begin{tabular}{||l}
$\mid$ \\
1.49
\end{tabular} & 4.24 & 1.49 & 4.35 & 1.49 & 4.73 \\
\hline
\end{tabular}


Table 4.13. (contd)

\begin{tabular}{|c|c|c|c|c|c|c|c|c|c|c|c|c|}
\hline $\begin{array}{c}\text { Stratigraphic Unit } \\
\text { (Hanford formation) }\end{array}$ & \multicolumn{2}{|c|}{ H2 } & \multicolumn{2}{|c|}{ H2 } & \multicolumn{2}{|c|}{ H2 } & \multicolumn{2}{|c|}{ H2 } & \multicolumn{2}{|c|}{ H2 } & \multicolumn{2}{|c|}{ H2 } \\
\hline $\begin{array}{c}\text { Sample depth } \\
\text { (ft bgs) }\end{array}$ & \multicolumn{2}{|c|}{160.5} & \multicolumn{2}{|c|}{164.5} & \multicolumn{2}{|c|}{185.5} & \multicolumn{2}{|c|}{200.5} & \multicolumn{2}{|c|}{210.5} & \multicolumn{2}{|c|}{225.5} \\
\hline & $\begin{array}{c}\text { Diameter } \\
(\mu \mathrm{m})\end{array}$ & $\begin{array}{c}\% \\
\text { finer than }\end{array}$ & \begin{tabular}{|c|} 
Diameter \\
$(\mu \mathrm{m})$
\end{tabular} & $\begin{array}{c}\% \\
\text { finer than }\end{array}$ & $\begin{array}{c}\text { Diameter } \\
(\mu \mathrm{m})\end{array}$ & $\begin{array}{c}\% \\
\text { finer than }\end{array}$ & $\begin{array}{c}\text { Diameter } \\
(\mu \mathrm{m})\end{array}$ & $\begin{array}{c}\% \\
\text { finer than }\end{array}$ & $\begin{array}{c}\text { Diameter } \\
(\mu \mathrm{m})\end{array}$ & $\begin{array}{c}\% \\
\text { finer than }\end{array}$ & $\begin{array}{c}\text { Diameter } \\
(\mu \mathrm{m})\end{array}$ & $\begin{array}{c}\% \\
\text { finer than }\end{array}$ \\
\hline & \multicolumn{12}{|c|}{ Wet Sieve } \\
\hline & 2,000 & 84.2 & 2,000 & 96.8 & 2,000 & 82.2 & 2,000 & 82.7 & 2,000 & 82.8 & 2,000 & 88.3 \\
\hline & 1,000 & 59.1 & 1,000 & 79.7 & 1,000 & 62.3 & 1,000 & 60.2 & 1,000 & 59.4 & 1,000 & 61.0 \\
\hline & 500 & 37.5 & 500 & 39.9 & 500 & 44.4 & 500 & 33.1 & 500 & 40.7 & 500 & 34.8 \\
\hline & 250 & 27.9 & 250 & 18.4 & 250 & 36.1 & 250 & 21.1 & 250 & 29.8 & 250 & 25.5 \\
\hline & 105 & 19.9 & 105 & 10.4 & 105 & 27.2 & 105 & 12.5 & 105 & 18.9 & 105 & 15.5 \\
\hline & 74 & 17.8 & 74 & 8.94 & 74 & 25.9 & 74 & 10.9 & 74 & 15.9 & 74 & 13.8 \\
\hline & 53 & 15.5 & 53 & 7.54 & 53 & 25.0 & 53 & 9.24 & 53 & 14.0 & 53 & 12.0 \\
\hline & \multicolumn{12}{|c|}{ Hydrometer } \\
\hline & 82.80 & 15.3 & 80.98 & 8.86 & 84.22 & 20.0 & 81.35 & 10.4 & 83.16 & 15.9 & 82.08 & 13.5 \\
\hline & 58.29 & 13.9 & 57.13 & 8.12 & 59.30 & 18.7 & 57.52 & 10.4 & 58.67 & 15.3 & 57.78 & 12.0 \\
\hline & 33.43 & 11.8 & | 32.91 & 7.38 & 33.95 & 16.0 & 32.99 & 8.15 & 33.66 & 13.3 & 33.21 & 10.5 \\
\hline & 18.23 & 10.4 & 18.03 & 7.38 & 18.43 & 12.7 & 18.03 & 7.41 & 18.27 & 10.6 & 18.11 & 8.97 \\
\hline & 10.48 & 9.01 & 10.34 & 5.17 & 10.57 & 10.7 & 10.36 & 5.92 & 10.50 & 9.28 & 10.41 & 7.47 \\
\hline & 7.39 & 8.32 & 7.31 & 5.17 & 7.44 & 9.34 & 7.33 & 5.18 & 7.39 & 7.29 & 7.36 & 7.47 \\
\hline & 6.01 & 6.93 & 5.97 & 5.17 & 6.06 & 8.67 & 5.97 & 4.44 & 6.01 & 5.97 & 5.98 & 5.23 \\
\hline & 5.20 & 6.93 & 5.17 & 5.17 & 5.25 & 8.67 & 5.17 & 4.44 & 5.20 & 5.97 & 5.18 & 5.23 \\
\hline & 1.49 & 4.16 & 1.49 & 4.43 & 1.50 & 6.67 & 1.49 & 4.44 & 1.50 & 5.30 & 1.49 & 4.48 \\
\hline
\end{tabular}




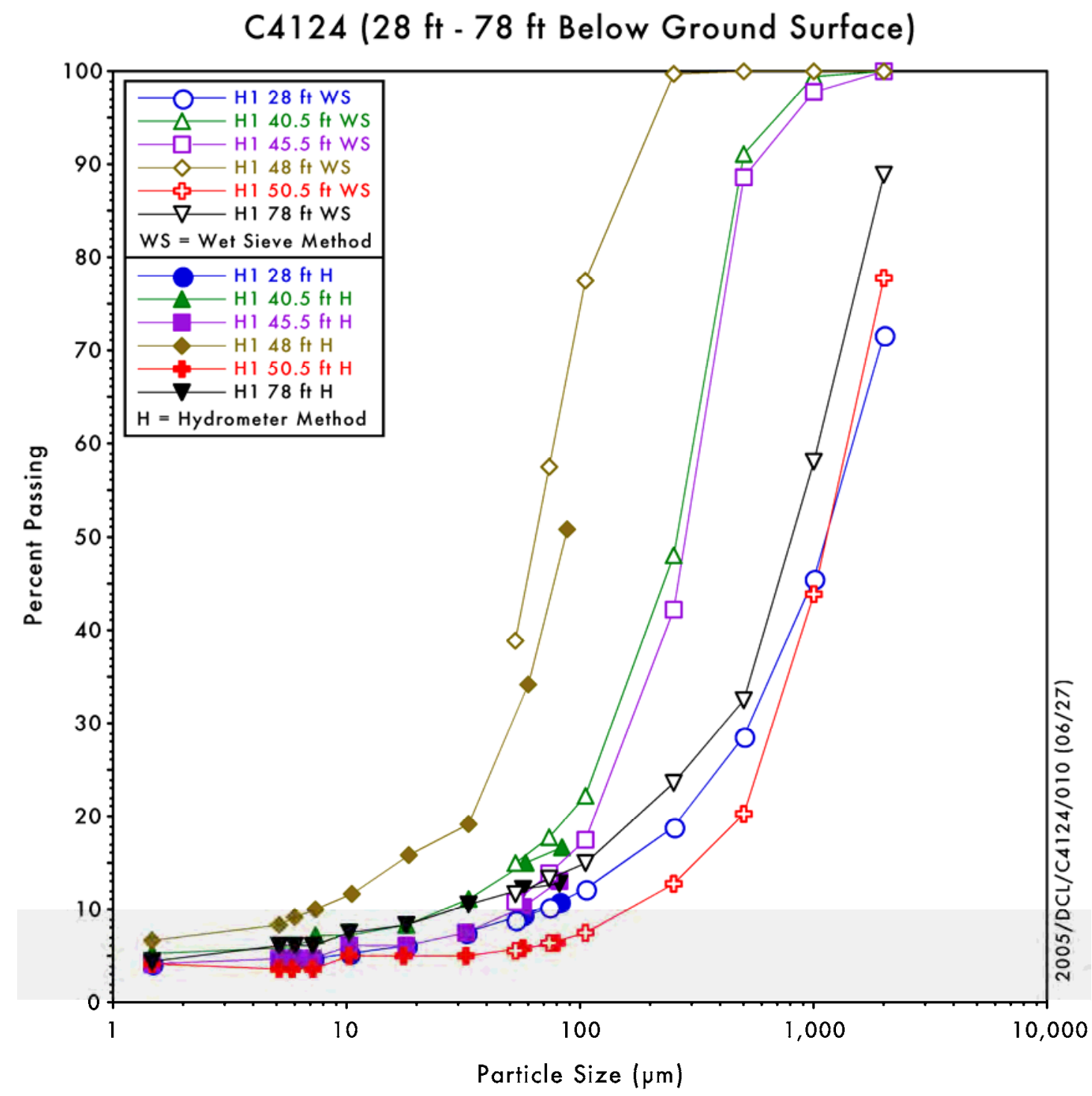

Figure 4.9. Particle-Size Distribution of Hanford formation H1 Unit Sub-Samples from Borehole 299-E27-22

The status of soil water can be defined by either the amount of water in the soil (water content) or by the force that holds water to the soil matrix (i.e., the matric potential or suction) (Or and Wraith 2002). In recent studies, Serne et al. (2002b, 2002c, 2002e, and 2002f) and Lindenmeier et al. (2002) measured both water content (gravimetrically) and matric water potential (filter paper method, ASTM 2002) on core samples obtained from boreholes in the SX and B-BX Tank Farm environs. The same measurements were made at borehole 299-E27-22 near the C Tank Farm. At 299-E27-22, continuous coring was performed from approximately 19 to $111 \mathrm{ft}$ bgs. An additional 45 spilt-spoon samples were collected at 5-ft intervals from approximately 114 to $231 \mathrm{ft}$ bgs. The water table in this region was at $230.5 \mathrm{ft}$ bgs; therefore, the profile of matric potential data presented in this report is inclusive for borehole 299-E27-22 from ground surface to the water table. 
C4124 (82 ft - $225.5 \mathrm{ft}$ Below Ground Surface)

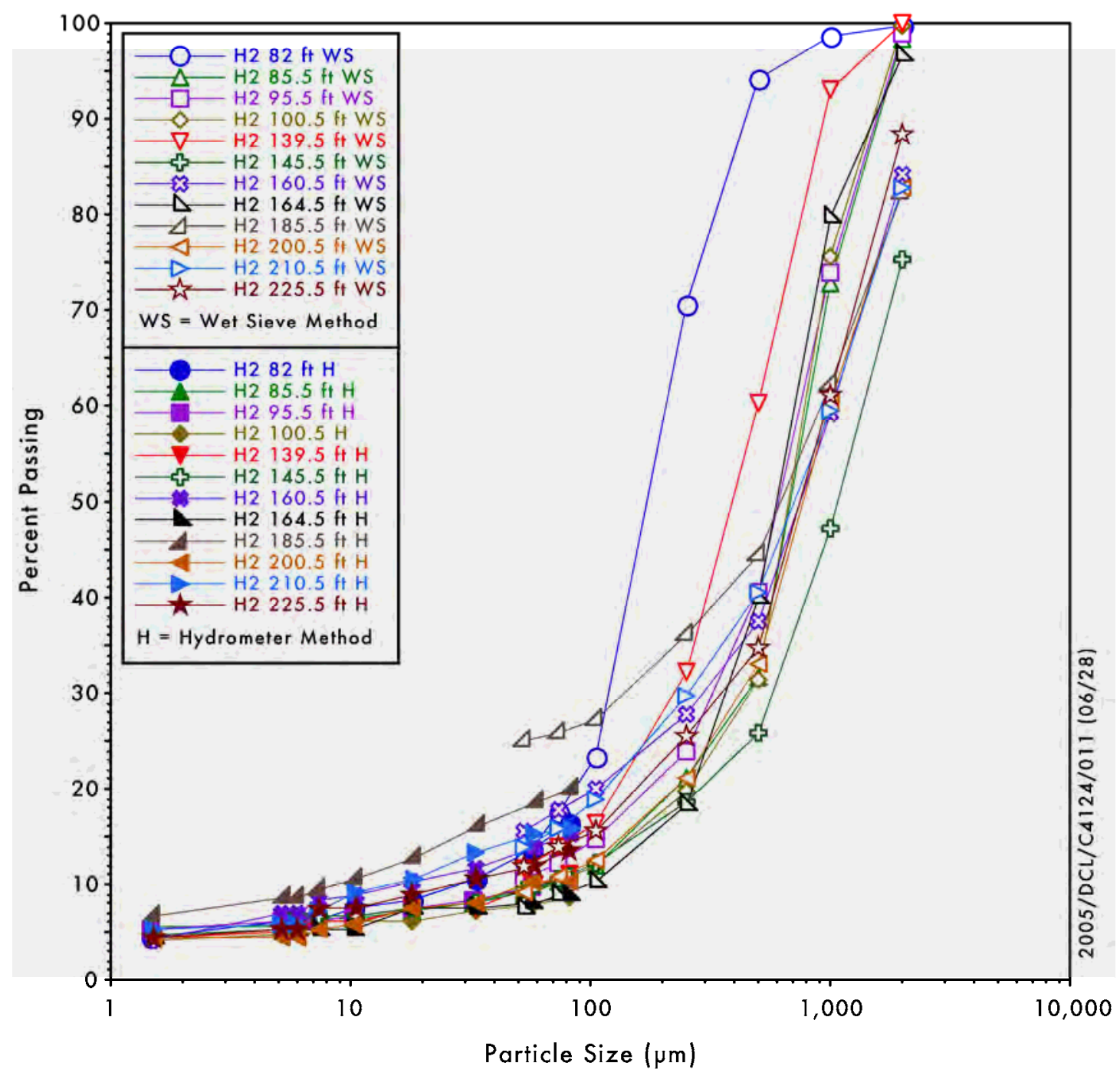

Figure 4.10. Particle-Size Distribution of Hanford formation H2 Unit Sub-Samples from Borehole 299-E27-22

Table 4.14 and Figure 4.11 show the matric potentials as a function of depth. Also plotted in Figure 4.11 is the gravity head expressed in pressure units (MPa). The gravity head is zero at the water table and increases linearly with height to the soil surface. For the core samples available from borehole 299-E27 22, the water potentials are generally much less than the gravity potential from the shallowest core at $19.5 \mathrm{ft}$ bgs down to the deepest core taken at $225.5 \mathrm{ft}$ bgs, representing both the Hanford formation $\mathrm{H} 1$ and $\mathrm{H} 2$ units. Three of the samples (27.0, 72.0, and $74.5 \mathrm{ft}$ bgs) showed very high matric potentials that appear to be erroneous because of inadvertent drying of the samples or weighing errors. The red line, labeled "theoretical value" in Figure 4.11 is the theoretical line that represents the steady-state unit gradient condition. This condition represents the profile for matric potential in a sediment profile that is neither draining nor drier than (actively evapotranspiring) a profile at equilibrium. Matric potential values to the left of the unit gradient line suggest a draining profile. The general trend for the data from 299-E27-22 is that the water potentials are consistent with a draining profile. 
Table 4.14. Matric Potential as Measured by Filter Paper Method for Borehole 299-E27-22 Core Sediments

\begin{tabular}{|c|c|c|c|c|c|c|c|}
\hline $\begin{array}{l}\text { Depth } \\
\text { (ft bgs) }\end{array}$ & $\begin{array}{l}\text { Stratigraphic Unit } \\
\text { (Hanford formation) }\end{array}$ & $\begin{array}{c}\text { Matric } \\
\text { Potential } \\
\text { (MPa) }\end{array}$ & $\begin{array}{c}\text { Theoretical } \\
\text { Potential } \\
\text { (MPa) }\end{array}$ & $\begin{array}{c}\text { Depth } \\
\text { (ft bgs) }\end{array}$ & $\begin{array}{l}\text { Stratigraphic Unit } \\
\text { (Hanford formation) }\end{array}$ & $\begin{array}{c}\text { Matric } \\
\text { Potential } \\
\text { (MPa) }\end{array}$ & $\begin{array}{c}\text { Theoretical } \\
\text { Potential } \\
\text { (MPa) }\end{array}$ \\
\hline 19.5 & $\mathrm{H} 1$ & 0.0000 & 0.6431 & 42.0 & $\mathrm{H} 1$ & 0.1048 & 0.5745 \\
\hline 20.5 & H1 & 0.0042 & 0.6401 & 43.0 & H1 & 0.1122 & 0.5715 \\
\hline 22.0 & H1 & 0.3271 & 0.6355 & 44.5 & H1 & 0.1206 & 0.5669 \\
\hline 23.0 & H1 & 0.1839 & 0.6325 & 45.5 & H1 & 0.0901 & 0.5639 \\
\hline 24.5 & H1 & 0.2910 & 0.6279 & 47.0 & H1 & 0.0579 & 0.5593 \\
\hline 25.5 & $\mathrm{H} 1$ & 0.2986 & 0.6248 & 48.0 & H1 & 0.0346 & 0.5563 \\
\hline 27.0 & H1 & 3.6014 & 0.6203 & 49.5 & H1 & 0.1167 & 0.5517 \\
\hline 28.0 & H1 & 0.2188 & 0.6172 & 50.5 & H1 & 0.1625 & 0.5486 \\
\hline 29.5 & H1 & 0.3141 & 0.6126 & 52.0 & $\mathrm{H} 1$ & 0.0957 & 0.5441 \\
\hline 30.5 & $\mathrm{H} 1$ & 0.1384 & 0.6096 & 53.0 & $\mathrm{H} 1$ & 0.2446 & 0.5410 \\
\hline 32.0 & $\mathrm{H} 1$ & 0.1866 & 0.6050 & 54.5 & H1 & 0.1348 & 0.5364 \\
\hline 33.0 & $\mathrm{H} 1$ & 0.2719 & 0.6020 & 55.5 & H1 & 0.1633 & 0.5334 \\
\hline 34.5 & H1 & 0.1575 & 0.5974 & 57.0 & $\mathrm{H} 1$ & 0.2972 & 0.5288 \\
\hline 35.5 & $\mathrm{H} 1$ & 0.0751 & 0.5944 & 58.0 & $\mathrm{H} 1$ & 0.2323 & 0.5258 \\
\hline 37.0 & $\mathrm{H} 1$ & 0.1092 & 0.5898 & 62.0 & $\mathrm{H} 1$ & 0.1521 & 0.5136 \\
\hline 38.0 & $\mathrm{H} 1$ & 0.1293 & 0.5867 & 63.0 & $\mathrm{H} 1$ & 0.8838 & 0.5105 \\
\hline 39.5 & H1 & 0.0378 & 0.5822 & 65.5 & H1 & 0.7341 & 0.5029 \\
\hline 40.5 & H1 & 0.0671 & 0.5791 & 67.0 & $\mathrm{H} 1$ & 0.1503 & 0.4983 \\
\hline 68.0 & $\mathrm{H} 1$ & 0.2713 & 0.4953 & 93.0 & $\mathrm{H} 2$ & 0.0899 & 0.4191 \\
\hline 72.0 & $\mathrm{H} 1$ & 3.0117 & 0.4831 & 94.5 & $\mathrm{H} 2$ & 0.0456 & 0.4145 \\
\hline 73.0 & H1 & 0.3076 & 0.4801 & 95.5 & $\mathrm{H} 2$ & 0.0671 & 0.4115 \\
\hline 74.5 & H1 & 2.3981 & 0.4755 & 97.0 & $\mathrm{H} 2$ & 0.1530 & 0.4069 \\
\hline 75.5 & H1 & 0.6900 & 0.4724 & 98.0 & $\mathrm{H} 2$ & 0.0138 & 0.4039 \\
\hline 77.0 & $\mathrm{H} 1$ & 0.1376 & 0.4679 & 99.5 & $\mathrm{H} 2$ & 0.0588 & 0.3993 \\
\hline 78.0 & H1 & 0.8746 & 0.4648 & 100.5 & $\mathrm{H} 2$ & 0.3827 & 0.3962 \\
\hline 79.5 & $\mathrm{H} 1$ & 0.5453 & 0.4602 & 102.0 & H2 & 0.2789 & 0.3917 \\
\hline 80.5 & $\mathrm{H} 1$ & 0.1679 & 0.4572 & 103.0 & $\mathrm{H} 2$ & 0.1552 & 0.3886 \\
\hline 82.0 & $\mathrm{H} 2$ & 0.0048 & 0.4526 & 104.5 & $\mathrm{H} 2$ & 0.1435 & 0.3840 \\
\hline 83.0 & $\mathrm{H} 2$ & 0.0111 & 0.4496 & 105.5 & $\mathrm{H} 2$ & 0.1163 & 0.3810 \\
\hline 84.5 & $\mathrm{H} 2$ & 0.0171 & 0.4450 & 107.0 & $\mathrm{H} 2$ & 0.0483 & 0.3764 \\
\hline 85.5 & H2 & 0.1946 & 0.4420 & 108.0 & $\mathrm{H} 2$ & 0.1400 & 0.3734 \\
\hline 87.0 & $\mathrm{H} 2$ & 0.0349 & 0.4374 & 109.5 & $\mathrm{H} 2$ & 0.0621 & 0.3688 \\
\hline 88.0 & $\mathrm{H} 2$ & 0.1622 & 0.4343 & 110.5 & $\mathrm{H} 2$ & 0.1410 & 0.3658 \\
\hline 89.5 & $\mathrm{H} 2$ & 0.4228 & 0.4298 & 114.5 & $\mathrm{H} 2$ & 0.0281 & 0.3536 \\
\hline
\end{tabular}


Table 4.14. (contd)

\begin{tabular}{|l|l|l|l||l|l|l|l||}
\hline $\begin{array}{c}\text { Depth } \\
\text { (ft bgs) }\end{array}$ & $\begin{array}{c}\text { Stratigraphic } \\
\text { Unit }\end{array}$ & $\begin{array}{c}\text { Matric } \\
\text { Potential } \\
\text { (MPa) }\end{array}$ & $\begin{array}{c}\text { Theoretical } \\
\text { Potential } \\
\text { (MPa) }\end{array}$ & $\begin{array}{c}\text { Depth } \\
\text { (ft bgs) }\end{array}$ & $\begin{array}{c}\text { Stratigraphic } \\
\text { Unit }\end{array}$ & $\begin{array}{c}\text { Matric } \\
\text { Potential } \\
\text { (MPa) }\end{array}$ & $\begin{array}{c}\text { Theoretical } \\
\text { Potential } \\
\text { (MPa) }\end{array}$ \\
\hline 90.5 & H2 & 0.1935 & 0.4267 & 115.5 & H2 & 0.1626 & 0.3505 \\
\hline 92.0 & H2 & 0.0470 & 0.4221 & 119.5 & H2 & 0.0492 & 0.3383 \\
\hline 120.5 & H2 & 0.1942 & 0.3353 & 174.5 & H2 & 0.0304 & 0.1707 \\
\hline 124.5 & H2 & 0.0287 & 0.3231 & 175.5 & H2 & 0.1120 & 0.1676 \\
\hline 125.5 & H2 & 0.1558 & 0.3200 & 179.5 & H2 & 0.1066 & 0.1554 \\
\hline 129.5 & H2 & 0.5799 & 0.3078 & 180.5 & H2 & 0.1771 & 0.1524 \\
\hline 130.5 & H2 & 0.0129 & 0.3048 & 184.5 & H2 & 0.1057 & 0.1402 \\
\hline 134.5 & H2 & 0.1178 & 0.2926 & 185.5 & H2 & 0.1104 & 0.1372 \\
\hline 135.5 & H2 & 0.1799 & 0.2896 & 189.5 & H2 & 0.0794 & 0.1250 \\
\hline 139.5 & H2 & 0.1189 & 0.2774 & 190.5 & H2 & 0.1672 & 0.1219 \\
\hline 140.5 & H2 & 0.0962 & 0.2743 & 194.5 & H2 & 0.3962 & 0.1097 \\
\hline 144.5 & H2 & 0.0814 & 0.2621 & 195.5 & H2 & 0.2874 & 0.1067 \\
\hline 145.5 & H2 & 0.1161 & 0.2591 & 199.5 & H2 & 0.1461 & 0.0945 \\
\hline 149.5 & H2 & 0.0813 & 0.2469 & 200.5 & H2 & 0.2107 & 0.0914 \\
\hline 150.5 & H2 & 0.1906 & 0.2438 & 204.5 & H2 & 0.2172 & 0.0792 \\
\hline 154.5 & H2 & 0.4380 & 0.2316 & 205.5 & H2 & 0.1419 & 0.0762 \\
\hline 159.5 & H2 & 0.1799 & 0.2164 & 209.5 & H2 & 0.3146 & 0.0640 \\
\hline 160.5 & H2 & 0.3508 & 0.2134 & 209.5 & H2 & 0.7139 & 0.0640 \\
\hline 164.5 & H2 & 0.0351 & 0.2012 & 219.5 & H2 & 0.4723 & 0.0335 \\
\hline 165.5 & H2 & 0.1275 & 0.1981 & 224.5 & H2 & 0.0313 & 0.0183 \\
\hline 169.5 & H2 & 0.1076 & 0.1859 & 225.5 & H2 & 0.1208 & 0.0152 \\
\hline 170.5 & H2 & 0.1024 & 0.1829 & & & & \\
\hline
\end{tabular}

\subsection{Vadose Zone Sediment from Borehole C4297}

Borehole C4297 was pushed into the vadose zone sediment approximately $30 \mathrm{ft}$ southwest of the edge of tank C-105 and $18 \mathrm{ft}$ to the southwest of drywell 30-05-07, which was drilled in 1974 (Figure 2.3 in Section 2.2). Borehole C4297 was drilled to investigate apparent tank waste contamination in the vadose zone near drywell 30-05-07, where two high cesium-137 zones are located near and just below the bottom of tank C-105. The C4297 borehole reached a depth of $196.5 \mathrm{ft}$ bgs at which time drilling was stopped due to the lack of measurable contamination (nitrate or technetium-99).

\subsubsection{Moisture Content}

The moisture content of the 37 core liners and 119 grab samples as a function of depth are shown in Table 4.15 and lithology in Figure 4.12. The backfill splitspoon samples had a mean moisture content of $5.0 \%$ by weight with little variation. The Hanford formation H1 splitspoon samples (40 to $65 \mathrm{ft}$ bgs) had a mean moisture content of $2.9 \%$ with less variability than the backfill material. The Hanford formation $\mathrm{H} 2$ sub-unit splitspoon samples had an average moisture content of 3.1\% with little variability among the 
samples. The average moisture content of the H1 unit samples measured in borehole C4297 was about one half of one percent by weight lower than the average for the same stratigraphic unit in the RCRA borehole 299-E27-22. The average moisture content of the H2 unit samples measured in C4297 sediments was about one half of one percent by weight higher than the average for the same stratigraphic unit in the RCRA borehole 299-E27-22. Therefore, it cannot be stated that tank farm operations have caused increased moisture accumulation and specifically, there is no current indication of excess moisture from the past assumed leak event.

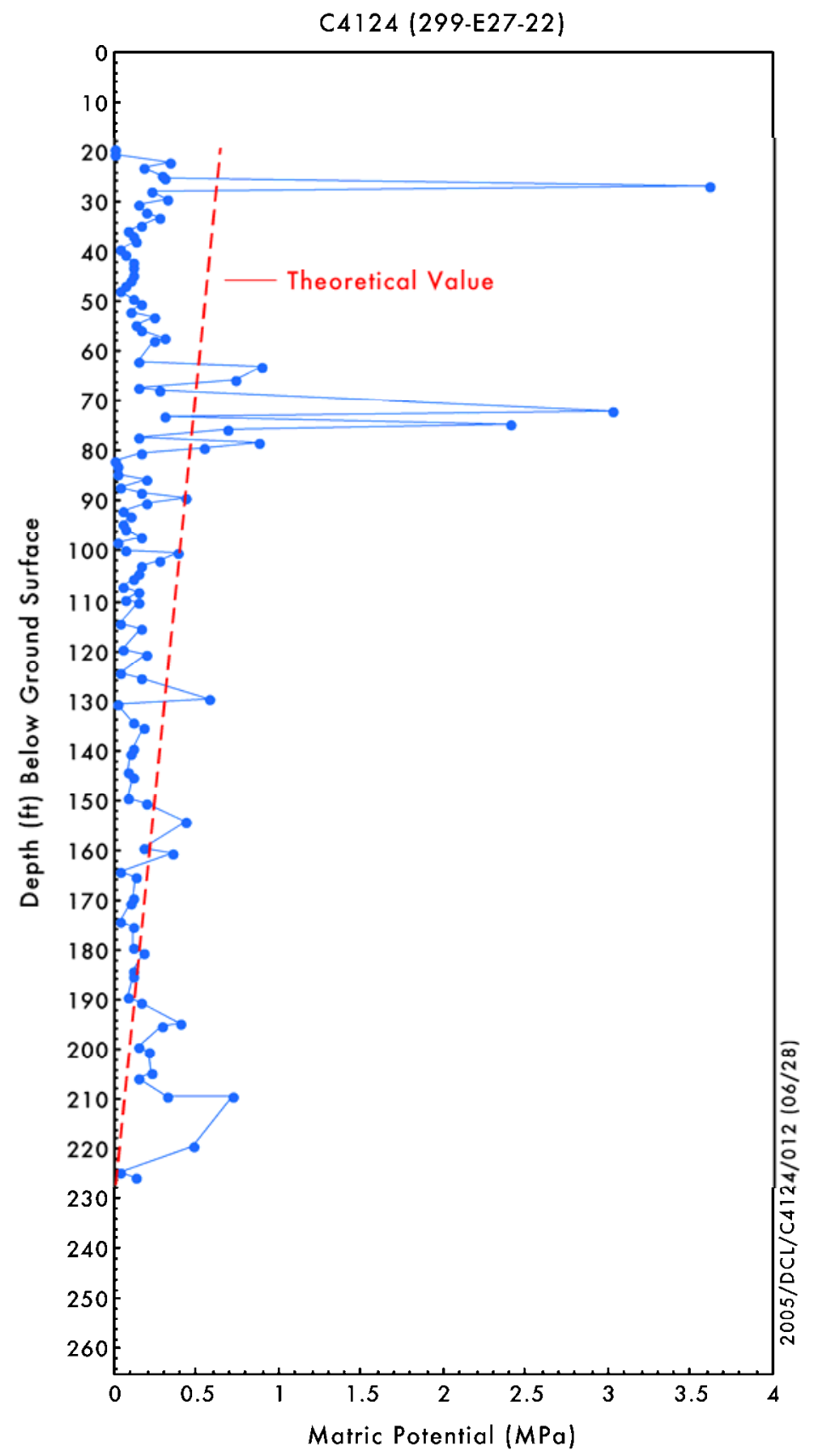

Figure 4.11. Matric Water Potential Measured by Filter Paper Technique on Core Samples from Borehole 299-E27-22 
Table 4.15. Moisture Content for Borehole C4297 Core and Grab Samples

\begin{tabular}{|c|c|c|c|c|c|}
\hline $\begin{array}{l}\text { Depth } \\
\text { (ft bgs) }\end{array}$ & $\begin{array}{c}\text { Stratigraphic Unit } \\
\text { (Hanford formation) }\end{array}$ & $\begin{array}{c}\text { MC } \\
(\% \mathrm{Wt})\end{array}$ & $\begin{array}{l}\text { Depth } \\
\text { (ft bgs) }\end{array}$ & $\begin{array}{c}\text { Stratigraphic Unit } \\
\text { (Hanford formation) }\end{array}$ & $\begin{array}{c}\text { MC } \\
(\% \mathrm{Wt})\end{array}$ \\
\hline 2.50 & Backfill & $6.53 \%$ & 40.80 & H1 & $3.43 \%$ \\
\hline 7.00 & Backfill & $6.72 \%$ & 41.20 & H1 & $4.10 \%$ \\
\hline 12.00 & Backfill & $6.99 \%$ & 42.18 & H1 & 3.99\% \\
\hline 17.00 & Backfill & $4.91 \%$ & 43.75 & H1 & $3.18 \%$ \\
\hline 22.00 & Backfill & $5.71 \%$ & 44.45 & $\mathrm{H} 1$ & $2.93 \%$ \\
\hline 24.25 & Backfill & $5.47 \%$ & 44.95 & $\mathrm{H} 1$ & $2.62 \%$ \\
\hline 24.75 & Backfill & $4.59 \%$ & 45.45 & H1 & $2.79 \%$ \\
\hline 25.25 & Backfill & $3.75 \%$ & 45.85 & H1 & $3.64 \%$ \\
\hline 25.75 & Backfill & $3.50 \%$ & 47.00 & H1 & $3.12 \%$ \\
\hline 26.15 & Backfill & $3.94 \%$ & 49.25 & H1 & $3.23 \%$ \\
\hline 27.15 & Backfill & $4.77 \%$ & 51.25 & H1 & $2.98 \%$ \\
\hline 28.60 & Backfill & $4.92 \%$ & 53.00 & H1 & $3.59 \%$ \\
\hline 31.40 & Backfill & $5.05 \%$ & 55.20 & $\mathrm{H} 1$ & $3.67 \%$ \\
\hline 29.50 & Backfill & $7.60 \%$ & 57.20 & H1 & $3.34 \%$ \\
\hline 30.00 & Backfill & $3.79 \%$ & 58.50 & $\mathrm{H} 1$ & $3.42 \%$ \\
\hline 30.50 & Backfill & $4.05 \%$ & 60.00 & H1 & $3.33 \%$ \\
\hline 31.00 & Backfill & $5.59 \%$ & 61.50 & H1 & $2.80 \%$ \\
\hline 32.28 & Backfill & $5.22 \%$ & 62.00 & H1 & $2.43 \%$ \\
\hline 32.28 & Backfill & $5.44 \%$ & 62.50 & H1 & $2.72 \%$ \\
\hline 33.75 & Backfill & $4.98 \%$ & 62.90 & H1 & $3.10 \%$ \\
\hline 35.25 & Backfill & $6.27 \%$ & 63.50 & H1 & $3.71 \%$ \\
\hline 36.25 & Backfill & $5.72 \%$ & 64.85 & H1 & $3.85 \%$ \\
\hline 37.55 & Backfill & $4.61 \%$ & 66.20 & $\mathrm{H} 2$ & $3.73 \%$ \\
\hline 36.65 & Backfill & $5.39 \%$ & 67.70 & $\mathrm{H} 2$ & $4.45 \%$ \\
\hline 37.15 & Backfill & $4.23 \%$ & 68.95 & $\mathrm{H} 2$ & $4.38 \%$ \\
\hline 38.35 & Backfill & 9.39\% & 69.75 & H2 & $3.77 \%$ \\
\hline 38.53 & Backfill & $5.93 \%$ & 70.25 & H2 & $3.19 \%$ \\
\hline 39.30 & Backfill & $5.88 \%$ & 70.75 & $\mathrm{H} 2$ & $2.88 \%$ \\
\hline 39.80 & $\mathrm{H} 1$ & $6.43 \%$ & \begin{tabular}{||l}
1.25 \\
\end{tabular} & $\mathrm{H} 2$ & $2.44 \%$ \\
\hline 40.30 & H1 & $2.90 \%$ & 71.65 & H2 & $2.40 \%$ \\
\hline 72.65 & H2 & $3.40 \%$ & 125.85 & H2 & $2.79 \%$ \\
\hline 74.25 & $\mathrm{H} 2$ & $3.07 \%$ & 126.35 & H2 & $2.57 \%$ \\
\hline 76.00 & $\mathrm{H} 2$ & $4.43 \%$ & \begin{tabular}{|l|}
126.75 \\
\end{tabular} & $\mathrm{H} 2$ & $3.09 \%$ \\
\hline 77.40 & $\mathrm{H} 2$ & $3.52 \%$ & 127.85 & $\mathrm{H} 2$ & $2.82 \%$ \\
\hline 78.05 & $\mathrm{H} 2$ & $2.70 \%$ & 127.85 & $\mathrm{H} 2$ & $3.33 \%$ \\
\hline
\end{tabular}


Table 4.15. (contd)

\begin{tabular}{|c|c|c|c|c|c|}
\hline $\begin{array}{l}\text { Depth } \\
\text { (ft bgs) }\end{array}$ & $\begin{array}{c}\text { Stratigraphic Unit } \\
\text { (Hanford formation) }\end{array}$ & $\begin{array}{c}\text { MC } \\
(\% \text { Wt })\end{array}$ & $\begin{array}{l}\text { Depth } \\
\text { (ft bgs) }\end{array}$ & $\begin{array}{c}\text { Stratigraphic Unit } \\
\text { (Hanford formation) }\end{array}$ & $\begin{array}{c}\text { MC } \\
(\% \text { Wt })\end{array}$ \\
\hline 78.55 & H2 & $3.32 \%$ & 129.40 & H2 & $4.01 \%$ \\
\hline 79.05 & H2 & $3.95 \%$ & 130.65 & $\mathrm{H} 2$ & $4.58 \%$ \\
\hline 79.55 & H2 & $3.25 \%$ & 132.15 & H2 & $4.58 \%$ \\
\hline 79.95 & H2 & $3.38 \%$ & 133.75 & H2 & $8.23 \%$ \\
\hline 81.05 & H2 & $3.58 \%$ & 135.25 & H2 & $4.73 \%$ \\
\hline 82.75 & $\mathrm{H} 2$ & $3.64 \%$ & 136.75 & H2 & $4.66 \%$ \\
\hline 84.75 & $\mathrm{H} 2$ & $5.71 \%$ & 138.25 & $\mathrm{H} 2$ & $3.43 \%$ \\
\hline 86.75 & $\mathrm{H} 2$ & $3.53 \%$ & 127.85 & $\mathrm{H} 2$ & $2.82 \%$ \\
\hline 88.50 & $\mathrm{H} 2$ & $4.07 \%$ & 127.85 & $\mathrm{H} 2$ & $3.33 \%$ \\
\hline 96.60 & H2 & $2.73 \%$ & 129.40 & H2 & $4.01 \%$ \\
\hline 98.00 & H2 & $2.88 \%$ & 130.65 & H2 & $4.58 \%$ \\
\hline 99.60 & $\mathrm{H} 2$ & $3.59 \%$ & 132.15 & H2 & $4.58 \%$ \\
\hline 101.20 & $\mathrm{H} 2$ & $3.20 \%$ & 133.75 & $\mathrm{H} 2$ & $8.23 \%$ \\
\hline 102.75 & $\mathrm{H} 2$ & $3.12 \%$ & 135.25 & $\mathrm{H} 2$ & $4.73 \%$ \\
\hline 104.00 & H2 & $3.51 \%$ & 136.75 & H2 & $4.66 \%$ \\
\hline 104.55 & $\mathrm{H} 2$ & $3.92 \%$ & 138.25 & H2 & $3.43 \%$ \\
\hline 105.05 & $\mathrm{H} 2$ & $3.45 \%$ & 140.00 & $\mathrm{H} 2$ & $2.83 \%$ \\
\hline 105.55 & $\mathrm{H} 2$ & $3.03 \%$ & 141.75 & $\mathrm{H} 2$ & $2.50 \%$ \\
\hline 106.05 & $\mathrm{H} 2$ & $3.72 \%$ & 143.25 & $\mathrm{H} 2$ & $2.69 \%$ \\
\hline 106.45 & $\mathrm{H} 2$ & $3.85 \%$ & 144.50 & H2 & $2.94 \%$ \\
\hline 107.20 & $\mathrm{H} 2$ & $3.88 \%$ & 146.25 & H2 & $3.53 \%$ \\
\hline 110.15 & $\mathrm{H} 2$ & $3.28 \%$ & 148.30 & $\mathrm{H} 2$ & $3.08 \%$ \\
\hline 112.25 & $\mathrm{H} 2$ & $3.40 \%$ & 150.05 & $\mathrm{H} 2$ & $3.39 \%$ \\
\hline 114.20 & $\mathrm{H} 2$ & $4.75 \%$ & 151.50 & H2 & $3.92 \%$ \\
\hline 115.95 & $\mathrm{H} 2$ & $2.65 \%$ & 153.00 & H2 & $3.21 \%$ \\
\hline 117.40 & $\mathrm{H} 2$ & $3.03 \%$ & 154.65 & $\mathrm{H} 2$ & $3.29 \%$ \\
\hline 119.00 & $\mathrm{H} 2$ & $3.39 \%$ & 156.65 & $\mathrm{H} 2$ & $3.36 \%$ \\
\hline 120.25 & $\mathrm{H} 2$ & $3.83 \%$ & 156.65 & H2 & $3.45 \%$ \\
\hline 122.00 & $\mathrm{H} 2$ & $3.34 \%$ & 159.00 & H2 & $2.84 \%$ \\
\hline 123.65 & $\mathrm{H} 2$ & $3.29 \%$ & 161.25 & H2 & $2.78 \%$ \\
\hline 124.60 & $\mathrm{H} 2$ & $2.54 \%$ & 163.75 & $\mathrm{H} 2$ & $3.56 \%$ \\
\hline 124.85 & $\mathrm{H} 2$ & $2.57 \%$ & 165.75 & $\mathrm{H} 2$ & $3.41 \%$ \\
\hline 125.35 & $\mathrm{H} 2$ & $2.86 \%$ & 167.75 & H2 & $3.31 \%$ \\
\hline 170.25 & $\mathrm{H} 2$ & $3.42 \%$ & 182.25 & H2 & $3.15 \%$ \\
\hline 172.30 & $\mathrm{H} 2$ & $3.14 \%$ & 184.25 & $\mathrm{H} 2$ & $3.09 \%$ \\
\hline 174.05 & $\mathrm{H} 2$ & $3.23 \%$ & 186.25 & $\mathrm{H} 2$ & $3.04 \%$ \\
\hline
\end{tabular}


Table 4.15. (contd)

\begin{tabular}{|l|c|l||l|c|l||}
\hline \multicolumn{1}{|c|}{$\begin{array}{c}\text { Depth } \\
\text { (ft bgs) }\end{array}$} & $\begin{array}{c}\text { Stratigraphic Unit } \\
\text { (Hanford formation) }\end{array}$ & $\begin{array}{c}\text { MC } \\
\text { (\% Wt) }\end{array}$ & $\begin{array}{c}\text { Depth } \\
\text { (ft bgs) }\end{array}$ & $\begin{array}{c}\text { Stratigraphic Unit } \\
\text { (Hanford formation) }\end{array}$ & $\begin{array}{c}\text { MC } \\
\text { (\% Wt) }\end{array}$ \\
\hline \hline 175.65 & $\mathrm{H} 2$ & $3.25 \%$ & 188.50 & $\mathrm{H} 2$ & $3.21 \%$ \\
\hline 176.90 & $\mathrm{H} 2$ & $2.92 \%$ & 191.25 & $\mathrm{H} 2$ & $3.00 \%$ \\
\hline 178.70 & $\mathrm{H} 2$ & $3.22 \%$ & 193.25 & $\mathrm{H} 2$ & $3.23 \%$ \\
\hline 180.70 & $\mathrm{H} 2$ & $3.38 \%$ & 195.25 & $\mathrm{H} 2$ & $3.23 \%$ \\
\hline $\begin{array}{l}\text { Shaded cells indicate core samples. } \\
\text { Unshaded cells indicate grab samples. } \\
\text { MC = Moisture content }\end{array}$
\end{tabular}

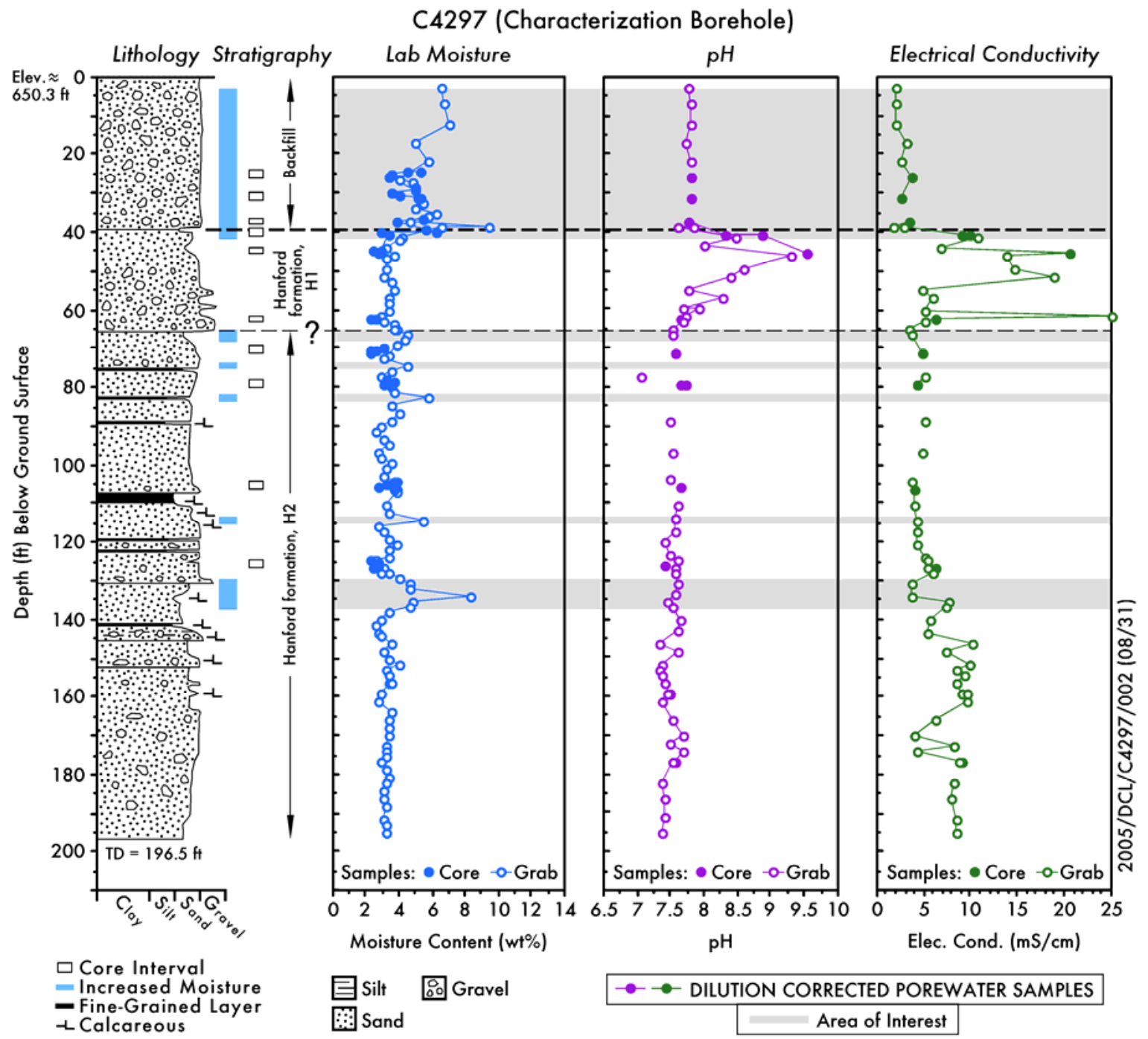

Figure 4.12. Borehole C4297 Sediment:Water Extract pH, Actual, and Calculated Pore Water Electrical Conductivity 


\subsubsection{1:1 Sediment:Water Extracts and Pore Water Samples for Borehole C4297}

The A liners (the deepest of the four liners) from ten of the splitspoon samples and select grab samples were characterized by performing 1:1 sediment:water extracts. Tables 4.16 through 4.30 present the mass of a given constituent leached per gram of sediment as measured in the water extracts to allow direct comparison to the same data for the sediments from borehole 299-E27-22. Other tables and figures in the remainder of this chapter show dilution-corrected values that represent concentrations in vadose zone pore water. As discussed in several other Vadose Zone Characterization Project reports (Serne et al. 2002a, 2002b, 2002c, 2002e, 2002f), the dilution-corrected 1:1 sediment:water extracts are a reasonable estimate of the actual vadose zone pore water when there is significant contamination present; for uncontaminated sediments dilution corrected 1:1 water extracts slightly over-predict actual pore water compositions.

\subsubsection{1 $\quad \mathrm{pH}$ and Electrical Conductivity}

The 1:1 sediment:water extract $\mathrm{pH}$ and EC data are shown in Table 4.16. Both the measured values and dilution-corrected EC values are shown. Figure 4.12 shows the 1:1 sediment:water extract $\mathrm{pH}$ value and EC as a function of depth and stratigraphy. A comparison of the data in Table 4.16 with the $\mathrm{pH}$ and EC of the 299-E27-22 extracts (RCRA borehole) indicated that there was elevated pH (up to 9.5) and EC (up to $20.5 \mathrm{mS} / \mathrm{cm}$ ) in the $\mathrm{C} 4297$ borehole sediments between 40.8 and $51.3 \mathrm{ft}$ bgs. This implies the presence of some higher than normal salinity fluids in the pore waters, such as tank liquors. As found at boreholes in the SX and T Tank Farms, sediment water extract $\mathrm{pH}$ values range from 8.3 to almost 10 where caustic fluids have percolated through the vadose zone. Although the dilution-corrected pore water EC was above the background values, the highest value measured (20.5 mS/cm at $45.5 \mathrm{ft} \mathrm{bgs)} \mathrm{is}$ equivalent to a pore solution of $0.15 \mathrm{M}$ potassium chloride $(\mathrm{KCl})$, the salt solution used to calibrate the conductivity probe. The leaks near the SX-108, SX-109, and BX-102 tanks had peak vadose zone pore water concentrations that were equivalent to much more concentrated waste fluids, 7 to 17 and 0.7 to $1 \mathrm{M} \mathrm{KCl}$ solutions, respectively.

\subsubsection{Water Extract Composition of the 1:1 Sediment:Water Extracts from Borehole C4297}

The water extract values for the major anions, cations, and several trace constituents are discussed in this section. The anion data are tabulated in Table 4.17 and Figure 4.13 in units of mass per gram of dry sediment. The nitrite and bromide data for borehole C4297 water extracts did not differ significantly from the same data for the sediments from borehole C4124. However, there were obvious signs of elevated carbonate, fluoride, and chloride, and slightly elevated phosphate, nitrate, and sulfate in the water extracts of C4297 sediments. Peak concentrations of carbonate and fluoride were six times higher in C4297 water extracts than in extracts of samples from borehole C4124. The peak chloride concentration in C4297 water extracts was twenty times greater than extracts of C4124 samples. Peak concentrations of nitrate, phosphate, and sulfate in water extracts from C4297 were approximately twice as great as extracts of samples collected within the same formations from borehole C4124.

The agreement between measuring the water extracts for sulfate directly with the IC and indirectly by converting the ICP measurements for sulfur was very good (Figure 4.14). Besides validating the IC data, it can be stated that the water-extractable sulfur was in fact sulfate. Phosphate was not detected above the limit of quantification via IC analysis; therefore, the ICP-OES data presented in Table 4.18 should be relied on for information about the total phosphorous (as phosphate) content of the samples. 
Table 4.16. $\quad \mathrm{pH}$ and Pore Water Corrected Electrical Conductivity Data for Sediment:Water Extracts from Borehole C4297

\begin{tabular}{||l|l|l|l||}
\hline $\begin{array}{c}\text { Depth } \\
\text { (ft bgs) }\end{array}$ & \multicolumn{1}{|c|}{$\begin{array}{c}\text { Stratigraphic Unit } \\
\text { (Hanford formation) }\end{array}$} & $\begin{array}{c}\text { Conductivity } \\
\text { (mS/cm) }\end{array}$ \\
\hline \hline 2.50 & Backfill & 7.75 & 1.96 \\
\hline 7.00 & Backfill & 7.79 & 1.86 \\
\hline 12.00 & Backfill & 7.80 & 2.00 \\
\hline 17.00 & Backfill & 7.72 & 3.04 \\
\hline 22.00 & Backfill & 7.79 & 2.54 \\
\hline 25.75 & Backfill & 7.79 & 3.61 \\
\hline 31.00 & Backfill & 7.81 & 2.63 \\
\hline 37.15 & Backfill & 7.75 & 3.29 \\
\hline 38.35 & Backfill & 7.83 & 1.76 \\
\hline 38.53 & Backfill & 7.62 & 2.76 \\
\hline 40.80 & H1 & $\mathbf{8 . 3 0}$ & 8.95 \\
\hline 40.80 Dup & H1 & $\mathbf{8 . 8 8}$ & 10.0 \\
\hline 41.20 & H1 & $\mathbf{8 . 4 8}$ & 10.8 \\
\hline 43.75 & H1 & $\mathbf{8 . 0 0}$ & 6.74 \\
\hline 45.45 & H1 & $\mathbf{9 . 5 3}$ & 20.5 \\
\hline 45.85 & H1 & $\mathbf{9 . 2 8}$ & 13.9 \\
\hline 49.25 & H1 & $\mathbf{8 . 5 8}$ & 14.7 \\
\hline 51.25 & H1 & $\mathbf{8 . 3 8}$ & 18.9 \\
\hline 55.20 & H1 & 7.78 & 4.79 \\
\hline 57.20 & H1 & 8.28 & 5.90 \\
\hline 60.00 & H1 & 7.70 & 5.20 \\
\hline 60.00 Dup & H1 & 7.91 & 5.10 \\
\hline 61.50 & H1 & 7.71 & 25.0 \\
\hline 62.50 & H1 & 7.63 & 6.21 \\
\hline 62.90 & H1 & 7.67 & 5.03 \\
\hline 64.85 & H1 & 7.51 & 3.51 \\
\hline 66.20 & H2 & 7.52 & 3.78 \\
\hline 71.25 & H2 & 4.57 & 4.87 \\
\hline 77.40 & H2 & 5.00 \\
\hline 79.55 & H2 & 4.39 \\
\hline 79.55 Dup & H2 & H2 & \\
\hline 88.50 & H2 & 7.30 \\
\hline 96.60 & H2 & & \\
\hline \hline & & 7.65 & \\
\hline
\end{tabular}


Table 4.16. (contd)

\begin{tabular}{|c|c|c|c|}
\hline $\begin{array}{l}\text { Depth } \\
\text { (ft bgs) }\end{array}$ & $\begin{array}{c}\text { Stratigraphic Unit } \\
\text { (Hanford formation) }\end{array}$ & pH & $\begin{array}{c}\text { Conductivity } \\
(\mathrm{mS} / \mathrm{cm})\end{array}$ \\
\hline 104.00 & $\mathrm{H} 2$ & 7.47 & 3.76 \\
\hline 106.05 & $\mathrm{H} 2$ & 7.64 & 4.09 \\
\hline 110.15 & $\mathrm{H} 2$ & 7.59 & 3.94 \\
\hline 114.20 & $\mathrm{H} 2$ & 7.56 & 4.20 \\
\hline 117.40 & $\mathrm{H} 2$ & 7.56 & 4.22 \\
\hline 120.25 & H2 & 7.42 & 4.16 \\
\hline 123.65 & $\mathrm{H} 2$ & 7.48 & 5.20 \\
\hline 124.60 & $\mathrm{H} 2$ & 7.62 & 5.51 \\
\hline 126.35 & $\mathrm{H} 2$ & 7.40 & 6.09 \\
\hline 126.75 & $\mathrm{H} 2$ & 7.57 & 5.47 \\
\hline 127.85 & $\mathrm{H} 2$ & 7.56 & 5.94 \\
\hline 130.65 & $\mathrm{H} 2$ & 7.61 & 3.56 \\
\hline 133.75 & $\mathrm{H} 2$ & 7.58 & 3.71 \\
\hline 135.25 & $\mathrm{H} 2$ & 7.43 & 7.68 \\
\hline 136.75 & $\mathrm{H} 2$ & 7.54 & 7.38 \\
\hline 140.00 & $\mathrm{H} 2$ & 7.64 & 5.58 \\
\hline 143.25 & $\mathrm{H} 2$ & 7.62 & 5.30 \\
\hline 146.25 & $\mathrm{H} 2$ & 7.32 & 10.2 \\
\hline 148.30 & $\mathrm{H} 2$ & 7.59 & 7.21 \\
\hline 148.30 Dup & $\mathrm{H} 2$ & 7.61 & 7.42 \\
\hline 151.50 & $\mathrm{H} 2$ & 7.36 & 9.97 \\
\hline 153.00 & $\mathrm{H} 2$ & 7.34 & 8.48 \\
\hline 154.65 & $\mathrm{H} 2$ & 7.35 & 9.30 \\
\hline 156.65 & $\mathrm{H} 2$ & 7.40 & 8.52 \\
\hline 156.65 & $\mathrm{H} 2$ & 7.41 & 8.40 \\
\hline 159.00 & $\mathrm{H} 2$ & 7.48 & 8.92 \\
\hline 159.00 Dup & $\mathrm{H} 2$ & 7.44 & 9.47 \\
\hline 161.25 & $\mathrm{H} 2$ & 7.37 & 9.50 \\
\hline 165.75 & $\mathrm{H} 2$ & 7.53 & 6.14 \\
\hline 170.25 & $\mathrm{H} 2$ & 7.68 & 3.98 \\
\hline 172.30 & $\mathrm{H} 2$ & 7.48 & 8.21 \\
\hline 174.05 & $\mathrm{H} 2$ & 7.69 & 4.15 \\
\hline 176.90 & $\mathrm{H} 2$ & 7.58 & 8.99 \\
\hline 176.90 Dup & $\mathrm{H} 2$ & 7.51 & 8.86 \\
\hline 182.25 & $\mathrm{H} 2$ & 7.38 & 8.22 \\
\hline
\end{tabular}


Table 4.16. (contd)

\begin{tabular}{|c|c|c|c|}
\hline $\begin{array}{c}\text { Depth } \\
\text { (ft bgs) }\end{array}$ & $\begin{array}{c}\text { Stratigraphic Unit } \\
\text { (Hanford formation) }\end{array}$ & pH & $\begin{array}{c}\text { Conductivity } \\
(\mathrm{mS} / \mathrm{cm})\end{array}$ \\
\hline 186.25 & $\mathrm{H} 2$ & 7.40 & 7.99 \\
\hline 191.25 & H2 & 7.39 & 8.47 \\
\hline 195.25 & H2 & 7.36 & 8.50 \\
\hline \multicolumn{4}{|c|}{$\begin{array}{l}\text { Shaded values designate the core sample data. } \\
\text { Unshaded are grab samples } \\
\text { Bold pH values show the region of caustic waste interaction. } \\
\text { Dup = duplicate sample. }\end{array}$} \\
\hline
\end{tabular}

Table 4.17. Water-Extractable Anions in Borehole C4297 Vadose Zone Sediments ( $\mu \mathrm{g} / \mathrm{g}$ dry sediment)

\begin{tabular}{||l|c|c|c|c|c|c|c|c||}
\hline $\begin{array}{c}\text { Depth } \\
\text { (ft bgs) }\end{array}$ & $\begin{array}{c}\text { Stratigraphic Unit } \\
\text { (Hanford formation) }\end{array}$ & Fluoride & Chloride & Nitrate & CO $_{3}$ & Sulfate & Nitrite & Bromide \\
\hline \hline 2.50 & Backfill & 0.542 & 0.474 & ND & 31.2 & 1.48 & ND & ND \\
\hline 7.00 & Backfill & 0.593 & 0.554 & ND & 32.4 & 1.69 & ND & ND \\
\hline 12.00 & Backfill & 0.691 & 0.552 & 0.520 & 36.5 & 2.43 & ND & ND \\
\hline 17.00 & Backfill & 0.660 & 0.333 & ND & 40.0 & 1.76 & ND & ND \\
\hline 22.00 & Backfill & 0.919 & 0.323 & ND & 37.6 & 2.89 & ND & ND \\
\hline 25.75 & Backfill & 1.10 & ND & ND & 31.6 & 1.65 & ND & ND \\
\hline 31.00 & Backfill & 0.617 & ND & ND & 39.5 & 1.91 & ND & ND \\
\hline 37.15 & Backfill & 0.447 & ND & ND & 32.9 & 2.50 & ND & ND \\
\hline 38.35 & Backfill & 0.677 & 0.477 & 0.791 & 40.8 & 5.47 & ND & ND \\
\hline 38.53 & Backfill & 0.689 & 2.36 & 1.21 & NM & 6.96 & ND & ND \\
\hline 40.80 & H1 & 1.02 & ND & ND & $\mathbf{9 8 . 8}$ & 2.83 & ND & ND \\
\hline 40.80 Dup & H1 & 1.00 & ND & ND & $\mathbf{9 8 . 4}$ & 3.05 & ND & ND \\
\hline 41.20 & H1 & 1.43 & 0.263 & ND & $\mathbf{1 3 4 . 5}$ & 2.98 & 0.450 & ND \\
\hline 43.75 & H1 & 1.46 & 0.489 & 3.13 & $\mathbf{5 6 . 1}$ & 5.50 & ND & ND \\
\hline 45.45 & H1 & 1.46 & ND & ND & $\mathbf{1 5 7}$ & 2.33 & ND & ND \\
\hline 45.85 & H1 & 1.60 & 0.347 & ND & $\mathbf{1 4 6}$ & 2.51 & ND & ND \\
\hline 49.25 & H1 & 1.33 & ND & ND & $\mathbf{1 3 7}$ & 1.55 & ND & ND \\
\hline 51.25 & H1 & 2.06 & 0.381 & 2.68 & $\mathbf{1 5 7}$ & 4.38 & ND & ND \\
\hline 55.20 & H1 & 0.380 & ND & ND & $\mathbf{4 7 . 9}$ & 4.89 & ND & ND \\
\hline 57.20 & H1 & 0.637 & 0.271 & ND & $\mathbf{4 9 . 8}$ & 9.48 & ND & ND \\
\hline 60.00 & & 0.410 & ND & ND & $\mathbf{4 4 . 0}$ & 5.59 & ND & ND \\
\hline 60.00 Dup & N1 & ND & $\mathbf{4 7 . 0}$ & 6.75 & ND & ND \\
\hline 61.50 & & 0.270 & 3.25 & 29.0 & 17.8 & ND & ND \\
\hline
\end{tabular}


Table 4.17. (contd)

\begin{tabular}{|c|c|c|c|c|c|c|c|c|}
\hline $\begin{array}{c}\text { Depth } \\
\text { (ft bgs) }\end{array}$ & $\begin{array}{c}\text { Stratigraphic Unit } \\
\text { (Hanford formation) }\end{array}$ & $\begin{array}{l}\text { Fluoride } \\
\end{array}$ & Chloride & Nitrate & $\mathrm{CO}_{3}$ & Sulfate & Nitrite & Bromide \\
\hline 62.50 & $\mathrm{H} 1$ & 0.360 & 0.382 & 2.09 & 80.1 & 18.5 & ND & ND \\
\hline 62.90 & H1 & 0.411 & 0.377 & 2.44 & 28.0 & 19.2 & ND & ND \\
\hline 64.85 & H1 & 0.355 & ND & ND & 30.3 & 9.49 & ND & ND \\
\hline 66.20 & H1 & 0.334 & ND & 9.69 & 28.6 & 15.6 & ND & ND \\
\hline 68.95 & $\mathrm{H} 2$ & 0.378 & 0.334 & 2.74 & 26.8 & 14.3 & ND & ND \\
\hline 71.25 & $\mathrm{H} 2$ & 0.246 & 0.378 & 0.621 & 22.0 & 9.65 & ND & ND \\
\hline 77.40 & $\mathrm{H} 2$ & 0.288 & 0.307 & 4.17 & NM & 9.53 & ND & ND \\
\hline 79.55 & $\mathrm{H} 2$ & 0.363 & 0.403 & 1.50 & 26.4 & 13.6 & ND & ND \\
\hline 79.55 Dup & $\mathrm{H} 2$ & 0.377 & 0.408 & 2.22 & 29.9 & 13.9 & ND & ND \\
\hline 88.50 & $\mathrm{H} 2$ & 0.405 & 0.834 & 5.40 & $\mathrm{NM}$ & 18.7 & ND & ND \\
\hline 96.60 & $\mathrm{H} 2$ & 0.215 & 0.347 & 3.77 & $\mathrm{NM}$ & 9.13 & ND & ND \\
\hline 104.00 & $\mathrm{H} 2$ & 0.274 & 0.495 & 5.57 & $\mathrm{NM}$ & 12.2 & ND & ND \\
\hline 106.05 & $\mathrm{H} 2$ & 0.257 & 0.941 & 5.35 & 23.3 & 17.8 & ND & ND \\
\hline 110.15 & $\mathrm{H} 2$ & 0.331 & ND & 0.535 & 34.3 & 7.89 & ND & ND \\
\hline 114.20 & $\mathrm{H} 2$ & 0.357 & 0.841 & 6.26 & $\mathrm{NM}$ & 22.4 & ND & ND \\
\hline 117.40 & $\mathrm{H} 2$ & 0.263 & ND & 1.10 & 24.6 & 11.4 & ND & ND \\
\hline 120.25 & $\mathrm{H} 2$ & 0.263 & ND & 3.06 & 33.0 & 18.8 & ND & ND \\
\hline 123.65 & $\mathrm{H} 2$ & 0.248 & ND & 4.88 & 30.7 & 27.1 & ND & ND \\
\hline 124.60 & $\mathrm{H} 2$ & 0.275 & 0.655 & 4.43 & $\mathrm{NM}$ & 22.2 & ND & ND \\
\hline 126.35 & $\mathrm{H} 2$ & 0.276 & 0.515 & 1.41 & 22.8 & 20.9 & ND & ND \\
\hline 126.75 & $\mathrm{H} 2$ & 0.287 & ND & 2.24 & 28.6 & 24.7 & ND & ND \\
\hline 127.85 & $\mathrm{H} 2$ & 0.265 & ND & 1.75 & 23.3 & 39.7 & ND & ND \\
\hline 130.65 & $\mathrm{H} 2$ & 0.272 & ND & 1.90 & 26.4 & 23.3 & ND & ND \\
\hline 133.75 & $\mathrm{H} 2$ & 0.313 & ND & 12.8 & 23.3 & 80.9 & ND & ND \\
\hline 135.25 & $\mathrm{H} 2$ & 0.286 & 4.27 & 17.3 & $\mathrm{NM}$ & 104 & ND & ND \\
\hline 136.75 & $\mathrm{H} 2$ & 0.257 & ND & 19.5 & 24.6 & 96.0 & ND & ND \\
\hline 140.00 & $\mathrm{H} 2$ & 0.298 & ND & 1.34 & 27.2 & 21.8 & ND & ND \\
\hline 143.25 & $\mathrm{H} 2$ & 0.284 & ND & $N D$ & 34.9 & 18.1 & ND & ND \\
\hline 146.25 & $\mathrm{H} 2$ & 0.213 & 3.49 & 13.5 & $\mathrm{NM}$ & 123 & ND & ND \\
\hline 148.30 & $\mathrm{H} 2$ & 0.316 & ND & 0.724 & 25.1 & 52.9 & ND & ND \\
\hline 148.30 Dup & $\mathrm{H} 2$ & 0.280 & ND & 1.43 & $\mathrm{NM}$ & 54.8 & ND & ND \\
\hline 151.50 & $\mathrm{H} 2$ & 0.364 & 3.61 & 12.8 & NM & 133 & ND & ND \\
\hline 153.00 & $\mathrm{H} 2$ & 0.412 & 4.78 & 13.7 & $\mathrm{NM}$ & 64.1 & ND & ND \\
\hline 154.65 & $\mathrm{H} 2$ & 0.739 & 6.33 & 15.6 & NM & 74.8 & ND & ND \\
\hline 156.65 & $\mathrm{H} 2$ & 0.397 & 5.62 & 12.9 & $\mathrm{NM}$ & 69.7 & ND & ND \\
\hline 156.65 & H2 & 0.356 & 5.55 & 12.8 & NM & 67.4 & ND & ND \\
\hline
\end{tabular}


Table 4.17. (contd)

\begin{tabular}{|c|c|c|c|c|c|c|c|c|}
\hline $\begin{array}{l}\text { Depth } \\
\text { (ft bgs) }\end{array}$ & $\begin{array}{c}\text { Stratigraphic Unit } \\
\text { (Hanford formation) }\end{array}$ & Fluoride & Chloride & Nitrate & $\mathrm{CO}_{3}$ & Sulfate & Nitrite & Bromide \\
\hline 159.00 & $\mathrm{H} 2$ & 0.369 & 5.63 & 12.2 & $\mathrm{NM}$ & 63.6 & ND & ND \\
\hline 159.00 Dup & $\mathrm{H} 2$ & 0.398 & 6.06 & 13.0 & NM & 66.1 & ND & ND \\
\hline 161.25 & $\mathrm{H} 2$ & 0.390 & 5.51 & 11.3 & NM & 61.9 & ND & ND \\
\hline 165.75 & $\mathrm{H} 2$ & 0.290 & ND & 3.01 & 25.0 & 41.5 & ND & ND \\
\hline 170.25 & $\mathrm{H} 2$ & 0.285 & ND & ND & 27.7 & 15.1 & ND & ND \\
\hline 172.30 & $\mathrm{H} 2$ & 0.271 & 8.07 & 6.72 & $\mathrm{NM}$ & 60.8 & ND & ND \\
\hline 174.05 & $\mathrm{H} 2$ & 0.257 & ND & ND & 24.6 & 15.3 & ND & ND \\
\hline 176.90 & $\mathrm{H} 2$ & 0.378 & 9.01 & 7.19 & $\mathrm{NM}$ & 63.2 & ND & ND \\
\hline 176.90 Dup & $\mathrm{H} 2$ & 0.368 & 9.16 & 7.32 & $\mathrm{NM}$ & 64.9 & ND & ND \\
\hline 182.25 & $\mathrm{H} 2$ & 0.320 & 11.0 & 4.87 & NM & 60.0 & ND & ND \\
\hline 186.25 & $\mathrm{H} 2$ & 0.315 & 11.3 & 4.25 & $\mathrm{NM}$ & 53.0 & ND & ND \\
\hline 191.25 & $\mathrm{H} 2$ & 0.321 & 16.1 & 5.38 & $\mathrm{NM}$ & 52.7 & ND & ND \\
\hline 195.25 & $\mathrm{H} 2$ & 0.300 & 21.1 & 6.96 & $\mathrm{NM}$ & 55.8 & ND & ND \\
\hline \multicolumn{9}{|c|}{$\begin{array}{l}\text { Shaded values designate the core samples and unshaded values are grab samples. } \\
\text { Bold values are higher than others for given constituent. } \\
\text { Italicized values are lower than others for a given constituent. }\end{array}$} \\
\hline
\end{tabular}

The water-extractable major cations in the C4297 borehole sediments are tabulated in Table 4.19 and the distribution with depth is shown in Figure 4.14. The distribution of the divalent-alkaline-earth cations (magnesium, calcium, and strontium and to some extent barium), showed decreasing quantities beginning at $7 \mathrm{ft}$ bgs, with very low (less than $2 \mu \mathrm{g} / \mathrm{g}$ ) to non-detectable water-extractable quantities between 40.8 and $60 \mathrm{ft}$ bgs, and lower than background levels through $120 \mathrm{ft}$ bgs. Conversely, the distribution of water-extractable sodium was higher than the mass that was water-leachable from sediments in the profile from 7 to $110 \mathrm{ft}$ bgs, with the primary elevated range occurring between 40.8 and $60 \mathrm{ft}$ bgs. It should be noted that although sodium was the dominant water-extractable cation (which is an indication that the sediment properties have been altered by a tank process waste stream) beginning at approximately $7 \mathrm{ft}$ bgs, it wasn't present in a significant excess compared to the common divalent cations (calcium and magnesium) until approximately $45 \mathrm{ft}$ bgs. These trends suggest that tank fluids that were high in sodium did seep into the vadose zone at two locations near this borehole. The first source occurred shallow in the vadose zone, beginning at approximately $7 \mathrm{ft}$ bgs. The source appears to be a relatively dilute sodiumbearing waste solution. The sodium from this source has pushed the natural divalent cations off the sediment cation exchange sites in the sediments at least as far as the tank bottom, approximately $40 \mathrm{ft}$ bgs, where a more concentrated or larger sodium-bearing waste source has been intercepted by this borehole. This second waste source has pushed the natural divalent cations off the sediment cation exchange sites in the sediments at least as far as $120 \mathrm{ft}$ bgs. We have observed similar cation distribution and ion exchange fronts, where divalent cations and sometimes potassium are depleted in the shallow sediments, and high levels of water-extractable sodium are present, at both the SX and BX Tank Farms where tank fluids have 
been confirmed as being present (see Serne et al. 2002b, 2002c, 2002e, 2002f for details). At and right below the leading edge of the sodium plume, one finds elevated levels of the divalent cations that were displaced. For the three more common divalent cations (calcium, magnesium, and strontium), the highest concentrations occurred in the $136.75 \mathrm{ft}$ sample. The water-extractable sodium concentration approached background levels below $110 \mathrm{ft}$ bgs.

The water-extractable aluminum, silicon, iron, manganese, zinc, copper, phosphorous, and sulfur in the C4297 borehole sediments are shown in Table 4.19 and Figures 4.15 and 4.16. The phosphorous and sulfur data were converted to water-extractable phosphate and sulfate and are plotted with the data in Figure 4.13. The water-soluble aluminum and iron data both showed elevated values between the depths of 40 and 60 bgs. We speculate that these elevated values indicated some chemical reaction between alkaline tank fluids and native sediments that formed precipitates of amorphous aluminum and/or iron phases that are more water soluble than aluminum- and iron-rich phases in the native sediments.

The manganese, zinc, and copper water extract data were all below the instrument limit of quantification. 


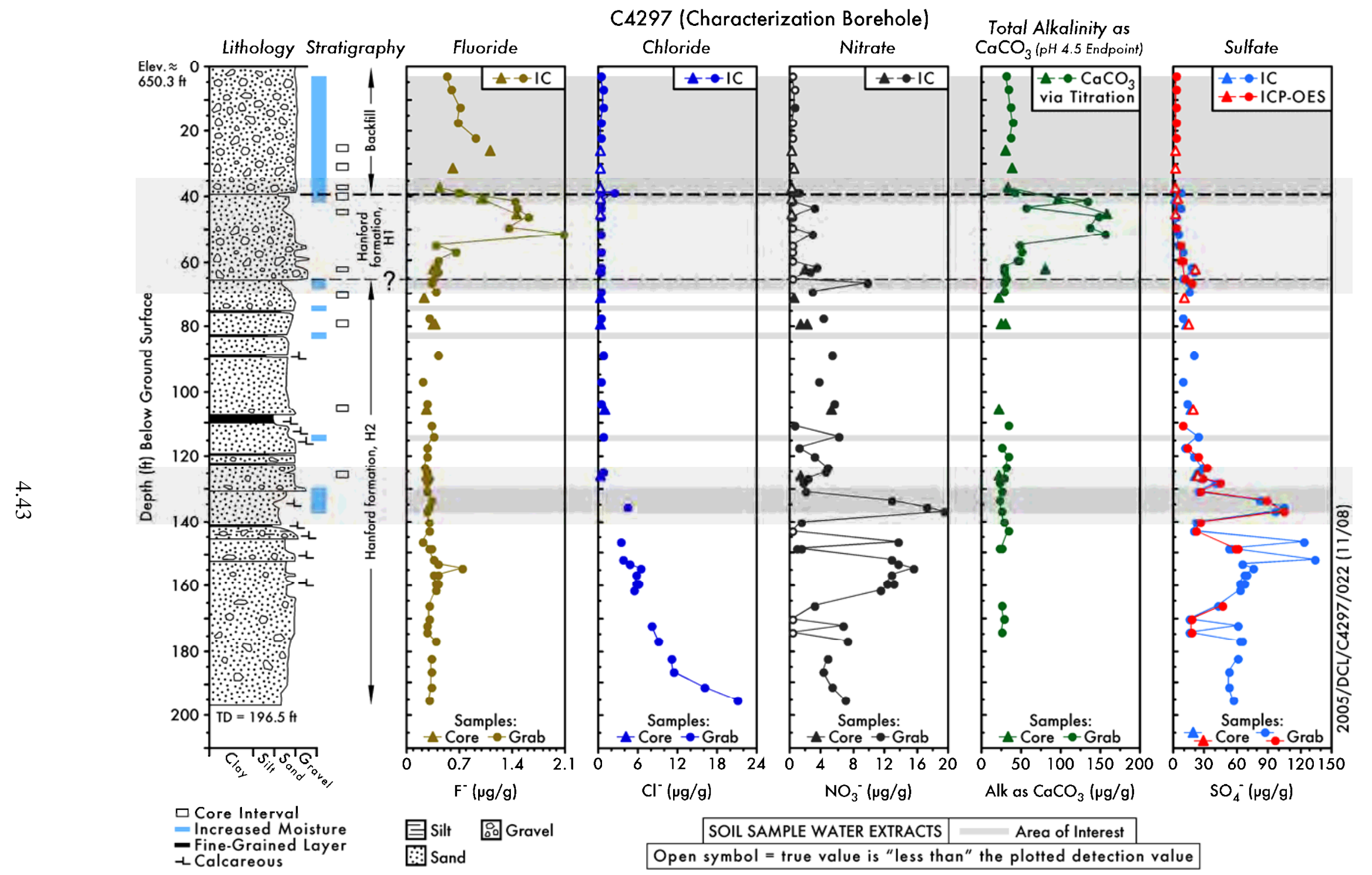

Figure 4.13. Borehole C4297 Water-Extractable Anions ( $\mu \mathrm{g} / \mathrm{g}$ dry sediment) 


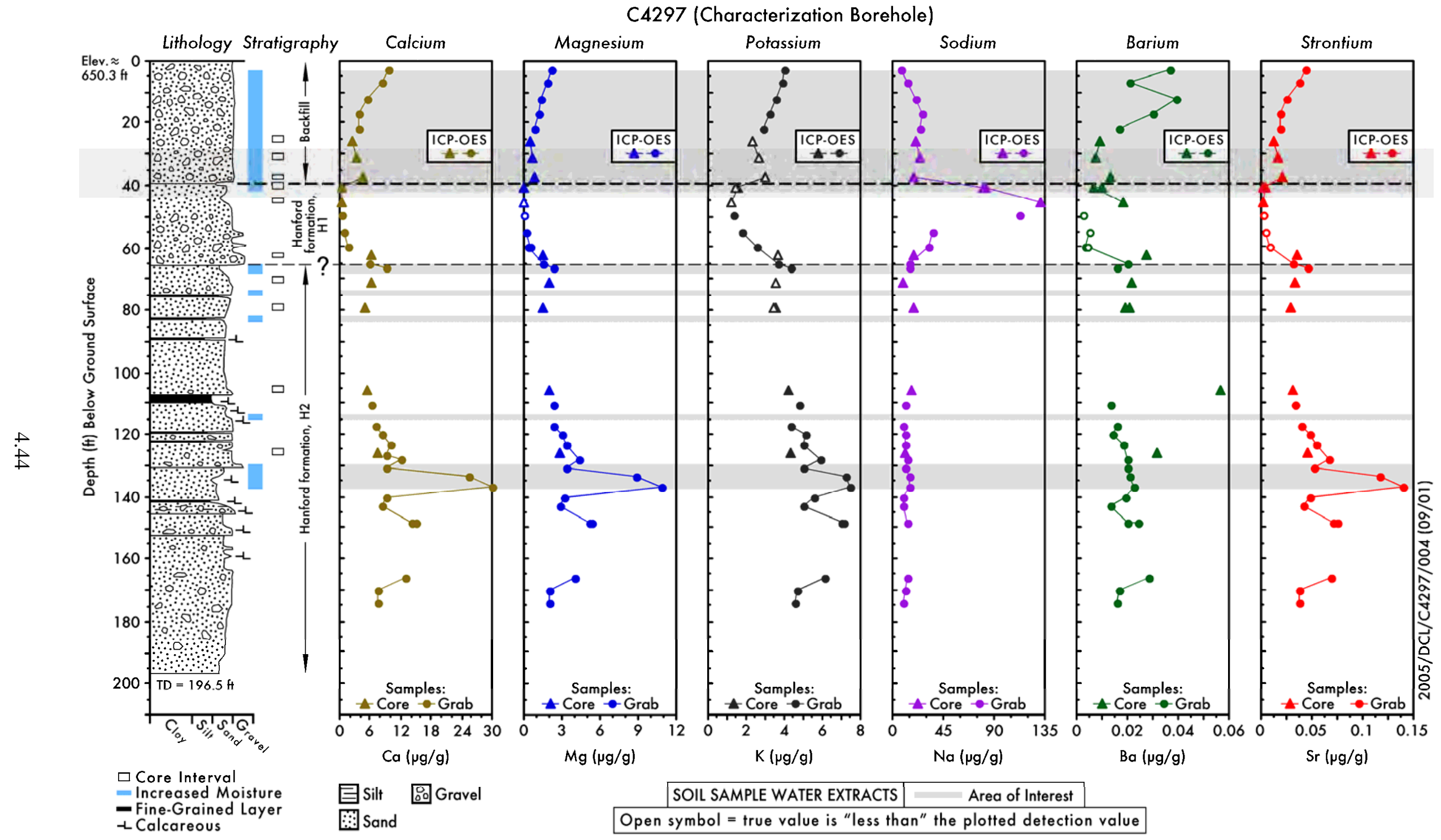

Figure 4.14. Water-Extractable Cations in C4297 Vadose Zone Sediments ( $\mu \mathrm{g} / \mathrm{g})$ 
Table 4.18. Water-Extractable Concentrations of Other Metals in C4297 Vadose Zone Sediments ( $\mu \mathrm{g} / \mathrm{g}$ dry sediment)

\begin{tabular}{|c|c|c|c|c|c|c|c|c|c|}
\hline $\begin{array}{l}\text { Depth } \\
\text { (ft bgs) }\end{array}$ & $\begin{array}{l}\text { Stratigraphic Unit } \\
\text { (Hanford formation) }\end{array}$ & Aluminum & Silicon & Iron & Manganese & Zinc & Phosphorous as $\mathrm{PO}_{4}$ & Sulfur as $\mathrm{SO}_{4}$ & Copper \\
\hline 2.50 & Backfill & $(2.58 \mathrm{E}-02)$ & $1.40 \mathrm{E}+01$ & $(1.78 \mathrm{E}-02)$ & ND & $(4.98 \mathrm{E}-02)$ & $(2.62 \mathrm{E}-01)$ & $1.93 \mathrm{E}+00$ & $(3.58 \mathrm{E}-02)$ \\
\hline 7.00 & Backfill & $(3.89 \mathrm{E}-02)$ & $1.38 \mathrm{E}+01$ & $(2.50 \mathrm{E}-02)$ & ND & $(5.14 \mathrm{E}-02)$ & $(2.75 \mathrm{E}-01)$ & $2.17 \mathrm{E}+00$ & (3.57E-02) \\
\hline 12.00 & Backfill & $(4.00 \mathrm{E}-02)$ & $1.40 \mathrm{E}+01$ & $(2.75 \mathrm{E}-02)$ & ND & $(4.05 \mathrm{E}-02)$ & $(2.47 \mathrm{E}-01)$ & $2.86 \mathrm{E}+00$ & (3.23E-02) \\
\hline 17.00 & Backfill & (5.99E-02) & $1.39 \mathrm{E}+01$ & 5.07E-02 & ND & (7.69E-02) & $(2.64 \mathrm{E}-01)$ & $2.08 \mathrm{E}+00$ & (3.15E-02) \\
\hline 22.00 & Backfill & (5.91E-02) & $1.27 \mathrm{E}+01$ & 7.63E-02 & ND & $(4.22 \mathrm{E}-02)$ & $(2.31 \mathrm{E}-01)$ & $3.19 \mathrm{E}+00$ & $(2.79 \mathrm{E}-02)$ \\
\hline 25.75 & Backfill & $(5.91 \mathrm{E}-02)$ & $9.94 \mathrm{E}+00$ & (5.32E-02) & $(1.34 \mathrm{E}-03)$ & (4.05E-02) & $(4.40 \mathrm{E}-02)$ & $(2.33 \mathrm{E}+00)$ & $(1.04 \mathrm{E}-02)$ \\
\hline 31.00 & Backfill & $(4.74 \mathrm{E}-02)$ & $1.25 \mathrm{E}+01$ & (3.90E-02) & $(1.08 \mathrm{E}-03)$ & $(2.28 \mathrm{E}-02)$ & $(1.26 \mathrm{E}-01)$ & $(2.21 \mathrm{E}+00)$ & (8.82E-03) \\
\hline 37.15 & Backfill & $(4.40 \mathrm{E}-02)$ & $1.31 \mathrm{E}+01$ & $(4.57 \mathrm{E}-02)$ & $(2.62 \mathrm{E}-04)$ & $(4.01 \mathrm{E}-02)$ & (5.18E-01) & $(3.27 \mathrm{E}+00)$ & (1.06E-02) \\
\hline 40.80 & $\mathrm{H} 1$ & 2.21E-01 & $1.38 \mathrm{E}+01$ & $1.69 \mathrm{E}-01$ & $(2.30 \mathrm{E}-03)$ & (5.29E-02) & (7.10E-01) & $(3.44 \mathrm{E}+00)$ & (1.25E-02) \\
\hline 40.80 Dup & H1 & 2.18E-01 & $1.37 \mathrm{E}+01$ & 1.73E-01 & (2.69E-03) & $(4.90 \mathrm{E}-02)$ & (8.16E-01) & $(3.34 \mathrm{E}+00)$ & $(2.29 \mathrm{E}-02)$ \\
\hline 45.45 & $\mathrm{H} 1$ & 3.53E-01 & $1.43 \mathrm{E}+01$ & 2.21E-01 & $(4.60 \mathrm{E}-03)$ & $(2.20 \mathrm{E}-02)$ & $1.56 \mathrm{E}+00$ & $(2.69 \mathrm{E}+00)$ & (1.73E-02) \\
\hline 49.25 & $\mathrm{H} 1$ & $2.50 \mathrm{E}-01$ & $1.36 \mathrm{E}+01$ & $1.93 E-01$ & $(3.67 E-03)$ & $(4.59 \mathrm{E}-02)$ & $1.16 E+00$ & $1.72 E+00$ & $(2.89 \mathrm{E}-02)$ \\
\hline 55.20 & $\mathrm{H} 1$ & 1.13E-01 & $1.07 \mathrm{E}+01$ & 7.74E-02 & $(6.48 \mathrm{E}-04)$ & (4.24E-02) & $(2.42 \mathrm{E}-01)$ & $5.95 \mathrm{E}+00$ & (2.36E-02) \\
\hline 60.00 & $\mathrm{H} 1$ & $1.08 E-01$ & $9.61 \mathrm{E}+00$ & 8.79E-02 & $(9.62 E-04)$ & $(5.84 \mathrm{E}-02)$ & 7.18E-01 & $6.72 \mathrm{E}+00$ & $(2.22 \mathrm{E}-02)$ \\
\hline 60.00 Dup & $\mathrm{H} 1$ & $1.27 \mathrm{E}-01$ & $9.68 \mathrm{E}+00$ & 1.11E-01 & $(1.27 \mathrm{E}-03)$ & $(4.27 \mathrm{E}-02)$ & 6.22E-01 & $8.17 E+00$ & (5.78E-03) \\
\hline 62.50 & $\mathrm{H} 1$ & $(4.18 \mathrm{E}-02)$ & $1.01 \mathrm{E}+01$ & $(1.59 \mathrm{E}-02)$ & ND & $(4.21 \mathrm{E}-02)$ & $(4.45 \mathrm{E}-02)$ & $(2.12 \mathrm{E}+01)$ & $(1.30 \mathrm{E}-02)$ \\
\hline 64.85 & $\mathrm{H} 1$ & $(4.52 \mathrm{E}-02)$ & $1.11 \mathrm{E}+01$ & $(2.88 \mathrm{E}-02)$ & ND & (5.29E-02) & $(1.02 \mathrm{E}-01)$ & $1.07 \mathrm{E}+01$ & (2.42E-02) \\
\hline 66.20 & $\mathrm{H} 1$ & $(3.85 \mathrm{E}-02)$ & $1.19 \mathrm{E}+01$ & (1.73E-02) & ND & (5.38E-02) & (1.10E-01) & $1.77 \mathrm{E}+01$ & $(1.80 \mathrm{E}-02)$ \\
\hline 71.25 & $\mathrm{H} 2$ & (5.45E-02) & $7.46 \mathrm{E}+00$ & (8.08E-03) & ND & $(2.83 \mathrm{E}-02)$ & ND & $(1.11 \mathrm{E}+01)$ & $(1.38 \mathrm{E}-02)$ \\
\hline 79.55 & $\mathrm{H} 2$ & (5.15E-02) & $8.17 \mathrm{E}+00$ & $(1.66 \mathrm{E}-02)$ & $\mathrm{ND}$ & (3.73E-02) & (1.47E-01) & $(1.53 \mathrm{E}+01)$ & (1.01E-02) \\
\hline 79.55 Dup & $\mathrm{H} 2$ & $(4.40 \mathrm{E}-02)$ & $8.35 \mathrm{E}+00$ & $(1.47 \mathrm{E}-02)$ & ND & $(4.14 \mathrm{E}-02)$ & ND & $(1.58 \mathrm{E}+01)$ & (1.22E-02) \\
\hline 106.05 & $\mathrm{H} 2$ & $(4.62 \mathrm{E}-02)$ & $7.71 \mathrm{E}+00$ & $(1.87 \mathrm{E}-02)$ & ND & (5.38E-02) & (1.07E-01) & $(1.97 \mathrm{E}+01)$ & (1.29E-02) \\
\hline 110.15 & $\mathrm{H} 2$ & (6.00E-02) & $8.87 \mathrm{E}+00$ & (2.63E-02) & ND & $2.12 \mathrm{E}-01$ & (8.00E-02) & $9.29 \mathrm{E}+00$ & $(1.92 \mathrm{E}-02)$ \\
\hline 117.40 & $\mathrm{H} 2$ & $(5.70 \mathrm{E}-02)$ & $8.18 \mathrm{E}+00$ & $(2.84 \mathrm{E}-02)$ & ND & (5.33E-02) & $(7.28 \mathrm{E}-02)$ & $1.33 \mathrm{E}+01$ & $(1.26 \mathrm{E}-02)$ \\
\hline
\end{tabular}


Table 4.18. (contd)

\begin{tabular}{|c|c|c|c|c|c|c|c|c|c|}
\hline $\begin{array}{l}\text { Depth } \\
\text { (ft bgs) }\end{array}$ & $\begin{array}{l}\begin{array}{l}\text { Stratigraphic Unit } \\
\text { (Hanford formation) }\end{array} \\
\end{array}$ & Aluminum & Silicon & Iron & Manganese & Zinc & Phosphorous as $\mathrm{PO}_{4}$ & Sulfur as $\mathrm{SO}_{4}$ & Copper \\
\hline 120.25 & $\mathrm{H} 2$ & $(5.21 \mathrm{E}-02)$ & $8.12 \mathrm{E}+00$ & $(1.41 \mathrm{E}-02)$ & ND & (5.15E-02) & (9.45E-02) & $2.21 \mathrm{E}+01$ & (1.03E-02) \\
\hline 123.65 & $\mathrm{H} 2$ & $(5.28 \mathrm{E}-02)$ & $8.31 \mathrm{E}+00$ & $(2.05 \mathrm{E}-02)$ & ND & $(4.45 \mathrm{E}-02)$ & $(6.76 \mathrm{E}-02)$ & $3.11 \mathrm{E}+01$ & (8.98E-03) \\
\hline 126.35 & $\mathrm{H} 2$ & $(5.58 \mathrm{E}-02)$ & $8.10 \mathrm{E}+00$ & $(7.35 \mathrm{E}-03)$ & ND & $(3.36 \mathrm{E}-02)$ & ND & $(2.34 \mathrm{E}+01)$ & (8.95E-03) \\
\hline 126.75 & $\mathrm{H} 2$ & $(6.72 \mathrm{E}-02)$ & $8.33 \mathrm{E}+00$ & $(1.93 \mathrm{E}-02)$ & ND & $(3.84 \mathrm{E}-02)$ & $(7.89 \mathrm{E}-02)$ & $2.80 \mathrm{E}+01$ & (8.53E-03) \\
\hline 127.85 & $\mathrm{H} 2$ & $(5.02 \mathrm{E}-02)$ & $8.08 \mathrm{E}+00$ & $(1.09 \mathrm{E}-02)$ & ND & $(2.36 \mathrm{E}-02)$ & $(5.06 \mathrm{E}-02)$ & $4.42 \mathrm{E}+01$ & (9.93E-03) \\
\hline 130.65 & $\mathrm{H} 2$ & (5.53E-02) & $8.79 \mathrm{E}+00$ & $(1.90 \mathrm{E}-02)$ & ND & $(1.39 \mathrm{E}-02)$ & $(7.50 \mathrm{E}-02)$ & $2.55 \mathrm{E}+01$ & (6.74E-03) \\
\hline 133.75 & $\mathrm{H} 2$ & $(1.54 \mathrm{E}-02)$ & $1.07 \mathrm{E}+01$ & $(1.38 \mathrm{E}-02)$ & ND & $(2.51 \mathrm{E}-02)$ & $(2.72 \mathrm{E}-02)$ & 8.87E+01 & (5.17E-03) \\
\hline 136.75 & $\mathrm{H} 2$ & $(5.50 \mathrm{E}-03)$ & $9.94 \mathrm{E}+00$ & $(2.30 \mathrm{E}-02)$ & ND & $(2.35 \mathrm{E}-02)$ & $(1.09 \mathrm{E}-01)$ & $1.04 \mathrm{E}+02$ & $(1.65 \mathrm{E}-02)$ \\
\hline 140.00 & $\mathrm{H} 2$ & (6.94E-02) & $7.59 \mathrm{E}+00$ & $(1.90 \mathrm{E}-02)$ & $(1.14 \mathrm{E}-03)$ & $(4.71 \mathrm{E}-02)$ & (5.09E-02) & $2.48 \mathrm{E}+01$ & $(1.11 \mathrm{E}-02)$ \\
\hline 143.25 & $\mathrm{H} 2$ & $(6.78 \mathrm{E}-02)$ & $7.43 \mathrm{E}+00$ & $(2.08 \mathrm{E}-02)$ & $(6.61 \mathrm{E}-04)$ & (4.23E-02) & $(4.00 \mathrm{E}-02)$ & $2.01 \mathrm{E}+01$ & (7.52E-03) \\
\hline 148.30 & $\mathrm{H} 2$ & $(4.64 \mathrm{E}-02)$ & $8.32 \mathrm{E}+00$ & $(1.29 \mathrm{E}-02)$ & $(1.32 \mathrm{E}-03)$ & $(5.28 \mathrm{E}-02)$ & (9.17E-02) & $5.89 \mathrm{E}+01$ & (6.19E-03) \\
\hline 148.30 Dup & $\mathrm{H} 2$ & (4.19E-02) & $7.85 \mathrm{E}+00$ & $(1.25 \mathrm{E}-02)$ & $(1.24 \mathrm{E}-03)$ & $(4.47 \mathrm{E}-02)$ & $(5.88 \mathrm{E}-02)$ & $6.07 \mathrm{E}+01$ & $(1.61 \mathrm{E}-03)$ \\
\hline 165.75 & $\mathrm{H} 2$ & (5.74E-02) & $9.13 \mathrm{E}+00$ & $(1.87 \mathrm{E}-02)$ & ND & $8.46 \mathrm{E}-02$ & $(4.06 \mathrm{E}-02)$ & $4.59 \mathrm{E}+01$ & $(4.71 \mathrm{E}-03)$ \\
\hline 170.25 & $\mathrm{H} 2$ & $(5.25 \mathrm{E}-02)$ & $9.13 \mathrm{E}+00$ & 3.31E-02 & ND & $(2.39 \mathrm{E}-02)$ & (5.55E-02) & $1.67 \mathrm{E}+01$ & (3.49E-03) \\
\hline 174.05 & $\mathrm{H} 2$ & $(5.45 \mathrm{E}-02)$ & $8.37 \mathrm{E}+00$ & $(2.17 \mathrm{E}-02)$ & ND & (4.49E-02) & $(3.81 \mathrm{E}-02)$ & $1.70 \mathrm{E}+01$ & $(2.81 \mathrm{E}-03)$ \\
\hline \multicolumn{10}{|c|}{ Parentheses signify values below level of quantitation. } \\
\hline
\end{tabular}


Table 4.19. Water-Extractable Cations in C4297 Vadose Zone Sediments ( $\mu \mathrm{g} / \mathrm{g}$ dry sediment)

\begin{tabular}{|c|c|c|c|c|c|c|c|}
\hline $\begin{array}{l}\text { Depth } \\
\text { (ft bgs) }\end{array}$ & $\begin{array}{c}\text { Strat Unit } \\
\text { (Hanford formation) }\end{array}$ & Calcium & Magnesium & Barium & Strontium & Sodium & Potassium \\
\hline 2.50 & Backfill & $9.83 \mathrm{E}+00$ & $2.11 \mathrm{E}+00$ & 3.65E-02 & 4.40E-02 & $8.26 \mathrm{E}+00$ & $4.02 \mathrm{E}+00$ \\
\hline 7.00 & Backfill & $8.24 E+00$ & $1.80 E+00$ & $2.10 E-02$ & $3.69 E-02$ & $1.26 \mathrm{E}+01$ & $3.86 E+00$ \\
\hline 12.00 & Backfill & $5.39 E+00$ & $1.29 E+00$ & 3.95E-02 & $2.55 E-02$ & $2.01 E+01$ & $3.58 E+00$ \\
\hline 17.00 & Backfill & $3.74 E+00$ & $1.13 E+00$ & $3.04 E-02$ & $1.93 E-02$ & $2.58 \mathrm{E}+01$ & $3.20 E+00$ \\
\hline 22.00 & Backfill & $3.86 E+00$ & $9.05 E-01$ & $1.68 E-02$ & $1.91 E-02$ & $2.39 E+01$ & $2.91 E+00$ \\
\hline 25.75 & Backfill & $2.58 E+00$ & $5.78 E-01$ & $9.16 E-03$ & $1.37 E-02$ & $2.10 E+01$ & $(2.29 E+00)$ \\
\hline 31.00 & Backfill & $3.44 E+00$ & $7.55 E-01$ & $7.96 E-03$ & $1.77 E-02$ & $2.38 E+01$ & $(2.68 E+00)$ \\
\hline 37.15 & Backfill & $4.56 E+00$ & $8.65 E-01$ & $1.32 E-02$ & $2.05 E-02$ & $1.85 E+01$ & $(3.01 E+00)$ \\
\hline 40.80 & H1 & $5.04 E-01$ & $9.50 E-02$ & $1.00 E-02$ & $3.04 E-03$ & 8.15E +01 & $(1.47 E+00)$ \\
\hline 40.80 Dup & H1 & $5.31 E-01$ & $9.97 E-02$ & $6.65 E-03$ & $3.45 E-03$ & $8.36 E+01$ & $(1.58 E+00)$ \\
\hline 45.45 & H1 & $4.54 E-01$ & $(6.70 E-02)^{a}$ & $1.86 E-02$ & $3.16 E-03$ & $1.31 E+02$ & $(1.28 E+00)$ \\
\hline 49.25 & H1 & $4.73 E-01$ & $(9.13 E-02)$ & $(2.67 E-03)$ & $(2.13 E-03)$ & $1.12 E+02$ & $1.34 E+00$ \\
\hline 55.20 & H1 & $1.04 E+00$ & $2.25 E-01$ & $(4.67 E-03)$ & $(4.96 E-03)$ & $3.49 E+01$ & $1.79 E+00$ \\
\hline 60.00 & H1 & $1.81 E+00$ & $4.48 E-01$ & (3.37E-03) & (8.49E-03) & $3.24 \mathrm{E}+01$ & $2.56 E+00$ \\
\hline 60.00 Dup & H1 & $1.71 E+00$ & $4.05 E-01$ & $(4.37 E-03)$ & $(8.31 E-03)$ & $3.26 \mathrm{E}+01$ & $2.56 E+00$ \\
\hline 62.50 & H1 & $6.39 E+00$ & $1.55 \mathrm{E}+00$ & $2.78 \mathrm{E}-02$ & $3.50 \mathrm{E}-02$ & $1.83 \mathrm{E}+01$ & $(3.69 E+00)$ \\
\hline 64.85 & H1 & $5.94 \mathrm{E}+00$ & $1.47 \mathrm{E}+00$ & 2.00E-02 & 3.13E-02 & $1.52 \mathrm{E}+01$ & $3.68 \mathrm{E}+00$ \\
\hline 66.20 & H1 & $9.20 \mathrm{E}+00$ & $2.43 E+00$ & $1.55 \mathrm{E}-02$ & 4.69E-02 & $1.51 \mathrm{E}+01$ & $4.34 \mathrm{E}+00$ \\
\hline 71.25 & $\mathrm{H} 2$ & $6.45 \mathrm{E}+00$ & $1.95 \mathrm{E}+00$ & $2.16 \mathrm{E}-02$ & 3.38E-02 & $8.78 E+00$ & $(3.60 \mathrm{E}+00)$ \\
\hline 79.55 & $\mathrm{H} 2$ & $5.04 \mathrm{E}+00$ & $1.45 \mathrm{E}+00$ & 1.90E-02 & 2.85E-02 & $1.80 \mathrm{E}+01$ & $(3.42 E+00)$ \\
\hline 79.55 Dup & $\mathrm{H} 2$ & $5.08 \mathrm{E}+00$ & $1.47 \mathrm{E}+00$ & 2.12E-02 & 2.90E-02 & $1.83 \mathrm{E}+01$ & $(3.57 E+00)$ \\
\hline 106.05 & $\mathrm{H} 2$ & $5.64 \mathrm{E}+00$ & $2.08 \mathrm{E}+00$ & 5.67E-02 & 3.23E-02 & $1.70 \mathrm{E}+01$ & $4.22 \mathrm{E}+00$ \\
\hline 110.15 & H2 & $6.32 \mathrm{E}+00$ & $2.36 \mathrm{E}+00$ & 1.38E-02 & 3.41E-02 & $1.16 \mathrm{E}+01$ & $4.77 \mathrm{E}+00$ \\
\hline 117.40 & H2 & $6.95 \mathrm{E}+00$ & $2.41 \mathrm{E}+00$ & $1.56 \mathrm{E}-02$ & 3.88E-02 & $9.52 \mathrm{E}+00$ & $4.32 \mathrm{E}+00$ \\
\hline 120.25 & $\mathrm{H} 2$ & $8.44 \mathrm{E}+00$ & $2.99 \mathrm{E}+00$ & 1.44E-02 & 4.84E-02 & $1.14 \mathrm{E}+01$ & $5.16 \mathrm{E}+00$ \\
\hline 123.65 & $\mathrm{H} 2$ & $9.88 \mathrm{E}+00$ & $3.38 \mathrm{E}+00$ & 1.83E-02 & $5.44 \mathrm{E}-02$ & $1.17 \mathrm{E}+01$ & $4.99 \mathrm{E}+00$ \\
\hline 126.35 & $\mathrm{H} 2$ & $7.57 \mathrm{E}+00$ & $2.82 \mathrm{E}+00$ & 3.16E-02 & 4.64E-02 & $1.07 \mathrm{E}+01$ & $4.39 \mathrm{E}+00$ \\
\hline 126.75 & $\mathrm{H} 2$ & $9.07 \mathrm{E}+00$ & $3.32 \mathrm{E}+00$ & $1.66 \mathrm{E}-02$ & 5.08E-02 & $1.29 \mathrm{E}+01$ & $5.34 \mathrm{E}+00$ \\
\hline 127.85 & H2 & $1.23 \mathrm{E}+01$ & $4.32 \mathrm{E}+00$ & 1.97E-02 & 6.62E-02 & $1.28 \mathrm{E}+01$ & $5.94 \mathrm{E}+00$ \\
\hline 130.65 & $\mathrm{H} 2$ & $9.34 \mathrm{E}+00$ & $3.35 \mathrm{E}+00$ & 2.03E-02 & 5.21E-02 & $1.20 \mathrm{E}+01$ & $5.05 \mathrm{E}+00$ \\
\hline 133.75 & $\mathrm{H} 2$ & $2.53 E+01$ & $8.86 E+00$ & 2.05E-02 & 1.16E-01 & $1.58 \mathrm{E}+01$ & $7.18 \mathrm{E}+00$ \\
\hline 136.75 & $\mathrm{H} 2$ & $3.00 \mathrm{E}+01$ & $1.09 \mathrm{E}+01$ & 2.27E-02 & 1.39E-01 & $1.46 \mathrm{E}+01$ & $7.46 \mathrm{E}+00$ \\
\hline 140.00 & $\mathrm{H} 2$ & $9.26 \mathrm{E}+00$ & $3.25 \mathrm{E}+00$ & 1.91E-02 & 4.89E-02 & $1.04 \mathrm{E}+01$ & $5.60 \mathrm{E}+00$ \\
\hline 143.25 & $\mathrm{H} 2$ & $8.49 \mathrm{E}+00$ & $2.87 \mathrm{E}+00$ & 1.31E-02 & 4.22E-02 & $8.74 \mathrm{E}+00$ & $5.05 \mathrm{E}+00$ \\
\hline 148.30 & $\mathrm{H} 2$ & $1.44 \mathrm{E}+01$ & $5.16 \mathrm{E}+00$ & $1.98 \mathrm{E}-02$ & 7.04E-02 & $1.31 \mathrm{E}+01$ & $7.10 \mathrm{E}+00$ \\
\hline
\end{tabular}


Table 4.19. (contd)

\begin{tabular}{||l|l|l|l|l|l|l|l||}
\hline $\begin{array}{c}\text { Depth } \\
\text { (ft bgs) }\end{array}$ & $\begin{array}{c}\text { Stratigraphic Unit } \\
\text { (Hanford formation) }\end{array}$ & Calcium & Magnesium & Barium & Strontium & Sodium & Potassium \\
\hline \hline $\begin{array}{l}148.30 \\
\text { Dup }\end{array}$ & H2 & $1.49 \mathrm{E}+01$ & $5.32 \mathrm{E}+00$ & $2.39 \mathrm{E}-02$ & $7.48 \mathrm{E}-02$ & $1.25 \mathrm{E}+01$ & $7.06 \mathrm{E}+00$ \\
\hline 165.75 & $\mathrm{H} 2$ & $1.30 \mathrm{E}+01$ & $3.94 \mathrm{E}+00$ & $2.83 \mathrm{E}-02$ & $6.82 \mathrm{E}-02$ & $1.40 \mathrm{E}+01$ & $6.10 \mathrm{E}+00$ \\
\hline 170.25 & $\mathrm{H} 2$ & $7.34 \mathrm{E}+00$ & $1.98 \mathrm{E}+00$ & $1.65 \mathrm{E}-02$ & $3.83 \mathrm{E}-02$ & $1.08 \mathrm{E}+01$ & $4.65 \mathrm{E}+00$ \\
\hline 174.05 & $\mathrm{H} 2$ & $7.66 \mathrm{E}+00$ & $2.05 \mathrm{E}+00$ & $1.62 \mathrm{E}-02$ & $3.78 \mathrm{E}-02$ & $9.94 \mathrm{E}+00$ & $4.61 \mathrm{E}+00$ \\
\hline $\begin{array}{l}\text { Parentheses signify values below level of quantitation. } \\
\text { Shaded values designate the core sample and unshaded values are grab samples. } \\
\text { Bold values are higher than others for given constituent. } \\
\text { Italicized values are lower than others for a given constituent. } \\
\text { Dup = Duplicate sample. }\end{array}$ \\
\hline
\end{tabular}

The water extract data for potentially mobile metals such as technetium-99, uranium-238, chromium, molybdenum and ruthenium are shown in Table 4.20 and Figures 4.17 and 4.18. Water-leachable technetium 99 was present in the borehole C4297 sediment from 40.8 to $159 \mathrm{ft}$ bgs. The concentration versus depth profile for technetium-99 could be characterized as having two peaks. The first peak occurred between 40 and $66 \mathrm{ft}$ bgs. The second peak, which contained the bulk of the technetium-99, resided between the depths of 133 and $154 \mathrm{ft}$ bgs in the Hanford formation $\mathrm{H} 2$ unit. The maximum waterleachable technetium-99 in this zone ranged from 2.2 to $8.4 \mathrm{pCi} / \mathrm{g}$. This range is similar to values found at contaminated boreholes in the BX and B Tank Farms (5 to $20 \mathrm{pCi} / \mathrm{g}$ ), as described in Serne et al. (2002e, 2002f). Elevated water-leachable uranium-238 was found from ground surface to $60 \mathrm{ft}$ bgs at borehole C4297, with values ranging from 7.57E-4 to 2.17E-2 $\mu \mathrm{g} / \mathrm{g}$. The uranium concentration versus depth profile in sediment from borehole C4297 could also be characterized as having two peaks. The first peak occurred between 7 and $22 \mathrm{ft}$ bgs. The second peak, which contained the bulk of the waterextractable uranium, resided between the depths of 40 and $60 \mathrm{ft}$ bgs. The water-extractable uranium concentrations from both zones at C4297 were low compared to values found in the contaminated sediment east of the BX-102 tank, where values reached $500 \mu \mathrm{g} / \mathrm{g}$. Furthermore, based on the relatively high dissolved (bi)carbonate concentration measured in samples taken from the 40 to $60 \mathrm{ft}$ bgs, some of the water-extractable uranium could be associated with natural labile uranium released as a function of uranyl-carbonate complexation. These samples were scanned using inductively coupled plasma mass spectrometry for the presence of uranium-236, which was not observed; therefore, it is unlikely that the majority of the uranium present over this zone resulted from Hanford processing activities. Molybdenum, which is a fission product generated during the operation of nuclear reactors, can sometimes be used to delineate the profile of waste plumes in the subsurface. In the case of samples from borehole C4297, fission-produced molybdenum was clearly present between 26 and $64 \mathrm{ft}$ bgs. The primary zone of fission-produced molybdenum occurred between 55 and $64 \mathrm{ft}$ bgs; however, unlike the technetium-99 and nitrate contamination, it appears that all the fission-produced molybdenum in this borehole form a contiguous plume that is the result of a single contamination event. Therefore, the bimodal technetium-99 contamination profiles versus a single contaminant plume for molybdenum supports a two source contamination model. 


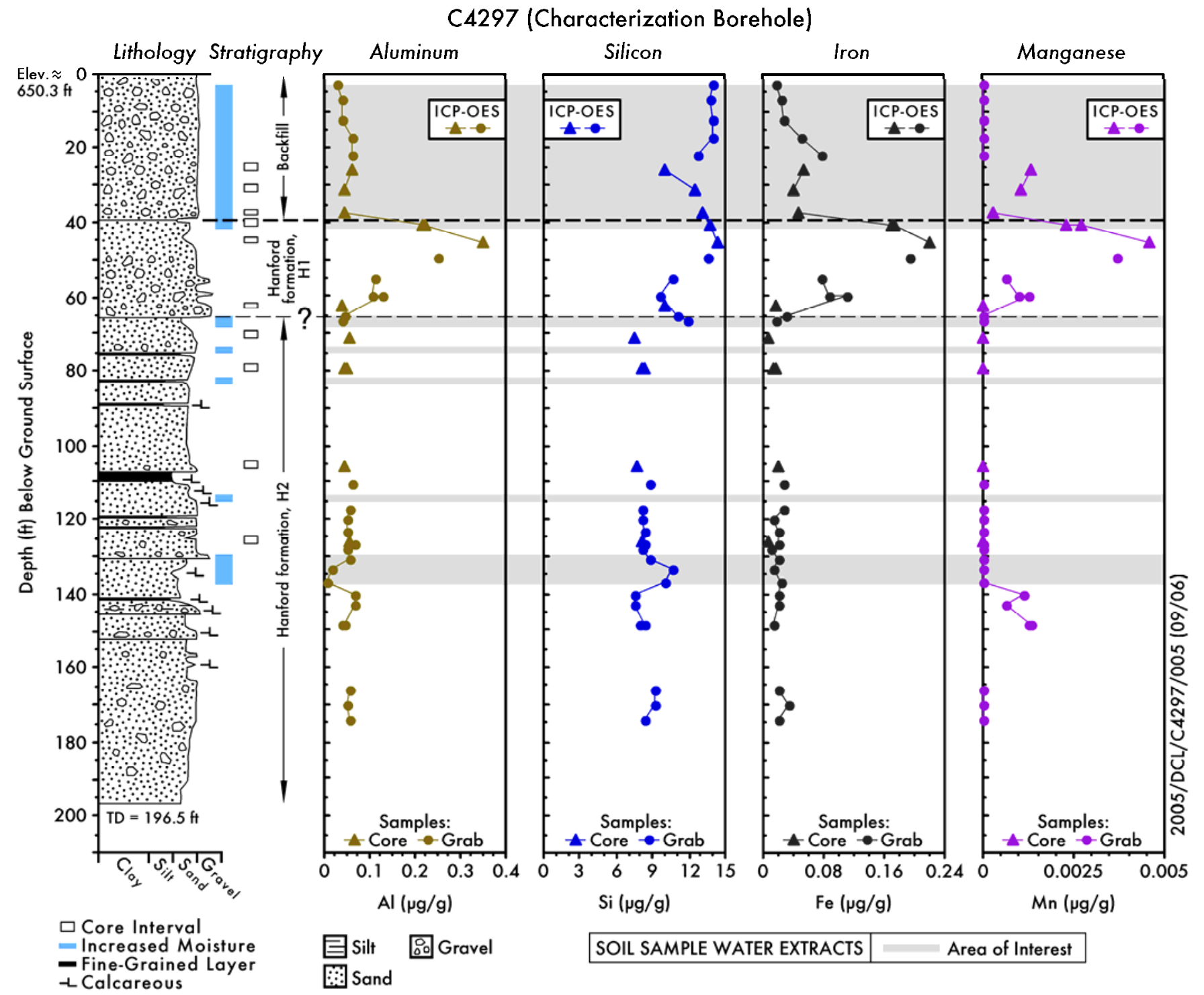

Figure 4.15. Water-Extractable Metals in C4297 Vadose Sediments ( $\mu \mathrm{g} / \mathrm{g}$ dry sediment) 


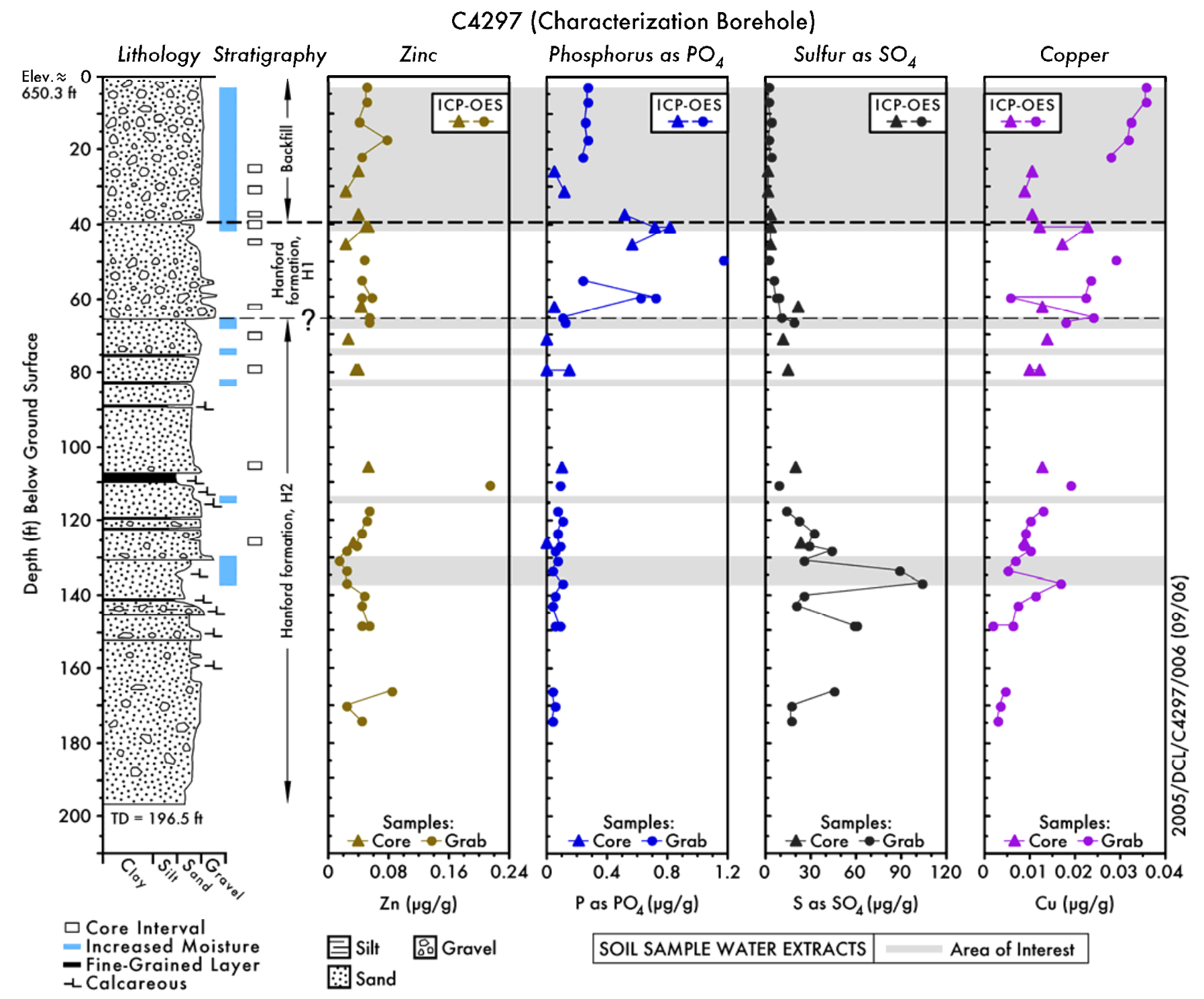

Figure 4.16. Water-Extractable Metals in C4297 Vadose Sediments ( $\mu \mathrm{g} / \mathrm{g}$ dry sediment) 
Table 4.20. Water-Extractable Concentrations of Mobile Metals in C4297 Vadose Sediments ( $\mu$ g/g dry sediment)

\begin{tabular}{|c|c|c|c|c|c|c|c|c|c|c|}
\hline $\begin{array}{c}\text { Depth } \\
\text { (ft bgs) }\end{array}$ & $\begin{array}{c}\text { Tc-99 } \\
\text { (pCi/g soil) }\end{array}$ & U-238 & $\begin{array}{c}\mathbf{C r} \\
\text { (ICP-MS) }\end{array}$ & $\begin{array}{c}\mathrm{Cr} \\
\text { (ICP) }\end{array}$ & $\begin{array}{c}\text { Mo-95 } \\
\text { (ICP-MS) }\end{array}$ & $\begin{array}{c}\text { Mo-97 } \\
\text { (ICP-MS) }\end{array}$ & $\begin{array}{c}\text { Mo-98 } \\
\text { (ICP-MS) }\end{array}$ & $\begin{array}{c}\text { Mo } \\
\text { (ICP) }\end{array}$ & $\begin{array}{c}\text { Ru-101 } \\
\text { (ICP-MS) }\end{array}$ & $\begin{array}{c}\text { Ru-102 } \\
\text { (ICP-MS) }\end{array}$ \\
\hline 2.50 & ND & 7.57E-04 & (6.72E-04) & $(1.66 \mathrm{E}-03)$ & $1.25 \mathrm{E}-03$ & 1.17E-03 & $1.28 \mathrm{E}-03$ & (5.14E-03) & (9.25E-06) & $(2.66 \mathrm{E}-05)$ \\
\hline 7.00 & ND & 1.05E-03 & (7.38E-04) & (1.07E-03) & 1.65E-03 & 1.62E-03 & 1.66E-03 & ND & (4.09E-06) & (2.04E-05) \\
\hline 12.00 & ND & 1.97E-03 & (6.20E-04) & $(1.39 \mathrm{E}-03)$ & $2.48 \mathrm{E}-03$ & 2.49E-03 & 2.49E-03 & (2.09E-03) & (3.58E-06) & (1.78E-05) \\
\hline 17.00 & ND & 2.59E-03 & (1.72E-04) & (1.56E-03) & 3.61E-03 & 3.70E-03 & 3.70E-03 & ND & (2.95E-06) & (1.63E-05) \\
\hline 22.00 & (8.54E-03) & 2.11E-03 & $(2.86 \mathrm{E}-04)$ & $(9.94 \mathrm{E}-04)$ & 4.15E-03 & 4.18E-03 & 4.25E-03 & $(2.03 \mathrm{E}-03)$ & $(2.29 \mathrm{E}-06)$ & $(1.69 \mathrm{E}-05)$ \\
\hline 25.75 & ND & $7.90 \mathrm{E}-04$ & $(3.10 \mathrm{E}-04)$ & ND & 5.00E-03 & 4.58E-03 & 2.14E-03 & ND & ND & $(9.00 \mathrm{E}-06)$ \\
\hline 31.00 & ND & $1.41 \mathrm{E}-03$ & (3.20E-04) & ND & 4.44E-03 & 4.29E-03 & 1.93E-03 & ND & $(1.61 \mathrm{E}-05)$ & $(2.14 \mathrm{E}-05)$ \\
\hline 37.15 & ND & 7.97E-04 & (2.75E-04) & ND & 5.82E-03 & $5.50 \mathrm{E}-03$ & 2.62E-03 & ND & ND & (7.00E-06) \\
\hline 38.35 & $(1.70 \mathrm{E}-02)$ & $1.46 \mathrm{E}-03$ & $(2.47 \mathrm{E}-04)$ & $(1.01 \mathrm{E}-03)$ & 1.11E-02 & $1.04 \mathrm{E}-02$ & 4.76E-03 & $(8.76 \mathrm{E}-03)$ & (2.10E-05) & ND \\
\hline 38.53 & $(8.60 \mathrm{E}-03)$ & $1.11 \mathrm{E}-03$ & NM & NM & NM & NM & NM & NM & NM & NM \\
\hline 40.80 & 1.44E-01 & 7.58E-03 & $(1.10 \mathrm{E}-03)$ & $(2.36 \mathrm{E}-04)$ & 5.52E-03 & $5.11 \mathrm{E}-03$ & $2.72 \mathrm{E}-03$ & ND & $(1.43 \mathrm{E}-04)$ & $(5.60 \mathrm{E}-05)$ \\
\hline 40.80 & 1.70E-01 & 6.81E-03 & (8.63E-04) & ND & 6.09E-03 & $5.52 \mathrm{E}-03$ & $2.92 \mathrm{E}-03$ & ND & $(1.31 \mathrm{E}-04)$ & $(5.20 \mathrm{E}-05)$ \\
\hline 41.20 & 3.30E-01 & 1.08E-02 & (8.66E-04) & (8.19E-04) & 5.01E-03 & $3.98 \mathrm{E}-03$ & $2.51 \mathrm{E}-03$ & (6.99E-03) & (1.98E-04) & $(1.34 \mathrm{E}-04)$ \\
\hline 43.75 & $5.80 \mathrm{E}-01$ & 8.97E-03 & (5.15E-04) & ND & 7.36E-03 & 6.16E-03 & 3.91E-03 & $(8.88 \mathrm{E}-03)$ & $(4.42 \mathrm{E}-04)$ & 2.06E-04 \\
\hline 45.45 & 4.83E- 01 & 1.13E-02 & $(2.36 \mathrm{E}-03)$ & $(1.11 \mathrm{E}-02)$ & 3.81E-03 & $2.98 \mathrm{E}-03$ & 2.13E-03 & ND & $(1.68 \mathrm{E}-04)$ & $(9.28 \mathrm{E}-05)$ \\
\hline 45.85 & 4.33E-01 & 1.33E-02 & (5.79E-04) & ND & 4.63E-03 & 3.55E-03 & 2.53E-03 & ND & $(2.34 \mathrm{E}-04)$ & $1.06 \mathrm{E}-04$ \\
\hline 49.25 & $(1.11 \mathrm{E}-01)$ & 9.51E-03 & $(4.90 \mathrm{E}-04)$ & (1.14E-03) & 6.49E-04 & 7.83E-04 & 5.13E-04 & ND & 1.07E-04 & (6.01E-05) \\
\hline 51.25 & 7.94E-01 & 2.06E-02 & (6.37E-04) & (1.49E-02) & $5.90 \mathrm{E}-03$ & 4.83E-03 & $3.58 \mathrm{E}-03$ & ND & $(2.09 \mathrm{E}-04)$ & 1.12E-04 \\
\hline 55.20 & $(1.02 \mathrm{E}-01)$ & 7.64E-03 & (5.90E-04) & (5.87E-04) & 1.35E-02 & $1.80 \mathrm{E}-02$ & 1.00E-02 & (8.34E-03) & 1.83E-04 & $(9.90 \mathrm{E}-05)$ \\
\hline 57.20 & 4.85E- 01 & 2.17E-02 & $(2.65 \mathrm{E}-04)$ & ND & 2.90E-02 & $1.98 \mathrm{E}-02$ & 1.77E-02 & ND & $(2.53 \mathrm{E}-04)$ & $(9.04 \mathrm{E}-05)$ \\
\hline 60.00 & $(2.61 \mathrm{E}-01)$ & 2.98E-03 & (6.23E-04) & (7.37E-04) & 5.14E-02 & 7.10E-02 & 3.70E-02 & (8.34E-03) & 2.26E-04 & 1.13E-04 \\
\hline 60.00 & (2.62E-01) & 3.53E-03 & (6.39E-04) & ND & 5.49E-02 & 7.45E-02 & 3.93E-02 & (8.34E-03) & 2.15E-04 & 1.23E-04 \\
\hline 61.50 & 9.43E-01 & 4.87E-04 & (4.27E-04) & ND & 1.15E-01 & 7.67E-02 & 7.38E-02 & $(6.84 \mathrm{E}-02)$ & $(2.45 \mathrm{E}-04)$ & $(8.06 \mathrm{E}-05)$ \\
\hline 62.50 & $1.29 \mathrm{E}+00$ & $3.88 \mathrm{E}-04$ & $(9.24 \mathrm{E}-04)$ & ND & 9.98E-02 & 7.34E-02 & 5.89E-02 & $(3.90 \mathrm{E}-02)$ & $(1.56 \mathrm{E}-04)$ & $(8.36 \mathrm{E}-05)$ \\
\hline 62.50 & $1.14 \mathrm{E}+00$ & $3.74 \mathrm{E}-04$ & (7.81E-04) & (4.14E-03) & 5.63E-02 & 4.50E-02 & 3.15E-02 & $(2.40 \mathrm{E}-02)$ & $(2.12 \mathrm{E}-04)$ & $(1.02 \mathrm{E}-04)$ \\
\hline 64.85 & (8.91E-02) & 4.27E-04 & (6.25E-04) & $(1.10 \mathrm{E}-03)$ & 2.51E-02 & 3.04E-02 & 2.12E-02 & $(2.28 \mathrm{E}-02)$ & 1.43E-04 & (7.67E-05) \\
\hline
\end{tabular}


Table 4.20. (contd)

\begin{tabular}{|c|c|c|c|c|c|c|c|c|c|c|}
\hline $\begin{array}{c}\text { Depth } \\
\text { (ft bgs) }\end{array}$ & $\begin{array}{c}\text { Tc-99 } \\
\text { (pCi/g soil) } \\
\end{array}$ & U-238 & $\begin{array}{c}\mathrm{Cr} \\
\text { (ICP-MS) } \\
\end{array}$ & $\begin{array}{c}\mathrm{Cr} \\
\text { (ICP) } \\
\end{array}$ & $\begin{array}{c}\text { Mo-95 } \\
\text { (ICP-MS) } \\
\end{array}$ & $\begin{array}{c}\text { Mo-97 } \\
\text { (ICP-MS) } \\
\end{array}$ & $\begin{array}{c}\text { Mo-98 } \\
\text { (ICP-MS) } \\
\end{array}$ & $\begin{array}{l}\text { Mo } \\
\text { (ICP) } \\
\end{array}$ & $\begin{array}{c}\text { Ru-101 } \\
\text { (ICP-MS) } \\
\end{array}$ & $\begin{array}{c}\text { Ru-102 } \\
\text { (ICP-MS) } \\
\end{array}$ \\
\hline 66.20 & $2.62 \mathrm{E}+00$ & 5.42E-04 & (8.59E-04) & (9.10E-04) & 9.82E-03 & 9.76E-03 & 9.86E-03 & (6.69E-03) & 3.39E-04 & $1.68 \mathrm{E}-04$ \\
\hline 68.95 & 7.63E-02 & 4.05E-04 & $(3.90 \mathrm{E}-05)$ & (5.67E-03) & 9.27E-03 & 8.97E-03 & 4.17E-03 & (6.51E-03) & $(3.00 \mathrm{E}-05)$ & $(9.00 \mathrm{E}-06)$ \\
\hline 71.25 & 8.49E-02 & 2.58E-04 & $(3.53 \mathrm{E}-04)$ & ND & 8.16E-03 & 7.42E-03 & 3.48E-03 & ND & ND & ND \\
\hline 77.40 & 7.38E-02 & 3.78E-04 & NM & NM & NM & NM & NM & NM & NM & NM \\
\hline 79.55 & 1.19E-01 & 6.90E-04 & $(6.17 \mathrm{E}-04)$ & (4.90E-04) & 1.53E-02 & $1.28 \mathrm{E}-02$ & 8.26E-03 & $(2.45 \mathrm{E}-03)$ & (8.58E-05) & $(2.40 \mathrm{E}-05)$ \\
\hline 79.55 & 1.02E-01 & $6.82 \mathrm{E}-04$ & $(2.44 \mathrm{E}-04)$ & ND & $1.58 \mathrm{E}-02$ & 1.32E-02 & 8.59E-03 & ND & $(1.12 \mathrm{E}-04)$ & $(4.30 \mathrm{E}-05)$ \\
\hline 88.50 & 1.02E-01 & 3.48E-04 & NM & NM & NM & NM & NM & NM & NM & NM \\
\hline 96.60 & 1.11E-01 & 1.69E-04 & NM & NM & NM & NM & NM & NM & NM & NM \\
\hline 104.00 & 2.88E-01 & 2.25E-04 & NM & NM & NM & NM & NM & NM & NM & NM \\
\hline 106.05 & 7.01E-01 & 4.07E-04 & $(4.84 \mathrm{E}-04)$ & ND & 9.73E-03 & 9.30E-03 & 4.32E-03 & ND & (5.90E-05) & $(2.30 \mathrm{E}-05)$ \\
\hline 110.15 & (7.96E-02) & 3.23E-04 & $(6.64 \mathrm{E}-04)$ & (6.91E-04) & 1.03E-02 & $1.04 \mathrm{E}-02$ & $1.05 \mathrm{E}-02$ & $(8.48 \mathrm{E}-03)$ & $(1.20 \mathrm{E}-05)$ & $(2.20 \mathrm{E}-05)$ \\
\hline 114.20 & 4.07E-01 & 2.38E-04 & NM & $\mathrm{NM}$ & NM & NM & NM & NM & NM & NM \\
\hline 117.40 & $(1.80 \mathrm{E}-01)$ & 3.22E-04 & $(2.61 \mathrm{E}-04)$ & ND & 7.12E-03 & 7.16E-03 & 7.23E-03 & (7.25E-03) & $(2.32 \mathrm{E}-05)$ & $(4.81 \mathrm{E}-05)$ \\
\hline 120.25 & $(4.22 \mathrm{E}-01)$ & 2.40E-04 & $(2.06 \mathrm{E}-04)$ & ND & 8.33E-03 & 8.37E-03 & 8.45E-03 & $(9.58 \mathrm{E}-03)$ & $(3.21 \mathrm{E}-05)$ & $(3.48 \mathrm{E}-05)$ \\
\hline 123.65 & (8.35E-01) & 2.78E-04 & $(3.20 \mathrm{E}-04)$ & ND & 7.50E-03 & 7.46E-03 & 7.56E-03 & (5.90E-03) & (6.08E-05) & $(4.25 \mathrm{E}-05)$ \\
\hline 124.60 & 6.32E-01 & $1.50 \mathrm{E}-04$ & NM & $\mathrm{NM}$ & NM & NM & NM & NM & NM & NM \\
\hline 126.35 & 6.71E-01 & 2.43E-04 & $(6.22 \mathrm{E}-04)$ & ND & 6.55E-03 & $6.00 \mathrm{E}-03$ & 2.79E-03 & ND & ND & ND \\
\hline 126.75 & $(6.56 \mathrm{E}-01)$ & 2.16E-04 & $(3.42 \mathrm{E}-04)$ & ND & 1.07E-02 & $1.08 \mathrm{E}-02$ & $1.08 \mathrm{E}-02$ & (4.01E-03) & $(4.01 \mathrm{E}-05)$ & $(4.17 \mathrm{E}-05)$ \\
\hline 127.85 & $(5.05 \mathrm{E}-01)$ & 3.03E-04 & $(4.61 \mathrm{E}-04)$ & ND & 8.90E-03 & 8.87E-03 & 8.99E-03 & (6.48E-03) & $(2.57 \mathrm{E}-05)$ & $(3.37 \mathrm{E}-05)$ \\
\hline 130.65 & (6.31E-01) & $2.56 \mathrm{E}-04$ & $(2.14 \mathrm{E}-04)$ & ND & 8.14E-03 & 8.15E-03 & 8.27E-03 & (5.65E-03) & $(2.71 \mathrm{E}-05)$ & $(2.98 \mathrm{E}-05)$ \\
\hline 133.75 & $5.60 \mathrm{E}+00$ & 4.88E-04 & $(5.90 \mathrm{E}-04)$ & ND & 6.86E-03 & 6.90E-03 & 6.91E-03 & (7.74E-03) & $2.41 \mathrm{E}-04$ & 1.34E-04 \\
\hline 135.25 & $4.04 \mathrm{E}+00$ & 3.23E-04 & NM & NM & NM & NM & NM & NM & NM & NM \\
\hline 136.75 & 8.42E+00 & 4.37E-04 & $(3.41 \mathrm{E}-04)$ & ND & 6.21E-03 & 6.16E-03 & $6.22 \mathrm{E}-03$ & (9.69E-03) & $2.74 \mathrm{E}-04$ & $1.47 \mathrm{E}-04$ \\
\hline 140.00 & (5.00E-01) & $1.50 \mathrm{E}-04$ & $(7.68 \mathrm{E}-04)$ & ND & 5.71E-03 & 5.69E-03 & 5.75E-03 & (2.94E-03) & $(1.34 \mathrm{E}-05)$ & $(2.42 \mathrm{E}-05)$ \\
\hline 143.25 & $(9.65 \mathrm{E}-02)$ & $1.65 \mathrm{E}-04$ & $(1.18 \mathrm{E}-04)$ & (7.03E-04) & 5.25E-03 & 5.12E-03 & $5.30 \mathrm{E}-03$ & (1.22E-03) & (3.89E-06) & $(2.21 \mathrm{E}-05)$ \\
\hline 146.25 & $5.84 \mathrm{E}+00$ & 2.72E-04 & NM & $\mathrm{NM}$ & NM & NM & NM & NM & $\mathrm{NM}$ & NM \\
\hline 148.30 & $(4.62 \mathrm{E}-01)$ & 2.90E-04 & $(1.36 \mathrm{E}-04)$ & (5.35E-04) & 6.30E-03 & $6.28 \mathrm{E}-03$ & 6.29E-03 & $(2.66 \mathrm{E}-03)$ & $(1.46 \mathrm{E}-05)$ & (2.94E-05) \\
\hline
\end{tabular}


Table 4.20. (contd)

\begin{tabular}{|c|c|c|c|c|c|c|c|c|c|c|}
\hline $\begin{array}{l}\text { Depth } \\
\text { (ft bgs) }\end{array}$ & $\begin{array}{c}\text { Tc-99 } \\
\text { (pCi/g soil) }\end{array}$ & U-238 & $\begin{array}{c}\mathrm{Cr} \\
\text { (ICP-MS) }\end{array}$ & $\begin{array}{c}\mathrm{Cr} \\
\text { (ICP) }\end{array}$ & $\begin{array}{c}\text { Mo-95 } \\
\text { (ICP-MS) }\end{array}$ & $\begin{array}{c}\text { Mo-97 } \\
\text { (ICP-MS) }\end{array}$ & $\begin{array}{c}\text { Mo-98 } \\
\text { (ICP-MS) }\end{array}$ & $\begin{array}{l}\text { Mo } \\
\text { (ICP) }\end{array}$ & $\begin{array}{c}\text { Ru-101 } \\
\text { (ICP-MS) }\end{array}$ & $\begin{array}{c}\text { Ru-102 } \\
\text { (ICP-MS) }\end{array}$ \\
\hline 148.30 & $(7.08 E-01)$ & 2.97E-04 & $(1.34 \mathrm{E}-05)$ & ND & 5.39E-03 & 5.40E-03 & 5.48E-03 & (5.64E-03) & $(3.00 \mathrm{E}-05)$ & (3.73E-05) \\
\hline 151.50 & $2.20 \mathrm{E}+00$ & 3.05E-04 & NM & NM & NM & NM & NM & NM & NM & NM \\
\hline 153.00 & $2.93 E+00$ & 3.94E-04 & $(2.00 \mathrm{E}-04)$ & NM & 1.04E-02 & 9.80E-03 & 4.70E-03 & NM & $(2.88 \mathrm{E}-04)$ & $(1.38 \mathrm{E}-04)$ \\
\hline 154.65 & $2.43 \mathrm{E}+00$ & 5.18E-04 & $(2.48 \mathrm{E}-04)$ & NM & 1.04E-02 & 9.84E-03 & 4.56E-03 & NM & $(2.96 \mathrm{E}-04)$ & \begin{tabular}{|l|}
$(1.40 \mathrm{E}-04)$ \\
\end{tabular} \\
\hline 156.65 & 8.32E-01 & 4.74E-04 & $(3.45 \mathrm{E}-04)$ & NM & 9.03E-03 & $8.58 \mathrm{E}-03$ & 3.94E-03 & NM & $(2.68 \mathrm{E}-04)$ & \begin{tabular}{|l|}
$(1.09 \mathrm{E}-04)$ \\
\end{tabular} \\
\hline 156.65 & 8.94E-01 & 4.73E-04 & $(1.27 \mathrm{E}-04)$ & NM & 8.58E-03 & $8.24 \mathrm{E}-03$ & 3.64E-03 & NM & $(2.46 \mathrm{E}-04)$ & $(1.33 \mathrm{E}-04)$ \\
\hline 159.00 & 4.50E-01 & 4.60E-04 & (3.91E-04) & NM & 1.13E-02 & 1.05E-02 & 4.94E-03 & NM & $(2.83 \mathrm{E}-04)$ & $(1.56 \mathrm{E}-04)$ \\
\hline 159.00 & 4.41E-01 & 4.59E-04 & $(5.05 E-04)$ & NM & 1.16E-02 & 1.08E-02 & 5.06E-03 & NM & $(2.72 \mathrm{E}-04)$ & \begin{tabular}{|l|}
$(1.39 \mathrm{E}-04)$ \\
\end{tabular} \\
\hline 161.25 & (3.05E-02) & 2.97E-04 & NM & NM & NM & NM & NM & NM & NM & NM \\
\hline 165.75 & $(2.52 \mathrm{E}-02)$ & 2.39E-04 & $(3.43 E-04)$ & ND & 6.65E-03 & 6.66E-03 & 6.74E-03 & $(2.66 \mathrm{E}-03)$ & $(4.92 \mathrm{E}-05)$ & $(4.57 \mathrm{E}-05)$ \\
\hline 170.25 & $(9.10 \mathrm{E}-03)$ & 1.84E-04 & $(2.14 \mathrm{E}-04)$ & ND & 6.16E-03 & 6.23E-03 & 6.19E-03 & $(5.64 \mathrm{E}-03)$ & $(3.21 \mathrm{E}-06)$ & (1.79E-05) \\
\hline 172.30 & ND & 2.26E-04 & NM & NM & NM & NM & NM & NM & NM & NM \\
\hline 174.05 & ND & 1.55E-04 & $(6.02 \mathrm{E}-05)$ & ND & 5.67E-03 & 5.52E-03 & 5.74E-03 & $(1.62 \mathrm{E}-03)$ & $(2.73 \mathrm{E}-06)$ & (1.76E-05) \\
\hline 176.90 & ND & 2.88E-04 & NM & NM & NM & NM & NM & NM & NM & NM \\
\hline 176.90 & ND & 2.72E-04 & NM & NM & NM & NM & NM & NM & NM & NM \\
\hline 182.25 & $(1.70 \mathrm{E}-02)$ & 3.18E-04 & $(2.65 \mathrm{E}-04)$ & NM & 6.69E-03 & 5.89E-03 & 2.87E-03 & NM & ND & $(8.00 \mathrm{E}-06)$ \\
\hline 186.25 & $(8.48 \mathrm{E}-03)$ & 2.61E-04 & $(6.52 \mathrm{E}-04)$ & NM & $8.22 \mathrm{E}-03$ & 7.57E-03 & 3.55E-03 & NM & $(4.40 \mathrm{E}-05)$ & ND \\
\hline 191.25 & (8.48E-03) & 3.12E-04 & $(7.07 \mathrm{E}-04)$ & NM & 8.82E-03 & 8.07E-03 & 3.72E-03 & NM & ND & $(2.70 \mathrm{E}-05)$ \\
\hline 195.25 & ND & 3.37E-04 & (8.36E-04) & NM & 5.69E-03 & 5.34E-03 & $2.50 \mathrm{E}-03$ & NM & ND & (6.34E-06) \\
\hline \multicolumn{11}{|c|}{$\begin{array}{l}\text { Parentheses signify values below level of quantitation. } \\
\text { Shaded values designate the core samples and unshaded values are grab samples. } \\
\text { Bold values are higher than others for given constituent. } \\
\text { ND = Not determined. } \\
\text { NM = Not measured. }\end{array}$} \\
\hline
\end{tabular}




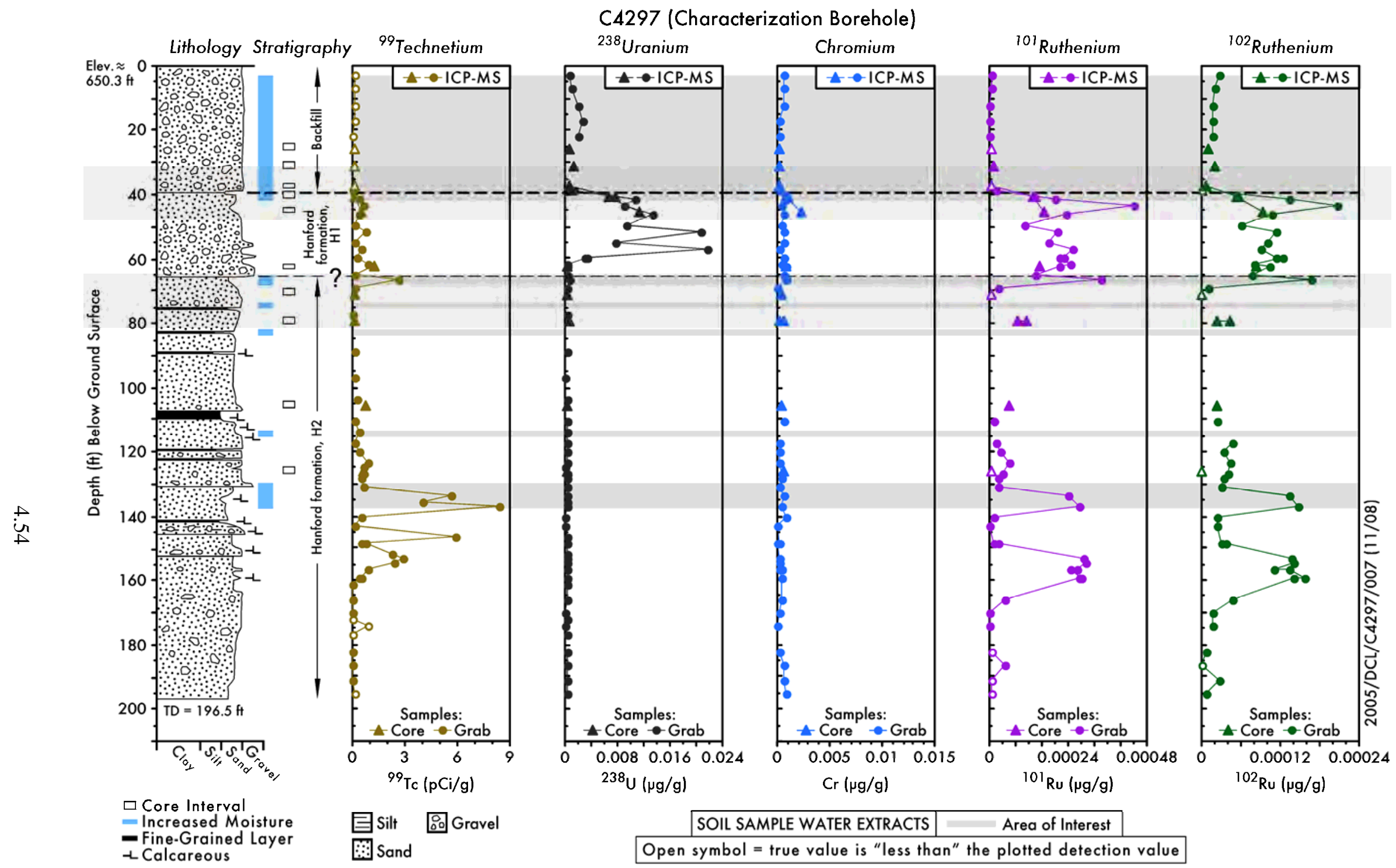

Figure 4.17. Distribution of Mobile Metals in Water Extracts of C4297 Vadose Zone Sediments 


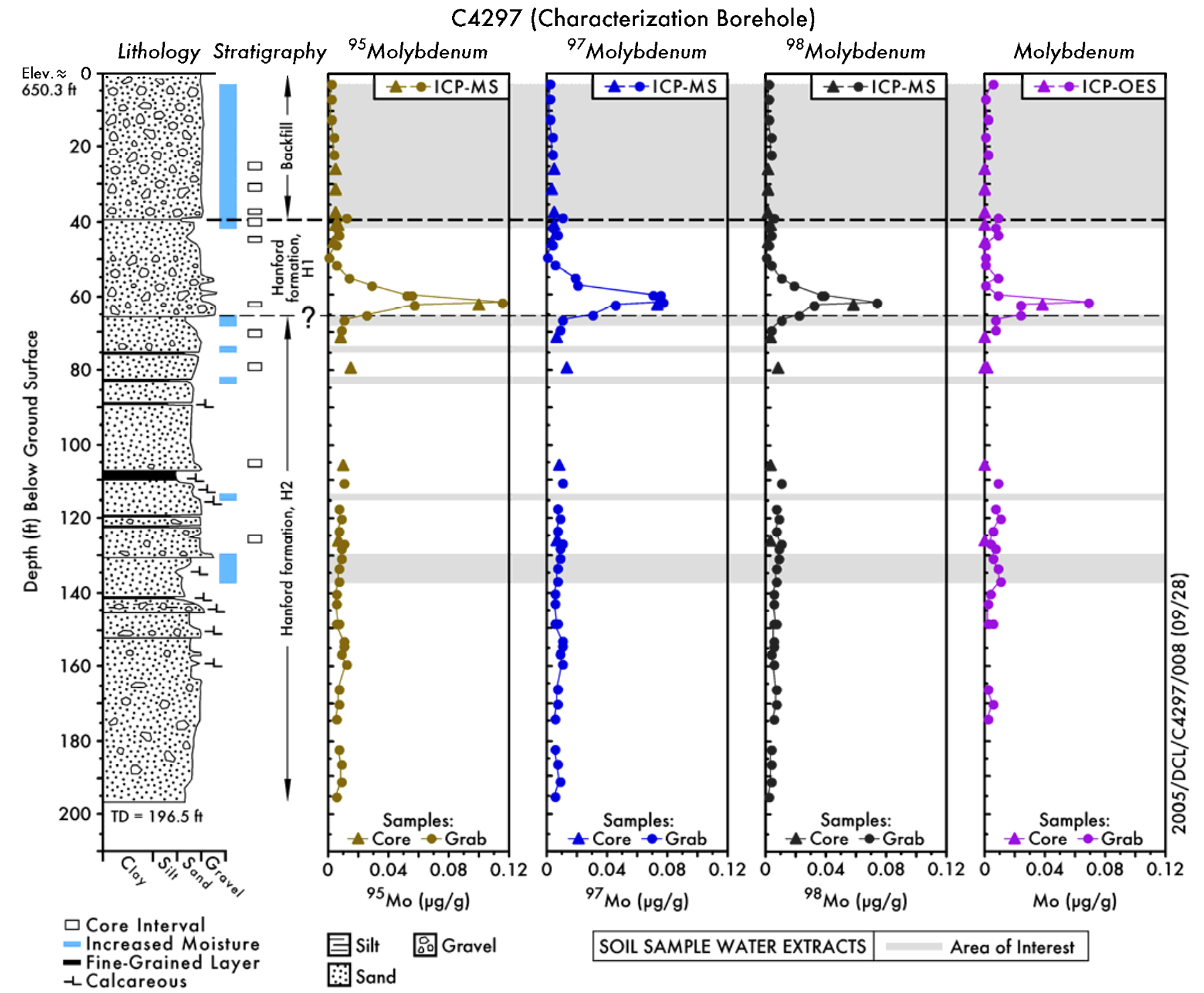

Figure 4.18. Distribution of Mobile Metals in Water Extracts of C4297 Vadose Zone Sediments 


\subsubsection{Vadose Zone Pore water Chemical Composition}

The 1:1 water extract data was manipulated to derive the pore water composition of the vadose zone sediments. From knowledge of the moisture content of the sediment samples taken from the liners of each core and the grab samples, the amount of de-ionized water that would be needed to make the water extract exactly one part water (total of native pore water and added de-ionized water) to one part by weight dry sediment was calculated. The ratio of the total volume of water in the extract to the native mass of pore water is the dilution factor. The assumption was that the de-ionized water acted solely as a diluent of the existing pore water and that the de-ionized water did not dissolve any of the solids in the sediments. Thus, by correcting for the dilution, an estimate could be made of the actual chemical composition of the native pore-water in the vadose zone sediments.

The assumption that none of the solid is dissolved during the water extraction process is simplistic. In comparisons of actual vadose zone sediment pore water, which was obtained via ultracentrifugation of sediments using UFA, to the dilution-corrected calculated pore waters from both contaminated and uncontaminated sediments from the SX and B-BX Tank Farms (see Serne et al. 2002b, 2002c, 2002d, 2002e, 2002f), it was found that for highly contaminated sediments, the comparison is quite good.

For slightly contaminated or uncontaminated sediments, the dilution-corrected water extract data is biased high by a factor of 2 to 7 for many constituents such that the true pore water is less saline. For the C4297 data set, we did not have any pore waters to compare with the derived pore waters from the 1:1 sediment:water extracts, but based on other slightly contaminated boreholes, we suspect that our derived pore water concentrations are slightly biased to higher concentrations.

Tables 4.21 through 4.24 and Figures 4.19 through 4.24 show the derived pore water composition of key constituents as a function of depth and stratigraphy. The primary region of the C4297 borehole vadose zone profile that contained high dissolved salt pore water was from 40.8 to $49.25 \mathrm{ft}$ bgs. The most concentrated pore water on a total dissolved salts basis was found at approximately $45 \mathrm{ft}$ bgs and had a total concentration of $212 \mathrm{meq} / \mathrm{L}$ cations and $223 \mathrm{meq} / \mathrm{L}$ anions. The sample composition consisted of $209 \mathrm{meq} / \mathrm{L}$ sodium, with trace amounts of calcium $(0.83 \mathrm{meq} / \mathrm{L})$ and no detectable magnesium or potassium. The cation charge for this sample was compensated primarily by bicarbonate $(218 \mathrm{meq} / \mathrm{L})$ with minor amounts of nitrate $(0.26 \mathrm{meq} / \mathrm{L})$, fluoride $(2.8 \mathrm{meq} / \mathrm{L})$, and sulfate $(1.8 \mathrm{meq} / \mathrm{L})$.

These concentrations are very dilute compared to the vadose zone pore waters found at the SX and BX Tank Farms where the total ionic strength was as high as 7,000 to 17,000 at the SX Tank Farm and $1,000 \mathrm{meq} / \mathrm{L}$ at the BX Tank Farm. At the borehole emplaced near tank B-110, the most saline pore water contained 150 to $160 \mathrm{meq} / \mathrm{L}$ of both cations and anions.

Sodium was present as the dominant cation between 7 and $133 \mathrm{ft}$ bgs. Calcium was the dominant cation in the shallowest sample collected (2.5 ft bgs) and from $133 \mathrm{ft}$ bgs to the bottom of the borehole. Bicarbonate (measured as carbonate via IC) was the primary anionic species throughout the entire borehole. Again, this was not surprising given the relatively small waste signal observed in the C4297 borehole samples. The transition between sodium and calcium as the dominant cation in solution at approximately $130 \mathrm{ft}$ bgs correlated well with the total cation/metal data reported in the previous section and adds further credence to the conclusion that the cation exchange front has reached a total depth in excess of $130 \mathrm{ft}$ bgs at this location. 
Table 4.21. Calculated Pore water Anion Concentrations in C4297 Vadose Zone Sediments

\begin{tabular}{|c|c|c|c|c|c|c|c|}
\hline $\begin{array}{c}\text { Depth } \\
\text { (ft bgs) }\end{array}$ & $\begin{array}{c}\text { Fluoride } \\
\text { (mg/L) }\end{array}$ & $\begin{array}{c}\text { Chloride } \\
\text { (mg/L) }\end{array}$ & $\begin{array}{l}\text { Nitrate } \\
(\mathrm{mg} / \mathrm{L})\end{array}$ & $\begin{array}{c}\mathrm{CO}_{3} \\
(\mathrm{mg} / \mathrm{L})\end{array}$ & $\begin{array}{c}\text { Alkalinity } \\
\text { (mg/L) }\end{array}$ & $\begin{array}{l}\text { Sulfate } \\
\text { (mg/L) }\end{array}$ & $\begin{array}{l}\text { Nitrite } \\
(\mathrm{mg} / \mathrm{L})\end{array}$ \\
\hline 2.50 & $8.29 \mathrm{E}+00$ & $7.26 \mathrm{E}+00$ & ND & ND & $3.61 E+02$ & $2.27 \mathrm{E}+01$ & ND \\
\hline 7.00 & $8.82 \mathrm{E}+00$ & $8.23 \mathrm{E}+00$ & ND & ND & $3.65 E+02$ & $2.51 \mathrm{E}+01$ & ND \\
\hline 12.00 & $9.89 \mathrm{E}+00$ & $7.89 \mathrm{E}+00$ & $7.44 \mathrm{E}+00$ & ND & $3.95 \mathrm{E}+02$ & $3.48 \mathrm{E}+01$ & ND \\
\hline 17.00 & $1.34 \mathrm{E}+01$ & $6.77 \mathrm{E}+00$ & ND & ND & $6.16 \mathrm{E}+02$ & $3.59 \mathrm{E}+01$ & ND \\
\hline 22.00 & $1.61 \mathrm{E}+01$ & $5.66 \mathrm{E}+00$ & ND & ND & $4.98 \mathrm{E}+02$ & $5.05 \mathrm{E}+01$ & ND \\
\hline 25.75 & $3.22 \mathrm{E}+01$ & ND & ND & ND & $6.98 \mathrm{E}+02$ & $4.81 \mathrm{E}+01$ & ND \\
\hline 31.00 & $1.16 \mathrm{E}+01$ & ND & ND & ND & $5.61 \mathrm{E}+02$ & $3.57 \mathrm{E}+01$ & ND \\
\hline 37.15 & $1.19 \mathrm{E}+01$ & ND & ND & ND & $6.62 E+02$ & $6.64 \mathrm{E}+01$ & ND \\
\hline 38.35 & $7.21 \mathrm{E}+00$ & $5.08 \mathrm{E}+00$ & $8.43 \mathrm{E}+00$ & $5.91 \mathrm{E}+02$ & $3.30 \mathrm{E}+02$ & $5.83 \mathrm{E}+01$ & ND \\
\hline 38.53 & $1.06 \mathrm{E}+01$ & $3.63 \mathrm{E}+01$ & $1.87 \mathrm{E}+01$ & ND & NM & $1.07 \mathrm{E}+02$ & ND \\
\hline 40.80 & $2.97 E+01$ & ND & ND & $5.85 E+03$ & $2.18 \mathrm{E}+03$ & $8.25 \mathrm{E}+01$ & ND \\
\hline 40.80 Dup & $2.94 \mathrm{E}+01$ & ND & ND & $5.96 E+03$ & $2.19 \mathrm{E}+03$ & $8.96 \mathrm{E}+01$ & ND \\
\hline 41.20 & $3.49 E+01$ & $6.42 \mathrm{E}+00$ & ND & $7.41 E+03$ & $2.49 \mathrm{E}+03$ & $7.27 \mathrm{E}+01$ & $1.10 \mathrm{E}+01$ \\
\hline 43.75 & $4.61 \mathrm{E}+01$ & $1.54 \mathrm{E}+01$ & $9.85 \mathrm{E}+01$ & ND & $1.34 \mathrm{E}+03$ & $1.73 \mathrm{E}+02$ & ND \\
\hline 45.45 & $5.38 \mathrm{E}+01$ & ND & ND & $1.33 E+04$ & $4.38 \mathrm{E}+03$ & $8.56 \mathrm{E}+01$ & ND \\
\hline 45.85 & $4.39 \mathrm{E}+01$ & $9.52 \mathrm{E}+00$ & ND & $1.00 \mathrm{E}+04$ & $3.05 E+03$ & $6.88 \mathrm{E}+01$ & ND \\
\hline 49.25 & $4.12 E+01$ & NM & ND & $9.83 E+03$ & NM & $4.79 \mathrm{E}+01$ & ND \\
\hline 51.25 & $6.91 \mathrm{E}+01$ & $1.28 \mathrm{E}+01$ & $8.99 \mathrm{E}+01$ & $6.88 E+03$ & $3.98 \mathrm{E}+03$ & $1.47 \mathrm{E}+02$ & ND \\
\hline 55.20 & $1.03 \mathrm{E}+01$ & NM & ND & $1.75 E+03$ & NM & $1.33 \mathrm{E}+02$ & ND \\
\hline 57.20 & $1.91 \mathrm{E}+01$ & $8.13 \mathrm{E}+00$ & ND & $2.18 E+03$ & $1.13 \mathrm{E}+03$ & $2.84 \mathrm{E}+02$ & ND \\
\hline 60.00 & $1.23 \mathrm{E}+01$ & NM & ND & $1.59 E+03$ & NM & $1.68 \mathrm{E}+02$ & ND \\
\hline 60.00 Dup & $1.25 \mathrm{E}+01$ & NM & ND & ND & NM & $2.03 \mathrm{E}+02$ & ND \\
\hline 61.50 & $1.34 \mathrm{E}+01$ & $9.63 \mathrm{E}+00$ & $1.16 \mathrm{E}+02$ & ND & $7.85 \mathrm{E}+02$ & $6.37 \mathrm{E}+02$ & ND \\
\hline 62.50 & $1.44 \mathrm{E}+01$ & $1.53 \mathrm{E}+01$ & $8.36 \mathrm{E}+01$ & ND & $2.43 \mathrm{E}+03$ & $7.42 \mathrm{E}+02$ & ND \\
\hline 62.90 & $1.33 \mathrm{E}+01$ & $1.21 \mathrm{E}+01$ & $7.86 \mathrm{E}+01$ & ND & $6.84 \mathrm{E}+02$ & $6.19 \mathrm{E}+02$ & ND \\
\hline 64.85 & $9.24 \mathrm{E}+00$ & NM & ND & ND & NM & $2.47 \mathrm{E}+02$ & ND \\
\hline 66.20 & $7.52 \mathrm{E}+00$ & NM & $2.18 \mathrm{E}+02$ & ND & NM & $3.50 \mathrm{E}+02$ & ND \\
\hline 68.95 & $1.00 \mathrm{E}+01$ & $8.87 \mathrm{E}+00$ & $7.26 \mathrm{E}+01$ & ND & $5.38 \mathrm{E}+02$ & $3.79 \mathrm{E}+02$ & ND \\
\hline 71.25 & $1.07 \mathrm{E}+01$ & $1.64 \mathrm{E}+01$ & $2.70 \mathrm{E}+01$ & ND & $7.24 \mathrm{E}+02$ & $4.19 \mathrm{E}+02$ & ND \\
\hline 77.40 & $1.02 \mathrm{E}+01$ & $1.09 \mathrm{E}+01$ & $1.48 \mathrm{E}+02$ & ND & NM & $3.38 \mathrm{E}+02$ & ND \\
\hline 79.55 & $1.11 \mathrm{E}+01$ & $1.23 \mathrm{E}+01$ & $4.57 \mathrm{E}+01$ & ND & $6.08 \mathrm{E}+02$ & $4.14 \mathrm{E}+02$ & ND \\
\hline 79.55 Dup & $1.11 \mathrm{E}+01$ & $1.20 \mathrm{E}+01$ & $6.54 \mathrm{E}+01$ & ND & $6.66 \mathrm{E}+02$ & $4.10 \mathrm{E}+02$ & ND \\
\hline 88.50 & $1.22 \mathrm{E}+01$ & $2.52 \mathrm{E}+01$ & $1.63 \mathrm{E}+02$ & ND & NM & $5.65 \mathrm{E}+02$ & ND \\
\hline 96.60 & $7.94 \mathrm{E}+00$ & $1.28 \mathrm{E}+01$ & $1.39 \mathrm{E}+02$ & ND & NM & $3.37 \mathrm{E}+02$ & ND \\
\hline
\end{tabular}


Table 4.21. (contd)

\begin{tabular}{|c|c|c|c|c|c|c|c|}
\hline $\begin{array}{c}\text { Depth } \\
\text { (ft bgs) }\end{array}$ & $\begin{array}{c}\text { Fluoride } \\
\text { (mg/L) }\end{array}$ & $\begin{array}{c}\text { Chloride } \\
\text { (mg/L) }\end{array}$ & $\begin{array}{l}\text { Nitrate } \\
(\mathrm{mg} / \mathrm{L})\end{array}$ & $\begin{array}{c}\mathrm{CO}_{3} \\
(\mathrm{mg} / \mathrm{L})\end{array}$ & $\begin{array}{c}\text { Alkalinity } \\
\text { (mg/L) }\end{array}$ & $\begin{array}{l}\text { Sulfate } \\
(\mathrm{mg} / \mathrm{L})\end{array}$ & $\begin{array}{c}\text { Nitrite } \\
\mathbf{v}\end{array}$ \\
\hline 104.00 & $7.36 \mathrm{E}+00$ & $1.33 \mathrm{E}+01$ & $1.49 \mathrm{E}+02$ & ND & NM & $3.26 \mathrm{E}+02$ & ND \\
\hline 106.05 & $6.91 \mathrm{E}+00$ & $2.53 \mathrm{E}+01$ & $1.44 \mathrm{E}+02$ & ND & $4.74 \mathrm{E}+02$ & $4.80 \mathrm{E}+02$ & ND \\
\hline 110.15 & $1.01 \mathrm{E}+01$ & NM & $1.63 \mathrm{E}+01$ & ND & NM & $2.41 \mathrm{E}+02$ & ND \\
\hline 114.20 & $8.74 \mathrm{E}+00$ & $2.06 \mathrm{E}+01$ & $1.53 \mathrm{E}+02$ & ND & NM & $5.49 \mathrm{E}+02$ & ND \\
\hline 117.40 & $8.66 \mathrm{E}+00$ & NM & $3.63 E+01$ & ND & NM & $3.76 \mathrm{E}+02$ & ND \\
\hline 120.25 & $6.88 \mathrm{E}+00$ & NM & $7.99 \mathrm{E}+01$ & ND & NM & $4.91 \mathrm{E}+02$ & ND \\
\hline 123.65 & $7.52 \mathrm{E}+00$ & NM & $1.48 \mathrm{E}+02$ & ND & NM & $8.23 E+02$ & ND \\
\hline 124.60 & $1.08 \mathrm{E}+01$ & $2.57 \mathrm{E}+01$ & $1.74 \mathrm{E}+02$ & ND & NM & $8.72 \mathrm{E}+02$ & ND \\
\hline 126.35 & $1.14 \mathrm{E}+01$ & $2.14 \mathrm{E}+01$ & $5.83 \mathrm{E}+01$ & ND & $7.17 \mathrm{E}+02$ & $8.68 \mathrm{E}+02$ & ND \\
\hline 126.75 & $9.27 \mathrm{E}+00$ & NM & $7.26 \mathrm{E}+01$ & ND & NM & $7.98 \mathrm{E}+02$ & ND \\
\hline 127.85 & $7.96 \mathrm{E}+00$ & NM & $5.25 \mathrm{E}+01$ & ND & NM & $1.19 \mathrm{E}+03$ & ND \\
\hline 130.65 & $5.92 \mathrm{E}+00$ & NM & $4.14 \mathrm{E}+01$ & ND & NM & $5.07 \mathrm{E}+02$ & ND \\
\hline 133.75 & $3.80 \mathrm{E}+00$ & NM & $1.55 \mathrm{E}+02$ & ND & NM & $9.83 \mathrm{E}+02$ & ND \\
\hline 135.25 & $6.05 \mathrm{E}+00$ & $9.03 \mathrm{E}+01$ & $3.66 \mathrm{E}+02$ & ND & NM & $2.21 E+03$ & ND \\
\hline 136.75 & $5.51 \mathrm{E}+00$ & NM & $4.18 \mathrm{E}+02$ & ND & NM & $2.06 \mathrm{E}+03$ & ND \\
\hline 140.00 & $1.05 \mathrm{E}+01$ & ND & $4.74 \mathrm{E}+01$ & ND & NM & $7.70 \mathrm{E}+02$ & ND \\
\hline 143.25 & $1.05 \mathrm{E}+01$ & ND & ND & ND & NM & $6.72 \mathrm{E}+02$ & ND \\
\hline 146.25 & $6.05 \mathrm{E}+00$ & $9.90 \mathrm{E}+01$ & $3.81 \mathrm{E}+02$ & ND & NM & $3.48 E+03$ & ND \\
\hline 148.30 & $1.02 \mathrm{E}+01$ & ND & $2.35 \mathrm{E}+01$ & ND & NM & $1.71 \mathrm{E}+03$ & ND \\
\hline 148.30 Dup & $9.09 \mathrm{E}+00$ & ND & $4.63 \mathrm{E}+01$ & ND & NM & $1.78 \mathrm{E}+03$ & ND \\
\hline 151.50 & $9.28 \mathrm{E}+00$ & $9.19 \mathrm{E}+01$ & $3.27 \mathrm{E}+02$ & ND & NM & $3.38 E+03$ & ND \\
\hline 153.00 & $1.28 \mathrm{E}+01$ & $1.49 \mathrm{E}+02$ & $4.27 \mathrm{E}+02$ & ND & NM & $2.00 E+03$ & ND \\
\hline 154.65 & $2.24 \mathrm{E}+01$ & $1.92 \mathrm{E}+02$ & $4.74 \mathrm{E}+02$ & ND & NM & $2.27 E+03$ & ND \\
\hline 156.65 & $1.18 \mathrm{E}+01$ & $1.68 \mathrm{E}+02$ & $3.85 E+02$ & ND & NM & $2.08 E+03$ & ND \\
\hline 156.65 & $1.03 \mathrm{E}+01$ & $1.61 E+02$ & $3.70 \mathrm{E}+02$ & ND & NM & $1.95 \mathrm{E}+03$ & ND \\
\hline 159.00 & $1.36 \mathrm{E}+01$ & $2.07 E+02$ & $4.50 \mathrm{E}+02$ & ND & NM & $2.34 \mathrm{E}+03$ & ND \\
\hline 159.00 Dup & $1.35 \mathrm{E}+01$ & $2.06 \mathrm{E}+02$ & $4.39 \mathrm{E}+02$ & ND & NM & $2.24 \mathrm{E}+03$ & ND \\
\hline 161.25 & $1.40 \mathrm{E}+01$ & $1.98 \mathrm{E}+02$ & $4.05 E+02$ & ND & NM & $2.23 E+03$ & ND \\
\hline 165.75 & $8.51 \mathrm{E}+00$ & ND & $8.82 \mathrm{E}+01$ & ND & NM & $1.22 \mathrm{E}+03$ & ND \\
\hline 170.25 & $8.32 \mathrm{E}+00$ & ND & ND & ND & NM & $4.42 \mathrm{E}+02$ & ND \\
\hline 172.30 & $8.62 \mathrm{E}+00$ & $2.57 \mathrm{E}+02$ & $2.14 \mathrm{E}+02$ & ND & NM & $1.94 \mathrm{E}+03$ & ND \\
\hline 174.05 & $7.96 \mathrm{E}+00$ & ND & ND & ND & NM & $4.74 \mathrm{E}+02$ & ND \\
\hline 176.90 & $1.30 \mathrm{E}+01$ & $3.09 \mathrm{E}+02$ & $2.46 \mathrm{E}+02$ & ND & NM & $2.16 \mathrm{E}+03$ & ND \\
\hline 176.90 Dup & $1.26 \mathrm{E}+01$ & $3.13 E+02$ & $2.51 \mathrm{E}+02$ & ND & NM & $2.22 \mathrm{E}+03$ & ND \\
\hline
\end{tabular}


Table 4.21. (contd)

\begin{tabular}{|c|c|c|c|c|c|c|c|}
\hline $\begin{array}{c}\text { Depth } \\
\text { (ft bgs) }\end{array}$ & $\begin{array}{c}\text { Fluoride } \\
\text { (mg/L) }\end{array}$ & $\begin{array}{c}\text { Chloride } \\
\text { (mg/L) }\end{array}$ & $\begin{array}{l}\text { Nitrate } \\
\text { (mg/L) }\end{array}$ & $\begin{array}{c}\mathrm{CO}_{3} \\
(\mathrm{mg} / \mathrm{L})\end{array}$ & $\begin{array}{c}\text { Alkalinity } \\
\text { (mg/L) }\end{array}$ & $\begin{array}{l}\text { Sulfate } \\
(\mathrm{mg} / \mathrm{L})\end{array}$ & $\begin{array}{l}\text { Nitrite } \\
\text { (mg/L) }\end{array}$ \\
\hline 182.25 & $1.02 \mathrm{E}+01$ & $3.49 \mathrm{E}+02$ & $1.55 \mathrm{E}+02$ & ND & NM & $1.91 \mathrm{E}+03$ & ND \\
\hline 186.25 & $1.04 \mathrm{E}+01$ & 3.72E+02 & $1.40 \mathrm{E}+02$ & ND & NM & $1.74 \mathrm{E}+03$ & ND \\
\hline 191.25 & $1.07 \mathrm{E}+01$ & $5.36 \mathrm{E}+02$ & $1.79 \mathrm{E}+02$ & ND & NM & $1.76 \mathrm{E}+03$ & ND \\
\hline 195.25 & $9.26 \mathrm{E}+00$ & $6.53 E+02$ & $2.15 \mathrm{E}+02$ & ND & NM & $1.72 \mathrm{E}+03$ & ND \\
\hline \multicolumn{8}{|c|}{$\begin{array}{l}\text { Shaded values designate the core samples and unshaded values are grab samples. } \\
\text { Bold values are higher than others for given constituent. } \\
\text { Dup = Duplicate sample. } \\
\text { ND = Not detected. } \\
\text { NM = Not measured. }\end{array}$} \\
\hline
\end{tabular}

The maximum concentration of technetium-99 in the C4297 vadose zone pore water was found between the depths of 133 to $154 \mathrm{ft}$ bgs. Concentrations ranged between 68,000 and 165,000 pCi/L. This range in pore water concentration exceeds the drinking water standard by 75 to 183 times. In general, the whole sediment profile from 40.8 to $160 \mathrm{ft}$ bgs had derived pore water technetium-99 concentrations that exceeded the drinking water standard by at least 5 times. The maximum concentration of dissolved uranium was found at $51.25 \mathrm{ft}$ bgs at a concentration of $0.691 \mathrm{mg} / \mathrm{L}$. However, as previously mentioned in Section 4.2.2.2, the elevated water-extractable uranium detected in this region was likely natural labile uranium released from the sediment as a function of uranyl carbonate complexation.

\subsubsection{M Nitric Acid-Extractable Amounts of Selected Elements in Borehole C4297 Sediments}

The same cores and some of the grab samples that were characterized for water-extractable constituents were also characterized to see how much of the various constituents could be leached with hot $8 \mathrm{M}$ nitric acid. A comparison between the quantities that were acid extractable with those that are water extractable often indicates the relative mobility of a given constituent and can sometimes differentiate man-disposed from naturally occurring constituents. The quantities of various constituents in the C4297 vadose zone sediments that were acid extractable are shown in Tables 4.25 through 4.28 and Figures 4.25 through 4.30 .

Upon comparing the acid extract data for borehole C4297 with similar lithologies (grain size and perceived mineral content) in the RCRA borehole, C4124, most of the variation in mass leached per gram of sediment versus depth was found to be lithology-related. That is, for most constituents, there was no sign of elevated values of acid-leachable concentrations in borehole C4297 sediments with the exception of acid-extractable sodium, aluminum, iron, and technetium-99. The acid-extractable sodium, likely tank waste derived, was elevated between 40.8 and $62.5 \mathrm{ft}$ bgs and had an average concentration that was about 2 times higher than in comparable aliquots of sediment from borehole C4124. The acid-extractable aluminum and iron were also elevated between 40.8 and $60 \mathrm{ft}$ bgs, but unlike the sodium, their presence was likely an artifact of interaction between the caustic tank waste and vadose zone sediment. The acidextractable technetium-99 profile in the C4297 borehole splitspoon samples was elevated from $45 \mathrm{ft}$ bgs to $63 \mathrm{ft}$ bgs by a factor of 3 to 4 over the distribution of acid extractable technetium-99 in the background 
sediment, which was a measure of our detection limit. The quantities of technetium-99 that were acid extractable per gram of sediment and the quantities that were water soluble differ. The acid extract data are variable and, as shown in Table 4.28, mostly qualified with parentheses that mean values were below our level of quantification. As found in sediments at borehole 299-E33-46 (Serne et al. 2002f), measuring technetium-99 at low levels by acid extraction yields results that are not as reliable as water extraction data. Thus, we place more confidence in the water extract data for technetium-99 shown in Table 4.20.

Table 4.22. Calculated Pore Water Cation Concentrations in C4297 Vadose Zone Sediments

\begin{tabular}{|c|c|c|c|c|c|c|c|}
\hline $\begin{array}{l}\text { Depth } \\
\text { (ft bgs) }\end{array}$ & $\begin{array}{c}\text { Stratigraphic Unit } \\
\text { (Hanford formation) }\end{array}$ & $\begin{array}{c}\text { Magnesium } \\
(\mathrm{mg} / \mathrm{L})\end{array}$ & \begin{tabular}{|c|} 
Calcium \\
(mg/L)
\end{tabular} & $\begin{array}{c}\text { Strontium } \\
(\mu \mathrm{g} / \mathrm{L})\end{array}$ & $\begin{array}{c}\text { Barium } \\
(\mathrm{mg} / \mathrm{L})\end{array}$ & $\begin{array}{l}\text { Sodium } \\
\text { (mg/L) }\end{array}$ & $\begin{array}{c}\begin{array}{c}\text { Potassium } \\
\text { (mg/L) }\end{array} \\
\end{array}$ \\
\hline 2.50 & Backfill & $3.23 \mathrm{E}+01$ & $1.50 \mathrm{E}+02$ & 6.73E+02 & 5.59E-01 & $1.26 \mathrm{E}+02$ & $6.15 \mathrm{E}+01$ \\
\hline 7.00 & Backfill & $2.67 \mathrm{E}+01$ & $1.22 \mathrm{E}+02$ & $5.50 \mathrm{E}+02$ & 3.13E-01 & $1.87 \mathrm{E}+02$ & $5.74 \mathrm{E}+01$ \\
\hline 12.00 & Backfill & $1.85 \mathrm{E}+01$ & $7.71 \mathrm{E}+01$ & $3.65 \mathrm{E}+02$ & 5.65E-01 & $2.88 \mathrm{E}+02$ & $5.13 \mathrm{E}+01$ \\
\hline 17.00 & Backfill & $2.30 \mathrm{E}+01$ & 7.61E+01 & $3.92 \mathrm{E}+02$ & 6.19E-01 & $5.25 \mathrm{E}+02$ & $6.52 \mathrm{E}+01$ \\
\hline 22.00 & Backfill & $1.58 \mathrm{E}+01$ & $6.76 \mathrm{E}+01$ & $3.35 \mathrm{E}+02$ & 2.93E-01 & 4.19E +02 & $5.10 \mathrm{E}+01$ \\
\hline 25.75 & Backfill & $1.68 \mathrm{E}+01$ & $7.52 \mathrm{E}+01$ & 3.99E+02 & 2.67E-01 & $6.12 \mathrm{E}+02$ & $(6.68 \mathrm{E}+01)$ \\
\hline 31.00 & Backfill & $1.41 \mathrm{E}+01$ & $6.44 \mathrm{E}+01$ & $3.31 \mathrm{E}+02$ & $1.49 \mathrm{E}-01$ & $4.46 \mathrm{E}+02$ & $(5.02 \mathrm{E}+01)$ \\
\hline 37.15 & Backfill & $2.30 \mathrm{E}+01$ & $1.21 \mathrm{E}+02$ & $5.43 \mathrm{E}+02$ & 3.51E-01 & $4.91 \mathrm{E}+02$ & $(8.00 \mathrm{E}+01)$ \\
\hline 40.80 & H1 & $2.77 E+00$ & $1.47 E+01$ & $8.85 E+01$ & $2.92 E-01$ & $2.38 \mathrm{E}+03$ & $(4.29 \mathrm{E}+01)$ \\
\hline 40.80 Dup & H1 & $2.93 E+00$ & $1.56 E+01$ & $1.01 E+02$ & $1.95 E-01$ & $2.45 \mathrm{E}+03$ & $(4.63 E+01)$ \\
\hline 45.45 & H1 & $2.46 E+00$ & $1.67 E+01$ & $1.16 E+02$ & $6.85 E-01$ & $4.80 \mathrm{E}+03$ & $(4.72 \mathrm{E}+01)$ \\
\hline 49.25 & H1 & $2.83 E+00$ & $1.46 E+01$ & $(6.60 E+01)$ & $(8.26 E-02)$ & $3.47 \mathrm{E}+03$ & 4.16E+01 \\
\hline 55.20 & H1 & $6.13 E+00$ & $2.84 E+01$ & $(1.35 E+02)$ & $(1.27 E-01)$ & $9.50 \mathrm{E}+02$ & $4.88 \mathrm{E}+01$ \\
\hline 60.00 & H1 & $1.35 E+01$ & $5.43 E+01$ & $(2.55 E+02)$ & $(1.01 E-01)$ & $9.71 \mathrm{E}+02$ & 7.68E+01 \\
\hline 60.00 Dup & H1 & $1.22 E+01$ & $5.14 E+01$ & $(2.49 E+02)$ & $(1.31 E-01)$ & 9.77E+02 & 7.68E+01 \\
\hline 62.50 & H1 & $6.21 \mathrm{E}+01$ & $2.56 \mathrm{E}+02$ & $1.40 \mathrm{E}+03$ & $1.11 \mathrm{E}+00$ & $7.33 E+02$ & $(1.48 \mathrm{E}+02)$ \\
\hline 64.85 & H1 & $3.82 \mathrm{E}+01$ & $1.54 \mathrm{E}+02$ & 8.14E+02 & 5.19E-01 & $3.95 \mathrm{E}+02$ & 9.57E+01 \\
\hline 66.20 & H1 & $5.46 \mathrm{E}+01$ & $2.07 \mathrm{E}+02$ & $1.05 \mathrm{E}+03$ & 3.48E-01 & $3.39 \mathrm{E}+02$ & 9.75E+01 \\
\hline 71.25 & H2 & $8.48 \mathrm{E}+01$ & $2.80 \mathrm{E}+02$ & $1.47 \mathrm{E}+03$ & $9.38 \mathrm{E}-01$ & $3.81 \mathrm{E}+02$ & $(1.56 \mathrm{E}+02)$ \\
\hline 79.55 & H2 & $4.42 \mathrm{E}+01$ & $1.54 \mathrm{E}+02$ & $8.68 \mathrm{E}+02$ & 5.78E-01 & $5.50 \mathrm{E}+02$ & $(1.04 \mathrm{E}+02)$ \\
\hline 79.55 Dup & H2 & $4.34 \mathrm{E}+01$ & $1.50 \mathrm{E}+02$ & $8.53 E+02$ & 6.25E-01 & $5.39 \mathrm{E}+02$ & $(1.05 E+02)$ \\
\hline 106.05 & $\mathrm{H} 2$ & $5.60 \mathrm{E}+01$ & $1.52 \mathrm{E}+02$ & 8.69E+02 & $1.52 \mathrm{E}+00$ & $4.57 \mathrm{E}+02$ & $(1.13 E+02)$ \\
\hline 110.15 & H2 & $7.21 \mathrm{E}+01$ & $1.93 \mathrm{E}+02$ & $1.04 \mathrm{E}+03$ & 4.20E-01 & $3.53 \mathrm{E}+02$ & $1.46 \mathrm{E}+02$ \\
\hline 117.40 & $\mathrm{H} 2$ & 7.95E+01 & $2.29 \mathrm{E}+02$ & $1.28 \mathrm{E}+03$ & 5.13E-01 & $3.14 \mathrm{E}+02$ & $1.42 \mathrm{E}+02$ \\
\hline 120.25 & $\mathrm{H} 2$ & 7.80E+01 & $2.20 \mathrm{E}+02$ & $1.26 \mathrm{E}+03$ & 3.77E-01 & $2.97 \mathrm{E}+02$ & $1.35 \mathrm{E}+02$ \\
\hline 123.65 & H2 & $1.03 E+02$ & $3.00 \mathrm{E}+02$ & $1.65 E+03$ & 5.56E-01 & $3.54 \mathrm{E}+02$ & $1.52 \mathrm{E}+02$ \\
\hline 126.35 & H2 & $1.17 \mathrm{E}+02$ & $3.13 E+02$ & $1.92 \mathrm{E}+03$ & $1.31 \mathrm{E}+00$ & $4.45 \mathrm{E}+02$ & $1.82 \mathrm{E}+02$ \\
\hline
\end{tabular}


Table 4.22. (contd)

\begin{tabular}{|c|c|c|c|c|c|c|c|}
\hline $\begin{array}{l}\text { Depth } \\
\text { (ft bgs) }\end{array}$ & $\begin{array}{c}\text { Stratigraphic Unit } \\
\text { (Hanford formation) }\end{array}$ & $\begin{array}{c}\text { Magnesium } \\
(\mathrm{mg} / \mathrm{L})\end{array}$ & $\begin{array}{c}\text { Calcium } \\
\text { (mg/L) }\end{array}$ & $\begin{array}{l}\text { Strontium } \\
(\mu \mathrm{g} / \mathrm{L})\end{array}$ & $\begin{array}{c}\text { Barium } \\
\text { (mg/L) }\end{array}$ & $\begin{array}{l}\text { Sodium } \\
\text { (mg/L) }\end{array}$ & $\begin{array}{c}\begin{array}{c}\text { Potassium } \\
\text { (mg/L) }\end{array} \\
\end{array}$ \\
\hline 126.75 & H2 & $1.07 \mathrm{E}+02$ & $2.93 \mathrm{E}+02$ & $1.64 \mathrm{E}+03$ & 5.37E-01 & $4.17 \mathrm{E}+02$ & $1.73 \mathrm{E}+02$ \\
\hline 127.85 & H2 & $1.30 \mathrm{E}+02$ & $3.69 \mathrm{E}+02$ & $1.99 \mathrm{E}+03$ & 5.90E-01 & $3.85 E+02$ & $1.78 \mathrm{E}+02$ \\
\hline 130.65 & H2 & 7.30E +01 & $2.04 \mathrm{E}+02$ & $1.14 \mathrm{E}+03$ & 4.42E-01 & $2.61 \mathrm{E}+02$ & $1.10 \mathrm{E}+02$ \\
\hline 133.75 & H2 & $1.08 \mathrm{E}+02$ & $3.07 \mathrm{E}+02$ & $1.42 \mathrm{E}+03$ & 2.49E-01 & $1.92 \mathrm{E}+02$ & 8.73E+01 \\
\hline 136.75 & H2 & $2.35 \mathrm{E}+02$ & 6.42E+02 & $2.98 \mathrm{E}+03$ & 4.86E-01 & $3.13 E+02$ & $1.60 \mathrm{E}+02$ \\
\hline 140.00 & H2 & $1.15 \mathrm{E}+02$ & $3.27 \mathrm{E}+02$ & $1.73 E+03$ & 6.74E-01 & $3.67 \mathrm{E}+02$ & $1.98 \mathrm{E}+02$ \\
\hline 143.25 & H2 & $1.07 \mathrm{E}+02$ & $3.15 E+02$ & $1.57 \mathrm{E}+03$ & 4.87E-01 & $3.25 E+02$ & $1.88 \mathrm{E}+02$ \\
\hline 148.30 & H2 & $1.67 \mathrm{E}+02$ & $4.67 \mathrm{E}+02$ & $2.28 \mathrm{E}+03$ & $6.41 \mathrm{E}-01$ & $4.26 \mathrm{E}+02$ & $2.30 \mathrm{E}+02$ \\
\hline 148.30 Dup & H2 & $1.73 \mathrm{E}+02$ & $4.82 \mathrm{E}+02$ & $2.42 \mathrm{E}+03$ & 7.74E-01 & $4.06 \mathrm{E}+02$ & $2.29 \mathrm{E}+02$ \\
\hline 165.75 & H2 & $1.16 \mathrm{E}+02$ & $3.83 \mathrm{E}+02$ & $2.00 \mathrm{E}+03$ & 8.31E-01 & $4.11 \mathrm{E}+02$ & $1.79 \mathrm{E}+02$ \\
\hline 170.25 & H2 & $5.80 \mathrm{E}+01$ & $2.15 E+02$ & $1.12 \mathrm{E}+03$ & 4.84E-01 & $3.16 \mathrm{E}+02$ & $1.36 \mathrm{E}+02$ \\
\hline 174.05 & H2 & $6.34 \mathrm{E}+01$ & $2.37 \mathrm{E}+02$ & $1.17 \mathrm{E}+03$ & 5.02E-01 & $3.08 \mathrm{E}+02$ & $1.43 \mathrm{E}+02$ \\
\hline \multicolumn{8}{|c|}{$\begin{array}{l}\text { Parentheses signify values below level of quantitation. } \\
\text { Shaded values designate the core samples and unshaded values are grab sample data. } \\
\text { Bold values are higher than others for given constituent. } \\
\text { Italicized values are lower than others for a given constituent. } \\
\text { Dup = Duplicate sample. }\end{array}$} \\
\hline
\end{tabular}

The data set for acid-extractable metals such as nickel, zinc, copper and silver did not indicate the presence of tank waste constituents above the background levels observed in cores from C4124, the "clean" borehole for C Tank Farm. Unlike water extract data, acid extract analyses are not diagnostic for tank waste source uranium or molybdenum, which are both present as naturally occurring elements in the sediment. Therefore, the lack of a waste source signature from uranium in the acid extract samples was not surprising. Additionally, the agreement between the two molybdenum isotopes reported in Table 4.28 indicated that any fission product molybdenum present has been masked by the naturally occurring molybdenum in the sediment. One curious result was the occurrence of quantifiable ruthenium in several zones between 26 and $126 \mathrm{ft}$ bgs. We have not observed measurable concentrations of ruthenium in any uncontaminated sediments studied to date. Further, the discrepancy between the reported total ruthenium concentrations based on the analysis of ruthenium-102 and ruthenium-104 could be an indication of the presence of fission-product material. When fission product ruthenium is present, the ratios of each ruthenium isotope are not the same as their respective natural abundances, which forces the instrument generated total ruthenium concentrations based on each isotope to not agree. 
Table 4.23. Calculated Pore Water Concentrations of Selected Constituents in C4297 Vadose Zone Sediments

\begin{tabular}{|c|c|c|c|c|c|c|c|c|c|}
\hline Sample & $\begin{array}{c}\text { Depth } \\
\text { (ft bgs) }\end{array}$ & $\begin{array}{c}\text { Aluminum } \\
(\mu \mathrm{g} / \mathrm{L})\end{array}$ & $\begin{array}{l}\text { Silicon } \\
\text { (mg/L) }\end{array}$ & $\begin{array}{c}\text { Iron } \\
(\mu g / L)\end{array}$ & $\begin{array}{c}\text { Manganese } \\
(\mu \mathrm{g} / \mathrm{L})\end{array}$ & $\begin{array}{c}\text { Zinc } \\
(\mathrm{mg} / \mathrm{L})\end{array}$ & $\begin{array}{c}\mathrm{PO}_{4}(\mathrm{ICP}) \\
\text { (mg/L) }\end{array}$ & $\begin{array}{c}\mathrm{SO}_{4}(\mathrm{ICP}) \\
(\mathrm{mg} / \mathrm{L})\end{array}$ & $\begin{array}{l}\text { Nickel } \\
(\mu \mathrm{g} / \mathrm{L})\end{array}$ \\
\hline 2.50 & Backfill & $(3.95 E+02)$ & $2.14 \mathrm{E}+02$ & $\begin{array}{c}(2.73 \mathrm{E}+02) \\
\end{array}$ & ND & $\begin{array}{c}\text { (7.63E-01) } \\
\end{array}$ & $(4.01 \mathrm{E}+00)$ & $2.95 \mathrm{E}+01$ & $(1.14 \mathrm{E}+02)$ \\
\hline 7.00 & Backfill & $(5.78 \mathrm{E}+02)$ & $2.06 \mathrm{E}+02$ & $(3.72 \mathrm{E}+02)$ & ND & (7.65E-01) & $(4.09 \mathrm{E}+00)$ & $3.23 \mathrm{E}+01$ & $(1.11 \mathrm{E}+02)$ \\
\hline 12.00 & Backfill & $(5.73 \mathrm{E}+02)$ & $2.00 \mathrm{E}+02$ & $(3.94 \mathrm{E}+02)$ & ND & $(5.80 \mathrm{E}-01)$ & $(3.53 E+00)$ & $4.08 \mathrm{E}+01$ & $(8.83 E+01)$ \\
\hline 17.00 & Backfill & $(1.22 \mathrm{E}+03)$ & $2.83 \mathrm{E}+02$ & $(1.03 \mathrm{E}+03)$ & ND & $(1.56 \mathrm{E}+00)$ & $(5.36 \mathrm{E}+00)$ & $4.22 \mathrm{E}+01$ & $(1.11 \mathrm{E}+02)$ \\
\hline 22.00 & Backfill & $(1.03 E+03)$ & $2.23 \mathrm{E}+02$ & $(1.34 \mathrm{E}+03)$ & ND & (7.39E-01) & $(4.05 E+00)$ & $5.57 \mathrm{E}+01$ & $(1.29 E+02)$ \\
\hline 25.75 & Backfill & $(1.72 \mathrm{E}+03)$ & $2.90 \mathrm{E}+02$ & $(1.55 \mathrm{E}+03)$ & $(3.91 \mathrm{E}+01)$ & $(1.18 \mathrm{E}+00)$ & $(1.28 \mathrm{E}+00)$ & $(6.78 \mathrm{E}+01)$ & ND \\
\hline 31.00 & Backfill & $(8.87 \mathrm{E}+02)$ & $2.35 \mathrm{E}+02$ & $(7.30 \mathrm{E}+02)$ & $(2.03 \mathrm{E}+01)$ & $(4.27 \mathrm{E}-01)$ & $(2.36 \mathrm{E}+00)$ & $(4.14 \mathrm{E}+01)$ & ND \\
\hline 37.15 & Backfill & $(1.17 \mathrm{E}+03)$ & $3.47 \mathrm{E}+02$ & $(1.21 \mathrm{E}+03)$ & $(6.95 \mathrm{E}+00)$ & $(1.06 \mathrm{E}+00)$ & $(1.37 \mathrm{E}+01)$ & $(8.67 \mathrm{E}+01)$ & $(2.98 \mathrm{E}+01)$ \\
\hline 40.80 & H1 & $6.43 E+03$ & $4.02 E+02$ & $4.92 E+03$ & $(6.71 \mathrm{E}+01)$ & $(1.54 \mathrm{E}+00)$ & $(2.07 \mathrm{E}+01)$ & $(1.00 \mathrm{E}+02)$ & ND \\
\hline 40.80 Dup & H1 & $6.40 \mathrm{E}+03$ & $4.03 \mathrm{E}+02$ & $5.09 \mathrm{E}+03$ & $(7.91 \mathrm{E}+01)$ & $(1.44 \mathrm{E}+00)$ & $(2.40 \mathrm{E}+01)$ & $(9.80 \mathrm{E}+01)$ & ND \\
\hline 45.45 & $\mathrm{H} 1$ & $1.30 \mathrm{E}+04$ & $5.25 \mathrm{E}+02$ & $8.14 E+03$ & $(1.69 \mathrm{E}+02)$ & $(8.09 \mathrm{E}-01)$ & $(5.74 \mathrm{E}+01)$ & $(9.87 \mathrm{E}+01)$ & $(2.17 \mathrm{E}+02)$ \\
\hline 49.25 & H1 & $7.75 \mathrm{E}+03$ & $4.22 \mathrm{E}+02$ & $5.99 \mathrm{E}+03$ & $(1.14 \mathrm{E}+02)$ & $(1.42 \mathrm{E}+00)$ & $(3.58 \mathrm{E}+01)$ & $5.33 \mathrm{E}+01$ & $(1.42 \mathrm{E}+02)$ \\
\hline 55.20 & H1 & $3.08 \mathrm{E}+03$ & $2.92 \mathrm{E}+02$ & $2.11 \mathrm{E}+03$ & $(1.76 \mathrm{E}+01)$ & $(1.15 \mathrm{E}+00)$ & $(6.59 \mathrm{E}+00)$ & $1.62 \mathrm{E}+02$ & $(1.51 \mathrm{E}+02)$ \\
\hline 60.00 & H1 & $3.25 E+03$ & $2.88 \mathrm{E}+02$ & $2.64 \mathrm{E}+03$ & $(2.89 \mathrm{E}+01)$ & $(1.75 \mathrm{E}+00)$ & $(2.15 \mathrm{E}+01)$ & $2.01 \mathrm{E}+02$ & $(1.35 \mathrm{E}+02)$ \\
\hline 60.00 Dup & H1 & $3.81 E+03$ & $2.91 \mathrm{E}+02$ & $3.34 \mathrm{E}+03$ & $(3.81 \mathrm{E}+01)$ & $(1.28 \mathrm{E}+00)$ & $(1.87 \mathrm{E}+01)$ & $2.45 \mathrm{E}+02$ & $(8.53 E+01)$ \\
\hline 62.50 & H1 & $(1.67 \mathrm{E}+03)$ & $4.03 \mathrm{E}+02$ & $(6.38 \mathrm{E}+02)$ & ND & $(1.69 \mathrm{E}+00)$ & $(1.78 \mathrm{E}+00)$ & $8.49 \mathrm{E}+02$ & $(3.01 E+02)$ \\
\hline 64.85 & H1 & $(1.18 \mathrm{E}+03)$ & $2.88 \mathrm{E}+02$ & $(7.48 \mathrm{E}+02)$ & ND & $(1.38 \mathrm{E}+00)$ & $(2.65 \mathrm{E}+00)$ & $2.77 \mathrm{E}+02$ & $(2.10 \mathrm{E}+02)$ \\
\hline 66.20 & H1 & $(8.65 \mathrm{E}+02)$ & $2.69 \mathrm{E}+02$ & $(3.89 \mathrm{E}+02)$ & ND & $(1.21 \mathrm{E}+00)$ & $(2.47 \mathrm{E}+00)$ & $3.96 \mathrm{E}+02$ & $(1.32 \mathrm{E}+02)$ \\
\hline 71.25 & $\mathrm{H} 2$ & $(2.37 \mathrm{E}+03)$ & $3.24 \mathrm{E}+02$ & $(3.51 \mathrm{E}+02)$ & ND & $(1.23 \mathrm{E}+00)$ & ND & $(4.83 \mathrm{E}+02)$ & ND \\
\hline 79.55 & $\mathrm{H} 2$ & $(1.57 \mathrm{E}+03)$ & $2.49 \mathrm{E}+02$ & $(5.07 \mathrm{E}+02)$ & ND & $(1.14 \mathrm{E}+00)$ & $(4.48 \mathrm{E}+00)$ & $(4.65 \mathrm{E}+02)$ & ND \\
\hline 79.55 Dup & $\mathrm{H} 2$ & $(1.30 \mathrm{E}+03)$ & $2.46 \mathrm{E}+02$ & $(4.34 \mathrm{E}+02)$ & ND & $(1.22 \mathrm{E}+00)$ & ND & $(4.64 \mathrm{E}+02)$ & ND \\
\hline 106.05 & $\mathrm{H} 2$ & $(1.24 \mathrm{E}+03)$ & $2.07 \mathrm{E}+02$ & $(5.02 \mathrm{E}+02)$ & ND & $(1.45 \mathrm{E}+00)$ & $(2.87 \mathrm{E}+00)$ & $5.30 \mathrm{E}+02$ & ND \\
\hline 110.15 & $\mathrm{H} 2$ & $(1.83 \mathrm{E}+03)$ & $2.71 \mathrm{E}+02$ & $(8.03 \mathrm{E}+02)$ & ND & $(6.47 \mathrm{E}+00)$ & $(2.44 \mathrm{E}+00)$ & $2.83 \mathrm{E}+02$ & $(1.62 \mathrm{E}+02)$ \\
\hline 117.40 & $\mathrm{H} 2$ & $(1.88 \mathrm{E}+03)$ & $2.70 \mathrm{E}+02$ & $(9.35 \mathrm{E}+02)$ & ND & $(1.76 \mathrm{E}+00)$ & $(2.40 \mathrm{E}+00)$ & $4.38 \mathrm{E}+02$ & $(1.67 \mathrm{E}+02)$ \\
\hline 120.25 & $\mathrm{H} 2$ & $(1.36 \mathrm{E}+03)$ & $2.12 \mathrm{E}+02$ & $(3.69 \mathrm{E}+02)$ & ND & $(1.34 \mathrm{E}+00)$ & $(2.47 \mathrm{E}+00)$ & $5.75 \mathrm{E}+02$ & $(1.34 \mathrm{E}+02)$ \\
\hline
\end{tabular}


Table 4.23. (contd)

\begin{tabular}{|c|c|c|c|c|c|c|c|c|c|}
\hline Sample & $\begin{array}{l}\text { Depth } \\
\text { (ft bgs) }\end{array}$ & $\underset{(\mu g / L)}{A l}$ & $\begin{array}{c}\mathrm{Si} \\
(\mathrm{mg} / \mathrm{L})\end{array}$ & $\underset{(\mu \mathrm{g} / \mathrm{L})}{\mathrm{Fe}}$ & $\underset{(\mu \mathrm{g} / \mathrm{L})}{\mathrm{Mn}}$ & $\begin{array}{c}\mathrm{Zn} \\
(\mathrm{mg} / \mathrm{L})\end{array}$ & $\begin{array}{c}\mathrm{PO}_{4}(\mathrm{ICP}) \\
(\mathrm{mg} / \mathrm{L})\end{array}$ & $\begin{array}{c}\mathrm{SO}_{4}(\mathrm{ICP}) \\
(\mathrm{mg} / \mathrm{L})\end{array}$ & $\begin{array}{c}\mathrm{Ni} \\
(\mu \mathrm{g} / \mathrm{L})\end{array}$ \\
\hline 123.65 & $\mathrm{H} 2$ & $(1.61 \mathrm{E}+03)$ & $2.53 \mathrm{E}+02$ & $(6.24 \mathrm{E}+02)$ & ND & $(1.35 \mathrm{E}+00)$ & $(2.06 \mathrm{E}+00)$ & $9.43 \mathrm{E}+02$ & $(1.26 E+02)$ \\
\hline 126.35 & H2 & $(2.31 \mathrm{E}+03)$ & $3.36 \mathrm{E}+02$ & $(3.05 E+02)$ & ND & $(1.39 \mathrm{E}+00)$ & ND & $9.66 \mathrm{E}+02$ & ND \\
\hline 126.75 & $\mathrm{H} 2$ & $(2.17 \mathrm{E}+03)$ & $2.69 \mathrm{E}+02$ & $(6.24 \mathrm{E}+02)$ & ND & $(1.24 \mathrm{E}+00)$ & $(2.55 \mathrm{E}+00)$ & $9.05 \mathrm{E}+02$ & $(9.80 \mathrm{E}+01)$ \\
\hline 127.85 & $\mathrm{H} 2$ & $(1.51 \mathrm{E}+03)$ & $2.42 \mathrm{E}+02$ & $(3.28 \mathrm{E}+02)$ & ND & $(7.08 \mathrm{E}-01)$ & $(1.52 \mathrm{E}+00)$ & $1.32 \mathrm{E}+03$ & $(1.21 \mathrm{E}+02)$ \\
\hline 130.65 & $\mathrm{H} 2$ & $(1.21 \mathrm{E}+03)$ & $1.92 \mathrm{E}+02$ & $(4.14 \mathrm{E}+02)$ & ND & (3.03E-01) & $(1.64 \mathrm{E}+00)$ & $5.56 \mathrm{E}+02$ & $(8.43 E+01)$ \\
\hline 133.75 & $\mathrm{H} 2$ & $(1.87 \mathrm{E}+02)$ & $1.30 \mathrm{E}+02$ & $(1.68 \mathrm{E}+02)$ & ND & $(3.05 \mathrm{E}-01)$ & (3.31E-01) & $1.08 \mathrm{E}+03$ & $(4.37 \mathrm{E}+01)$ \\
\hline 136.75 & $\mathrm{H} 2$ & $(1.18 \mathrm{E}+02)$ & $2.13 \mathrm{E}+02$ & $(4.94 \mathrm{E}+02)$ & ND & $(5.04 \mathrm{E}-01)$ & $(2.34 \mathrm{E}+00)$ & $2.23 E+03$ & $(1.56 \mathrm{E}+02)$ \\
\hline 140.00 & $\mathrm{H} 2$ & $(2.45 \mathrm{E}+03)$ & $2.68 \mathrm{E}+02$ & $(6.70 \mathrm{E}+02)$ & $(4.02 \mathrm{E}+01)$ & $(1.66 \mathrm{E}+00)$ & $(1.80 \mathrm{E}+00)$ & $8.77 \mathrm{E}+02$ & $(1.67 \mathrm{E}+02)$ \\
\hline 143.25 & $\mathrm{H} 2$ & $(2.52 E+03)$ & $2.76 \mathrm{E}+02$ & $(7.71 \mathrm{E}+02)$ & $(2.46 \mathrm{E}+01)$ & $(1.57 \mathrm{E}+00)$ & $(1.49 \mathrm{E}+00)$ & $7.45 \mathrm{E}+02$ & $(1.15 \mathrm{E}+02)$ \\
\hline 148.30 & $\mathrm{H} 2$ & $(1.50 \mathrm{E}+03)$ & $2.70 \mathrm{E}+02$ & $(4.19 \mathrm{E}+02)$ & $(4.29 \mathrm{E}+01)$ & $(1.71 \mathrm{E}+00)$ & $(2.97 \mathrm{E}+00)$ & $1.91 \mathrm{E}+03$ & $(1.38 E+02)$ \\
\hline 148.30 Dup & $\mathrm{H} 2$ & $(1.36 \mathrm{E}+03)$ & $2.54 \mathrm{E}+02$ & $(4.04 \mathrm{E}+02)$ & $(4.02 \mathrm{E}+01)$ & $(1.45 \mathrm{E}+00)$ & $(1.91 \mathrm{E}+00)$ & $1.97 \mathrm{E}+03$ & $(7.20 \mathrm{E}+01)$ \\
\hline 165.75 & $\mathrm{H} 2$ & $(1.68 \mathrm{E}+03)$ & $2.68 \mathrm{E}+02$ & $(5.50 \mathrm{E}+02)$ & $\mathrm{ND}$ & $2.48 \mathrm{E}+00$ & $(1.19 \mathrm{E}+00)$ & $1.35 \mathrm{E}+03$ & $(8.79 \mathrm{E}+01)$ \\
\hline 170.25 & $\mathrm{H} 2$ & $(1.54 \mathrm{E}+03)$ & $2.67 \mathrm{E}+02$ & $9.69 \mathrm{E}+02$ & ND & $(7.00 \mathrm{E}-01)$ & $(1.62 \mathrm{E}+00)$ & $4.87 \mathrm{E}+02$ & $(7.90 \mathrm{E}+01)$ \\
\hline 174.05 & $\mathrm{H} 2$ & $(1.69 \mathrm{E}+03)$ & $2.59 \mathrm{E}+02$ & $(6.72 E+02)$ & ND & $(1.39 \mathrm{E}+00)$ & $(1.18 \mathrm{E}+00)$ & $5.27 \mathrm{E}+02$ & $(1.01 \mathrm{E}+02)$ \\
\hline \multicolumn{10}{|c|}{$\begin{array}{l}\text { Parentheses signify values below level of quantitation. } \\
\text { Shaded values designate the core samples and unshaded values are grab sample data. } \\
\text { Bold values are higher than others for given constituent. } \\
\text { Dup = Duplicate sample. } \\
\text { ND = Not detected. }\end{array}$} \\
\hline
\end{tabular}


Table 4.24. Calculated Pore Water Concentrations of Potentially Mobile Constituents in C4297 Vadose Sediments

\begin{tabular}{|c|c|c|c|c|c|c|c|c|c|c|}
\hline $\begin{array}{c}\text { Depth } \\
\text { (ft bgs) }\end{array}$ & $\begin{array}{c}\text { Tc-99 } \\
\text { ICP-MS } \\
\text { (pCi/L) }\end{array}$ & $\begin{array}{c}\text { U-238 } \\
\text { ICP-MS } \\
(\mu \mathrm{g} / \mathrm{L})\end{array}$ & $\begin{array}{c}\text { Cr } \\
\text { ICP-OES } \\
(\mu \mathrm{g} / \mathrm{L})\end{array}$ & $\begin{array}{c}\text { Cr } \\
\text { ICP-MS } \\
(\mu \mathrm{g} / \mathrm{L})\end{array}$ & $\begin{array}{c}\text { Mo } \\
\text { ICP-OES } \\
(\mu \mathrm{g} / \mathrm{L})\end{array}$ & $\begin{array}{c}\text { Mo 95 } \\
\text { ICP-MS } \\
(\mu \mathrm{g} / \mathrm{L})\end{array}$ & $\begin{array}{c}\text { Mo 98 } \\
\text { ICP-MS } \\
(\mu \mathrm{g} / \mathrm{L})\end{array}$ & $\begin{array}{c}\text { Ru } 101 \\
\text { ICP-MS } \\
(\mu g / L)\end{array}$ & $\begin{array}{c}\text { Ru } 102 \\
\text { ICP-MS } \\
(\mu g / L)\end{array}$ & $\begin{array}{c}\text { Ru } 104 \\
\text { ICP-MS } \\
(\mu g / L)\end{array}$ \\
\hline 2.50 & $\mathrm{ND}^{\mathrm{c}}$ & $1.16 \mathrm{E}+01$ & $(2.54 \mathrm{E}+01)^{\mathrm{a}}$ & $(1.03 E+01)$ & $(9.16 \mathrm{E}+00)$ & $1.91 \mathrm{E}+01$ & $1.79 \mathrm{E}+01$ & $(1.42 \mathrm{E}-01)$ & $(4.08 \mathrm{E}-01)$ & $(9.82 \mathrm{E}-02)$ \\
\hline 7.00 & ND & $1.56 \mathrm{E}+01$ & $(1.58 \mathrm{E}+01)$ & $(1.10 \mathrm{E}+01)$ & ND & $2.46 \mathrm{E}+01$ & $2.42 \mathrm{E}+01$ & $(6.08 \mathrm{E}-02)$ & (3.03E-01) & (8.19E-02) \\
\hline 12.00 & ND & $2.82 E+01$ & $(1.99 \mathrm{E}+01)$ & $(8.87 E+00)$ & $(1.59 E+01)$ & $3.54 \mathrm{E}+01$ & $3.57 \mathrm{E}+01$ & $(5.12 \mathrm{E}-02)$ & $(2.54 \mathrm{E}-01)$ & (7.45E-02) \\
\hline 17.00 & ND & $5.27 \mathrm{E}+01$ & $(3.18 \mathrm{E}+01)$ & $(3.51 \mathrm{E}+00)$ & $\mathrm{ND}$ & $7.34 \mathrm{E}+01$ & 7.52E+01 & $(6.00 \mathrm{E}-02)$ & $(3.31 \mathrm{E}-01)$ & $(5.75 \mathrm{E}-02)$ \\
\hline 22.00 & $(1.49 \mathrm{E}+02)$ & $3.69 \mathrm{E}+01$ & $(1.74 \mathrm{E}+01)$ & $(5.01 \mathrm{E}+00)$ & $(5.31 \mathrm{E}+01)$ & 7.27E+01 & $7.31 \mathrm{E}+01$ & $(4.01 \mathrm{E}-02)$ & $(2.96 \mathrm{E}-01)$ & $(3.51 \mathrm{E}-02)$ \\
\hline 25.75 & ND & $2.30 \mathrm{E}+01$ & ND & $(9.03 E+00)$ & NM & $1.46 \mathrm{E}+02$ & $1.33 \mathrm{E}+02$ & ND & $(2.62 \mathrm{E}-01)$ & $(1.40 \mathrm{E}+00)$ \\
\hline 31.00 & ND & $2.64 \mathrm{E}+01$ & ND & $(6.00 \mathrm{E}+00)$ & NM & $8.31 \mathrm{E}+01$ & $8.04 \mathrm{E}+01$ & $(3.01 \mathrm{E}-01)$ & $(4.01 \mathrm{E}-01)$ & $(3.01 \mathrm{E}-01)$ \\
\hline 37.15 & ND & $2.11 \mathrm{E}+01$ & ND & $(7.30 \mathrm{E}+00)$ & NM & $1.54 \mathrm{E}+02$ & $1.46 \mathrm{E}+02$ & $\mathrm{ND}$ & $(1.86 \mathrm{E}-01)$ & $(1.01 \mathrm{E}+00)$ \\
\hline 38.35 & $(1.81 \mathrm{E}+02)$ & $1.56 \mathrm{E}+01$ & NM & $(2.63 \mathrm{E}+00)$ & NM & $1.19 \mathrm{E}+02$ & $1.11 \mathrm{E}+02$ & $(0.224)$ & NM & $(0.234)$ \\
\hline 38.53 & $(1.32 \mathrm{E}+02)$ & $1.70 \mathrm{E}+01$ & NM & NM & NM & NM & NM & NM & NM & NM \\
\hline 40.80 & $4.20 \mathrm{E}+03$ & $2.21 \mathrm{E}+02$ & $(6.88 \mathrm{E}+00)$ & $(3.20 \mathrm{E}+01)$ & NM & $1.61 \mathrm{E}+02$ & $1.49 \mathrm{E}+02$ & $(4.17 \mathrm{E}+00)$ & $(1.63 E+00)$ & $(1.84 \mathrm{E}+00)$ \\
\hline 40.80 & $4.98 \mathrm{E}+03$ & $2.00 \mathrm{E}+02$ & ND & $(2.53 \mathrm{E}+01)$ & NM & $1.79 \mathrm{E}+02$ & $1.62 \mathrm{E}+02$ & $(3.85 E+00)$ & $(1.53 \mathrm{E}+00)$ & $(1.94 \mathrm{E}+00)$ \\
\hline 41.20 & $8.05 E+03$ & $2.63 E+02$ & NM & $(2.11 \mathrm{E}+01)$ & NM & $1.22 \mathrm{E}+02$ & $9.72 \mathrm{E}+01$ & $(4.82 \mathrm{E}+00)$ & $(3.26 \mathrm{E}+00)$ & (9.50E-01) \\
\hline 43.75 & $1.83 \mathrm{E}+04$ & $2.82 \mathrm{E}+02$ & NM & $(1.62 \mathrm{E}+01)$ & NM & $2.32 \mathrm{E}+02$ & $1.94 \mathrm{E}+02$ & $(1.39 \mathrm{E}+01)$ & $(6.49 \mathrm{E}+00)$ & $(2.69 \mathrm{E}+00)$ \\
\hline 45.45 & $1.78 \mathrm{E}+04$ & $4.14 \mathrm{E}+02$ & ND & $(8.69 \mathrm{E}+01)$ & NM & $1.40 \mathrm{E}+02$ & $1.09 \mathrm{E}+02$ & $(6.18 \mathrm{E}+00)$ & $(3.41 \mathrm{E}+00)$ & $(3.26 \mathrm{E}+00)$ \\
\hline 45.85 & $1.19 \mathrm{E}+04$ & $3.64 \mathrm{E}+02$ & NM & $(1.59 \mathrm{E}+01)$ & NM & $1.27 \mathrm{E}+02$ & $9.77 \mathrm{E}+01$ & $(6.43 \mathrm{E}+00)$ & $2.91 \mathrm{E}+00$ & $(9.35 \mathrm{E}-01)$ \\
\hline 49.25 & $(3.44 \mathrm{E}+03)$ & $2.95 E+02$ & $(3.53 \mathrm{E}+01)$ & $(1.52 E+01)$ & $\mathrm{ND}$ & $2.01 \mathrm{E}+01$ & $2.42 \mathrm{E}+01$ & $3.31 \mathrm{E}+00$ & $(1.86 \mathrm{E}+00)$ & $(1.02 \mathrm{E}+00)$ \\
\hline 51.25 & $2.66 \mathrm{E}+04$ & $6.91 \mathrm{E}+02$ & NM & $(2.14 \mathrm{E}+01)$ & NM & $1.98 \mathrm{E}+02$ & $1.62 \mathrm{E}+02$ & $(7.01 \mathrm{E}+00)$ & $3.76 \mathrm{E}+00$ & $(5.03 \mathrm{E}-01)$ \\
\hline 55.20 & $(2.79 \mathrm{E}+03)$ & $2.08 E+02$ & $(1.60 \mathrm{E}+01)$ & $(1.61 \mathrm{E}+01)$ & $(2.27 \mathrm{E}+02)$ & $3.67 \mathrm{E}+02$ & $4.90 \mathrm{E}+02$ & $4.99 \mathrm{E}+00$ & $(2.70 \mathrm{E}+00)$ & $(2.92 \mathrm{E}-01)$ \\
\hline 57.20 & $1.46 \mathrm{E}+04$ & $6.50 \mathrm{E}+02$ & NM & $(7.95 E+00)$ & NM & $8.69 \mathrm{E}+02$ & $5.95 \mathrm{E}+02$ & $(7.59 \mathrm{E}+00)$ & $(2.71 \mathrm{E}+00)$ & $(6.92 \mathrm{E}-01)$ \\
\hline 60.00 & $(7.83 \mathrm{E}+03)$ & $8.95 E+01$ & $(2.21 \mathrm{E}+01)$ & $(1.87 \mathrm{E}+01)$ & $9.22 \mathrm{E}+02$ & $1.54 \mathrm{E}+03$ & $2.13 \mathrm{E}+03$ & $6.79 \mathrm{E}+00$ & $3.39 \mathrm{E}+00$ & $(6.14 \mathrm{E}-01)$ \\
\hline 60.00 & $(7.86 \mathrm{E}+03)$ & $1.06 \mathrm{E}+02$ & ND & $(1.92 \mathrm{E}+01)$ & $1.02 \mathrm{E}+03$ & $1.65 \mathrm{E}+03$ & $2.24 \mathrm{E}+03$ & $6.46 \mathrm{E}+00$ & $3.69 \mathrm{E}+00$ & $(8.16 \mathrm{E}-01)$ \\
\hline 61.50 & $3.37 \mathrm{E}+04$ & $1.74 \mathrm{E}+01$ & NM & $(1.52 \mathrm{E}+01)$ & NM & $4.11 \mathrm{E}+03$ & $2.74 \mathrm{E}+03$ & $(8.75 \mathrm{E}+00)$ & $(2.88 \mathrm{E}+00)$ & $(1.07 \mathrm{E}-01)$ \\
\hline
\end{tabular}


Table 4.24. (contd)

\begin{tabular}{|c|c|c|c|c|c|c|c|c|c|c|}
\hline $\begin{array}{c}\text { Depth } \\
\text { (ft bgs) }\end{array}$ & $\begin{array}{c}\text { Tc-99 } \\
\text { ICP-MS } \\
\text { (pCi/L) }\end{array}$ & $\begin{array}{c}\text { U-238 } \\
\text { ICP-MS } \\
(\mu \mathrm{g} / \mathrm{L})\end{array}$ & $\begin{array}{c}\mathrm{Cr} \\
\text { ICP-OES } \\
(\mu \mathrm{g} / \mathrm{L}) \\
\end{array}$ & $\begin{array}{c}\mathrm{Cr} \\
\text { ICP-MS } \\
(\mu \mathrm{g} / \mathrm{L}) \\
\end{array}$ & $\begin{array}{c}\text { Mo } \\
\text { ICP-OES } \\
(\mu \mathrm{g} / \mathrm{L}) \\
\end{array}$ & $\begin{array}{c}\text { Mo } 95 \\
\text { ICP-MS } \\
(\mu \mathrm{g} / \mathrm{L})\end{array}$ & $\begin{array}{c}\text { Mo } 98 \\
\text { ICP-MS } \\
(\mu \mathrm{g} / \mathrm{L})\end{array}$ & $\begin{array}{c}\text { Ru } 101 \\
\text { ICP-MS } \\
(\mu \mathrm{g} / \mathrm{L})\end{array}$ & $\begin{array}{c}\text { Ru } 102 \\
\text { ICP-MS } \\
(\mu \mathrm{g} / \mathrm{L}) \\
\end{array}$ & $\begin{array}{c}\text { Ru } 104 \\
\text { ICP-MS } \\
(\mu \mathrm{g} / \mathrm{L})\end{array}$ \\
\hline 62.50 & $5.17 \mathrm{E}+04$ & $1.55 \mathrm{E}+01$ & ND & $(3.70 \mathrm{E}+01)$ & NM & $3.99 \mathrm{E}+03$ & $2.94 \mathrm{E}+03$ & $(6.25 E+00)$ & $(3.35 \mathrm{E}+00)$ & $(4.80 E+00)$ \\
\hline 62.50 & $3.67 \mathrm{E}+04$ & $1.21 \mathrm{E}+01$ & NM & $(2.52 \mathrm{E}+01)$ & NM & $1.81 \mathrm{E}+03$ & $1.45 \mathrm{E}+03$ & $(6.85 \mathrm{E}+00)$ & $(3.29 \mathrm{E}+00)$ & (1.03E-01) \\
\hline 64.85 & $(2.32 \mathrm{E}+03)$ & $1.11 \mathrm{E}+01$ & $(2.86 \mathrm{E}+01)$ & $(1.62 \mathrm{E}+01)$ & $(5.93 \mathrm{E}+02)$ & $6.51 \mathrm{E}+02$ & $7.91 \mathrm{E}+02$ & $3.72 \mathrm{E}+00$ & $(1.99 \mathrm{E}+00)$ & (2.09E-01) \\
\hline 66.20 & $5.89 \mathrm{E}+04$ & $1.22 \mathrm{E}+01$ & $(2.05 E+01)$ & $(1.93 \mathrm{E}+01)$ & $(1.50 \mathrm{E}+02)$ & $2.21 \mathrm{E}+02$ & $2.19 \mathrm{E}+02$ & $7.62 \mathrm{E}+00$ & $3.79 \mathrm{E}+00$ & (5.06E-01) \\
\hline 68.95 & $2.02 \mathrm{E}+03$ & $1.07 \mathrm{E}+01$ & NM & $(1.03 \mathrm{E}+00)$ & NM & $2.46 \mathrm{E}+02$ & $2.38 \mathrm{E}+02$ & (7.96E-01) & (2.39E-01) & (2.39E-01) \\
\hline 71.25 & $3.69 \mathrm{E}+03$ & $1.12 \mathrm{E}+01$ & ND & $(1.54 \mathrm{E}+01)$ & NM & $3.55 \mathrm{E}+02$ & $3.22 \mathrm{E}+02$ & ND & ND & (7.39E-01) \\
\hline 77.40 & $2.62 \mathrm{E}+03$ & $1.34 \mathrm{E}+01$ & $\mathrm{NM}$ & NM & NM & $\mathrm{NM}$ & $\mathrm{NM}$ & NM & $\mathrm{NM}$ & NM \\
\hline 79.55 & $3.62 \mathrm{E}+03$ & $2.10 \mathrm{E}+01$ & $(1.49 \mathrm{E}+01)$ & $(1.88 \mathrm{E}+01)$ & NM & $4.67 \mathrm{E}+02$ & $3.91 \mathrm{E}+02$ & $(2.61 \mathrm{E}+00)$ & (7.31E-01) & $(1.98 \mathrm{E}+00)$ \\
\hline 79.55 & $3.00 \mathrm{E}+03$ & $2.01 \mathrm{E}+01$ & ND & $(7.18 \mathrm{E}+00)$ & NM & $4.66 \mathrm{E}+02$ & $3.88 \mathrm{E}+02$ & $(3.30 \mathrm{E}+00)$ & $(1.27 \mathrm{E}+00)$ & $(2.65 \mathrm{E}+00)$ \\
\hline 88.50 & $3.08 \mathrm{E}+03$ & $1.05 \mathrm{E}+01$ & NM & NM & NM & NM & $\mathrm{NM}$ & NM & NM & NM \\
\hline 96.60 & $4.08 \mathrm{E}+03$ & $6.24 \mathrm{E}+00$ & NM & NM & NM & NM & $\mathrm{NM}$ & NM & NM & NM \\
\hline 104.00 & $7.73 \mathrm{E}+03$ & $6.02 \mathrm{E}+00$ & $\mathrm{NM}$ & NM & NM & $\mathrm{NM}$ & $\mathrm{NM}$ & $\mathrm{NM}$ & $\mathrm{NM}$ & NM \\
\hline 106.05 & $1.89 \mathrm{E}+04$ & $1.09 \mathrm{E}+01$ & ND & $(1.30 \mathrm{E}+01)$ & NM & $2.61 \mathrm{E}+02$ & $2.50 \mathrm{E}+02$ & $(1.59 \mathrm{E}+00)$ & $(6.18 \mathrm{E}-01)$ & $(1.53 \mathrm{E}+00)$ \\
\hline 110.15 & $(2.43 E+03)$ & $9.87 \mathrm{E}+00$ & $(2.11 \mathrm{E}+01)$ & $(2.03 \mathrm{E}+01)$ & $(2.59 \mathrm{E}+02)$ & $3.14 \mathrm{E}+02$ & $3.18 \mathrm{E}+02$ & $(3.67 \mathrm{E}-01)$ & (6.73E-01) & $(2.51 \mathrm{E}-02)$ \\
\hline 114.20 & $9.95 \mathrm{E}+03$ & $5.82 \mathrm{E}+00$ & $\mathrm{NM}$ & NM & NM & NM & $\mathrm{NM}$ & NM & NM & NM \\
\hline 117.40 & $(5.94 \mathrm{E}+03)$ & $1.06 \mathrm{E}+01$ & ND & $(8.60 \mathrm{E}+00)$ & $(2.39 \mathrm{E}+02)$ & $2.35 \mathrm{E}+02$ & $2.36 \mathrm{E}+02$ & $(7.66 \mathrm{E}-01)$ & $(1.59 \mathrm{E}+00)$ & $(3.93 \mathrm{E}-01)$ \\
\hline 120.25 & $(1.10 \mathrm{E}+04)$ & $6.26 \mathrm{E}+00$ & ND & $(5.39 \mathrm{E}+00)$ & $(2.50 \mathrm{E}+02)$ & $2.18 \mathrm{E}+02$ & $2.19 \mathrm{E}+02$ & $(8.37 \mathrm{E}-01)$ & $(9.09 \mathrm{E}-01)$ & $(1.24 \mathrm{E}-01)$ \\
\hline 123.65 & $(2.54 \mathrm{E}+04)$ & $8.46 \mathrm{E}+00$ & ND & $(9.72 \mathrm{E}+00)$ & $(1.79 \mathrm{E}+02)$ & $2.28 \mathrm{E}+02$ & $2.27 \mathrm{E}+02$ & $(1.85 \mathrm{E}+00)$ & $(1.29 \mathrm{E}+00)$ & (6.79E-01) \\
\hline 124.60 & $2.48 \mathrm{E}+04$ & $5.89 \mathrm{E}+00$ & NM & NM & NM & NM & NM & NM & NM & NM \\
\hline 126.35 & $2.78 \mathrm{E}+04$ & $1.01 \mathrm{E}+01$ & ND & $(2.58 \mathrm{E}+01)$ & NM & $2.71 \mathrm{E}+02$ & $2.49 \mathrm{E}+02$ & ND & ND & $(1.53 E+00)$ \\
\hline 126.75 & $(2.12 \mathrm{E}+04)$ & $6.99 \mathrm{E}+00$ & ND & $(1.10 \mathrm{E}+01)$ & $(1.30 \mathrm{E}+02)$ & $3.47 \mathrm{E}+02$ & $3.49 \mathrm{E}+02$ & $(1.29 \mathrm{E}+00)$ & $(1.35 E+00)$ & $(4.04 \mathrm{E}-02)$ \\
\hline 127.85 & $(1.51 \mathrm{E}+04)$ & $9.08 \mathrm{E}+00$ & ND & $(1.38 \mathrm{E}+01)$ & $(1.95 \mathrm{E}+02)$ & $2.67 \mathrm{E}+02$ & $2.66 \mathrm{E}+02$ & $(7.72 \mathrm{E}-01)$ & $(1.01 \mathrm{E}+00)$ & (6.05E-02) \\
\hline
\end{tabular}


Table 4.24. (contd)

\begin{tabular}{|c|c|c|c|c|c|c|c|c|c|c|}
\hline $\begin{array}{c}\text { Depth } \\
\text { (ft bgs) }\end{array}$ & $\begin{array}{c}\text { Tc-99 } \\
\text { ICP-MS } \\
\text { (pCi/L) }\end{array}$ & $\begin{array}{c}\text { U-238 } \\
\text { ICP-MS } \\
(\mu \mathrm{g} / \mathrm{L})\end{array}$ & $\begin{array}{c}\mathrm{Cr} \\
\text { ICP-OES } \\
(\mu \mathrm{g} / \mathrm{L})\end{array}$ & $\begin{array}{c}\text { Cr } \\
\text { ICP-MS } \\
(\mu \mathrm{g} / \mathrm{L})\end{array}$ & $\begin{array}{c}\text { Mo } \\
\text { ICP-OES } \\
(\mu \mathrm{g} / \mathrm{L})\end{array}$ & $\begin{array}{c}\text { Mo 95 } \\
\text { ICP-MS } \\
(\mu \mathrm{g} / \mathrm{L})\end{array}$ & $\begin{array}{c}\text { Mo 98 } \\
\text { ICP-MS } \\
(\mu \mathrm{g} / \mathrm{L})\end{array}$ & $\begin{array}{c}\text { Ru } 101 \\
\text { ICP-MS } \\
(\mu \mathrm{g} / \mathrm{L})\end{array}$ & $\begin{array}{c}\text { Ru } 102 \\
\text { ICP-MS } \\
(\mu \mathrm{g} / \mathrm{L})\end{array}$ & $\begin{array}{c}\text { Ru } 104 \\
\text { ICP-MS } \\
(\mu \mathrm{g} / \mathrm{L})\end{array}$ \\
\hline 130.65 & $(1.38 \mathrm{E}+04)$ & $5.58 \mathrm{E}+00$ & ND & $(4.67 E+00)$ & $(1.23 \mathrm{E}+02)$ & $1.78 \mathrm{E}+02$ & $1.78 \mathrm{E}+02$ & $(5.92 \mathrm{E}-01)$ & $(6.50 \mathrm{E}-01)$ & ND \\
\hline 133.75 & $6.81 E+04$ & $5.94 \mathrm{E}+00$ & ND & $(7.17 \mathrm{E}+00)$ & $(9.41 \mathrm{E}+01)$ & $8.33 \mathrm{E}+01$ & $8.38 \mathrm{E}+01$ & 2.930 & 1.632 & $(3.49 \mathrm{E}-02)$ \\
\hline 135.25 & $8.53 E+04$ & $6.83 \mathrm{E}+00$ & NM & NM & $\mathrm{NM}$ & NM & NM & NM & NM & $\mathrm{NM}$ \\
\hline 136.75 & $1.81 E+05$ & $9.37 \mathrm{E}+00$ & ND & $(7.31 \mathrm{E}+00)$ & $(2.08 \mathrm{E}+02)$ & $1.33 \mathrm{E}+02$ & $1.32 \mathrm{E}+02$ & $5.88 \mathrm{E}+00$ & $3.16 \mathrm{E}+00$ & $(3.23 \mathrm{E}-02)$ \\
\hline 140.00 & $(1.76 \mathrm{E}+04)$ & $5.30 \mathrm{E}+00$ & ND & $(2.71 \mathrm{E}+01)$ & $(1.04 \mathrm{E}+02)$ & $2.02 \mathrm{E}+02$ & $2.01 \mathrm{E}+02$ & $(4.72 \mathrm{E}-01)$ & $(8.55 \mathrm{E}-01)$ & $(3.36 \mathrm{E}+00)$ \\
\hline 143.25 & $(3.59 \mathrm{E}+03)$ & $6.14 \mathrm{E}+00$ & $(2.61 \mathrm{E}+01)$ & $(4.40 \mathrm{E}+00)$ & $(4.53 \mathrm{E}+01)$ & $1.95 \mathrm{E}+02$ & $1.90 \mathrm{E}+02$ & $(1.45 \mathrm{E}-01)$ & $(8.20 \mathrm{E}-01)$ & (1.29E-01) \\
\hline 146.25 & $1.65 \mathrm{E}+05$ & $7.70 \mathrm{E}+00$ & NM & $\mathrm{NM}$ & NM & NM & $\mathrm{NM}$ & NM & NM & NM \\
\hline 148.30 & $(1.50 \mathrm{E}+04)$ & $9.40 \mathrm{E}+00$ & $(1.73 \mathrm{E}+01)$ & $(4.40 \mathrm{E}+00)$ & $(8.63 \mathrm{E}+01)$ & $2.04 \mathrm{E}+02$ & $2.04 \mathrm{E}+02$ & $(4.72 \mathrm{E}-01)$ & $(9.54 \mathrm{E}-01)$ & ND \\
\hline 148.30 & $(2.29 \mathrm{E}+04)$ & $9.63 \mathrm{E}+00$ & ND & $(4.36 \mathrm{E}-01)$ & $(1.83 \mathrm{E}+02)$ & $1.75 \mathrm{E}+02$ & $1.75 \mathrm{E}+02$ & (9.71E-01) & $(1.21 \mathrm{E}+00)$ & ND \\
\hline 151.50 & $5.60 \mathrm{E}+04$ & $7.76 \mathrm{E}+00$ & NM & NM & $\mathrm{NM}$ & NM & NM & NM & NM & $\mathrm{NM}$ \\
\hline 153.00 & $9.14 E+04$ & $1.23 \mathrm{E}+01$ & NM & $(6.24 \mathrm{E}+00)$ & NM & $3.24 \mathrm{E}+02$ & $3.06 \mathrm{E}+02$ & $(8.98 \mathrm{E}+00)$ & $(4.30 \mathrm{E}+00)$ & ND \\
\hline 154.65 & $7.36 \mathrm{E}+04$ & $1.57 \mathrm{E}+01$ & NM & $(7.51 \mathrm{E}+00)$ & $\mathrm{NM}$ & $3.15 \mathrm{E}+02$ & $2.99 \mathrm{E}+02$ & $(8.99 \mathrm{E}+00)$ & $(4.25 \mathrm{E}+00)$ & ND \\
\hline 156.65 & $2.48 \mathrm{E}+04$ & $1.41 \mathrm{E}+01$ & NM & $(1.03 \mathrm{E}+01)$ & NM & $2.69 \mathrm{E}+02$ & $2.56 \mathrm{E}+02$ & $(7.99 \mathrm{E}+00)$ & $(3.25 \mathrm{E}+00)$ & ND \\
\hline 156.65 & $2.59 \mathrm{E}+04$ & $1.37 \mathrm{E}+01$ & NM & $(3.67 E+00)$ & $\mathrm{NM}$ & $2.48 \mathrm{E}+02$ & $2.39 \mathrm{E}+02$ & $(7.14 \mathrm{E}+00)$ & $(3.86 \mathrm{E}+00)$ & ND \\
\hline 159.00 & $1.66 \mathrm{E}+04$ & $1.69 \mathrm{E}+01$ & NM & $(1.44 \mathrm{E}+01)$ & NM & $4.17 \mathrm{E}+02$ & $3.87 \mathrm{E}+02$ & $(1.04 \mathrm{E}+01)$ & $(5.75 \mathrm{E}+00)$ & ND \\
\hline 159.00 & $1.50 \mathrm{E}+04$ & $1.56 \mathrm{E}+01$ & NM & $(1.71 \mathrm{E}+01)$ & NM & $3.95 \mathrm{E}+02$ & $3.65 \mathrm{E}+02$ & $(9.23 \mathrm{E}+00)$ & $(4.72 \mathrm{E}+00)$ & ND \\
\hline 161.25 & $(1.10 \mathrm{E}+03)$ & $1.07 \mathrm{E}+01$ & NM & NM & NM & NM & $\mathrm{NM}$ & NM & NM & NM \\
\hline 165.75 & $(7.39 \mathrm{E}+02)$ & $7.02 \mathrm{E}+00$ & ND & $(1.01 \mathrm{E}+01)$ & $(1.82 \mathrm{E}+02)$ & $1.95 \mathrm{E}+02$ & $1.96 \mathrm{E}+02$ & $(1.44 \mathrm{E}+00)$ & $(1.34 \mathrm{E}+00)$ & $(9.86 \mathrm{E}-02)$ \\
\hline 170.25 & $(2.66 \mathrm{E}+02)$ & $5.40 \mathrm{E}+00$ & ND & $(6.26 \mathrm{E}+00)$ & $(1.56 \mathrm{E}+02)$ & $1.80 \mathrm{E}+02$ & $1.82 \mathrm{E}+02$ & $(9.38 \mathrm{E}-02)$ & $(5.24 \mathrm{E}-01)$ & $(2.42 \mathrm{E}-01)$ \\
\hline 172.30 & ND & $7.21 \mathrm{E}+00$ & NM & NM & NM & NM & $\mathrm{NM}$ & NM & NM & NM \\
\hline 174.05 & ND & $4.79 \mathrm{E}+00$ & ND & $(1.86 \mathrm{E}+00)$ & $(5.03 \mathrm{E}+01)$ & $1.75 \mathrm{E}+02$ & $1.71 \mathrm{E}+02$ & $(8.44 \mathrm{E}-02)$ & $(5.45 \mathrm{E}-01)$ & ND \\
\hline 176.90 & ND & $9.87 \mathrm{E}+00$ & NM & NM & NM & NM & NM & NM & NM & NM \\
\hline
\end{tabular}


Table 4.24. (contd)

\begin{tabular}{|c|c|c|c|c|c|c|c|c|c|c|}
\hline $\begin{array}{c}\text { Depth } \\
\text { (ft bgs) }\end{array}$ & $\begin{array}{c}\text { Tc-99 } \\
\text { ICP-MS } \\
\text { (pCi/L) }\end{array}$ & $\begin{array}{c}\text { U-238 } \\
\text { ICP-MS } \\
(\mu \mathrm{g} / \mathrm{L})\end{array}$ & $\begin{array}{c}\mathrm{Cr} \\
\text { ICP-OES } \\
(\mu \mathrm{g} / \mathrm{L})\end{array}$ & $\begin{array}{c}\text { Cr } \\
\text { ICP-MS } \\
(\mu g / L)\end{array}$ & $\begin{array}{c}\text { Mo } \\
\text { ICP-OES } \\
(\mu \mathrm{g} / \mathrm{L})\end{array}$ & $\begin{array}{c}\text { Mo } 95 \\
\text { ICP-MS } \\
(\mu \mathrm{g} / \mathrm{L})\end{array}$ & $\begin{array}{c}\text { Mo } 98 \\
\text { ICP-MS } \\
(\mu \mathrm{g} / \mathrm{L})\end{array}$ & $\begin{array}{c}\text { Ru } 101 \\
\text { ICP-MS } \\
(\mu \mathrm{g} / \mathrm{L})\end{array}$ & $\begin{array}{c}\text { Ru } 102 \\
\text { ICP-MS } \\
(\mu g / L)\end{array}$ & $\begin{array}{c}\text { Ru } 104 \\
\text { ICP-MS } \\
(\mu \mathrm{g} / \mathrm{L})\end{array}$ \\
\hline 176.90 & ND & $9.31 \mathrm{E}+00$ & NM & NM & NM & NM & NM & NM & NM & NM \\
\hline 182.25 & $(5.38 E+02)$ & $1.01 \mathrm{E}+01$ & NM & $(8.41 \mathrm{E}+00)$ & NM & $2.13 \mathrm{E}+02$ & $1.87 \mathrm{E}+02$ & ND & $(2.54 \mathrm{E}-01)$ & ND \\
\hline 186.25 & $(2.79 \mathrm{E}+02)$ & $8.58 \mathrm{E}+00$ & NM & $(2.14 \mathrm{E}+01)$ & NM & $2.70 \mathrm{E}+02$ & $2.49 \mathrm{E}+02$ & $(1.45 E+00)$ & ND & ND \\
\hline 191.25 & $(2.83 E+02)$ & $1.04 \mathrm{E}+01$ & $\mathrm{NM}$ & $(2.36 \mathrm{E}+01)$ & $\mathrm{NM}$ & $2.94 \mathrm{E}+02$ & $2.69 \mathrm{E}+02$ & ND & $(9.00 \mathrm{E}-01)$ & ND \\
\hline 195.25 & ND & $1.04 \mathrm{E}+01$ & $\mathrm{NM}$ & $(2.59 \mathrm{E}+01)$ & NM & $1.76 \mathrm{E}+02$ & $1.65 \mathrm{E}+02$ & ND & $(1.96 \mathrm{E}-01)$ & ND \\
\hline \multicolumn{11}{|c|}{$\begin{array}{l}\text { Parentheses signify values below level of quantitation. } \\
\text { Shaded values designate the core samples and unshaded values are grab sample data. } \\
\text { Bold values are higher than others for given constituent. } \\
\text { Dup Duplicate sample. } \\
\text { ND = Not detected. } \\
\text { NM = Not measured. }\end{array}$} \\
\hline
\end{tabular}




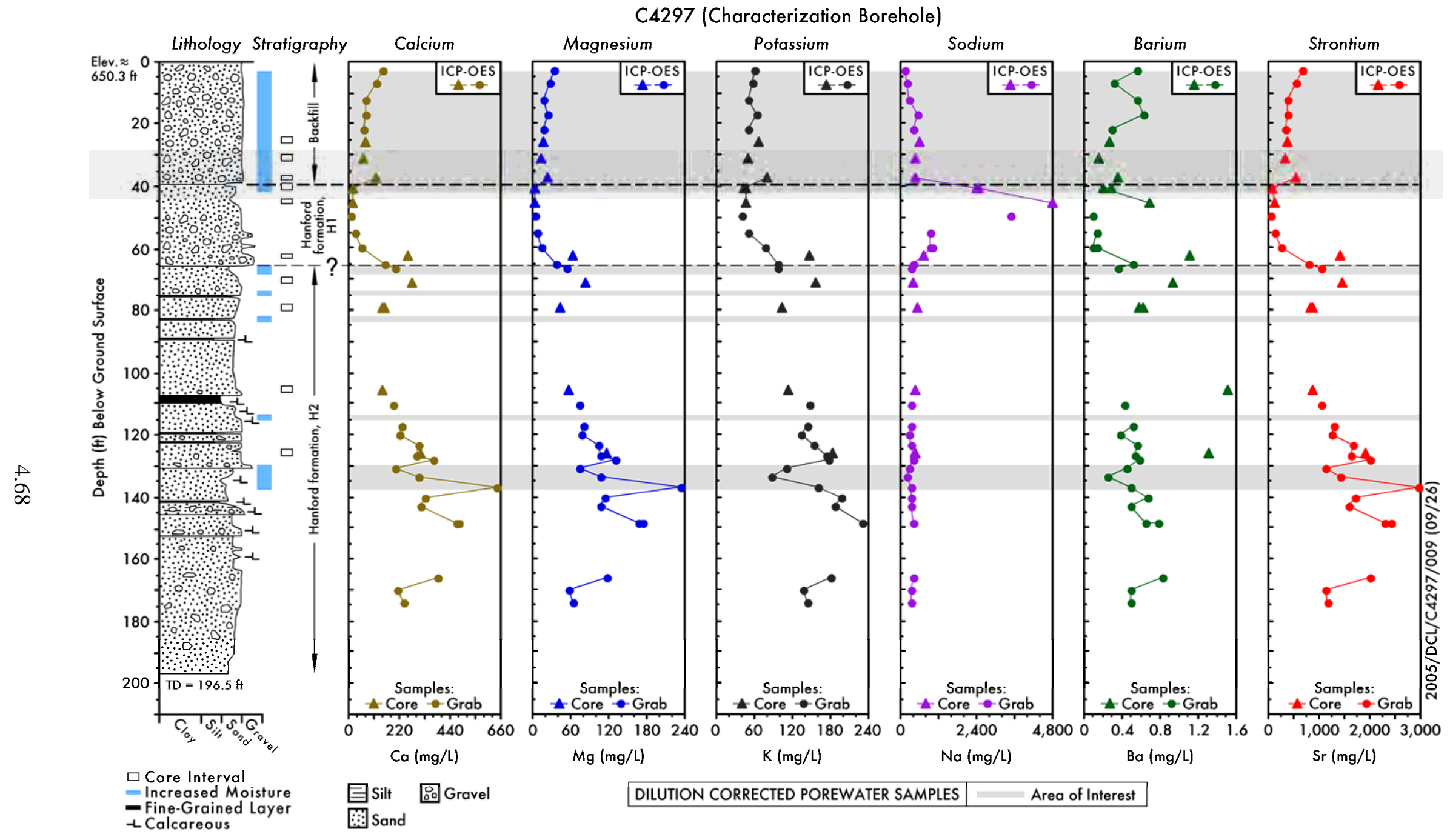

Figure 4.19. Derived Pore Water Composition of Major Cations in C4297 Vadose Zone Sediments 


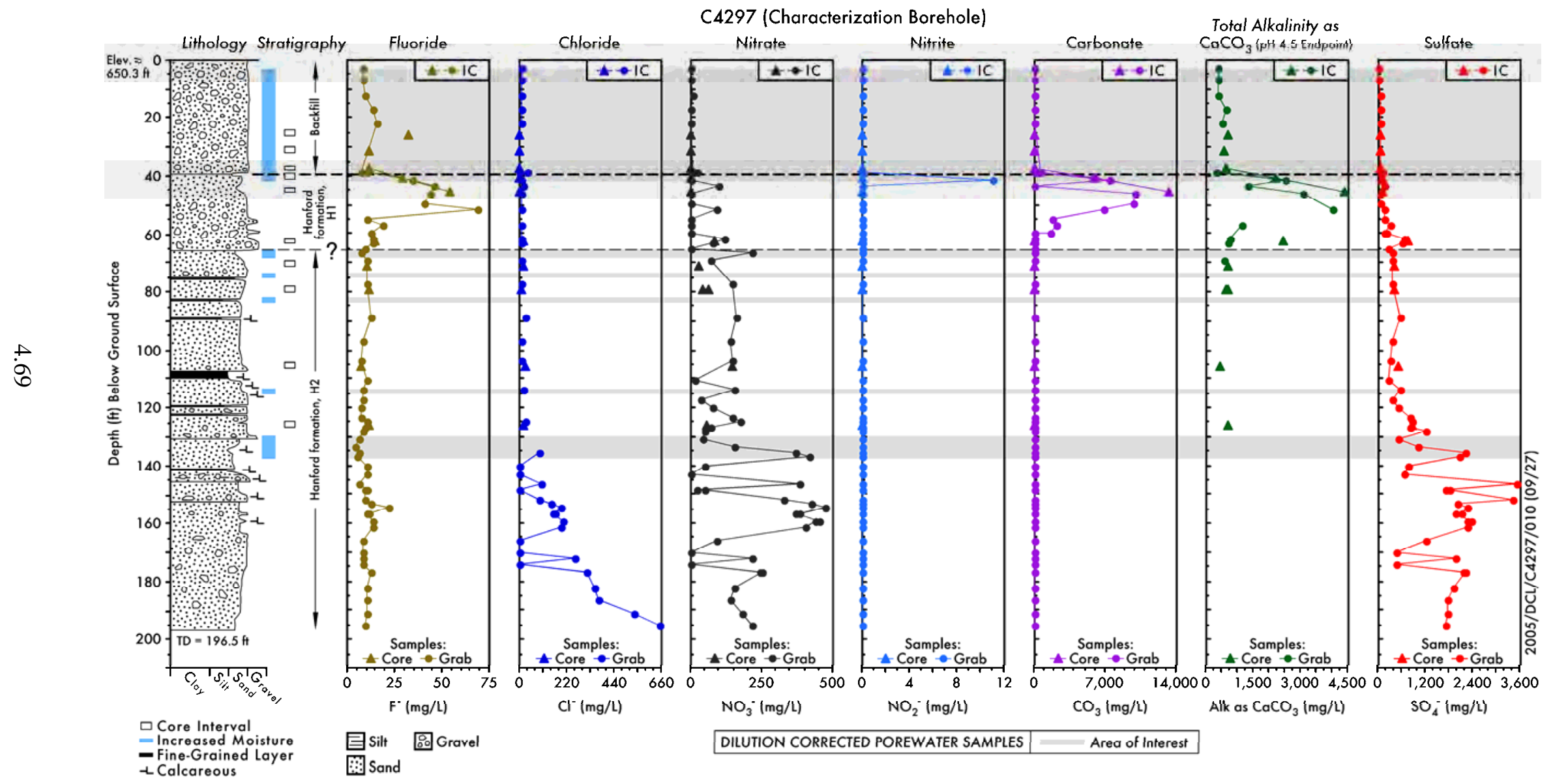

Figure 4.20. Derived Pore Water Anion Composition in C4297 Vadose Zone Sediments 
C4297 (Characterization Borehole)

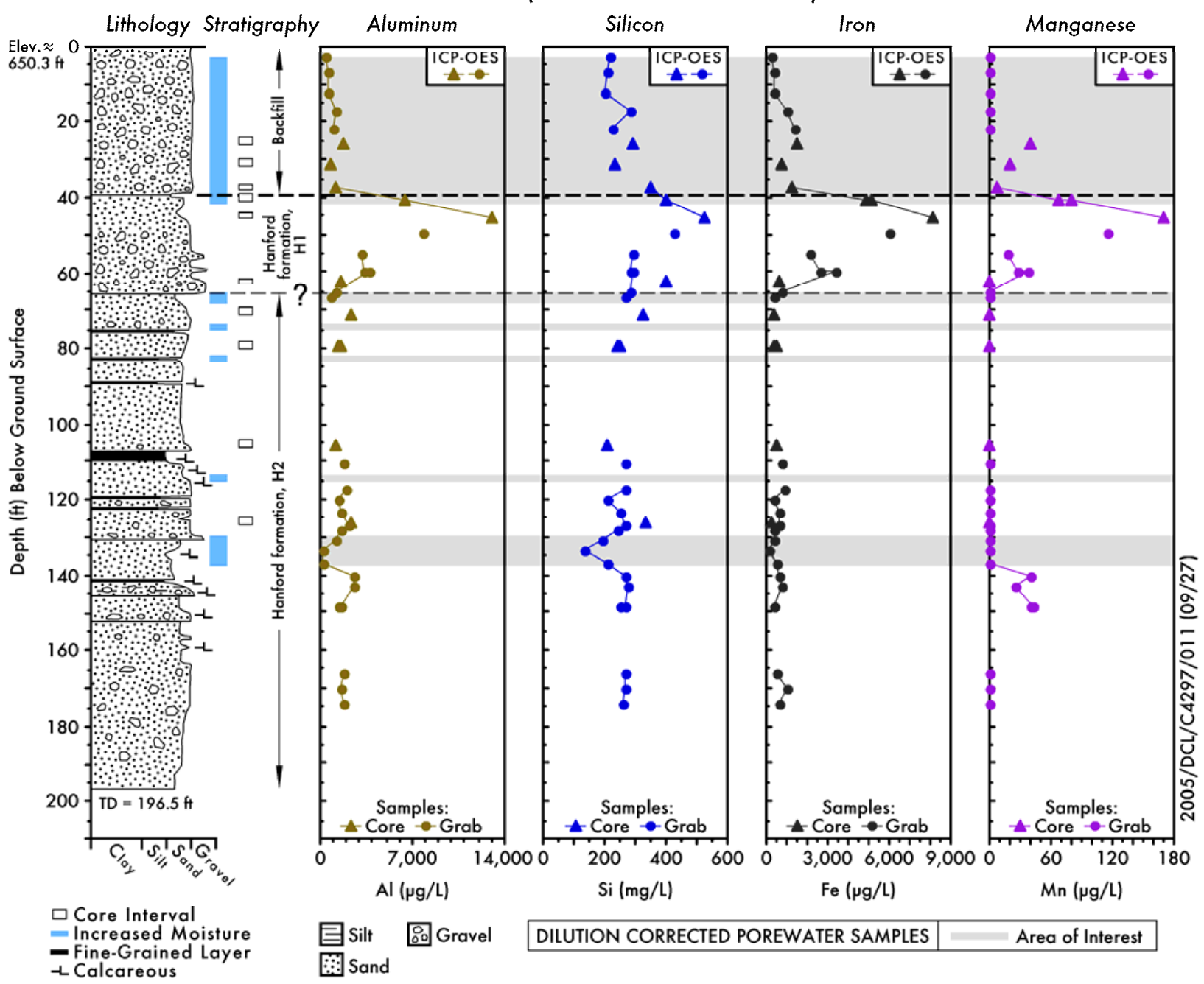

Figure 4.21. Derived Pore Water Composition for Selected Metals in C4297 Vadose Zone Sediments 


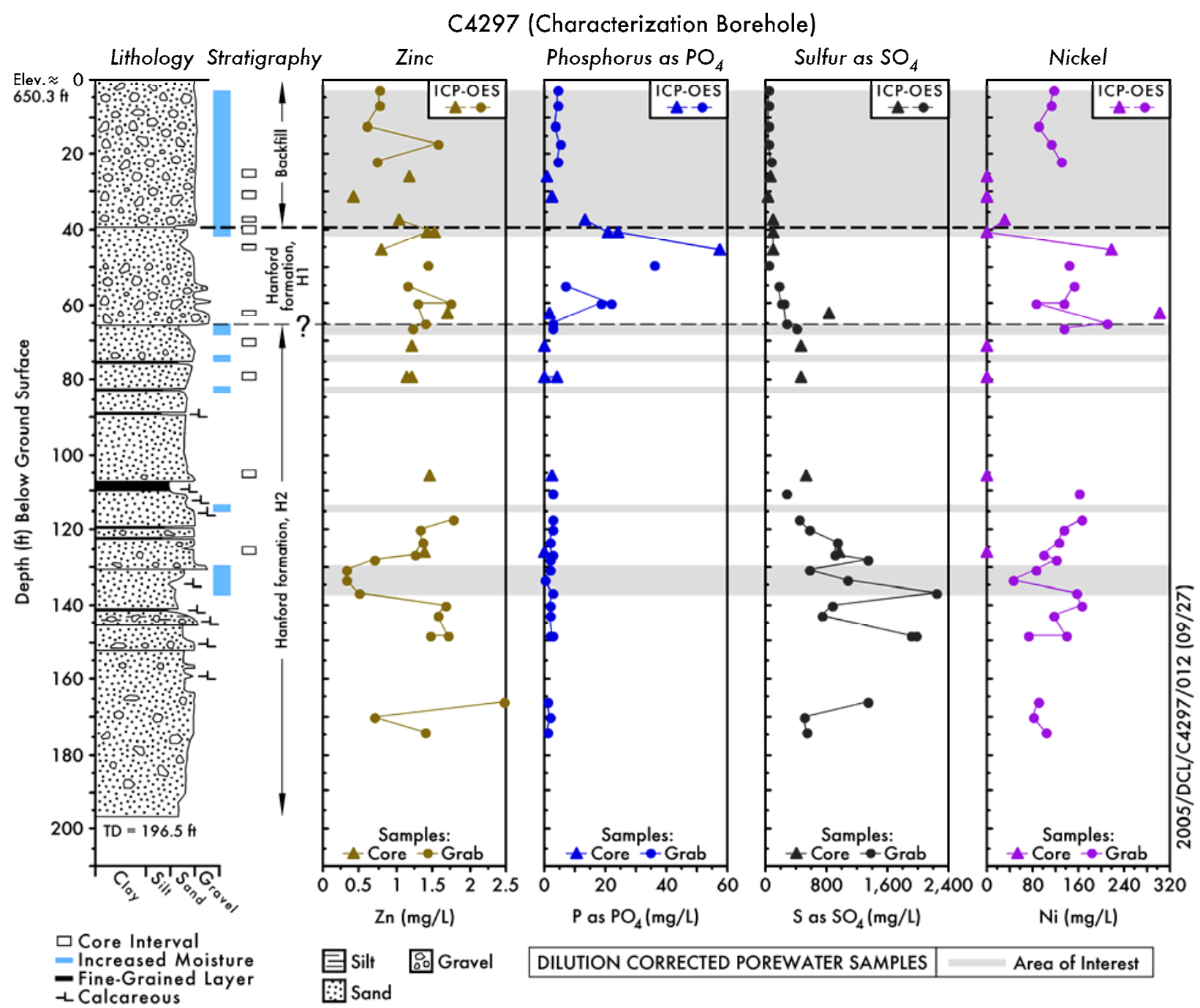

Figure 4.22. Derived Pore Water Composition for Selected Metals in C4297 Vadose Zone Sediments 


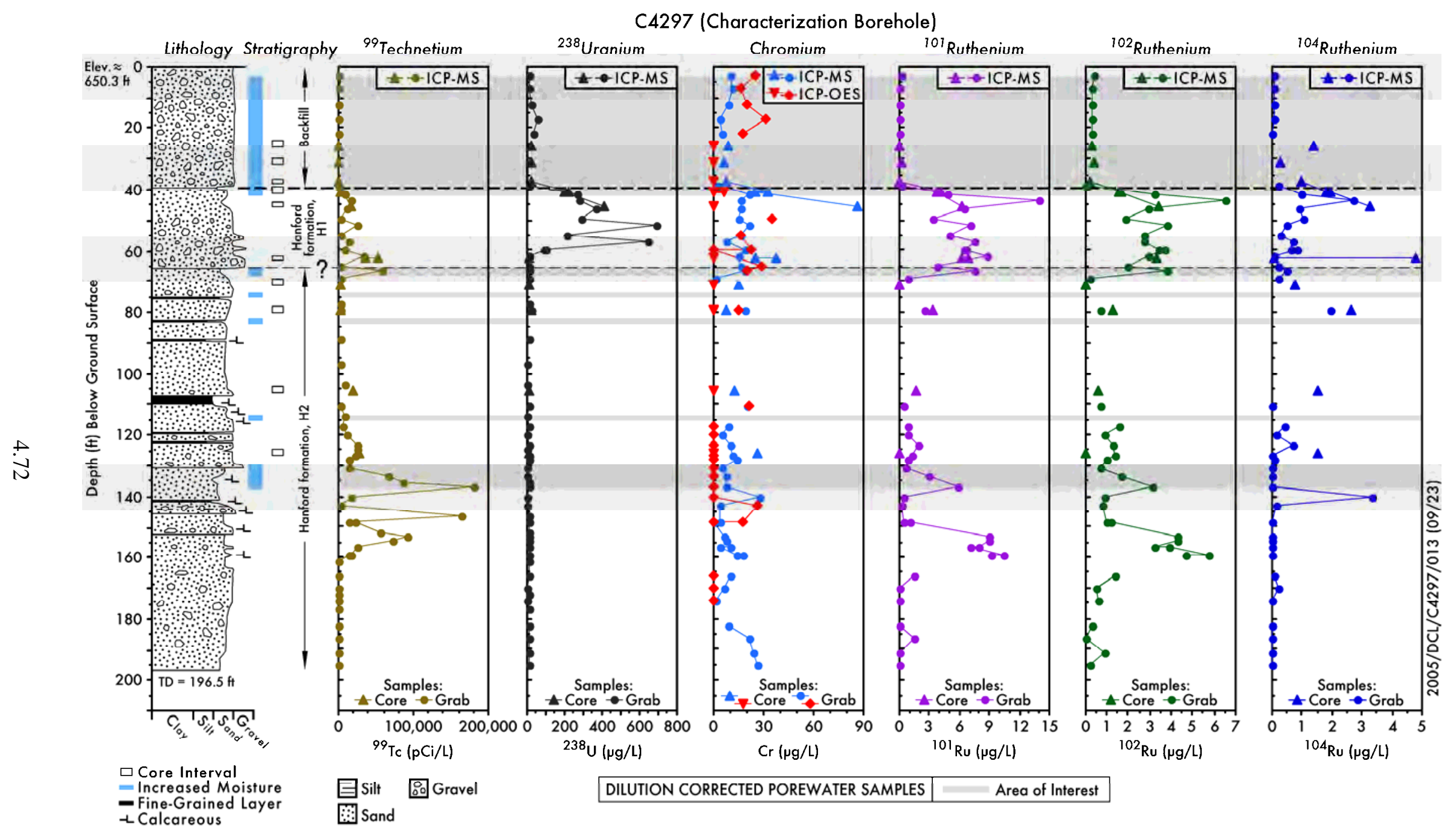

Figure 4.23. Derived Pore Water Composition of Mobile Metals in C4297 Vadose Zone Sediments 


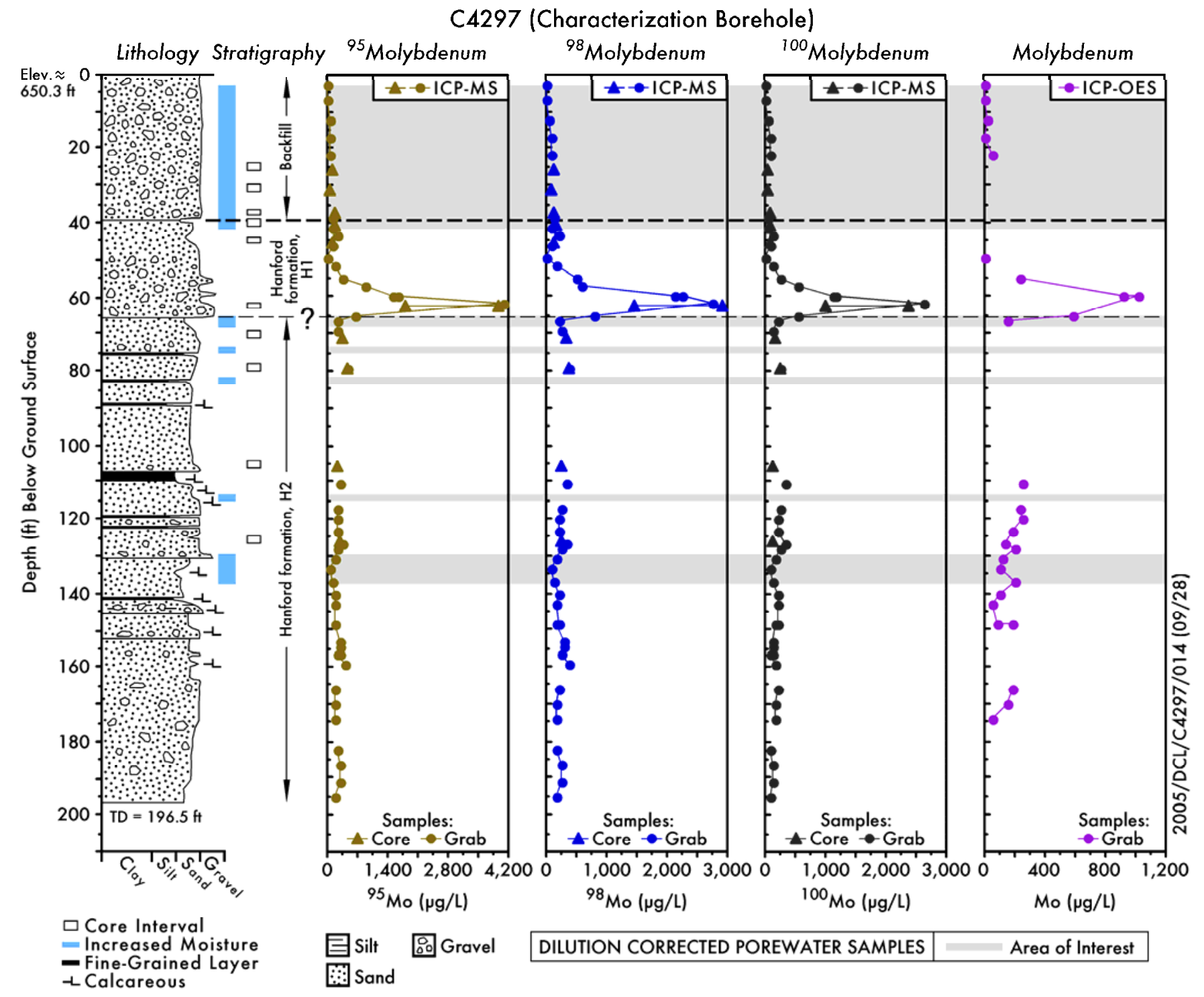

Figure 4.24. Derived Pore Water Composition of Mobile Metals in C4297 Vadose Zone Sediments 
Table 4.25. Acid-Extractable Cations from C4297 Vadose Zone Sediments ( $\mu \mathrm{g} / \mathrm{g}$ dry sediment)

\begin{tabular}{|c|c|c|c|c|c|c|c|c|}
\hline $\begin{array}{l}\text { Depth } \\
\text { (ft bgs) }\end{array}$ & $\begin{array}{l}\text { Stratigraphic Unit } \\
\text { (Hanford formation) }\end{array}$ & Magnesium & Calcium & Strontium & Barium & Sod & ium & Potassium \\
\hline 2.50 & Backfill & $4.23 \mathrm{E}+03$ & $7.94 \mathrm{E}+03$ & $3.05 E+01$ & 7.99E+01 & $-\quad-$ & - & $9.19 \mathrm{E}+02$ \\
\hline 7.00 & Backfill & $4.25 \mathrm{E}+03$ & $7.83 \mathrm{E}+03$ & $2.78 \mathrm{E}+01$ & $7.19 \mathrm{E}+01$ & $-\quad-$ & - & $8.68 \mathrm{E}+02$ \\
\hline 12.00 & Backfill & $4.05 E+03$ & $7.71 \mathrm{E}+03$ & $2.77 \mathrm{E}+01$ & $7.17 \mathrm{E}+01$ & $-\quad-$ & - & $9.22 \mathrm{E}+02$ \\
\hline 17.00 & Backfill & $4.14 \mathrm{E}+03$ & $6.95 \mathrm{E}+03$ & $2.99 \mathrm{E}+01$ & $6.85 \mathrm{E}+01$ & $-\quad-$ & - & $9.47 \mathrm{E}+02$ \\
\hline 22.00 & Backfill & $3.86 \mathrm{E}+03$ & $6.67 \mathrm{E}+03$ & $2.89 \mathrm{E}+01$ & $7.36 \mathrm{E}+01$ & $-\quad-$ & - & $9.21 \mathrm{E}+02$ \\
\hline 25.75 & Backfill & $4.10 \mathrm{E}+03$ & $6.63 \mathrm{E}+03$ & $2.65 \mathrm{E}+01$ & $5.41 \mathrm{E}+01$ & $-\quad-$ & - & $8.36 \mathrm{E}+02$ \\
\hline 31.00 & Backfill & $4.22 \mathrm{E}+03$ & $7.62 \mathrm{E}+03$ & $3.07 \mathrm{E}+01$ & $6.61 \mathrm{E}+01$ & $-\quad-$ & - & $9.01 \mathrm{E}+02$ \\
\hline 37.15 & Backfill & $3.75 \mathrm{E}+03$ & $6.99 \mathrm{E}+03$ & $2.72 \mathrm{E}+01$ & $5.60 \mathrm{E}+01$ & $-\quad-$ & - & $8.94 \mathrm{E}+02$ \\
\hline 40.80 & H1 & $3.88 \mathrm{E}+03$ & $7.08 \mathrm{E}+03$ & $2.86 \mathrm{E}+01$ & $5.28 \mathrm{E}+01$ & $-\quad-$ & - & $8.86 \mathrm{E}+02$ \\
\hline 40.80 & H1 & $4.35 \mathrm{E}+03$ & $7.79 \mathrm{E}+03$ & $3.17 \mathrm{E}+01$ & $5.61 \mathrm{E}+01$ & $-\quad-$ & - & $9.59 \mathrm{E}+02$ \\
\hline 45.45 & H1 & $3.86 \mathrm{E}+03$ & $6.79 \mathrm{E}+03$ & $2.79 \mathrm{E}+01$ & $5.20 \mathrm{E}+01$ & $-\quad-$ & - & $8.06 \mathrm{E}+02$ \\
\hline 49.25 & H1 & $4.76 \mathrm{E}+03$ & $8.67 \mathrm{E}+03$ & $3.87 \mathrm{E}+01$ & $7.24 \mathrm{E}+01$ & $-\quad-$ & - & $1.13 \mathrm{E}+03$ \\
\hline 55.20 & H1 & $4.57 \mathrm{E}+03$ & $7.91 \mathrm{E}+03$ & $3.22 \mathrm{E}+01$ & $5.67 \mathrm{E}+01$ & $-\quad-$ & - & $8.81 \mathrm{E}+02$ \\
\hline 60.00 & H1 & $4.26 \mathrm{E}+03$ & $7.84 \mathrm{E}+03$ & $3.40 \mathrm{E}+01$ & $6.70 \mathrm{E}+01$ & $-\quad-$ & - & $9.01 \mathrm{E}+02$ \\
\hline 60.00 & H1 & $4.44 \mathrm{E}+03$ & $7.92 \mathrm{E}+03$ & $3.17 \mathrm{E}+01$ & $6.23 \mathrm{E}+01$ & $-\quad-$ & - & $9.71 \mathrm{E}+02$ \\
\hline 62.50 & H1 & $3.17 \mathrm{E}+03$ & $5.64 \mathrm{E}+03$ & $2.32 \mathrm{E}+01$ & $5.76 \mathrm{E}+01$ & $-\quad-$ & - & $6.49 \mathrm{E}+02$ \\
\hline 64.85 & H1 & $3.98 \mathrm{E}+03$ & $7.37 \mathrm{E}+03$ & $3.51 \mathrm{E}+01$ & $6.56 \mathrm{E}+01$ & $-\quad-$ & - & $9.63 \mathrm{E}+02$ \\
\hline 66.20 & H1 & $4.29 \mathrm{E}+03$ & $7.41 \mathrm{E}+03$ & $3.57 \mathrm{E}+01$ & $6.73 \mathrm{E}+01$ & $-\quad-$ & - & $1.26 \mathrm{E}+03$ \\
\hline 71.25 & $\mathrm{H} 2$ & $4.76 \mathrm{E}+03$ & $8.31 \mathrm{E}+03$ & $3.27 \mathrm{E}+01$ & $5.68 \mathrm{E}+01$ & $-\quad-$ & - & $9.87 \mathrm{E}+02$ \\
\hline 79.55 & H2 & $4.63 \mathrm{E}+03$ & $8.06 \mathrm{E}+03$ & $3.29 \mathrm{E}+01$ & $6.53 \mathrm{E}+01$ & $-\quad-$ & - & $1.05 \mathrm{E}+03$ \\
\hline 79.55 & H2 & $3.65 \mathrm{E}+03$ & $7.74 \mathrm{E}+03$ & $3.08 \mathrm{E}+01$ & $6.48 \mathrm{E}+01$ & $-\quad-$ & - & $9.26 \mathrm{E}+02$ \\
\hline 106.05 & H2 & $4.17 \mathrm{E}+03$ & $7.91 E+03$ & $2.55 \mathrm{E}+01$ & $4.98 \mathrm{E}+01$ & $-\quad-$ & - & $9.01 \mathrm{E}+02$ \\
\hline 110.15 & $\mathrm{H} 2$ & $4.81 \mathrm{E}+03$ & $9.17 \mathrm{E}+03$ & $4.09 \mathrm{E}+01$ & $6.62 \mathrm{E}+01$ & $-\quad-$ & - & $1.24 \mathrm{E}+03$ \\
\hline 117.40 & H2 & $3.97 \mathrm{E}+03$ & $7.84 \mathrm{E}+03$ & $2.86 \mathrm{E}+01$ & $5.52 \mathrm{E}+01$ & $-\quad-$ & - & $8.83 \mathrm{E}+02$ \\
\hline 120.25 & H2 & $4.05 E+03$ & $7.82 \mathrm{E}+03$ & $3.24 \mathrm{E}+01$ & $5.84 \mathrm{E}+01$ & $-\quad-$ & - & $9.99 \mathrm{E}+02$ \\
\hline 123.65 & H2 & $4.25 \mathrm{E}+03$ & $7.71 \mathrm{E}+03$ & $3.70 \mathrm{E}+01$ & $6.04 \mathrm{E}+01$ & $-\quad-$ & - & $1.00 \mathrm{E}+03$ \\
\hline 126.35 & $\mathrm{H} 2$ & $3.44 \mathrm{E}+03$ & $6.22 \mathrm{E}+03$ & $2.39 \mathrm{E}+01$ & $4.56 \mathrm{E}+01$ & $-\quad-$ & - & $7.09 \mathrm{E}+02$ \\
\hline 126.75 & $\mathrm{H} 2$ & $4.64 \mathrm{E}+03$ & 8.39E+03 & $3.25 \mathrm{E}+01$ & $6.56 \mathrm{E}+01$ & $-\quad-$ & - & $1.13 \mathrm{E}+03$ \\
\hline 127.85 & H2 & $4.57 \mathrm{E}+03$ & $8.70 \mathrm{E}+03$ & $3.72 \mathrm{E}+01$ & $7.17 \mathrm{E}+01$ & $-\quad-$ & - & $1.20 \mathrm{E}+03$ \\
\hline 130.65 & H2 & $4.04 \mathrm{E}+03$ & $8.50 \mathrm{E}+03$ & $3.37 \mathrm{E}+01$ & $6.16 \mathrm{E}+01$ & $-\quad-$ & - & $9.38 \mathrm{E}+02$ \\
\hline 133.75 & $\mathrm{H} 2$ & $5.54 \mathrm{E}+03$ & $9.90 \mathrm{E}+03$ & $3.89 \mathrm{E}+01$ & $7.68 \mathrm{E}+01$ & $-\quad-$ & - & $1.69 \mathrm{E}+03$ \\
\hline 136.75 & H2 & $5.75 \mathrm{E}+03$ & $1.00 \mathrm{E}+04$ & $3.95 \mathrm{E}+01$ & $7.66 \mathrm{E}+01$ & $-\quad-$ & - & $1.21 \mathrm{E}+03$ \\
\hline 140.00 & H2 & $3.86 \mathrm{E}+03$ & $6.57 \mathrm{E}+03$ & $3.12 \mathrm{E}+01$ & $6.03 \mathrm{E}+01$ & $-\quad-$ & - & $1.03 \mathrm{E}+03$ \\
\hline 143.25 & H2 & $2.94 \mathrm{E}+03$ & $6.23 \mathrm{E}+03$ & $2.17 \mathrm{E}+01$ & $5.01 \mathrm{E}+01$ & $-\quad-$ & - & $7.31 \mathrm{E}+02$ \\
\hline
\end{tabular}


Table 4.25. (contd)

\begin{tabular}{|c|c|c|c|c|c|c|c|}
\hline $\begin{array}{c}\text { Depth } \\
\text { (ft bgs) }\end{array}$ & $\begin{array}{l}\text { Stratigraphic Unit } \\
\text { (Hanford formation) }\end{array}$ & Magnesium & Calcium & Strontium & Barium & Sodium & Potassium \\
\hline 148.30 & $\mathrm{H} 2$ & $4.12 \mathrm{E}+03$ & $8.10 \mathrm{E}+03$ & $2.82 \mathrm{E}+01$ & $5.91 \mathrm{E}+01$ & $1-\quad-$ & $9.39 \mathrm{E}+02$ \\
\hline 148.30 & H2 & $3.10 \mathrm{E}+03$ & $6.16 \mathrm{E}+03$ & $2.56 \mathrm{E}+01$ & $4.90 \mathrm{E}+01$ & $-\quad-\quad$ & $7.33 \mathrm{E}+02$ \\
\hline 165.75 & H2 & $3.12 \mathrm{E}+03$ & $5.27 \mathrm{E}+03$ & $2.24 \mathrm{E}+01$ & $5.98 \mathrm{E}+01$ & $-\quad-$ & $7.68 \mathrm{E}+02$ \\
\hline 170.25 & $\mathrm{H} 2$ & $3.03 E+03$ & $5.45 \mathrm{E}+03$ & $2.45 \mathrm{E}+01$ & $8.49 \mathrm{E}+01$ & $-\quad-$ & $7.84 \mathrm{E}+02$ \\
\hline \begin{tabular}{|l|}
174.05 \\
\end{tabular} & H2 & $4.07 \mathrm{E}+03$ & $5.82 \mathrm{E}+03$ & $2.46 \mathrm{E}+01$ & $5.88 \mathrm{E}+01$ & $-\quad-$ & $8.79 \mathrm{E}+02$ \\
\hline
\end{tabular}

Table 4.26. Acid-Extractable Constituents in C4297 Vadose Zone Sediments ( $\mu$ g/g dry sediment)

\begin{tabular}{|c|c|c|c|c|c|c|}
\hline Depth (ft bgs) & $\begin{array}{c}\text { Stratigraphic Unit } \\
\text { (Hanford formation) }\end{array}$ & Aluminum & Iron & Manganese & Phosphorus as $\mathrm{PO}_{4}$ & Sulfur as $\mathrm{SO}_{4}$ \\
\hline 2.50 & Backfill & $5.03 \mathrm{E}+03$ & $1.52 \mathrm{E}+04$ & $3.42 \mathrm{E}+02$ & $2.83 \mathrm{E}+03$ & $2.31 \mathrm{E}+02$ \\
\hline 7.00 & Backfill & $4.62 \mathrm{E}+03$ & $1.53 \mathrm{E}+04$ & $2.84 \mathrm{E}+02$ & $3.05 \mathrm{E}+03$ & $2.34 \mathrm{E}+02$ \\
\hline 12.00 & Backfill & $4.72 \mathrm{E}+03$ & $1.50 \mathrm{E}+04$ & $2.76 \mathrm{E}+02$ & $2.87 \mathrm{E}+03$ & $2.21 \mathrm{E}+02$ \\
\hline 17.00 & Backfill & $4.77 \mathrm{E}+03$ & $1.35 \mathrm{E}+04$ & $2.48 \mathrm{E}+02$ & $2.57 \mathrm{E}+03$ & $1.90 \mathrm{E}+02$ \\
\hline 22.00 & Backfill & $4.80 \mathrm{E}+03$ & $1.34 \mathrm{E}+04$ & $2.34 \mathrm{E}+02$ & $2.37 \mathrm{E}+03$ & $1.93 \mathrm{E}+02$ \\
\hline 25.75 & Backfill & $5.39 \mathrm{E}+03$ & $1.43 \mathrm{E}+04$ & $2.45 \mathrm{E}+02$ & $2.14 \mathrm{E}+03$ & $(1.03 E+02)$ \\
\hline 31.00 & Backfill & $6.21 \mathrm{E}+03$ & $1.81 \mathrm{E}+04$ & $3.02 \mathrm{E}+02$ & $2.85 \mathrm{E}+03$ & $(1.35 E+02)$ \\
\hline 37.15 & Backfill & $4.50 \mathrm{E}+03$ & $1.23 \mathrm{E}+04$ & $2.28 \mathrm{E}+02$ & $2.44 \mathrm{E}+03$ & $(9.64 \mathrm{E}+01)$ \\
\hline 40.80 & $\mathrm{H} 1$ & $5.22 \mathrm{E}+03$ & $1.28 \mathrm{E}+04$ & $2.26 \mathrm{E}+02$ & $2.14 \mathrm{E}+03$ & $(9.40 \mathrm{E}+01)$ \\
\hline 40.80 & H1 & $6.02 \mathrm{E}+03$ & $1.40 \mathrm{E}+04$ & $2.37 \mathrm{E}+02$ & $1.94 \mathrm{E}+03$ & $(1.35 E+02)$ \\
\hline 45.45 & $\mathrm{H} 1$ & $7.18 \mathrm{E}+03$ & $1.80 \mathrm{E}+04$ & $2.65 E+02$ & $2.17 \mathrm{E}+03$ & $2.48 \mathrm{E}+02$ \\
\hline 49.25 & $\mathrm{H} 1$ & $6.29 \mathrm{E}+03$ & $1.58 \mathrm{E}+04$ & $2.56 \mathrm{E}+02$ & $2.05 E+03$ & $2.02 \mathrm{E}+02$ \\
\hline 55.20 & $\mathrm{H} 1$ & $6.14 \mathrm{E}+03$ & $1.86 \mathrm{E}+04$ & $2.63 E+02$ & $2.37 \mathrm{E}+03$ & $2.10 \mathrm{E}+02$ \\
\hline 60.00 & $\mathrm{H} 1$ & $6.51 \mathrm{E}+03$ & $1.80 \mathrm{E}+04$ & $2.75 E+02$ & $2.21 \mathrm{E}+03$ & $2.45 \mathrm{E}+02$ \\
\hline 60.00 & $\mathrm{H} 1$ & $4.79 \mathrm{E}+03$ & $1.22 \mathrm{E}+04$ & $2.16 \mathrm{E}+02$ & $2.02 E+03$ & $(1.30 \mathrm{E}+02)$ \\
\hline 62.50 & H1 & $3.83 E+03$ & $1.28 \mathrm{E}+04$ & $1.82 \mathrm{E}+02$ & $2.61 \mathrm{E}+03$ & $(1.11 E+02)$ \\
\hline 64.85 & $\mathrm{H} 1$ & $5.51 \mathrm{E}+03$ & $1.31 \mathrm{E}+04$ & $2.49 \mathrm{E}+02$ & $1.94 \mathrm{E}+03$ & $1.80 \mathrm{E}+02$ \\
\hline 66.20 & $\mathrm{H} 1$ & $6.21 \mathrm{E}+03$ & $1.30 \mathrm{E}+04$ & $2.64 \mathrm{E}+02$ & $1.25 \mathrm{E}+03$ & $1.62 \mathrm{E}+02$ \\
\hline 71.25 & $\mathrm{H} 2$ & $5.97 \mathrm{E}+03$ & $1.30 \mathrm{E}+04$ & $2.52 E+02$ & $1.73 E+03$ & $(7.13 E+01)$ \\
\hline 79.55 & $\mathrm{H} 2$ & $6.25 E+03$ & $1.30 \mathrm{E}+04$ & $2.71 \mathrm{E}+02$ & $1.71 \mathrm{E}+03$ & $(1.02 E+02)$ \\
\hline 79.55 & $\mathrm{H} 2$ & $4.28 \mathrm{E}+03$ & $9.30 \mathrm{E}+03$ & $2.31 \mathrm{E}+02$ & $1.62 \mathrm{E}+03$ & $(1.15 E+02)$ \\
\hline 106.05 & $\mathrm{H} 2$ & $4.68 \mathrm{E}+03$ & $1.03 E+04$ & $2.11 \mathrm{E}+02$ & $1.49 \mathrm{E}+03$ & $(1.10 \mathrm{E}+02)$ \\
\hline 110.15 & $\mathrm{H} 2$ & $7.13 \mathrm{E}+03$ & $1.54 \mathrm{E}+04$ & $2.70 \mathrm{E}+02$ & $1.68 \mathrm{E}+03$ & $2.36 \mathrm{E}+02$ \\
\hline 117.40 & $\mathrm{H} 2$ & $5.00 \mathrm{E}+03$ & $1.25 \mathrm{E}+04$ & $2.18 \mathrm{E}+02$ & $1.73 \mathrm{E}+03$ & $2.38 \mathrm{E}+02$ \\
\hline
\end{tabular}


Table 4.26. (contd)

\begin{tabular}{||l|l|l|l|l|l|l||}
\hline Depth (ft bgs) & $\begin{array}{l}\text { Stratigraphic Unit } \\
\text { (Hanford formation) }\end{array}$ & Aluminum & Iron & Manganese & ${\text { Phosphorus as } \text { PO }_{4}}$ & Sulfur as SO $_{4}$ \\
\hline \hline 120.25 & H2 & $5.75 \mathrm{E}+03$ & $1.33 \mathrm{E}+04$ & $2.15 \mathrm{E}+02$ & $1.81 \mathrm{E}+03$ & $2.16 \mathrm{E}+02$ \\
\hline 123.65 & H2 & $5.70 \mathrm{E}+03$ & $1.44 \mathrm{E}+04$ & $2.70 \mathrm{E}+02$ & $1.93 \mathrm{E}+03$ & $1.97 \mathrm{E}+02$ \\
\hline 126.35 & H2 & $3.78 \mathrm{E}+03$ & $9.75 \mathrm{E}+03$ & $1.82 \mathrm{E}+02$ & $1.70 \mathrm{E}+03$ & $(9.29 \mathrm{E}+01)$ \\
\hline 126.75 & H2 & $6.58 \mathrm{E}+03$ & $1.57 \mathrm{E}+04$ & $2.70 \mathrm{E}+02$ & $1.89 \mathrm{E}+03$ & $2.37 \mathrm{E}+02$ \\
\hline 127.85 & H2 & $7.23 \mathrm{E}+03$ & $1.65 \mathrm{E}+04$ & $2.61 \mathrm{E}+02$ & $1.73 \mathrm{E}+03$ & $2.75 \mathrm{E}+02$ \\
\hline 130.65 & H2 & $6.51 \mathrm{E}+03$ & $1.39 \mathrm{E}+04$ & $2.39 \mathrm{E}+02$ & $1.43 \mathrm{E}+03$ & $2.48 \mathrm{E}+02$ \\
\hline 133.75 & H2 & $7.97 \mathrm{E}+03$ & $1.53 \mathrm{E}+04$ & $3.20 \mathrm{E}+02$ & $1.49 \mathrm{E}+03$ & $2.69 \mathrm{E}+02$ \\
\hline 136.75 & H2 & $7.73 \mathrm{E}+03$ & $1.99 \mathrm{E}+04$ & $3.08 \mathrm{E}+02$ & $2.53 \mathrm{E}+03$ & $3.27 \mathrm{E}+02$ \\
\hline 140.00 & H2 & $5.74 \mathrm{E}+03$ & $1.11 \mathrm{E}+04$ & $2.20 \mathrm{E}+02$ & $1.11 \mathrm{E}+03$ & $2.11 \mathrm{E}+02$ \\
\hline 143.25 & H2 & $3.39 \mathrm{E}+03$ & $8.89 \mathrm{E}+03$ & $1.80 \mathrm{E}+02$ & $2.03 \mathrm{E}+03$ & $2.13 \mathrm{E}+02$ \\
\hline 148.30 & H2 & $4.79 \mathrm{E}+03$ & $1.23 \mathrm{E}+04$ & $2.26 \mathrm{E}+02$ & $2.22 \mathrm{E}+03$ & $3.12 \mathrm{E}+02$ \\
\hline 148.30 & H2 & $3.49 \mathrm{E}+03$ & $8.67 \mathrm{E}+03$ & $1.72 \mathrm{E}+02$ & $1.71 \mathrm{E}+03$ & $2.31 \mathrm{E}+02$ \\
\hline 165.75 & H2 & $3.76 \mathrm{E}+03$ & $1.02 \mathrm{E}+04$ & $1.92 \mathrm{E}+02$ & $2.21 \mathrm{E}+03$ & $2.29 \mathrm{E}+02$ \\
\hline 170.25 & H2 & $3.72 \mathrm{E}+03$ & $9.68 \mathrm{E}+03$ & $1.64 \mathrm{E}+02$ & $2.45 \mathrm{E}+03$ & $2.21 \mathrm{E}+02$ \\
\hline 174.05 & H2 & $5.23 \mathrm{E}+03$ & $1.40 \mathrm{E}+04$ & $2.25 \mathrm{E}+02$ & $2.15 \mathrm{E}+03$ & $2.04 \mathrm{E}+02$ \\
\hline $\begin{array}{l}\text { Parentheses signify values below level of quantitation. } \\
\text { Shaded values designate the core samples and unshaded represent grab samples. }\end{array}$ & & \\
\hline
\end{tabular}

Table 4.27. Acid-Extractable Trace Metals in C4297 Vadose Zone Sediments ( $\mu \mathrm{g} / \mathrm{g}$ dry sediment)

\begin{tabular}{|c|c|c|c|c|c|c|c|c|}
\hline $\begin{array}{c}\text { Depth } \\
\text { (ft bgs) }\end{array}$ & $\begin{array}{c}\text { Stratigraphic } \\
\text { Unit } \\
\text { (Hanford } \\
\text { formation) }\end{array}$ & $\begin{array}{c}\text { Nickel } \\
\text { ICP-OES } \\
(\mu \mathrm{g} / \mathrm{g})\end{array}$ & $\begin{array}{c}\text { Zinc } \\
\text { ICP-OES } \\
(\mu \mathrm{g} / \mathrm{g})\end{array}$ & $\begin{array}{c}\text { Copper } \\
\text { ICP-OES } \\
(\mu \mathrm{g} / \mathrm{g})\end{array}$ & $\begin{array}{c}\text { Vanadium } \\
\text { ICP-OES } \\
(\mu \mathrm{g} / \mathrm{g})\end{array}$ & $\begin{array}{c}\text { Silver-109 } \\
\text { ICP-MS } \\
(\mu \mathrm{g} / \mathrm{g})\end{array}$ & $\begin{array}{c}\text { Cadmium-114 } \\
\text { ICP-MS } \\
(\mu \mathrm{g} / \mathrm{g})\end{array}$ & $\begin{array}{c}\text { Lead-208 } \\
\text { ICP-MS } \\
(\mu \mathrm{g} / \mathrm{g})\end{array}$ \\
\hline 2.50 & Backfill & $(8.09 \mathrm{E}+00)$ & $3.06 \mathrm{E}+01$ & $(1.31 \mathrm{E}+01)$ & $5.62 \mathrm{E}+00$ & 3.38E-02 & 6.39E-02 & $3.84 \mathrm{E}+00$ \\
\hline 7.00 & Backfill & $9.07 \mathrm{E}+00$ & $3.23 E+01$ & $(1.31 \mathrm{E}+01)$ & $5.83 \mathrm{E}+00$ & 3.04E-02 & $6.41 \mathrm{E}-02$ & $3.68 \mathrm{E}+00$ \\
\hline 12.00 & Backfill & $7.09 \mathrm{E}+00$ & $2.95 \mathrm{E}+01$ & $(1.23 E+01)$ & $5.39 \mathrm{E}+00$ & $3.27 \mathrm{E}-02$ & 5.93E-02 & $3.45 \mathrm{E}+00$ \\
\hline 17.00 & Backfill & $1.34 \mathrm{E}+01$ & $2.77 \mathrm{E}+01$ & $(1.11 \mathrm{E}+01)$ & $5.06 \mathrm{E}+00$ & $2.54 \mathrm{E}-02$ & $4.42 \mathrm{E}-02$ & $2.66 \mathrm{E}+00$ \\
\hline 22.00 & Backfill & $8.81 \mathrm{E}+00$ & $2.79 \mathrm{E}+01$ & $(1.11 \mathrm{E}+01)$ & $4.89 \mathrm{E}+00$ & $3.17 \mathrm{E}-02$ & 4.44E-02 & $2.94 \mathrm{E}+00$ \\
\hline 25.75 & Backfill & $7.86 \mathrm{E}+00$ & $(2.92 \mathrm{E}+01)$ & $(9.96 \mathrm{E}+00)$ & $3.05 E+01$ & 2.14E-02 & 5.03E-02 & $2.63 \mathrm{E}+00$ \\
\hline 31.00 & Backfill & $7.00 \mathrm{E}+00$ & $(3.58 \mathrm{E}+01)$ & $(1.17 \mathrm{E}+01)$ & $4.16 \mathrm{E}+01$ & $2.26 \mathrm{E}-02$ & $6.53 \mathrm{E}-02$ & $2.46 \mathrm{E}+00$ \\
\hline 37.15 & Backfill & $(6.00 \mathrm{E}+00)$ & $(2.69 \mathrm{E}+01)$ & $(9.28 \mathrm{E}+00)$ & $1.91 \mathrm{E}+01$ & 2.13E-02 & $5.68 \mathrm{E}-02$ & $2.82 \mathrm{E}+00$ \\
\hline 40.80 & H1 & $7.38 \mathrm{E}+00$ & $(2.64 \mathrm{E}+01)$ & $(9.26 \mathrm{E}+00)$ & $2.48 \mathrm{E}+01$ & 2.26E-02 & $5.24 \mathrm{E}-02$ & $2.24 \mathrm{E}+00$ \\
\hline 40.80 & H1 & $8.34 \mathrm{E}+00$ & $(2.95 \mathrm{E}+01)$ & $(9.80 \mathrm{E}+00)$ & $3.03 \mathrm{E}+01$ & 2.23E-02 & 4.89E-02 & $2.49 \mathrm{E}+00$ \\
\hline 45.45 & H1 & $9.19 E+00$ & $3.95 E+01$ & $(1.06 E+01)$ & $2.77 \mathrm{E}+01$ & $2.11 \mathrm{E}-02$ & $4.24 \mathrm{E}-02$ & $2.33 E+00$ \\
\hline
\end{tabular}


Table 4.27. (contd)

\begin{tabular}{|c|c|c|c|c|c|c|c|c|}
\hline $\begin{array}{c}\text { Depth } \\
\text { (ft bgs) }\end{array}$ & $\begin{array}{c}\text { Stratigraphic } \\
\text { Unit } \\
\text { (Hanford } \\
\text { formation) }\end{array}$ & $\begin{array}{c}\text { Nickel } \\
\text { ICP-OES } \\
(\mu \mathrm{g} / \mathrm{g})\end{array}$ & $\begin{array}{c}\text { Zinc } \\
\text { ICP-OES } \\
(\mu \mathrm{g} / \mathrm{g})\end{array}$ & $\begin{array}{c}\text { Copper } \\
\text { ICP-OES } \\
(\mu \mathrm{g} / \mathrm{g})\end{array}$ & $\begin{array}{c}\text { Vanadium } \\
\text { ICP-OES } \\
(\mu \mathrm{g} / \mathrm{g})\end{array}$ & $\begin{array}{c}\text { Silver-109 } \\
\text { ICP-MS } \\
(\mu \mathrm{g} / \mathrm{g})\end{array}$ & $\begin{array}{c}\text { Cadmium-114 } \\
\text { ICP-MS } \\
(\mu \mathrm{g} / \mathrm{g})\end{array}$ & $\begin{array}{c}\text { Lead-208 } \\
\text { ICP-MS } \\
(\mu \mathrm{g} / \mathrm{g})\end{array}$ \\
\hline 49.25 & $\mathrm{H} 1$ & $9.39 \mathrm{E}+00$ & $3.35 \mathrm{E}+01$ & $(1.04 \mathrm{E}+01)$ & $2.08 \mathrm{E}+01$ & 3.20E-02 & 6.13E-02 & $3.00 \mathrm{E}+00$ \\
\hline 55.20 & H1 & $7.97 \mathrm{E}+00$ & $3.66 \mathrm{E}+01$ & $(1.12 \mathrm{E}+01)$ & $3.01 \mathrm{E}+01$ & \begin{tabular}{|l|}
$3.02 \mathrm{E}-02$ \\
\end{tabular} & $5.00 \mathrm{E}-02$ & $3.34 \mathrm{E}+00$ \\
\hline 60.00 & H1 & $8.72 \mathrm{E}+00$ & $3.78 \mathrm{E}+01$ & $(1.18 \mathrm{E}+01)$ & $3.00 \mathrm{E}+01$ & $2.80 \mathrm{E}-02$ & $6.35 \mathrm{E}-02$ & $2.80 \mathrm{E}+00$ \\
\hline 60.00 & H1 & $7.22 \mathrm{E}+00$ & $(2.72 \mathrm{E}+01)$ & $(9.21 \mathrm{E}+00)$ & $2.27 \mathrm{E}+01$ & $2.70 \mathrm{E}-02$ & 4.99E-02 & $2.69 \mathrm{E}+00$ \\
\hline 62.50 & H1 & $6.66 \mathrm{E}+00$ & $(2.55 \mathrm{E}+01)$ & $1.94 \mathrm{E}+01$ & $2.39 \mathrm{E}+01$ & $2.18 \mathrm{E}-02$ & $5.14 \mathrm{E}-02$ & $1.65 \mathrm{E}+00$ \\
\hline 64.85 & H1 & $9.41 \mathrm{E}+00$ & $3.06 \mathrm{E}+01$ & $(9.24 \mathrm{E}+00)$ & $1.15 \mathrm{E}+01$ & 2.89E-02 & $4.48 \mathrm{E}-02$ & $2.29 \mathrm{E}+00$ \\
\hline 66.20 & H1 & $9.32 \mathrm{E}+00$ & $3.27 \mathrm{E}+01$ & $(7.84 \mathrm{E}+00)$ & $1.34 \mathrm{E}+01$ & $2.33 \mathrm{E}-02$ & $4.39 \mathrm{E}-02$ & $2.75 \mathrm{E}+00$ \\
\hline 71.25 & H2 & $1.01 \mathrm{E}+01$ & $(3.02 E+01)$ & $(8.66 \mathrm{E}+00)$ & $2.61 \mathrm{E}+01$ & 2.17E-02 & $5.43 \mathrm{E}-02$ & $2.59 \mathrm{E}+00$ \\
\hline 79.55 & H2 & $1.09 \mathrm{E}+01$ & $(3.29 \mathrm{E}+01)$ & $(9.81 E+00)$ & $2.55 \mathrm{E}+01$ & $2.71 \mathrm{E}-02$ & $6.49 \mathrm{E}-02$ & $2.78 \mathrm{E}+00$ \\
\hline 79.55 & $\mathrm{H} 2$ & $7.08 \mathrm{E}+00$ & $(2.38 \mathrm{E}+01)$ & $(9.92 E+00)$ & $1.36 \mathrm{E}+01$ & $2.61 \mathrm{E}-02$ & $5.04 \mathrm{E}-02$ & $2.60 \mathrm{E}+00$ \\
\hline 106.05 & $\mathrm{H} 2$ & $1.12 \mathrm{E}+01$ & $(2.78 \mathrm{E}+01)$ & $(9.40 \mathrm{E}+00)$ & $1.58 \mathrm{E}+01$ & $2.74 \mathrm{E}-02$ & $5.10 \mathrm{E}-02$ & $2.61 \mathrm{E}+00$ \\
\hline 110.15 & $\mathrm{H} 2$ & $8.01 \mathrm{E}+00$ & $3.55 \mathrm{E}+01$ & $(8.57 \mathrm{E}+00)$ & $1.95 \mathrm{E}+01$ & $3.11 \mathrm{E}-02$ & $7.94 \mathrm{E}-02$ & $3.44 \mathrm{E}+00$ \\
\hline 117.40 & $\mathrm{H} 2$ & $8.19 E+00$ & $2.93 \mathrm{E}+01$ & $(8.34 \mathrm{E}+00)$ & $8.48 \mathrm{E}+00$ & $2.71 \mathrm{E}-02$ & 4.77E-02 & $3.39 \mathrm{E}+00$ \\
\hline 120.25 & $\mathrm{H} 2$ & $7.40 \mathrm{E}+00$ & $3.11 \mathrm{E}+01$ & $(8.41 \mathrm{E}+00)$ & $1.21 \mathrm{E}+01$ & $2.81 \mathrm{E}-02$ & $4.54 \mathrm{E}-02$ & $4.27 \mathrm{E}+00$ \\
\hline 123.65 & $\mathrm{H} 2$ & $8.68 \mathrm{E}+00$ & $3.20 \mathrm{E}+01$ & $(1.08 \mathrm{E}+01)$ & $1.28 \mathrm{E}+01$ & 2.91E-02 & $5.40 \mathrm{E}-02$ & $2.88 \mathrm{E}+00$ \\
\hline 126.35 & $\mathrm{H} 2$ & $(5.65 E+00)$ & $(2.15 \mathrm{E}+01)$ & $(7.92 \mathrm{E}+00)$ & $1.35 \mathrm{E}+01$ & $2.10 \mathrm{E}-02$ & $4.48 \mathrm{E}-02$ & $2.10 \mathrm{E}+00$ \\
\hline 126.75 & H2 & $8.17 \mathrm{E}+00$ & $3.57 \mathrm{E}+01$ & $(8.81 E+00)$ & $2.08 \mathrm{E}+01$ & 2.88E-02 & $5.00 \mathrm{E}-02$ & $2.80 \mathrm{E}+00$ \\
\hline 127.85 & H2 & $9.13 \mathrm{E}+00$ & $3.63 \mathrm{E}+01$ & $(8.25 E+00)$ & $2.50 \mathrm{E}+01$ & $2.75 \mathrm{E}-02$ & $6.02 \mathrm{E}-02$ & $3.08 \mathrm{E}+00$ \\
\hline 130.65 & $\mathrm{H} 2$ & $6.81 \mathrm{E}+00$ & $3.09 \mathrm{E}+01$ & $(7.23 E+00)$ & $1.85 \mathrm{E}+01$ & $2.57 \mathrm{E}-02$ & $4.57 \mathrm{E}-02$ & $3.08 \mathrm{E}+00$ \\
\hline 133.75 & $\mathrm{H} 2$ & $9.90 \mathrm{E}+00$ & $4.09 \mathrm{E}+01$ & $(9.68 \mathrm{E}+00)$ & $1.19 \mathrm{E}+01$ & 3.39E-02 & $7.00 \mathrm{E}-02$ & $4.62 \mathrm{E}+00$ \\
\hline 136.75 & $\mathrm{H} 2$ & $1.09 \mathrm{E}+01$ & $4.23 \mathrm{E}+01$ & $1.36 \mathrm{E}+01$ & $2.68 \mathrm{E}+01$ & $4.30 \mathrm{E}-02$ & $6.68 \mathrm{E}-02$ & $3.45 \mathrm{E}+00$ \\
\hline 140.00 & $\mathrm{H} 2$ & $8.66 \mathrm{E}+00$ & $2.87 \mathrm{E}+01$ & $(6.48 \mathrm{E}+00)$ & $1.32 \mathrm{E}+01$ & $2.40 \mathrm{E}-02$ & $4.26 \mathrm{E}-02$ & $2.51 \mathrm{E}+00$ \\
\hline 143.25 & $\mathrm{H} 2$ & $7.24 \mathrm{E}+00$ & $2.02 \mathrm{E}+01$ & $(8.02 E+00)$ & $(1.92 \mathrm{E}+00)$ & 2.32E-02 & $4.48 \mathrm{E}-02$ & $2.22 \mathrm{E}+00$ \\
\hline 148.30 & $\mathrm{H} 2$ & $9.88 \mathrm{E}+00$ & $2.68 \mathrm{E}+01$ & $(9.48 \mathrm{E}+00)$ & $3.84 \mathrm{E}+00$ & 3.38E-02 & $6.15 \mathrm{E}-02$ & $4.46 \mathrm{E}+00$ \\
\hline 148.30 & $\mathrm{H} 2$ & $7.60 \mathrm{E}+00$ & $2.00 \mathrm{E}+01$ & $(7.34 \mathrm{E}+00)$ & $(1.76 \mathrm{E}+00)$ & $2.56 \mathrm{E}-02$ & $4.41 \mathrm{E}-02$ & $2.27 \mathrm{E}+00$ \\
\hline 165.75 & $\mathrm{H} 2$ & $8.27 \mathrm{E}+00$ & $2.19 \mathrm{E}+01$ & $(9.35 E+00)$ & $4.57 \mathrm{E}+00$ & 2.95E-02 & $4.29 \mathrm{E}-02$ & $2.10 \mathrm{E}+00$ \\
\hline 170.25 & H2 & $8.87 \mathrm{E}+00$ & $2.14 \mathrm{E}+01$ & $(8.45 \mathrm{E}+00)$ & $3.67 \mathrm{E}+00$ & 2.72E-02 & $4.48 \mathrm{E}-02$ & $2.02 \mathrm{E}+00$ \\
\hline 174.05 & $\mathrm{H} 2$ & $9.25 E+00$ & $2.78 \mathrm{E}+01$ & $(9.74 \mathrm{E}+00)$ & $1.30 \mathrm{E}+01$ & $2.98 \mathrm{E}-02$ & $4.44 \mathrm{E}-02$ & $2.22 \mathrm{E}+00$ \\
\hline
\end{tabular}


Table 4.28. Acid-Extractable Mobile Metals in C4297 Vadose Zone Sediments

\begin{tabular}{|c|c|c|c|c|c|c|c|c|c|c|}
\hline $\begin{array}{l}\text { Depth } \\
\text { (ft bgs) }\end{array}$ & $\begin{array}{c}\text { Stratigraphic } \\
\text { Unit } \\
\text { (Hanford } \\
\text { formation) }\end{array}$ & $\begin{array}{c}\text { Technetium-99 } \\
\text { ICP-MS } \\
\text { (pCi/g soil) }\end{array}$ & $9 \begin{array}{c}\text { Uranium-238 } \\
\text { ICP-MS } \\
(\mu \mathrm{g} / \mathrm{g} \text { soil) } \\
\end{array}$ & $\begin{array}{c}\text { Chromium-52 } \\
\text { ICP-MS } \\
(\mu \mathrm{g} / \mathrm{g} \text { soil) }\end{array}$ & $\begin{array}{l}\text { Chromium } \\
\text { ICP-OES } \\
(\mu \mathrm{g} / \mathrm{g} \text { soil }) \\
\end{array}$ & $\begin{array}{c}\text { Molybdenum-95 } \\
\text { ICP-MS } \\
\text { ( } \mu \mathrm{g} / \mathrm{g} \text { soil) }\end{array}$ & \begin{tabular}{|c} 
Molybdenum-98 \\
ICP-MS \\
( $\mathrm{g} / \mathrm{g}$ soil)
\end{tabular} & $\begin{array}{c}\text { Ruthenium-101 } \\
\text { ICP-MS } \\
(\mu \mathrm{g} / \mathrm{g} \text { soil })\end{array}$ & $\begin{array}{c}\text { Ruthenium-102 } \\
\text { ICP-MS } \\
(\mu \mathrm{g} / \mathrm{g} \text { soil })\end{array}$ & \begin{tabular}{|c||} 
Ruthenium-104 \\
ICP-MS \\
( $\mu \mathrm{g} / \mathrm{g}$ soil)
\end{tabular} \\
\hline 2.50 & Backfill & ND & 3.61E-01 & $5.66 \mathrm{E}+00$ & $4.66 \mathrm{E}+00$ & 1.32E-01 & 1.29E-01 & (2.13E-04) & ND & NM \\
\hline 7.00 & Backfill & ND & $4.00 \mathrm{E}-01$ & $5.42 \mathrm{E}+00$ & $4.77 \mathrm{E}+00$ & 1.05E-01 & 1.03E-01 & (2.43E-04) & ND & NM \\
\hline 12.00 & Backfill & ND & 3.81E-01 & $5.10 \mathrm{E}+00$ & $4.57 \mathrm{E}+00$ & 1.15E-01 & $1.14 \mathrm{E}-01$ & (1.48E-04) & ND & NM \\
\hline 17.00 & Backfill & ND & 3.94E-01 & $7.40 \mathrm{E}+00$ & $6.55 \mathrm{E}+00$ & $1.01 \mathrm{E}-01$ & $9.88 \mathrm{E}-02$ & $(2.28 \mathrm{E}-04)$ & ND & NM \\
\hline 22.00 & Backfill & ND & 7.70E-01 & $6.10 \mathrm{E}+00$ & $5.29 \mathrm{E}+00$ & 1.17E-01 & 1.17E-01 & (2.85E-04) & ND & NM \\
\hline 25.75 & Backfill & $(3.86 \mathrm{E}+00)$ & $9.11 \mathrm{E}-01$ & $9.04 \mathrm{E}+00$ & $8.71 \mathrm{E}+00$ & 1.92E-01 & $1.57 \mathrm{E}-01$ & (6.07E-04) & 3.55E-02 & 1.06E-01 \\
\hline 31.00 & Backfill & $(5.49 \mathrm{E}+00)$ & 4.73E-01 & $6.29 \mathrm{E}+00$ & $5.62 \mathrm{E}+00$ & 2.37E-01 & 1.99E-01 & (2.16E-04) & 3.91E-02 & 1.16E-01 \\
\hline 37.15 & Backfill & $(3.32 \mathrm{E}+00)$ & 3.97E-01 & $6.14 \mathrm{E}+00$ & $4.66 \mathrm{E}+00$ & $1.31 \mathrm{E}-01$ & $1.07 \mathrm{E}-01$ & $(8.88 E-04)$ & 3.89E-02 & 1.03E-01 \\
\hline 40.80 & $\mathrm{H} 1$ & $(4.56 \mathrm{E}+00)$ & 4.16E-01 & $8.16 \mathrm{E}+00$ & $7.44 \mathrm{E}+00$ & 1.77E-01 & $1.40 \mathrm{E}-01$ & (9.23E-03) & 4.48E-02 & 1.22E-01 \\
\hline 40.80 & H1 & $(5.99 \mathrm{E}+00)$ & 5.05E-01 & 7.30E +00 & $7.03 \mathrm{E}+00$ & 1.84E-01 & 1.49E-01 & (8.33E-03) & 4.26E-02 & 1.10E-01 \\
\hline 45.45 & H1 & $9.07 \mathrm{E}+00$ & 4.59E-01 & $6.64 \mathrm{E}+00$ & $6.03 \mathrm{E}+00$ & 1.54E-01 & 1.23E-01 & (4.21E-03) & 3.68E-02 & 1.02E-01 \\
\hline 49.25 & H1 & $(1.20 \mathrm{E}+01)$ & 6.34E-01 & $1.01 \mathrm{E}+01$ & $9.04 \mathrm{E}+00$ & 2.49E-01 & $2.40 \mathrm{E}-01$ & (3.50E-03) & ND & NM \\
\hline 55.20 & $\mathrm{H} 1$ & $(1.63 \mathrm{E}+00)$ & 5.11E-01 & $8.87 \mathrm{E}+00$ & $7.64 \mathrm{E}+00$ & 2.53E-01 & 2.30E-01 & (4.56E-03) & ND & NM \\
\hline 60.00 & H1 & ND & 4.60E-01 & $8.00 \mathrm{E}+00$ & $6.63 \mathrm{E}+00$ & 3.95E-01 & 3.63E-01 & (3.52E-03) & ND & NM \\
\hline 60.00 & H1 & ND & 4.84E-01 & $9.28 \mathrm{E}+00$ & $8.30 \mathrm{E}+00$ & 4.55E-01 & 4.16E-01 & (3.91E-03) & ND & NM \\
\hline 62.50 & H1 & $6.62 \mathrm{E}+00$ & 3.63E-01 & $4.74 \mathrm{E}+00$ & $3.93 \mathrm{E}+00$ & 2.82E-01 & 2.16E-01 & (4.65E-03) & 3.37E-02 & 9.49E-02 \\
\hline 64.85 & H1 & ND & 5.65E-01 & $7.37 \mathrm{E}+00$ & $6.54 \mathrm{E}+00$ & $1.72 \mathrm{E}-01$ & 1.64E-01 & (7.09E-03) & ND & NM \\
\hline 66.20 & H1 & ND & 5.18E-01 & $9.19 \mathrm{E}+00$ & $8.21 \mathrm{E}+00$ & $1.41 \mathrm{E}-01$ & $1.40 \mathrm{E}-01$ & (1.03E-02) & (8.99E-04) & NM \\
\hline 71.25 & $\mathrm{H} 2$ & $(5.87 \mathrm{E}+00)$ & 4.47E-01 & 8.95E+00 & $8.56 \mathrm{E}+00$ & 1.99E-01 & $1.60 \mathrm{E}-01$ & (1.85E-03) & 4.74E-02 & 1.26E-01 \\
\hline 79.55 & $\mathrm{H} 2$ & $(5.00 \mathrm{E}+00)$ & 4.67E-01 & $8.83 \mathrm{E}+00$ & $8.36 \mathrm{E}+00$ & 2.17E-01 & 1.79E-01 & (4.95E-03) & 5.33E-02 & 1.44E-01 \\
\hline 79.55 & $\mathrm{H} 2$ & $(3.92 \mathrm{E}+00)$ & 3.47E-01 & $7.05 \mathrm{E}+00$ & $6.07 \mathrm{E}+00$ & 1.24E-01 & $9.60 \mathrm{E}-02$ & (5.35E-03) & 4.40E-02 & $1.22 \mathrm{E}-01$ \\
\hline 106.05 & $\mathrm{H} 2$ & $(3.89 \mathrm{E}+00)$ & 3.65E-01 & $7.98 \mathrm{E}+00$ & $7.33 \mathrm{E}+00$ & 1.39E-01 & 1.13E-01 & (1.53E-03) & 4.12E-02 & 9.73E-02 \\
\hline 110.15 & $\mathrm{H} 2$ & ND & 7.21E-01 & $9.32 \mathrm{E}+00$ & $8.15 \mathrm{E}+00$ & 2.13E-01 & 2.09E-01 & (7.34E-04) & ND & NM \\
\hline
\end{tabular}


Table 4.28. (contd)

\begin{tabular}{|c|c|c|c|c|c|c|c|c|c|c|}
\hline $\begin{array}{l}\text { Depth } \\
\text { ft bgs) }\end{array}$ & $\begin{array}{c}\text { Stratigraphic } \\
\text { Unit } \\
\text { (Hanford } \\
\text { formation) }\end{array}$ & $\begin{array}{c}\text { Technetium-9 } \\
\text { ICP-MS } \\
\text { (pCi/g soil) }\end{array}$ & $\begin{array}{c}9 \text { Uranium-238 } \\
\text { ICP-MS } \\
(\mu \mathrm{g} / \mathrm{g} \text { soil) }\end{array}$ & $8 \begin{array}{c}\text { Chromium-52 } \\
\text { ICP-MS } \\
\text { ( } \mu \mathrm{g} / \mathrm{g} \text { soil) }\end{array}$ & \begin{tabular}{|l|} 
Chromium \\
ICP-OES \\
$(\mu \mathrm{g} / \mathrm{g}$ soil $)$
\end{tabular} & \begin{tabular}{|c|} 
Molybdenum-95 \\
ICP-MS \\
( $\mu \mathrm{g} / \mathrm{g}$ soil)
\end{tabular} & \begin{tabular}{|c}
$\begin{array}{c}\text { Molybdenum-98 } \\
\text { ICP-MS } \\
\text { ( } \mathrm{\mu g} / \mathrm{g} \text { soil) }\end{array}$ \\
\end{tabular} & $\begin{array}{c}\begin{array}{c}\text { Ruthenium-101 } \\
\text { ICP-MS } \\
(\mu \mathrm{g} / \mathrm{g} \text { soil })\end{array} \\
\end{array}$ & 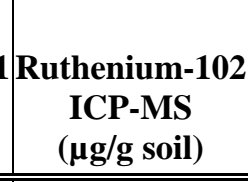 & $\begin{array}{c}\text { Ruthenium-104 } \\
\text { ICP-MS } \\
\text { ( } \mu \mathrm{g} / \mathrm{g} \text { soil) }\end{array}$ \\
\hline $\mid 117.40$ & H2 & ND & 4.55E-01 & $7.12 \mathrm{E}+00$ & $6.42 \mathrm{E}+00$ & $1.44 \mathrm{E}-01$ & $1.42 \mathrm{E}-01$ & $(7.44 \mathrm{E}-04)$ & ND & NM \\
\hline 120.25 & $\mathrm{H} 2$ & ND & 5.43E-01 & $8.17 \mathrm{E}+00$ & $6.96 \mathrm{E}+00$ & 1.51E-01 & 1.48E-01 & (6.93E-04) & ND & NM \\
\hline 123.65 & $\mathrm{H} 2$ & ND & 8.45E-01 & $7.45 \mathrm{E}+00$ & $6.73 E+00$ & $1.74 \mathrm{E}-01$ & $1.74 \mathrm{E}-01$ & (4.36E-04) & ND & NM \\
\hline 126.35 & $\mathrm{H} 2$ & $(4.12 \mathrm{E}+00)$ & 3.42E-01 & $5.32 \mathrm{E}+00$ & $3.81 \mathrm{E}+00$ & 1.08E-01 & 8.48E-02 & $(1.71 \mathrm{E}-03)$ & 3.87E-02 & 1.02E-01 \\
\hline 126.75 & $\mathrm{H} 2$ & ND & 9.58E-01 & $9.78 \mathrm{E}+00$ & $8.43 \mathrm{E}+00$ & 2.03E-01 & 2.02E-01 & (6.69E-04) & ND & NM \\
\hline 127.85 & $\mathrm{H} 2$ & $(4.45 E+00)$ & $5.04 \mathrm{E}-01$ & $9.42 \mathrm{E}+00$ & $8.27 \mathrm{E}+00$ & 2.16E-01 & 2.15E-01 & (5.23E-04) & ND & NM \\
\hline 130.65 & $\mathrm{H} 2$ & ND & $6.48 \mathrm{E}-01$ & $8.04 \mathrm{E}+00$ & 7.13E+00 & 1.89E-01 & 1.91E-01 & (6.74E-04) & ND & NM \\
\hline 133.75 & $\mathrm{H} 2$ & ND & 4.90E-01 & $1.24 \mathrm{E}+01$ & $1.07 \mathrm{E}+01$ & $1.56 \mathrm{E}-01$ & $1.56 \mathrm{E}-01$ & (1.41E-03) & ND & NM \\
\hline 136.75 & $\mathrm{H} 2$ & ND & $6.32 \mathrm{E}-01$ & $1.15 \mathrm{E}+01$ & $1.02 \mathrm{E}+01$ & 2.45E-01 & $2.45 \mathrm{E}-01$ & (4.33E-04) & ND & NM \\
\hline 140.00 & $\mathrm{H} 2$ & $(3.66 \mathrm{E}+00)$ & $6.15 \mathrm{E}-01$ & $8.98 \mathrm{E}+00$ & $7.89 \mathrm{E}+00$ & 1.44E-01 & 1.41E-01 & (6.56E-04) & ND & NM \\
\hline 143.25 & $\mathrm{H} 2$ & ND & 3.07E-01 & $5.05 E+00$ & $4.39 \mathrm{E}+00$ & 7.46E-02 & 7.54E-02 & $(2.31 \mathrm{E}-04)$ & ND & NM \\
\hline 148.30 & $\mathrm{H} 2$ & ND & 4.28E-01 & $7.31 \mathrm{E}+00$ & $6.86 \mathrm{E}+00$ & 1.12E-01 & 1.12E-01 & $(5.26 \mathrm{E}-04)$ & ND & NM \\
\hline 148.30 & $\mathrm{H} 2$ & ND & 3.25E-01 & $5.76 \mathrm{E}+00$ & $5.11 \mathrm{E}+00$ & 8.33E-02 & 8.17E-02 & (3.74E-04) & ND & NM \\
\hline 165.75 & $\mathrm{H} 2$ & ND & 4.72E-01 & $6.34 \mathrm{E}+00$ & $5.67 \mathrm{E}+00$ & 9.82E-02 & 9.53E-02 & (2.26E-04) & ND & NM \\
\hline 170.25 & $\mathrm{H} 2$ & ND & 6.89E-01 & $6.39 \mathrm{E}+00$ & $5.39 \mathrm{E}+00$ & 1.19E-01 & 1.18E-01 & $(2.89 \mathrm{E}-04)$ & ND & NM \\
\hline 174.05 & $\mathrm{H} 2$ & ND & 6.16E-01 & $9.35 \mathrm{E}+00$ & $8.10 \mathrm{E}+00$ & 1.83E-01 & $1.86 \mathrm{E}-01$ & (1.11E-04) & ND & NM \\
\hline \multicolumn{11}{|c|}{$\begin{array}{l}\text { Parentheses signify values below level of quantitation. } \\
\text { Shaded values designate the core samples and unshaded represent grab samples. } \\
\text { ND = Not detected. } \\
\text { NM = Not measured. }\end{array}$} \\
\hline
\end{tabular}




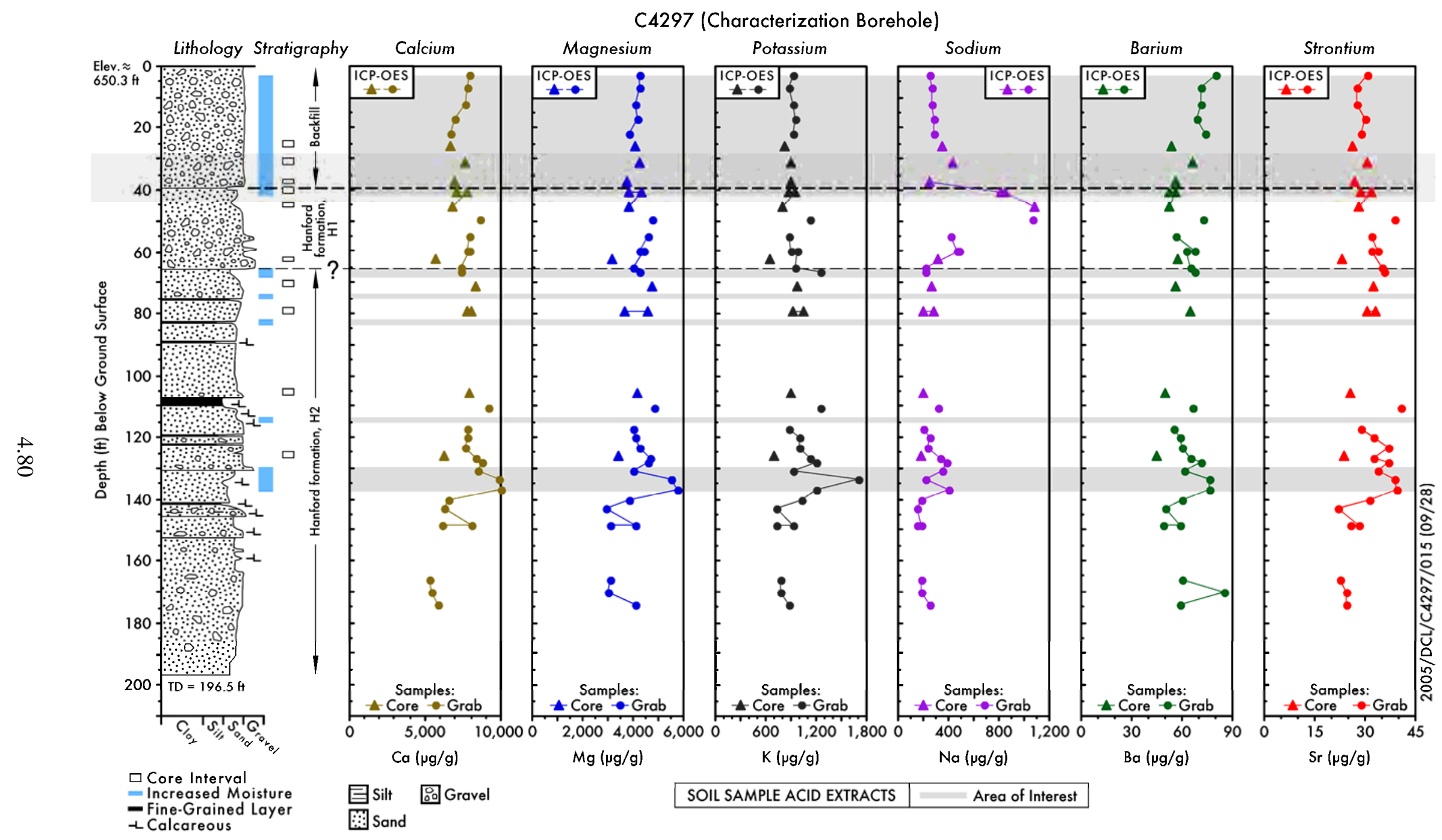

Figure 4.25. Acid-Extractable Cations in C4297 Vadose Zone Sediments ( $\mu \mathrm{g} / \mathrm{g}$ dry sediment) 


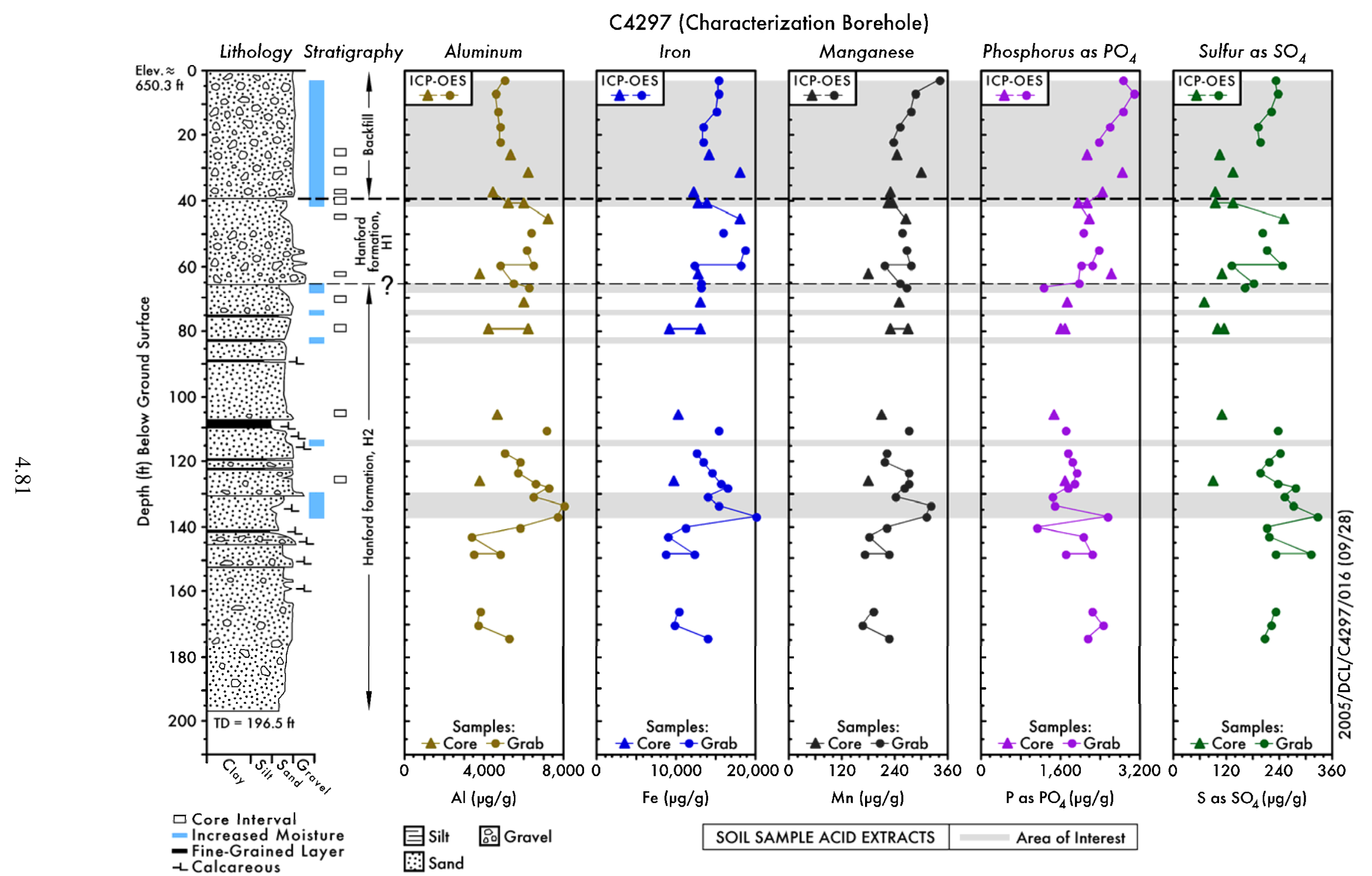

Figure 4.26. Acid-Extractable Major Metals in C4297 Vadose Zone Sediments ( $\mu$ g/g dry sediment) 


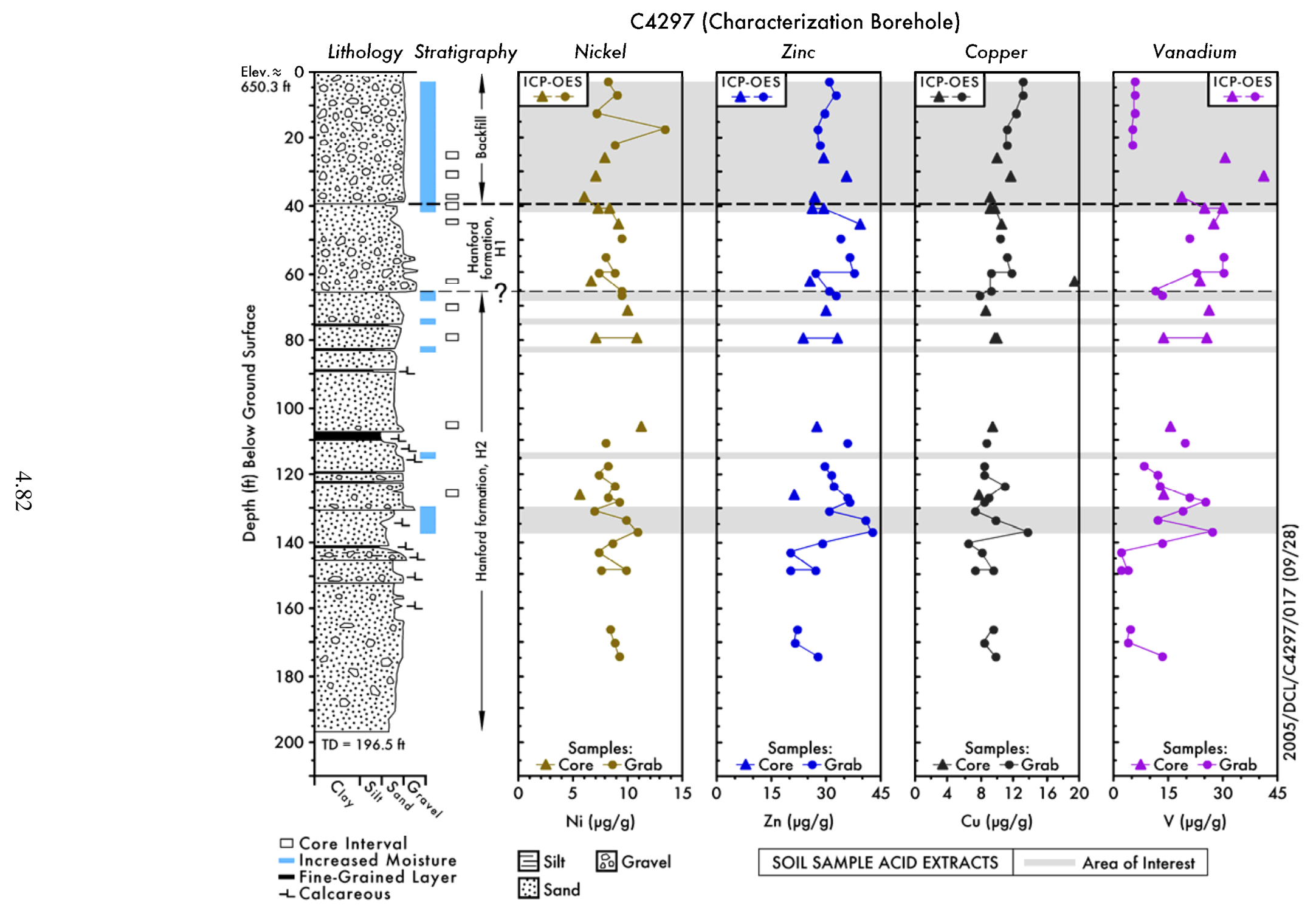

Figure 4.27. Acid-Extractable Trace Metals in C4297 Vadose Zone Sediments ( $\mu$ g/g dry sediment) 


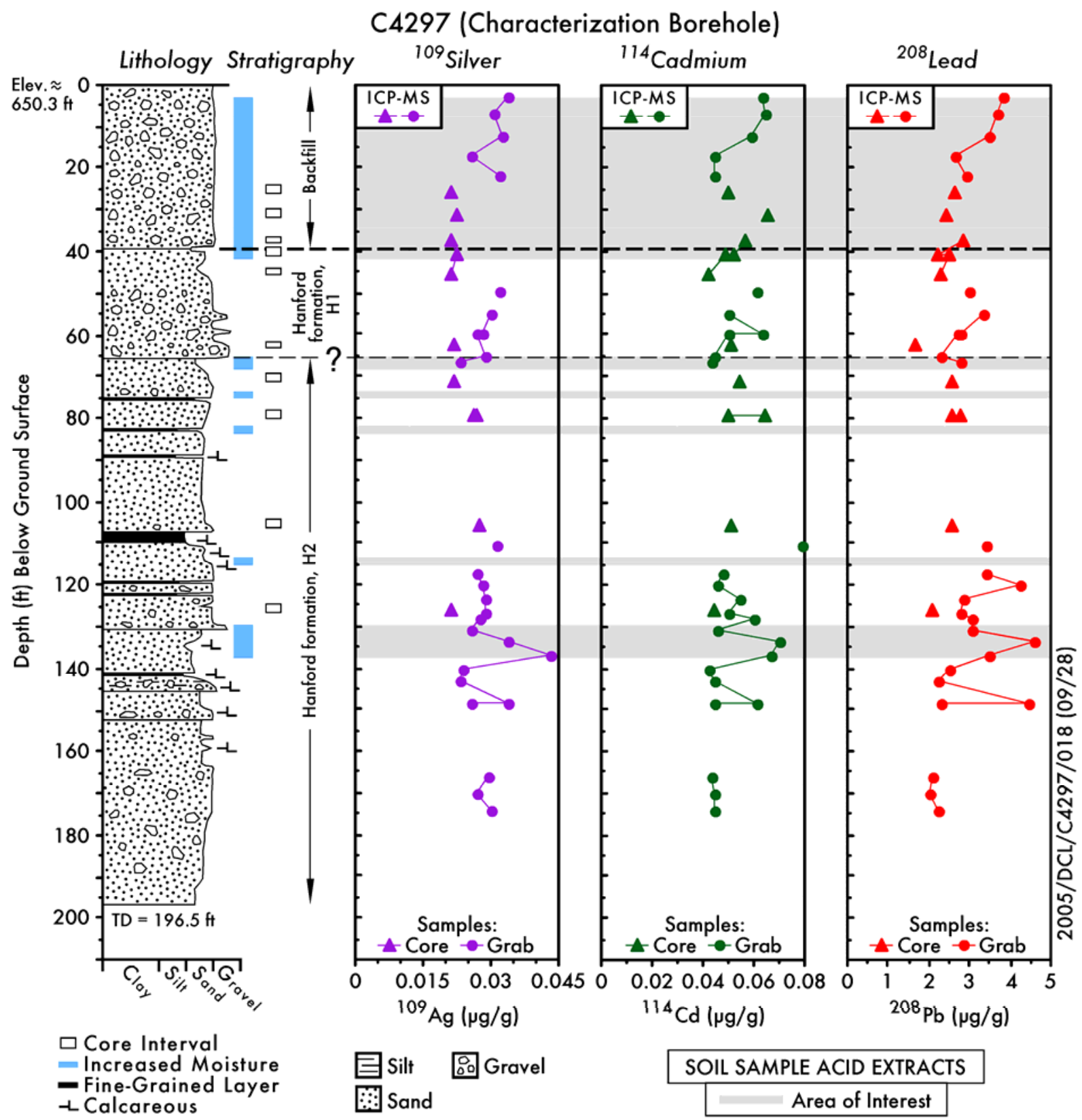

Figure 4.28. Acid-Extractable Trace Metals in C4297 Vadose Zone Sediments ( $\mu \mathrm{g} / \mathrm{g}$ dry sediment) 


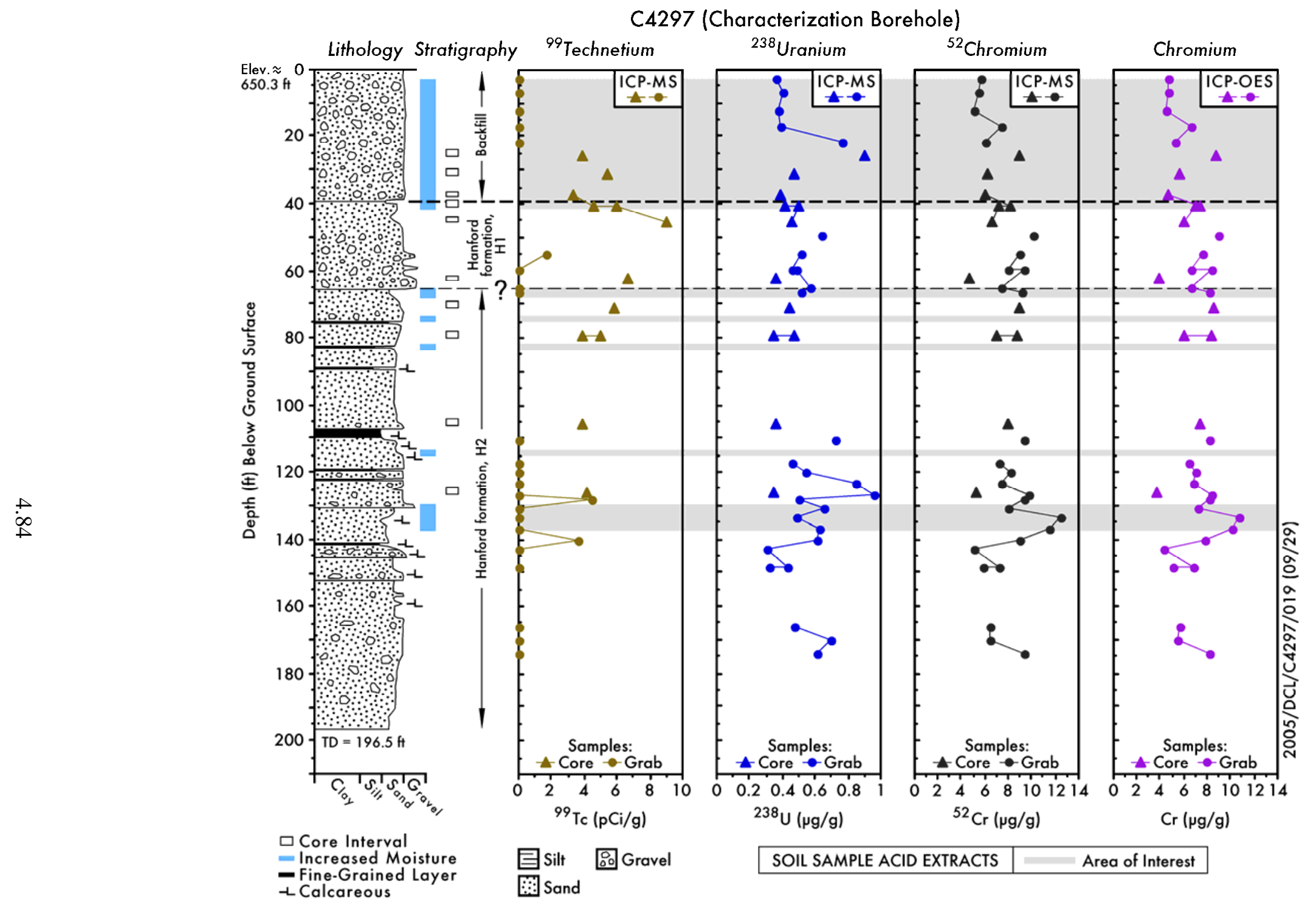

Figure 4.29. Acid-Extractable Mobile Metals in C4297 Vadose Zone Sediments (units vary) 


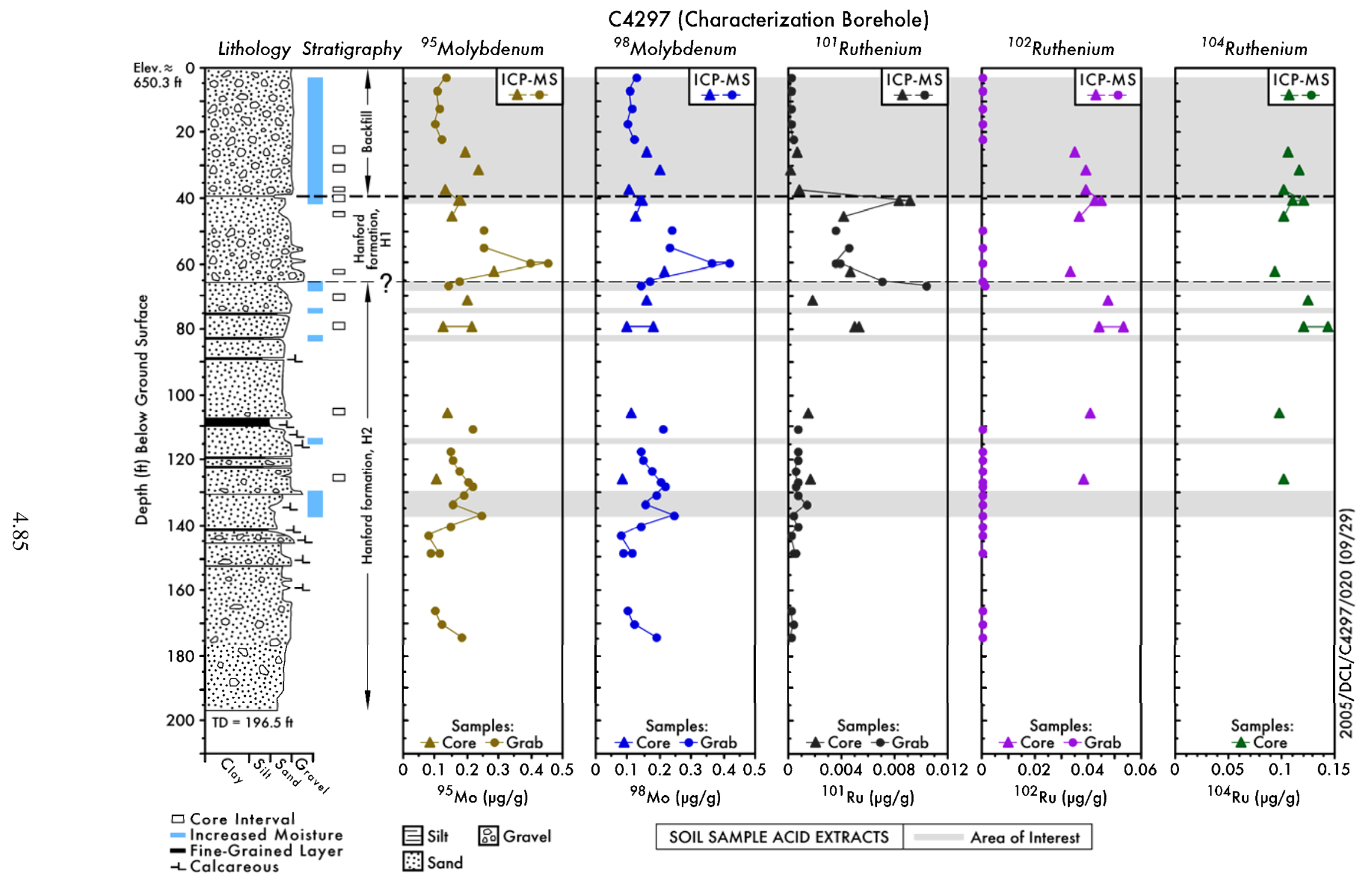

Figure 4.30. Acid-Extractable Mobile Metals in C4297 Vadose Zone Sediments ( $\mu \mathrm{g} / \mathrm{g}$ dry sediment) 
Comparison of the water to acid-extractable quantities of each constituent was performed by taking the data in Table 4.1 through 4.20 and dividing by the data in Tables 4.25 through 4.28. The data are not presented herein but show the same trends as found for the RCRA borehole (C4124), wherein less than $0.1 \%$ of the acid-extractable quantities of the following elements were water leachable: aluminum, iron, magnesium, manganese, chromium, and phosphorous as phosphate. Less than $0.3 \%$ of the acidextractable quantities of the following elements were water leachable: arsenic, calcium, potassium, strontium, zinc, and uranium. Less than $35 \%$ of the acid-extractable sodium, sulfur, and molybdenum were water extractable. The only indications of tank contamination in these sediments were the elevated sodium levels in the vicinity of the tank bottom and the presence of technetium-99 in both acid and water extracts.

\subsubsection{Radionuclide Content in Vadose Zone Sediment from Borehole C4297}

Aside from the technetium-99 data already presented, the direct measurement of bulk sediment samples for gamma-emitting radionuclides showed that only natural potassium- 40 and the fission product isotopes cobalt-60 and cesium-137 were present in selected samples. The gamma energy analyses data are shown in Table 4.29.

The spectral gamma log results in Figure 2.13 indicated that there was elevated gamma present between 10 and $20 \mathrm{ft}$ bgs. However, gamma energy analysis of direct aliquots of borehole sediment identified only low picocuries per gram concentrations of cesium-137 present from 2.5 to $12 \mathrm{ft}$ bgs (Table 4.29). The four samples collected deeper within the borehole that contained "measurable" amounts of cesium-137 were all below the minimum detection limit for the analysis. Several samples collected in the Hanford H1 subunit between 39.80 and $64.85 \mathrm{ft}$ bgs and one sample collected in the Hanford formation $\mathrm{H} 2$ subunit (66.20 ft bgs) contained quantifiable, yet trace amounts of cobalt-60 (less than $0.5 \mathrm{pCi} / \mathrm{g}$ ). The presence of trace amounts of cobalt-60 contamination at this location is likely a result of lateral migration of tank-related contamination along the backfill/Hanford formation H1 subunit boundary. The cobalt-60 is likely from the same source that supplied the deeper nitrate and technetium99 contamination observed in the C4297 cores between 130 and $170 \mathrm{ft}$ bgs and 130 to $160 \mathrm{ft}$ bgs, respectively.

Gross alpha and beta measurements were made on both the 1:1 sediment:water and sediment:acid extracts. With knowledge of the mass of dry sediment to extraction fluid used, the data were converted to activity of gross beta and gross alpha leached per gram of dry sediment. For the total beta analyses, our detection limits for the water extracts were 10 to $20 \mathrm{pCi} / \mathrm{g}$ dry sediment and 5 to $10 \mathrm{pCi} / \mathrm{g}$ dry sediment for the acid extracts. For the total alpha analyses, the detection limit for both extracts was 5 to $10 \mathrm{pCi} / \mathrm{g}$ dry sediment. None of the water extracts of the 46 samples tested (the A sleeves from all 10 of the cores as well as 36 grab samples collected between 2.5 and $174 \mathrm{ft} \mathrm{bgs)} \mathrm{showed} \mathrm{total} \mathrm{alpha} \mathrm{or} \mathrm{total} \mathrm{beta} \mathrm{activities}$ significantly greater than the detection limits for the procedures and are, therefore, not plotted or tabulated. Acid extracts of the core and grab samples (Table 4.30) indicated as much as $39 \mathrm{pCi} / \mathrm{g}$ total beta and no measurable total alpha in the shallowest core sample (26 ft bgs) tested. Further, detectable amounts of beta contamination (about $17 \mathrm{pCi} / \mathrm{g}$ ) were measured as deep as $126 \mathrm{ft}$ bgs. Although two samples deeper than $126 \mathrm{ft}$ bgs contained measurable amounts of acid-extractable beta; the reported values are both below the limit of quantification for the analysis. Surprisingly, all of the core samples analyzed contained measurable amounts of beta contamination, even when analysis of acid extracts of 
grab samples collected in close proximity depth-wise resulted in no detectable contamination. This likely indicates that the acid-extractable total beta data reported in Table 4.30 could be compromised due to field sampling contamination.

Table 4.29. Gamma Emitting Radionuclides in Borehole C4297 Vadose Zone Sediments (pCi/g)

\begin{tabular}{|c|c|c|c|c|}
\hline $\begin{array}{c}\text { Depth } \\
\text { (ft bgs) }\end{array}$ & $\begin{array}{l}\text { Stratigraphic Unit } \\
\text { (Hanford formation) }\end{array}$ & $\begin{array}{c}\text { Potassium-40 } \\
\text { (pCi/g sed.) }\end{array}$ & $\begin{array}{c}\text { Cobalt-60 } \\
\text { (pCi/g sed.) }\end{array}$ & $\begin{array}{l}\text { Cesium-137 } \\
\text { (pCi/g sed.) }\end{array}$ \\
\hline 2.50 & Backfill & $1.165 \mathrm{E}+01$ & ND & $3.140 \mathrm{E}+01$ \\
\hline 7.00 & Backfill & $1.184 \mathrm{E}+01$ & ND & $2.020 \mathrm{E}+01$ \\
\hline 12.00 & Backfill & $9.437 \mathrm{E}+00$ & ND & $2.996 \mathrm{E}+00$ \\
\hline 17.00 & Backfill & $1.138 \mathrm{E}+01$ & ND & ND \\
\hline 22.00 & Backfill & $1.143 E+01$ & ND & ND \\
\hline 25.25 & Backfill & $1.060 \mathrm{E}+01$ & ND & ND \\
\hline 31.00 & Backfill & $1.248 \mathrm{E}+01$ & ND & $(2.877 \mathrm{E}-02)$ \\
\hline 37.15 & Backfill & $1.432 \mathrm{E}+01$ & ND & ND \\
\hline 38.35 & Backfill & $1.164 \mathrm{E}+01$ & ND & ND \\
\hline 39.80 & H1 & $1.365 \mathrm{E}+01$ & 2.592E-01 & ND \\
\hline 40.80 & H1 & $1.290 \mathrm{E}+01$ & 9.852E-02 & $(2.802 \mathrm{E}-02)$ \\
\hline 40.80 & H1 & $1.437 \mathrm{E}+01$ & ND & ND \\
\hline 41.20 & $\mathrm{H} 1$ & $1.344 \mathrm{E}+01$ & $1.741 \mathrm{E}-01$ & ND \\
\hline 43.75 & $\mathrm{H} 1$ & $1.411 \mathrm{E}+01$ & 1.422E-01 & ND \\
\hline 44.45 & H1 & $1.344 \mathrm{E}+01$ & 2.293E-01 & ND \\
\hline 45.45 & H1 & $1.248 \mathrm{E}+01$ & 4.972E-01 & ND \\
\hline 45.85 & $\mathrm{H} 1$ & $1.314 \mathrm{E}+01$ & 3.303E-01 & $(4.278 \mathrm{E}-03)$ \\
\hline 49.25 & $\mathrm{H} 1$ & $1.437 \mathrm{E}+01$ & 4.921E-01 & ND \\
\hline 51.25 & $\mathrm{H} 1$ & $1.373 \mathrm{E}+01$ & 4.612E-01 & ND \\
\hline 55.20 & H1 & $1.329 \mathrm{E}+01$ & 2.272E-01 & ND \\
\hline 57.20 & H1 & $1.304 \mathrm{E}+01$ & $2.100 \mathrm{E}-01$ & ND \\
\hline 60.00 & $\mathrm{H} 1$ & $1.337 \mathrm{E}+01$ & $(9.564 \mathrm{E}-02)$ & ND \\
\hline 60.00 & $\mathrm{H} 1$ & $1.123 \mathrm{E}+01$ & 1.367E-01 & ND \\
\hline 61.50 & H1 & $1.108 \mathrm{E}+01$ & 8.746E-02 & ND \\
\hline 62.50 & H1 & $1.159 \mathrm{E}+01$ & $(6.371 \mathrm{E}-02)$ & ND \\
\hline 62.90 & H1 & $1.112 \mathrm{E}+01$ & $6.938 \mathrm{E}-02$ & ND \\
\hline
\end{tabular}


Table 4.29. (contd)

\begin{tabular}{|c|c|c|c|c|}
\hline $\begin{array}{l}\text { Depth } \\
\text { (ft bgs) }\end{array}$ & $\begin{array}{l}\text { Stratigraphic Unit } \\
\text { (Hanford formation) }\end{array}$ & $\begin{array}{c}\text { Potassium- } 40 \\
\text { (pCi/g sed.) }\end{array}$ & $\begin{array}{c}\text { Cobalt-60 } \\
\text { (pCi/g sed.) }\end{array}$ & $\begin{array}{l}\text { Cesium-137 } \\
\text { (pCi/g sed.) }\end{array}$ \\
\hline 64.85 & $\mathrm{H} 1$ & $1.236 \mathrm{E}+01$ & 6.583E-02 & ND \\
\hline 66.20 & $\mathrm{H} 2$ & $1.466 \mathrm{E}+01$ & $1.251 \mathrm{E}-01$ & ND \\
\hline 68.95 & $\mathrm{H} 2$ & $1.428 \mathrm{E}+01$ & ND & ND \\
\hline 71.25 & H2 & $1.547 \mathrm{E}+01$ & ND & ND \\
\hline 79.55 & H2 & $1.620 \mathrm{E}+01$ & ND & (1.076E-02) \\
\hline 79.55 & $\mathrm{H} 2$ & $1.581 \mathrm{E}+01$ & ND & ND \\
\hline 106.05 & $\mathrm{H} 2$ & $1.647 \mathrm{E}+01$ & ND & ND \\
\hline 110.15 & $\mathrm{H} 2$ & $1.554 \mathrm{E}+01$ & ND & ND \\
\hline 117.40 & $\mathrm{H} 2$ & $1.337 \mathrm{E}+01$ & ND & ND \\
\hline 120.25 & $\mathrm{H} 2$ & $1.591 \mathrm{E}+01$ & ND & ND \\
\hline 123.65 & $\mathrm{H} 2$ & $1.410 \mathrm{E}+01$ & ND & ND \\
\hline 126.35 & $\mathrm{H} 2$ & $1.487 \mathrm{E}+01$ & ND & ND \\
\hline 126.75 & $\mathrm{H} 2$ & $1.330 \mathrm{E}+01$ & ND & ND \\
\hline 127.85 & $\mathrm{H} 2$ & $1.411 \mathrm{E}+01$ & ND & ND \\
\hline 130.65 & $\mathrm{H} 2$ & $1.314 \mathrm{E}+01$ & ND & ND \\
\hline 133.75 & $\mathrm{H} 2$ & $1.416 \mathrm{E}+01$ & ND & ND \\
\hline 136.75 & $\mathrm{H} 2$ & $1.403 \mathrm{E}+01$ & ND & ND \\
\hline 140.00 & $\mathrm{H} 2$ & $1.351 \mathrm{E}+01$ & ND & ND \\
\hline 143.25 & $\mathrm{H} 2$ & $1.197 \mathrm{E}+01$ & ND & ND \\
\hline 148.30 & $\mathrm{H} 2$ & $1.249 \mathrm{E}+01$ & ND & ND \\
\hline 148.30 & $\mathrm{H} 2$ & $1.303 \mathrm{E}+01$ & ND & ND \\
\hline 165.75 & $\mathrm{H} 2$ & $1.069 \mathrm{E}+01$ & ND & ND \\
\hline 170.25 & $\mathrm{H} 2$ & $1.372 \mathrm{E}+01$ & ND & ND \\
\hline 174.05 & $\mathrm{H} 2$ & $1.158 \mathrm{E}+01$ & ND & ND \\
\hline \multicolumn{5}{|c|}{$\begin{array}{l}\text { Shaded values designate the core samples and unshaded represent grab samples. } \\
\text { Parentheses indicate reported value is less than the MDA. } \\
\text { ND = Not detected }\end{array}$} \\
\hline
\end{tabular}

Analysis of transuranic elements via ICP-MS was performed on acid extracts from the A sleeve shallow core samples. None of the samples analyzed contained neptunium-237, plutonium-239, or americium-241 at concentrations in excess of the limit of quantification for the analysis (Table 4.30). 
Table 4.30. Total Alpha, Beta, and Actinides in Borehole C4297 Vadose Zone Sediments

\begin{tabular}{|c|c|c|c|c|c|}
\hline $\begin{array}{c}\text { Method } \\
\text { Leachant Depth } \\
\text { (ft bgs) }\end{array}$ & $\begin{array}{c}\text { Rad Acid } \\
\text { Total Alpha } \\
\text { (pCi/g) }\end{array}$ & $\begin{array}{c}\text { Rad Acid } \\
\text { Total Beta } \\
\text { (pCi/g) } \\
\end{array}$ & $\begin{array}{c}\text { ICP-MS } \\
\text { Acid Np-237 } \\
\text { (pCi/g) }\end{array}$ & $\begin{array}{c}\text { ICP-MS } \\
\text { Acid Pu-239 } \\
\text { (pCi/g) }\end{array}$ & $\begin{array}{c}\text { ICP-MS } \\
\text { Acid Am-241 } \\
\text { (pCi/g) } \\
\end{array}$ \\
\hline 2.50 & ND & $1.177 \mathrm{E}+01$ & $(2.97 \mathrm{E}-01)$ & $(6.97 \mathrm{E}+01)$ & $(4.10 \mathrm{E}+03)$ \\
\hline 7.00 & ND & $1.46 \mathrm{E}+01$ & $(2.38 \mathrm{E}-01)$ & $(4.18 \mathrm{E}+01)$ & $(4.86 \mathrm{E}+03)$ \\
\hline 12.00 & ND & ND & (1.37E-01) & $(3.21 \mathrm{E}+01)$ & $(4.00 \mathrm{E}+03)$ \\
\hline 17.00 & ND & ND & (1.74E-01) & $(2.68 \mathrm{E}+01)$ & $(4.45 \mathrm{E}+03)$ \\
\hline 22.00 & ND & ND & $(1.45 \mathrm{E}-01)$ & $(2.13 \mathrm{E}+01)$ & $(4.71 \mathrm{E}+03)$ \\
\hline 25.75 & ND & $3.84 \mathrm{E}+01$ & $(1.30 \mathrm{E}-01)$ & $(2.29 \mathrm{E}+01)$ & $(4.01 \mathrm{E}+03)$ \\
\hline 31.00 & ND & $(2.62 \mathrm{E}+00)$ & (1.39E-01) & $(1.63 \mathrm{E}+01)$ & $(4.73 \mathrm{E}+03)$ \\
\hline 37.15 & ND & $2.37 \mathrm{E}+01$ & (1.34E-01) & $(1.97 \mathrm{E}+01)$ & $(5.02 \mathrm{E}+03)$ \\
\hline 40.80 & ND & $1.97 \mathrm{E}+01$ & $(1.32 \mathrm{E}-01)$ & $(1.93 \mathrm{E}+01)$ & $(4.28 \mathrm{E}+03)$ \\
\hline 40.80 Dup & ND & $3.63 \mathrm{E}+01$ & NM & NM & $\mathrm{NM}$ \\
\hline 45.45 & ND & $2.90 \mathrm{E}+01$ & $(1.98 \mathrm{E}-01)$ & $(1.40 \mathrm{E}+01)$ & $(3.09 \mathrm{E}+03)$ \\
\hline 49.25 & ND & ND & NM & NM & $\mathrm{NM}$ \\
\hline 55.20 & ND & ND & NM & NM & $\mathrm{NM}$ \\
\hline 60.00 & ND & ND & NM & NM & $\mathrm{NM}$ \\
\hline 60.00 Dup & ND & (8.60E-01) & NM & NM & $\mathrm{NM}$ \\
\hline 62.50 & ND & $3.05 \mathrm{E}+01$ & NM & NM & $\mathrm{NM}$ \\
\hline 64.85 & ND & ND & NM & $\mathrm{NM}$ & $\mathrm{NM}$ \\
\hline 66.20 & ND & ND & NM & NM & $\mathrm{NM}$ \\
\hline 71.25 & ND & $1.30 \mathrm{E}+01$ & NM & NM & $\mathrm{NM}$ \\
\hline 79.55 & ND & $2.18 \mathrm{E}+01$ & NM & NM & $\mathrm{NM}$ \\
\hline 79.55 Dup & ND & $1.35 \mathrm{E}+01$ & NM & NM & $\mathrm{NM}$ \\
\hline 106.05 & ND & $1.80 \mathrm{E}+01$ & NM & NM & NM \\
\hline |110.15 & ND & ND & NM & NM & NM \\
\hline 117.40 & ND & ND & $\mathrm{NM}$ & NM & $\mathrm{NM}$ \\
\hline 120.25 & ND & ND & NM & NM & NM \\
\hline 123.65 & ND & ND & NM & NM & $\mathrm{NM}$ \\
\hline 126.35 & ND & $1.66 \mathrm{E}+01$ & NM & NM & NM \\
\hline 126.75 & ND & ND & NM & NM & NM \\
\hline 127.85 & ND & $(2.80 \mathrm{E}+00)$ & NM & NM & NM \\
\hline 130.65 & ND & ND & $\mathrm{NM}$ & NM & NM \\
\hline 133.75 & ND & $(7.70 \mathrm{E}+00)$ & $\mathrm{NM}$ & NM & $\mathrm{NM}$ \\
\hline 136.75 & ND & ND & NM & NM & NM \\
\hline
\end{tabular}


Table 4.30. (contd)

\begin{tabular}{|c|c|c|c|c|c|}
\hline $\begin{array}{c}\text { Method } \\
\text { Leachant Depth } \\
\text { (ft bgs) }\end{array}$ & $\begin{array}{c}\text { Rad Acid } \\
\text { Total Alpha } \\
\text { (pCi/g) }\end{array}$ & $\begin{array}{c}\text { Rad Acid } \\
\text { Total Beta } \\
\text { (pCi/g) }\end{array}$ & $\begin{array}{c}\text { ICP-MS } \\
\text { Acid Np-237 } \\
\text { (pCi/g) }\end{array}$ & $\begin{array}{c}\text { ICP-MS } \\
\text { Acid Pu-239 } \\
\text { (pCi/g) }\end{array}$ & $\begin{array}{c}\text { ICP-MS } \\
\text { Acid Am-241 } \\
\text { (pCi/g) }\end{array}$ \\
\hline 140.00 & ND & ND & $\mathrm{NM}$ & NM & NM \\
\hline 143.25 & ND & ND & NM & NM & NM \\
\hline 148.30 & ND & ND & NM & NM & NM \\
\hline 148.30 Dup & ND & ND & $\mathrm{NM}$ & NM & NM \\
\hline 165.75 & ND & ND & NM & NM & NM \\
\hline 170.25 & ND & ND & NM & NM & NM \\
\hline 174.05 & ND & ND & NM & NM & NM \\
\hline \multicolumn{6}{|c|}{$\begin{array}{l}\text { Parentheses signify values below level of quantitation. } \\
\text { Shaded values designate the core samples and unshaded represent grab samples. } \\
\text { Dup = Duplicate sample } \\
\text { ND = Not detected } \\
\text { NM = Not measured }\end{array}$} \\
\hline
\end{tabular}

\subsubsection{Total Carbon, Calcium Carbonate, and Organic Carbon Content of Vadose Zone Sediment from Borehole C4297}

Table 4.31 shows the total carbon, inorganic carbon, and organic carbon contents of the vadose zone sediment collected from borehole C4297. The inorganic carbon was also converted to the equivalent calcium-carbonate content. The sediment in the Hanford formation $\mathrm{H} 1$ and $\mathrm{H} 2$ units was relatively low in calcium carbonate ( $<3 \mathrm{wt} \%$ ) with little to no organic carbon. As is found in most vadose sediments from the Hanford Reservation, there was very little (generally $<0.1 \%$ by weight) organic carbon present. These values are quite typical and compare well with other samples collected from various locations around the Hanford Site (Serne et al. 2004 a,b; Brown et al. 2005).

\subsubsection{Matric Potential of Borehole C4297 Vadose Zone Sediments}

Water potential measurements have been included in the Hanford Tank Farm Vadose Zone Characterization Program to document the energy state of pore waters in the tank farm sediments. At the tank farms, vegetation is absent, surface soils are coarse-textured, and the potential for drainage (recharge) is high (Gee 1987; Gee et al. 1992). However, actual drainage rates are generally unknown at the tank farms. Attempts are currently being made to determine the soil water matrix potential and use the analysis to confirm the occurrence of recharge within the Hanford Site tank farms. 
Table 4.31. Carbon Contents of Vadose Zone Sediments in Borehole C4297

\begin{tabular}{|c|c|c|c|c|c|}
\hline $\begin{array}{c}\text { Stratigraphic Unit } \\
\text { (Hanford formation) } \\
\end{array}$ & $\begin{array}{c}\text { Depth } \\
\text { (ft bgs) } \\
\end{array}$ & $\begin{array}{c}\text { Total Carbon } \\
\mathbf{( \% )} \\
\end{array}$ & \begin{tabular}{|c} 
Inorganic Carbon \\
$\mathbf{( \% )}$
\end{tabular} & $\begin{array}{c}\text { Inorganic Carbon } \\
\text { as } \mathrm{CaCO}_{3} \\
(\%) \\
\end{array}$ & $\begin{array}{c}\text { Organic Carbon } \\
\text { (\% by diff.) } \\
\end{array}$ \\
\hline Backfill & 25.75 & 0.29 & 0.19 & 1.54 & 0.11 \\
\hline Backfill & 31.00 & 0.22 & 0.13 & 1.08 & 0.09 \\
\hline Backfill & 37.15 & 0.26 & 0.16 & 1.31 & 0.11 \\
\hline H1 & 40.80 & 0.27 & 0.19 & 1.59 & 0.08 \\
\hline H1 & 40.80 & 0.24 & 0.17 & 1.44 & 0.07 \\
\hline H1 & 45.45 & 0.37 & 0.24 & 1.98 & 0.14 \\
\hline H1 & 49.25 & 0.27 & 0.17 & 1.41 & 0.10 \\
\hline $\mathrm{H} 1$ & 55.20 & 0.26 & 0.17 & 1.42 & 0.09 \\
\hline $\mathrm{H} 1$ & 60.00 & 0.28 & 0.13 & 1.06 & 0.16 \\
\hline $\mathrm{H} 1$ & 60.00 & 0.25 & 0.15 & 1.23 & 0.11 \\
\hline H1 & 62.50 & 0.18 & 0.11 & 0.89 & 0.07 \\
\hline $\mathrm{H} 1$ & 64.85 & 0.19 & 0.10 & 0.86 & 0.08 \\
\hline $\mathrm{H} 1$ & 66.20 & 0.25 & 0.18 & 1.50 & 0.07 \\
\hline $\mathrm{H} 2$ & 71.25 & 0.34 & 0.25 & 2.08 & 0.09 \\
\hline $\mathrm{H} 2$ & 79.55 & 0.32 & 0.23 & 1.89 & 0.09 \\
\hline $\mathrm{H} 2$ & 79.55 & 0.26 & \begin{tabular}{|l|}
0.17 \\
\end{tabular} & 1.46 & 0.09 \\
\hline $\mathrm{H} 2$ & 106.05 & 0.30 & 0.21 & 1.73 & 0.10 \\
\hline $\mathrm{H} 2$ & 110.15 & 0.22 & 0.15 & 1.26 & 0.07 \\
\hline $\mathrm{H} 2$ & 117.40 & 0.24 & 0.18 & 1.49 & 0.06 \\
\hline $\mathrm{H} 2$ & 120.25 & 0.21 & 0.16 & 1.33 & 0.05 \\
\hline $\mathrm{H} 2$ & 123.65 & 0.23 & 0.18 & 1.46 & 0.06 \\
\hline $\mathrm{H} 2$ & 126.35 & 0.31 & 0.21 & 1.74 & 0.10 \\
\hline $\mathrm{H} 2$ & 126.75 & 0.19 & 0.15 & 1.25 & 0.04 \\
\hline $\mathrm{H} 2$ & 127.85 & 0.22 & 0.17 & 1.38 & 0.06 \\
\hline $\mathrm{H} 2$ & 130.65 & 0.24 & 0.16 & 1.36 & 0.07 \\
\hline $\mathrm{H} 2$ & 133.75 & 0.28 & 0.25 & 2.10 & 0.03 \\
\hline $\mathrm{H} 2$ & 136.75 & 0.21 & 0.17 & 1.41 & 0.04 \\
\hline $\mathrm{H} 2$ & 140.00 & 0.16 & 0.09 & 0.74 & 0.07 \\
\hline $\mathrm{H} 2$ & 143.25 & 0.17 & 0.11 & 0.94 & 0.06 \\
\hline $\mathrm{H} 2$ & 148.30 & 0.19 & 0.16 & 1.37 & 0.03 \\
\hline $\mathrm{H} 2$ & 148.30 & 0.32 & 0.30 & 2.50 & 0.02 \\
\hline $\mathrm{H} 2$ & 165.75 & 0.14 & 0.08 & 0.70 & 0.05 \\
\hline $\mathrm{H} 2$ & 170.25 & 0.08 & 0.04 & 0.36 & 0.04 \\
\hline $\mathrm{H} 2$ & 174.05 & 0.09 & 0.07 & 0.58 & 0.02 \\
\hline
\end{tabular}


The status of soil water can be defined by either the amount of water in the soil (water content) or by the force that holds water to the soil matrix (i.e., the matric potential or suction) (Or and Wraith 2002). In recent studies, Serne et al. (2002b, 2002c, 2002e, and 2002f) and Lindenmeier et al. (2002) measured both water content (gravimetrically) and matric water potential (filter paper method, ASTM 2002) on core samples obtained from boreholes in the SX and B-BX Tank Farm environs. The same measurements were made at borehole C4297 on the sediments in each A liner several weeks after the samples had been opened and sub-sampled. Sandwiched filter papers were added to the air tight plastic storage containers that contained the residual sediment. The data are presented in Table 4.32 and Figure 4.31. To generate the theoretical unit gradient line (gravity head) shown in Figure 4.31, we estimated the water table to be present at an elevation of $448.32 \mathrm{ft}$ above mean sea level or $251 \mathrm{ft}$ bgs, based on nearby groundwater monitoring wells.

The gravity head is zero at the water table and increases linearly with height to the soil surface. For the core samples available from C4297, the measured water potentials were generally much less than the gravity potential from the shallowest core at $19.5 \mathrm{ft}$ bgs down to the deepest core taken at $195.25 \mathrm{ft}$ bgs, representing both the Hanford formation H1 and H2 units. The red line labeled "theoretical value" in Figure 4.31 is the theoretical line that represents the steady-state unit gradient condition, which represents the profile for matric potential in a sediment profile that is neither draining nor drier than (actively evapotranspiring) equilibrium. Matric potential values to the left of the unit gradient line suggest a draining profile. Only one sample, collected at $150 \mathrm{ft}$ bgs, had a measured matric potential in excess of the theoretical matric potential line plotted in Figure 4.31, which could be an artifact of inadvertent drying during sample storage. Nearly all of the matric potentials were very low in comparison of the gravity head. The general trend for the data from C4297 is that the water potentials were consistent with a draining profile. 
Table 4.32. Matric Potential of Vadose Zone Sediments in Borehole C4297

\begin{tabular}{|c|c|c|c|c|c|c|c|c|}
\hline $\begin{array}{l}\text { Depth } \\
\text { (ft bgs) }\end{array}$ & $\begin{array}{c}\text { Stratigraphic } \\
\text { Unit }\end{array}$ & $\begin{array}{l}\text { Matric Potential } \\
\text { (Mpa) }\end{array}$ & $\begin{array}{l}\text { Depth } \\
\text { (ft bgs) }\end{array}$ & $\begin{array}{c}\text { Stratigraphic } \\
\text { Unit }\end{array}$ & $\begin{array}{c}\text { Matric Potential } \\
\text { (Mpa) }\end{array}$ & \begin{tabular}{|l} 
Depth \\
(ft bgs)
\end{tabular} & $\begin{array}{c}\text { Stratigraphic } \\
\text { Unit }\end{array}$ & $\begin{array}{l}\text { Matric Potential } \\
\text { (Mpa) }\end{array}$ \\
\hline 2.5 & Backfill & 0.0055 & 63.5 & H1 & 0.1225 & 122 & $\mathrm{H} 2$ & 0.0464 \\
\hline 7 & Backfill & 0.0041 & 64.85 & H1 & 0.0094 & 123.65 & $\mathrm{H} 2$ & 0.0077 \\
\hline 12 & Backfill & 0.0063 & 64.85 & H1 & 0.0144 & 124.6 & $\mathrm{H} 2$ & 0.0214 \\
\hline 17 & Backfill & 0.0112 & 66.2 & H2 & 0.0122 & \begin{tabular}{|l|}
124.85 \\
\end{tabular} & $\mathrm{H} 2$ & 0.0495 \\
\hline 22 & Backfill & 0.0055 & 67.7 & $\mathrm{H} 2$ & 0.0054 & 125.35 & $\mathrm{H} 2$ & 0.0898 \\
\hline 24.25 & Backfill & 0.0095 & 68.95 & H2 & 0.0055 & 125.85 & H2 & 0.0341 \\
\hline 24.75 & Backfill & 0.0799 & 69.75 & $\mathrm{H} 2$ & 0.1633 & 126.35 & H2 & 0.0636 \\
\hline 25.25 & Backfill & 0.0048 & 70.25 & $\mathrm{H} 2$ & 0.0065 & 126.75 & $\mathrm{H} 2$ & 0.106 \\
\hline 25.75 & Backfill & 0.0047 & 70.75 & H2 & 0.0195 & 127.85 & $\mathrm{H} 2$ & 0.0894 \\
\hline 26.15 & Backfill & 0.0039 & 71.25 & H2 & 0.0565 & 127.85 & H2 & 0.0607 \\
\hline 27.15 & Backfill & 0.0137 & 71.65 & H2 & 0.0806 & 129.4 & $\mathrm{H} 2$ & 0.0999 \\
\hline 28.6 & Backfill & 0.0046 & 72.65 & H2 & 0.0188 & 130.65 & H2 & 0.0578 \\
\hline 29.5 & Backfill & 0.0105 & 74.25 & H2 & 0.0119 & 132.15 & $\mathrm{H} 2$ & 0.0049 \\
\hline 30 & Backfill & 0.0297 & 76 & H2 & 0.0255 & 133.75 & H2 & 0.0034 \\
\hline 30.5 & Backfill & 0.0116 & 77.4 & H2 & 0.0047 & \begin{tabular}{|l}
135.25 \\
\end{tabular} & H2 & 0.0054 \\
\hline 31 & Backfill & 0.0042 & 78.05 & $\mathrm{H} 2$ & 0.0066 & 136.75 & H2 & 0.0055 \\
\hline 31.4 & Backfill & 0.0036 & 78.55 & $\mathrm{H} 2$ & 0.0041 & 138.25 & H2 & 0.0185 \\
\hline 32.28 & Backfill & 0.0046 & 79.05 & $\mathrm{H} 2$ & 0.0169 & 140 & H2 & 0.0654 \\
\hline 32.28 & Backfill & 0.0043 & 79.55 & H2 & 0.0117 & 141.75 & $\mathrm{H} 2$ & 0.0048 \\
\hline 33.75 & Backfill & 0.0058 & 79.95 & H2 & 0.0101 & 143.25 & H2 & 0.0831 \\
\hline 35.25 & Backfill & 0.0059 & 81.05 & $\mathrm{H} 2$ & 0.0154 & 144.5 & $\mathrm{H} 2$ & 0.0098 \\
\hline 36.25 & Backfill & 0.0038 & 82.75 & $\mathrm{H} 2$ & 0.0051 & \begin{tabular}{|l|}
146.25 \\
\end{tabular} & $\mathrm{H} 2$ & 0.023 \\
\hline 36.65 & Backfill & 0.0113 & 84.75 & H2 & 0.0084 & 148.3 & $\mathrm{H} 2$ & 0.2257 \\
\hline 37.15 & Backfill & 0.0073 & 86.75 & H2 & 0.0046 & 150.05 & H2 & 0.3409 \\
\hline
\end{tabular}


Table 4.32. (contd)

\begin{tabular}{|c|c|c|c|c|c|c|c|c|}
\hline $\begin{array}{l}\text { Depth } \\
\text { (ft bgs) }\end{array}$ & $\begin{array}{c}\text { Stratigraphic } \\
\text { Unit }\end{array}$ & $\begin{array}{l}\text { Matric Potential } \\
\text { (Mpa) }\end{array}$ & $\begin{array}{c}\text { Depth } \\
\text { (ft bgs) }\end{array}$ & $\begin{array}{l}\text { Stratigraphic } \\
\text { Unit }\end{array}$ & $\begin{array}{c}\text { Matric Potential } \\
\text { (Mpa) }\end{array}$ & \begin{tabular}{|c} 
Depth \\
(ft bgs)
\end{tabular} & $\begin{array}{c}\text { Stratigraphic } \\
\text { Unit }\end{array}$ & $\begin{array}{l}\text { Matric Potential } \\
\text { (Mpa) }\end{array}$ \\
\hline 37.55 & Backfill & 0.0145 & 88.5 & $\mathrm{H} 2$ & 0.0629 & 151.5 & $\mathrm{H} 2$ & 0.2021 \\
\hline 38.35 & Backfill & 0.003 & 90.1 & $\mathrm{H} 2$ & 0.0373 & 153 & $\mathrm{H} 2$ & 0.0664 \\
\hline 38.53 & Backfill & 0.0044 & 91.6 & $\mathrm{H} 2$ & 0.0128 & 154.65 & $\mathrm{H} 2$ & 0.0456 \\
\hline 39.3 & Backfill & 0.0027 & 91.6 & $\mathrm{H} 2$ & 0.0123 & 156.65 & $\mathrm{H} 2$ & 0.0332 \\
\hline 39.8 & H1 & 0.0098 & 93.25 & $\mathrm{H} 2$ & 0.0047 & \begin{tabular}{|l|}
156.65 \\
\end{tabular} & $\mathrm{H} 2$ & 0.0298 \\
\hline 40.3 & H1 & 0.0049 & 95 & $\mathrm{H} 2$ & 0.0386 & 159 & $\mathrm{H} 2$ & 0.0532 \\
\hline 40.8 & H1 & 0.0043 & 96.6 & $\mathrm{H} 2$ & 0.005 & 161.25 & H2 & 0.1624 \\
\hline 41.2 & $\mathrm{H} 1$ & 0.0081 & 98 & $\mathrm{H} 2$ & 0.0376 & 163.75 & $\mathrm{H} 2$ & 0.0453 \\
\hline 42.18 & $\mathrm{H} 1$ & 0.006 & 99.6 & $\mathrm{H} 2$ & 0.0119 & 165.75 & $\mathrm{H} 2$ & 0.0919 \\
\hline 43.75 & $\mathrm{H} 1$ & 0.013 & 101.2 & $\mathrm{H} 2$ & 0.1616 & \begin{tabular}{|l|}
167.75 \\
\end{tabular} & H2 & 0.0382 \\
\hline 44.45 & H1 & 0.0089 & 102.75 & $\mathrm{H} 2$ & 0.0219 & 170.25 & H2 & 0.0347 \\
\hline 44.95 & H1 & 0.0126 & 104 & $\mathrm{H} 2$ & 0.0055 & 172.3 & H2 & 0.0385 \\
\hline 45.45 & H1 & 0.0389 & 104.55 & $\mathrm{H} 2$ & 0.0087 & 174.05 & H2 & 0.0267 \\
\hline 45.85 & H1 & 0.0277 & 105.05 & $\mathrm{H} 2$ & 0.0034 & 175.65 & $\mathrm{H} 2$ & 0.0818 \\
\hline 47 & H1 & 0.0081 & 105.55 & $\mathrm{H} 2$ & 0.0168 & 176.9 & $\mathrm{H} 2$ & 0.2146 \\
\hline 49.25 & H1 & 0.0043 & 106.05 & $\mathrm{H} 2$ & 0.0634 & 178.7 & H2 & 0.0253 \\
\hline 51.25 & H1 & 0.0156 & 106.45 & $\mathrm{H} 2$ & 0.0084 & 180.7 & H2 & 0.0429 \\
\hline 53 & $\mathrm{H} 1$ & 0.0111 & 107.2 & $\mathrm{H} 2$ & 0.0098 & 182.25 & $\mathrm{H} 2$ & 0.0635 \\
\hline 55.2 & $\mathrm{H} 1$ & 0.0057 & 110.15 & $\mathrm{H} 2$ & 0.0382 & \begin{tabular}{|l|}
184.25 \\
\end{tabular} & $\mathrm{H} 2$ & 0.1594 \\
\hline 57.2 & H1 & 0.0201 & 112.25 & $\mathrm{H} 2$ & 0.0417 & \begin{tabular}{|l|}
186.25 \\
\end{tabular} & $\mathrm{H} 2$ & 0.0873 \\
\hline 58.5 & H1 & 0.0366 & 114.2 & $\mathrm{H} 2$ & 0.0473 & 188.5 & H2 & 0.0713 \\
\hline 60 & H1 & 0.0152 & 115.95 & $\mathrm{H} 2$ & 0.0106 & \begin{tabular}{|l|}
191.25 \\
\end{tabular} & H2 & 0.1169 \\
\hline 61.5 & H1 & 0.0311 & 117.4 & $\mathrm{H} 2$ & 0.0111 & \begin{tabular}{|l|}
193.25 \\
\end{tabular} & $\mathrm{H} 2$ & 0.0234 \\
\hline 62 & H1 & 0.0894 & 119 & $\mathrm{H} 2$ & 0.0268 & \begin{tabular}{|l|}
195.25 \\
\end{tabular} & $\mathrm{H} 2$ & 0.0377 \\
\hline 62.5 & H1 & 0.3549 & 120.25 & $\mathrm{H} 2$ & 0.0225 & 249.75 & Water Table & 0 \\
\hline 62.9 & H1 & 0.1402 & & & & & & \\
\hline
\end{tabular}




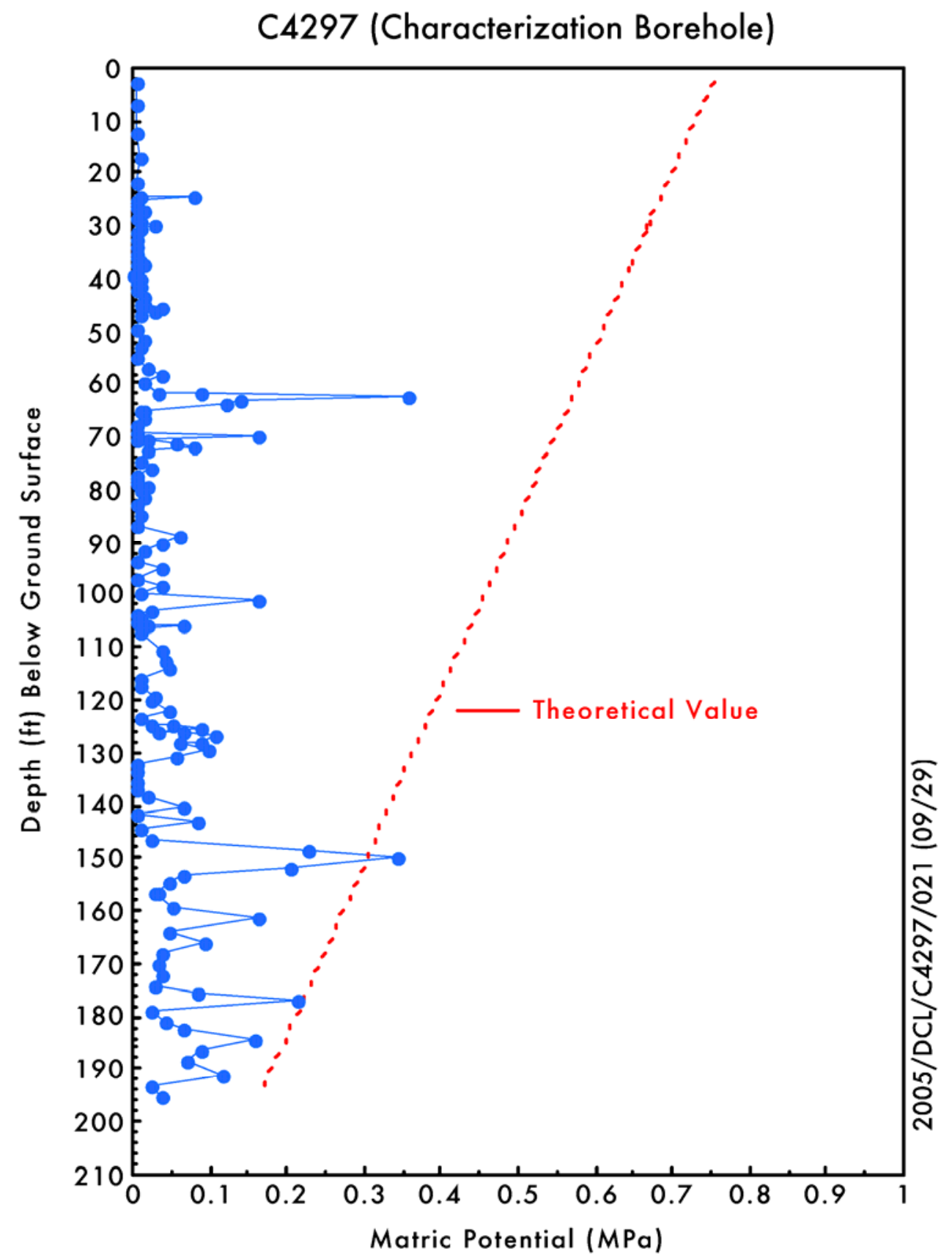

Figure 4.31. Matric Potential for Borehole C4297 Samples (measured after cores were sub-sampled) 


\subsection{Groundwater Status Below the C Tank Farm}

This section summarizes historical and recent groundwater data from the uppermost, unconfined aquifer in the vicinity of WMA C. Historical water levels, flow directions, and contaminant histories in key wells near the WMA are reviewed as background for understanding current groundwater contaminant distribution patterns and their relationship to possible contaminant sources.

Selected ratios of mobile contaminants in: (1) the water extracts of vadose zone sediments from borehole C4297 (Section 4.2), (2) the groundwater, and (3) estimates of contaminants from tank C-105 at the time of suspected leak are used to assess whether groundwater contamination is related to the current vadose zone contamination and to the tank leak.

\subsection{Aquifer Properties}

This section provides information on the properties of the uppermost, unconfined aquifer in the immediate region of WMA C. Much of the information presented in this section is taken from Reidel et al. (2006), Horton and Narbutovskih (2001), and Wood et al. (2003). Aquifer properties were determined from stratigraphic interpretations, current water-level elevations, and aquifer testing.

The base of the uppermost unconfined aquifer in the 200 East Area is generally regarded as the basalt surface and, where this is the case, the suprabasalt aquifer consists entirely of the uppermost and unconfined aquifer. In the south part of the 200 East Area, where the Ringold Formation is present in the suprabasalt aquifer, the silt and clay beds of the formation's hydrogeologic unit 8 (lower mud unit) form a confining layer that separates the suprabasalt aquifer into an upper unconfined aquifer and an underlying confined aquifer. These two aquifers make up the suprabasalt aquifer system (Williams et al. 2000). These aquifers have separate and distinct flow regimes.

The unconfined aquifer consists primarily of hydrogeologic unit 1 (undifferentiated Hanford formation), coarse grained CCU deposits, and hydrogeologic unit 5 (member of Wooded Island unit E of the Ringold Formation). Where hydrogeologic unit 8 has been removed by erosion, the unconfined aquifer may also include hydrogeologic unit 9 (member of Wooded Island unit A of the Ringold Formation). Hydrogeologic unit 8 has been removed from almost all the 200 East Area and is not present beneath WMA C. Therefore, the following discussion focuses only on the unconfined aquifer.

Two wells extend through the unconfined aquifer, near WMA C, to the top of basalt and can be used to determine the thickness of the aquifer. Table 5.1 gives information used to estimate the thickness of the unconfined aquifer based on March 2005 water levels. The data show that the unconfined aquifer is 9 to 10 meters thick beneath WMA C. The unconfined aquifer consists mostly of sandy gravels and gravelly sands of the Hanford formation. All wells in the WMA C monitoring network are screened in hydrogeologic unit 1. Currently, the water table at WMA C is approximately $122 \mathrm{~m}$ above sea level. Figure 5.1 shows the locations of the monitoring wells in the WMA C monitoring network. 
Table 5.1. Thickness of the Unconfined Aquifer beneath Waste Management Area C

\begin{tabular}{||l|l|l|l||}
\hline \hline \multicolumn{1}{|c|}{ Well Name } & \multicolumn{1}{|c||}{$\begin{array}{c}\text { Elevation of Aquifer Bottom } \\
(\mathbf{m} \text { amsl) }\end{array}$}
\end{tabular}

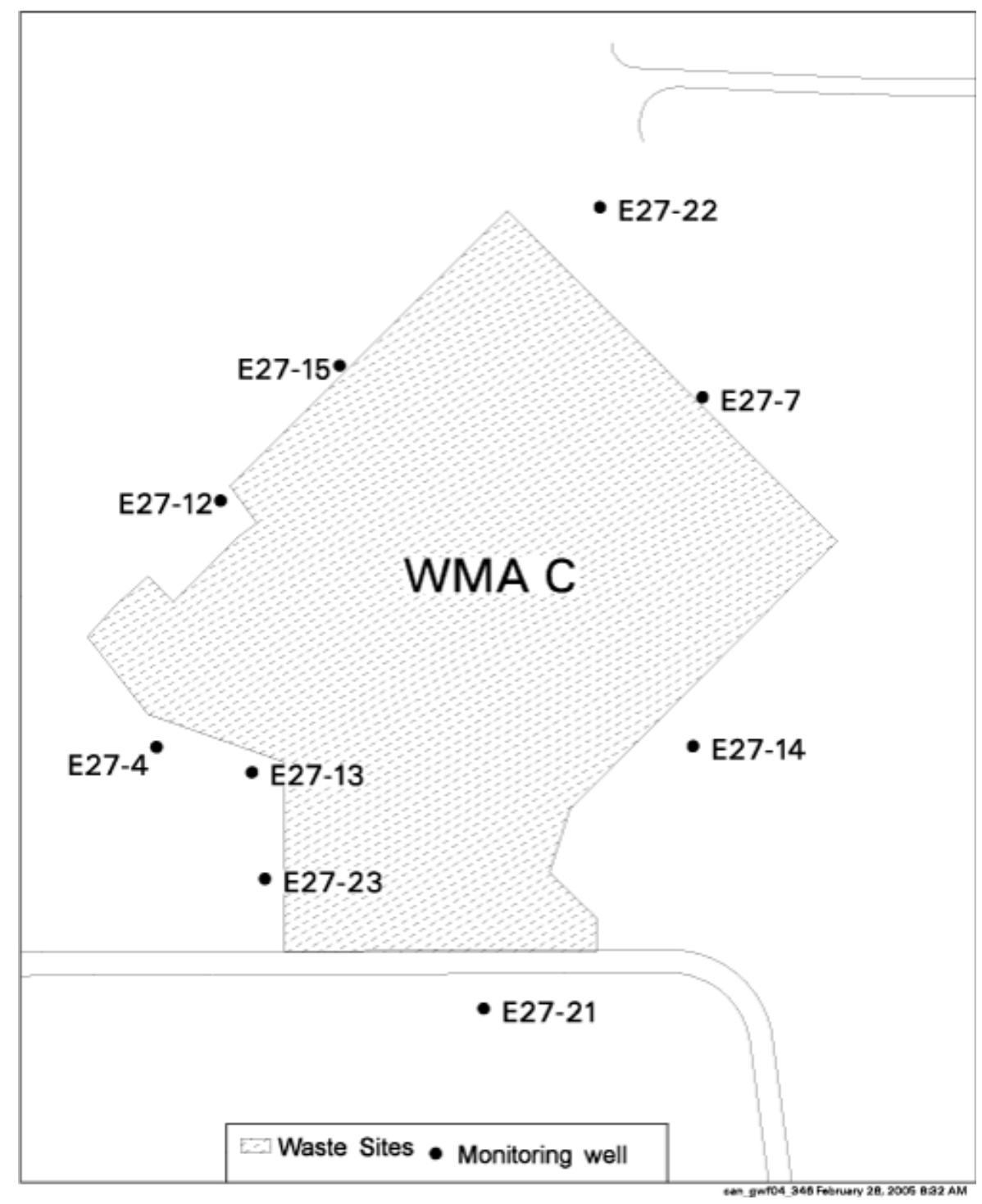

Figure 5.1. Well Location Map for Waste Management Area C 
The unconfined aquifer below WMA C has been impacted by past practice liquid waste disposal operations. Water levels in the upper unconfined aquifer raised as much as $9 \mathrm{~m}$ above the pre-Hanford natural water table beneath the north part of the 200 East Area because of artificial recharge from liquid waste disposal operations since the mid-1940s. The largest volumes of discharge were to the 216-B Pond system, located about 1.5 to 2 kilometers east of WMA C and to the 216-A-25 (Gable Mountain pond system) north of the 200 East Area; lesser but substantial volumes of liquid were discharged to several of the PUREX cribs east and south of WMA C. Figure 5.2 shows the liquid discharge history for the two pond systems. The 216-B Pond system is estimated to have received approximately 256 billion liters of effluent (see Virtual Library). The large-volume disposal to the ponds (and lesser volumes to cribs and ditches) artificially recharged the unconfined aquifer, creating large water table mounds.

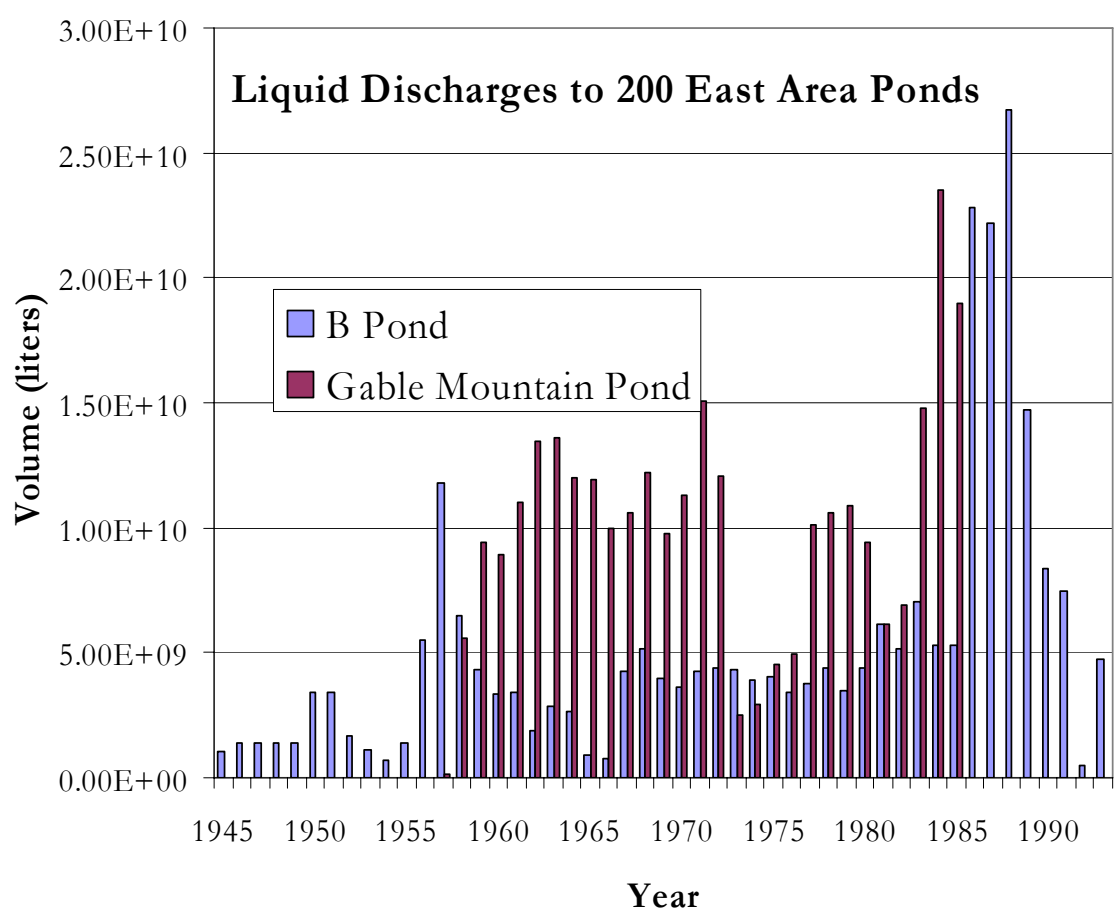

Figure 5.2. Discharge History for the 216-B Pond and the Gable Mountain Pond through 1993.

Data are from the Virtual Library

Figure 5.3 shows hydrographs for wells in the area of WMA C. The hydrographs illustrate the changes in water table elevations that occurred beneath the WMA since the late 1940s. All data used to make the hydrographs were obtained from the HydroDat database (see CD in back of: Hartman et al. 2004).

The hydrographs in Figure 5.3 show a maximum in water table elevation in about 1968 that corresponds to a time of high discharge to Gable Mountain pond (Figure 5.2). This maximum is followed by a minimum, centered around 1978, that corresponds to a minimum in the discharges to both pond systems. Finally, a second maximum is seen in 1986 to 1987 corresponding to peak discharge to the B Pond system. The water table began to decline in the early 1990s when non-permitted discharges to disposal facilities were reduced, and finally terminated in 1995, and this decline continues today. The decline in water levels may have implications for the groundwater monitoring network at the WMA C as discussed in Hanlon 2005. 


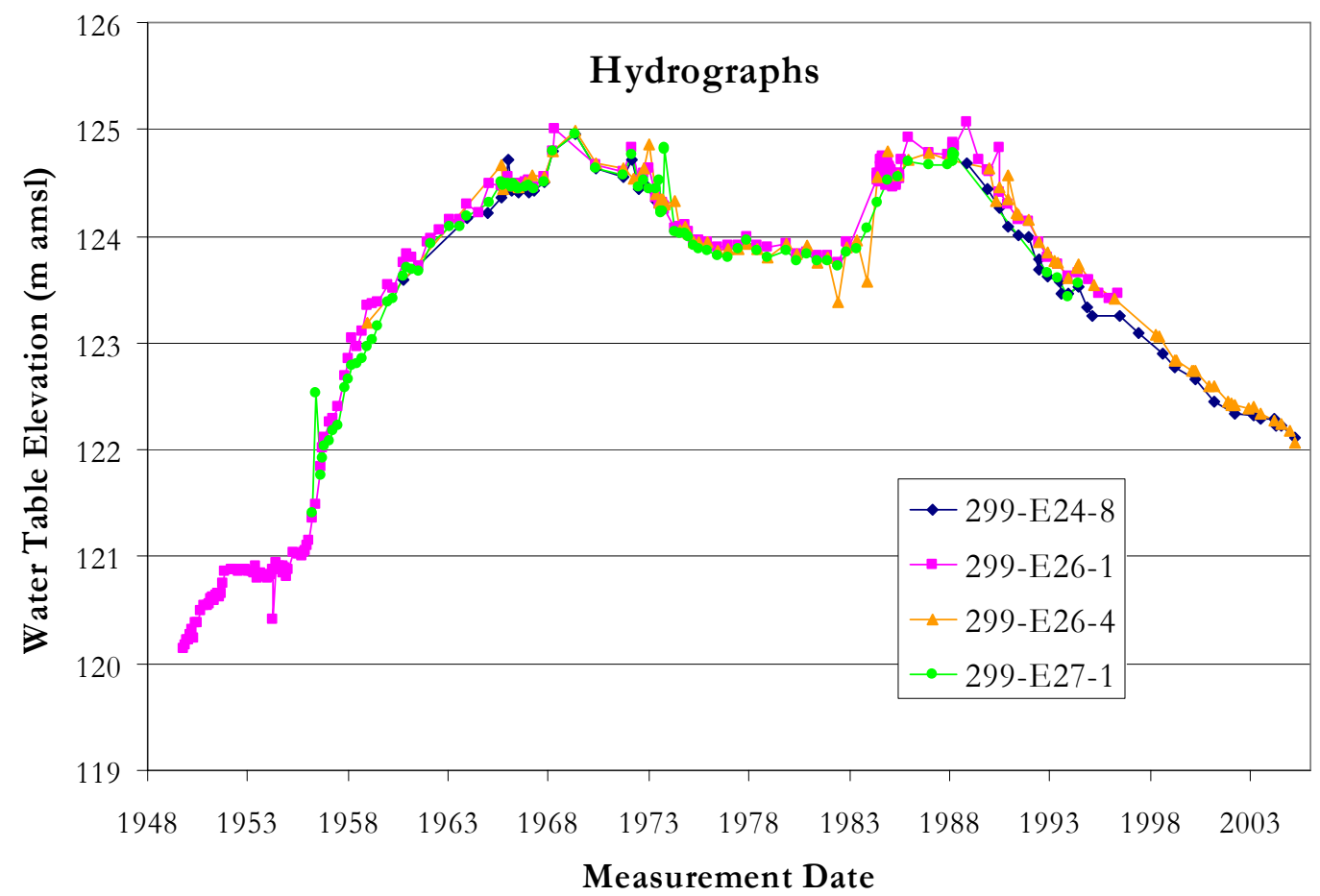

Figure 5.3. Hydrographs from Selected Wells around Waste Management Area C, 200 East Area. (Well 299-E24-8 is located about 650 meters south-southwest of C Tank Farm; well 299-E26-1 is located about 450 meters north of the C Tank Farm; well 299-E26-4 is located about 500 meters southeast of the C Tank Farm; well 299-E27-1 is located about 500 meters west of the C Tank Farm.)

Accompanying the changes in water level were changes in groundwater flow direction. Histograms (rose diagrams) showing groundwater flow directions beneath the C Tank Farm during different time periods are shown in Figure 5.4. Figure 5.4(a) shows historic groundwater flow directions in the area of WMA C between 1958 and 1994, and Figure 5.4(b) shows more recent flow directions between 1990 and 2003. The earlier historic flow directions are determined from relatively far field wells whereas the more recent flow directions are determined from wells in the RCRA monitoring network for the WMA. The pre-Hanford Site groundwater flow direction was toward the east (Kipp and Mudd 1974) in the area of WMA C. Figure 5.4 shows that the groundwater flow direction beneath the east-central part of 200 East Area had changed toward the southwest by the late 1950s due to the influence of the pond disposal systems. Water table maps in Kipp and Mudd (1974) show that the groundwater flow direction had actually changed toward the southwest by the early 1950s. The groundwater flow direction has been fairly constant and toward the southwest since that time. The general southwest flow direction for WMA C shown in Figure 5.4 is in general agreement with the flow direction inferred from the current water table map shown in Figure 5.5 (Hartman et al. 2005). 


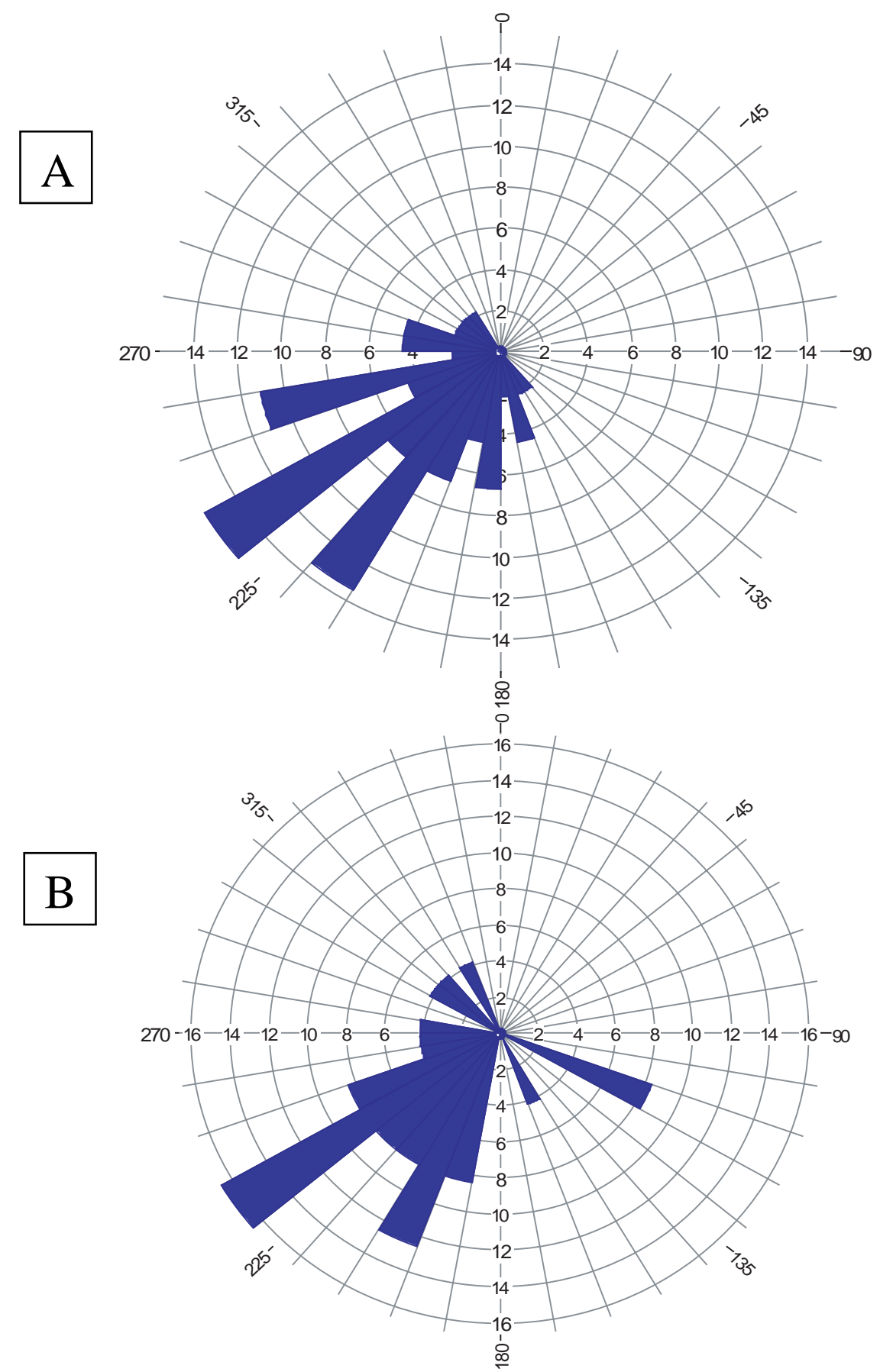

Figure 5.4. Groundwater Flow Directions in the Vicinity of the C Tank Farm (A) 1958 to 1994, Wells 299-E26-1, 299-E26-4, and 299-E27-1, 45 Measurements; and (B) 1990 to 2003, Wells 299-E27-12, 299-E27-14, and 299-E27-7, 24 Measurements 


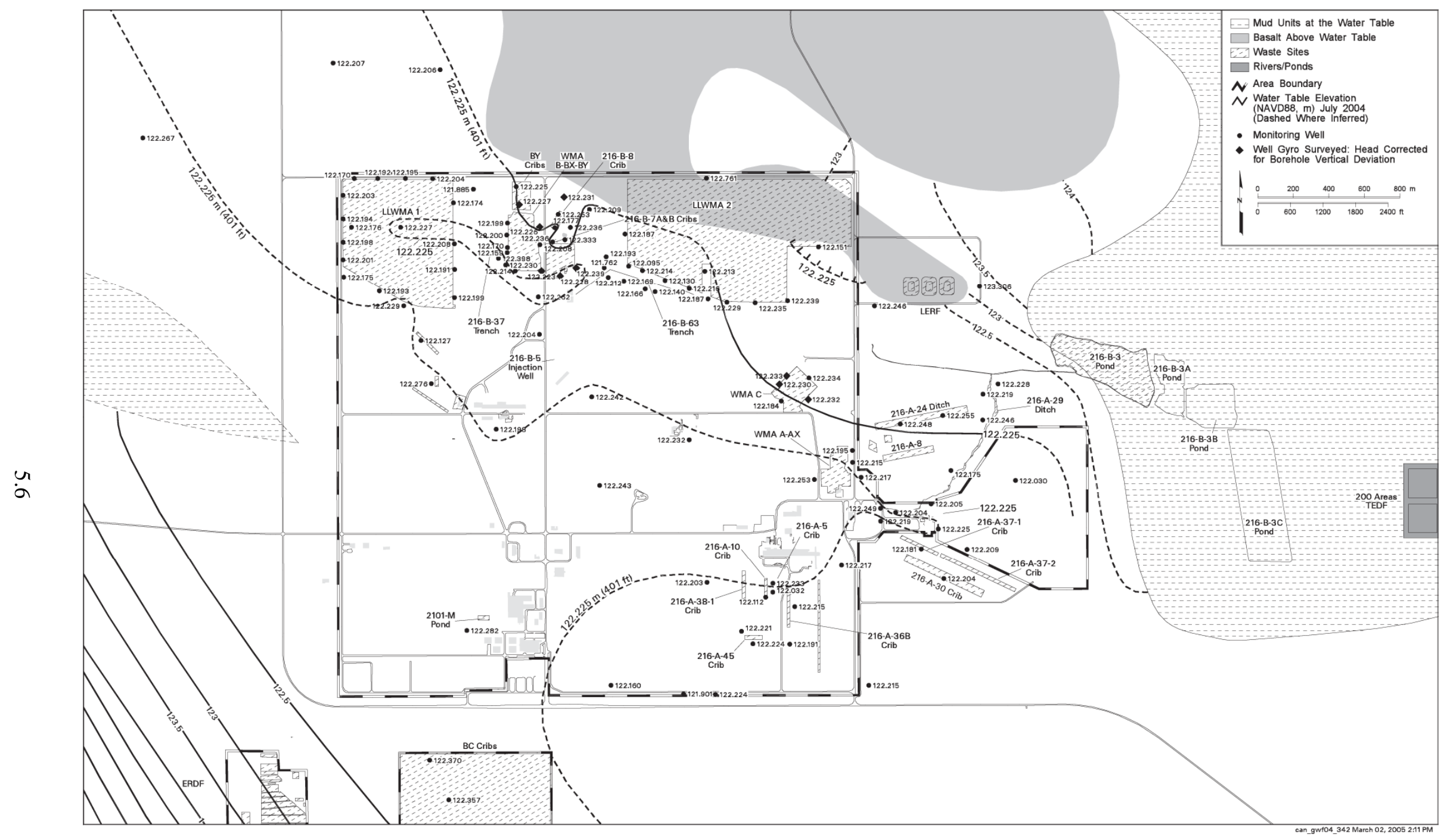

Figure 5.5. July 2004 Water Table Map for the 200 East Area (from Hartman et al. 2005) 
The large shift in groundwater flow direction resulting from intentional discharges to past practice disposal facilities may have broad implications for contaminant distribution in the uppermost aquifer beneath the C Tank Farm. Since the early 1950s, any contamination entering the aquifer in the region was spread toward the southwest. Contamination that was spread southwest from facilities in the northern part of the 200 East Area may return to the area of WMA C as groundwater returns to the pre-Hanford easterly direction.

Hydrologic testing (slug tests) has been done at only one well at WMA C in the past few years. Four slug tests were performed at selected test/depth intervals in well 299-E27-22 as the well was being drilled in 2003. Table 5.2 gives the results of the aquifer tests and the calculated groundwater flow velocity. Table 5.3 gives the resulting hydraulic conductivity and transmissivity data from slug tests done at three wells at WMA C during 1989 (Caggiano 1993) and flow velocities calculated from those data. Finally, estimates of groundwater flow velocity for WMA C are given in Appendix B of Hartman et al. (2005). Those estimates are 1.4 to $4.8 \mathrm{~m} /$ day.

Table 5.2. Results of Slug Testing in Well 299-E27-22 at Waste Management Area $C^{(a)}$

\begin{tabular}{||l|l|l||}
\hline \multicolumn{1}{|c||}{$\begin{array}{c}\text { Well (and Depth Interval Tested } \\
\text { (m bgs) }\end{array}$} & \multicolumn{1}{|c||}{$\begin{array}{c}\text { Hydraulic Conductivity } \\
\text { (m/day) }\end{array}$} & $\begin{array}{c}\text { Calculated Groundwater } \\
\text { Flow Velocity } \\
\text { (m/day) }\end{array}$ \\
\hline \hline 299-E27-22 (75.1 - 75.9) & $1900-2100$ & 2.31 \\
\hline 299-E27-22 (76.8 - 77.4) & 0.04 & 0.00004 \\
\hline 299-E27-22 (81.4 - 81.7) & $6000-6900$ & 7.59 \\
\hline $\begin{array}{l}\text { (a) Letter Report, FA Spane to JV Borghese, October 8, 2003, Slug Test Characterization Results for } \\
\text { Multi-Test/Depth Intervals Conducted During the Drilling of WMA C Well 299-E27-22 (C4124). } \\
\text { (b) Estimated using the maximum hydraulic conductivity from this table and effective porosity of } 0.3 \text { and } \\
\text { hydraulic gradient of 0.00033 from Hartman et al. (2004). }\end{array}$ \\
\hline
\end{tabular}

Table 5.3. Results of 1989 Slug Testing at Three Wells at Waste Management Area $C^{(a)}$

\begin{tabular}{|c|c|c|c|}
\hline Well Name & $\begin{array}{l}\text { Hydraulic Conductivity } \\
\text { (m/day) }\end{array}$ & $\begin{array}{c}\text { Transmissivity } \\
\left(\mathrm{m}^{2} / \text { day }\right)^{(\mathbf{b})}\end{array}$ & $\begin{array}{c}\text { Calculated Groundwater } \\
\text { Flow Velocity } \\
(\mathbf{m} / \text { day })^{(\mathbf{c})}\end{array}$ \\
\hline 299-E27-13 & 54.9 & 230 & 0.06 \\
\hline 299-E27-14 & 48.8 & 240 & 0.05 \\
\hline 299-E27-15 & 118.9 & 520 & 0.13 \\
\hline \multicolumn{4}{|c|}{$\begin{array}{l}\text { (a) Data from Caggiano (1993) have been converted to metric units and the reported values are rounded. } \\
\text { (b) Transmissivity calculated by multiplying hydraulic conductivity by thickness of test interval. } \\
\text { (c) Estimated using hydraulic conductivity from this table and effective porosity of } 0.3 \text { and hydraulic gradient } \\
\text { of } 0.00033 \text { from Hartman et al. } 2003 \text {. }\end{array}$} \\
\hline
\end{tabular}

The calculated flow velocities for groundwater beneath WMA C vary by several orders of magnitude (five) from 0.00004 to $7.59 \mathrm{~m} /$ day. These kinds of differences in hydraulic properties illustrate the difficulty in assigning accurate values to specific hydrogeologic units in the 200 East Area. The differences are due to different testing and analysis methods used through time, different assumed values 
for certain parameters, such as effective porosity, and natural variation in lithologic properties that affect the hydraulic properties. Also, the differences noted in the hydraulic conductivity among different depths in the same well (see well 299-E27-22 in Table 5.2) attest to the variations in hydraulic properties in the aquifer sediments.

Figure 5.6 shows hydrographs for selected wells in the WMA C RCRA monitoring network. The hydrographs show that water levels have declined by about 2 meters since 1990 beneath the C Tank Farm. This decline, resulting from decreasing effluent discharge and ultimately cessation of discharge to primarily the B Pond system, has been fairly constant at about $0.14 \mathrm{~m} / \mathrm{yr}$ during the last 15 years.

The pre-Manhattan Project water table was estimated at approximately 117 to 119 meters above sea level in the area of C Tank Farms by Kipp and Mudd (1974). Thus, water levels will probably continue to drop another 2 to 4 meters before reaching equilibrium with post-Hanford Site conditions.

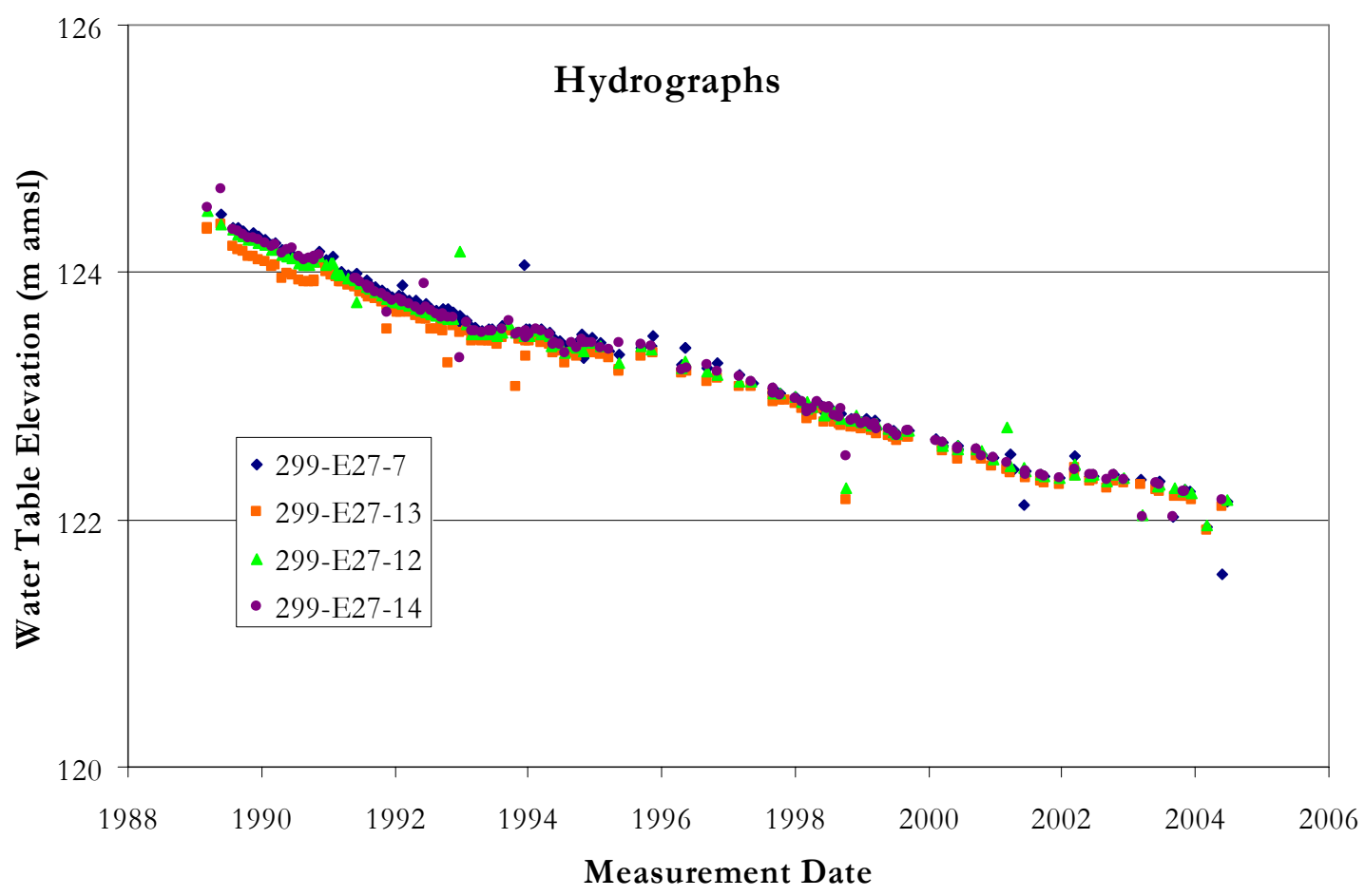

Figure 5.6. Historic Water Table Elevations in Selected Wells at Waste Management Area C

\subsection{Existing Groundwater Contamination}

This section discusses the current and historical groundwater contamination at WMA C. The evaluation of contamination includes descriptions of the types and concentrations of contaminants in the groundwater and the aerial extent of contamination in the area.

\subsubsection{Extent of Contamination - Depth Distribution}

Very little information is available concerning the vertical extent of contaminants in the uppermost aquifer beneath the $C$ tank farm. Well 299-E27-22 is the only well in the area that has been sampled at more than one depth in the aquifer. Air-lifted groundwater samples were collected during drilling of 
well 299-E27-22 from five intervals in the aquifer. Samples were analyzed for specific conductivity, nitrate, technetium-99, and pH (Williams and Narbutovskih 2004). Table 5.4 and Figure 5.7 show the analytical results.

The data show that specific conductance, nitrate, and technetium-99 all increase with increasing depth, although the magnitude of the increase is not great; all concentrations are greater than Hanford Site background. However, well 299-W27-22, is an upgradient well and the magnitude of the concentrations are less than the concentrations found in some downgradient wells at the time well 299-E27-22 was drilled.

The latest (September 2005) sampling of well 299-E27-22 yielded a nitrate concentration of $24.8 \mathrm{mg} / \mathrm{L}$ and technetium-99 concentration of $30.2 \mathrm{pCi} / \mathrm{L}$. These concentrations were obtained from the screened, upper 10 meters of the aquifer and appear reasonable when compared with the depth discrete data in Figure 5.7.

Table 5.4. Depth-Discrete Water Sample Results from Well 299-E27-22

(Williams and Narbutovskih 2004)

\begin{tabular}{|c|c|c|c|c|}
\hline $\begin{array}{c}\text { Sample Depth } \\
\text { (m below water table) }\end{array}$ & $\begin{array}{l}\text { Specific Conductivity } \\
(\mu \mathrm{S} / \mathrm{cm})\end{array}$ & pH & $\begin{array}{l}\text { Nitrate } \\
(\mathrm{mg} / \mathrm{L})\end{array}$ & $\begin{array}{c}\text { Tc-99 } \\
(\mathrm{pCi} / \mathrm{L})\end{array}$ \\
\hline $2.8-3.7$ & 447 & ND & 14.2 & 10.9 \\
\hline $5.0-5.9$ & 412 & 8.11 & 16.2 & $\mathrm{U}$ \\
\hline $6.6-7.2$ & 429 & 7.95 & 18.4 & 14 \\
\hline 9.0 & 439 & 7.98 & 20.1 & 38.5 \\
\hline 11.4 & 563 & 8.01 & 31.1 & 80.1 \\
\hline Hanford Site background $^{(\mathrm{a})}$ & 348 & 7.78 & 5.68 & 0.447 \\
\hline \multicolumn{5}{|l|}{$\begin{array}{l}\text { (a) Data from DOE (1997). } \\
\text { ND = Not determined. } \\
\mathrm{U}=\text { Not detected. }\end{array}$} \\
\hline
\end{tabular}




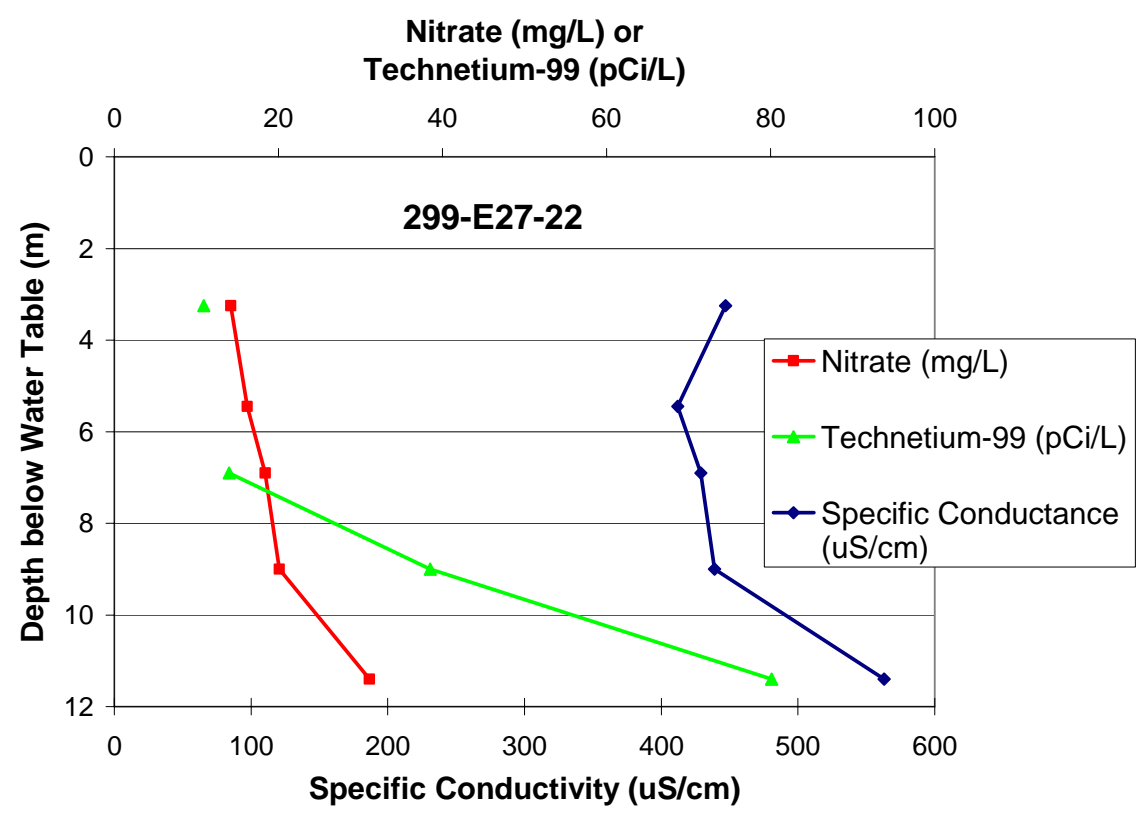

Figure 5.7. Specific Conductance and Concentrations of Nitrate and Technetium-99 versus Depth below the Water Table in Well 299-E27-22.

\subsubsection{Extent of Contamination - Geographic Distribution}

This section summarizes the aerial distribution of contaminants in groundwater at WMA C. The contaminants of concern for WMA C are cyanide, nitrate, iodine-129, technetium-99, and tritium. Spatial variation in contaminant concentrations may provide some clues about sources for the contamination.

Groundwater at the C Tank Farm contains elevated concentrations of calcium, chloride, cyanide, nitrate, sulfate, technetium-99, iodine-129, tritium, and to lesser extents sodium and magnesium. Much of the tritium, nitrate, and iodine-129 at Waste management Area C is attributed to regional plumes that extend across the 200 East Area. However, there is a local area of high nitrate concentration beneath the tank farm and high iodine-129 in one well at the WMA.

Very little data are available before the early 1990s, which is when most of the monitoring wells were drilled at the tank farm. The oldest well, well 299-E27-7, was drilled in 1982 and the oldest groundwater monitoring data associated with the well are gross beta values, beginning in 1984, and nitrate concentrations, beginning in 1985. Between 1984 and about 1998, gross beta values in well 299-E27-7 were only slightly greater than the Hanford Site background of $5.6 \mathrm{pCi} / \mathrm{L}$ (DOE 1997). Nitrate concentrations were close to or less than Hanford Site background concentrations (5,681 $\mu \mathrm{g} / \mathrm{L})$ until about 1992 when an increase in nitrate concentrations occurred, accompanied by increases in concentrations of most major cations and anions. Nitrate decreased to near background concentrations in 1993 and remained low until 1998. Thus, there are no data indicating groundwater contamination beneath WMA C prior to the early 1990s. 
Because concentrations change over time, a time-period must be chosen to examine spatial distribution patterns. For this purpose, the most recent data (average of fiscal year 2005 sampling events) were chosen and these data are tabulated in Table 5.5. Data were then plotted and inspected for distribution patterns or groupings. Contour maps of contaminant concentrations were drawn to identify spatial patterns that might be indicative of source areas. The maps are shown in the series of Figures 5.8 through 5.12.

The data for iodine-129 in Table 5.5 are somewhat misleading because in fiscal year 2005 analyses for iodine-129 were made only on one sample from each of the two wells on the east side of the WMA. Prior to about early 2001, iodine-129 was detected routinely in wells 299-E27-12, 299-E27-13, and 299-E27-15, located along the western edge of the WMA, at concentrations comparable to those in wells along the eastern edge. No analyses were done in the western wells since that time. The situation is similar for tritium in that tritium analyses from all wells done in 2004 and earlier showed concentrations similar to the concentrations for the two wells in Table 5.5 and to the regional trends.

Table 5.5. Average Concentration of Mobile Contaminants in Groundwater in the Vicinity of Waste Management Area C for Fiscal Year 2005 ${ }^{(a)}$

\begin{tabular}{|c|c|c|c|c|c|c|c|c|c|c|}
\hline Wells & $\mid \begin{array}{c}\mathrm{NO}_{3} \\
(\mu \mathrm{g} / \mathrm{L})\end{array}$ & $\begin{array}{c}\text { CN } \\
(\mu \mathrm{g} / \mathrm{L})\end{array}$ & $\begin{array}{c}\mathbf{C a} \\
(\mu \mathrm{g} / \mathrm{L})\end{array}$ & $\begin{array}{c}\mathrm{Na} \\
(\mu \mathrm{g} / \mathrm{L})\end{array}$ & $\begin{array}{c}\mathrm{Cl} \\
(\mu \mathrm{g} / \mathrm{L})\end{array}$ & $\begin{array}{c}\text { SO4 } \\
\text { (ug/L) }\end{array}$ & $\begin{array}{c}\mathrm{I}-129 \\
(\mathrm{pCi} / \mathrm{L})\end{array}$ & $\begin{array}{c}\text { Tc-99 } \\
(\mathbf{p C i} / \mathbf{L})\end{array}$ & $\begin{array}{l}\text { Tritium } \\
\text { (pCi/L) }\end{array}$ & $\begin{array}{c}\text { Specific } \\
\text { conductance } \\
(\mu \mathrm{S} / \mathrm{cm})^{\mathrm{b}}\end{array}$ \\
\hline 299-E27-4 & 18,175 & Not detected & $47,900^{\mathrm{e}}$ & $12,240^{\circ}$ & 10,550 & 70,425 & Not measured & 5,095 & Not measured & 388 \\
\hline 299-E27-7 & 26,225 & 29.7 & 77,675 & 15,450 & 31,300 & 156,500 & 3.81 & 81.4 & $987^{c}$ & $649^{\mathrm{f}}$ \\
\hline 299-E27-12 & 9,188 & Not detected & 41,100 & 11,900 & 9,825 & 50,075 & Not measured & 60.3 & Not measured & 352 \\
\hline 299-E27-13 & 12,200 & Not detected & 40,825 & 11,650 & 8,750 & 58,100 & Not measured & 2,170 & Not measured & 355 \\
\hline 299-E27-14 & 46,700 & Not detected & 97,150 & 17,875 & 29,725 & 205,500 & 4.95 & 2,038 & $1,060^{\mathrm{C}}$ & $771^{\mathrm{d}}$ \\
\hline 299-E27-15 & 17,925 & $5.6^{c}$ & 50,825 & 15,825 & 14,850 & 88,850 & Not measured & 208 & Not measured & 453 \\
\hline 299-E27-21 & 19,150 & Not detected & 42,500 & 13,700 & 8,525 & 63,200 & Not measured & 512 & Not measured & 369 \\
\hline 299-E27-22 & 20,150 & Not detected & 64,600 & 14,025 & 23,925 & 113,850 & Not measured & 38.2 & Not measured & 535 \\
\hline 299-E27-23e & 25,560 & Not detected & 50,260 & 13,360 & 12,520 & 82,180 & Not measured & 1,904 & Not measured & 427 \\
\hline $\begin{array}{l}\text { Hanford Site } \\
\text { Background }^{f}\end{array}$ & 5,681 & 5.43 & 36,518 & 13,402 & 7,052 & 27,102 & $2.88 \times 10^{-6}$ & 0.447 & 63.9 & 348 \\
\hline $\begin{array}{l}\text { (a) Average cc } \\
\text { (b) Average of } \\
\text { (c) One analys } \\
\text { (d) Average of } \\
\text { (e) Average of } \\
\text { (f) Average of } \\
\text { (g) Backgroun } \\
\text { Bold indicate }\end{array}$ & $\begin{array}{l}\text { oncentra } \\
\text { f } 16 \text { ana } \\
\text { sis } \\
\text { f } 12 \text { ana } \\
\text { f } 5 \text { analy } \\
\text { f } 13 \text { ana } \\
\text { d value } \\
\text { es upgra }\end{array}$ & $\begin{array}{l}\text { ation of four; } \\
\text { alyses } \\
\text { alyses } \\
\text { yses } \\
\text { lyses } \\
\text { es are from DC } \\
\text { adient wells. }\end{array}$ & quarterly & sample & s unless & specified & d otherwise. & & & \\
\hline
\end{tabular}


Tritium and iodine-129 are present in the unconfined aquifer beneath most of the 200 East Area (Figures 5.8 and 5.9), and both iodine-129 and tritium plumes have been mapped beneath the 200 East Area since at least the late 1970s (see for examples, Eddy 1979; Cline et al. 1985). The iodine-129 and tritium in the groundwater beneath WMA C are believed to be part of the regional 200 East Area plume, and are attributed to liquid discharges associated with the cribs and trenches near the PUREX facility.

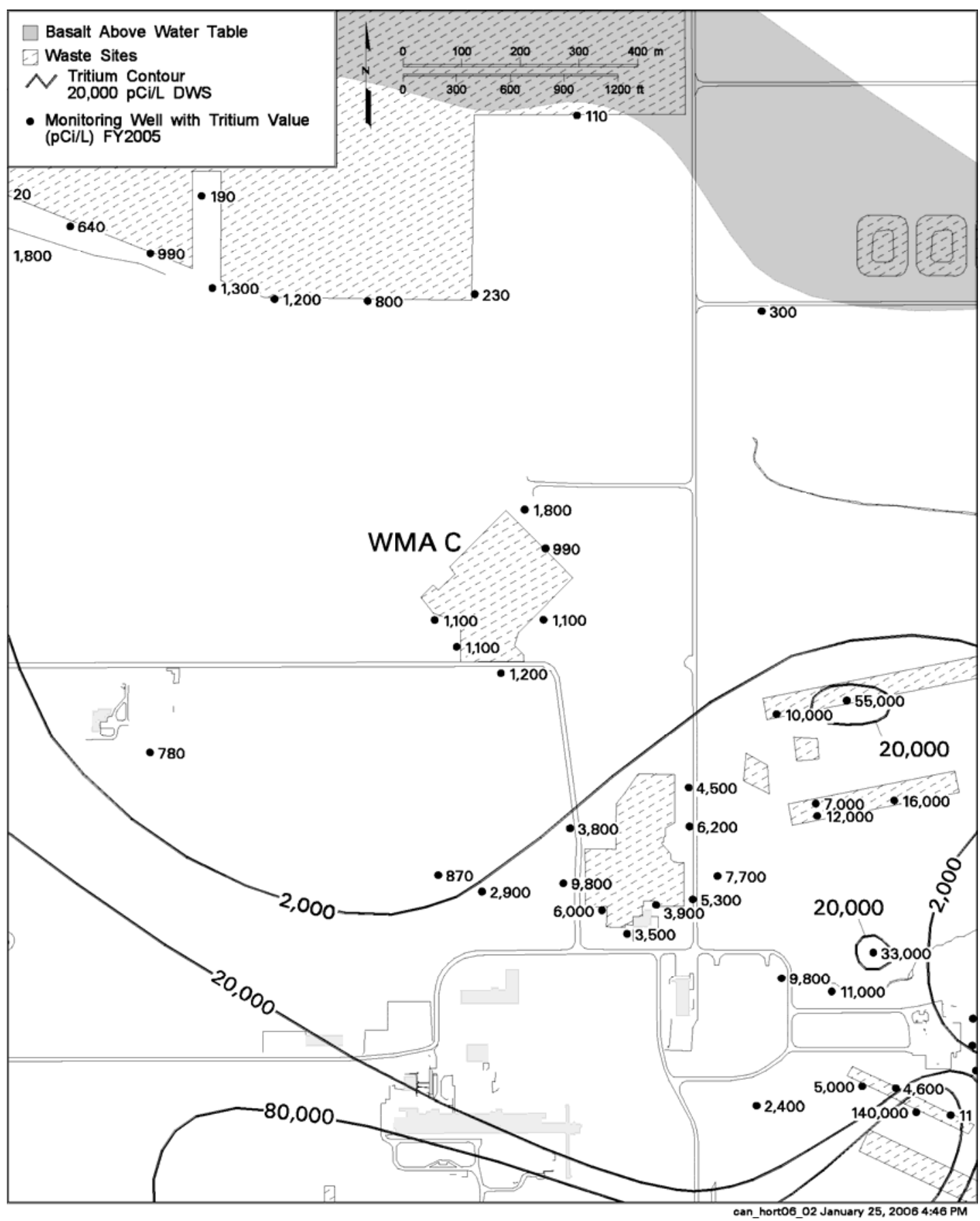

Figure 5.8. Tritium Concentration in the Area of WMA C and WMA A-AX, Top of the Aquifer, Fiscal Year 2005 


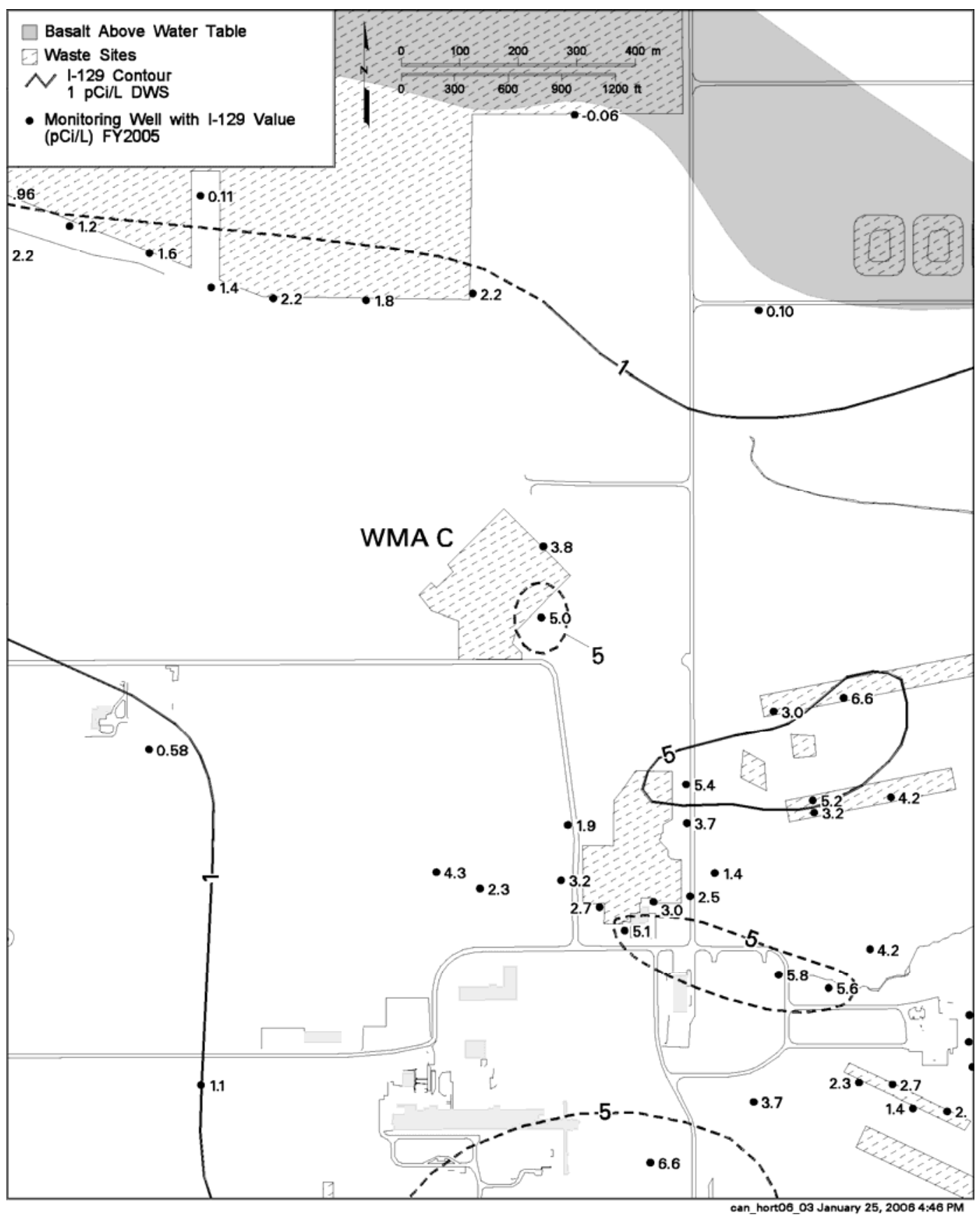

Figure 5.9. Iodine-129 Concentration in the Area of WMA C and WMA A-AX, Top of the Aquifer, Fiscal Year 2005

A nitrate plume underlies much of the 200 East Area (Figure 5.10) and much of this plume also is attributed to discharges to various cribs and ditches throughout the 200 East Area. However, a local plume of nitrate occurs in the area of WMA C (Figure 5.10) and some of this nitrate may be from the WMA. Prior to about 1998, the nitrate concentration at WMA C was less than or near background levels. Beginning in about 1998, the nitrate concentration started to increase in all wells at WMA C. The highest concentrations historically were in the upgradient wells 299-E27-7 and 299-E27-14 on the eastern side of the tank farm. These wells still had the largest nitrate concentrations in early 2005, but since about 2004, nitrate concentrations in some downgradient wells are similar to that in well 299-W27-7. 


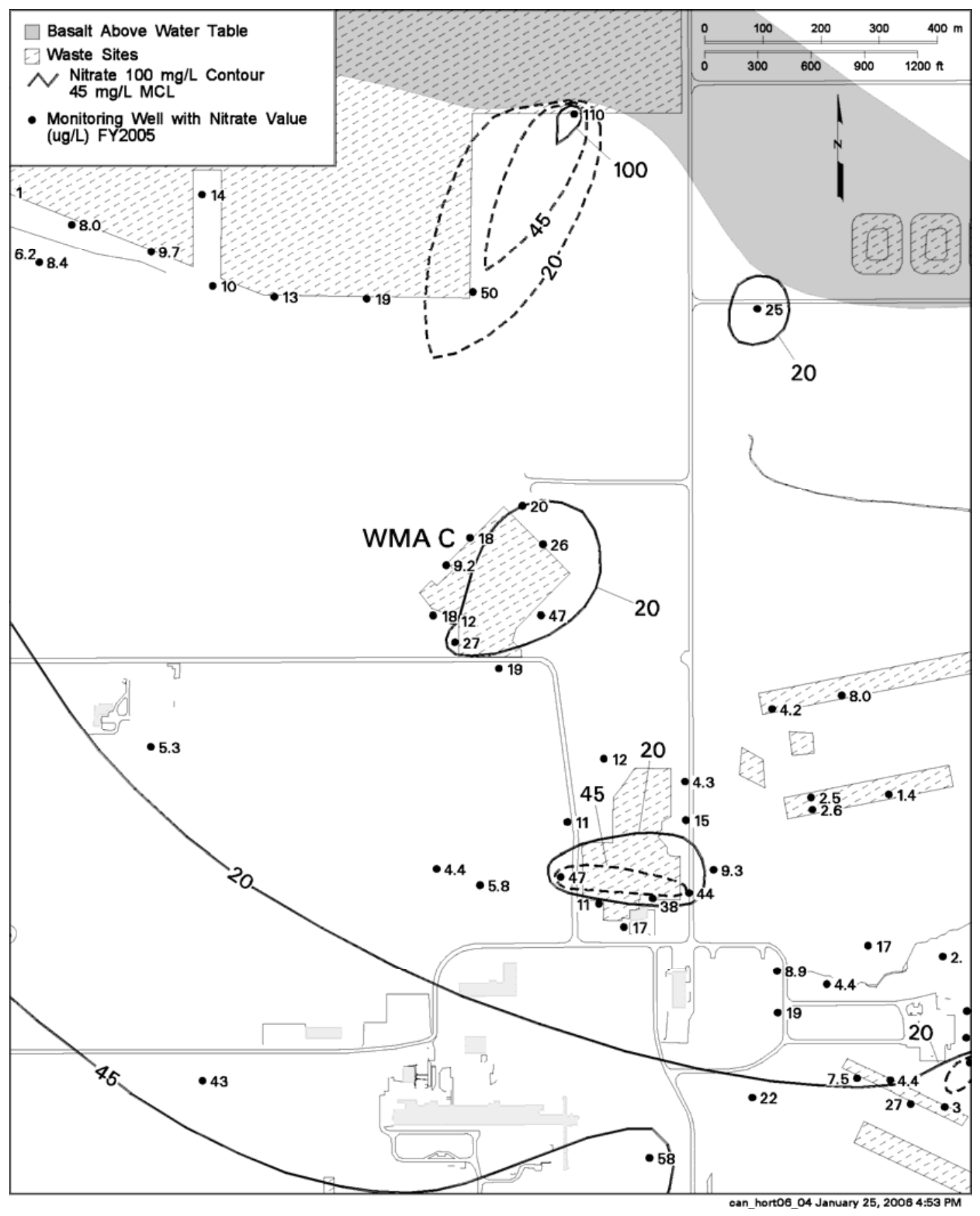

Figure 5.10. Nitrate Concentrations in the Area of WMA C and WMA A-AX. Top of the Aquifer, Fiscal Year 2005.

Figure 5.13 shows a plume map for technetium-99 in the top of the aquifer beneath WMA C in fiscal year 2005. Elevated technetium-99 was first noted in the area during the late part of 2000 when concentrations began to increase from less than $100 \mathrm{pCi} / \mathrm{L}$ to $2,730 \mathrm{pCi} / \mathrm{L}$ in early 2002 in upgradient well 299-E27-7 (Figure 5.11). Subsequently the technetium-99 concentration rapidly decreased to pre-2002 values of less than about $500 \mathrm{pCi} / \mathrm{L}$. The increase in technetium-99 was accompanied with an increase in sulfate and smaller increase in nitrate concentration (Figure 5.11). The sulfate concentration continued to increase as the technetium-99 plume passed the well and sulfate continues to increase today. The nitrate 
concentration showed a maximum that corresponded to the technetium-99 maximum, but the nitrate continues to increase today, although the rate of increase is not large.

The relationships among nitrate, sulfate, and technetium-99 are not constant from well to well at WMA C. Figure 5.12 shows concentrations for these constituents for four downgradient wells.

The concentrations of nitrate, sulfate, and technetium-99 began increasing simultaneously in well 299-E27-14 in 1998 to 1999 (Figure 5.12-A). The sulfate and nitrate concentrations also began to increase in well 299-E27-13 in 1998. However, the technetium-99 concentration did not begin increasing in the latter well until about two years later in 2000 (Figure 5.12-B). The other two downgradient wells with significant technetium-99, wells 299-E27-4 and 299-E27-23, were drilled after contamination arrived in the area such that the time of arrival of the contaminants is not recorded in the wells.

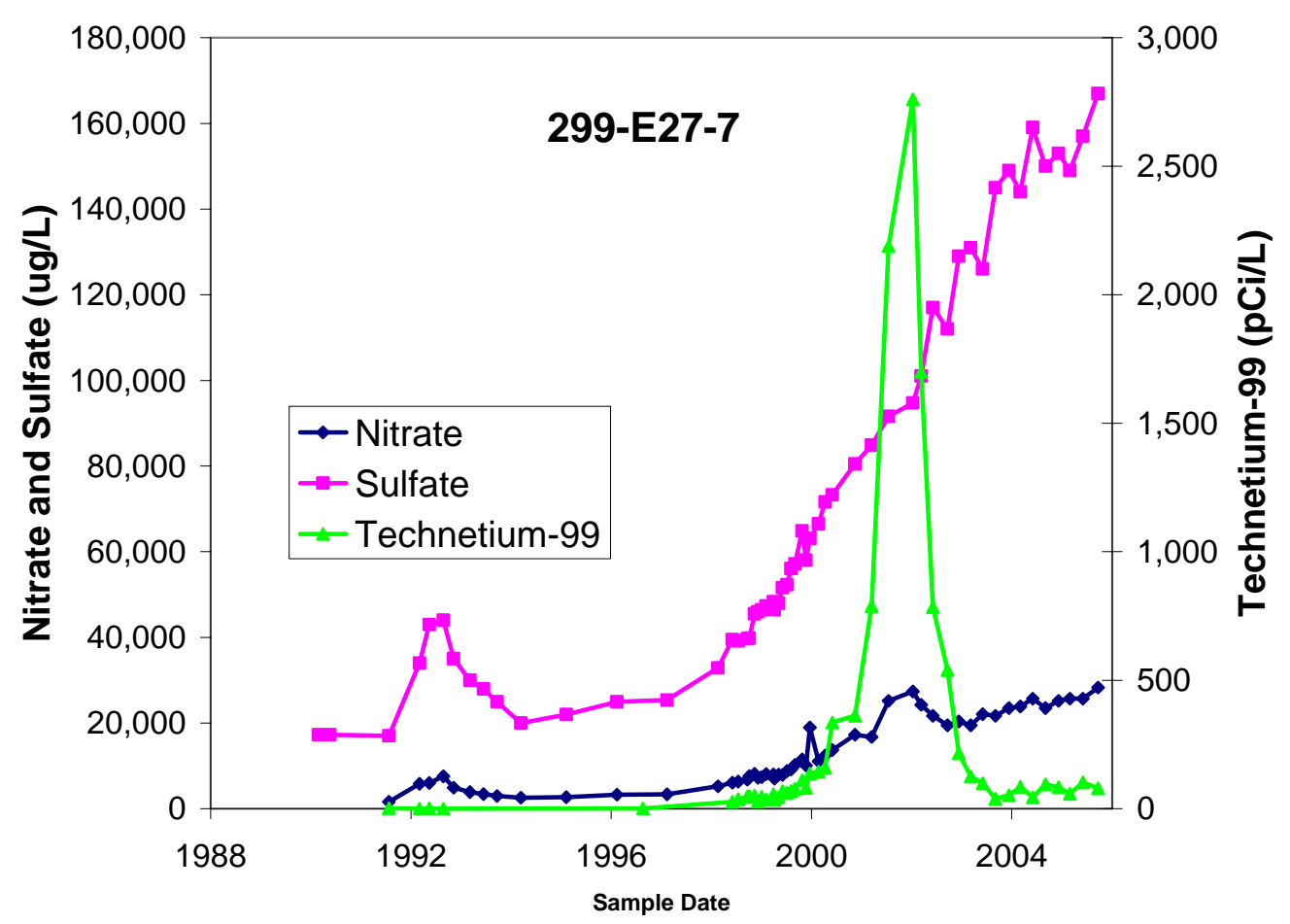

Figure 5.11. Nitrate, Sulfate, and Technetium-99 Concentrations in Upgradient Well 299-W27-7 at WMA C. 

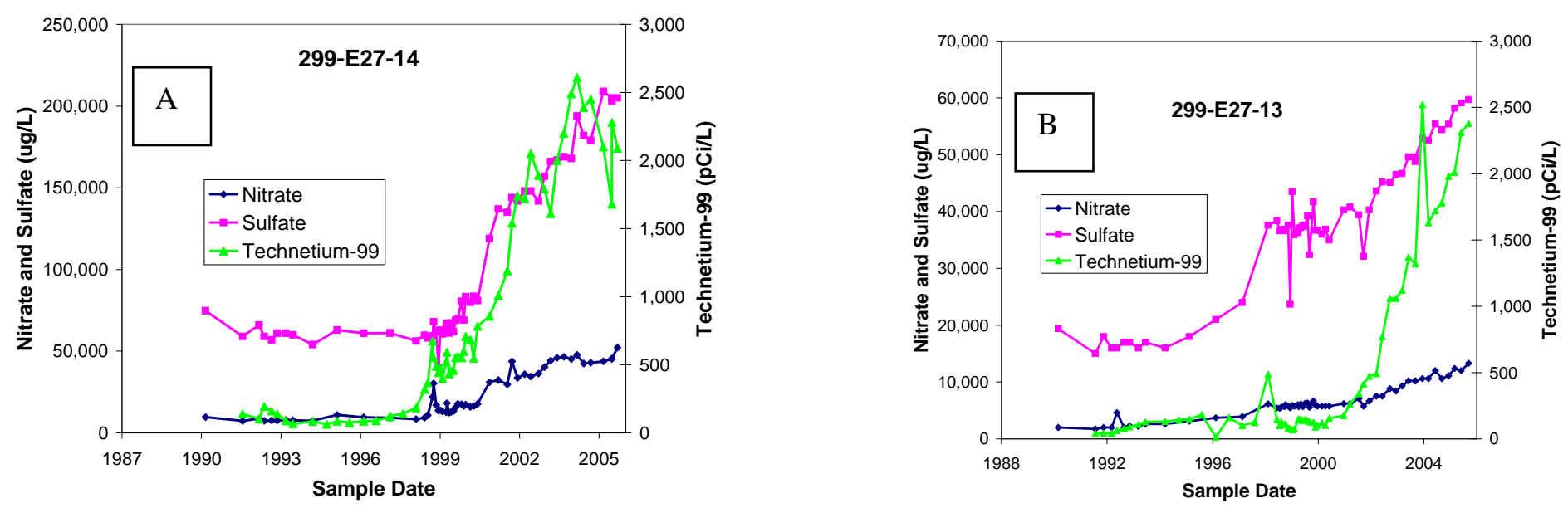

के
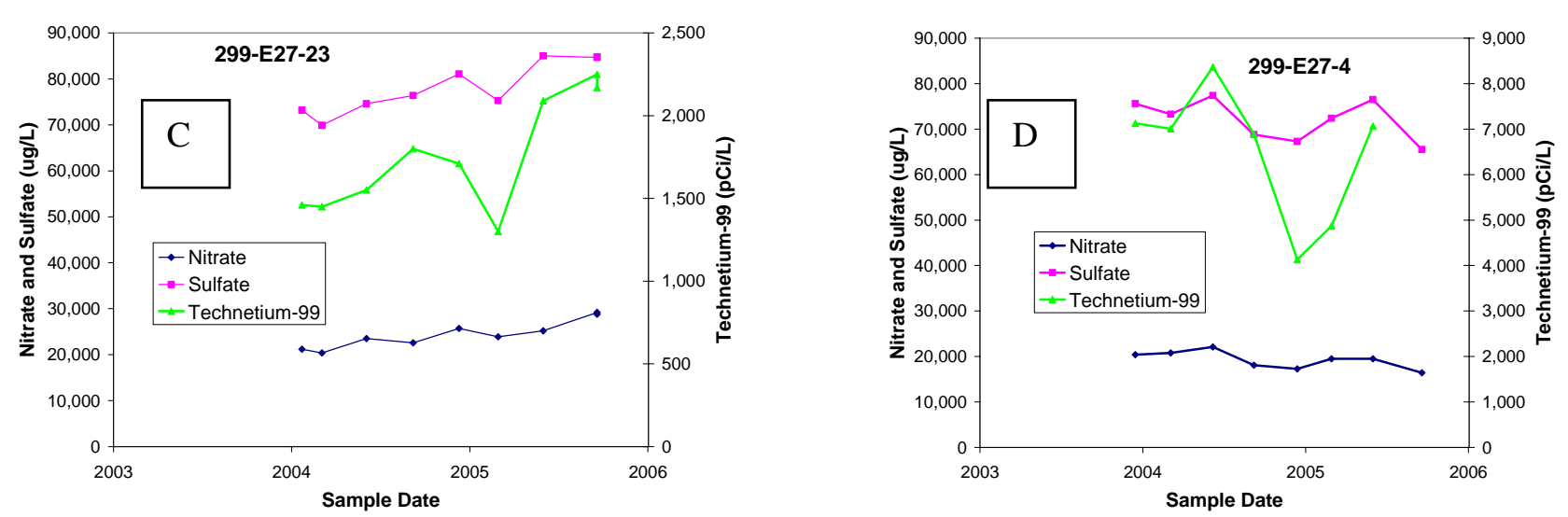

Figure 5.12. Sulfate, Nitrate, and Technetium-99 Concentrations in Selected Downgradient Wells at WMA C. 
Figure 5.14 shows the technetium-99/nitrate and technetium-99/sulfate ratios in those wells at WMA C that have elevated technetium-99. The ratios in the figure show that only in well 299-E27-14 do the concentrations of technetium-99, nitrate, and sulfate track with each other. In all other wells the concentration of technetium-99 increases more rapidly than nitrate and sulfate, especially in wells 299-E27-13 and 299-E27-4. These relationships show the difficulty in pinpointing a particular source for the contamination, and it is likely that more than one source may be involved. However, the presence of regional nitrate and sulfate plumes in the 200 East Area complicates the interpretation.

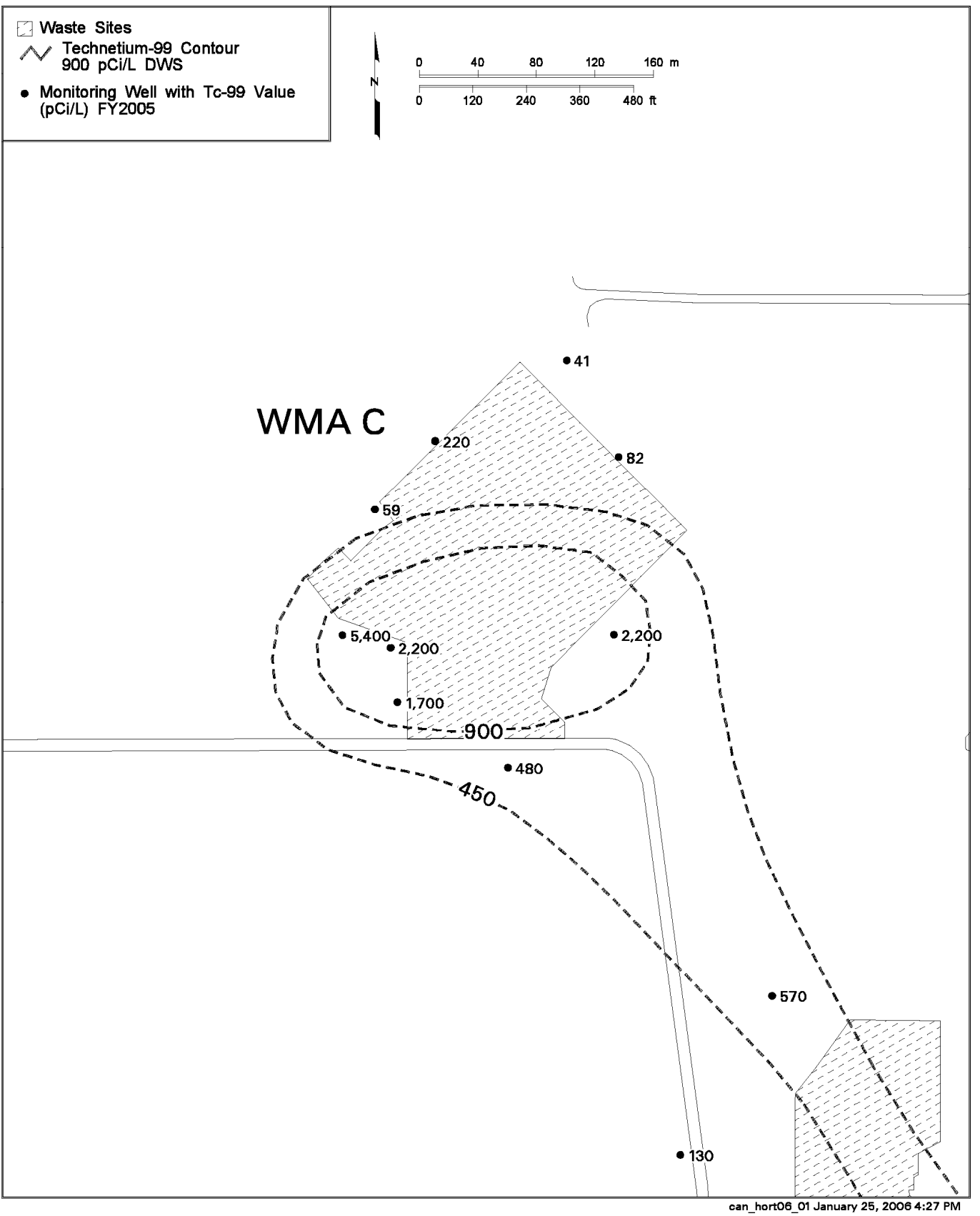

Figure 5.13. Plume Map for Technetium-99 in the Area of WMA C, Top of the Aquifer, Fiscal Year 2005. 

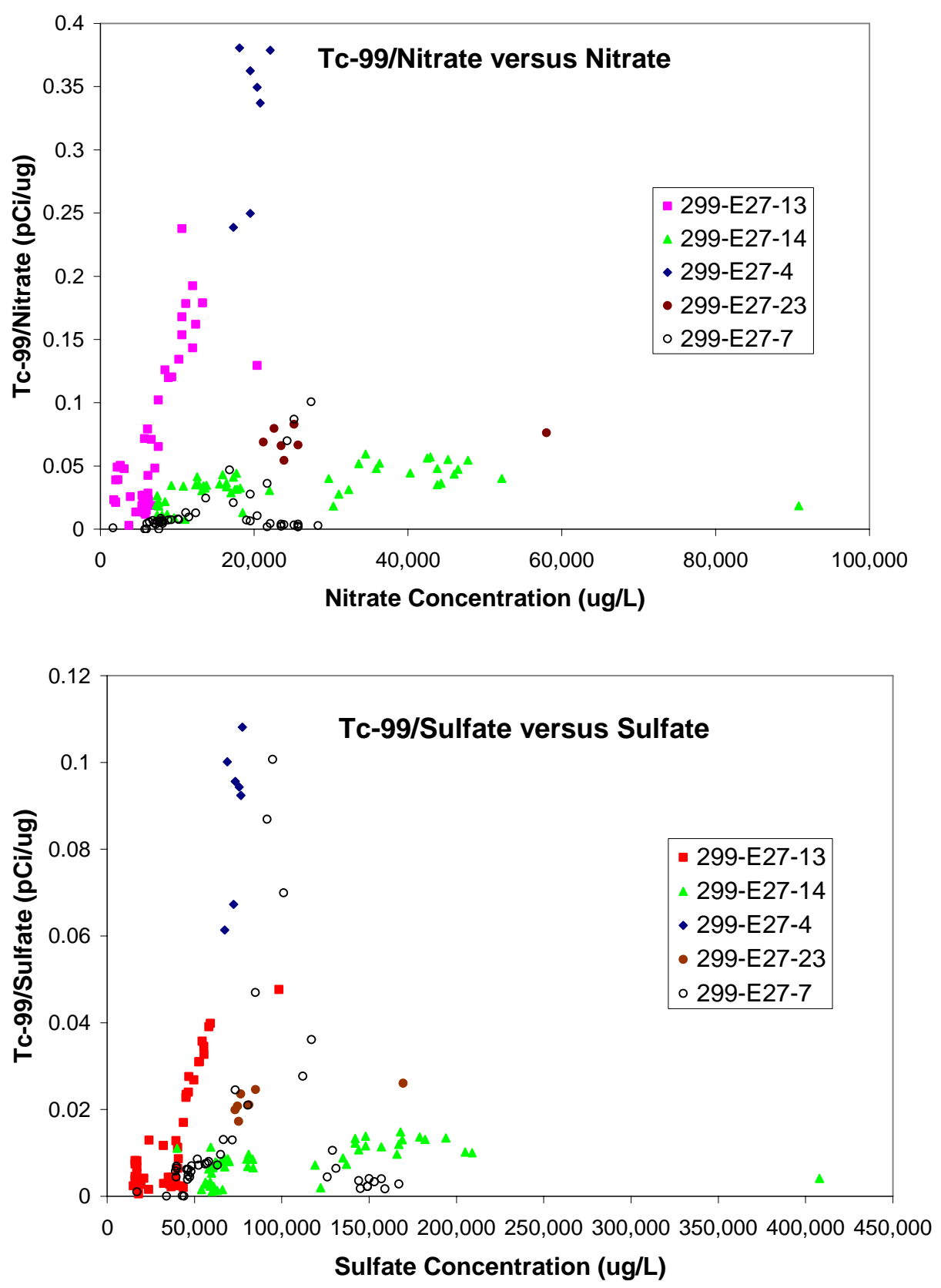

Figure 5.14. Technetium-99/Nitrate and Technetium-99/Sulfate Relationships for Selected Wells at WMA C.

Several wells at WMA C have had detectable cyanide concentrations in the past 5 to 6 years although, the concentrations have been erratic in most wells. Cyanide is of particular interest at WMA C because the WMA is the only known source for cyanide in the area (Hartman et al. 2005).

The earliest detected cyanide in the area was in wells 299-E27-14 and 299-E27-15, located on the west and east sides of the WMA respectively, in the early 1990s. Both wells had one detectable occurrence of cyanide at less that $6 \mu \mathrm{g} / \mathrm{L}$, but no subsequent analyses for cyanide were made until late in 2000 (Figure 5.15). 


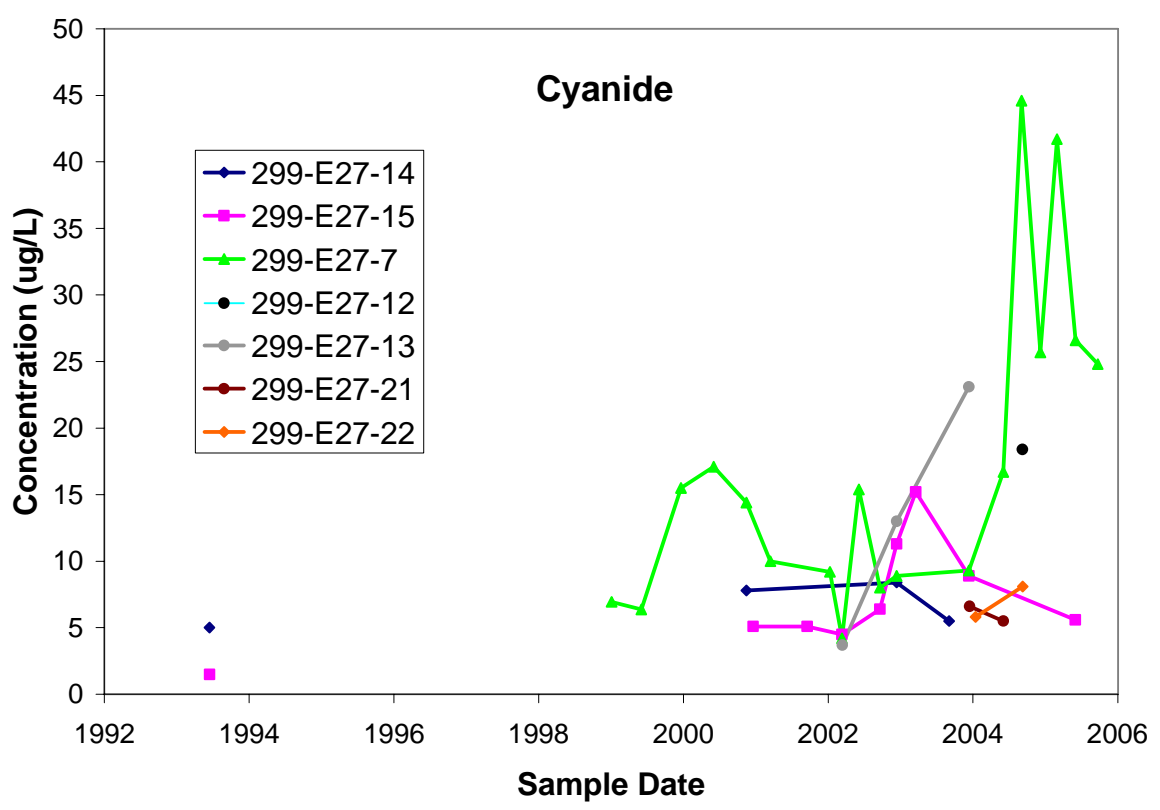

Figure 5.15. Cyanide Concentration in Wells at WMA C.

Since 2000, most wells in the WMA C monitoring network have had shown sporadic cyanide concentrations in the groundwater. The highest concentrations have been in upgradient well 299-E27-7. Although this is the well that showed the earliest technetium-99 plume in the area, the high cyanide postdates the passing of the technetium-99 plume by about 2 years. Although the most likely source for both the cyanide and the technetium-99 is the WMA, they apparently have two different sources. The identity of the specific sources is not known.

\subsection{Comparison of Groundwater, Vadose Zone Pore Water, and Tank Leak Chemical Compositions}

Four of the 100 series tanks in WMA C are reported to have leaked in the past. Corbin et al. (2005) compiled an updated estimate of the chemical compositions of the leaks. The estimate of technetium99/nitrate and technetium-99/sulfate chemical ratios for tank C-105 is given in Table 5.6. These particular ratios were chosen to compare with groundwater composition because technetium-99, nitrate, and sulfate are routinely analyzed in groundwater. The technetium-99/nitrate and technetium-99/sulfate rations from groundwater samples having elevated technetium-99 also are given in Table 5.6.

The estimated tank leak composition was based on historical records including fuel process records, chemical process knowledge, waste transfer information, data from samples collected from waste tanks, process control data, and any other historical waste management information available. It is recognized that there are significant limitations to the estimates. They are, however, the best available estimates. Comparison of the chemical ratios from the estimated tank leaks with those from groundwater analyses show that the ratios are not very similar. 
Table 5.6. Estimated Concentration Ratios for Selected Constituents in Tank Leaks from WMA C and in Groundwater beneath WMA C

\begin{tabular}{|c|c|c|}
\hline Contaminant Source & $\begin{array}{c}\text { Tc-99/Sulfate } \\
\text { (pCi/ } / \mu \mathrm{g})\end{array}$ & $\begin{array}{c}\text { Tc-99/Nitrate } \\
\text { (pCi// } / \mu \text { ) }\end{array}$ \\
\hline C-105 & 15.66 & 1.98 \\
\hline \multicolumn{3}{|c|}{ 299-E27-13 } \\
\hline 3/15/2001 & 0.042 & 0.006 \\
\hline $7 / 16 / 2001$ & 0.048 & 0.009 \\
\hline 9/17/2001 & 0.072 & 0.013 \\
\hline $12 / 6 / 2001$ & 0.071 & 0.012 \\
\hline 3/14/2002 & 0.065 & 0.011 \\
\hline 6/5/2002 & 0.102 & 0.017 \\
\hline $9 / 19 / 2002$ & 0.120 & 0.024 \\
\hline 12/12/2002 & 0.126 & 0.023 \\
\hline $3 / 7 / 2003$ & 0.120 & 0.024 \\
\hline $6 / 4 / 2003$ & 0.134 & 0.028 \\
\hline $9 / 5 / 2003$ & 0.129 & 0.027 \\
\hline $12 / 12 / 2003$ & 0.238 & 0.048 \\
\hline $3 / 4 / 2004$ & 0.154 & 0.031 \\
\hline $6 / 8 / 2004$ & 0.143 & 0.031 \\
\hline $9 / 7 / 2004$ & 0.168 & 0.033 \\
\hline $12 / 8 / 2004$ & 0.178 & 0.036 \\
\hline $3 / 1 / 2005$ & 0.162 & 0.035 \\
\hline $6 / 1 / 2005$ & 0.193 & 0.039 \\
\hline $9 / 12 / 2005$ & 0.179 & 0.040 \\
\hline
\end{tabular}


Table 5.6. (contd)

\begin{tabular}{|c|c|c|}
\hline Contaminant Source & $\begin{array}{c}\text { Tc-99/Sulfate } \\
\text { (pCi/ } / \mu \mathrm{g})\end{array}$ & $\begin{array}{c}\text { Tc-99/Nitrate } \\
\text { (pCi/ } / \mu \mathrm{g})\end{array}$ \\
\hline \multicolumn{3}{|c|}{ 299-E27-14 } \\
\hline 6/4/1998 & 0.035 & 0.005 \\
\hline 7/16/1998 & 0.034 & 0.006 \\
\hline 9/21/1998 & 0.031 & 0.011 \\
\hline $10 / 5 / 1998$ & 0.018 & 0.008 \\
\hline $11 / 11 / 1998$ & 0.029 & 0.008 \\
\hline 12/10/1998 & 0.033 & 0.011 \\
\hline $1 / 4 / 1999$ & 0.035 & 0.008 \\
\hline $2 / 4 / 1999$ & 0.030 & 0.007 \\
\hline 3/29/1999 & 0.042 & 0.008 \\
\hline 4/7/1999 & 0.033 & 0.009 \\
\hline 5/6/1999 & 0.035 & 0.007 \\
\hline 6/3/1999 & 0.036 & 0.007 \\
\hline $7 / 6 / 1999$ & 0.034 & 0.007 \\
\hline 8/5/1999 & 0.036 & 0.008 \\
\hline 9/2/1999 & 0.032 & 0.008 \\
\hline 10/25/1999 & 0.031 & 0.007 \\
\hline 11/22/1999 & 0.036 & 0.009 \\
\hline 12/20/1999 & 0.041 & 0.009 \\
\hline $2 / 22 / 2000$ & 0.043 & 0.009 \\
\hline $4 / 10 / 2000$ & 0.033 & 0.007 \\
\hline $6 / 2 / 2000$ & 0.044 & 0.010 \\
\hline $11 / 14 / 2000$ & 0.028 & 0.007 \\
\hline $3 / 15 / 2001$ & 0.031 & 0.007 \\
\hline $7 / 16 / 2001$ & 0.040 & 0.009 \\
\hline 9/18/2001 & 0.035 & 0.011 \\
\hline $12 / 4 / 2001$ & 0.052 & 0.012 \\
\hline $3 / 14 / 2002$ & 0.048 & 0.012 \\
\hline $6 / 5 / 2002$ & 0.059 & 0.014 \\
\hline 9/19/2002 & 0.052 & 0.013 \\
\hline $12 / 12 / 2002$ & 0.044 & 0.011 \\
\hline $3 / 6 / 2003$ & 0.036 & 0.010 \\
\hline $6 / 3 / 2003$ & 0.043 & 0.012 \\
\hline 9/3/2003 & 0.047 & 0.013 \\
\hline $12 / 15 / 2003$ & 0.055 & 0.015 \\
\hline 3/4/2004 & 0.055 & 0.013 \\
\hline
\end{tabular}


Table 5.6. (contd)

\begin{tabular}{|c|c|c|}
\hline Contaminant Source & $\begin{array}{c}\text { Tc-99/Sulfate } \\
\text { (pCi/ } / \mu \mathrm{g})\end{array}$ & $\begin{array}{c}\text { Tc-99/Nitrate } \\
\text { (pCi/ } / \mu \mathrm{g})\end{array}$ \\
\hline $6 / 3 / 2004$ & 0.056 & 0.013 \\
\hline $9 / 7 / 2004$ & 0.057 & 0.014 \\
\hline 3/1/2005 & 0.048 & 0.010 \\
\hline $6 / 27 / 2005$ & 0.019 & 0.004 \\
\hline $9 / 12 / 2005$ & 0.040 & 0.010 \\
\hline \multicolumn{3}{|c|}{ 299-E27-23 } \\
\hline $1 / 23 / 2004$ & 0.069 & 0.020 \\
\hline $6 / 3 / 2004$ & 0.066 & 0.021 \\
\hline 9/7/2004 & 0.080 & 0.024 \\
\hline $12 / 10 / 2004$ & 0.067 & 0.021 \\
\hline $2 / 28 / 2005$ & 0.054 & 0.017 \\
\hline $6 / 1 / 2005$ & 0.083 & 0.025 \\
\hline 9/19/2005 & 0.076 & 0.026 \\
\hline \multicolumn{3}{|c|}{ 299-E27-4 } \\
\hline $12 / 16 / 2003$ & 0.350 & 0.094 \\
\hline $3 / 4 / 2004$ & 0.337 & 0.096 \\
\hline $6 / 7 / 2004$ & 0.379 & 0.108 \\
\hline 9/7/2004 & 0.381 & 0.100 \\
\hline $12 / 13 / 2004$ & 0.239 & 0.061 \\
\hline $2 / 28 / 2005$ & 0.250 & 0.067 \\
\hline $6 / 1 / 2005$ & 0.363 & 0.092 \\
\hline \multicolumn{3}{|c|}{ 299-E27-7 } \\
\hline $4 / 10 / 2000$ & 0.013 & 0.002 \\
\hline $6 / 2 / 2000$ & 0.025 & 0.005 \\
\hline $11 / 14 / 2000$ & 0.021 & 0.005 \\
\hline $3 / 15 / 2001$ & 0.047 & 0.009 \\
\hline $7 / 16 / 2001$ & 0.087 & 0.024 \\
\hline $1 / 9 / 2002$ & 0.101 & 0.029 \\
\hline $3 / 11 / 2002$ & 0.070 & 0.017 \\
\hline $6 / 5 / 2002$ & 0.036 & 0.007 \\
\hline 9/19/2002 & 0.028 & 0.005 \\
\hline $12 / 12 / 2002$ & 0.011 & 0.002 \\
\hline
\end{tabular}

Borehole C4297 was drilled to investigate a possible leak from tank C-105 or a waste loss from a cascade line or inlet port associated with tank C-105. Table 5.7 compares the pore water from borehole C4297 with the estimated tank leak compositions using the same contaminant ratios used in Table 5.6. 
Discussions of the pore water compositions and how they were obtained are in Chapters 3.0 and 4.0. Comparisons of the borehole C4297 data with the estimates for the tank leaks show poor overall agreement between the two. If it is assumed that the pore water represents the fluid leaked from tank C-105, a much closer comparison is expected than what is shown in Table 5.7. The reason for the lack of agreement between the C4297 pore water composition and the estimated composition for the leak at tank C-105 is not known for certain, but is likely related to incompleteness or inaccuracies in the tank leak estimate.

Table 5.7. $\quad$ Estimated Concentration Ratios for Selected Constituents in Tank Leaks from WMA C and in Pore Water from Borehole C4297

\begin{tabular}{|c|c|c|c|c|}
\hline $\begin{array}{l}\text { Contaminant } \\
\text { Source }\end{array}$ & $\begin{array}{c}\text { Tc-99/Fluoride } \\
\text { (pCi/ } / \mu \mathrm{g})\end{array}$ & 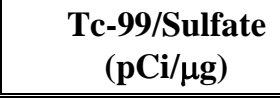 & $\begin{array}{c}\text { Tc-99/Nitrate } \\
\text { (pCi/ } / \mu \mathrm{g})\end{array}$ & $\begin{array}{c}\text { Sulfate/Nitrate } \\
\text { (pCi/ } / \mu \mathrm{g})\end{array}$ \\
\hline C-105 & 2,720 & 15.66 & 1.98 & 0.13 \\
\hline \multicolumn{5}{|c|}{ Borehole C4297 } \\
\hline $\begin{array}{c}\text { Sample Depth } \\
\text { (ft bgs) }\end{array}$ & $\begin{array}{c}\text { Tc-99/Fluoride } \\
\text { (pCi/ } / \mu \mathrm{g})\end{array}$ & $\begin{array}{c}\text { Tc-99/Sulfate } \\
\text { (pCi/ } / \mu \mathrm{g})\end{array}$ & $\begin{array}{c}\text { Tc-99/Nitrate } \\
\text { (pCi/ } / \mu \mathrm{g})\end{array}$ & $\begin{array}{c}\text { Sulfate/Nitrate } \\
(\mathrm{pCi} / \mu \mathrm{g})\end{array}$ \\
\hline 40.80 & 0.142 & 0.051 & & \\
\hline 41.20 & 0.231 & 0.111 & & \\
\hline 43.75 & 0.425 & 0.113 & & 1.758 \\
\hline 45.45 & 0.331 & \begin{tabular}{|l|}
0.208 \\
\end{tabular} & & \\
\hline 45.85 & 0.271 & 0.173 & & \\
\hline 51.25 & 0.391 & 0.184 & 0.300 & 1.633 \\
\hline 57.20 & 0.764 & 0.051 & & \\
\hline 61.50 & 1.751 & 0.037 & 0.201 & 5.481 \\
\hline 62.50 & 3.588 & 0.070 & 0.619 & 8.876 \\
\hline 62.90 & 2.770 & 0.059 & 0.467 & 7.870 \\
\hline 68.95 & 0.198 & 0.005 & 0.027 & 5.222 \\
\hline 71.25 & 0.345 & 0.009 & 0.137 & 15.55 \\
\hline 77.40 & 0.257 & 0.008 & 0.018 & 2.286 \\
\hline 79.55 & 0.327 & 0.009 & 0.079 & 9.057 \\
\hline 88.50 & 0.252 & 0.005 & 0.019 & 3.463 \\
\hline 96.60 & 0.514 & 0.012 & 0.029 & 2.419 \\
\hline 104.00 & 1.050 & 0.024 & 0.052 & 2.183 \\
\hline 106.05 & 2.735 & \begin{tabular}{|l|}
0.039 \\
\end{tabular} & 0.131 & 3.336 \\
\hline 114.20 & 1.138 & 0.018 & 0.065 & 3.583 \\
\hline 124.60 & 2.294 & 0.028 & 0.142 & 5.008 \\
\hline 126.35 & 2.428 & \begin{tabular}{|l|}
0.032 \\
\end{tabular} & 0.477 & 14.89 \\
\hline 135.25 & 14.10 & 0.039 & 0.233 & 6.032 \\
\hline
\end{tabular}


Table 5.7. (contd)

\begin{tabular}{|l|l|l|l|l||}
\hline $\begin{array}{c}\text { Sample Depth } \\
\text { (ft bgs) }\end{array}$ & \multicolumn{1}{|c|}{$\begin{array}{c}\text { Tc-99/Fluoride } \\
(\mathbf{p C i} / \boldsymbol{\mu g})\end{array}$} & $\begin{array}{c}\text { Tc-99/Sulfate } \\
(\mathbf{p C i} / \boldsymbol{\mu g})\end{array}$ & $\begin{array}{c}\text { Tc-99/Nitrate } \\
(\mathbf{p C i} / \boldsymbol{\mu g})\end{array}$ & $\begin{array}{c}\text { Sulfate/Nitrate } \\
(\mathbf{p C i} / \boldsymbol{\mu g})\end{array}$ \\
\hline \hline 146.25 & 27.27 & 0.047 & 0.433 & 9.125 \\
\hline 151.50 & 5.970 & 0.016 & 0.169 & 10.32 \\
\hline 153.00 & 7.118 & 0.046 & 0.214 & 4.675 \\
\hline 154.65 & 3.278 & 0.032 & 0.155 & 4.792 \\
\hline 156.65 & 0.012 & 0.064 & 5.399 \\
\hline 156.65 & 2.098 & 0.013 & 0.070 & 5.279 \\
\hline 159.00 & 2.510 & 0.007 & 0.037 & 5.206 \\
\hline
\end{tabular}

Unfortunately, there are not many measured constituents common to both groundwater and borehole C4297 pore water. The available constituents are limited to technetium-99, some metals and most anions. Figure 5.16 shows several concentration ratios from groundwater analyses and pore water from borehole C4297. The data on the figure show no clear relationship between the compositions of the groundwater and pore water. The data in Chapter 4 show two zones of technetium-99 contamination in borehole C4297; one zone is at about 40 to $60 \mathrm{ft}$ bgs and assumed to be associated with the bottom of tank C-105, and the other zone is between about 140 and $150 \mathrm{ft}$ bgs. The technetium-99/nitrate ratios of samples from the contaminated zones are generally greater than about 0.2 . Such values are greater than the technetium99/nitrate ratios in all groundwater wells except well 299-E27-4 (Figure 5.16). However, the agreement for the other ratios between groundwater from well 299-E27-4 and pore water from borehole C4297 is not good, which was likely a result of fractionation between technetium-99 and the other constituents.

In summary, there is no clear chemical fingerprint that indicates similarities among the estimated tank leak composition for tank C-105, groundwater contaminant compositions, or C4297 pore water composition. 

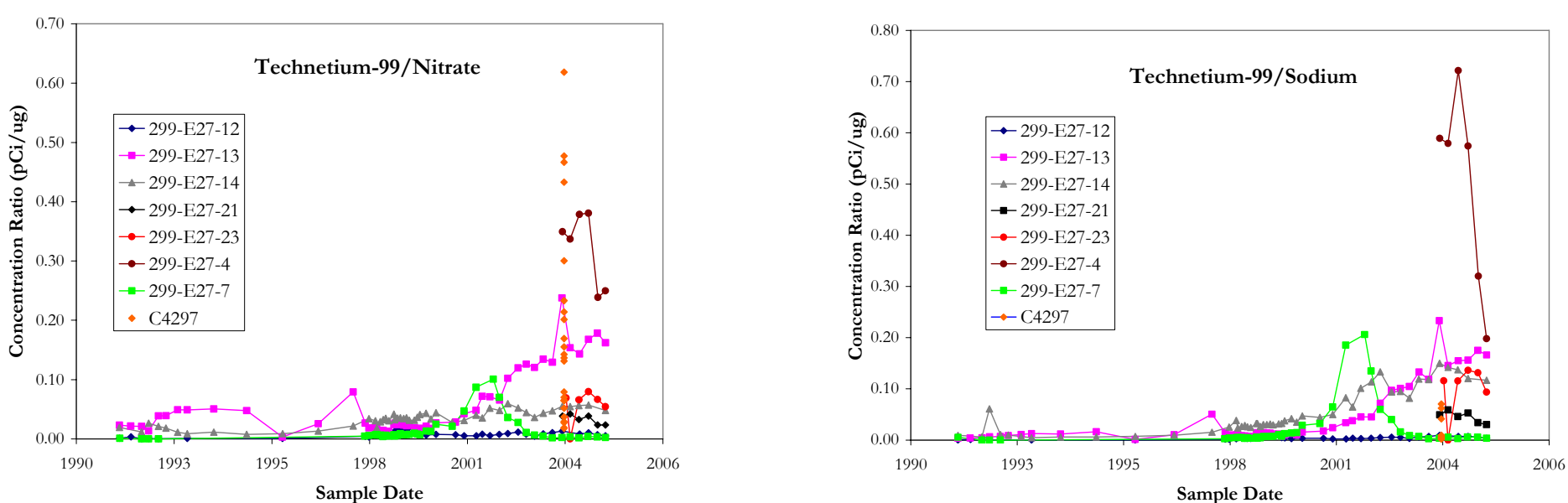

ปั
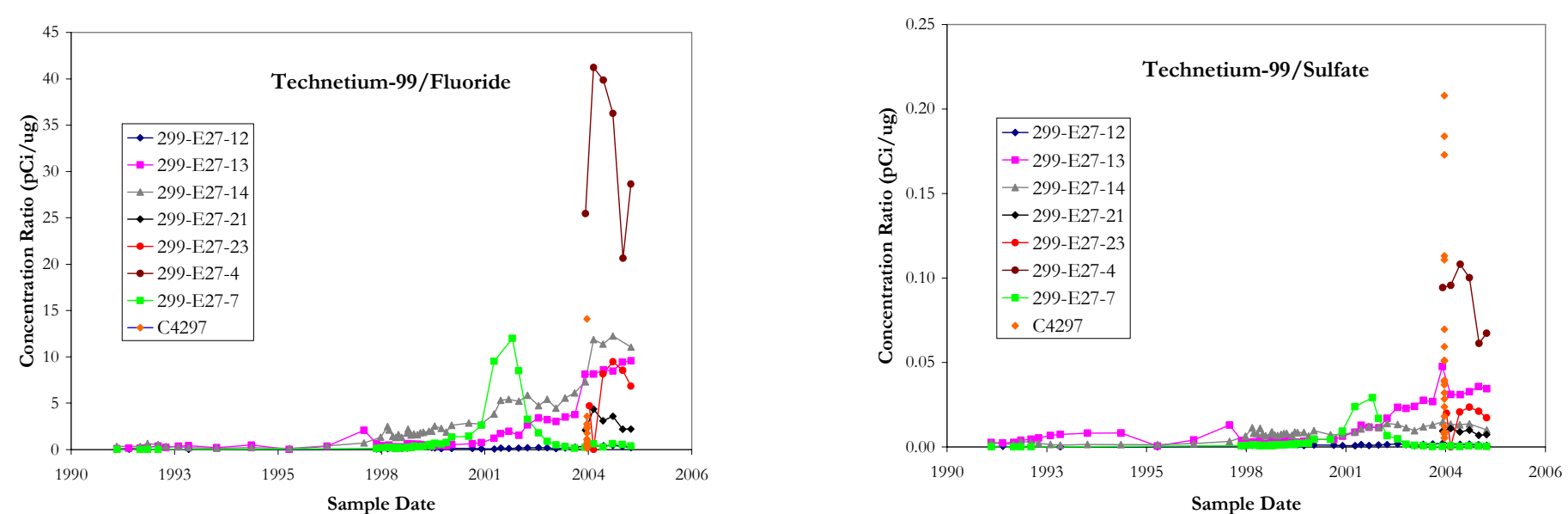

Figure 5.16. Selected Compositional Relationships between Groundwater Samples from Wells at WMA C and C4297 Pore Water. 


\subsection{Summary and Conclusions}

This section presents summary information about the interpretation of the $\mathrm{C}$ borehole sediment characterization data. Conclusions are included to aid in making decisions on what interim actions and future studies are needed to make sound waste-management decisions at the C Tank Farm.

\subsection{Drilling and Sampling Summary at the C Tank Farm}

A single borehole was placed inside the C Tank Farm area for the specific purpose of collecting core samples for physical and chemical characterization. Borehole C4297 was drilled between February 17 and March 18, 2004, using a cable-tool, splitspoon technique to a total depth of $196.5 \mathrm{ft}$ bgs. The borehole lies about equidistant between single-shell tanks 241-C-104 and C-105. Eleven core samples, 2.5-ft-long by 4 in. diameter, were collected at predetermined intervals within the borehole. Each core contained four, 0.5 -ft-long stainless steel liners that contained sediment. The hole was terminated within pebbly sands of the Hanford formation $\mathrm{H} 2$ unit once technetium-99 contamination was no longer detected in the samples. Additionally, 119 grab samples were collected at 1 to $5 \mathrm{ft}$ intervals from ground surface to total depth for supplemental characterization and analysis.

A RCRA borehole (299-E27 22) was drilled outside the northern boundary of the C Tank Farm using a different drilling procedure (Becker Hammer). Continuous core was collected between 19 and $111 \mathrm{ft}$ bgs; below this, from $111 \mathrm{ft}$ to $230 \mathrm{ft}$ bgs, one 2.5-ft splitspoon sample was collected every $5 \mathrm{ft}$. Two, 4in.-diameter, 1-ft-long Lexan-lined core samples were recovered from each 2.5-ft-long splitspoon. No core samples were collected between the ground surface and $19 \mathrm{ft}$, or between 230 to $268 \mathrm{ft}$. In all, a total of the $41 \%$ of the hole was cored.

All of the 1-ft-long liners from both boreholes were opened in the chemistry lab and geologically described during the subsampling process to obtain aliquots used in the various characterization activities. The geology between core samples was inferred and interpreted based on the geophysical log and blow-count data.

\subsection{Physical Model for C Tank Farm Geology}

Two primary stratigraphic units were encountered in the contaminated borehole: (1) backfill material and (2) the Hanford formation. The deeper CCU was not penetrated by either borehole (C4297 or C4124), but was likely encountered at the refusal point in the background borehole (C4124). Table 6.1 summarizes the contacts between the various stratigraphic units for both of the boreholes.

For the contaminated borehole (C4297), the backfill consisted of predominantly grayish-brown, moderately sorted, matrix-supported, pebbly sand to silty pebbly sand, which was weakly consolidated and only slightly calcareous. Most gravel clasts and sand grains were composed of basalt. This unit appeared to be rather homogeneous and lacked lithologic variation, except near the base, where a moisture spike may indicate the presence of a thin silty layer. Overall, the moisture content for backfill materials was slightly higher (averaging $5.2 \pm 1.3 \mathrm{wt} \%$ ) compared to the underlying Hanford formation. 
Table 6.1. Stratigraphic Units and Contacts (ft bgs)

\begin{tabular}{||l|l|l||}
\hline \multicolumn{1}{|c|}{ Formation } & \multicolumn{1}{c||}{ 299-E27-22 } & \multicolumn{1}{c||}{ C4297 (C-105) } \\
\hline \hline Recent Eolian & 0 to 5 & - \\
\hline Backfill & - & 0 to 39.8 \\
\hline H1 & 5 to 82 & 39.8 to 65 \\
\hline H2 & 82 to 228 & 65 to hole bottom \\
\hline CCU/R & 228 & - \\
\hline H1 $\begin{array}{l}\text { = Hanford formation Unit } 1-\text { gravel dominated cataclysmic flood } \\
\text { deposits. } \\
\text { = Hanford formation Unit 2 - sand dominated cataclysmic flood } \\
\text { deposits. }\end{array}$ \\
H2 $\begin{array}{l}\text { Cold Creek u and/or Ringold Formation - well-sorted silt and/or } \\
\text { fine sand of eolian and/or fluvial origin. }\end{array}$ \\
\hline
\end{tabular}

Pleistocene cataclysmic flood deposits of the Hanford formation underlie the backfill material in borehole C4297 to the bottom of the hole at $196.5 \mathrm{ft}$. Other units, including the CCU and/or Ringold Formation (CCU/R) were probably present at depth, but not penetrated by the relatively shallow depth of this hole. The Hanford formation at borehole C4297 was all sand dominated. There were no clast-supported, gravel-dominated facies in this hole, which are often observed toward the top of the Hanford formation; these have been classified as the $\mathrm{H} 1$ unit. However, there is a 15-ft-thick pebbly sand zone between 50 to $65 \mathrm{ft}$ bgs, which could be equivalent to the gravel-dominated facies of the $\mathrm{H} 1 \mathrm{unit}$. Below that is a thick sequence of the sand-dominated $\mathrm{H} 2$ unit.

The Hanford formation H1 unit may be present between 40 to $65 \mathrm{ft}$ (12.2 to $19.8 \mathrm{~m}$ ) bgs. A coarser 15-ft-thick layer of moderately sorted, basaltic, pebbly sand between 50 to $65 \mathrm{ft}$ bgs was interpreted as H1 unit (Figure 2.15). Small pebbles, mostly of subangular to subrounded basalt, made up about $30 \%$ of the total volume. Above the pebbly sand and below the backfill was $10 \mathrm{ft}$ of medium- to coarse-grained, "salt and pepper" sand, which is included with the H1 unit. A total of eight characterization samples were obtained from the Hanford formation H1 unit from C4297. Two of these samples were from the pebbly sand; the remaining six were of coarse sand. The average moisture content for the H1 unit in C4297 was $3.2 \pm 0.5 \%$.

The Hanford formation H2 unit consisted of grayish brown, loose, moderately to well sorted, medium- to coarse-grained sand to slightly pebbly sand. It appeared identical to the H1 unit, with the exception of having less gravel-sized sediment present. The salt-and-pepper-like sand consisted of $20 \%$ to $40 \%$ basalt rock fragments. A total of 16 characterization samples were collected from the $\mathrm{H} 2$ unit, with an average moisture content of $3.4 \pm 0.8 \%$.

The composition of the lower gravel sequence beneath C Tank Farm appeared to be multilithic, unlike Hanford formation gravels, which are concentrated in basalt (DOE 2002). Since the lithology of the unit was inconsistent with that of the Hanford formation, we conclude that the lower gravel sequence beneath C Tank Farm is composed of Ringold Formation Unit A, perhaps overlain with some mainstream-alluvial facies of the Cold Creek unit, which is also multilithic. Thus, in this report we designate this unit as CCU/R. Clearly more work needs to be done to establish the physical and mineralogical characteristics of the different coarse-grained facies of the Hanford formation, CCU, and 
Ringold Formation, in order to establish the true nature of the sediments in stratigraphically ambiguous areas such as C Tank Farm.

\subsection{Moisture Content}

In general, heterogeneities including fine-grained thin lenses in the Hanford formation $\mathrm{H} 1$ and $\mathrm{H} 2$ units likely cause anisotropy in water flow. Increased moisture was found to correlate with each of the fine-grained thin lenses intercepted by the coring. Average moisture contents for the Hanford formation H1 and H2 units in the RCRA borehole 299-E33-338 (Lindenmeier et al. 2002), which was chosen as a comparative uncontaminated borehole given the waste signature present in bore 299-E27-22 samples, were approximately the same as the moisture contents from the same units in the contaminated borehole (C4297). This is likely an indication that any leak that has occurred in the vicinity of borehole C4297 was either small in total volume or occurred sufficiently long ago that residual vadose zone moisture has returned to background or "natural” conditions.

\subsection{Vertical Extent of Contamination in Borehole C4297}

The following paragraphs describe measurements of various parameters that can be used to help determine the extent of vertical migration of tank or ancillary equipment leaks. Several parameters were used including $\mathrm{pH}$, electrical conductivity, nitrate, technetium-99, and sodium concentrations in water and acid extract as indicators to determine the leading edge of the plume. The concentrations of waterextractable (for mobile constituents) and acid-extractable or directly measured constituents in the sediment (for sorbing constituents) were used to delineate the total inventory of constituents within the plume. For technetium-99, the water-extractable data were judged to be a more accurate indication of past tank leaks than acid-extractable concentrations. This section provides information about all the parameters measured.

The first parameter measured was the $\mathrm{pH}$ of water extracts of the vadose zone sediment. Based on the assumption that tank fluids are generally caustic and often very caustic ( $>1 \mathrm{M}$ free hydroxide), elevated $\mathrm{pH}$ profiles should be indicative of the zones impacted by leaked fluids. The $\mathrm{pH}$ profiles for sediments from borehole C4297 showed elevated $\mathrm{pH}$ from 40.8 to $51.3 \mathrm{ft}$ bgs, which was indicative of alkaline tank fluid interactions. The first sample with a measurably elevated soil $\mathrm{pH}$, via 1:1 sediment:water extraction, was collected at a depth that coincided with the bottom of tank C-105. However, based on observations at other tank farms (SX and BX) where it is certain that caustic wastes are in the vadose zone, yet water extract $\mathrm{pH}$ values never exceed 10, we have concluded that $\mathrm{pH}$ is not a very sensitive parameter to use for evaluating the extent of plume migration in the vadose zone. However, the elevated zone of $\mathrm{pH}$ is considered to indicate the original tank waste contact zone.

The second parameter that was assessed to estimate the vertical extent of the leaked plume was dilution-corrected water extract EC. The EC depth profile for borehole C4297 showed elevated EC in comparison to background sediments from borehole 299-E33-338. The zone of elevated EC occurred in the Hanford formation $\mathrm{H} 1$ unit over the same depth range exhibiting elevated soil pH (40.8 to $51.3 \mathrm{ft}$ bgs). The highest dilution-corrected pore water EC was equivalent to a pore solution of $0.15 \mathrm{M} \mathrm{KCl}$, the salt solution used to calibrate the conductivity probe.

Despite the evidence of elevated EC in sediment samples from borehole C4297, the concentrations were not large. For example, the maximum dilution-corrected EC at borehole C4297 was $25.0 \mathrm{mS} / \mathrm{cm}$. 
The leaks near the SX-108-109 and BX-102 tanks had peak vadose zone pore water concentrations that were equivalent to much more concentrated waste fluids, 524 to 1774 and $77 \mathrm{mS} / \mathrm{cm}$, respectively.

At 299-E33-46 near tank B-110, the dilution-corrected EC was $15.1 \mathrm{mS} / \mathrm{cm}$, and at 299-W23-19 near tank SX-115, which contained dilute waste, the dilution-corrected EC was $33 \mathrm{mS} / \mathrm{cm}$.

The third parameter that can be used to investigate the extent of tank waste-related contamination in the vadose zone is sodium. Elevated sodium was measured in C4297 borehole samples beginning at approximately $7 \mathrm{ft}$ bgs and extending to a depth of $71 \mathrm{ft}$ bgs. These trends may indicate some chemical reaction between alkaline tank fluids and native sediments that formed a cation exchange front, whereby sodium replaced calcium and magnesium as the dominant exchangeable cation.

Water-extractable uranium is another parameter that can be used to investigate subsurface contamination. Naturally occurring uranium is present in a crystalline form that is very recalcitrant to leaching. Therefore, elevated amounts of uranium in the 1:1 sediment:water extracts are typically indicative of contaminant uranium. In the core and grab samples from borehole C4297, we observed a bimodal uranium concentration profile as a function of depth. A relatively small peak was measured in the $1: 1$ sediment:water extracts from 7 to $22 \mathrm{ft}$ bgs. The uranium present at this depth was likely associated with the cesium-137 activity measured shallow in the borehole ( 2.5 to $12 \mathrm{ft}$ bgs). The second node of elevated water-extractable uranium was observed at a depth corresponding to the bottom of tank $\mathrm{C}-105$ (40 ft bgs) extending to a total depth of $60 \mathrm{ft}$ bgs. The maximum water extractable uranium concentration over this depth occurred at $57.2 \mathrm{ft}$ bgs with a peak value of $2.17 \mathrm{E}-2 \mu \mathrm{g} / \mathrm{g}$. However, due to the high dissolved (bi)carbonate concentration in this zone, most of the water-extractable uranium could be associated with naturally present labile uranium released as a function of uranyl-carbonate complexation. Therefore, sediments associated with the C4297 borehole are not characterized as containing significant amounts of Hanford process uranium.

The fifth parameter evaluated to define the vertical extent of contamination was nitrate. The nitrate water extract values for borehole C4297 were elevated beginning at a depth that corresponded to the bottom of Tank C-105 (40 ft bgs) to as deep as $160 \mathrm{ft}$ bgs. Additionally, there were several anomalously high nitrate samples collected throughout the soil profile. Although the nitrate water extract values were elevated, some of the variability observed in C4297 soil nitrate values could be lithology related. Nitrate migration in the subsurface is considered to be entirely conservative; in other words, it will move freely with the infiltrating water. Thus, nitrate concentration can be used to estimate the total vertical extent of a contaminant plume. Based on data from borehole C4297, it appears that a multi-modal, at least bimodal, waste signature is present. Based on the dilute nitrate profile, it appears that the maximum penetration of the first or primary plume is currently at a depth of approximately $160 \mathrm{ft}$ bgs. The peak maximum of the second plume occurred perhaps as deep as $114 \mathrm{ft}$ bgs and appears to be less concentrated than the primary plume.

The final indicator species often used to define the vertical extent of contamination is technetium-99 in water extract samples. In sediment samples from borehole C4297, the first observance of technetium-99 occurred at $40.8 \mathrm{ft}$ bgs, a depth that corresponded to the bottom of tank C-105.

Technetium-99, like nitrate, is considered to be completely conservative hydrologically. Therefore, it is not surprising that technetium-99 exhibited a similar, although somewhat distinct, concentration profile to nitrate. As with nitrate, a bimodal concentration profile of technetium-99 contamination was present in C4297 borehole samples, with the primary peak occurring between 105 and $160 \mathrm{ft}$ bgs, and a smaller secondary peak present between 40 and $66 \mathrm{ft}$ bgs. Similarly to the nitrate, the peak technetium-99 
concentration present in these sediment samples was measured in the sample collected from approximately $137 \mathrm{ft}$ bgs.

Based on evaluating all these measurements, we conclude that the C4297 borehole data establish the vertical extent of tank contamination at this location. Tank waste related contaminants were observed from just below ground surface ( $2.5 \mathrm{ft}$ bgs) to a total depth of approximately $160 \mathrm{ft}$ bgs. Several of the parameters measured ( $\mathrm{pH}, \mathrm{EC}$, sodium, nitrate, and technetium-99) exhibited distinct contaminant profiles as a function of depth. Additionally, two of the contaminants (nitrate and technetium-99) could be further characterized as having bi- or multimodal profiles, indicating that at least two distinct waste sources have contributed to the contamination present in this borehole.

\subsection{Detailed Characterization to Elucidate Controlling Geochemical Processes}

The more detailed characterization activities of the cores from borehole 299-E27-22 and the contaminated borehole (C4297) added some insight on 1) the processes that control the observed vertical distribution of contaminants and 2) the migration potential of key contaminants in the future. The pore waters, calculated by dilution correction of the 1:1 water extracts, in the sediment from borehole C4297 in the Hanford formation unit (H1) were dominated by sodium and bicarbonate for sediments with obvious signs of tank fluids. The most concentrated pore water in the $\mathrm{H} 1$ unit is shown in Table 6.2 in units of $\mathrm{meq} / \mathrm{L}$. Also included in the table for comparison are the maximum pore water concentrations found in other characterization work previously reported for the BX, B, SX, and TX Tank Farms.

For borehole C4297, the most saline calculated pore water resided in the H1 unit and had a chemical composition of sodium $(0.209 \mathrm{~N})$, calcium $(0.00083 \mathrm{~N})$, nitrate $(0.00026 \mathrm{~N})$, bicarbonate $(0.218 \mathrm{~N})$, sulfate $(0.0018 \mathrm{~N})$, and fluoride $(0.0028 \mathrm{~N})$. As shown in Table 6.2, the most concentrated calculated pore water from borehole C4297 was more concentrated than that found near TX-104 and B-110, but less concentrated, and in some cases much less concentrated, than pore waters found in the vadose zone sediments from either the BX or SX Tank Farms. 
Table 6.2. Maximum Pore Water Concentrations in Sediments from Hanford formation Unit (reported in units of mN)

\begin{tabular}{|c|c|c|c|c|c|c|c|}
\hline \multirow[b]{2}{*}{ Tank } & \multicolumn{7}{|c|}{ Closest Single-Shell Tank and Borehole or Borehole Number } \\
\hline & C-105 & TX-104 & BX-102 & B-110 & SX-115 & SX-109 & SX-108 \\
\hline Borehole/Strata & C4297-H1 & C3832-H2 & E33-45 & E33-46 & W23-19 & 41-09-39 & Slant \\
\hline $\mathrm{Na}$ & 209 & 39.1 & 525 & 150 & 35.6 & 6066 & 16900 \\
\hline $\mathrm{Ca}$ & 0.93 & 1.1 & 114 & 4 & 281 & 619 & 90 \\
\hline $\mathrm{Mg}$ & 0 & 0.44 & 62 & 2.5 & 94.6 & 24 & 10 \\
\hline $\mathrm{K}$ & 0 & 1.4 & 13 & 0.5 & 3.6 & 42 & 92 \\
\hline $\mathrm{Sr}$ & 0 & 0 & 0 & 0 & 1.5 & 4.4 & 1 \\
\hline $\mathrm{UO}_{2}$ & 0 & 0 & 2 & 0 & 0 & 0 & 0 \\
\hline Total Cats & 212 & 42 & 716 & 157 & 416 & 6755 & 17093 \\
\hline $\mathrm{NO}_{3}$ & \begin{tabular}{|l|}
0.23 \\
\end{tabular} & \begin{tabular}{|l|}
0.6 \\
\end{tabular} & 100 & 3 & 420 & 6710 & 15677 \\
\hline $\mathrm{NO}_{2}$ & 0 & 0 & 0 & 0 & 0 & 28 & 32 \\
\hline $\mathrm{SO}_{4}$ & 1.8 & 5.8 & 570 & 14 & 3.3 & 95 & 500 \\
\hline $\mathrm{CrO}_{4}$ & 0 & 0 & 0 & 0 & 100 & 0 & 0 \\
\hline $\mathrm{PO}_{4}$ & 0 & 0.3 & 0 & 0 & 0 & 0 & 0 \\
\hline $\mathrm{Cl}$ & 0 & 0.4 & 5 & 0 & 6 & 119 & 147 \\
\hline $\mathrm{F}$ & 2.8 & 0.5 & 1 & 10 & 0 & 0 & 0 \\
\hline $\mathrm{HCO}_{3} / \mathrm{CO}_{3}$ & 218 & 37.3 & 40 & 130 & 7 & 0 & 666 \\
\hline Total Anions & 223 & 42 & 716 & 157 & 536 & 6952 & 17022 \\
\hline $\begin{array}{l}\text { dilution-corrected } \\
\text { EC }(\mathrm{mS} / \mathrm{cm})\end{array}$ & 20.5 & 4.54 & 76.8 & 15.1 & 33.1 & 524 & 1772 \\
\hline
\end{tabular}


The distribution of the water-extractable major cations in sediment samples from borehole C4297 indicates that an ion-exchange process dominates the pore water/sediment interactions where tank fluid has passed by or currently exists. The depth profiles for the divalent alkaline earth cations (calcium, magnesium, and strontium) versus sodium show depleted alkaline earth cation concentrations in the shallow Hanford formation H1 sediments below the tank bottom. Conversely, the water-extractable sodium concentrations in this zone were elevated. At borehole C4297, the distribution of the divalent alkaline earth cations (magnesium, calcium, barium, and strontium) and the monovalent cation potassium show low water-extractable quantities from 40 to $60 \mathrm{ft}$ bgs with the lowest values of all at 45 to $49 \mathrm{ft}$ bgs. Conversely, the distribution of water-extractable sodium was higher over this 20 -ft zone, with a peak water-extractable concentration occurring in the samples collected from $45 \mathrm{ft}$ bgs. Not surprisingly, the peak EC values also occurred at this depth. These trends suggest that tank fluids that are high in sodium did seep into the vadose zone near this borehole. The lack of a significant amount of nitrate at this depth coupled with a measurable increase in nitrate deeper in the borehole indicates that the contamination has been present for a sufficiently long period of time to facilitate the migration of more conservative contaminants (i.e., nitrate and technetium-99).

\subsection{Estimates of Contaminant Inventory and Sorption-Desorption Values}

This section provides the measurements and data synthesis used to quantify the inventory of key risk contaminants and our estimates of their adsorption-desorption tendencies. We did not perform any site-specific sorption or desorption studies per se because none of the contaminants were present at large enough concentrations to make testing practical. However, by combining the data from the dilutioncorrected 1:1 water extracts, which represent the pore water, with the concentrations measured on the sediment, we could estimate the desorption $\mathrm{K}_{\mathrm{d}}$ values for contaminants of interest. For a contaminant that has very little water-soluble mass such as cesium-137, the in situ desorption $\mathrm{K}_{\mathrm{d}}$ can be approximated as the mass in the total sample per gram of dry sediment divided by the mass in the pore water per milliliter. For a contaminant that is quite soluble in the water extract (this is approximately equivalent to stating that the contaminant resides mainly in the pore water within the sediment), one needs to subtract the amount that was present in the pore water from the total amount present in the moist sediment sample to obtain a value for the amount that would remain on the solid at equilibrium with the pore fluid. Potential contaminants of concern that have been selected for discussion include technetium-99, uranium, chromium(VI), and nitrate.

The concentrations of chromium found in the sediment were below our detection limit and will not be discussed further, but the others are present at high enough concentrations that we are comfortable that precise and accurate data were obtained. For the technetium-99 inventory, we suggest that the water extract data is most accurate and should be used to estimate technetium-99 inventory versus depth. However, we do present the technetium-99 acid extract data as the worst-case maximum inventory estimate. We assume that all technetium is water soluble in the sediments, as found during our characterization studies at BX, SX, T, and TX WMAs (Serne et al. 2002b, 2002c, 2002d, 2002e, 2004a, and 2004b).

For uranium, it was found that the natural background concentrations must be separated from Hanford added material in discussing risk potential. Natural uranium is almost entirely resistant to water leaching and to becoming mobile, whereas the material added by Hanford activities is somewhat mobile. We thus recommend using the water-extractable uranium data as representative of the concentrations that could 
enter the water table for future risk calculations. However, we present the acid-extractable uranium inventories to allow very conservative risk calculations to be performed that assume all acid-extractable masses could ultimately become released to percolating recharge waters.

For nitrate, as for technetium-99, we assumed that the water extract concentrations represent the total inventory. We have no other method to measure nitrate besides the water extract method. We use $8 \mathrm{M}$ nitric acid as our technique to measure the total amount of a constituent that is acid leachable. Thus, the nitric acid leachant overwhelms any nitrate present in the sediment. Therefore, nitrate data contained in Table 6.3 is based on analysis of 1:1 sediment:water extract samples.

Semi-quantitative estimates of desorption $\mathrm{K}_{\mathrm{d}}$ values for technetium-99 and uranium can be calculated using the inventory estimates (mass or activity per gram of sediment) divided by the estimated pore water concentration of the constituent. These values are found in Tables 4.28 (acid extract) and 4.24 (pore waters), respectively. Table 6.4 shows the estimated desorption $\mathrm{K}_{\mathrm{d}}$ values for the sediment cores obtained from borehole C4297. In Table 6.4, the depths where the bulk of the contamination was present are highlighted in red (bold) type and the desorption $\mathrm{K}_{\mathrm{d}}$ values that suggest contamination being present at even very low concentrations are highlighted in yellow (darker) shading. The faint blue (lighter) shading in Table 6.3 designates data that are more dominated by natural constituents or impacted by low precision analytical values. From the table, two trends can be seen. First where there are significant concentrations of contaminants in the sediments (between 40 and $60 \mathrm{ft}$ bgs), the $\mathrm{K}_{\mathrm{d}}$ values for uranium and technetium99 are smaller than their values at shallower and deeper depths. This is caused both by the presence of more saline pore waters (competing ions) and higher contributions of complexed species (uranyl carbonates) for uranium, which are generally more water leachable. The changes in $\mathrm{K}_{\mathrm{d}}$ values for technetium-99 outside the zone of significant contamination are likely more a function of imprecision in the acid versus water extract analytical results.

The in situ desorption $\mathrm{K}_{\mathrm{d}}$ results presented herein suggest that of the potential contaminants, technetium-99 is the most mobile, with uranium being considerably less mobile. Although we could not directly calculate a desorption $\mathrm{K}_{\mathrm{d}}$ value for nitrate, it would likely be as mobile as technetium-99. For conservative modeling purposes, we recommend using $\mathrm{K}_{\mathrm{d}}$ values of $0 \mathrm{~mL} / \mathrm{g}$ for nitrate and technetium-99, and a value of $1 \mathrm{~mL} / \mathrm{g}$ for uranium to represent the entire vadose zone profile from the bottoms of the tanks to the water table. The technetium in situ desorption $\mathrm{K}_{\mathrm{d}}$ value of zero is consistent with a wealth of literature that finds essentially no technetium adsorption onto Hanford Site sediment (Kaplan and Serne 1995, 2000). 
Table 6.3. Estimated Inventory of Contaminants in Borehole C4297

\begin{tabular}{|c|c|c|c|c|c|c|}
\hline $\begin{array}{c}\text { Depth } \\
\text { (ft bgs) }\end{array}$ & Strat. Unit & $\begin{array}{c}\text { Nitrate } \\
(\mu \mathrm{g} / \mathrm{g})\end{array}$ & $\begin{array}{c}\text { Tc-99 } \\
\text { (pCi/g) }\end{array}$ & $\begin{array}{l}\text { U-238 } \\
(\mu \mathrm{g} / \mathrm{g})\end{array}$ & $\begin{array}{c}\text { Tc-99 } \\
\text { (pCi/g) }\end{array}$ & $\begin{array}{l}\text { U-238 } \\
(\mu g / g)\end{array}$ \\
\hline & & \multicolumn{3}{|c|}{ Water Extract } & \multicolumn{2}{|c|}{ Acid Extract } \\
\hline 2.50 & Backfill & $<0.433$ & $<8.48 \mathrm{E}-02$ & 7.57E-04 & ND & 3.61E-01 \\
\hline 7.00 & Backfill & $<0.450$ & $<8.82 \mathrm{E}-02$ & 1.05E-03 & ND & 4.00E-01 \\
\hline 12.00 & Backfill & 0.52 & $<8.48 \mathrm{E}-02$ & 1.97E-03 & ND & 3.81E-01 \\
\hline 17.00 & Backfill & $<0.443$ & $<8.67 \mathrm{E}-02$ & 2.59E-03 & ND & 3.94E-01 \\
\hline 22.00 & Backfill & $<0.436$ & (8.54E-03) & 2.11E-03 & ND & 7.70E-01 \\
\hline 25.75 & H1 & $<0.433$ & $<8.48 \mathrm{E}-02$ & 7.90E-04 & $(3.86 E+00)$ & $9.11 \mathrm{E}-01$ \\
\hline 31.00 & H1 & $<0.464$ & $<9.08 \mathrm{E}-02$ & 1.41E-03 & $(5.49 \mathrm{E}+00)$ & 4.73E-01 \\
\hline 37.15 & H1 & $<0.433$ & $<8.48 \mathrm{E}-02$ & 7.97E-04 & $(3.32 \mathrm{E}+00)$ & 3.97E-01 \\
\hline 40.80 & H1 & $<0.433$ & 1.44E-01 & 7.58E-03 & $(4.56 \mathrm{E}+00)$ & 4.16E-01 \\
\hline 40.80 & H1 & $<0.433$ & 1.70E-01 & $6.81 \mathrm{E}-03$ & $(5.99 \mathrm{E}+00)$ & 5.05E-01 \\
\hline 45.45 & H1 & $<0.433$ & 4.83E-01 & 1.13E-02 & $9.07 \mathrm{E}+00$ & 4.59E-01 \\
\hline 49.25 & H1 & $<0.433$ & (1.11E-01) & 9.51E-03 & $(1.20 \mathrm{E}+01)$ & 6.34E-01 \\
\hline 55.20 & H1 & $<0.433$ & (1.02E-01) & 7.64E-03 & $(1.63 \mathrm{E}+00)$ & 5.11E-01 \\
\hline 60.00 & H1 & $<0.434$ & $(2.61 \mathrm{E}-01)$ & 2.98E-03 & ND & 4.60E-01 \\
\hline 60.00 & H1 & $<0.433$ & $(2.62 \mathrm{E}-01)$ & 3.53E-03 & ND & 4.84E-01 \\
\hline 62.50 & H1 & 2.09 & $1.29 \mathrm{E}+00$ & 3.88E-04 & $6.62 \mathrm{E}+00$ & 3.63E-01 \\
\hline 64.85 & H1 & $<0.433$ & $(8.91 \mathrm{E}-02)$ & 4.27E-04 & ND & 5.65E-01 \\
\hline 66.20 & H1 & 9.69 & $2.62 \mathrm{E}+00$ & 5.42E-04 & ND & 5.18E-01 \\
\hline 71.25 & $\mathrm{H} 2$ & 0.621 & 8.49E-02 & 2.58E-04 & $(5.87 \mathrm{E}+00)$ & 4.47E-01 \\
\hline 79.55 & $\mathrm{H} 2$ & 1.5 & 1.19E-01 & 6.90E-04 & $(5.00 \mathrm{E}+00)$ & 4.67E-01 \\
\hline 79.55 & H2 & 2.22 & 1.02E-01 & 6.82E-04 & $(3.92 \mathrm{E}+00)$ & 3.47E-01 \\
\hline 106.05 & H2 & 5.35 & 7.01E-01 & 4.07E-04 & $(3.89 \mathrm{E}+00)$ & 3.65E-01 \\
\hline 110.15 & H2 & 0.535 & $(7.96 \mathrm{E}-02)$ & 3.23E-04 & ND & 7.21E-01 \\
\hline 117.40 & $\mathrm{H} 2$ & 1.1 & $(1.80 \mathrm{E}-01)$ & 3.22E-04 & ND & 4.55E-01 \\
\hline 120.25 & H2 & 3.06 & $(4.22 \mathrm{E}-01)$ & 2.40E-04 & ND & 5.43E-01 \\
\hline 123.65 & H2 & 4.88 & (8.35E-01) & 2.78E-04 & ND & 8.45E-01 \\
\hline 126.35 & $\mathrm{H} 2$ & 1.41 & 6.71E-01 & $2.43 \mathrm{E}-04$ & $(4.12 \mathrm{E}+00)$ & $3.42 \mathrm{E}-01$ \\
\hline 126.75 & $\mathrm{H} 2$ & 2.24 & (6.56E-01) & 2.16E-04 & ND & 9.58E-01 \\
\hline 127.85 & $\mathrm{H} 2$ & 1.75 & (5.05E-01) & 3.03E-04 & $(4.45 \mathrm{E}+00)$ & 5.04E-01 \\
\hline 130.65 & H2 & 1.9 & (6.31E-01) & 2.56E-04 & ND & 6.48E-01 \\
\hline 133.75 & H2 & 12.8 & $5.60 \mathrm{E}+00$ & 4.88E-04 & ND & 4.90E-01 \\
\hline 136.75 & H2 & 19.5 & $8.42 \mathrm{E}+00$ & 4.37E-04 & ND & 6.32E-01 \\
\hline 140.00 & $\mathrm{H} 2$ & 1.34 & (5.00E-01) & 1.50E-04 & $(3.66 \mathrm{E}+00)$ & 6.15E-01 \\
\hline 143.25 & $\mathrm{H} 2$ & $<0.435$ & $(9.65 E-02)$ & 1.65E-04 & ND & 3.07E-01 \\
\hline
\end{tabular}


Table 6.3. (contd)

\begin{tabular}{|c|c|c|c|c|c|c|}
\hline $\begin{array}{c}\text { Depth } \\
\text { (ft bgs) }\end{array}$ & Strat. Unit & $\begin{array}{c}\text { Nitrate } \\
(\mu g / g)\end{array}$ & $\begin{array}{c}\text { Tc-99 } \\
\text { (pCi/g) }\end{array}$ & $\begin{array}{l}\text { U-238 } \\
(\mu g / g)\end{array}$ & $\begin{array}{c}\text { Tc-99 } \\
\text { (pCi/g) }\end{array}$ & $\begin{array}{l}\text { U-238 } \\
(\mu \mathrm{g} / \mathrm{g})\end{array}$ \\
\hline & & \multicolumn{3}{|c|}{ Water Extract } & \multicolumn{2}{|c|}{ Acid Extract } \\
\hline 148.30 & H2 & 0.724 & $(4.62 \mathrm{E}-01)$ & 2.90E-04 & ND & $4.28 \mathrm{E}-01$ \\
\hline 148.30 & $\mathrm{H} 2$ & 1.43 & $(7.08 \mathrm{E}-01)$ & 2.97E-04 & ND & 3.25E-01 \\
\hline 165.75 & H2 & 3.01 & $(2.52 \mathrm{E}-02)$ & $2.39 \mathrm{E}-04$ & ND & 4.72E-01 \\
\hline 170.25 & $\mathrm{H} 2$ & $<0.433$ & $(9.10 \mathrm{E}-03)$ & $1.84 \mathrm{E}-04$ & ND & $6.89 \mathrm{E}-01$ \\
\hline 174.05 & H2 & $<0.433$ & $<8.48 \mathrm{E}-01$ & 1.55E-04 & ND & $6.16 \mathrm{E}-01$ \\
\hline $\begin{array}{l}\text { Faint blue (l } \\
\text { data (techl } \\
\text { Grey shadin } \\
\text { Red (bold) t } \\
\text { Yellow (dar } \\
\text { Hanford c }\end{array}$ & $\begin{array}{l}\text { t) shading data } \\
\text { ium-99). } \\
\text { ignifies core san } \\
\text { signifies depth } \\
\text { shading signifies } \\
\text { tituents. }\end{array}$ & $\begin{array}{l}\text { likely mc } \\
\text { les. } \\
\text { vhere sedi } \\
\text { alues that }\end{array}$ & $\begin{array}{l}\text { re dominated b } \\
\text { nents show ob } \\
\text { are dominated }\end{array}$ & $\begin{array}{l}\text { atural constitu } \\
\text { s signs of son } \\
\text { ank fluids as }\end{array}$ & $\begin{array}{l}\text { (uranium) or } \\
\text { ink related flu } \\
\text { sed to a mix c }\end{array}$ & recise analytic \\
\hline
\end{tabular}

\subsection{Other Geochemical Characterization Observations}

Comparison of the water to acid-extractable quantities of each constituent was performed by dividing the data in Tables 4.18 through 4.20 by the data in Tables 4.25 through 4.28 . The data are not presented herein but show the same trends as found for the RCRA borehole (C4124), wherein less than $0.1 \%$ of the acid-extractable quantities of the following elements are water leachable: aluminum, iron, magnesium, manganese, chromium, and phosphorous as phosphate. Less than $0.3 \%$ of the acid-extractable quantities of the following elements were water leachable: arsenic, calcium, potassium, strontium, zinc, and uranium. Less than 35\% of the acid-extractable sodium, sulfur, and molybdenum were water extractable. The only clear indications of tank contamination in these sediments were the elevated sodium levels in the vicinity of the tank bottom and the presence of technetium-99 in both acid and water extracts.

As part of our characterization strategy for contaminated sediments, other parameters that can control contaminant migration were measured. Particle size measurements were performed only on select sediment from borehole 299-E27-22; however, photographs in Appendix A and the field moisture log, blow counts, and laboratory moisture contents identify three-thin (1 ft or less), fine-grained, silty layers were present within the Hanford formation $\mathrm{H} 2$ unit. A fourth spike in moisture occurred at the interface between the compacted backfill material and the Hanford formation H1 unit. These types of stratigraphic changes can promote lateral spreading of leaked fluids and/or lead to perching conditions (Serne 2004b). 
Table 6.4. Desorption $\mathrm{K}_{\mathrm{d}}$ Values (mL/g) for Potential Contaminants of Concern

\begin{tabular}{|c|c|c|c|}
\hline \multicolumn{2}{|r|}{$\begin{array}{c}\text { C4297 } \\
\end{array}$} & \multirow{2}{*}{$\begin{array}{c}\text { Tc-99 } \\
\mathbf{K}_{\mathrm{d}} \\
(\mathrm{mL} / \mathrm{g})\end{array}$} & \multirow{2}{*}{$\underset{(\mathbf{m L} / \mathbf{g})}{\mathbf{U}}$} \\
\hline $\begin{array}{l}\text { Depth } \\
\text { (ft bgs) }\end{array}$ & Stratigraphic Unit & & \\
\hline 2.50 & Backfill & ND & 31.1 \\
\hline 7.00 & Backfill & ND & 25.6 \\
\hline 12.00 & Backfill & ND & 13.5 \\
\hline 17.00 & Backfill & ND & 7.48 \\
\hline 22.00 & Backfill & ND & 20.9 \\
\hline 25.75 & H1 & ND & 39.6 \\
\hline 31.00 & $\mathrm{H} 1$ & ND & 17.9 \\
\hline 37.15 & $\mathrm{H} 1$ & ND & 18.8 \\
\hline 40.80 & H1 & (1.09) & 1.88 \\
\hline 40.80 & $\mathrm{H} 1$ & $(1.20)$ & 2.53 \\
\hline 45.45 & $\mathrm{H} 1$ & 0.510 & 1.11 \\
\hline 49.25 & H1 & (3.49) & 2.15 \\
\hline 55.20 & $\mathrm{H} 1$ & $(0.584)$ & 2.46 \\
\hline 60.00 & H1 & ND & 5.14 \\
\hline 60.00 & H1 & ND & 4.57 \\
\hline 62.50 & $\mathrm{H} 1$ & 0.128 & 23.4 \\
\hline 64.85 & H1 & ND & 50.9 \\
\hline 66.20 & $\mathrm{H} 1$ & ND & 42.5 \\
\hline 71.25 & $\mathrm{H} 2$ & (1.59) & 39.9 \\
\hline 79.55 & $\mathrm{H} 2$ & $(1.38)$ & 22.2 \\
\hline 79.55 & $\mathrm{H} 2$ & $(1.31)$ & 17.3 \\
\hline 106.05 & $\mathrm{H} 2$ & $(0.206)$ & 33.5 \\
\hline 110.15 & $\mathrm{H} 2$ & ND & 73.0 \\
\hline 117.40 & $\mathrm{H} 2$ & ND & 42.9 \\
\hline 120.25 & $\mathrm{H} 2$ & ND & 86.7 \\
\hline 123.65 & $\mathrm{H} 2$ & ND & 99.9 \\
\hline 126.35 & $\mathrm{H} 2$ & $(0.148)$ & 33.9 \\
\hline 126.75 & H2 & ND & 137 \\
\hline 127.85 & $\mathrm{H} 2$ & $(0.295)$ & 55.5 \\
\hline 130.65 & $\mathrm{H} 2$ & ND & 116 \\
\hline 133.75 & $\mathrm{H} 2$ & ND & 82.5 \\
\hline
\end{tabular}


Table 6.4. (contd)

\begin{tabular}{|c|c|c|c|}
\hline \multicolumn{2}{|r|}{ C4297 } & \multirow{2}{*}{$\begin{array}{c}\text { Tc-99 } \\
\mathbf{K}_{\mathrm{d}} \\
(\mathbf{m L} / \mathbf{g})\end{array}$} & \multirow{2}{*}{$\begin{array}{c}\mathbf{U} \\
\underset{(\mathbf{m L} / \mathbf{g})}{\mathbf{K}_{\mathrm{d}}}\end{array}$} \\
\hline $\begin{array}{l}\text { Depth } \\
\text { (ft bgs) }\end{array}$ & Stratigraphic Unit & & \\
\hline 136.75 & $\mathrm{H} 2$ & ND & 67.4 \\
\hline 140.00 & $\mathrm{H} 2$ & $(0.208)$ & 116 \\
\hline 143.25 & $\mathrm{H} 2$ & ND & 50.0 \\
\hline 148.30 & $\mathrm{H} 2$ & ND & 45.5 \\
\hline 148.30 & $\mathrm{H} 2$ & $\mathrm{ND}$ & 33.7 \\
\hline 165.75 & $\mathrm{H} 2$ & ND & 67.2 \\
\hline 170.25 & $\mathrm{H} 2$ & ND & 128 \\
\hline 174.05 & $\mathrm{H} 2$ & $\mathrm{ND}$ & 129 \\
\hline \multicolumn{4}{|c|}{ ND indicates the calculation resulted in a negative value. } \\
\hline \multicolumn{4}{|c|}{$\begin{array}{l}\text { Faint blue (light) shading data are likely more dominated by natural constituents } \\
\text { (uranium) or imprecise analytical data (technetium-99). }\end{array}$} \\
\hline \multicolumn{4}{|c|}{ Grey shading signifies core samples. } \\
\hline \multicolumn{4}{|c|}{$\begin{array}{l}\text { Red (bold) type signifies depths where sediments show obvious signs of some } \\
\text { tank related fluids. }\end{array}$} \\
\hline \multicolumn{4}{|c|}{$\begin{array}{l}\text { Yellow (dark) shading signifies } \mathrm{K}_{\mathrm{d}} \text { values that are dominated by tank fluids as } \\
\text { opposed to a mix of natural and Hanford constituents. }\end{array}$} \\
\hline
\end{tabular}

Based on the distribution of tank C-105 constituents, potentially mobile tank constituents (nitrate, technetium-99, and uranium, as well as the ion exchange front for sodium replacing the native calcium and magnesium), it appears that there is a small horizontal component to the path that the leaked fluids took if wastes leaked from the C-105 tank and percolated into the vadose zone sediments at the C4297 borehole location. That is, the zone of compaction associated with the tank bottom could have acted as a mechanism that provided at least some horizontal migration of contaminants. Lateral migration of less mobile contaminants (i.e., cesium-137) was not observed via analysis of the C4297 borehole samples. GEA analysis of the sediments from borehole C4297 did not confirm the gamma signature observed in the nearby drywell 30-05-07 between 34 and $44 \mathrm{ft}$ bgs and between 48 and $62 \mathrm{ft}$ bgs.

The matric potential data for the vadose zone profile represented by cores from borehole C4297 showed that measured water potentials were generally much less than the calculated gravity potential. Only one sample, collected at $150 \mathrm{ft}$ bgs, had a measured matric potential in excess of the theoretical matric potential line plotted in Figure 4.26. Nearly all of the matric potentials were very low in comparison to the gravity head, which could be an artifact of inadvertent drying during sample storage. The general trend for the data from borehole C4297 is that the water potentials were consistent with a draining profile, including the zones in which contamination is present. 


\subsection{Description of Waste Management Area C Upper Unconfined Aquifer}

The suprabasalt aquifer is separated into the uppermost unconfined aquifer and the underlying Ringold Formation confined aquifer beneath WMA C by the silt and clay deposits of the Ringold Formation lower mud unit. Currently, the unconfined aquifer is about $10 \mathrm{~m}$ (32.8 ft) thick at well 299-E27-22, north of WMA C. The unconfined aquifer consists mostly of sandy gravels and gravelly sands of the Hanford formation. All wells in the WMA C monitoring network are screened in hydrogeologic unit 1. Currently, the water table at WMA C is $123 \mathrm{~m}(403.5 \mathrm{ft})$ above sea level.

The unconfined aquifer below WMA C has been impacted by past practice and liquid waste disposal operations. Water levels in the upper unconfined aquifer raised as much as $9 \mathrm{~m}(29.5 \mathrm{ft})$ above the pre-Hanford natural water table, beneath the north part of the 200 East Area because of artificial recharge from liquid waste disposal operations since the mid-1940s. The largest volumes of discharge were to the 216-B Pond system, located about 1.5 to 2 kilometers east of WMA C and to the 216-A-25 (Gable Mountain) pond system north of the 200 East Area; lesser but substantial volumes of liquid were discharged to several of the PUREX cribs east and south of WMA C. The 216-B Pond system is estimated to have received approximately 256 billion liters of effluent. The large-volume disposal to the ponds (and, lesser volumes to cribs and ditches) artificially recharged the unconfined aquifer, creating large water table mounds.

Accompanying the changes in water level were changes in groundwater flow direction. The pre-Hanford Site groundwater flow direction was toward the east in the area of WMA C. The groundwater flow direction beneath the east-central part of 200 East Area had changed toward the southwest by the late 1950s due to the influence of the pond disposal systems. Water table maps in Kipp and Mudd (1974) show that the groundwater flow direction had actually changed toward the southwest by the early 1950s. The groundwater flow direction has been fairly constant and toward the southwest since that time.

The large shift in groundwater flow direction resulting from intentional discharges to past practice disposal facilities may have broad implications for contaminant distribution in the uppermost aquifer beneath the C Tank Farm. Since the early 1950s, any contamination entering the aquifer in the region was spread toward the southwest. Contamination that was spread southwest from facilities in the north part of the 200 East Area, may return to the area of WMA C as groundwater returns to the pre-Hanford easterly direction.

Hydrologic testing (slug tests) has been done at only one well at WMA C in the past few years. Four slug tests were performed at selected test/depth intervals in well 299-E27-22 as the well was being drilled in 2003. Additionally, hydraulic conductivity and transmissivity data from slug tests done at three wells at WMA C during 1989 as well as the flow velocities calculated from those data are available. Groundwater flow velocities derived during the 1989 study at a single depth in each well resulted in fairly consistent results: velocities ranged from 0.05 to $0.13 \mathrm{~m} /$ day $(0.16$ to $0.4 \mathrm{ft} /$ day). However, the study recently performed in well 299-E27-22, which included data from four discrete depths within the well, highlighted significantly more variability in groundwater flow velocities. The calculated flow velocities varied by several orders of magnitude from 0.00004 to $7.59 \mathrm{~m} /$ day ( 0.0001312 to $25.9 \mathrm{ft} /$ day). These kinds of differences in hydraulic properties illustrate the difficulty in assigning accurate values to specific hydrogeologic units in the 200 East Area. The differences are due to different testing and analysis methods used through time, different assumed values for certain parameters, such as effective 
porosity, and natural variation in lithologic properties that affect the hydraulic properties. Also, the differences noted in the hydraulic conductivity among different depths in well 299-E27-22 (varied from 0.04 to $6,900 \mathrm{~m} /$ day [1.3 to $22,637.7 \mathrm{ft} /$ day]) attest to the variations in hydraulic properties in the aquifer sediments.

\subsection{Existing Groundwater Contamination}

Groundwater at the C Tank Farm contains elevated concentrations of calcium, chloride, cyanide, nitrate, sulfate, technetium-99, iodine-129, tritium, and to lesser extents sodium and magnesium. Very little data are available before the early 1990s when most of the monitoring wells were drilled at the tank farm. The oldest well, 299-E27-7, was drilled in 1982 and the oldest groundwater monitoring data associated with the well are gross beta values, beginning in 1984, and nitrate concentrations, beginning in 1985. Between 1984 and about 1998, gross beta values in well 299-E27-7 were only slightly greater than the Hanford Site background of $5.6 \mathrm{pCi} / \mathrm{L}$. Nitrate concentrations were close to or less than Hanford Site background concentrations $(5,681 \mu \mathrm{g} / \mathrm{L})$ until about 1992 when an increase in nitrate concentrations occurred, accompanied by increases in concentrations of most major cations and anions. Nitrate decreased to near background concentrations in 1993 and remained low until 1998. This contamination appears to result from the mixing of wastes from a number of past waste-disposal activities, including liquid discharges associated with the cribs and trenches near the PUREX facility and leaks from single-shell tanks and transfer lines within the C Tank Farm.

Prior to about 1998, the nitrate concentration at WMA C was less than or near background levels. Beginning in about 1998, the nitrate concentration started to increase in all wells at WMA C. The highest concentrations historically were in the upgradient wells 299-E27-7 and 299-E27-14 on the eastern side of the tank farm. These wells still had the largest nitrate concentrations in early 2005, but since about 2004, nitrate concentrations in some downgradient wells are similar to that in well 299-W27-7.

Technetium-99 began to increase in well 299-E27-14, concurrent with the increase in nitrate at about the end of 1997. Near the end of 2000, the technetium-99 concentration began to increase in well 299-E27-13, located approximately downgradient from well 299-E27-14. The increase in technetium-99 in well 299-E27-13, located downgradient of well 299-E27-14 suggests that the plume impinging on well 299-E27-14 in 1997 had traveled to well 299-E27-13 by 2000. However, the technetium-99/nitrate ratios suggest that the contamination seen in upgradient wells 299-E27-7 and 299-E27-14 is not related to the contamination in well 299-E27-13. The data indicate that as the nitrate concentration increases in upgradient well 299-W27-14, the technetium-99 concentration increases proportionately because the technetium-99/nitrate ratio does not change appreciably. In contrast, the technetium-99 concentration increases significantly with respect to the nitrate concentration in downgradient well 299-W27-13. This suggests two sources for the two contaminants in the downgradient well.

The technetium-99 and nitrate concentrations increased in upgradient well 299-E27-7 during early 2001, reached maxima in late 2001 and early 2002, and decreased during early 2003. The transient plume at upgradient well 299-W27-7 is probably not the same contamination currently encountered in downgradient well 299-E27-4 because the technetium-99/nitrate ratios are very different between the two wells. However, the technetium-99 concentrations and the technetium-99/nitrate ratios from wells 299-E27-7 and 299-E27-23 are similar suggesting that these two wells have similar sources for the contamination. 
Several wells at WMA C have had detectable cyanide concentrations in the past 5 to 6 years, although the concentrations have been erratic in most wells. Cyanide is of particular interest at WMA C because the WMA is the only known source for cyanide in the area. The earliest detected cyanide in the area was in wells 299-E27-14 and 299-E27-15, located on the west and east sides of the WMA respectively, in the early 1990s. Both wells had one detectable occurrence of cyanide at less that $6 \mu \mathrm{g} / \mathrm{L}$, but no subsequent analyses for cyanide were made until late in 2000.

Since 2000, most wells in the WMA C monitoring network have shown sporadic cyanide concentrations in the groundwater. The source for the cyanide is not easy to determine because wells on all sides of WMA C have shown positive results. The highest concentrations have been in upgradient well 299-E27-7. This well also had the earliest and highest technetium-99 concentrations in the area. Although the most likely source for both the cyanide and the technetium-99 is the WMA, the concentrations of the two contaminants do not track each other, suggesting that two difference sources may be contributing to the technetium-99 and cyanide contamination. The identity of the sources is not known.

\subsection{Complexities in Groundwater Data (Vertical and Temporal Variations)}

The groundwater data are complicated by signs that vertical stratification in contaminant and common solutes is occurring. Significant differences in technetium-99 and nitrate concentrations with depth were observed in well 299-E27-22. After purging the well, the pumped samples do not appear to be representative of ambient water because purging the well causes mixing of strata with different contaminant concentrations. Thus, interpreting the contaminant distribution in wells, such as the 299-E27-22 groundwater monitoring well, is very difficult because groundwater at the well contains elevated concentrations of several contaminants that show different vertical concentration profiles and probably come from different sources in the area.

\subsection{Vadose Zone Pore Water and Groundwater Chemical Ratio Comparisons}

Selected concentration ratios of mobile contaminants in: (1) the vadose zone sediments sampled from borehole C4297, (2) the WMA C groundwater contaminant plumes, and (3) specific single-shell tanks, cribs and trenches at the time of suspected leaks and disposal campaigns, respectively, were used to assess whether there are indications that the groundwater contamination is related to current vadose zone contamination and can be associated with a specific facility or a specific tank leak.

Initial attempts to relate the groundwater and pore water compositions used the ratios of the concentrations of various contaminants (technetium-99, fluoride, sulfate, sodium, and nitrate) to one another. The agreement between the vadose zone pore water and contaminated groundwater data sets was not good. The technetium-99/nitrate ratios of samples from the contaminated zones in borehole C4297 were generally greater than about 0.2 . Such values are greater than the technetium-99/nitrate ratios in all of the groundwater wells except well 299-E27-4. However, the agreement for the other ratios between groundwater from well 299-E27-4 and pore water from borehole C4297 was not good, which was a result of fractionation between technetium-99 and the other constituents, especially sodium. 
The estimated concentration ratios for selected constituents in tank C-105 and those calculated in pore waters from borehole C4297 were also compared. Comparison of the two data sets resulted in poor overall agreement. Just as with the groundwater, there are no obvious similarities between the estimated composition of the tank "leak" and the measured pore water from borehole C4297.

The lack of agreement between the groundwater ratios, tank ratios and the contaminated borehole sediment pore water ratios suggests that the groundwater contamination has been influenced by fluids from nearby cribs and trenches. The ratios of most mobile species in the vadose zone pore waters should remain stable as tank fluids percolate through the sediment because the only reaction between the tank waste and the vadose zone sediment mobile constituents should be dilution, as dispersion and mixing occurs with native pore water.

In summary, there is no current similarity between the present or past groundwater contamination and current pore water compositions from the contaminated borehole sediments. Therefore, we cannot link the contaminants in the groundwater, currently or during the era of contamination introduction in the vadose zone, to the pore waters currently in the borehole sediments, which are believed to be derived from the liquids that leaked or were lost from tank C-105. 


\subsection{References}

American Society for Testing and Materials (ASTM) D2216-98. 1998. Test Method for Laboratory Determination of Water (Moisture) Content of Soil and Rock by Mass. American Society for Testing and Materials, West Conshohocken, Pennsylvania.

American Society for Testing and Materials (ASTM) D2488-93. 1993. Standard Practice for Description and Identification of Soils (Visual-Manual Procedure). American Society for Testing and Materials, West Conshohocken, Pennsylvania.

American Society for Testing and Materials (ASTM) D5298-94. 2002. Test Method for Measurement of Soil Potential (Suction) Using Filter Paper. American Society for Testing and Materials, West Conshohocken, Pennsylvania.

American Society of Agronomy (ASA). 1986a. "Hydrometer Method.” Chapter 15-5 in Methods of Soil Analysis-Part 1, 2nd edition of Physical and Mineralogical Methods, SSSA Book Series No. 5, ed. A Klute, pp. 404-408. Soil Science Society of America, Madison, Wisconsin.

American Society of Agronomy (ASA). 1986b. "Pynchnometer Method." Chapter 14-3 in Methods of Soil Analysis-Part 1, 2nd edition of Physical and Mineralogical Methods, SSSA Book Series No. 5, ed. A Klute, pp. 378-379. Soil Science Society of America, Madison, Wisconsin.

American Society of Agronomy (ASA). 1996. Methods of Soil Analysis-Part 3, Chemical Methods, SSSA Book Series 5, ed. DL Sparks, Soil Science Society of America, Madison, Wisconsin.

ASTM. 2001 Standard Test Methods for Analysis of Metal Bearing Ores and Related Materials by Combustion Infrared Absorption Spectrometry. ASTM Method E1915-01, American Society for Testing and Materials, West Conshohocken, Pennsylvania.

Baker VR and RC Bunker. 1985. "Cataclysmic Late-Pleistocene Flooding from Glacial Lake Missoula: A Review.” Quaternary Science Reviews 4:1-41.

Baker VR, BN Bjornstad, AJ Busacca, KR Fecht, EP Kiver, UL Moody, JG Rigby, DF Stradling, and AM Tallman. 1991. "Quaternary Geology of the Columbia Plateau”. In Morisson, R. B. ed., Quaternary Nonglacial Geology. Conterminous U.S. Geology of North America, Geol. Soc. Am. K 2:215-250, Boulder, Colorado.

Black RF. 1979. Clastic Dikes of the Pasco Basin, Southeastern Washington. RHO-BWI-C-64, Rockwell Hanford Operations, Richland, Washington.

Brodeur JR. 1993. Assessment of Unsaturated Zone Radionuclide Contamination around Single-Shell Tanks 241-C-105 and 241-C-106. WHC-SD-EN-TI-185, Westinghouse Hanford Company, Richland, Washington. 
Brown CF, RJ Serne, HT Schaef, BA Williams, MM Valenta, VL LeGore, MJ Lindberg, KN Geiszler, SR Baum, IV Kutnyakov, TS Vickerman, and RE Clayton. 2005. Investigation of Accelerated Casing Corrosion in Wells from Waste Management Area A-AX: Wells 299-E24-19 and 299-E25-46.

PNNL-15141, Pacific Northwest National Laboratory, Richland, Washington.

Brown RE. 1970. Interrelationships of Geologic Formations and Processes Affecting Ecology as Exposed at Rattlesnake Springs. BNWL-B-29, Battelle Northwest Laboratory, Richland, Washington.

Caggiano JA. 1993. Hydrologic Testing of the Single-Shell Tanks, 1989. WHC-SD-EN-TI-147, prepared by Pacific Northwest National Laboratory, Richland, Washington, for Westinghouse Hanford Company, Richland, Washington.

Cantrell KJ, RJ Serne, and GV Last. 2003. Hanford Contaminant Distribution Coefficient Database and Users Guide. PNNL-13895 Rev. 1, Pacific Northwest National Laboratory, Richland, Washington.

Cline CS, JT Rieger, JR Raymond, and PA Eddy. 1985. Ground-Water Monitoring at the Hanford Site, January - December 1984. PNL-5408, Pacific Northwest Laboratory, Richland, Washington.

Connelly MP, BH Ford, and JV Borghese. 1992a. Hydrogeologic Model for the 200 West Groundwater Aggregate Area. WHC-SD-EN-TI-014, Westinghouse Hanford Company, Richland, Washington.

Connelly MP, JV Borghese, CD Delaney, BH Ford, JW Lindberg, and SJ Trent. 1992b. Hydrogeologic Model for the 200 East Groundwater Aggregate Area. WHC-SD-EN-TI-019, Westinghouse Hanford Company, Richland, Washington.

Corbin RA, BC Simpson, MA Anderson, W Danielson III, JG Field, TE Jones, MD Freshley, and CT Kincaid. 2005. Hanford Soil Inventory Model, Rev. 1. RPP 26744, Rev. 0, CH2M HILL Hanford Group, Inc., Richland, Washington.

Crumpler JD. 2004. Site-Specific Single-Shell Tank Phase 1 RCRA Facility Investigation/Corrective Measures Study Work Plan Addendum for Waste Management Areas C, A-AX, and U. RPP-16608, Rev. 1, CH2M HILL Hanford Group, Inc., Richland, Washington.

Deka RN, M Wairiu, PW Mtakwa, CE Mullins, EM Veenendaal, and J Towend. 1995. "Use and Accuracy of the Filter Paper Method for Measuring Soil Matric Potential.” European J. of Soil Sci. 46:233-238.

DOE (U.S. Department of Energy). 1984. Draft Environmental Assessment, Reference Repository Location, Hanford Site, Washington, DOE/RW-0017, U.S. Department of Energy, Washington, D.C.

DOE (U.S. Department of Energy). 1988. Consultation Draft Site Characterization Plan.

DOE/RL-0164, 9 volumes, U.S. Department of Energy, Richland, Washington.

DOE (U.S. Department of Energy). 1997. Hanford Site Background: Part 3, Groundwater Background. DOE/RL-96-61, U.S. Department of Energy, Richland, Washington. 
DOE (U.S. Department of Energy). 1998a. Vadose Zone Characterization Project at the Hanford Tank Farms, C Tank Farm Report. GJO-HAN-27, prepared by U.S. Department of Energy, Grand Junction Office for U.S. Department of Energy, Richland Operations Office, Richland Washington.

DOE (U.S. Department of Energy). 1998b. Hanford Tank Farms Vadose Zone, C Tank Farm Report. GJO-98-39-TAR, GJO-HAN-18, prepared by U.S. Department of Energy, Albuquerque Operations Office and Grand Junction Office for Richland Operations Office, Richland, Washington.

DOE (U.S. Department of Energy). 1999. Phase 1 RCRA Facility Investigation/Corrective Measures Study Work Plan for the SST Waste Management Areas. DOE/RL-99-36, Rev. 0, U.S. Department of Energy, Richland, Washington.

DOE (U.S. Department of Energy). 2002. Standardized Stratigraphic Nomenclature for Post-RingoldFormation Sediments Within the Pasco Basin. DOE/RL-2002-39, U.S. Department of Energy, Richland, Washington.

Eddy PA. 1979. Radiological Status of the Ground-Water beneath the Hanford Project January December 1978. PNL-2899, Pacific Northwest Laboratory, Richland, Washington.

EPA Method 300.0A. 1984. Test Method for the Determination of Inorganic Anions in Water by Ion Chromatography. EPA-600/4-84-017, U.S. Environmental Protection Agency, Washington, D.C.

EPA Method 3050B. 2000a. “Acid Digestion of Sediments, Sludges, and Soils.” Test Methods for Evaluating Solid Waste, Physical/Chemical Methods. EPA Publication SW-846 [Online manual]. Available URL: http://www.epa.gov/epaoswer/hazwaste/test/sw846.htm

EPA Method 6010B. 2000b. "Inductively Coupled Plasma-Atomic Emission Spectrometry." Test Methods for Evaluating Solid Waste, Physical/Chemical Methods. EPA Publication SW-846 [Online manual]. Available URL: http://www.epa.gov/epaoswer/hazwaste/test/sw846.htm

EPA Method 6020. 2000c. "Inductively Coupled Plasma-Mass Spectrometry.” Test Methods for Evaluating Solid Waste, Physical/Chemical Methods. EPA Publication SW-846 [Online manual]. Available URL: http://www.epa.gov/epaoswer/hazwaste/test/sw846.htm

EPA. 1999. Understanding Variation in Partition Coefficient, Kd, Values: Volume II. Review of Geochemistry and Available Kd Values for Cadmium, Cesium, Chromium, Lead, Plutonium, Radon, Strontium, Thorium, Tritium (3H), and Uranium. EPA 402-R-99-004B, U.S. Environmental Protection Agency, Washington, D.C. prepared by KM Krupka, DI Kaplan, SV Mattigod, and RJ Serne at the Pacific Northwest National Laboratory, Richland, Washington (approx. 400 pages).

Fecht KR and DC Weekes. 1996. Geologic Field Inspection of the Sedimentary Sequence at the Environmental Restoration Disposal Facility. BHI-00230, Bechtel Hanford, Inc., Richland, Washington.

Fecht KR, BN Bjornstad, DG Horton, GV Last, SP Reidel, and KA Lindsey. 1999. Clastic Injection Dikes of the Pasco Basin and Vicinity: Geologic Atlas Series. BHI-01103, Rev. 0. Bechtel Hanford Company, Richland, Washington. 
Field JG and TE Jones. 2005. Tank Farm Vadose Zone Contamination Volume Estimates. RPP-23405, Rev. 1, CH2M HILL Hanford Group, Inc., Richland, Washington.

Flint RF. 1938. "Origin of the Cheney-Palouse Scabland Tract.” Geological Society of America Bulletin, v. 49, p. 461-524.

Folk RL. 1968. Petrology of Sedimentary Rocks. Hemphill, Austin, Texas.

Gee GW, MJ Fayer, ML Rockhold, and MD Campbell. 1992. "Variations in Recharge at the Hanford Site,” NW Sci. 66:237-250.

Gee GW. 1987. Recharge at the Hanford Site. Status Report. PNL-6403, Pacific Northwest Laboratory, Richland, Washington.

Hartman MJ, LF Morasch, and WD Webber (eds). 2003. Hanford Site Groundwater Monitoring for Fiscal Year 2002. PNNL-14187, Pacific Northwest National Laboratory, Richland, Washington.

Hartman MJ, LF Morasch, and WD Webber (eds). 2004. Hanford Site Groundwater Monitoring for Fiscal Year 2003. PNNL-14548, Pacific Northwest National Laboratory, Richland, Washington.

Hartman MJ, LF Morasch, and WD Webber (eds). 2005. Hanford Site Groundwater Monitoring for Fiscal Year 2004. PNNL-15070, Pacific Northwest National Laboratory, Richland, Washington.

Horton DG and SM Narbutovskih. 2001. RCRA Groundwater Monitoring Plan for Single-Shell Tank Waste Management Area C at the Hanford Site. PNNL-13024, Pacific Northwest National Laboratory, Richland, Washington.

Kaplan DI and RJ Serne. 1995. Distribution Coefficient Values Describing Iodine, Neptunium, Selenium, Technetium, and Uranium Sorption to Hanford Sediment. PNL-10379, Supplement 1, Pacific Northwest Laboratory, Richland, Washington.

Kaplan DI and RJ Serne. 2000. Geochemical Data Package for the Hanford Immobilized Low-Activity Tank Waste Performance Assessment (ILAW-PA). PNNL-13037, Rev.1, Pacific Northwest National Laboratory, Richland, Washington.

Kipp RL and RD Mudd. 1974. Selected Water Table Contour Maps and Well Hydrographs for the Hanford Reservation, 1944-1973. BNWL-B-360, Pacific Northwest Laboratories, Richland, Washington.

Last GV, BN Bjornstad, MP Bergeron, DW Wallace, DR Newcomer, JA Schramke, MA Chamness, CS Cline, SP Airhart, and JS Wilbur. 1989. Hydrogeology of the 200 Areas Low-Level Burial Grounds An Interim Report. PNL-6820, 2 volumes, Pacific Northwest Laboratory, Richland, Washington.

Lindenmeier CW, RJ Serne, BN Bjornstad, GW Gee, HT Schaef, DC Lanigan, MJ Lindberg, RE Clayton, VL LeGore, IV Kutnyakov, SR Baum, KN Geiszler, KMM Valenta, TS Vickerman, and LJ Royack. 2002. Characterization of Vadose Zone Sediment: RCRA Borehole 299 E33 338 Located Near the B-BX-BY Waste Management Area, PNNL 14121, Pacific Northwest National Laboratory, Richland, Washington. 
Lindsey KA, BN Bjornstad, JW Lindberg, and KM Hoffman. 1992a. Geologic Setting of the 200 East Area - An Update. WHC-SD-EN-TI-012, Westinghouse Hanford Company, Richland, Washington.

Lindsey KA, JL Slate, GK Jaeger, KJ Swett, and RB Mercer. 1994b. Geologic Setting of the Low-Level Burial Grounds. WHC-SD-EN-TI-290, Rev. 0, Westinghouse Hanford Company, Richland, Washington.

Lindsey KA, KD Reynolds, and VM Johnson. 2004. 241-C Tank Farm Geologic and Stratigraphic Analysis. RPP-18290, Rev. 1, CH2M HILL Hanford Group, Inc., Richland, Washington.

Lindsey KA, MP Connelly, and BN Bjornstad. 1992b. Geologic Setting of the 200 West Area An Update. WHC-SD-EN-TI-008, Westinghouse Hanford Company, Richland, Washington.

Lindsey KA, SE Kos, and KD Reynolds. 2001. Vadose Zone Geology of Boreholes 299-W10-27 and 299-W11-39 T-TX-TY Waste Management Area, Hanford Site, South-Central Washington. RPP 8531, Rev. 0, prepared for the U.S. Department of Energy, Office of River Protection, CH2M HILL Group, Inc., Richland, Washington.

Lindsey KA, SP Reidel, KR Fecht, JL Slate, AG Law, and AM Tallman. 1994a. "Geohydrologic Setting of the Hanford Site, South-Central Washington.” In Geologic Field Trips in the Pacific Northwest, (eds.) DA Swanson and RA Hagerud, pp. 1C-1 to 1C-16. Geological Society of America Meeting, Geological Society of America, Boulder, Colorado.

Lindsey KA. 1995. Miocene- to Pliocene-Aged Suprabasalt Sediments of the Hanford Site, South-Central Washington, BHI-00184, Bechtel Hanford, Inc., Richland, Washington.

Lindsey KA. 1996. Miocene-Pliocene Ringold Formation and Associated Deposits of the Ancestral Columbia River System, South-Central Washington and North-Central Oregon, Washington.

Department of Natural Resources, Division of Geology and Earth Resources Open-File Report 96-8, Olympia, Washington, $45 \mathrm{p}$.

Moody UL. 1987. Late Quaternary Stratigraphy of the Channeled Scabland and Adjacent Areas, Ph.D. Thesis, University of Idaho, Moscow, Idaho.

Myers CW and SM Price, eds. 1979. Geologic Studies of the Columbia Plateau - A Status Report. RHO-BWI-ST-4, Rockwell Hanford Operations, Richland, Washington.

O’Connor JE. 1993. Hydrology, Hydraulics, and Geomorphology of the Bonneville Flood. Special Paper \#274, Geological Society of America, Boulder, Colorado, 83 p.

Or D and JM Wraith. 2002. "Soil Water Content and Water Potential Relationships.” In Soil Physics Companion, ed. AW Warrick, pp. 49-84, CRC Press, Boca Raton, Florida.

Pacific Northwest Laboratory (PNL). 1990a. Procedures for Groundwater Investigations. PNL-MA-567, Pacific Northwest Laboratory, Richland, Washington.

Pacific Northwest Laboratory (PNL). 1990b. Procedures for Groundwater Investigations. PNL-MA-567-SFA-2, Pacific Northwest Laboratory, Richland, Washington. 
Pacific Northwest National Laboratory (PNNL). 1997. Gamma Energy Analysis Operation and Instrument Verification Using the Genie2000 ${ }^{\mathrm{TM}}$ Support Software. PNNL-RRL-01, Pacific Northwest National Laboratory, Richland, Washington.

Pacific Northwest National Laboratory (PNNL). 1998. Inductively Coupled Plasma Mass Spectrometric (ICP-MS) Analysis. PNNL-AGG-415, Pacific Northwest National Laboratory, Richland, Washington.

Pacific Northwest National Laboratory (PNNL). 1999. Visual Description and Classification of Potentially Contaminated Borehole Samples. PNL Procedure D9T81-99-GVL-1, Pacific Northwest National Laboratory, Richland, Washington.

Pacific Northwest National Laboratory (PNNL). 2000. Liquid Scintillation Counting and Instrument Verification Using the 1400 DSM ${ }^{\mathrm{TM}}$ Support Software. PNNL-AGG-002, Pacific Northwest National Laboratory, Richland, Washington.

Pacific Northwest National Laboratory (PNNL). 2005. Soil Water Content. PNNL-AGG-WC-001 Rev.0, Pacific Northwest National Laboratory.

Price WH and KR Fecht. 1976. Geology of the 241-C Tank Farm. ARH-LD-132, Atlantic Richfield Hanford Company, Richland, Washington.

Reidel SP, DG Horton, Y Chien, DB Barnett, and K Singleton. 2006. Geology, Hydrogeology, Geochemistry, and Mineralogy Data Package for the Single Shell Tank Waste Management Areas at the Hanford Site. RPP-23748, CH2M HILL Hanford Group, Inc., Richland, Washington.

Reidel SP, KA Lindsey, and KR Fecht. 1992. Field Trip Guide to the Hanford Site. WHC MR-0391, Westinghouse Hanford Company, Richland, Washington.

Resource Conservation and Recovery Act of 1976, 42 USC 6901 et seq.

Rhoades JD. 1996. “Salinity: Electrical Conductivity and Total Dissolved Solids.” In Methods of Soil Analysis Part 3, ed. JM Bigham, pp. 417-435. American Society of Agronomy, Madison, Wisconsin.

Serne RJ, HT Schaef, BN Bjornstad, BA Williams, DC Lanigan, DG Horton, RE Clayton, VL LeGore, MJ O’Hara, CF Brown, KE Parker, IV Kutnyakov, JN Serne, AV Mitroshkov, GV Last, SC Smith, CW Lindenmeier, JM Zachara, and DS Burke. 2002a. Characterization of Vadose Zone Sediment: Uncontaminated RCRA Borehole Core Samples and Composite Samples. PNNL-13757-1, Pacific Northwest National Laboratory, Richland, Washington.

Serne RJ, HT Schaef, BN Bjornstad, DC Lanigan, GW Gee, CW Lindenmeier, RE Clayton, VL LeGore, MJ O’Hara, CF Brown, RD Orr, G.V Last, IV Kutnyakov, DS Burke, TC Wilson, and BA Williams. 2002b. Characterization of Vadose Zone Sediment: Borehole 299-W23-19 [SX 115] in the S-SX Waste Management Area. PNNL-13757-2, Pacific Northwest National Laboratory, Richland, Washington.

Serne RJ, GV Last, HT Schaef, DC Lanigan, CW Lindenmeier, CC Ainsworth, RE Clayton, VL LeGore, MJ O’Hara, CF Brown, RD Orr, IV Kutnyakov, TC Wilson, KB Wagnon, BA Williams, and DB Burke. 2002c. Characterization of Vadose Zone Sediment, Part 4: Slant Borehole SX-108 in the S-SX Waste Management Area. PNNL-13757-4, Pacific Northwest National Laboratory, Richland, Washington. 
Serne RJ, GV Last, GW Gee, HT Schaef, DC Lanigan, CW Lindenmeier, RE Clayton, VL LeGore, RD Orr, MJ O’Hara, CF Brown, DS Burke, AT Owen, IV Kutnyakov, and TC Wilson. 2002d.

Characterization of Vadose Zone Sediment: Borehole 41-09-39 in the S-SX Waste Management Area. PNNL-13757-3, Pacific Northwest National Laboratory, Richland, Washington.

Serne RJ, GV Last, GW Gee, HT Schaef, DC Lanigan, CW Lindenmeier, MJ Lindberg, RE Clayton, VL LeGore, RD Orr, IV Kutnyakov, SR Baum, KN Geiszler, CF Brown, MM Valenta, and TS Vickerman. 2002e. Characterization of Vadose Zone Sediment: Borehole 299-E33-45 Near BX-102 in the B-BX-BY Waste Management Area. PNNL-14083, Pacific Northwest National Laboratory, Richland, Washington.

Serne RJ, BN Bjornstad, GW Gee, HT Schaef, DC Lanigan, CW Lindenmeier, RD Orr, VL LeGore, RE Clayton, MJ Lindberg, IV Kutnyakov, SR Baum, KN Geiszler, MM Valenta, TS Vickerman, and LJ Royack. 2002f. Characterization of Vadose Zone Sediment: Borehole 299-E33-46 Near B-110 in the $B-B X-B Y$ Waste Management Area. PNNL-14119, Pacific Northwest National Laboratory, Richland, Washington.

Serne RJ, BN Bjornstad, DG Horton, DC Lanigan, CW Lindenmeier, MJ Lindberg, RE Clayton, VL LeGore, RD Orr, IV Kutnyakov, SR Baum, KN Geiszler, MM Valenta, and TS Vickerman. 2004a. Characterization of Vadose Zone Sediments Below the TX Tank Farm: Boreholes C3830, C3831, C3832 and RCRA Borehole 299-W10-27. PNNL-14594, Pacific Northwest National Laboratory, Richland, Washington.

Serne RJ, BN Bjornstad, DG Horton, DC Lanigan, HT Schaef, CW Lindenmeier, MJ Lindberg, RE Clayton, VL LeGore, KN Geiszler, SR Baum, MM Valenta, IV Kutnyakov, TS Vickerman, RD Orr, and CF Brown. 2004b. Characterization of Vadose Zone Sediments Below the T Tank Farm: Boreholes C4104, C4105, 299-W10-196, and RCRA Borehole 299-W11-39. PNNL-14849, Pacific Northwest National Laboratory, Richland, Washington,

Shaw J, M Munro-Stasuik, B Sawyer, C Beaney, JE Lesemann, A Musacchio, B Rains, and RR Young. 1999. “The Channeled Scabland: Back to Bretz.” Geology 27:605-608.

Smith GA. 1993. "Missoula Flood Dynamics and Magnitudes Inferred from Sedimentology of Slack-Water Deposits on the Columbia Plateau.” Geological Society of America Bulletin, v. 195 , p. $77-100$.

Tallman AM, KR Fecht, MC Marratt, and GV Last. 1979. Geology of the Separations Areas, Hanford Site, South-Central Washington. RHO-ST-23, Rockwell Hanford Operations, Richland, Washington.

Tallman AM, JT Lillie, and KR Fecht. 1981. "Suprabasalt Sediment of the Cold Creek Syncline Area," In Subsurface Geology of the Cold Creek Syncline, eds. CW Myers and SM Price, RHO-BWI-ST-14, Rockwell Hanford Operations, Richland, Washington.

USGS (United States Geological Survey). 2001. Alkalinity and Acid Neutralizing Capacity. National Field Manual for the Collection of Water-Quality Data, 2nd ed., eds. SA Rounds and FD Wilde.

March 23, 2004 Available URL:

http://water.usgs.gov/owq/FieldManual/Chapter6/section6.6/html/section6.6.htm 
Virtual Library. Internet site maintained by Fluor Hanford, Inc., Richland, Washington. Available URL: http://vlprod.rl.gov/vlib/app/index.cfm

Webster GD and JW Crosby. 1982. Stratigraphic Investigation of the Skagit/Hanford Nuclear Project. S/HNP-PSAR, Appendix 2R, Puget Sound Power and Light Company, Bellevue, Washington.

Wentworth CK. 1922. “A Grade Scale and Class Terms for Clastic Sediments.” Journal of Geology, 30, p. 377-392.

Williams BA and SM Narbutovskih. 2004. Borehole Data Package for Four CY 2003 RCRA Wells 299-E27-4, 299-E27-21, 299-E27-22, 299-E27-23 at Single-Shell Tank, Waste Management Area C, Hanford Site, Washington. PNNL-14656, Pacific Northwest National Laboratory, Richland, Washington.

Williams BA, BN Bjornstad, R Schalla, and WD Webber. 2000. Revised Hydrogeology for the Suprabasalt Aquifer System, 200-East Area and Vicinity, Hanford Site, Washington. PNNL-12261, Pacific Northwest National Laboratory, Richland, Washington.

Wood MI, TE Jones, BN Bjornstad, DG Horton, SM Narbutovskih, and R Schalla. 2003. Subsurface Conditions Description of the C and A-AX Waste Management Areas. RPP-14430, Rev. 0, CH2M HILL Hanford Group, Inc., Richland, Washington.

Wood MI., TE Jones, R Schalla, BN Bjornstad, and SM Narbutovskih. 2000. Subsurface Conditions Description of the B-BX-BY Waste Management Area, HNF-5507, Rev. 0A, CH2M HILL Hanford Group, Inc., Richland, Washington. 


\section{Appendix A}

\section{Photographs of Core from Borehole C4297}




\section{Contents}

Appendix A. Photographs of Core from Borehole C4297.

A. 1

\section{Figures}

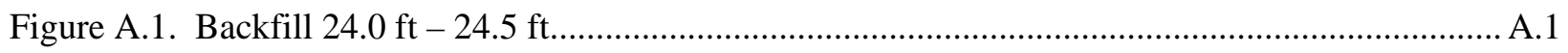

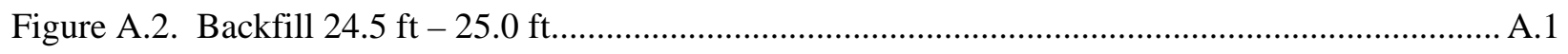

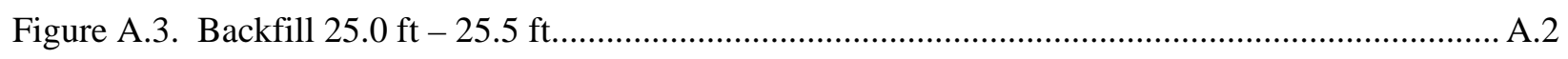

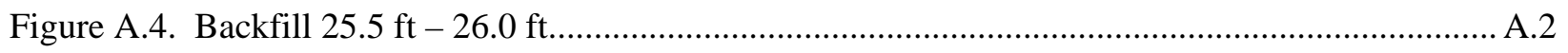

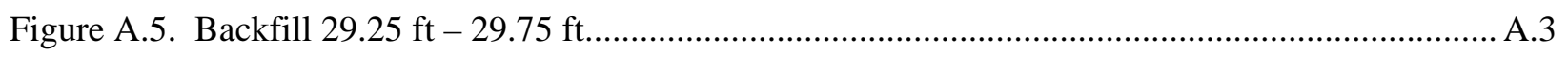

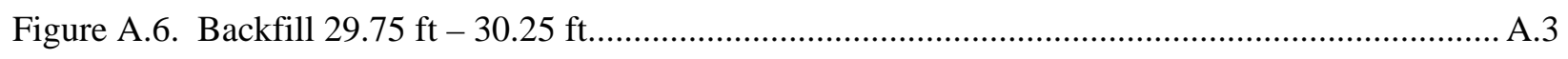

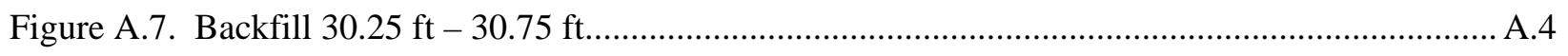

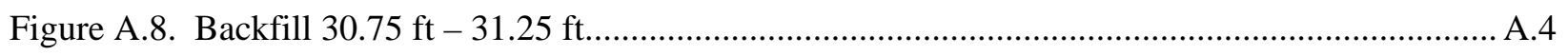

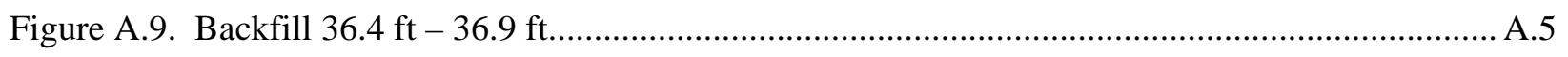

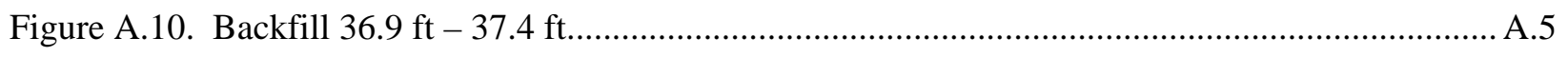

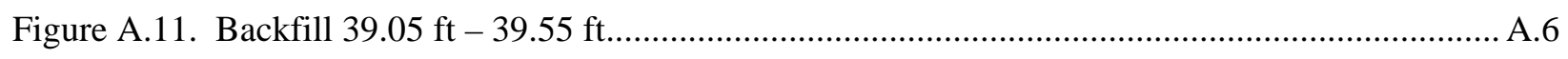

Figure A.12. Backfill $39.55 \mathrm{ft}-39.8 \mathrm{ft}$ to Hanford formation (H1 unit) $39.8 \mathrm{ft}-40.05 \mathrm{ft}$................... A.6

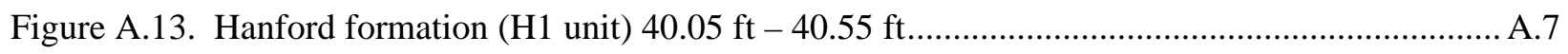

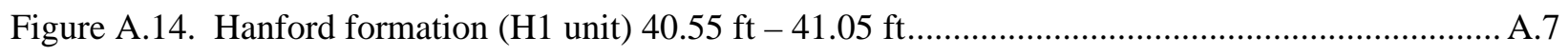

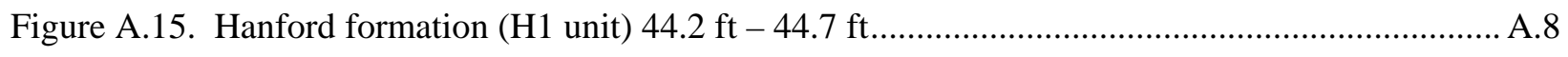

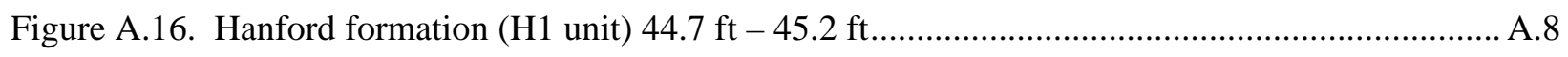

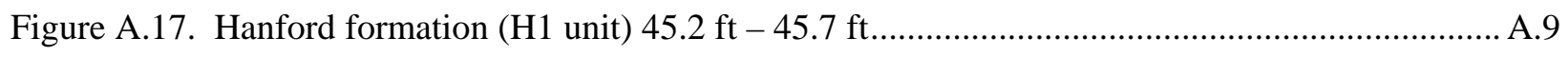

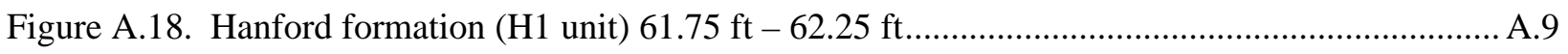

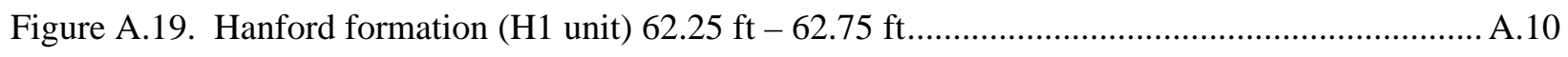

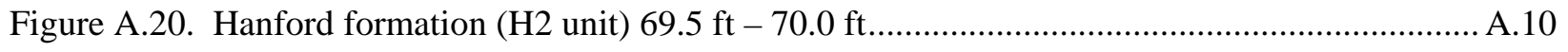




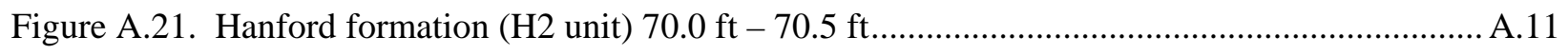

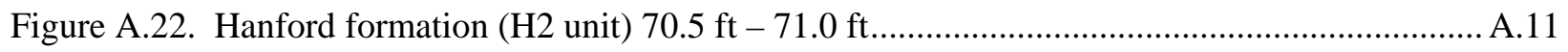

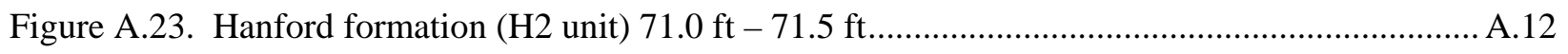

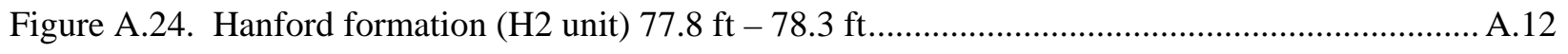

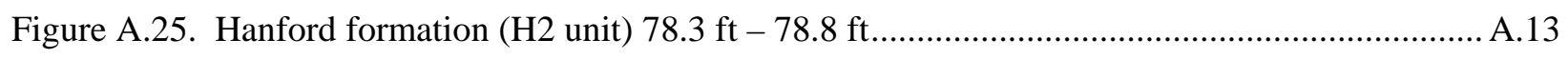

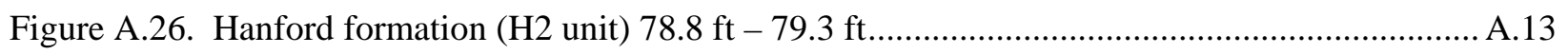

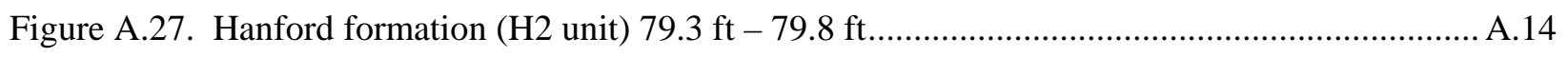

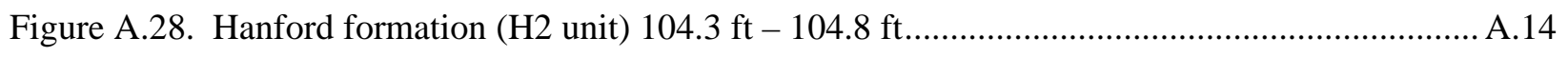

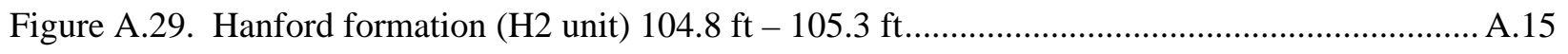

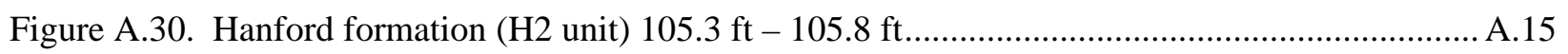

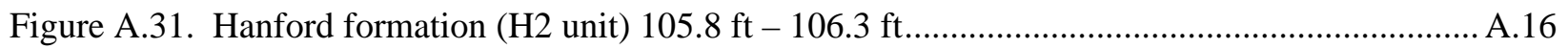

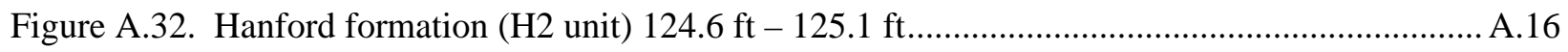

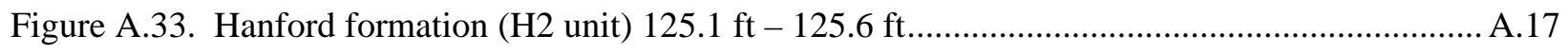

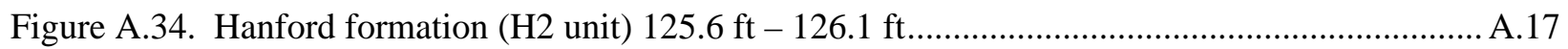


Appendix A. Photographs of Core from Borehole C4297

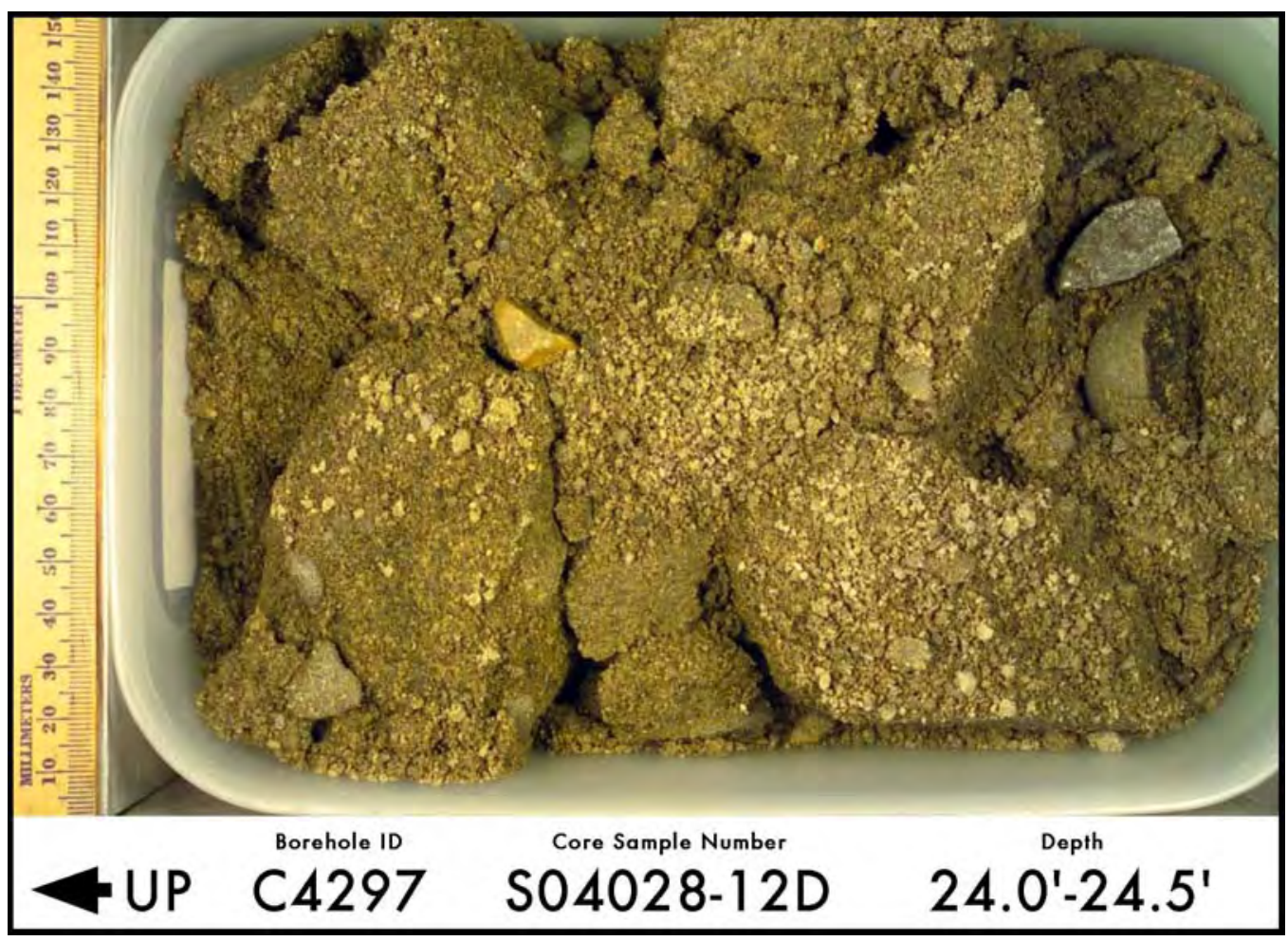

Figure A.1. Backfill $24.0 \mathrm{ft}-24.5 \mathrm{ft}$

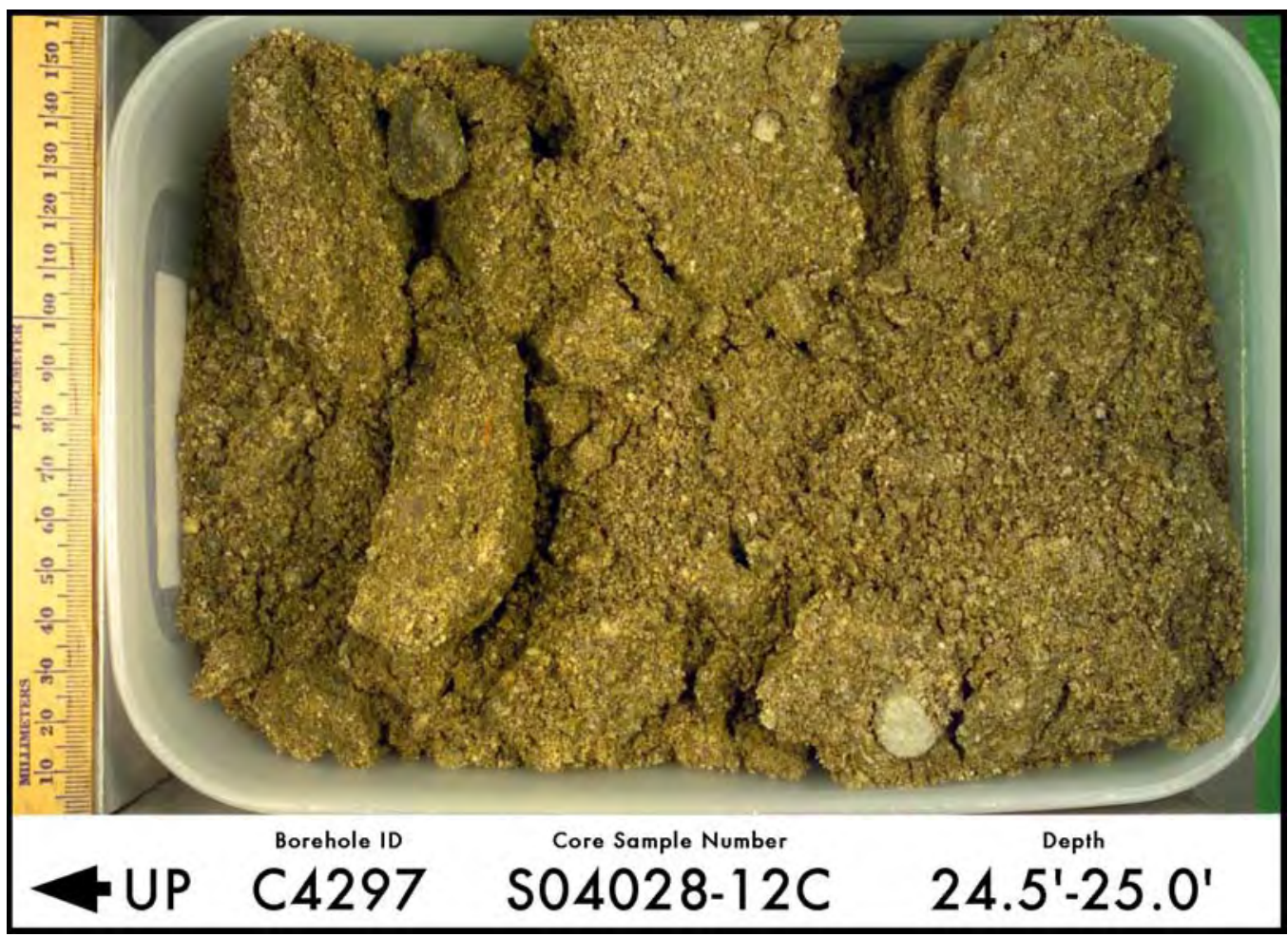

Figure A.2. Backfill $24.5 \mathrm{ft}-25.0 \mathrm{ft}$ 


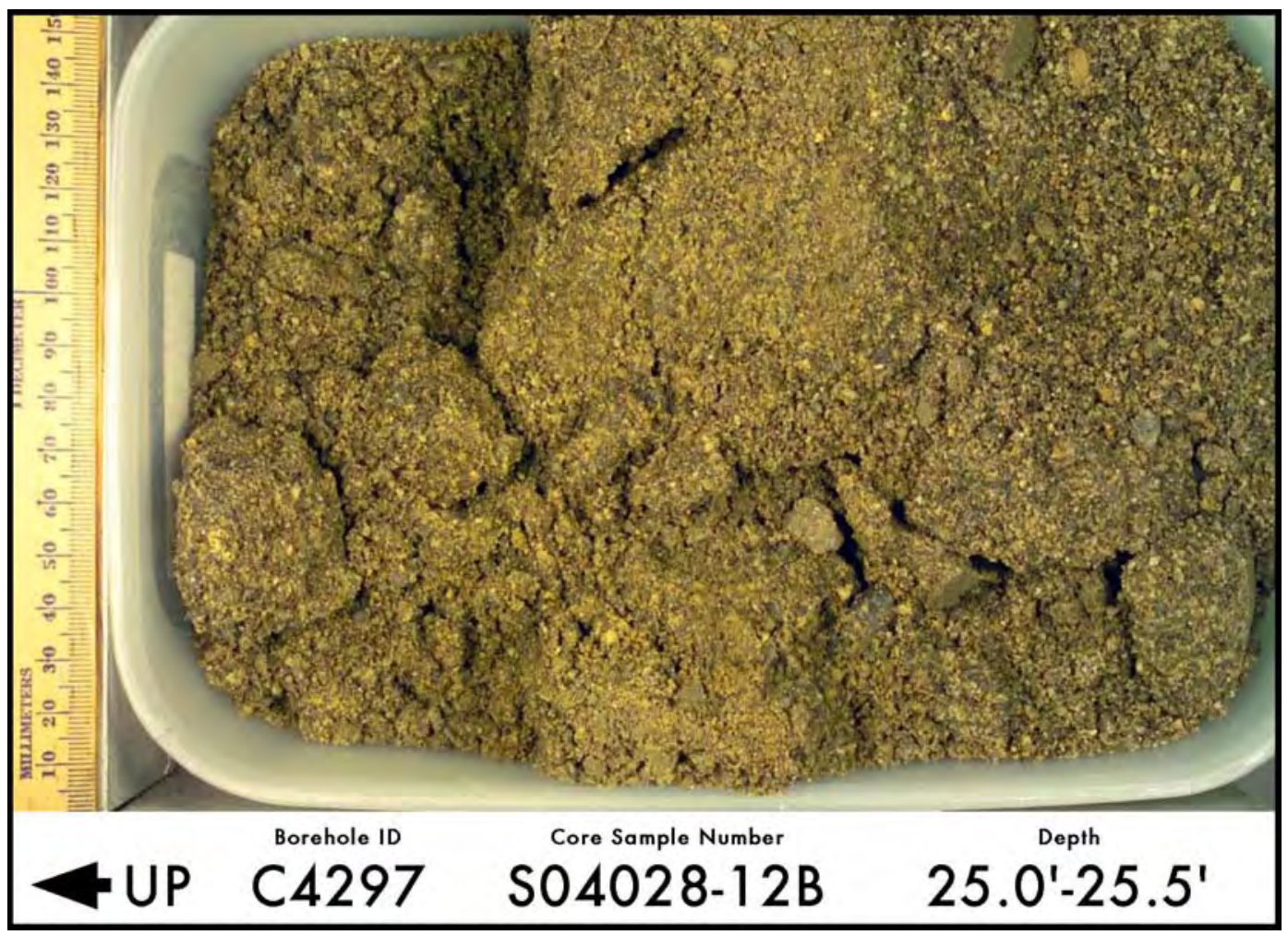

Figure A.3. Backfill $25.0 \mathrm{ft}-25.5 \mathrm{ft}$

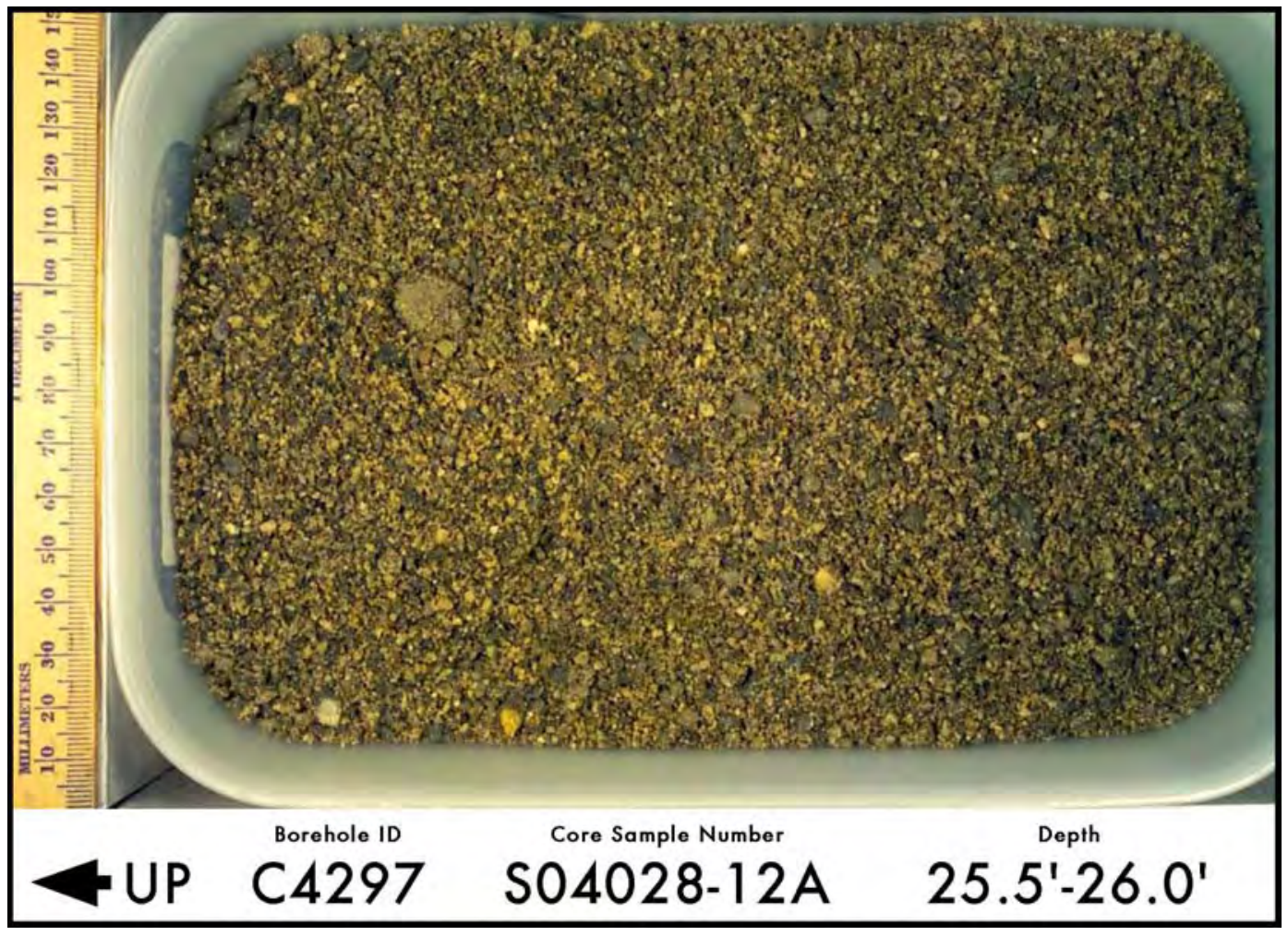

Figure A.4. Backfill $25.5 \mathrm{ft}-26.0 \mathrm{ft}$ 


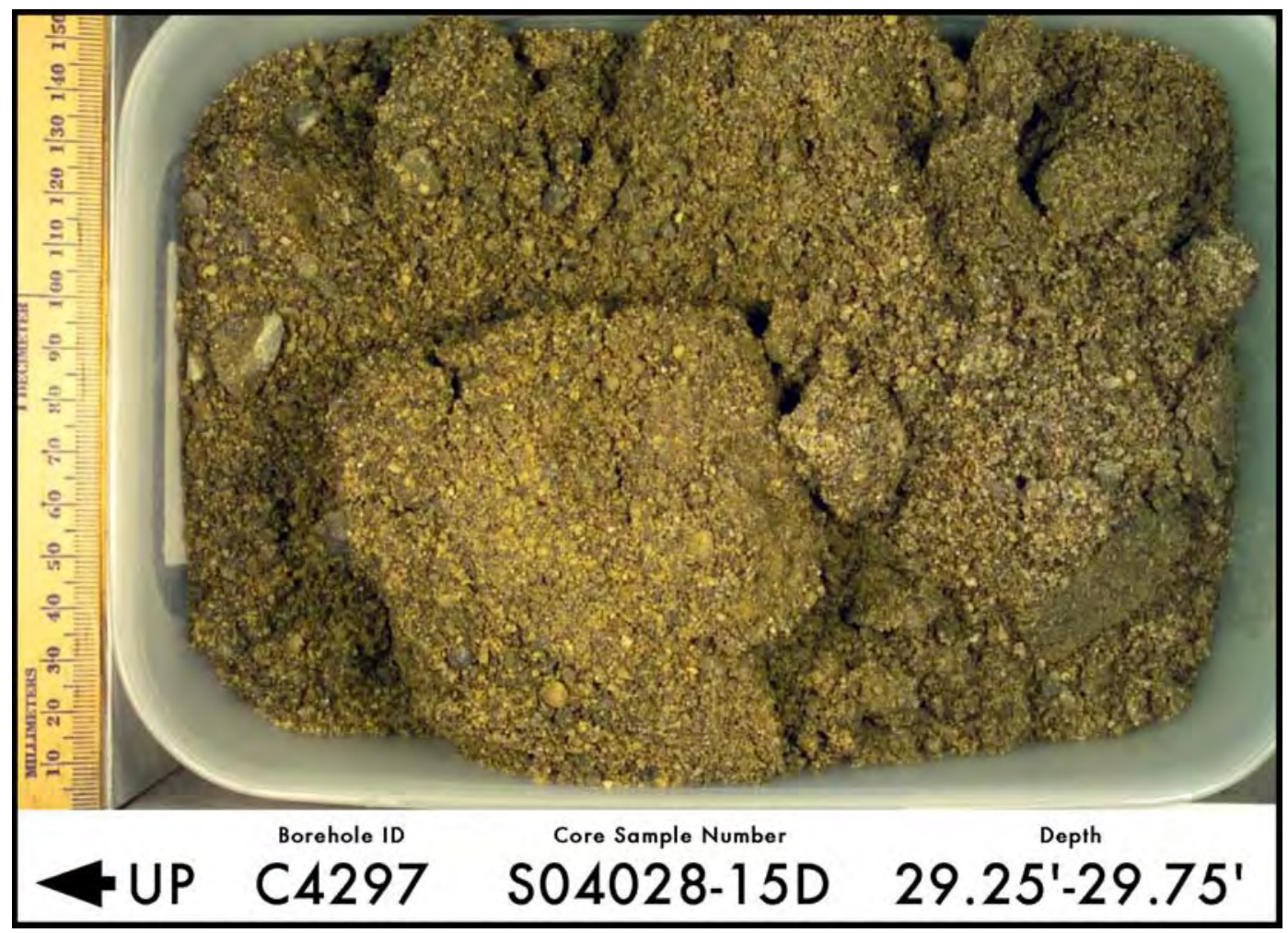

Figure A.5. Backfill $29.25 \mathrm{ft}-29.75 \mathrm{ft}$

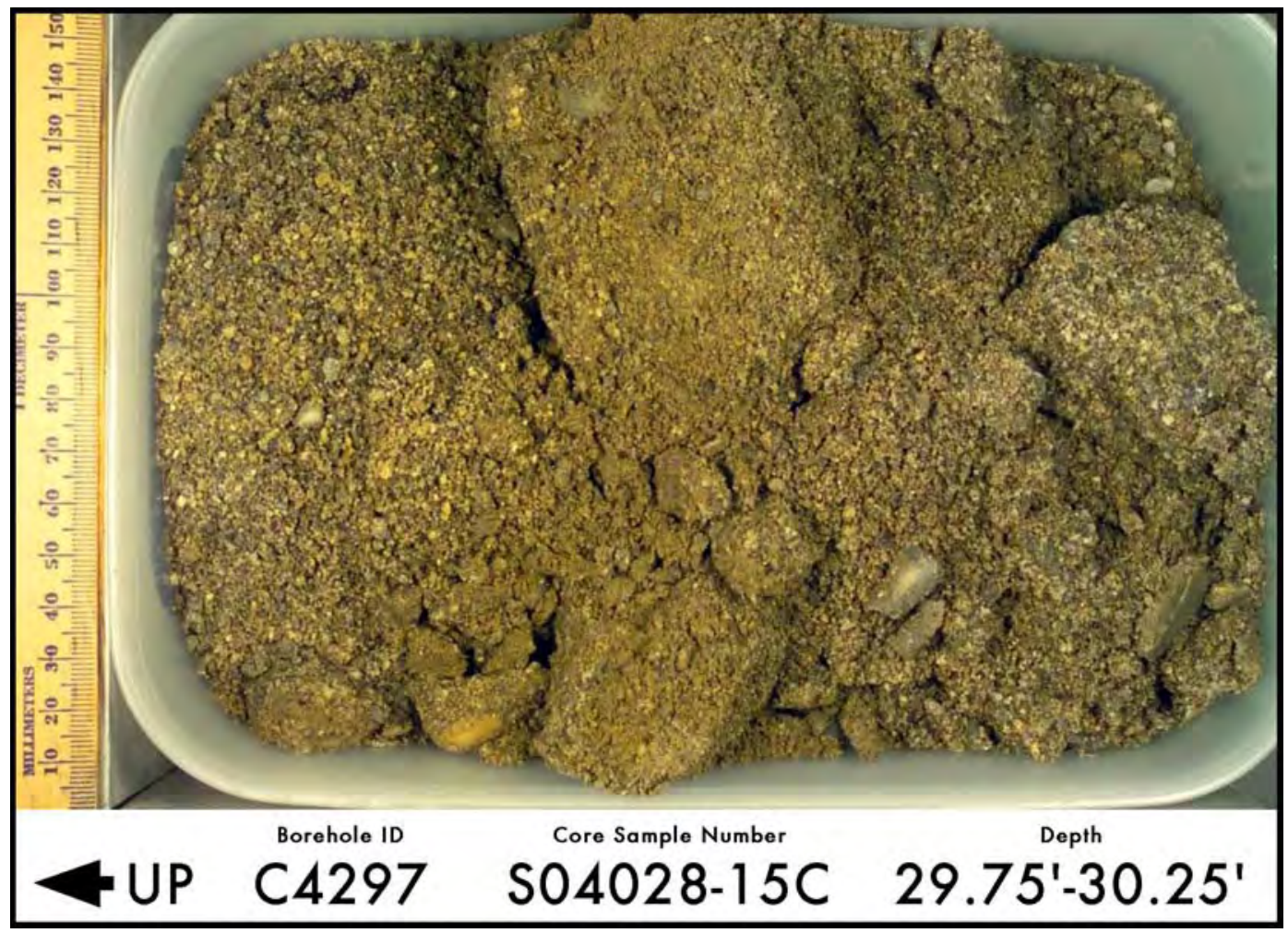

Figure A.6. Backfill $29.75 \mathrm{ft}-30.25 \mathrm{ft}$ 


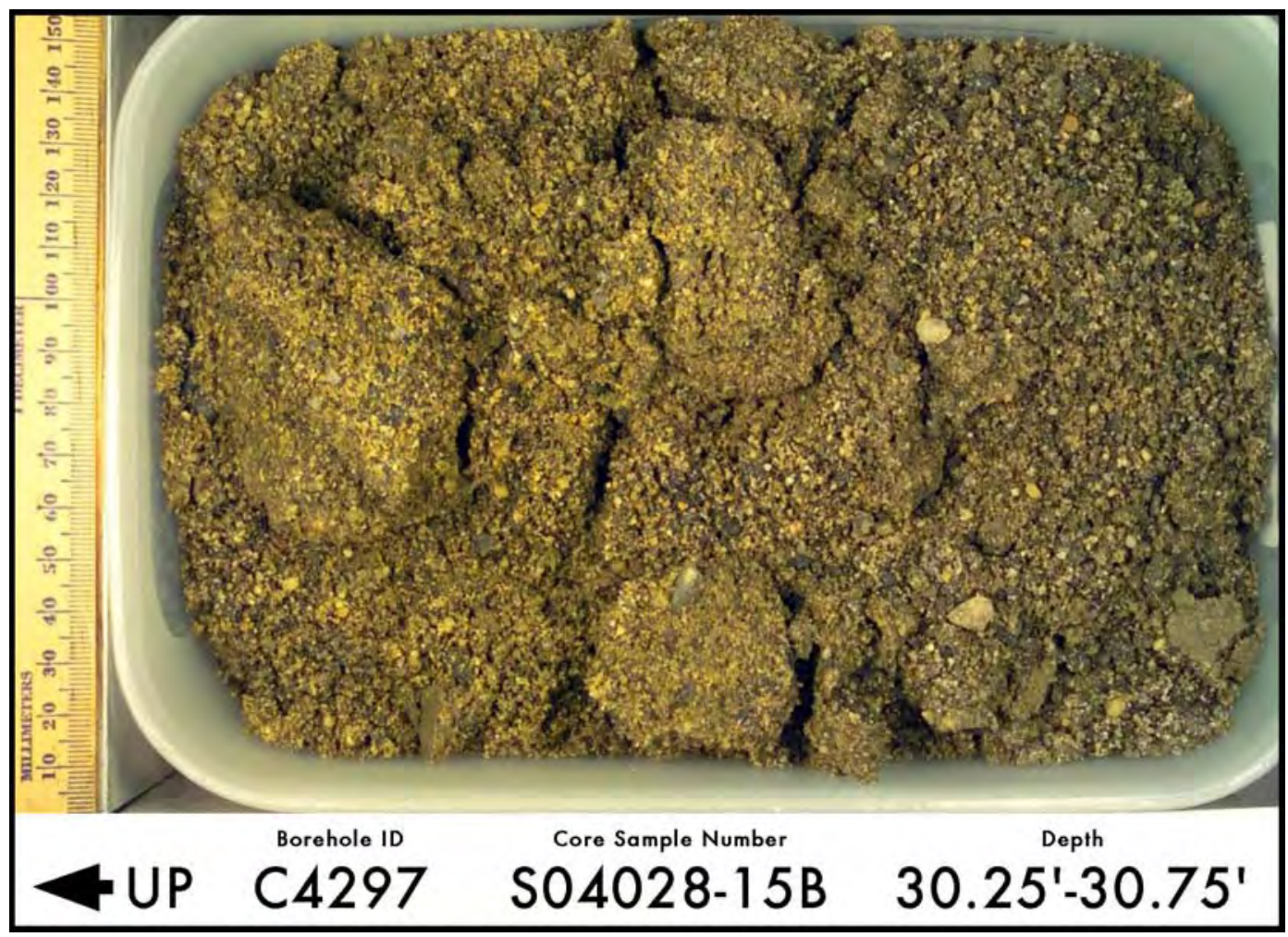

Figure A.7. Backfill $30.25 \mathrm{ft}-30.75 \mathrm{ft}$

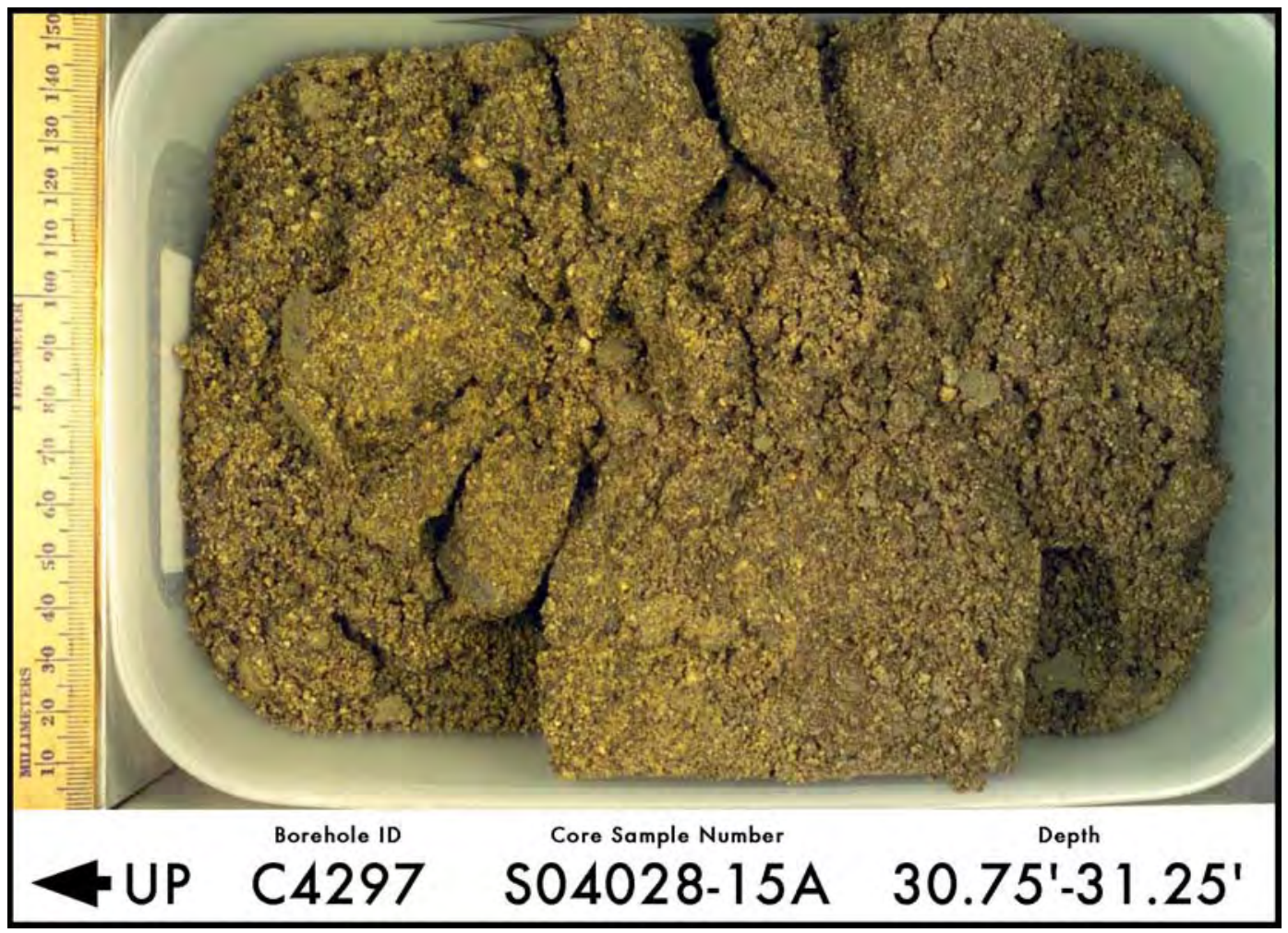

Figure A.8. Backfill $30.75 \mathrm{ft}-31.25 \mathrm{ft}$ 


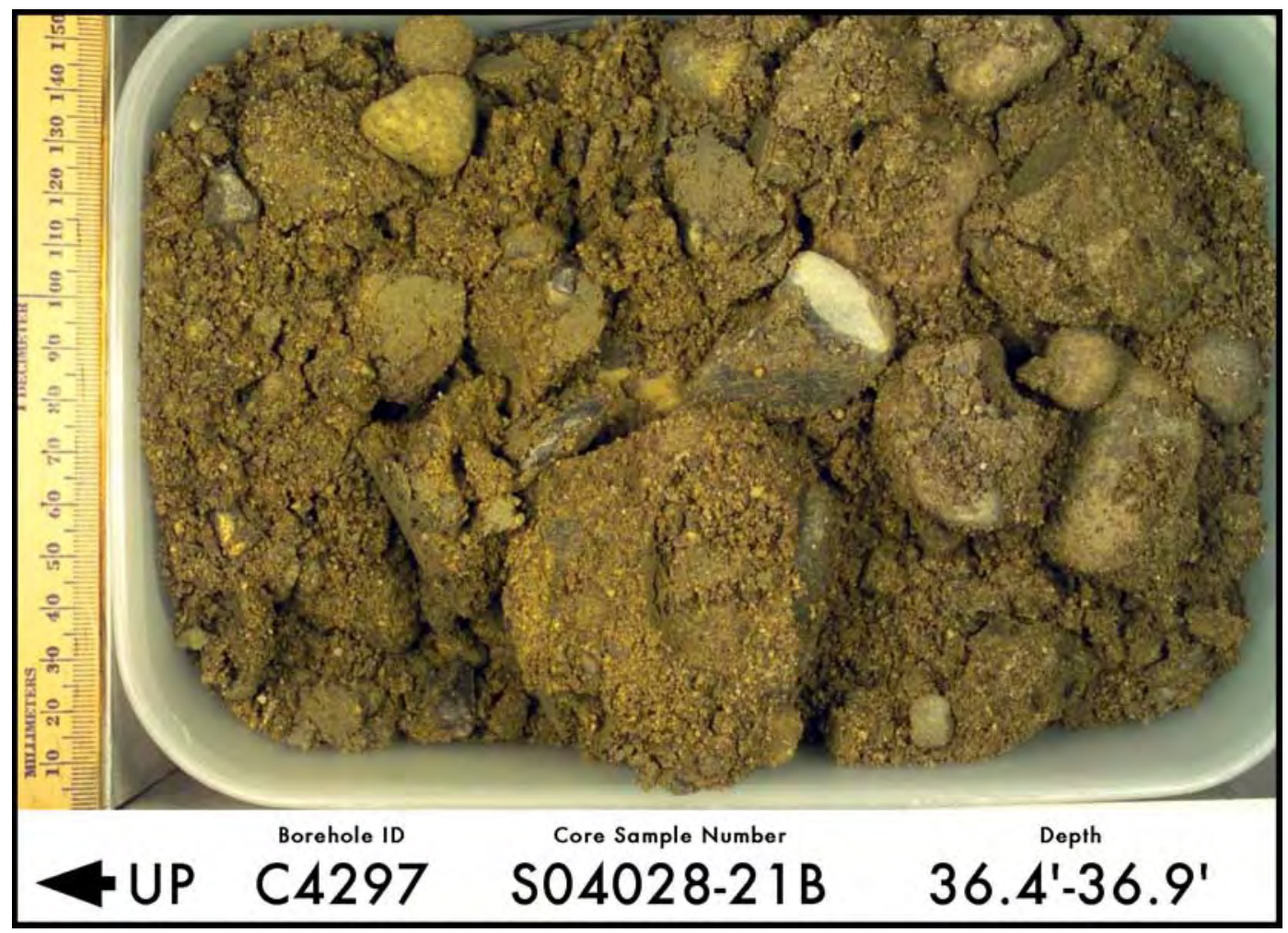

Figure A.9. Backfill $36.4 \mathrm{ft}-36.9 \mathrm{ft}$

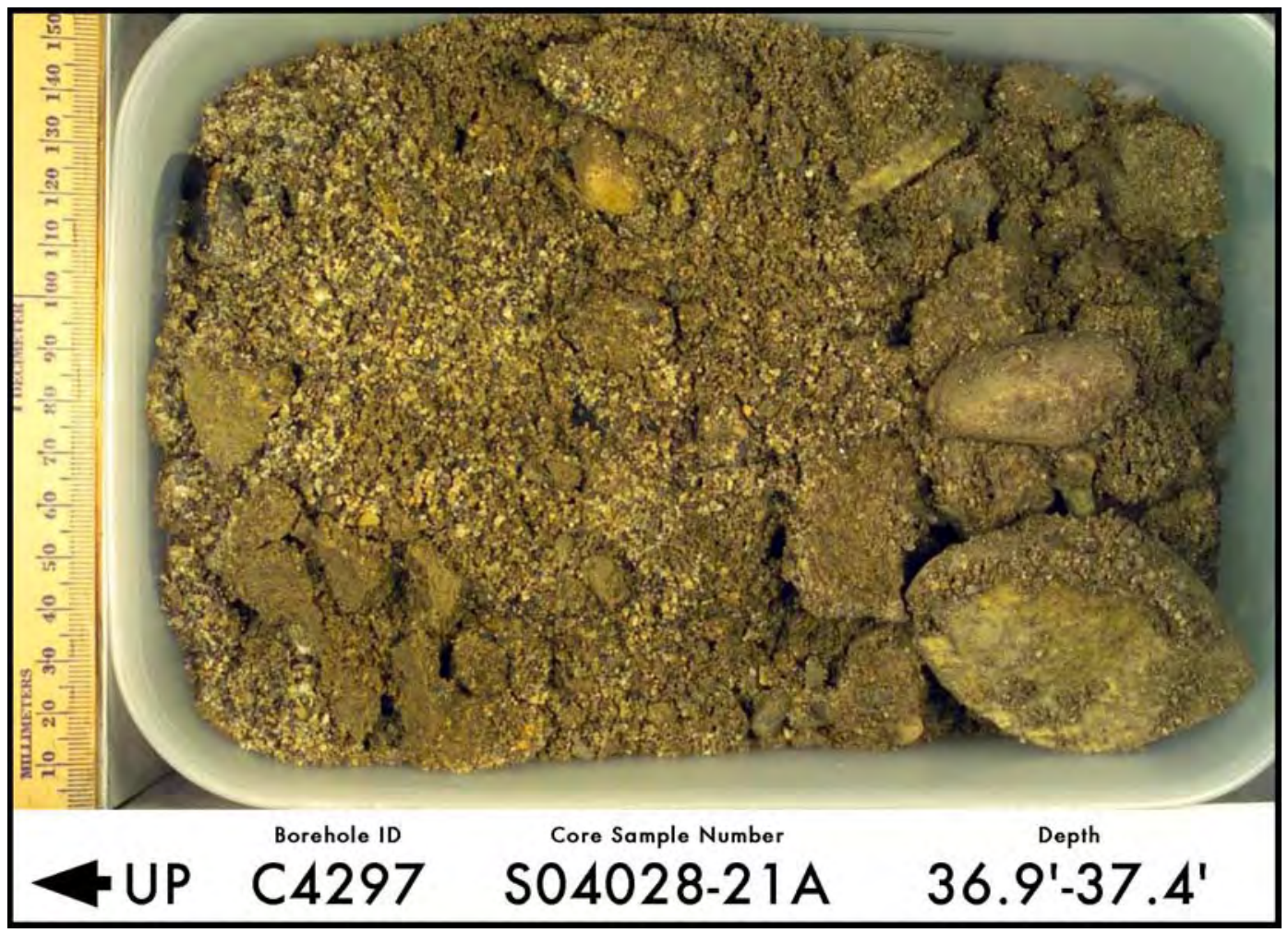

Figure A.10. Backfill $36.9 \mathrm{ft}-37.4 \mathrm{ft}$ 


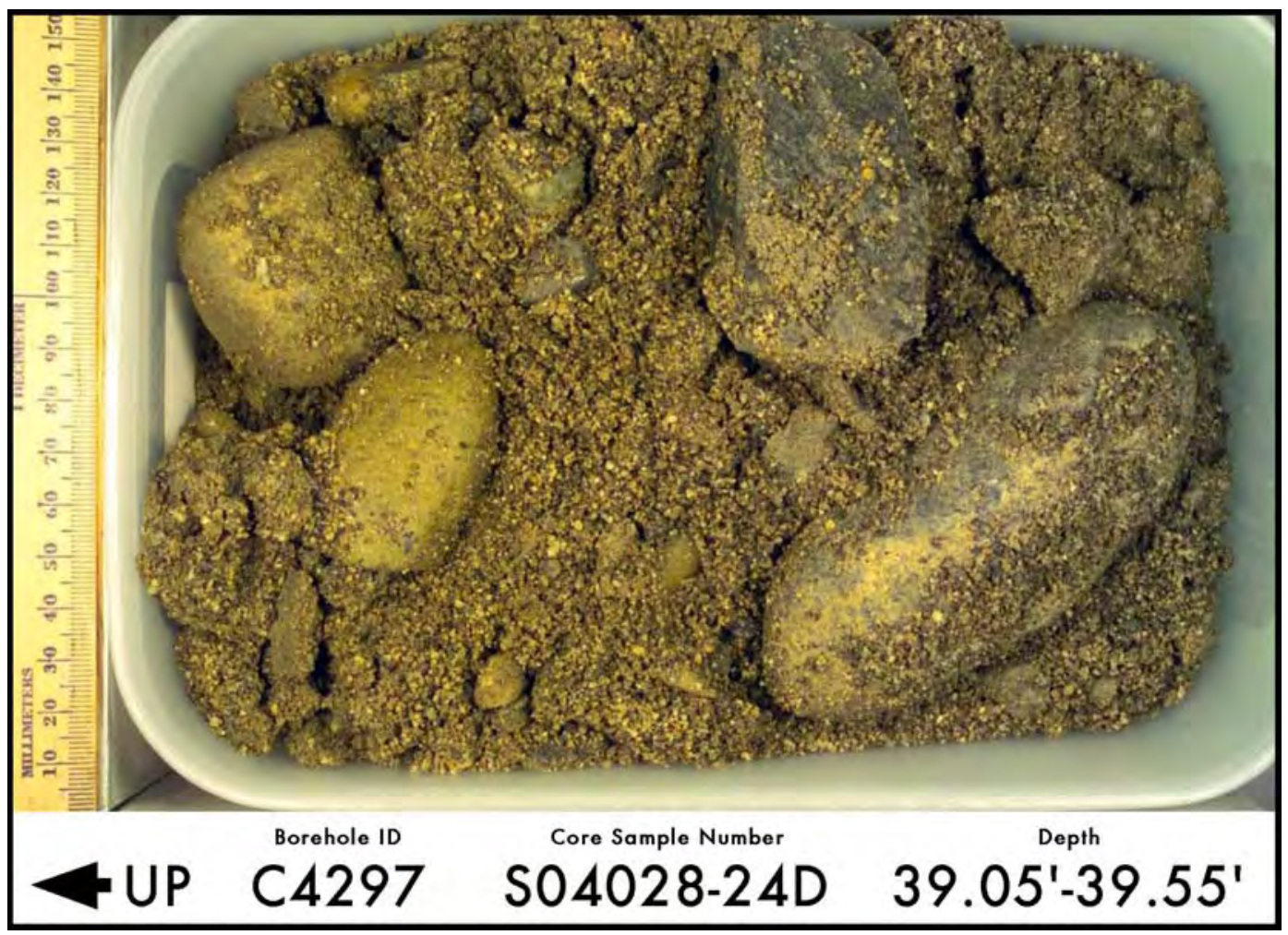

Figure A.11. Backfill $39.05 \mathrm{ft}-39.55 \mathrm{ft}$

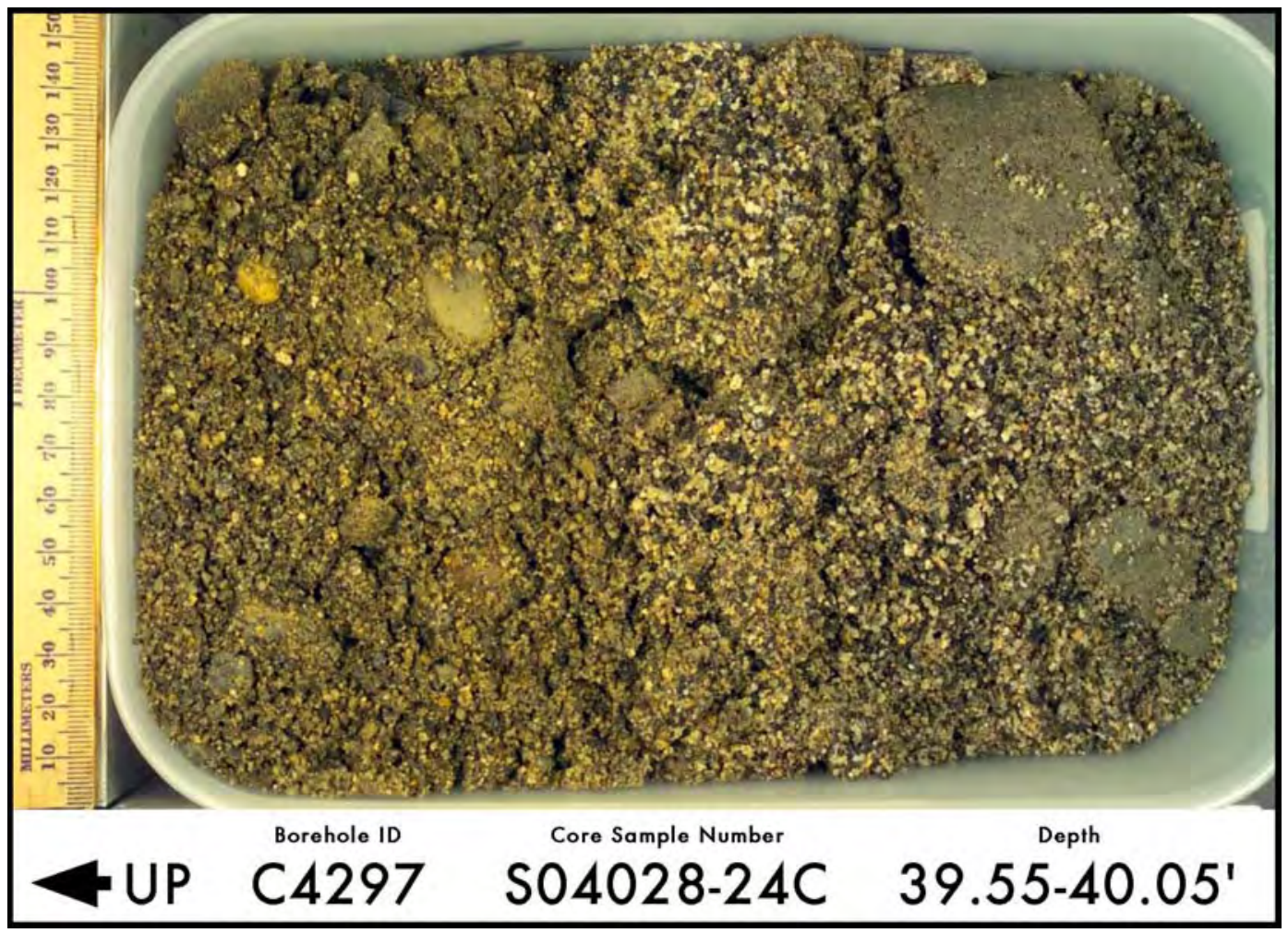

Figure A.12. Backfill $39.55 \mathrm{ft}$ - $39.8 \mathrm{ft}$ to Hanford formation (H1 unit) $39.8 \mathrm{ft}-40.05 \mathrm{ft}$ 


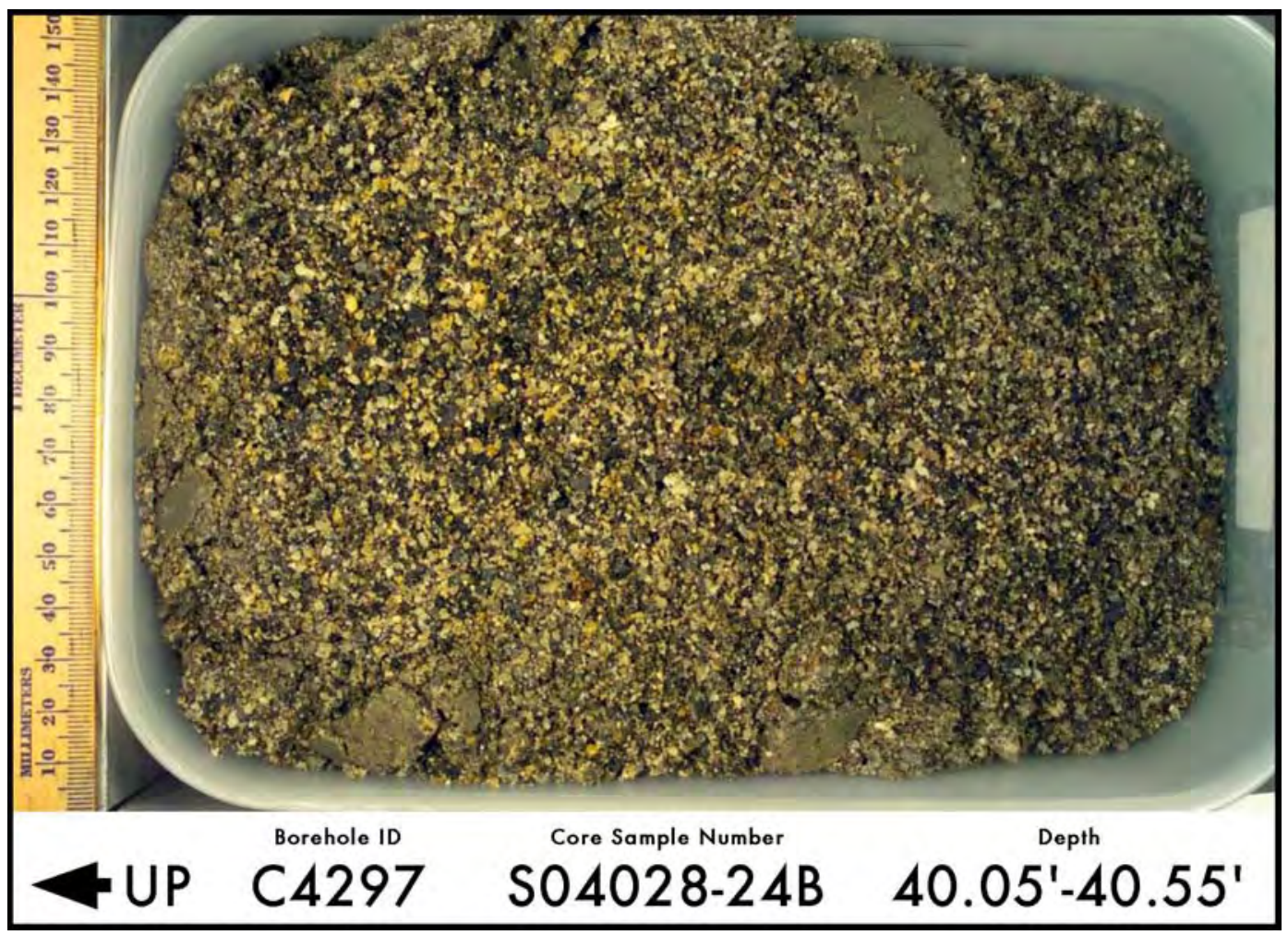

Figure A.13. Hanford formation (H1 unit) $40.05 \mathrm{ft}-40.55 \mathrm{ft}$

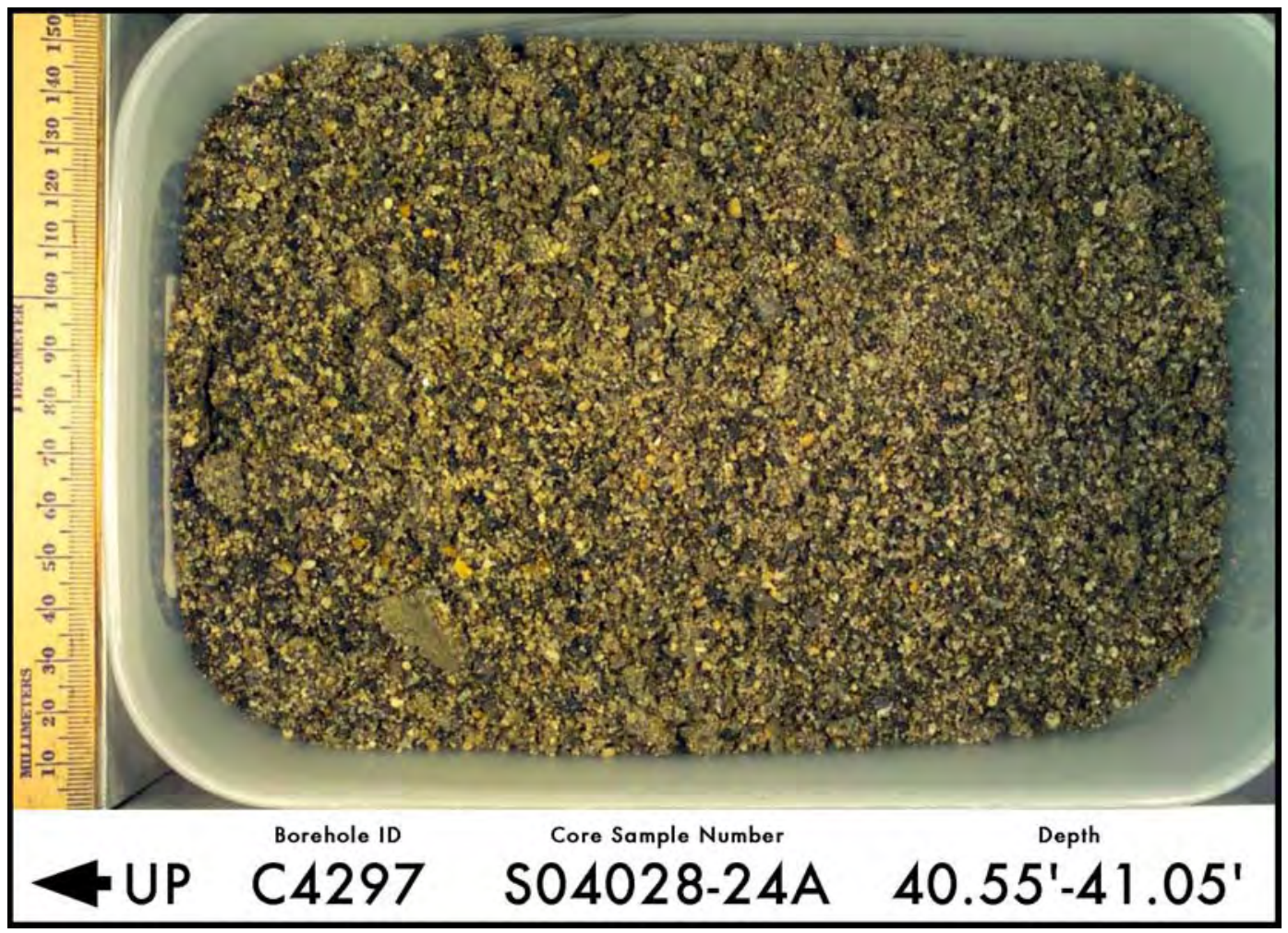

Figure A.14. Hanford formation (H1 unit) $40.55 \mathrm{ft}-41.05 \mathrm{ft}$ 


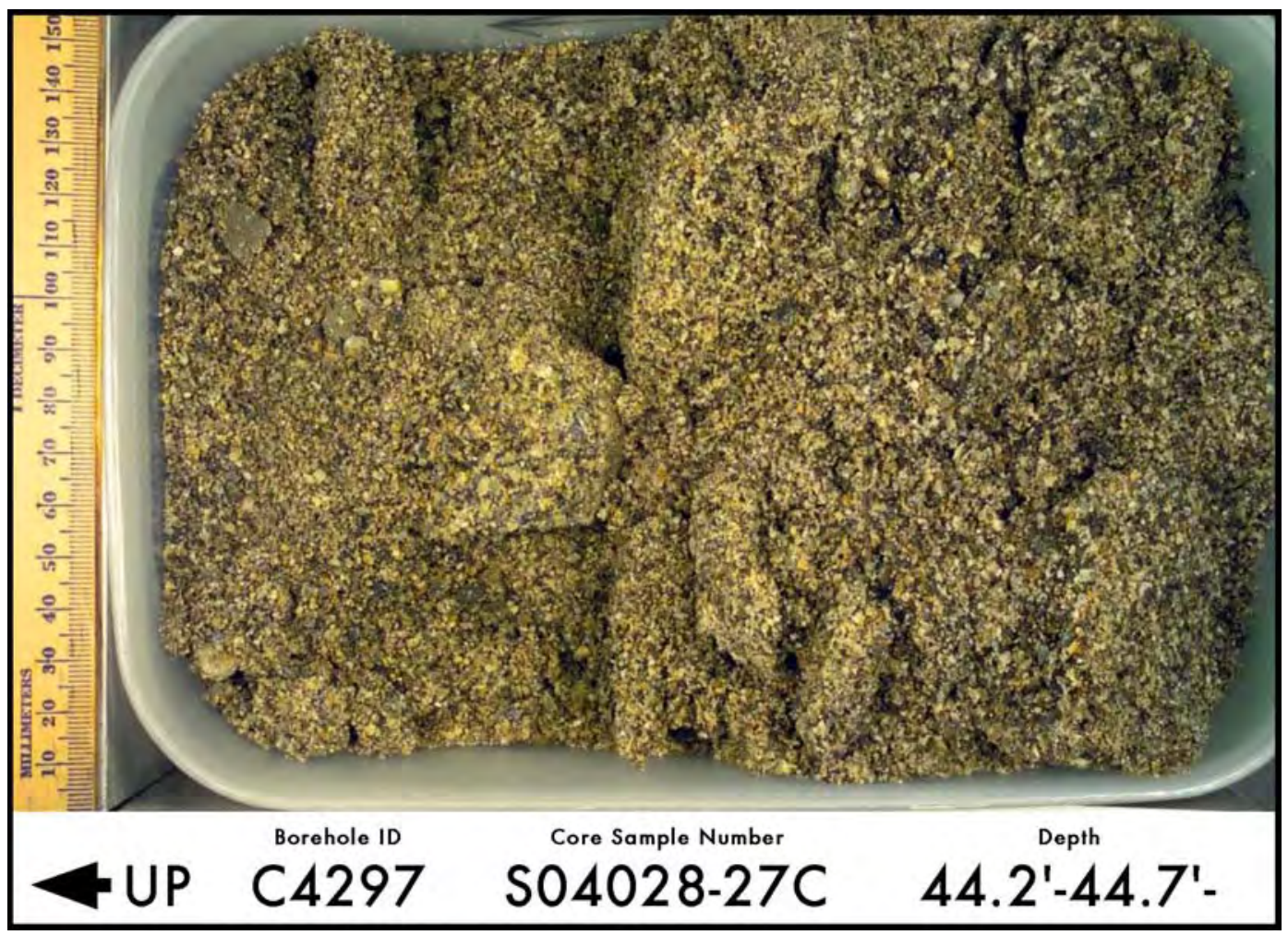

Figure A.15. Hanford formation (H1 unit) $44.2 \mathrm{ft}-44.7 \mathrm{ft}$

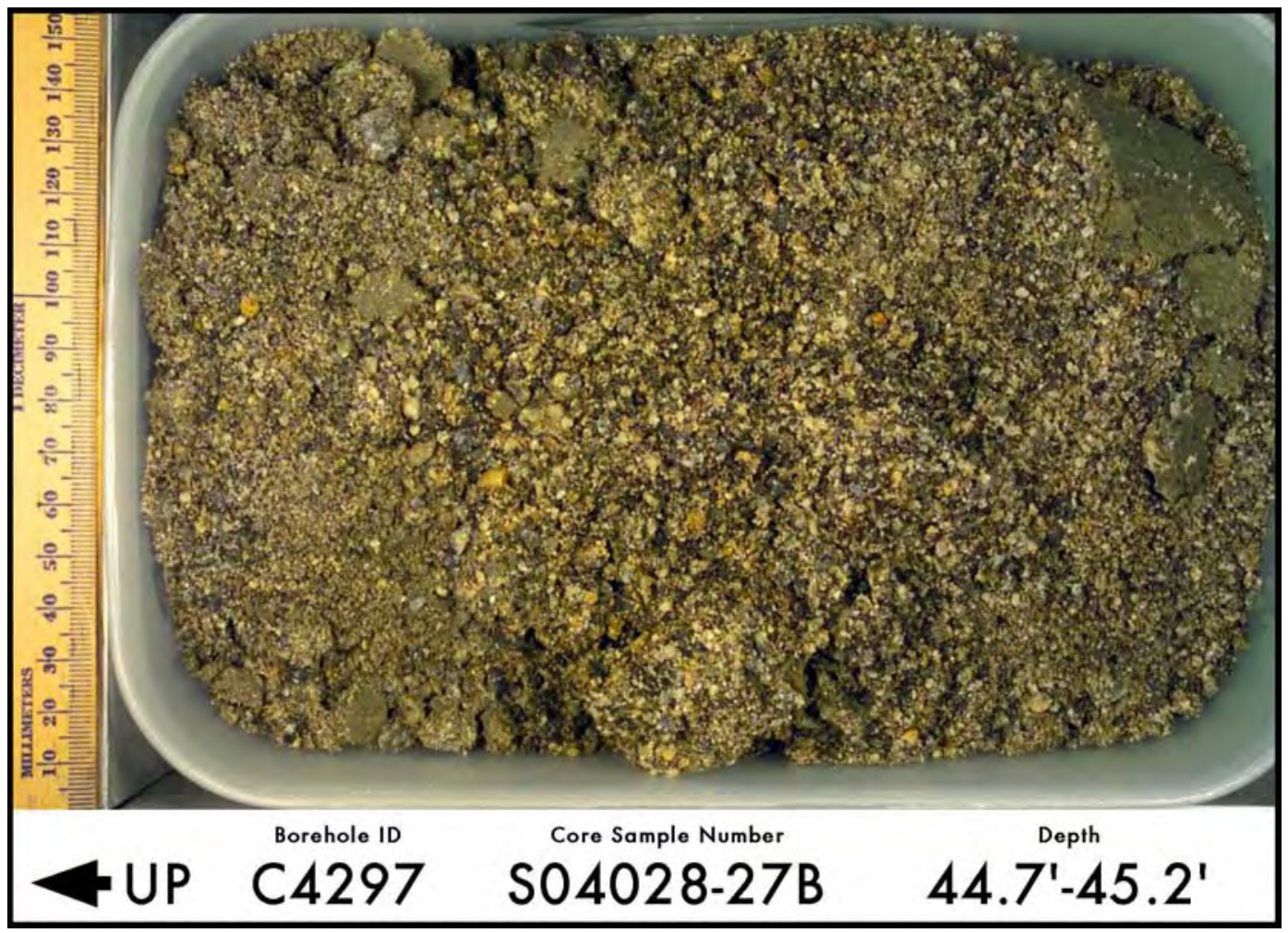

Figure A.16. Hanford formation (H1 unit) $44.7 \mathrm{ft}-45.2 \mathrm{ft}$ 


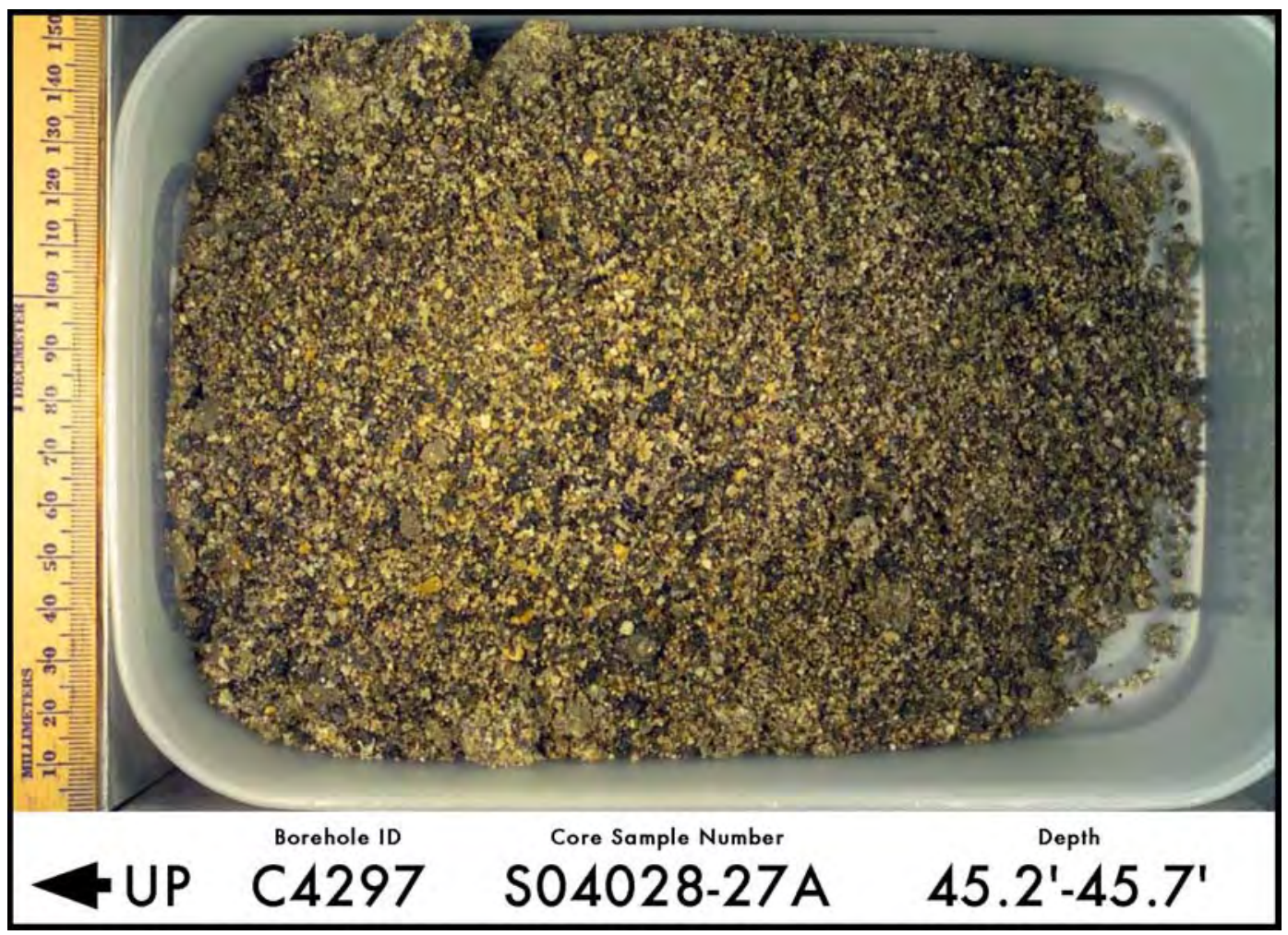

Figure A.17. Hanford formation (H1 unit) $45.2 \mathrm{ft}-45.7 \mathrm{ft}$

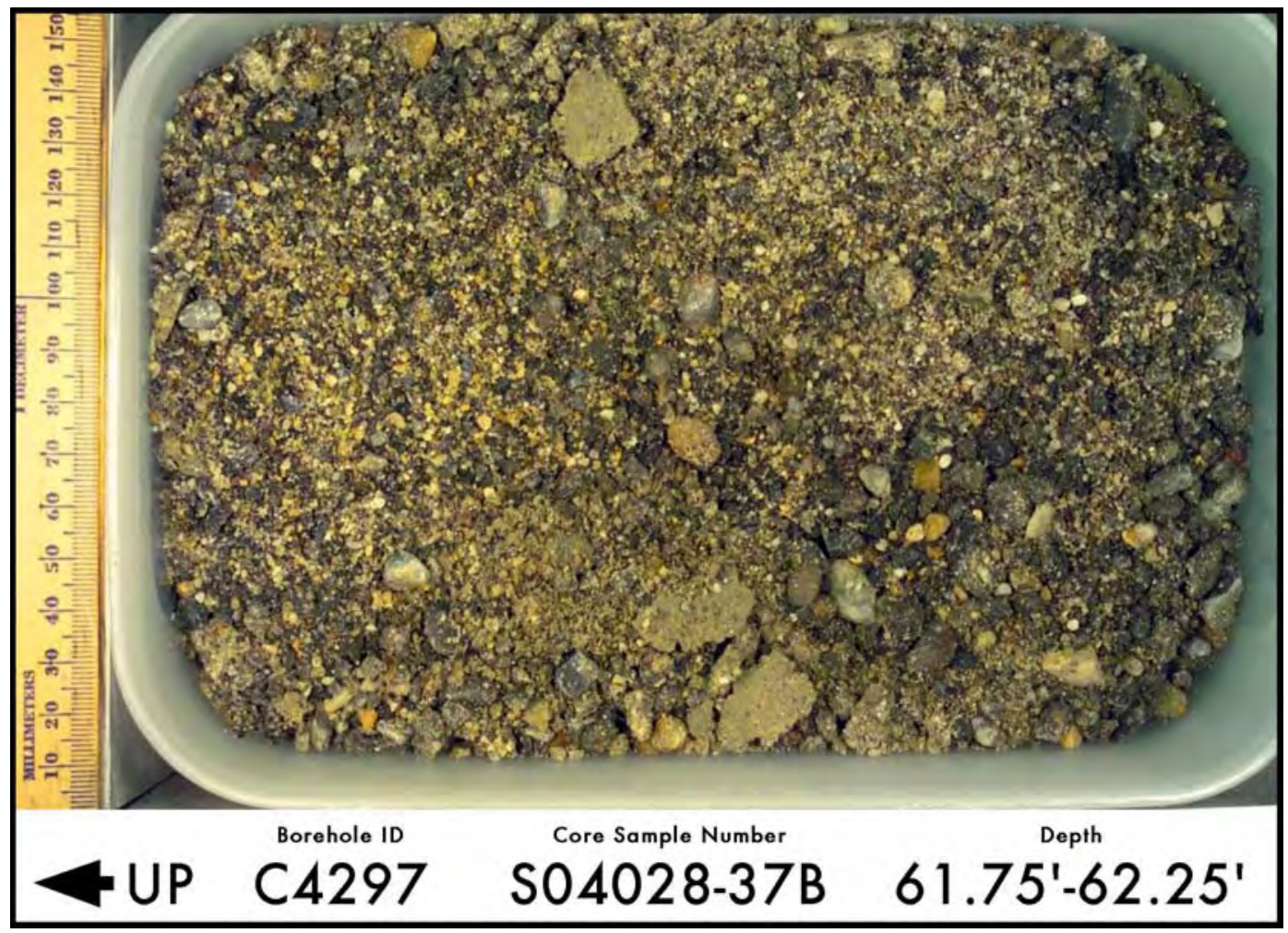

Figure A.18. Hanford formation (H1 unit) $61.75 \mathrm{ft}-62.25 \mathrm{ft}$ 


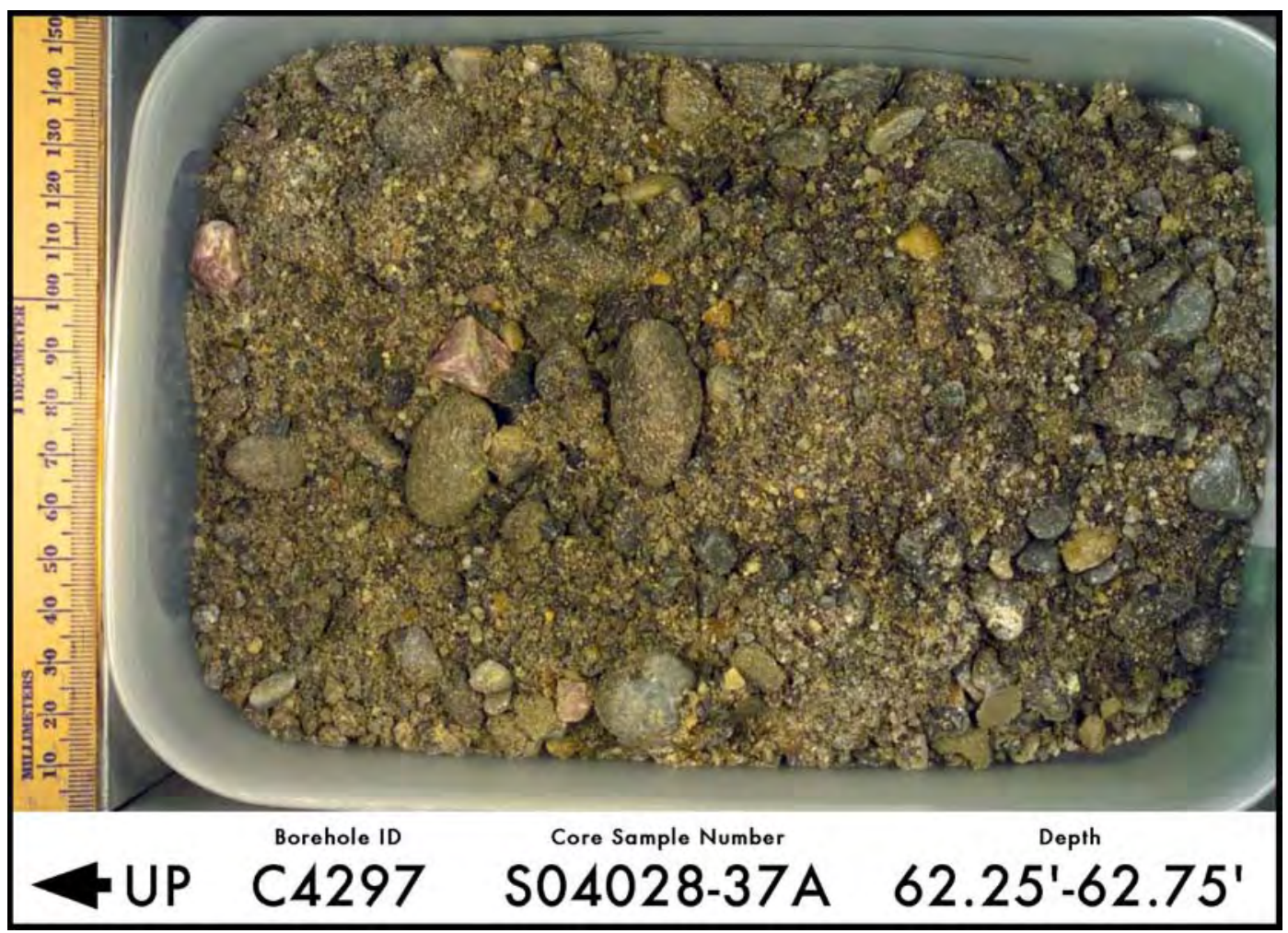

Figure A.19. Hanford formation (H1 unit) $62.25 \mathrm{ft}-62.75 \mathrm{ft}$

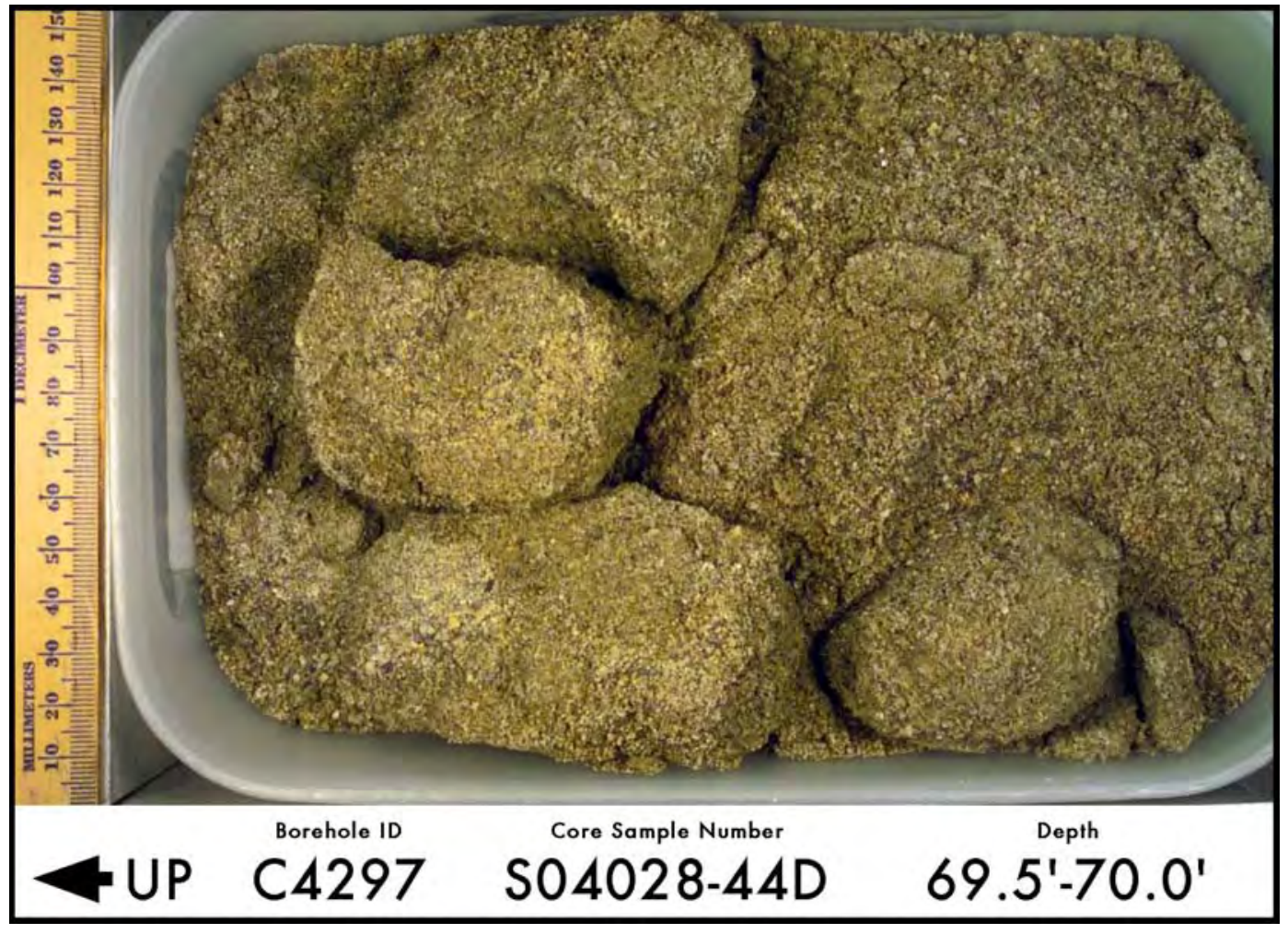

Figure A.20. Hanford formation (H2 unit) $69.5 \mathrm{ft}-70.0 \mathrm{ft}$ 


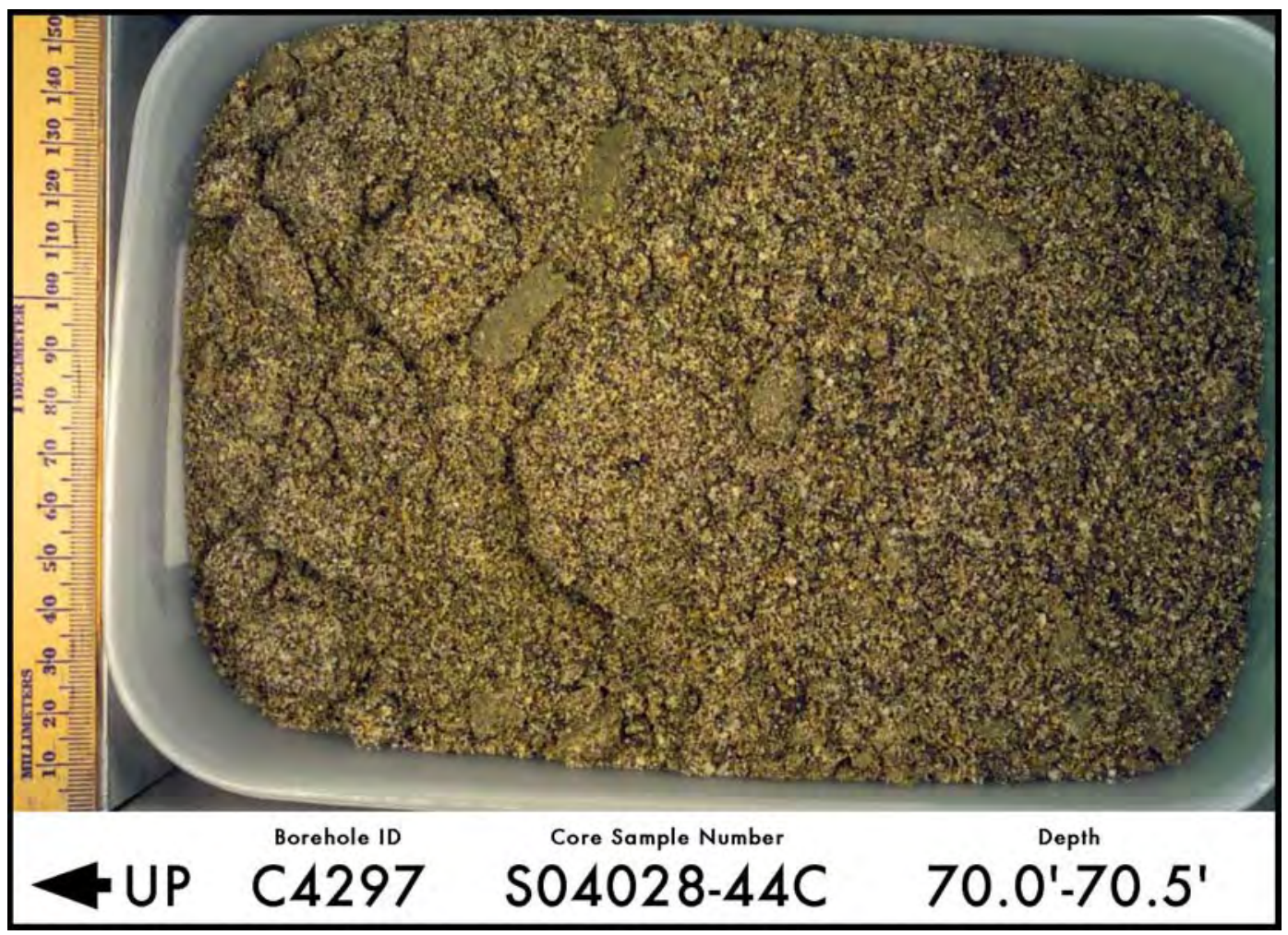

Figure A.21. Hanford formation (H2 unit) $70.0 \mathrm{ft}-70.5 \mathrm{ft}$

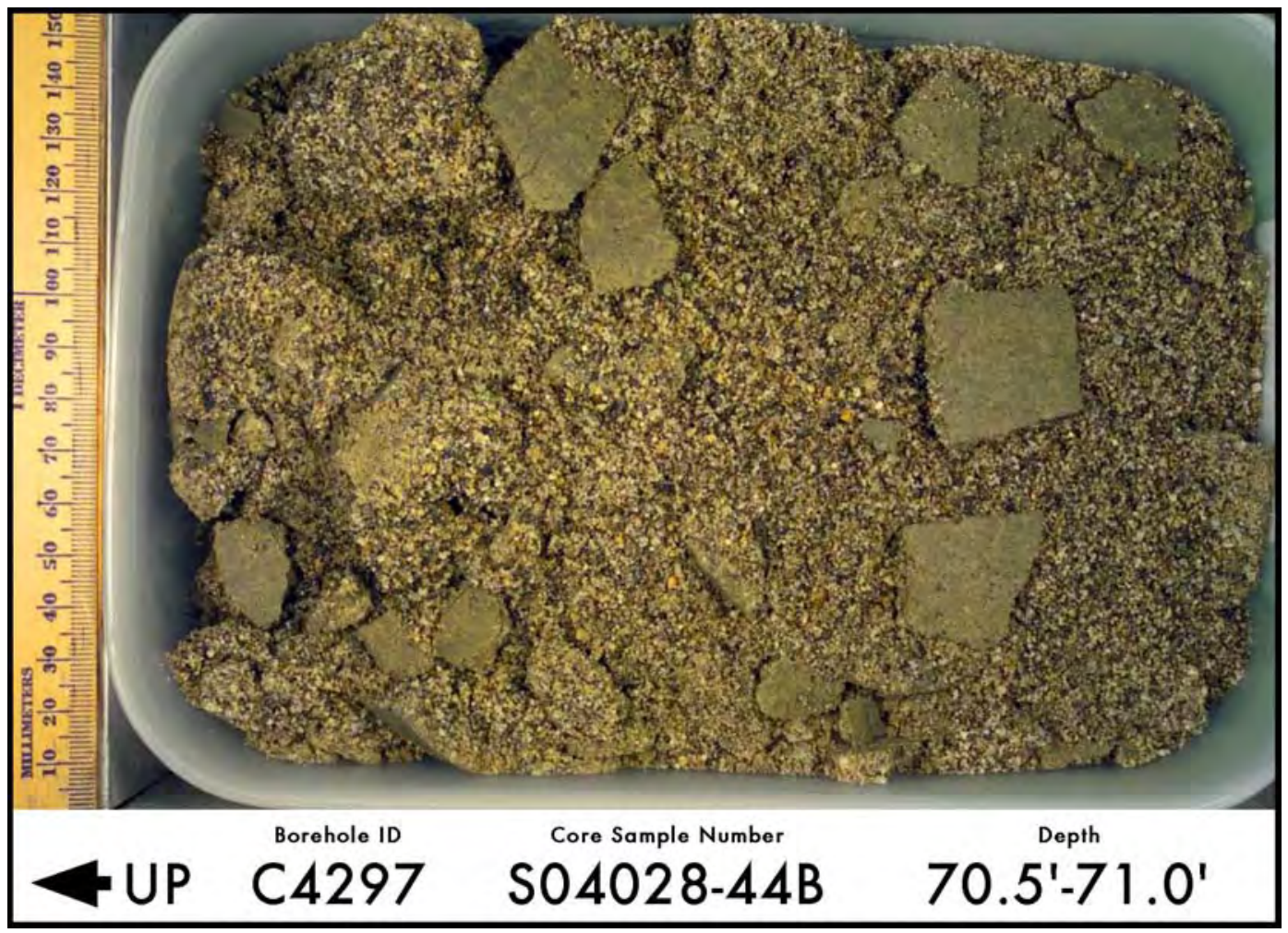

Figure A.22. Hanford formation (H2 unit) $70.5 \mathrm{ft}-71.0 \mathrm{ft}$ 


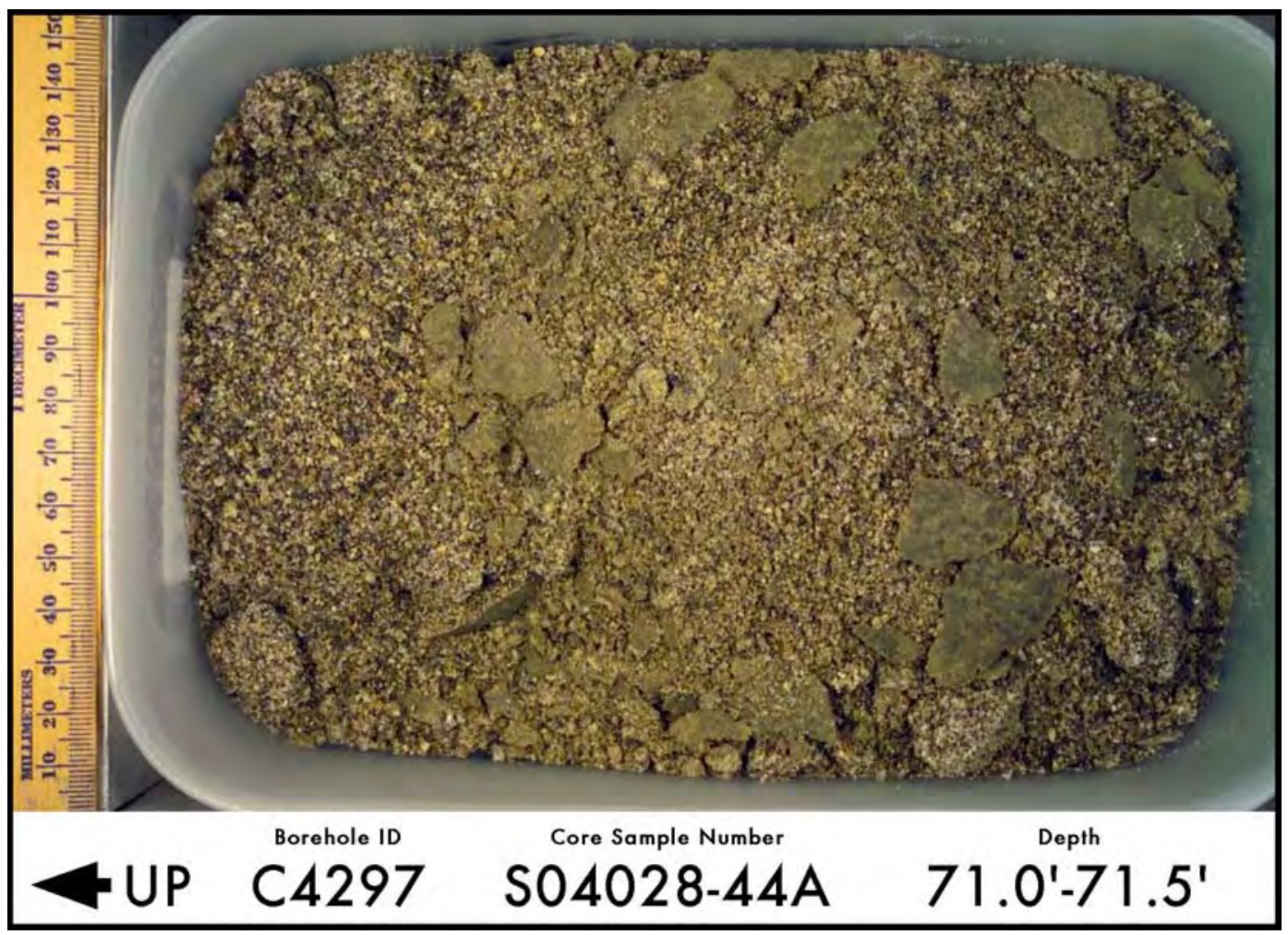

Figure A.23. Hanford formation (H2 unit) $71.0 \mathrm{ft}-71.5 \mathrm{ft}$

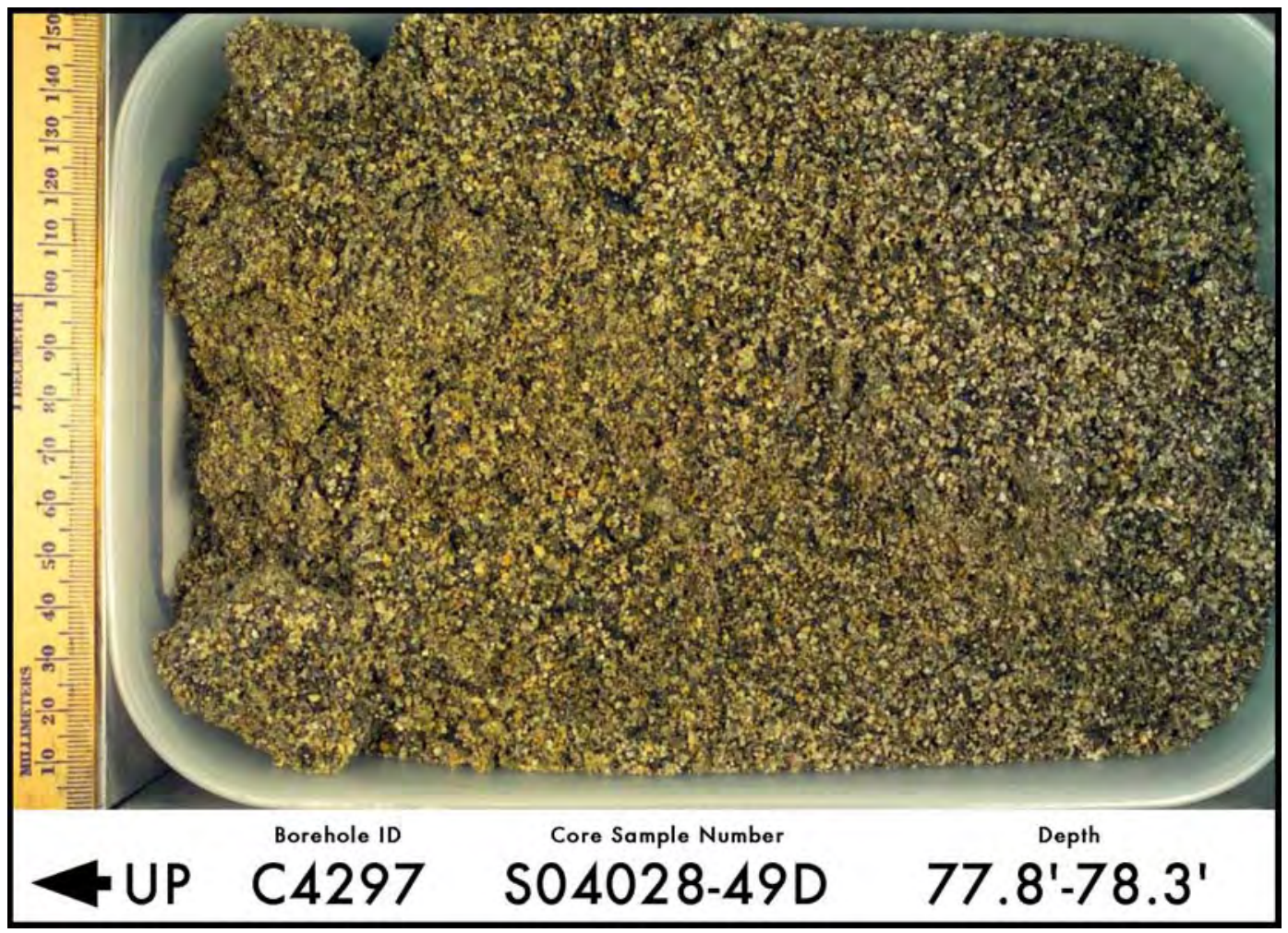

Figure A.24. Hanford formation (H2 unit) $77.8 \mathrm{ft}-78.3 \mathrm{ft}$ 


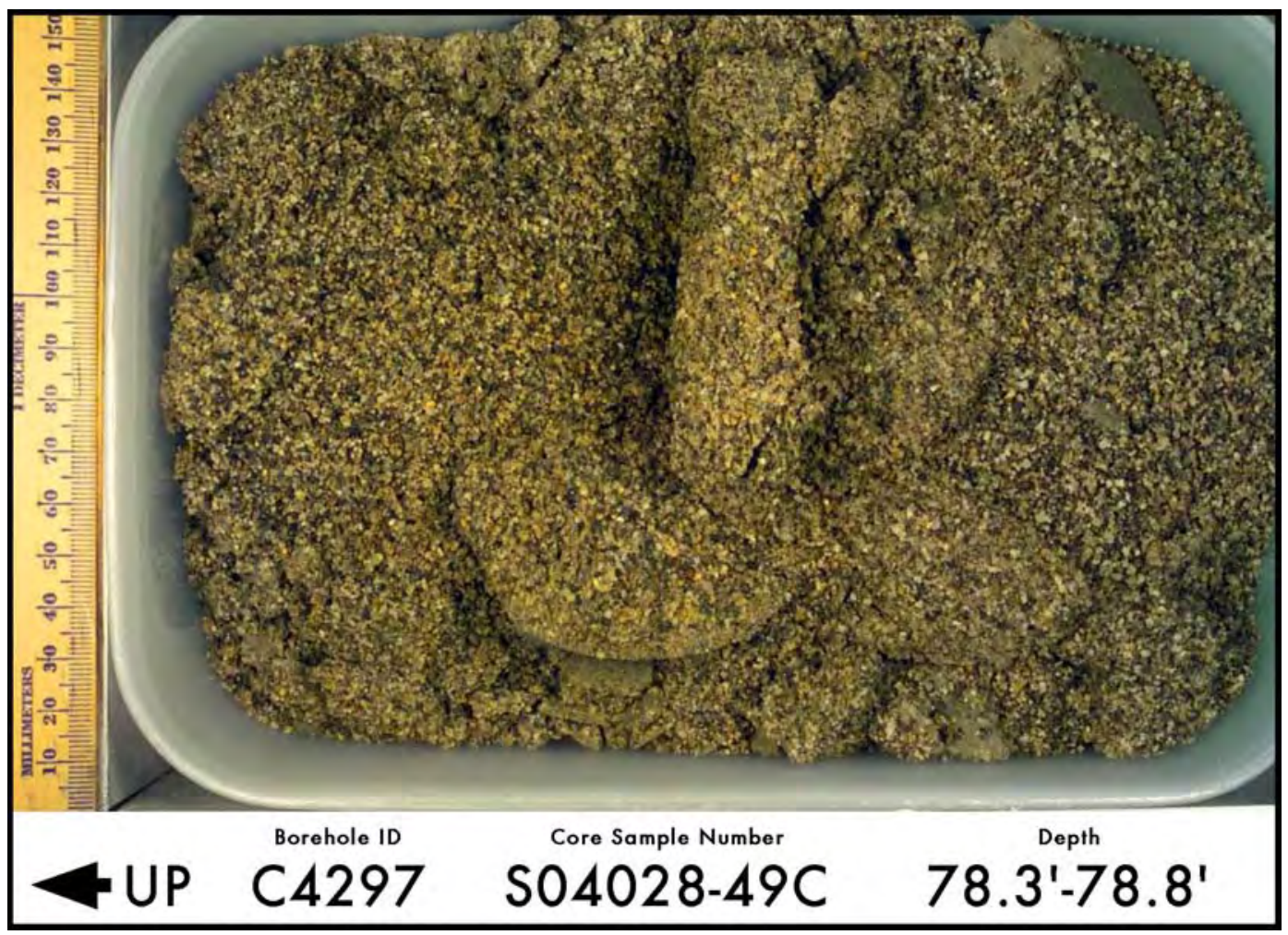

Figure A.25. Hanford formation (H2 unit) $78.3 \mathrm{ft}-78.8 \mathrm{ft}$

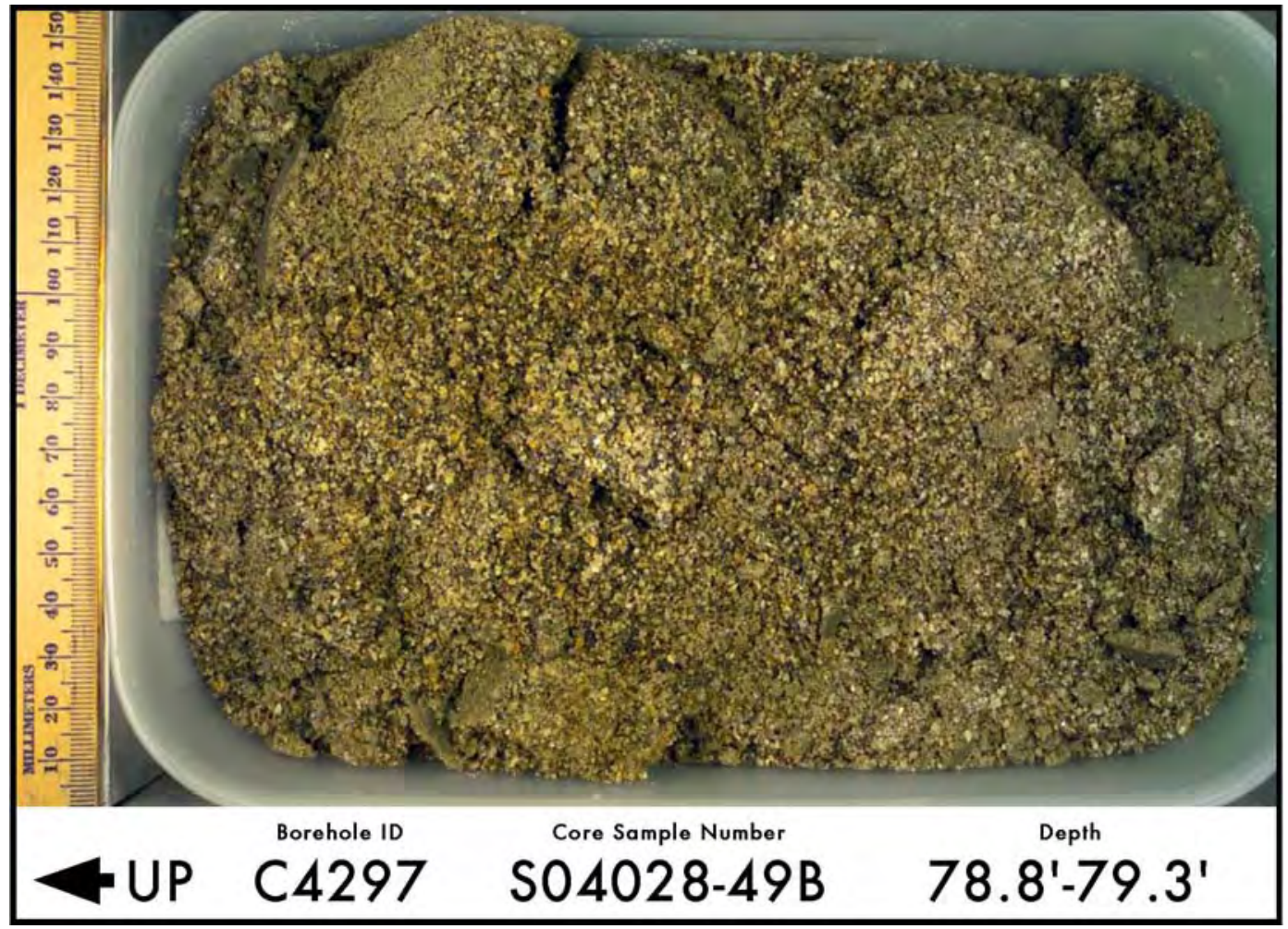

Figure A.26. Hanford formation (H2 unit) $78.8 \mathrm{ft}-79.3 \mathrm{ft}$ 


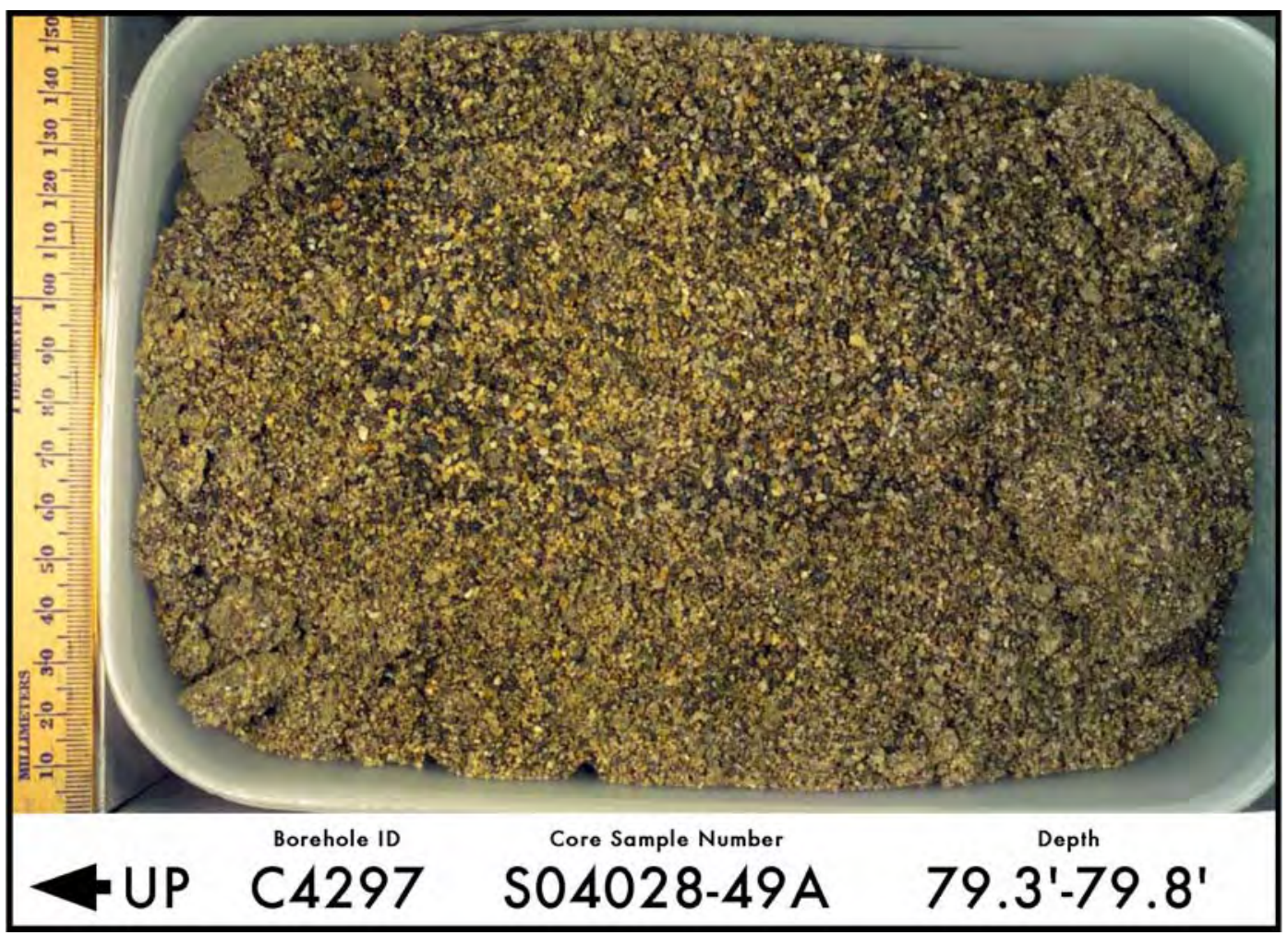

Figure A.27. Hanford formation (H2 unit) $79.3 \mathrm{ft}-79.8 \mathrm{ft}$

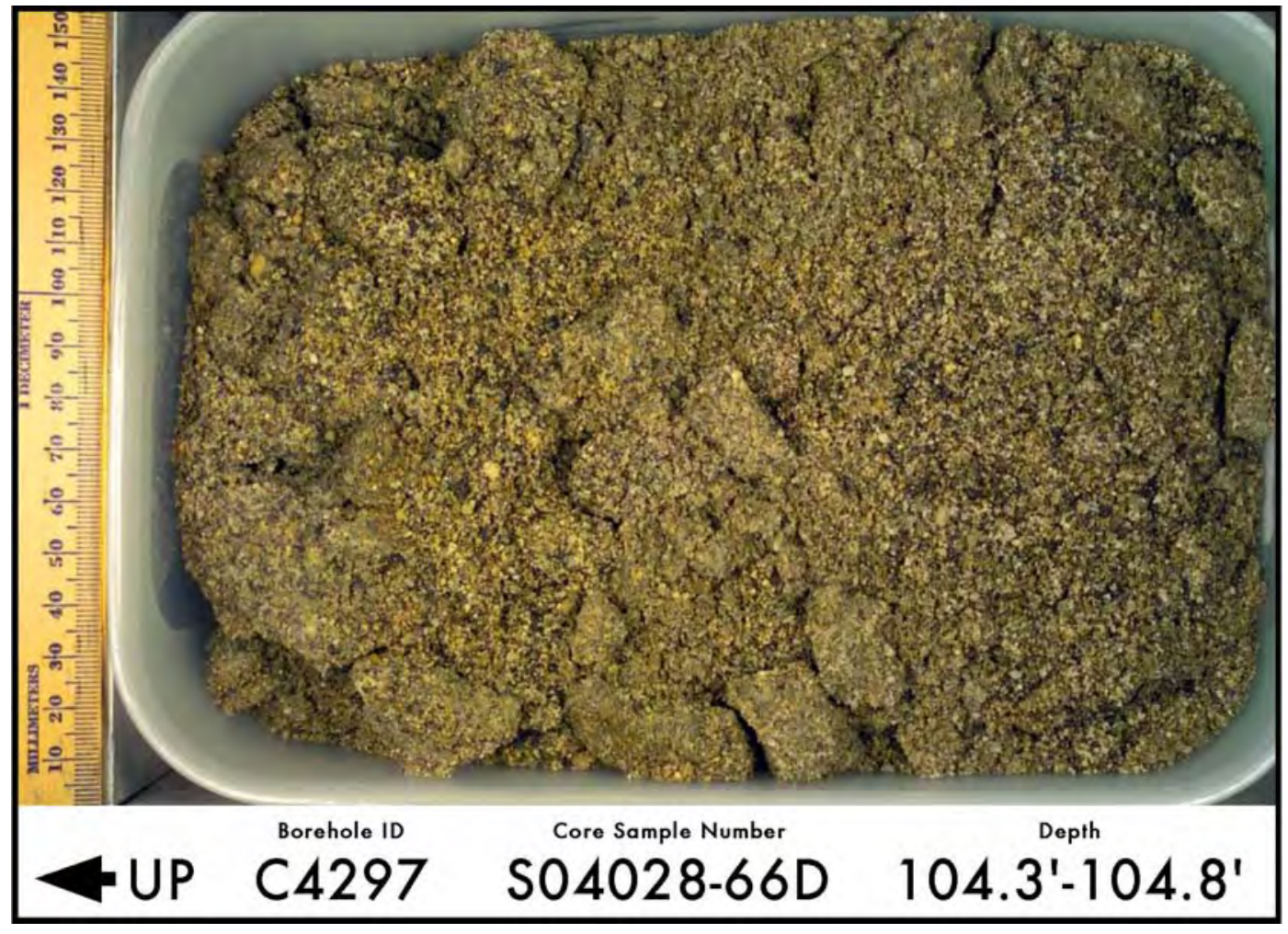

Figure A.28. Hanford formation (H2 unit) $104.3 \mathrm{ft}-104.8 \mathrm{ft}$ 


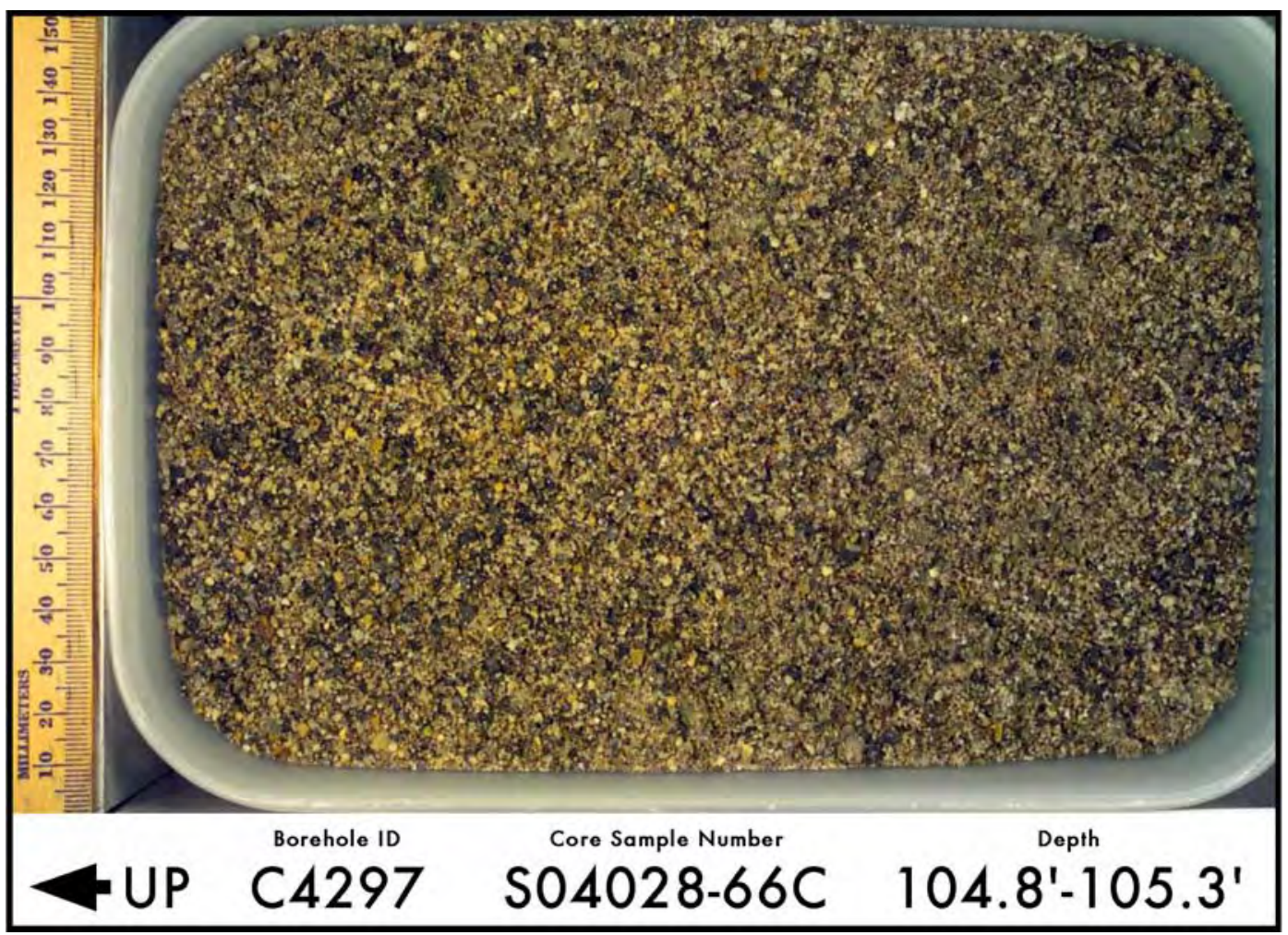

Figure A.29. Hanford formation (H2 unit) $104.8 \mathrm{ft}-105.3 \mathrm{ft}$

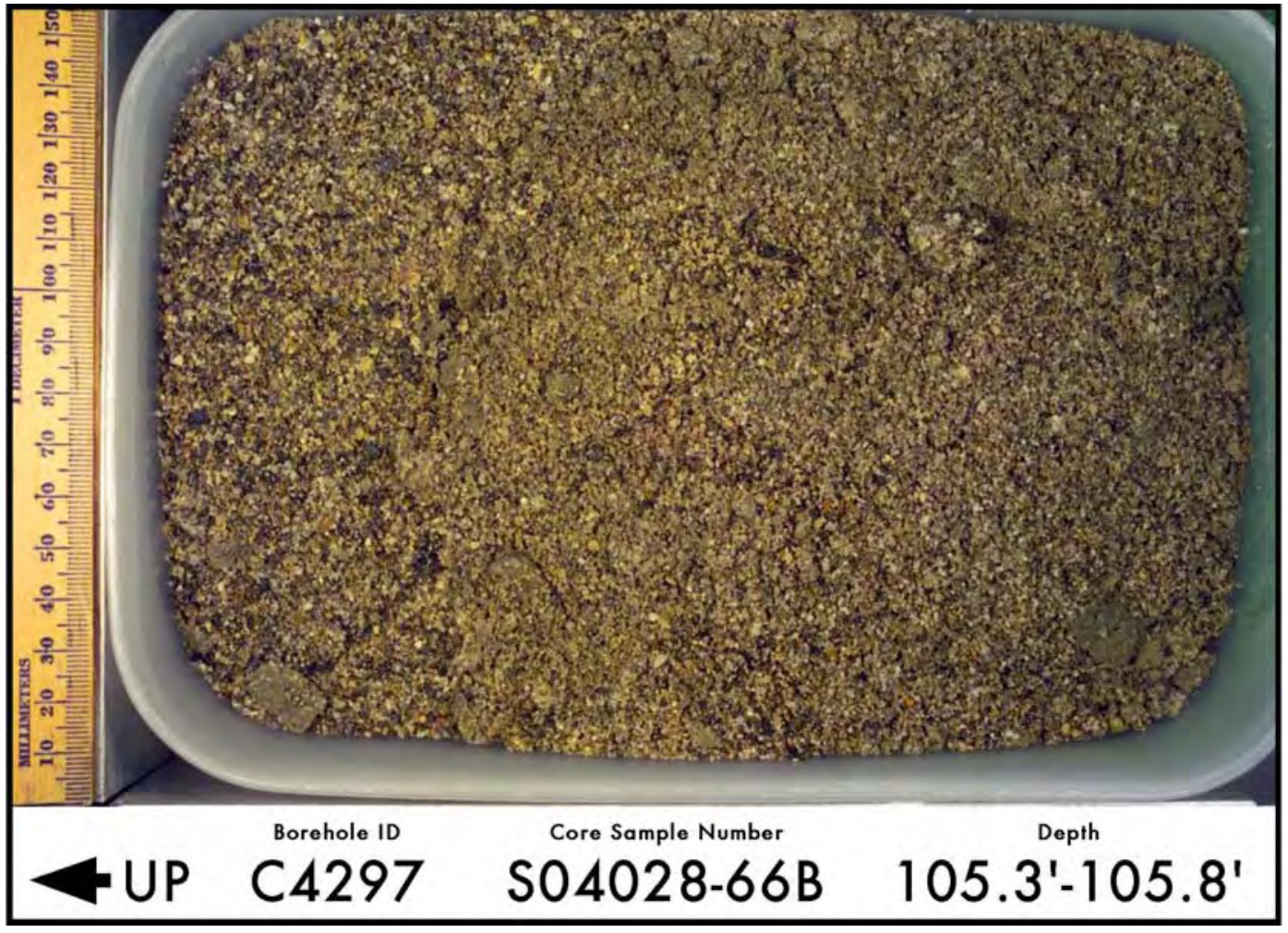

Figure A.30. Hanford formation (H2 unit) $105.3 \mathrm{ft}-105.8 \mathrm{ft}$ 


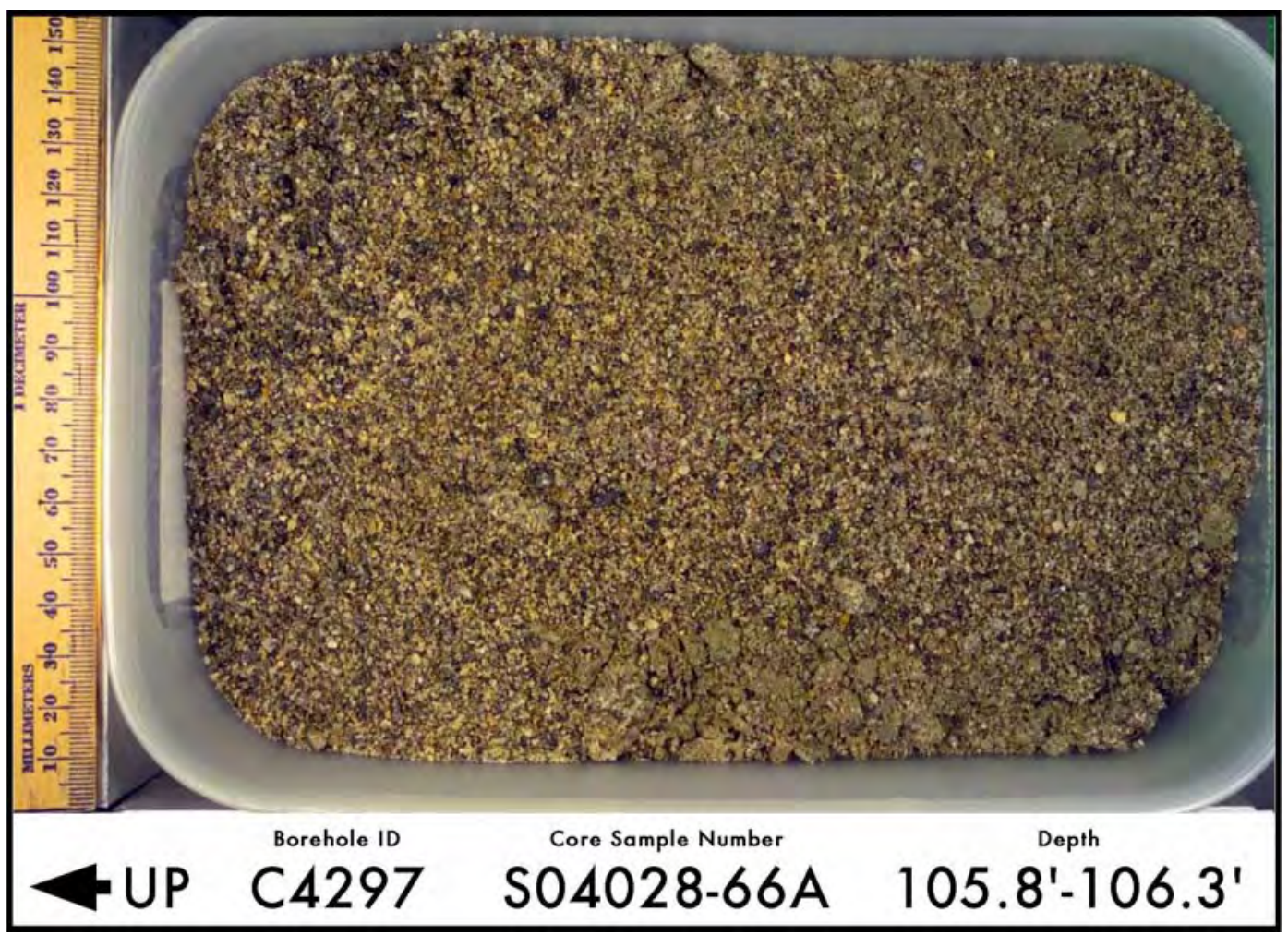

Figure A.31. Hanford formation (H2 unit) $105.8 \mathrm{ft}-106.3 \mathrm{ft}$

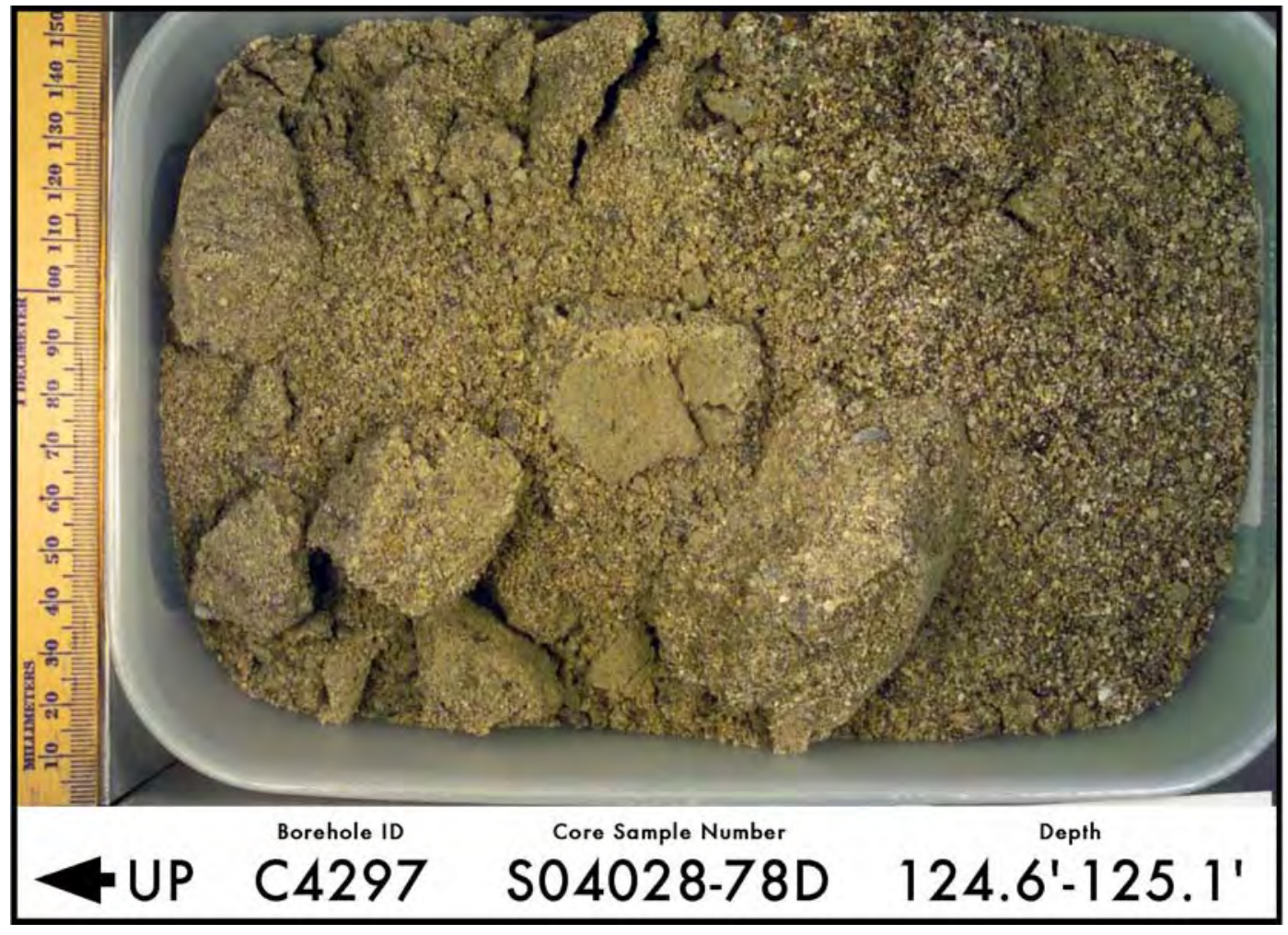

Figure A.32. Hanford formation (H2 unit) $124.6 \mathrm{ft}-125.1 \mathrm{ft}$ 


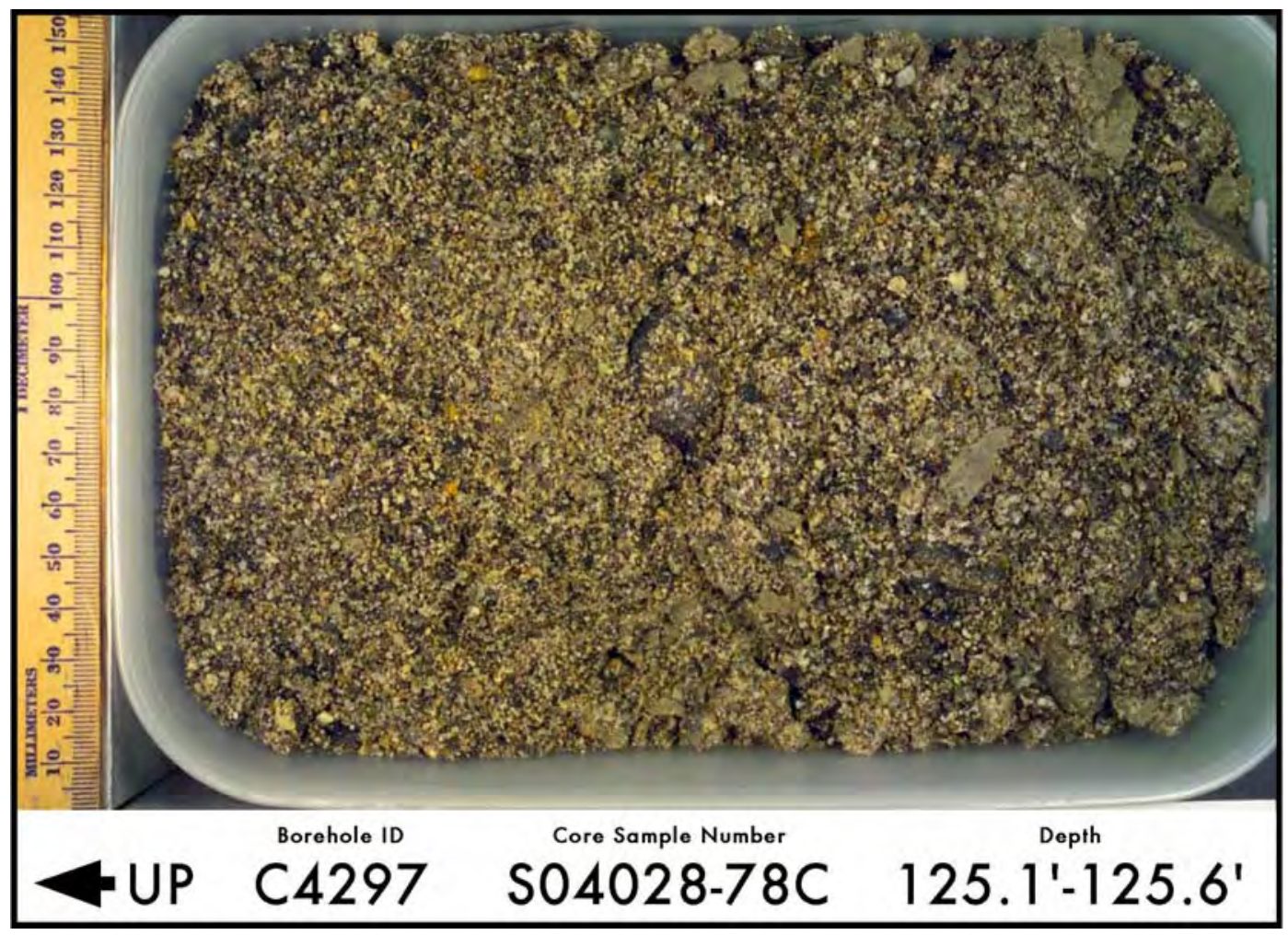

Figure A.33. Hanford formation (H2 unit) $125.1 \mathrm{ft}-125.6 \mathrm{ft}$

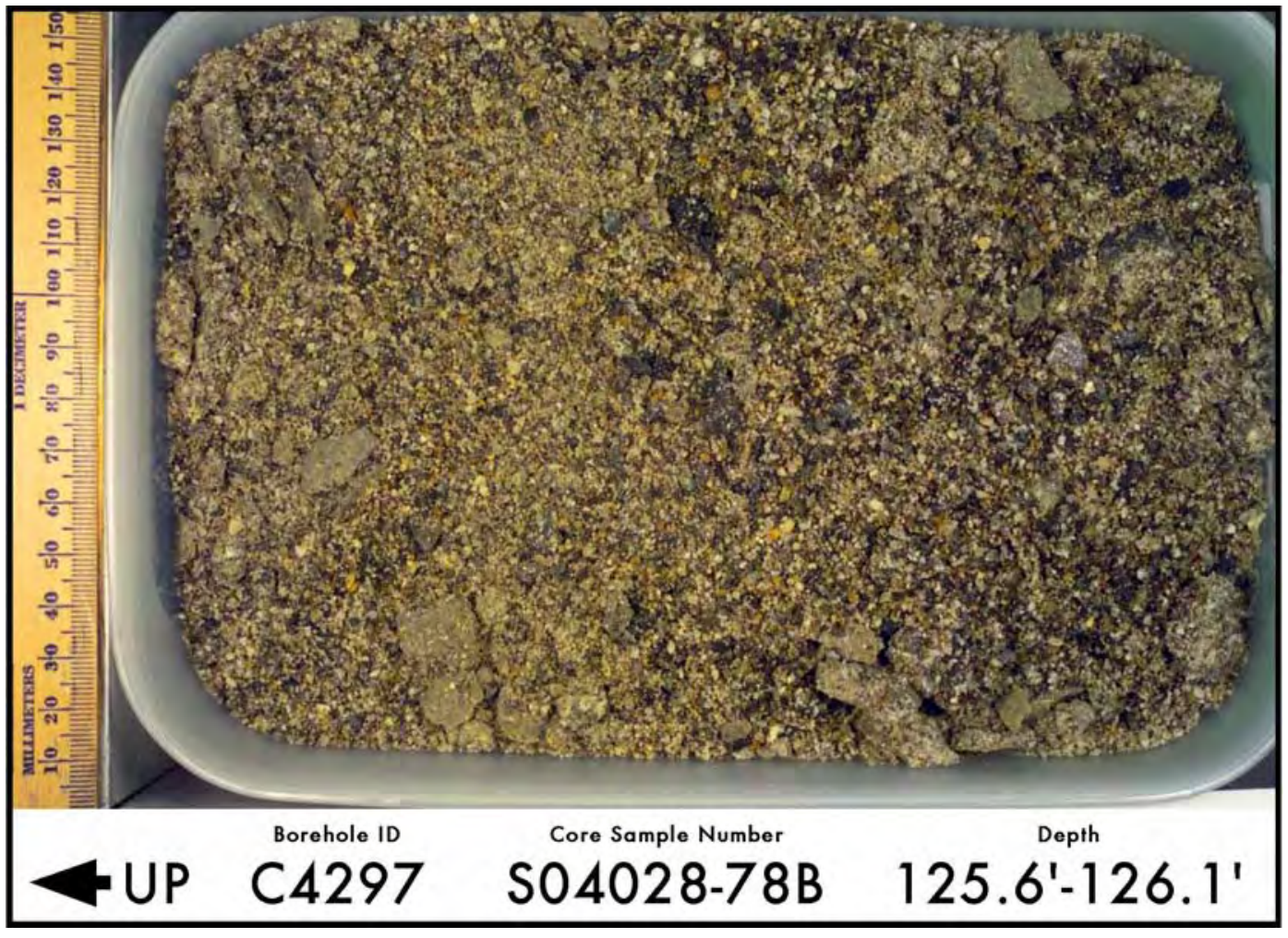

Figure A.34. Hanford formation (H2 unit) $125.6 \mathrm{ft}-126.1 \mathrm{ft}$ 


\section{Appendix B}

\section{Core Logs}

B1. C4124 (299-E27-22)

B2. $\mathrm{C} 4297$ 
Appendix B1

C4124 (299-E27-22)

\section{Geologic Description of Core}

Obtained During Opening in Laboratory 


\section{Contents}

Appendix B1 . Geologic Description of Core from Borehole C4124 (299-E27-22) ....................... B1.1

\section{Figures}

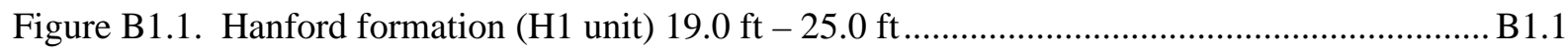

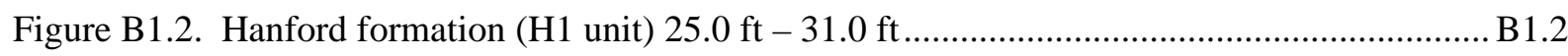

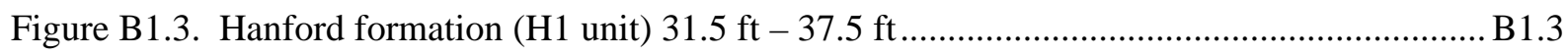

Figure B1.4. Hanford formation (H1 unit) $37.5 \mathrm{ft}-43.5 \mathrm{ft}$....................................................... B1.4

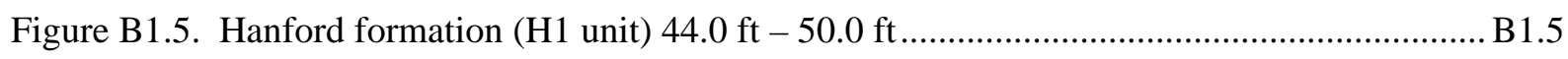

Figure B1.6. Hanford formation (H1 unit) $50.0 \mathrm{ft}-56.0 \mathrm{ft}$................................................... B1.6

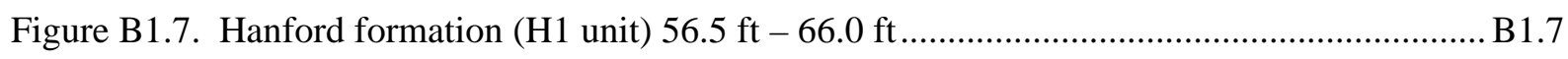

Figure B1.8. Hanford formation (H1 unit) $66.5 \mathrm{ft}-75.0 \mathrm{ft}$................................................... B1.8

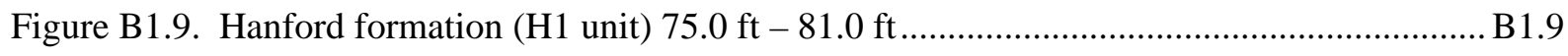

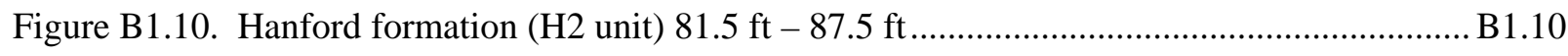

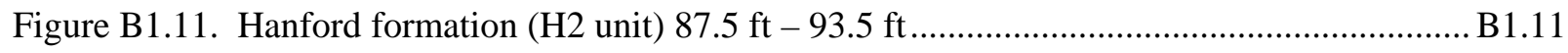

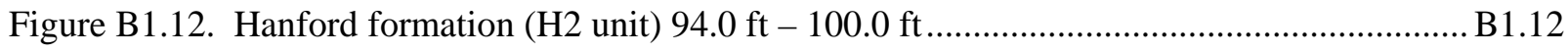

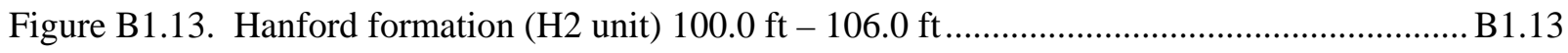

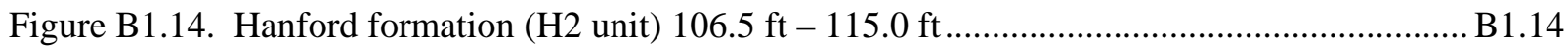

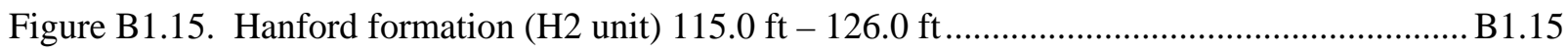

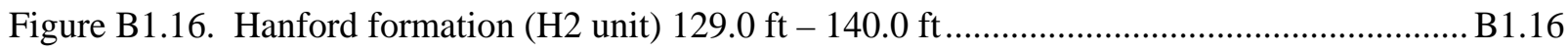

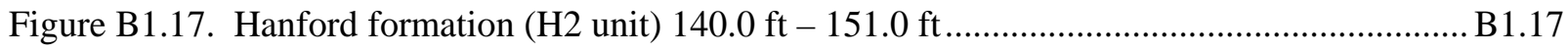

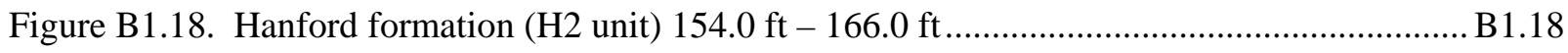

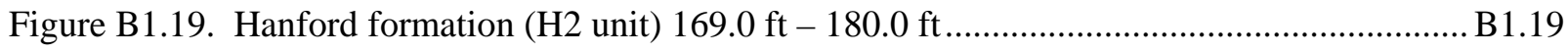

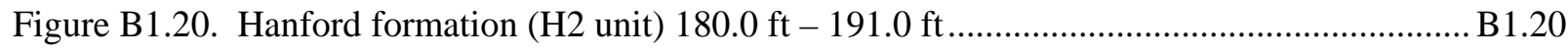

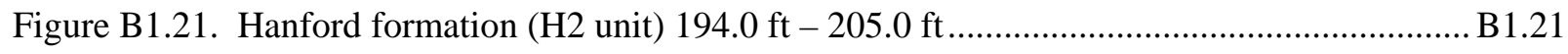




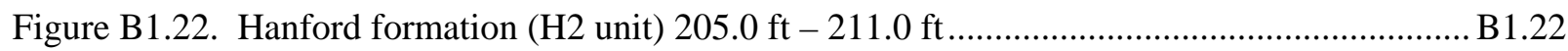

Figure B1.23. Hanford formation (H2 unit) $219.0 \mathrm{ft}-227.9 \mathrm{ft}$ to Cold Creek Unit/Ringold

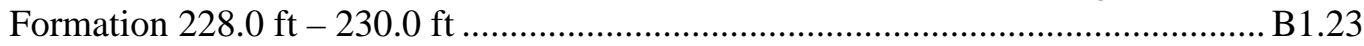




\section{Appendix B1. Geologic Description of Core from Borehole C4124 (299-E27-22)}

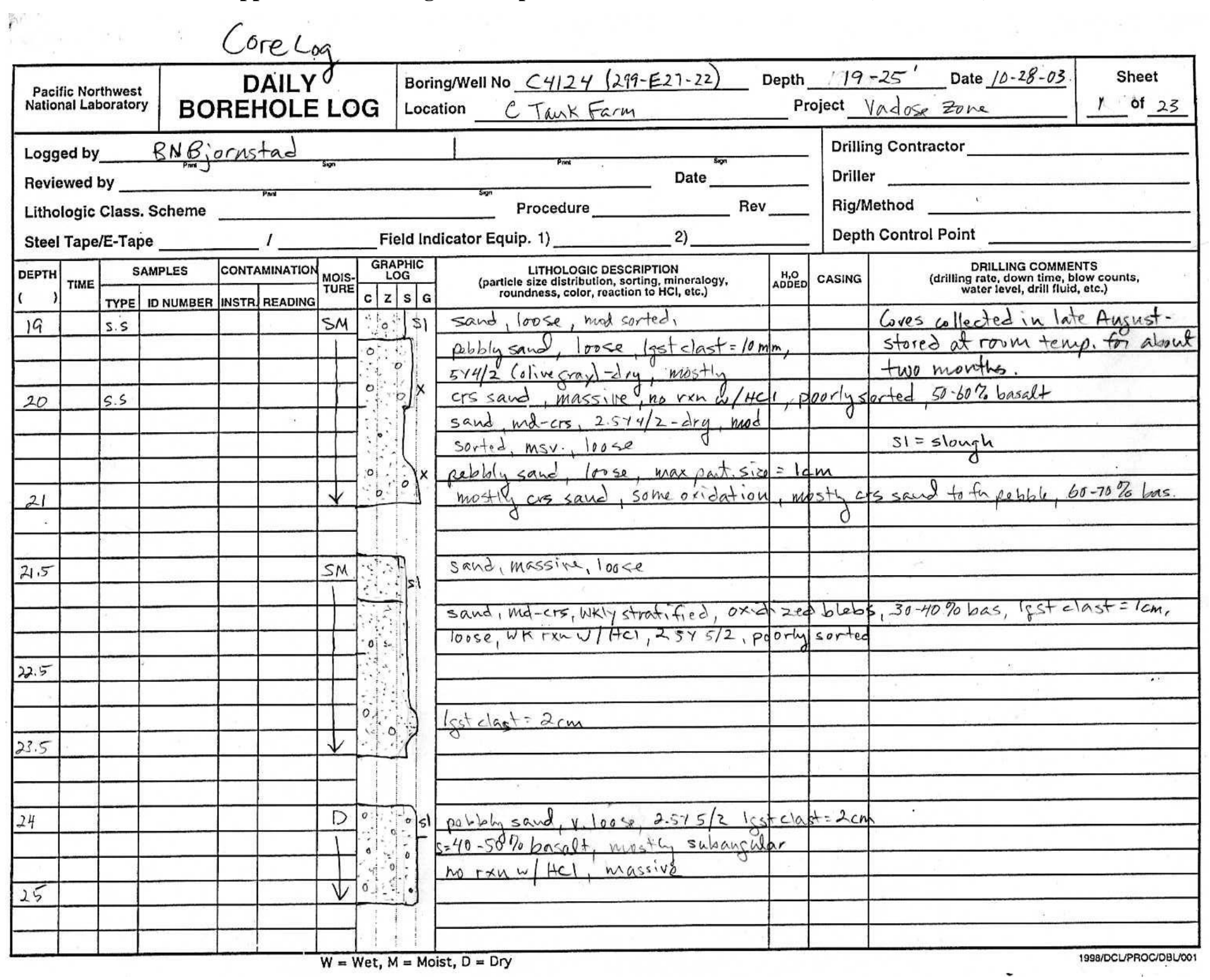

Figure B1.1. Hanford formation (H1 unit) $19.0 \mathrm{ft}-25.0 \mathrm{ft}$ 


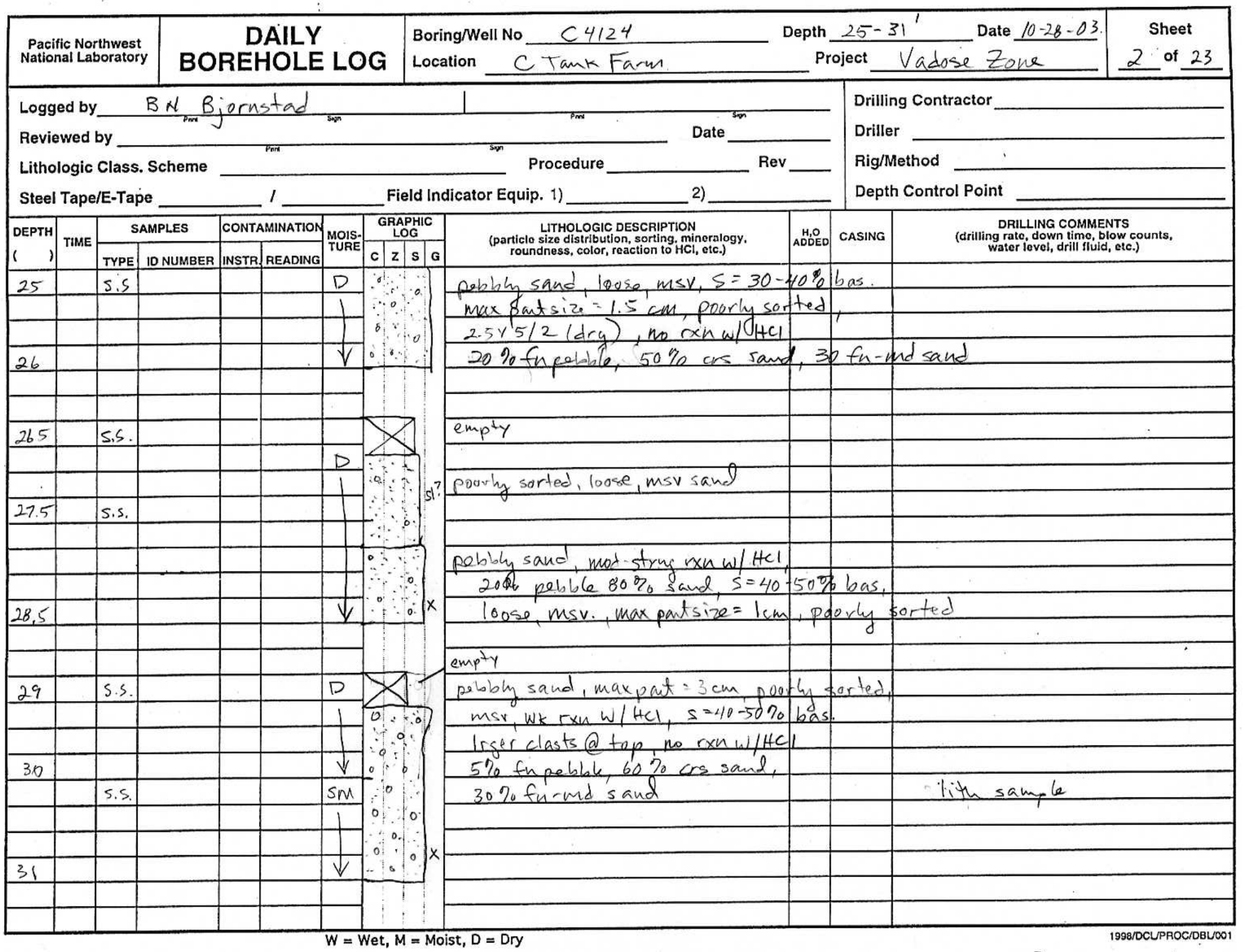

Figure B1.2. Hanford formation (H1 unit) $25.0 \mathrm{ft}-31.0 \mathrm{ft}$ 


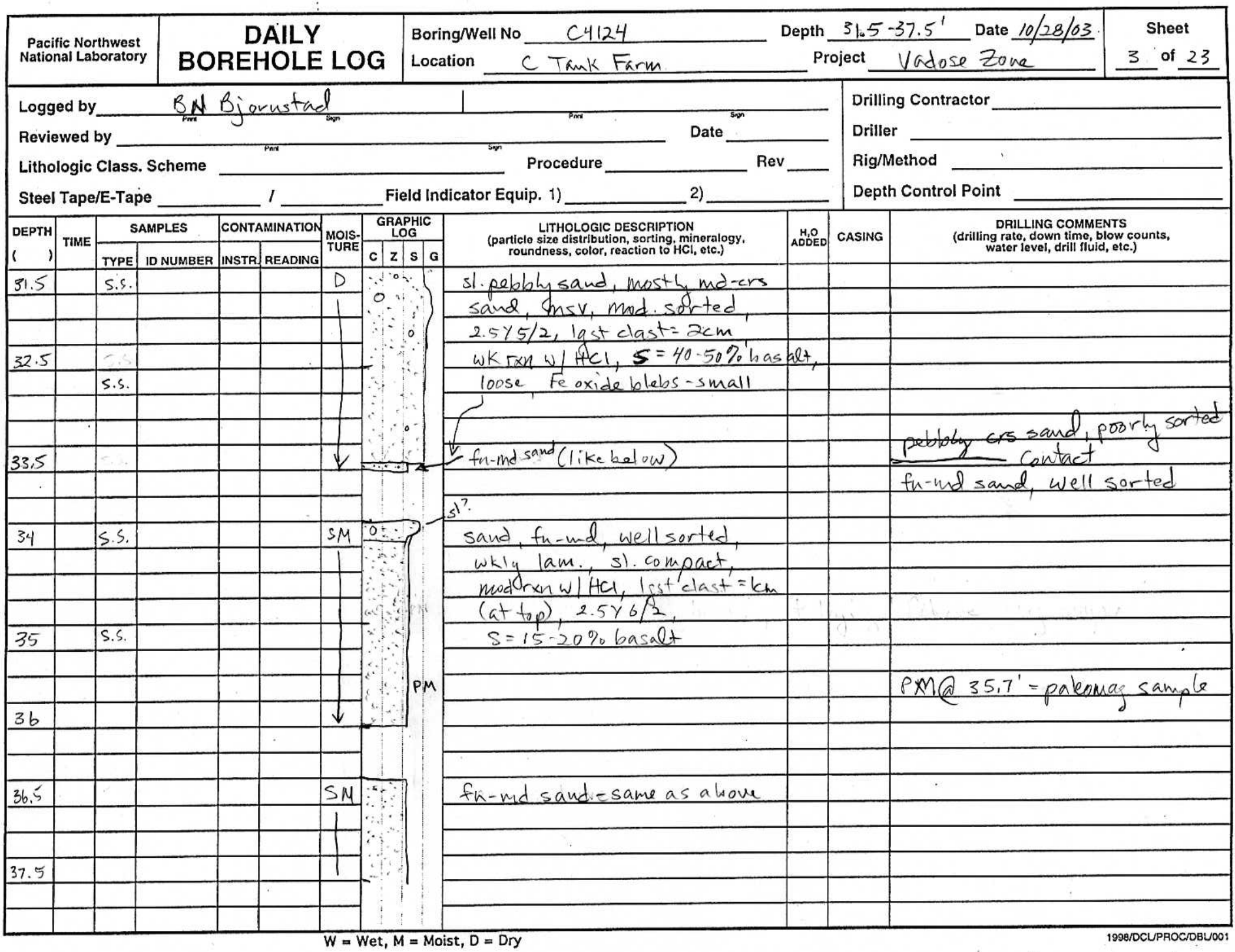

Figure B1.3. Hanford formation (H1 unit) $31.5 \mathrm{ft}-37.5 \mathrm{ft}$ 


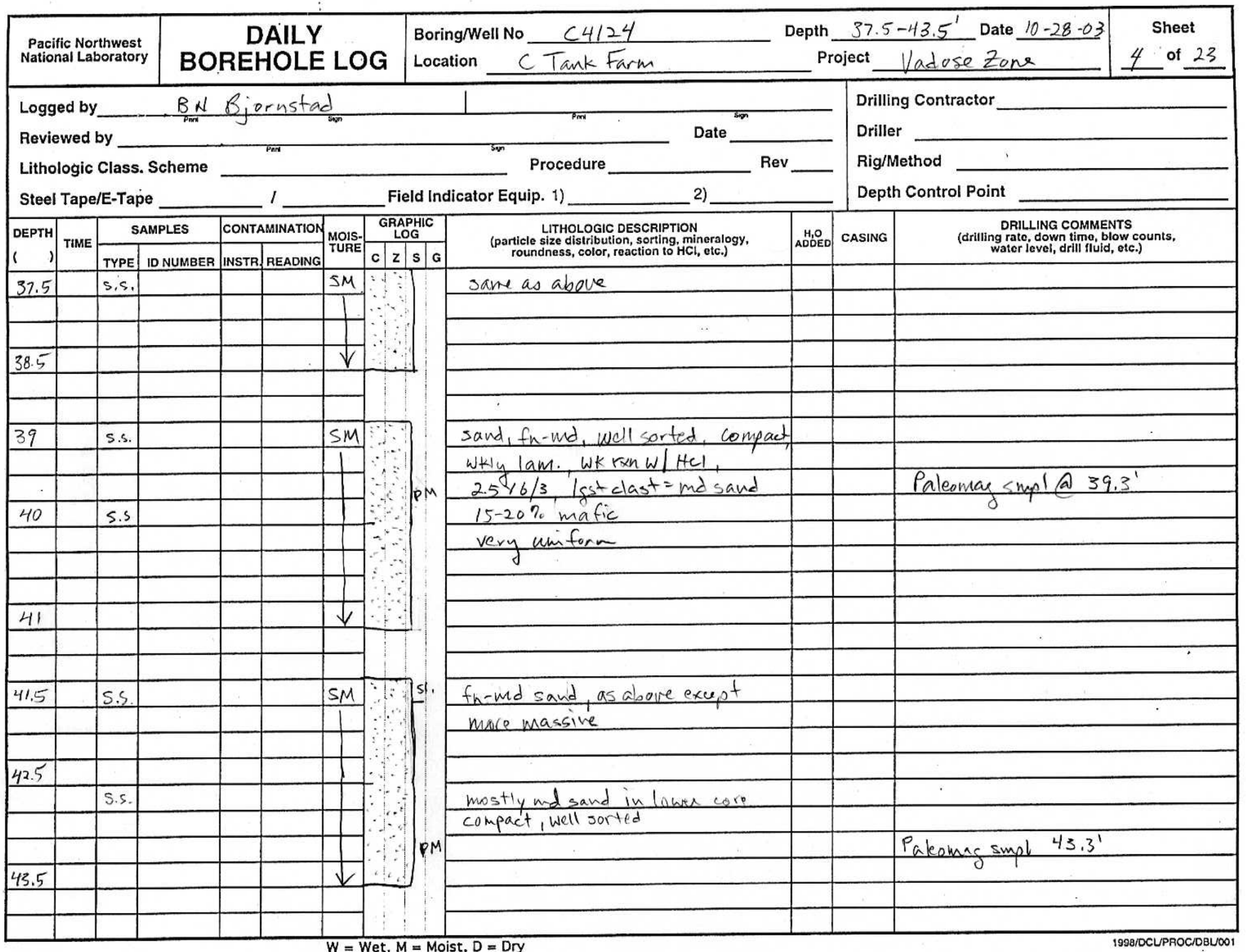

Figure B1.4. Hanford formation (H1 unit) $37.5 \mathrm{ft}-43.5 \mathrm{ft}$ 


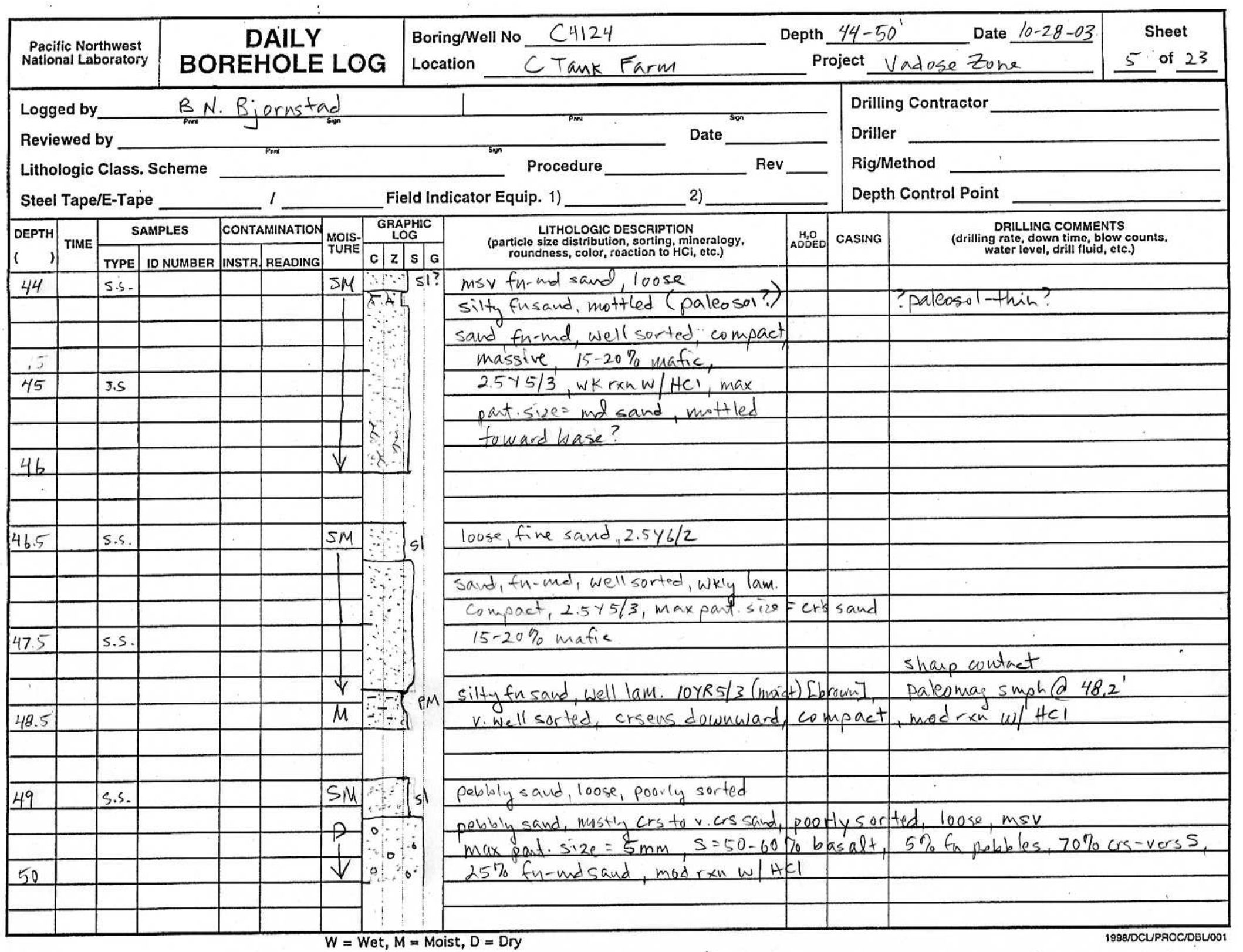

Figure B1.5. Hanford formation (H1 unit) $44.0 \mathrm{ft}-50.0 \mathrm{ft}$ 


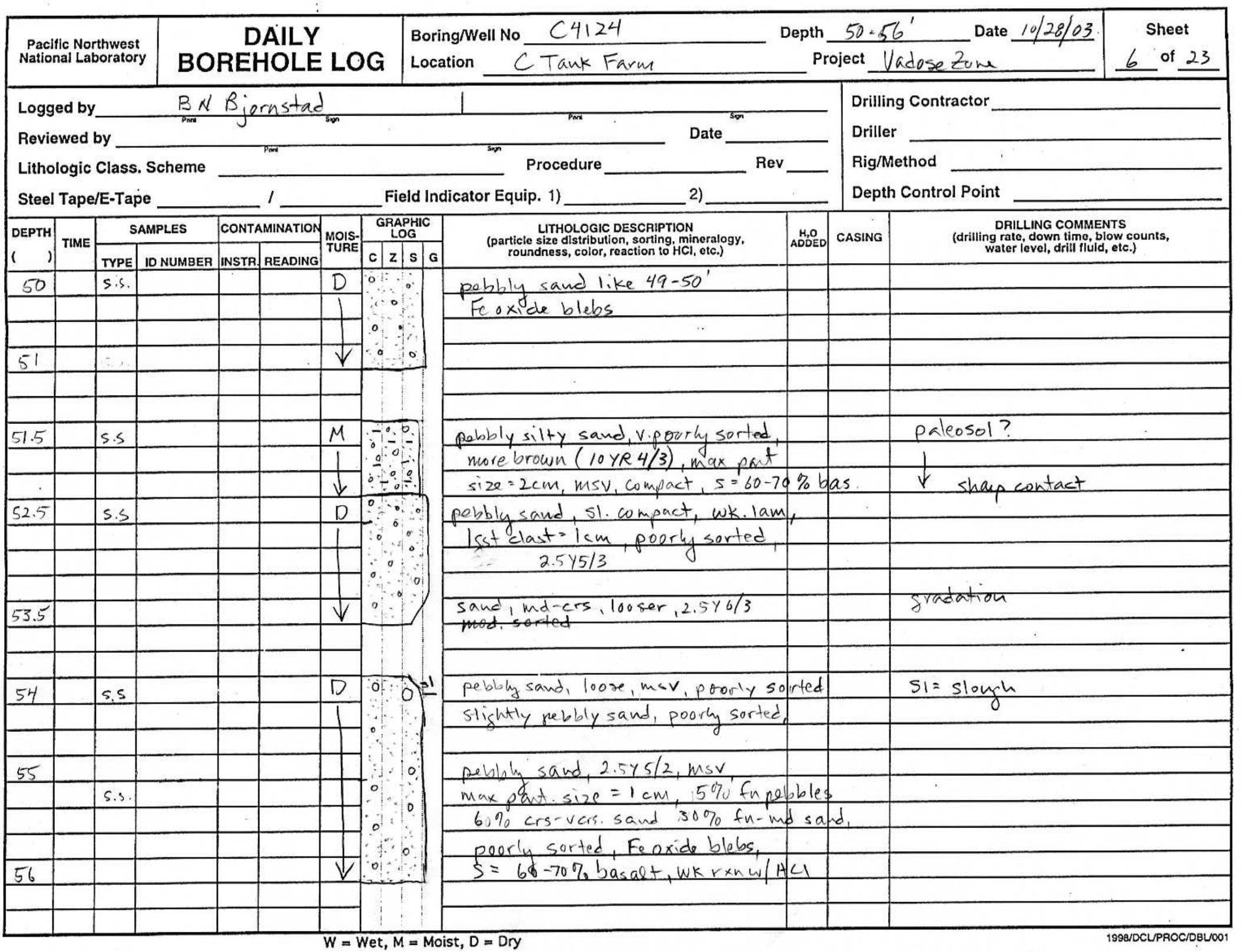

Figure B1.6. Hanford formation (H1 unit) $50.0 \mathrm{ft}-56.0 \mathrm{ft}$ 


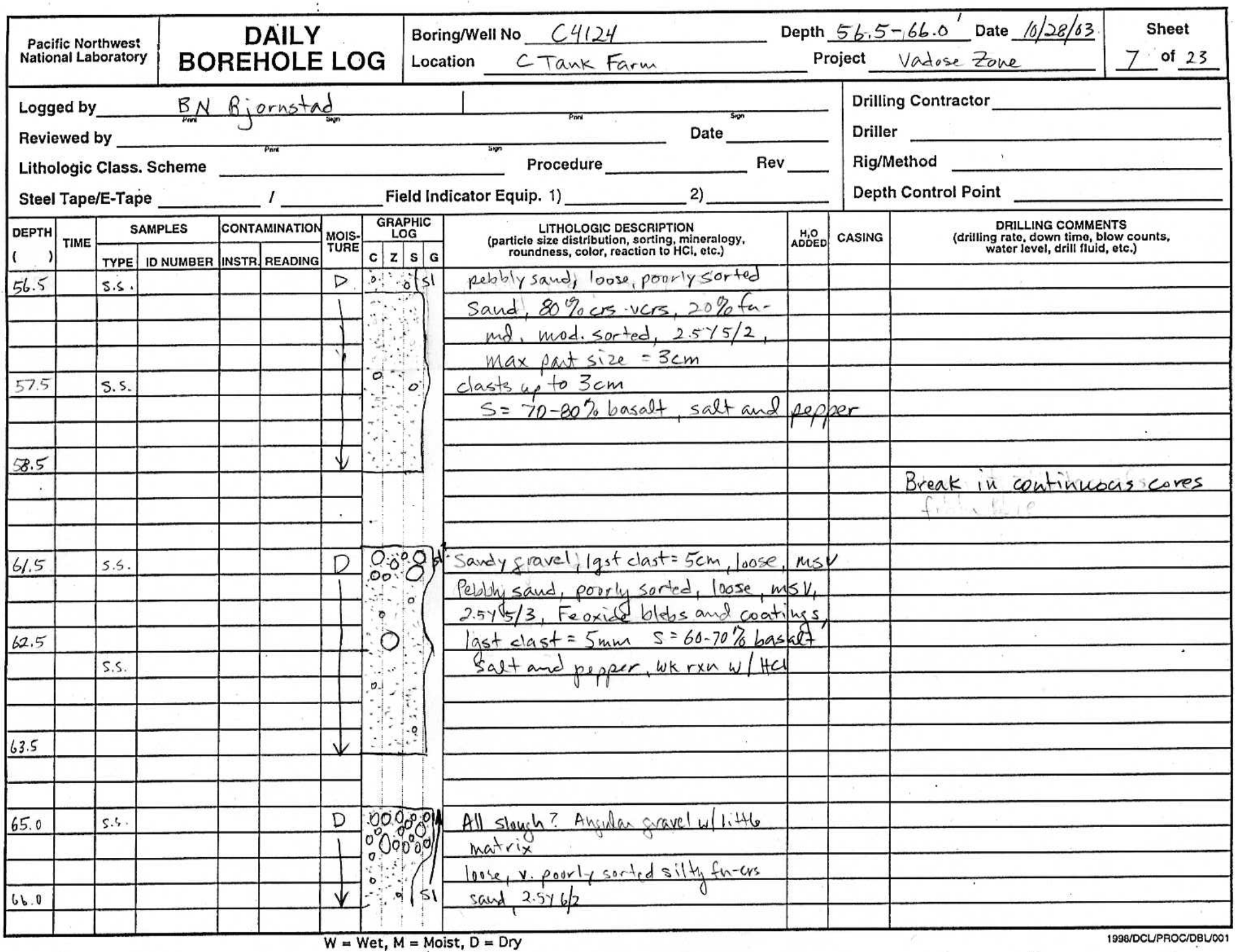

Figure B1.7. Hanford formation (H1 unit) $56.5 \mathrm{ft}-66.0 \mathrm{ft}$ 


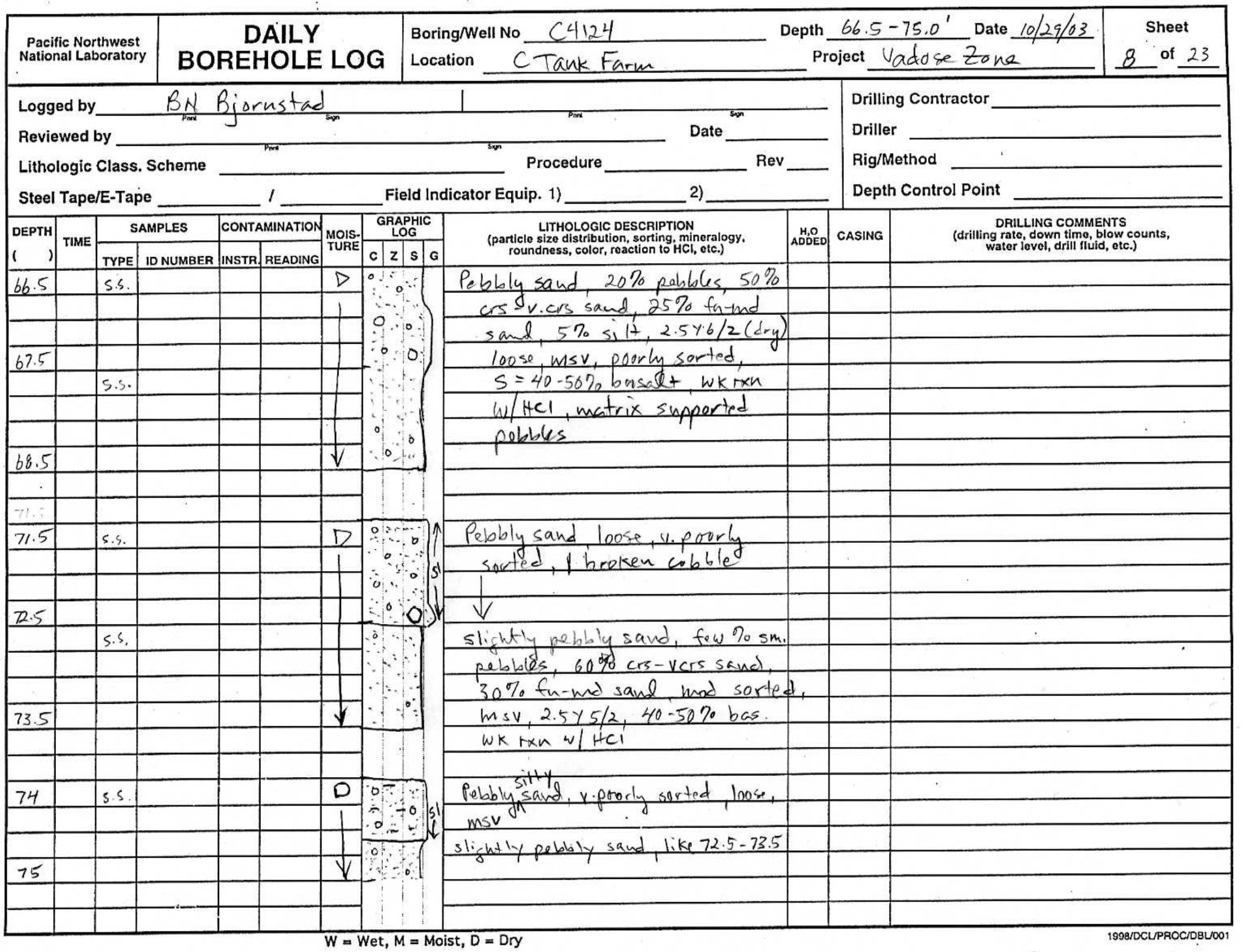

Figure B1.8. Hanford formation (H1 unit) $66.5 \mathrm{ft}-75.0 \mathrm{ft}$ 


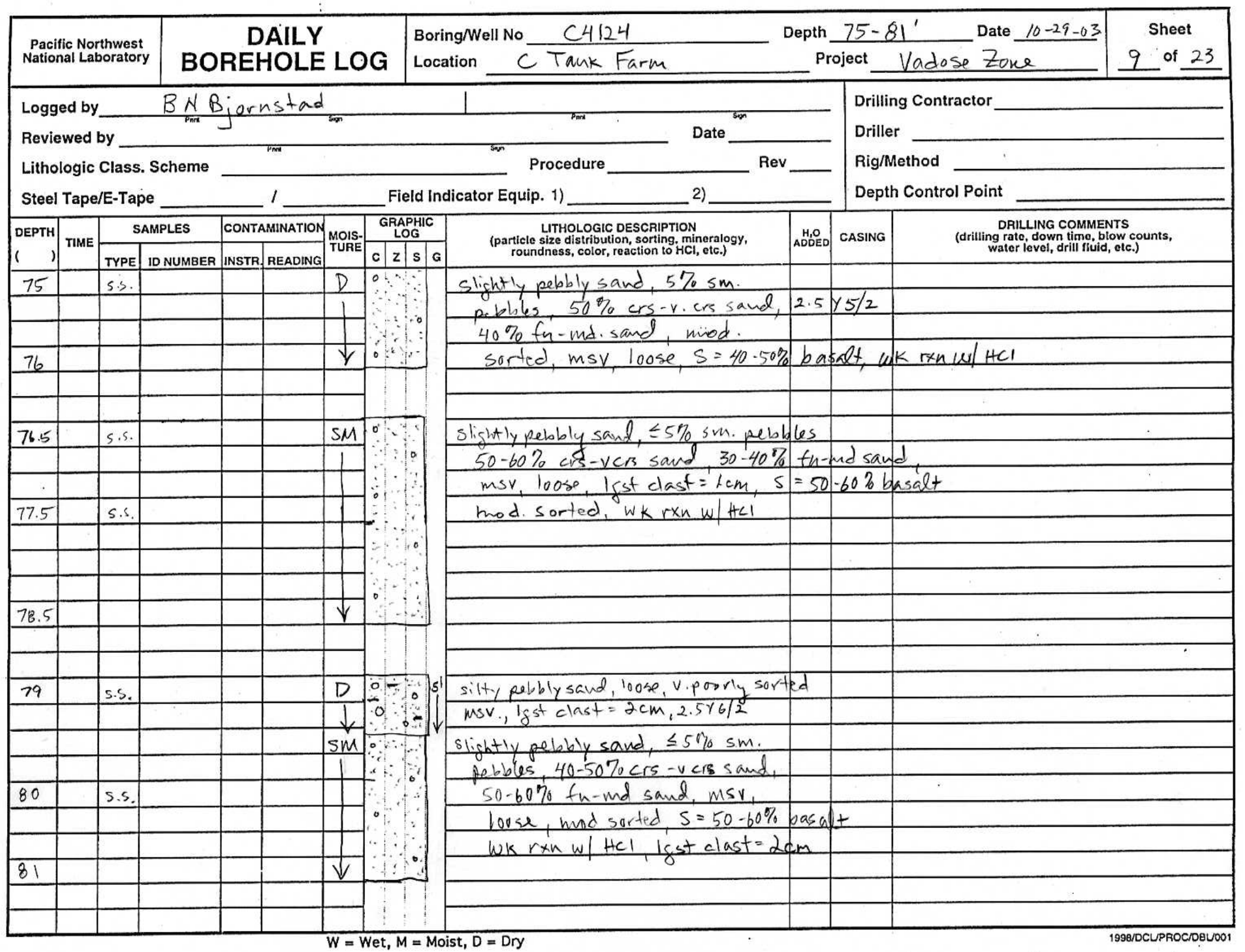

Figure B1.9. Hanford formation (H1 unit) $75.0 \mathrm{ft}-81.0 \mathrm{ft}$ 


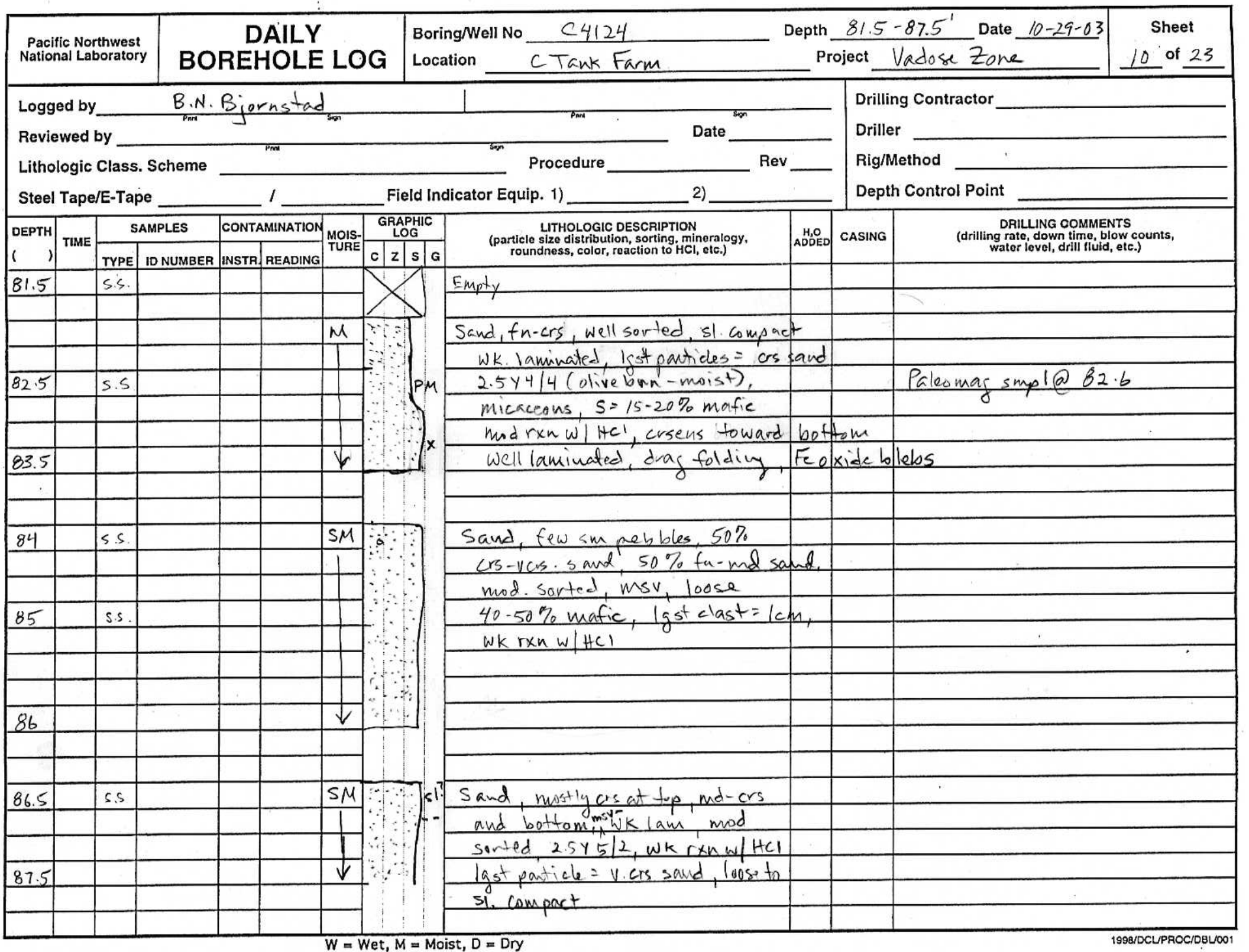

Figure B1.10. Hanford formation (H2 unit) $81.5 \mathrm{ft}-87.5 \mathrm{ft}$ 


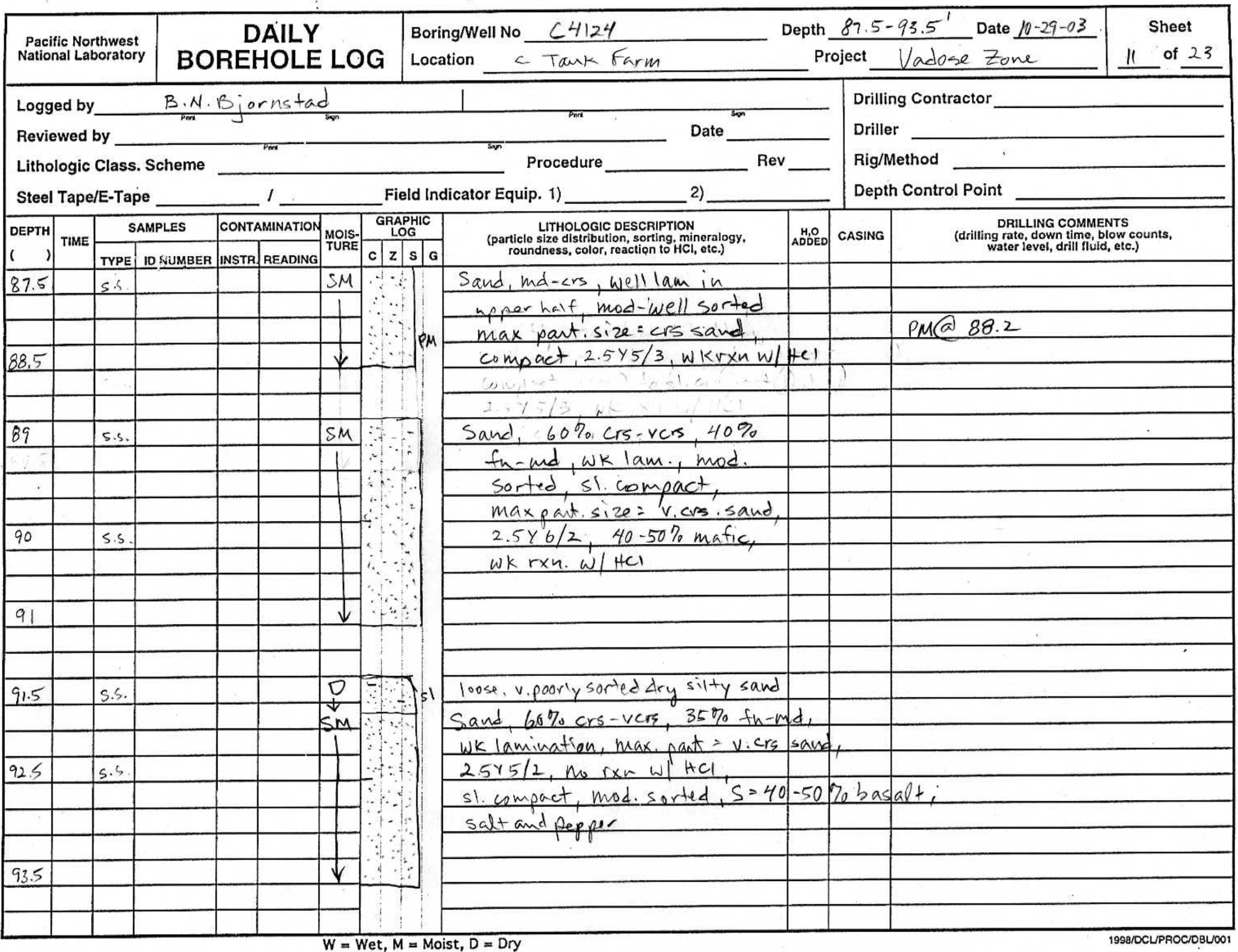

Figure B1.11. Hanford formation (H2 unit) $87.5 \mathrm{ft}-93.5 \mathrm{ft}$ 


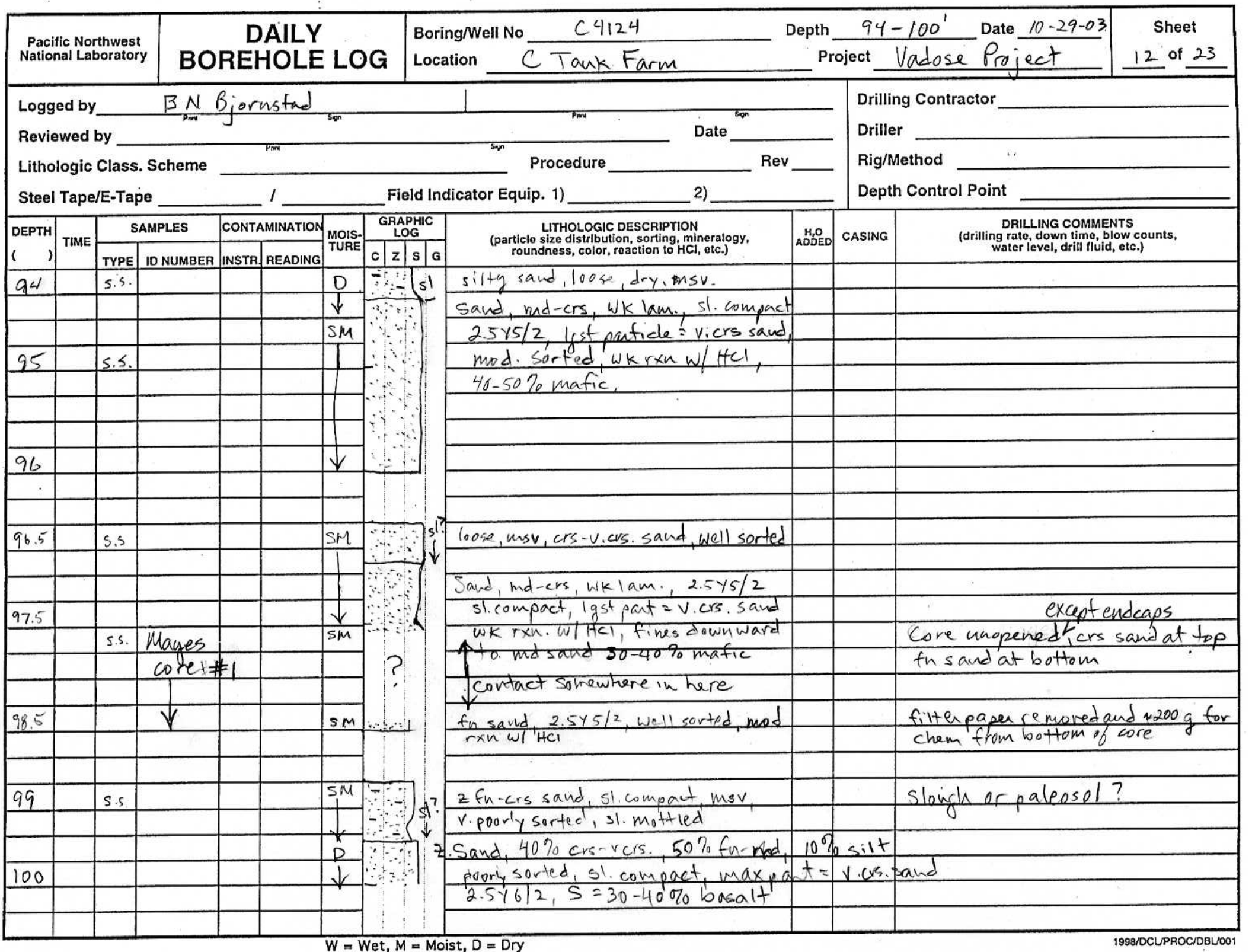

Figure B1.12. Hanford formation (H2 unit) $94.0 \mathrm{ft}-100.0 \mathrm{ft}$ 


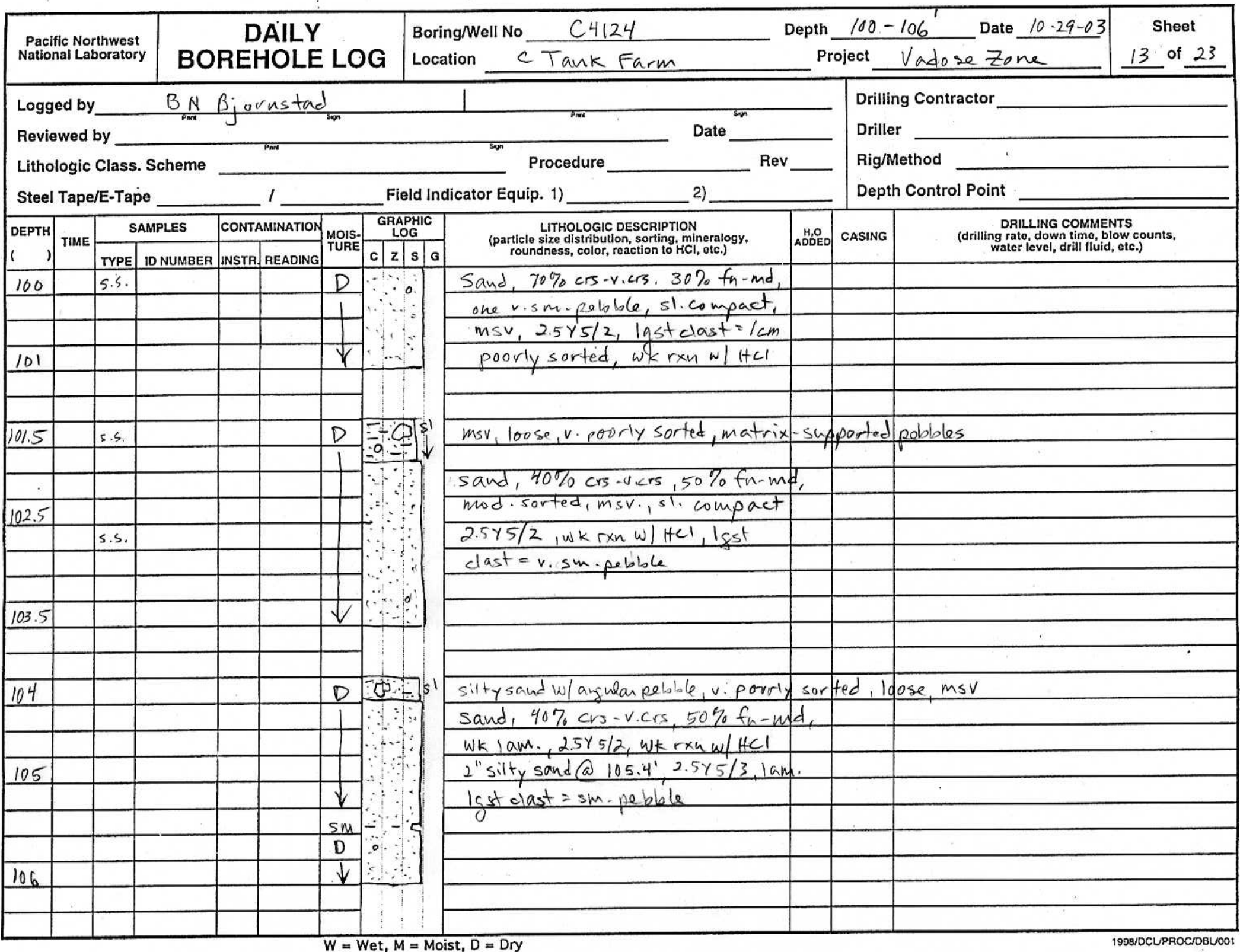

Figure B1.13. Hanford formation (H2 unit) $100.0 \mathrm{ft}-106.0 \mathrm{ft}$ 


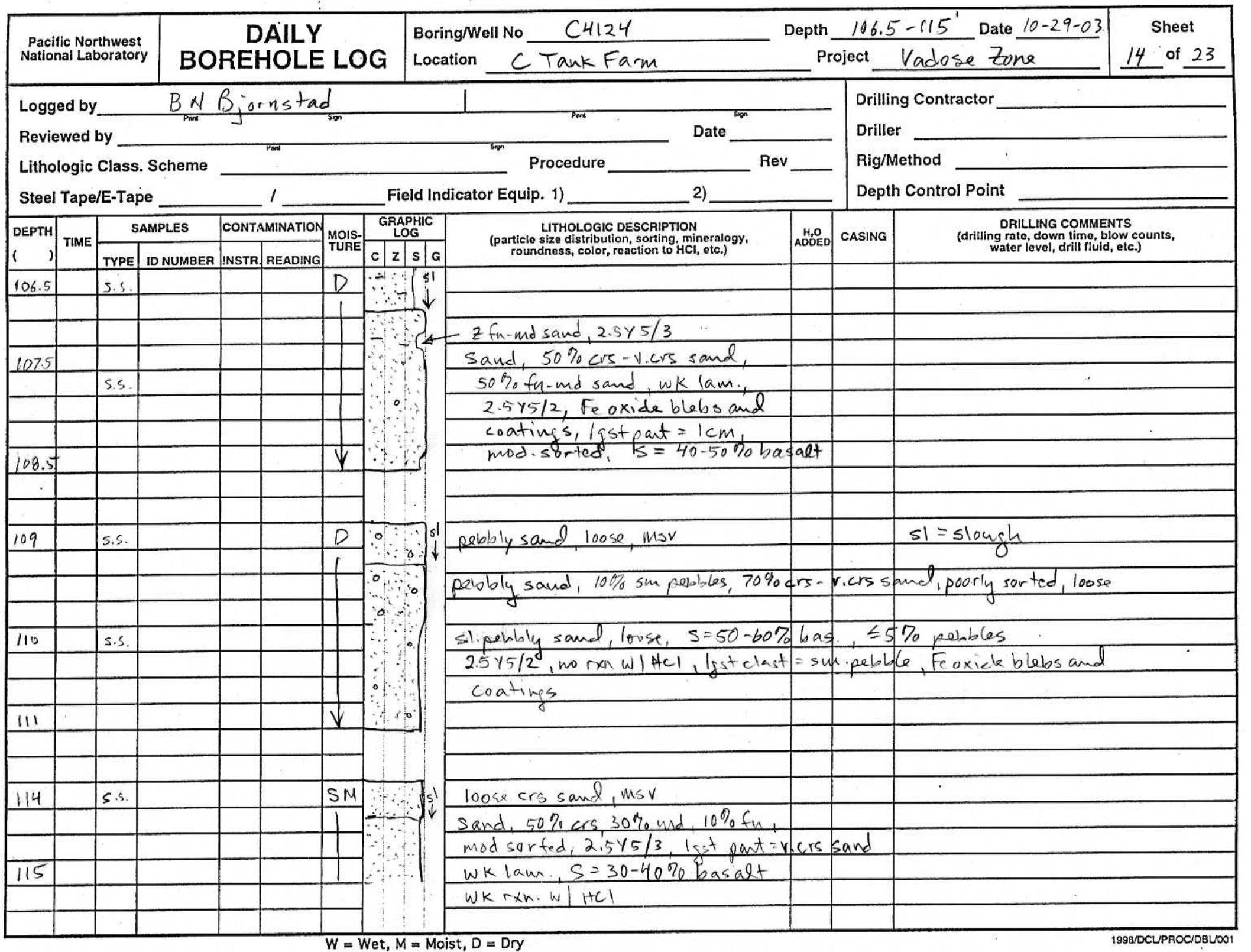

Figure B1.14. Hanford formation (H2 unit) $106.5 \mathrm{ft}-115.0 \mathrm{ft}$ 


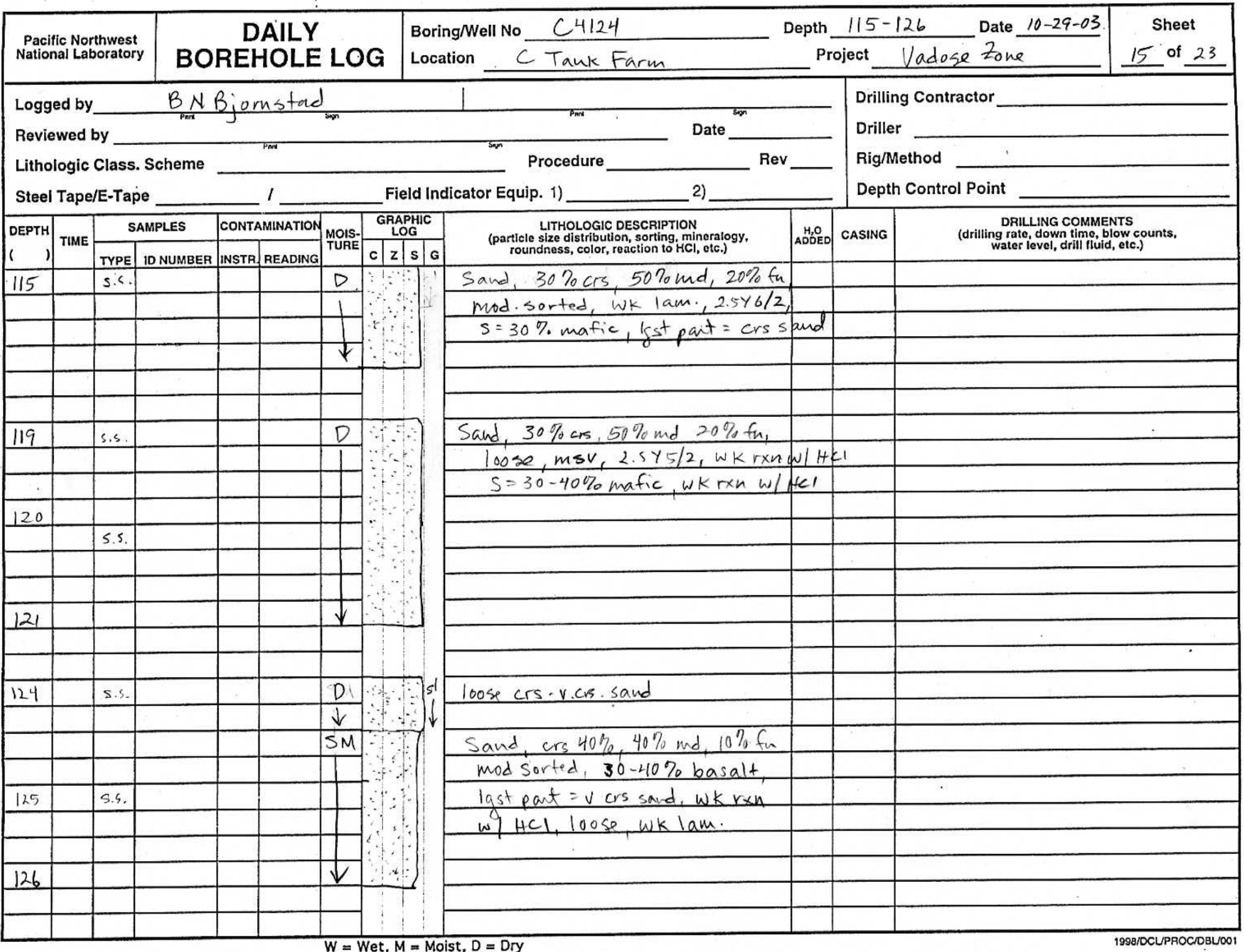

Figure B1.15. Hanford formation (H2 unit) $115.0 \mathrm{ft}-126.0 \mathrm{ft}$ 


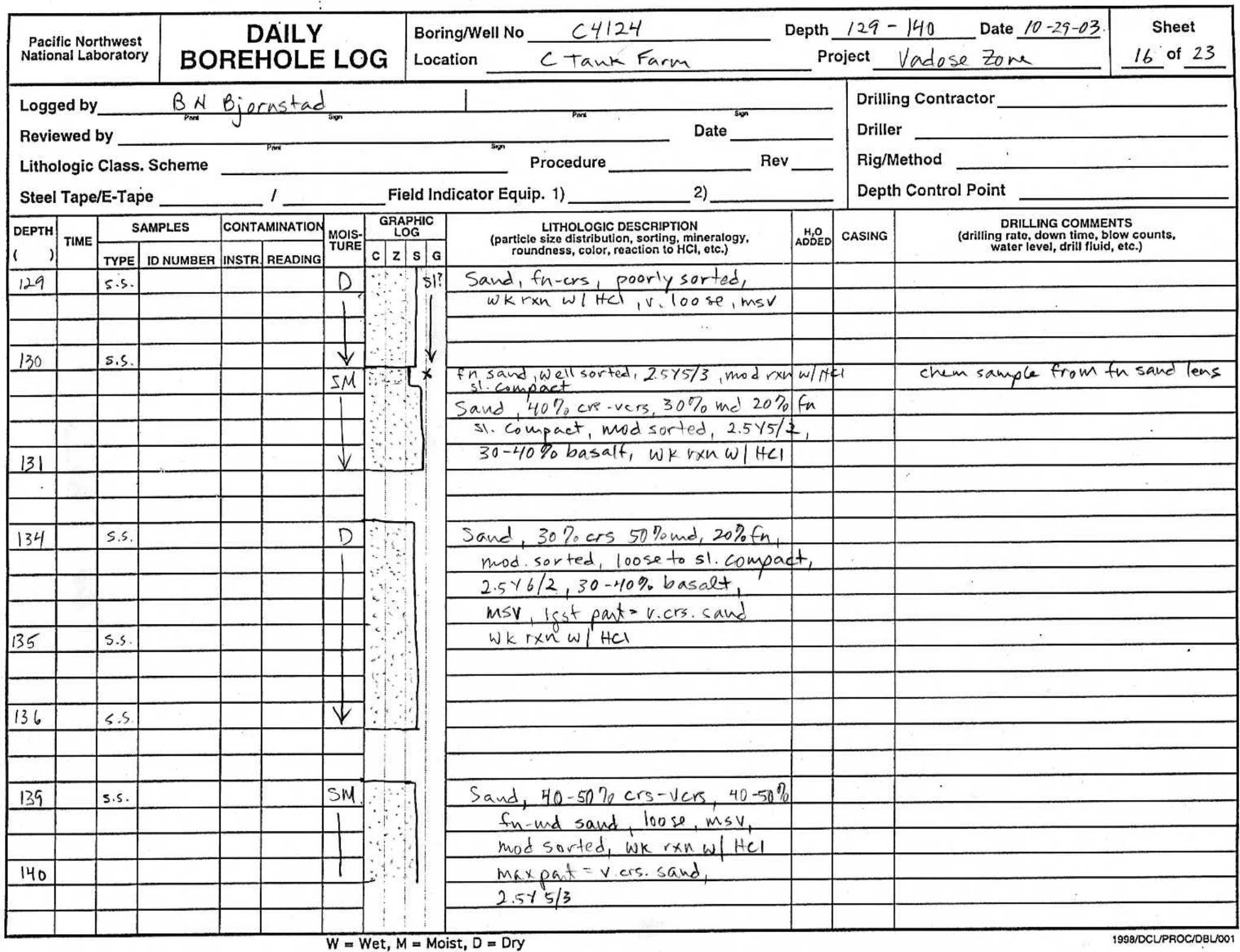

Figure B1.16. Hanford formation (H2 unit) $129.0 \mathrm{ft}-140.0 \mathrm{ft}$ 


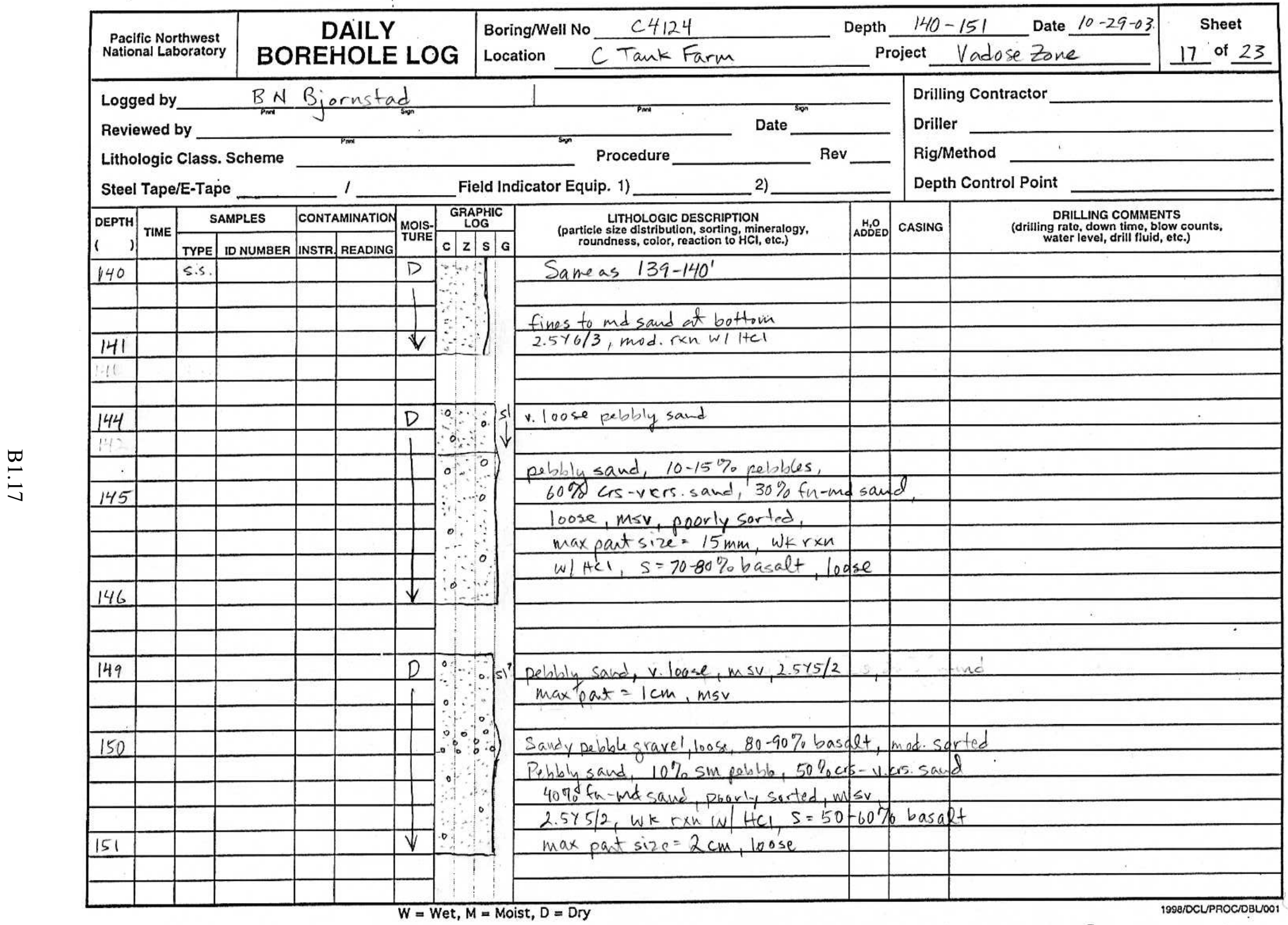

Figure B1.17. Hanford formation (H2 unit) $140.0 \mathrm{ft}-151.0 \mathrm{ft}$ 


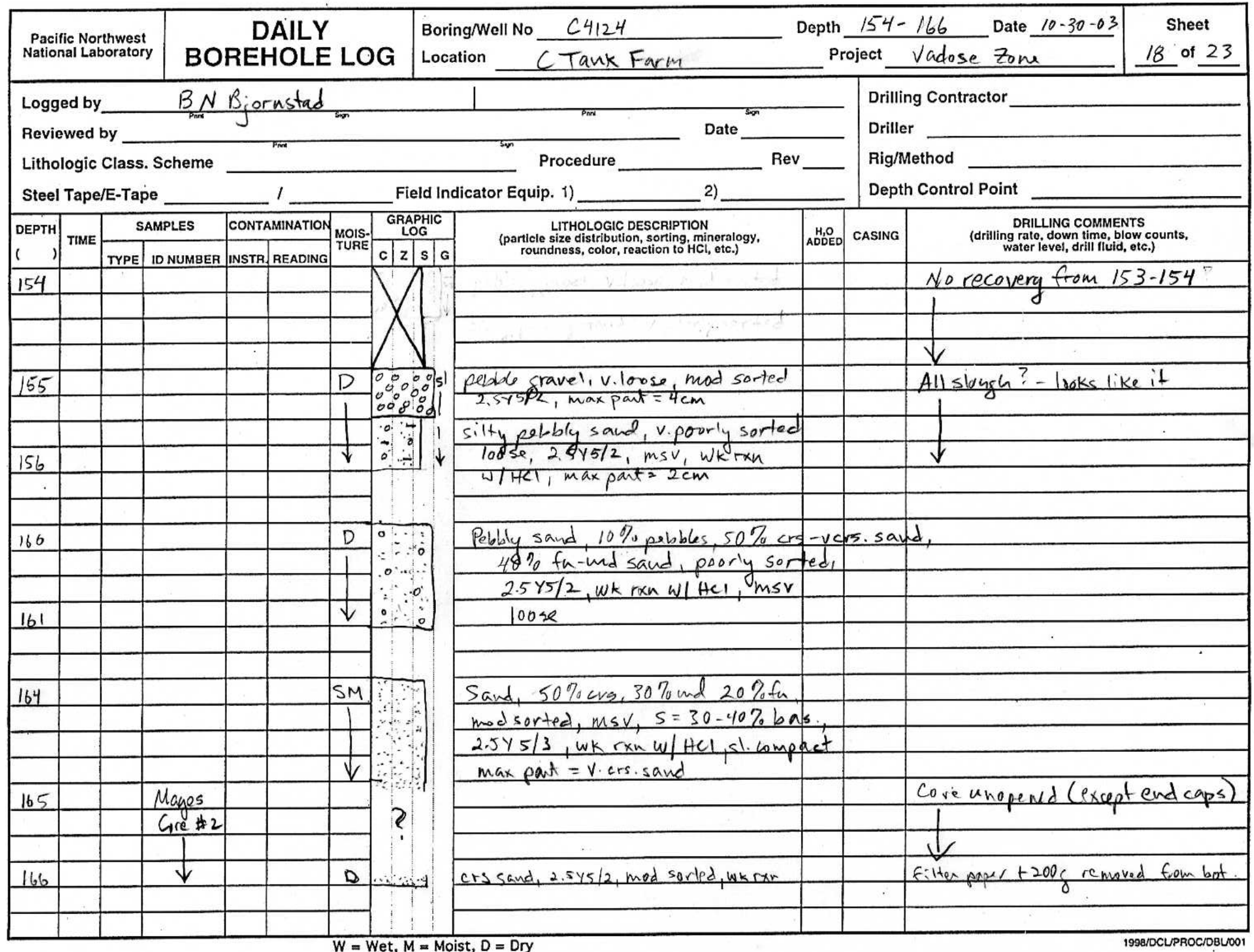

Figure B1.18. Hanford formation (H2 unit) $154.0 \mathrm{ft}-166.0 \mathrm{ft}$ 


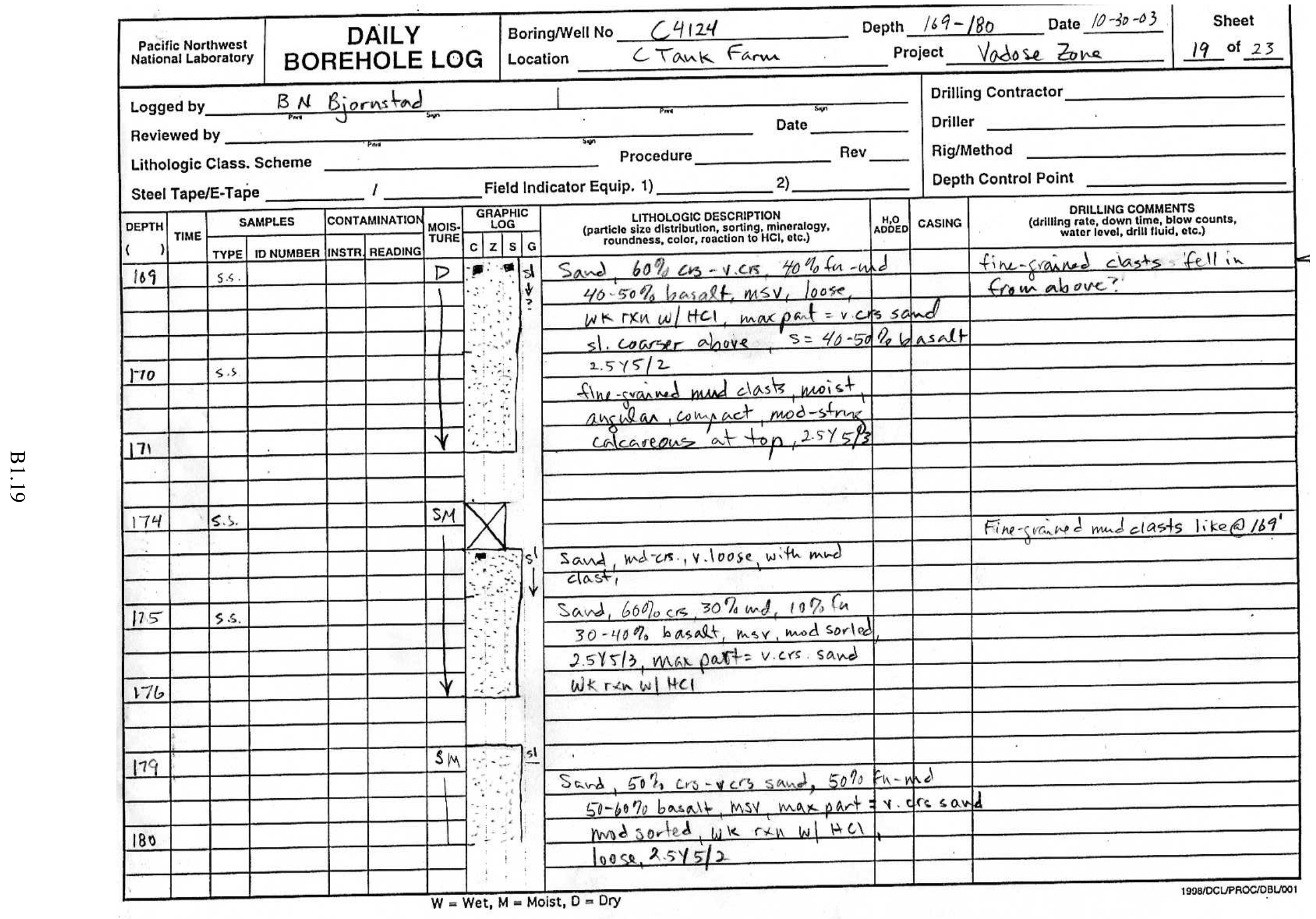

Figure B1.19. Hanford formation (H2 unit) $169.0 \mathrm{ft}-180.0 \mathrm{ft}$ 


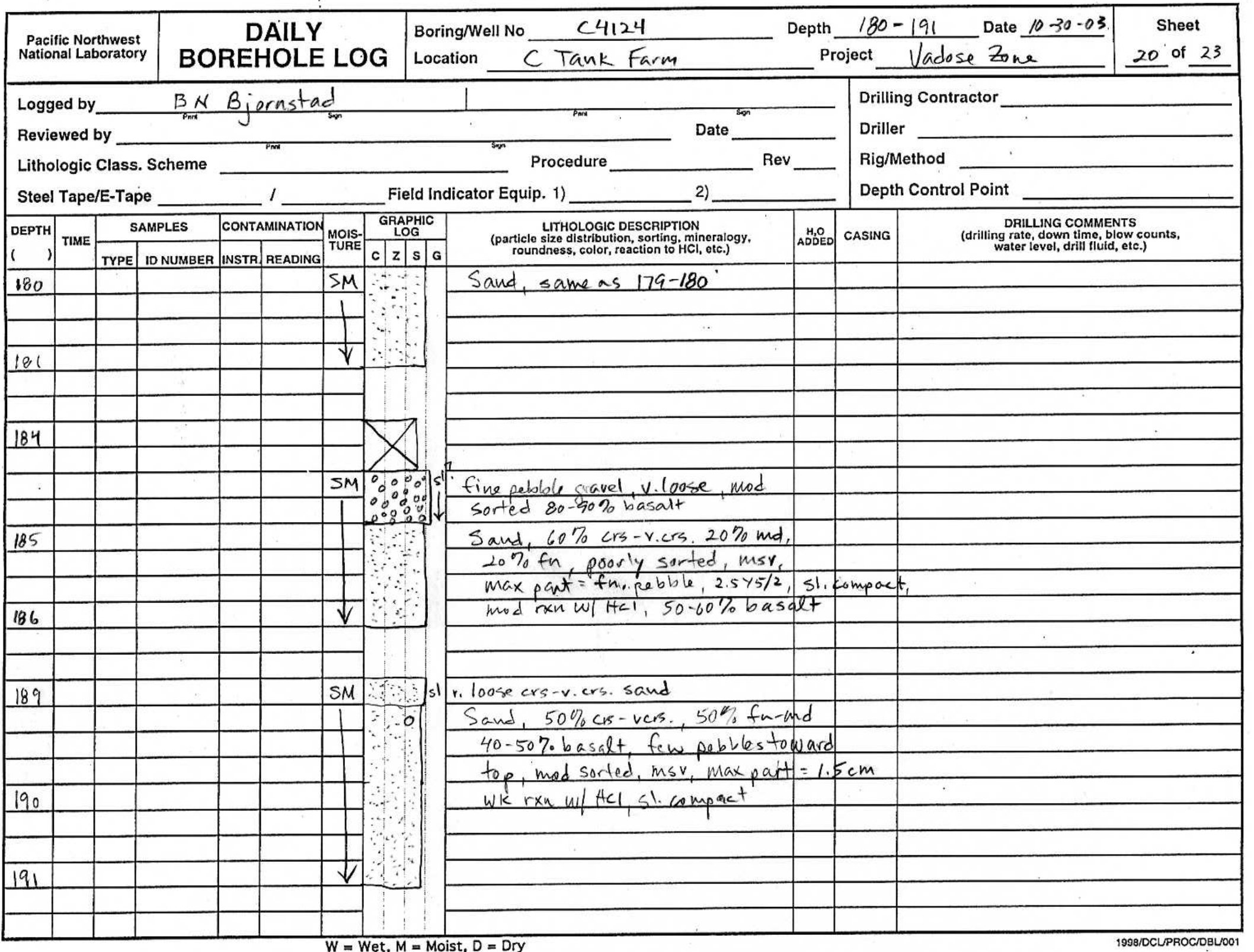

Figure B1.20. Hanford formation (H2 unit) $180.0 \mathrm{ft}-191.0 \mathrm{ft}$ 


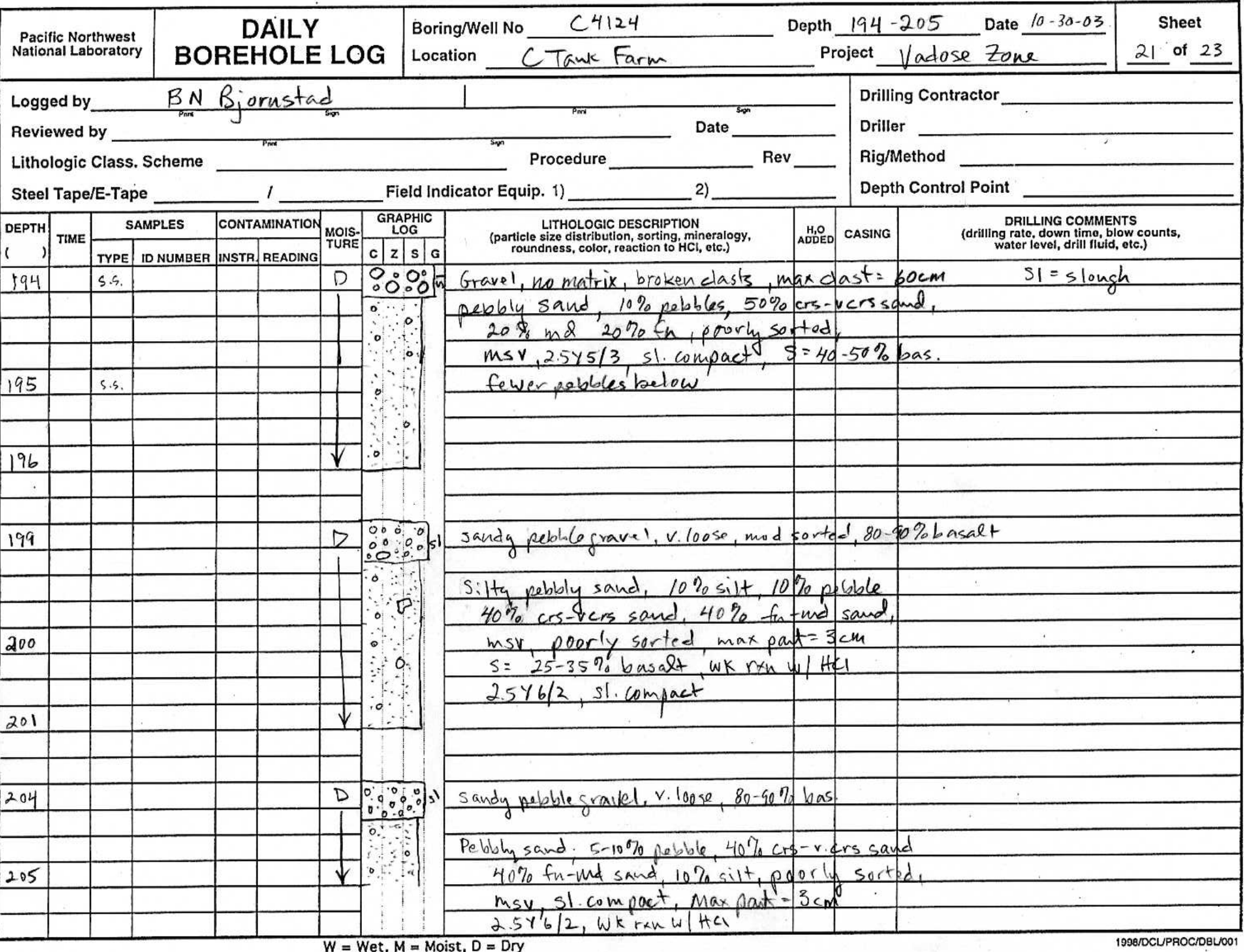

Figure B1.21. Hanford formation (H2 unit) $194.0 \mathrm{ft}-205.0 \mathrm{ft}$ 


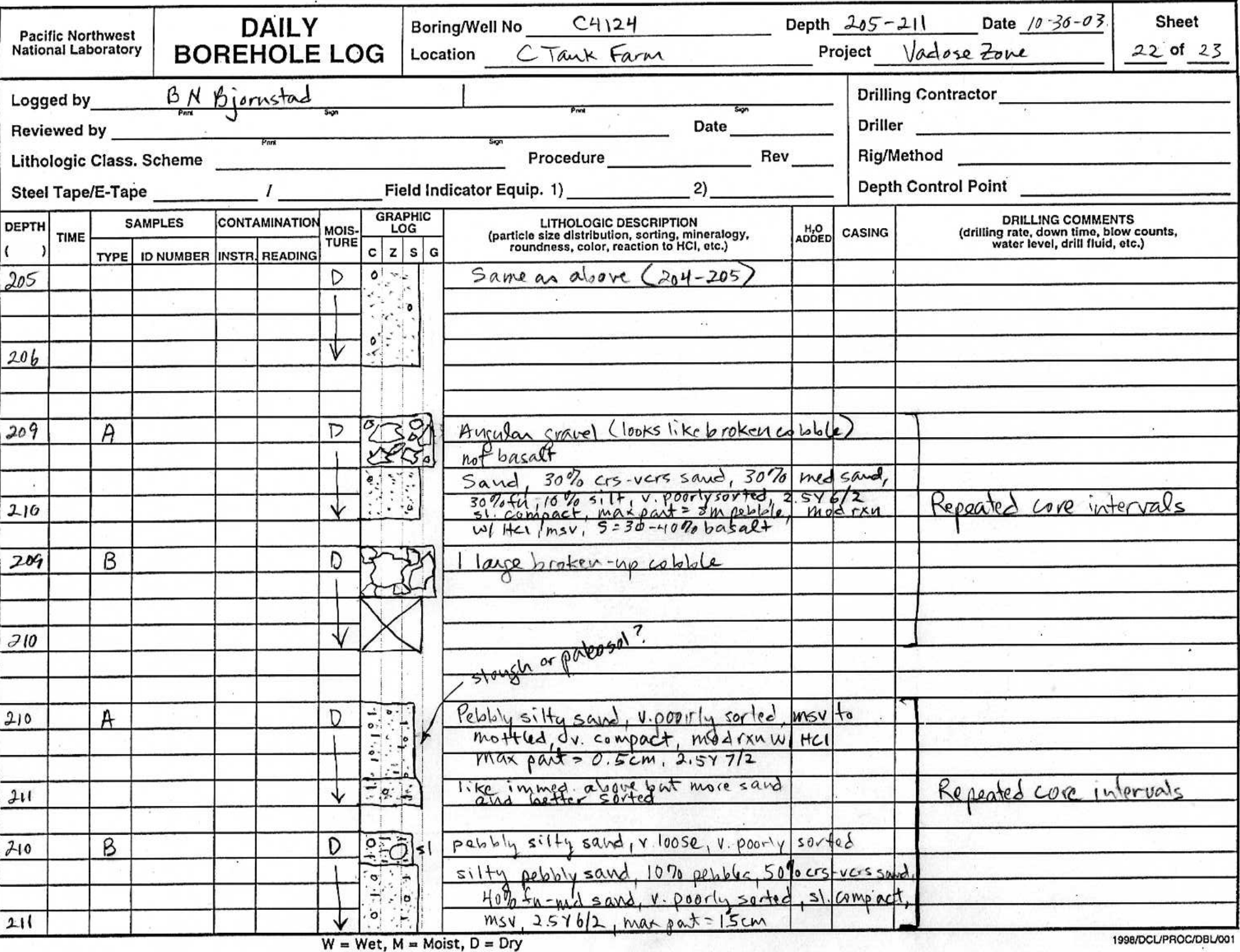

Figure B1.22. Hanford formation (H2 unit) $205.0 \mathrm{ft}-211.0 \mathrm{ft}$ 


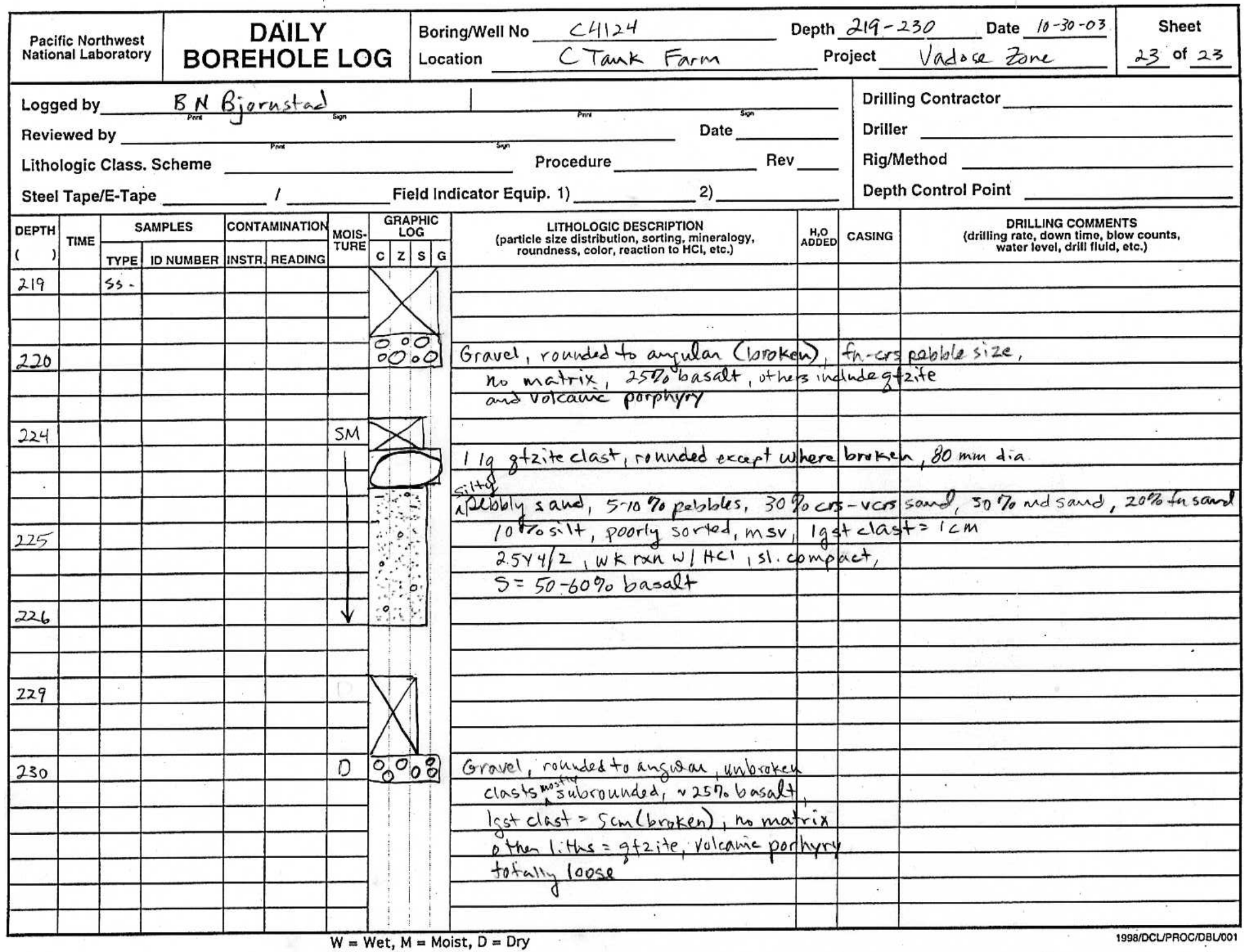

Figure B1.23. Hanford formation (H2 unit) $219.0 \mathrm{ft}-227.9 \mathrm{ft}$ to Cold Creek Unit/Ringold Formation $228.0 \mathrm{ft}-230.0 \mathrm{ft}$ 


\title{
Appendix B2
}

\author{
C4297 \\ Geologic Description of Core \\ Obtained During Opening in Laboratory
}




\section{Contents}

Appendix B-2 . Geologic Description of Core from Borehole C4297........

B2.1

\section{Figures}

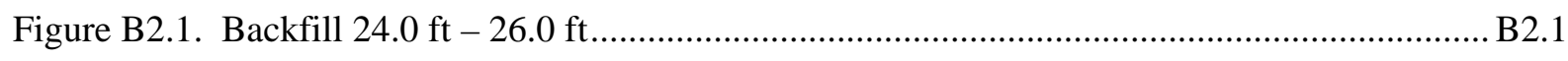

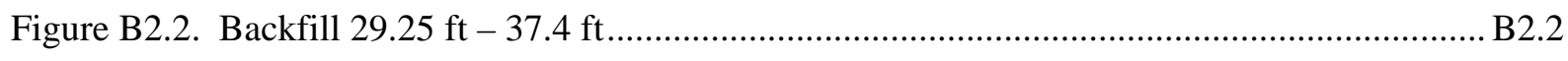

Figure B2.3. Backfill $39.05 \mathrm{ft}-39.8 \mathrm{ft}$ to Hanford formation (H1 unit) $39.8 \mathrm{ft}-41.05 \mathrm{ft}$............ B2.3

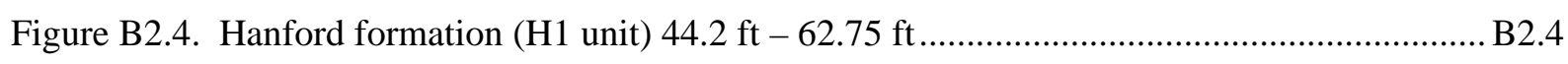

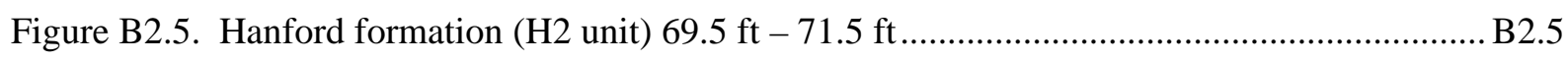

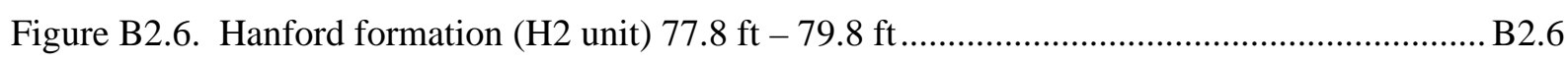

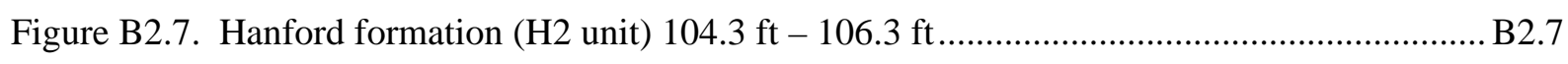


Appendix B2. Geologic Description of Core from Borehole C4297

Core $\log$

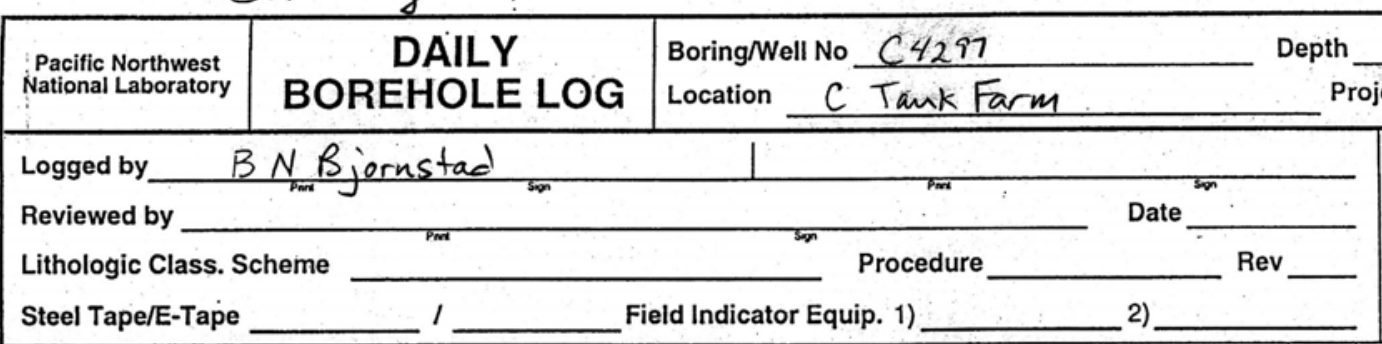

\begin{tabular}{ll|l}
$24-2 b^{\prime}$ & Date $4-1-04$ & Sheet \\
\hline Poject Vadose Zone & 1 of 8 \\
\hline
\end{tabular}

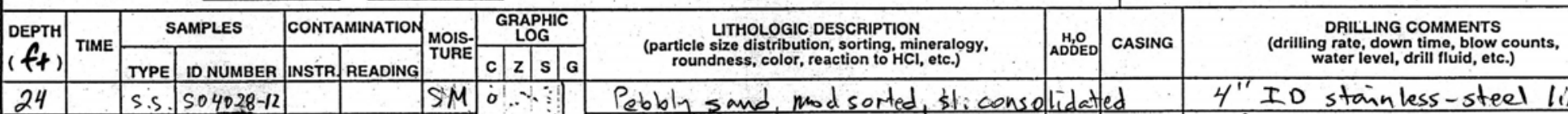

24 S.S. S04028-12 SM O.W Pebbly sand, mod sorted, sliconsolidated $4^{\prime \prime}$ ID stainless-steel liners

\begin{tabular}{l|c|c|c|c|c|c|c|}
\hline & & D & & & 1 \\
\hline
\end{tabular}

\begin{tabular}{|l|l|c|l|l|l|l|l}
\hline & & & $C$ & & & & \\
\hline & & & $\checkmark$ & & & & \\
\hline & & & $c$ & & & & \\
\hline
\end{tabular}

WKrxn w/ HCl, $2.5 y_{4} / 2$

mostly and-crs sand $\max$

partsize $=2 \mathrm{~cm}$

same as above

$S=40.50 \%$ basalt

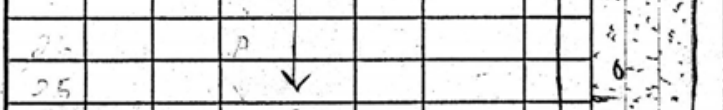

$G=90-100 \%$ basalt

Wh Feoxide

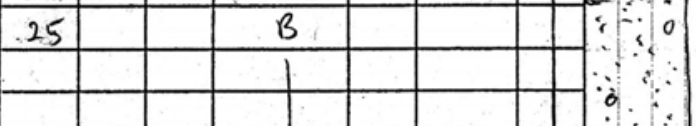

same as above
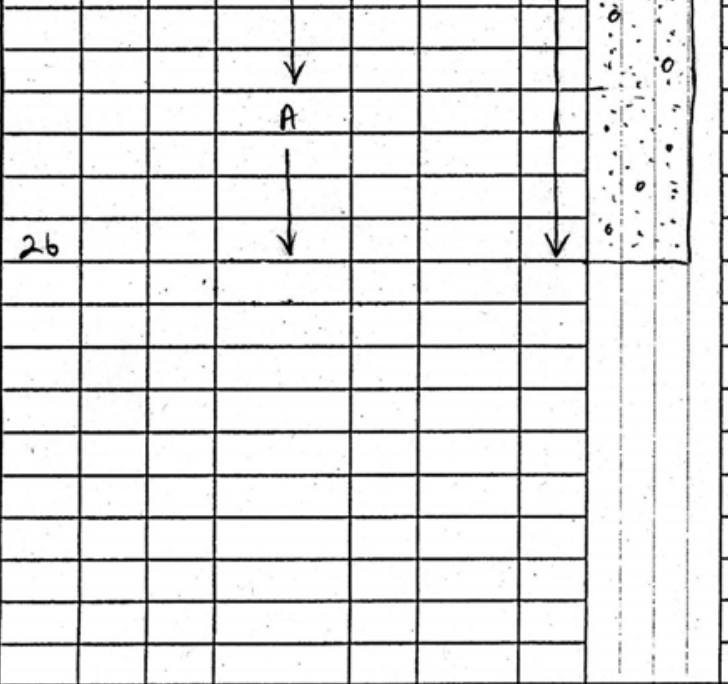

$\mathrm{W}=$ Wet, $\mathrm{M}=$ Moist, $\mathrm{D}=$ Dry

Figure B2.1. Backfill $24.0 \mathrm{ft}-26.0 \mathrm{ft}$ 


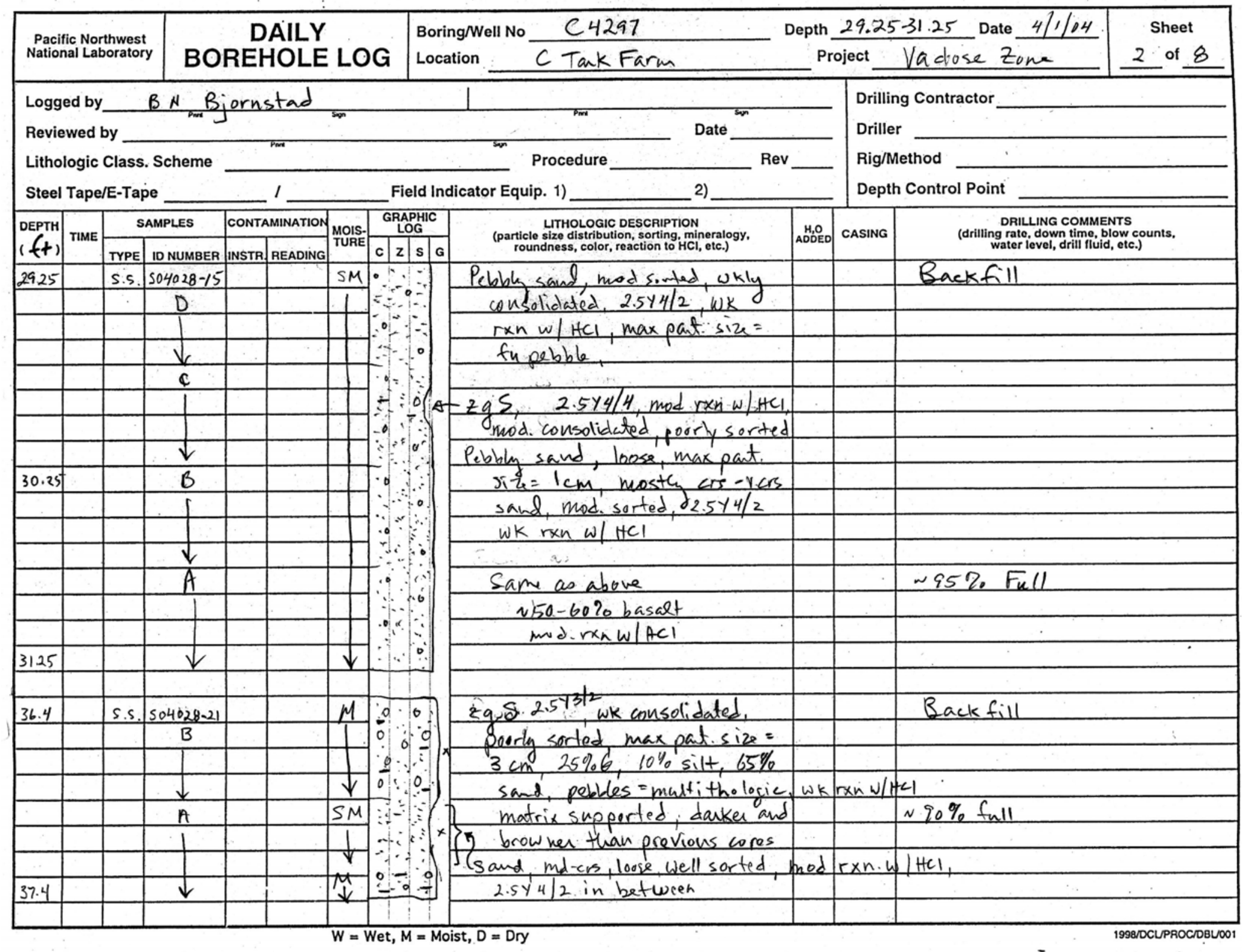

Figure B2.2. Backfill $29.25 \mathrm{ft}-37.4 \mathrm{ft}$ 


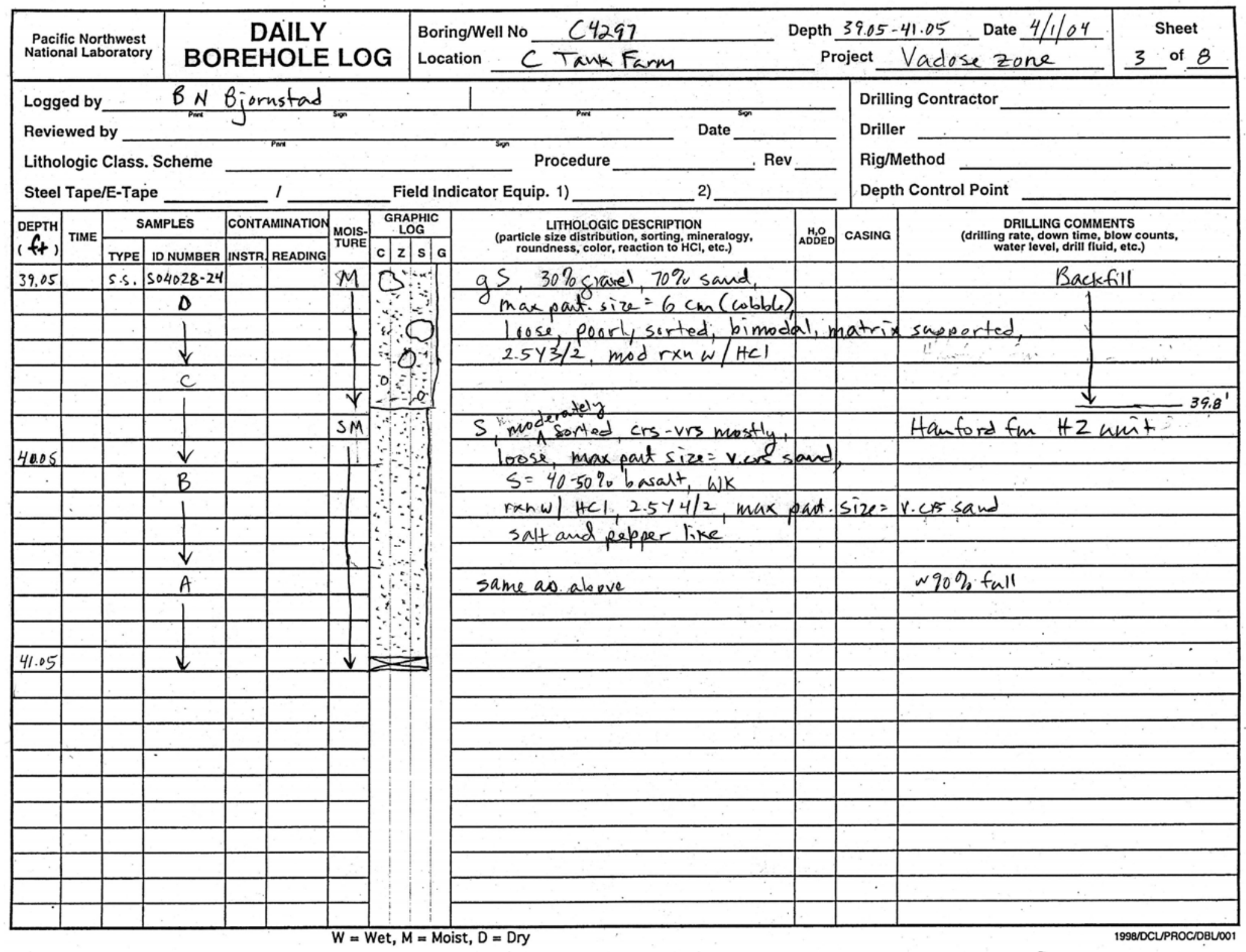

Figure B2.3. Backfill $39.05 \mathrm{ft}-39.8 \mathrm{ft}$ to Hanford formation (H1 unit) $39.8 \mathrm{ft}-41.05 \mathrm{ft}$ 


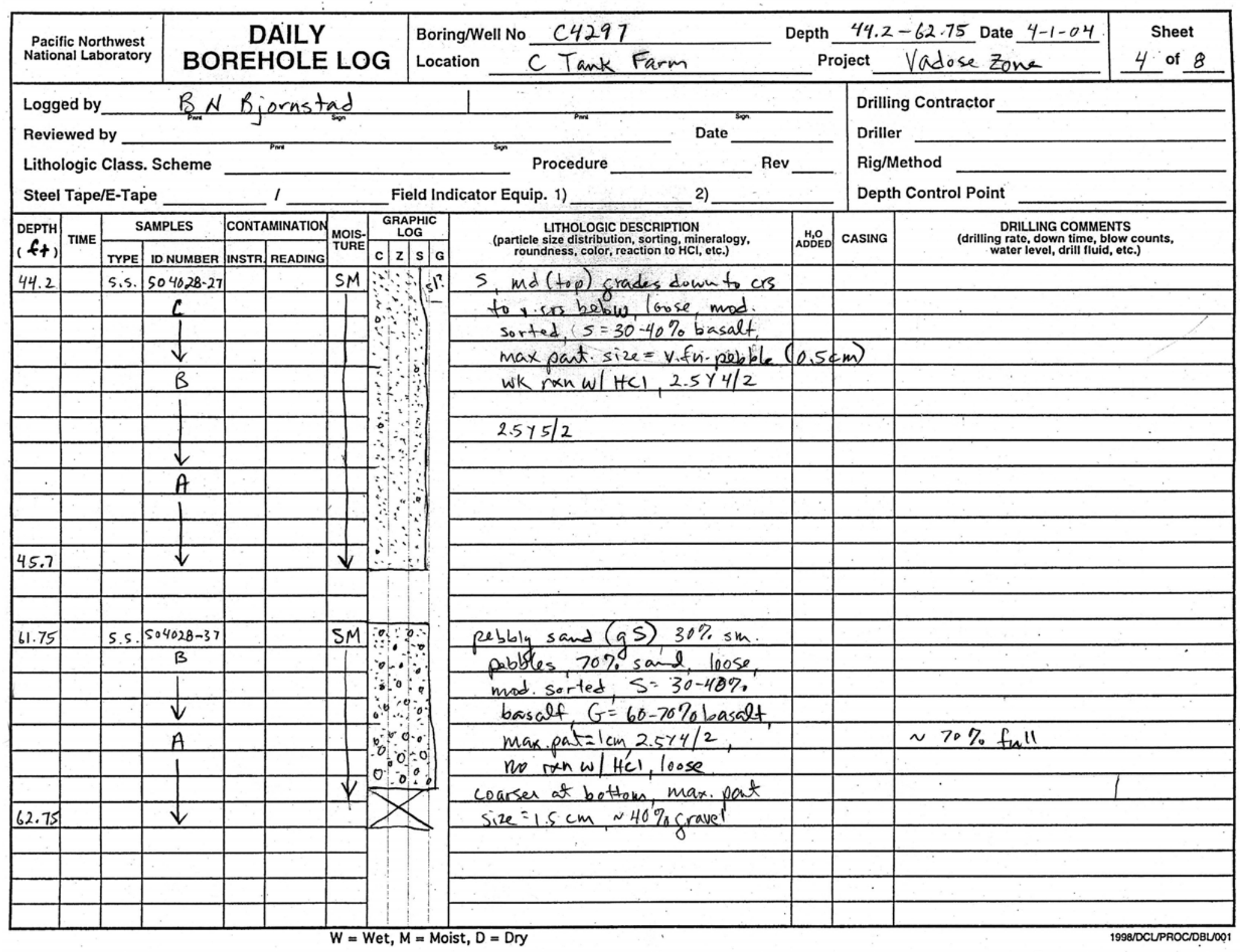

Figure B2.4. Hanford formation (H1 unit) $44.2 \mathrm{ft}-62.75 \mathrm{ft}$ 


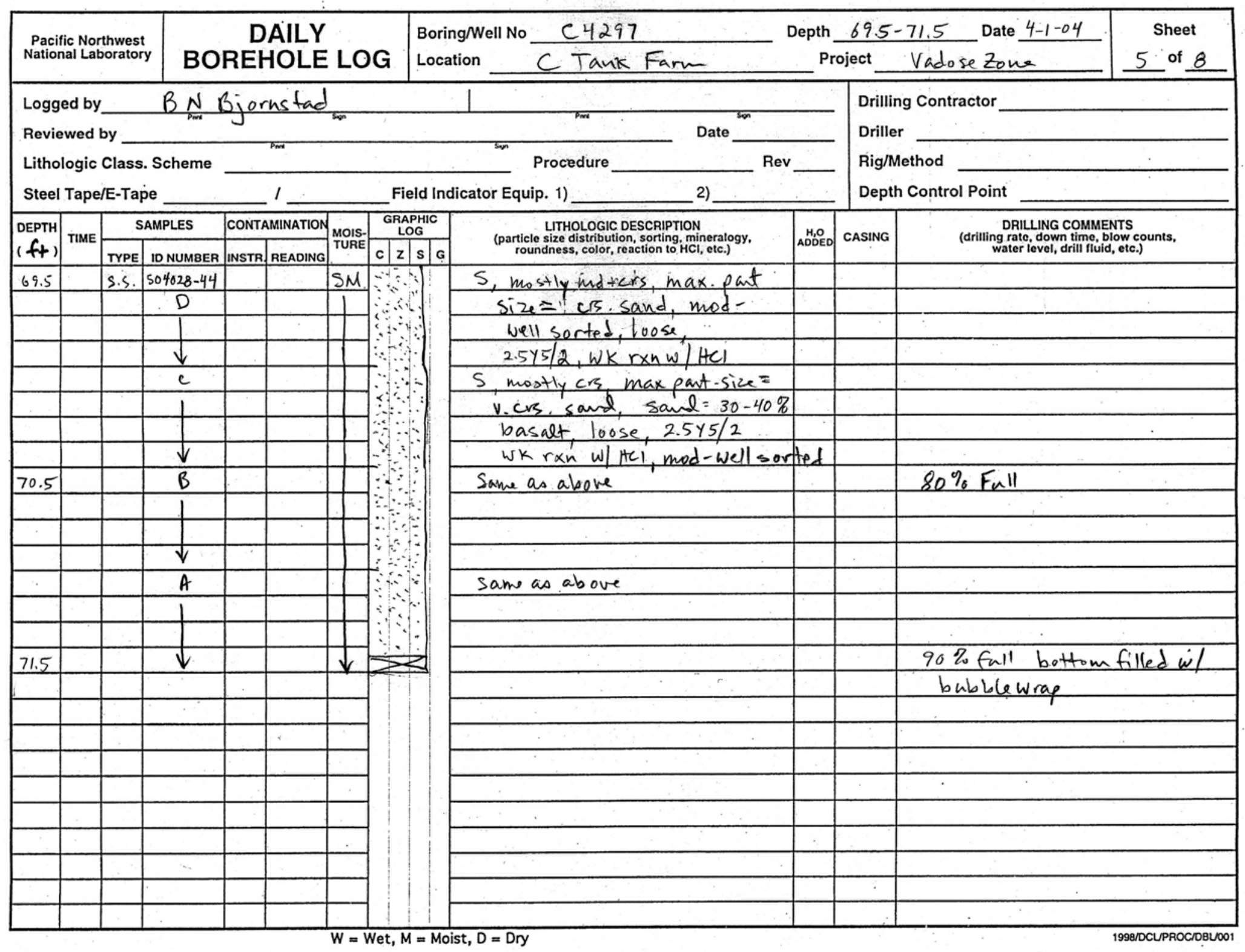

Figure B2.5. Hanford formation (H2 unit) $69.5 \mathrm{ft}-71.5 \mathrm{ft}$ 


\begin{tabular}{|c|c|c|c|c|c|c|c|c|c|c|c|c|c|}
\hline \multicolumn{3}{|c|}{$\begin{array}{l}\text { Pacific Northwest } \\
\text { National Laboratory }\end{array}$} & \multicolumn{5}{|c|}{$\begin{array}{c}\text { DAILY } \\
\text { BOREHOLE LOG }\end{array}$} & \multicolumn{2}{|c|}{ 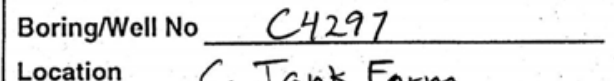 } & \multicolumn{3}{|c|}{ Depth $\frac{77.8-79.8}{\text { Project Vadose Zone }}$ Date $\frac{4-1-04}{\text { Vane }}$} & $\begin{array}{l}\text { Sheet } \\
6 \text { of } 8 \\
\end{array}$ \\
\hline \multicolumn{11}{|c|}{ Logged by $\quad B N$ Biornstad } & \multicolumn{3}{|c|}{ Drilling Contractor } \\
\hline \multicolumn{11}{|c|}{ Reviewed by } & \multirow{3}{*}{\multicolumn{3}{|c|}{$\begin{array}{l}\text { Driller } \\
\text { Rig/Method } \\
\text { Depth Control Point }\end{array}$}} \\
\hline \multirow{2}{*}{\multicolumn{4}{|c|}{$\begin{array}{l}\text { Lithologic Class. Scheme } \\
\text { Steel Tape/E-Tape }\end{array}$}} & & & & & & \multirow{2}{*}{\multicolumn{2}{|c|}{$\begin{array}{ll} & \text { Procedure Rev } \\
\text { Equip. 1) } & \text { 2) }\end{array}$}} & & & \\
\hline & & & & 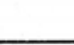 & 1 & & \multirow{3}{*}{\multicolumn{3}{|c|}{ 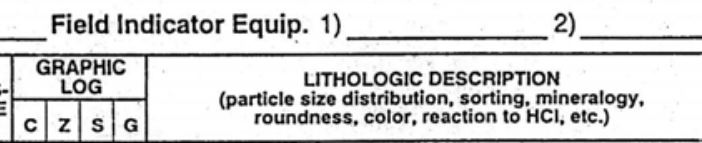 }} & & & Depth Control Point & \\
\hline \multirow{2}{*}{$\begin{array}{l}\text { DEPTH } \\
\text { ( } \mathrm{ft} \text { ) }\end{array}$} & \multirow{2}{*}{ TIME } & \multicolumn{2}{|c|}{ SAMPLES } & \multicolumn{3}{|c|}{ CONTAMINATION MOIS- } & & & & \multirow{2}{*}{$\mid \begin{array}{ll}\mathrm{H} O \mathrm{O} \\
\mathrm{AODODO}\end{array}$} & \multirow{2}{*}{ CASING } & \multirow{2}{*}{\multicolumn{2}{|c|}{$\begin{array}{l}\text { DRILLING COMMENTS } \\
\text { (drilling rato, down time, blow counts, } \\
\text { water ievel, drill filid, etc.) }\end{array}$}} \\
\hline & & TYPE & NUMBER & INSTR & READING & & & & & & & & \\
\hline \multirow[t]{8}{*}{77.8} & & & $4028-49$ & & & SM & $6 \sin ^{2}$ & & (a)S slichtly soblatusand max & & & & \\
\hline & & & $D$ & & & & & & part size $00.3 \mathrm{cul}(\mathrm{x}$ sm peloble $)$ & & & & \\
\hline & & & & & & & & & $<5 \%$ (rarel loose, $5=$ & & & & \\
\hline & & & $\downarrow$ & & & & & & $30-40 \%$ basalt 5 mostly & & & & \\
\hline & & & c & & & & & & crs-v.crs $2.5 \% 4 / 2$ no & & & & \\
\hline & & & $T$ & & & & $\because$ & & rin w/HCl mod.sorted & & & & \\
\hline & & & & & & & & & $S \mathrm{crs}-\mathrm{v} . \mathrm{crs}$ looce $2.5 \% 4 / 2$ & & & & \\
\hline & & & $\downarrow$ & & & & $\therefore$ & & v. WK $x_{n}$ will $\mathrm{HCl}$ no stravel & & & & \\
\hline \multirow[t]{7}{*}{78,8} & & & $B$ & & & & $T:$ & & max pait. size $=V$ crs, sand & & & & \\
\hline & & & 1 & & & & & & mo derately sorted & & & & \\
\hline & & & & & & & & & $\ldots$ & & & & \\
\hline & & & $\downarrow$ & & & & & & & & & & \\
\hline & & & A & & & & & & Sance as above & & & $80 \%$ full & \\
\hline & & & & & & & & & & & & & \\
\hline & & & & & & & $i$ & & & & & & \\
\hline \multirow{11}{*}{\multicolumn{2}{|c|}{79.8}} & & $\downarrow$ & & & & 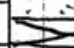 & & & & & bubblewrap & \\
\hline & & & & & & & & & & & & & \\
\hline & & & & & & & & & & & & & \\
\hline & & & & & & & & & & & & & \\
\hline & & & & & & & & & & & & & \\
\hline & & & & & & & & & & & & & \\
\hline & & & & & & & & & & & & & \\
\hline & & & & & & & & & & & & & \\
\hline & & & & & & & & & & & & & \\
\hline & & & & & & & & & & & 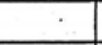 & & \\
\hline & & & & & & & & & & & & & \\
\hline
\end{tabular}

Figure B2.6. Hanford formation (H2 unit) $77.8 \mathrm{ft}-79.8 \mathrm{ft}$ 


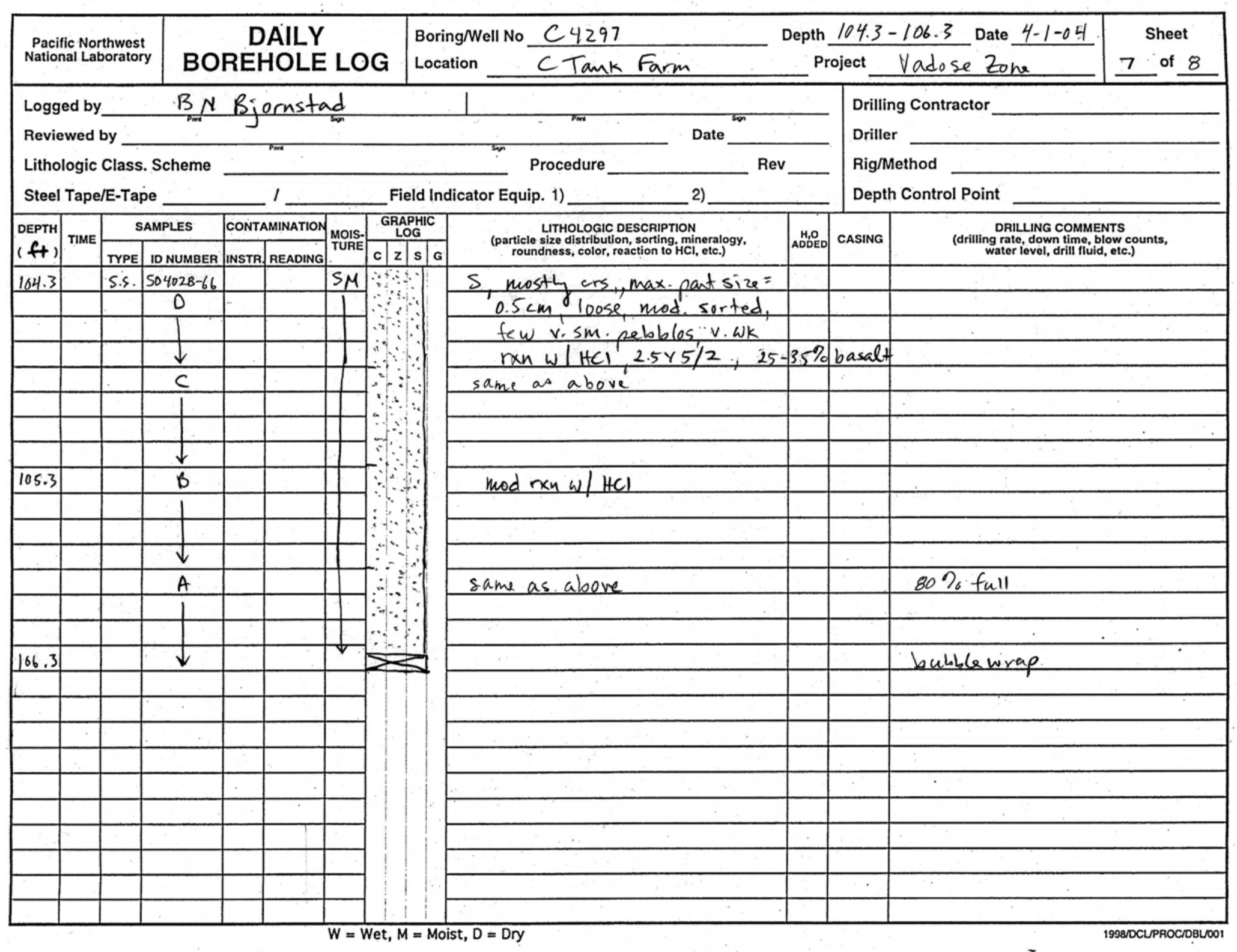

Figure B2.7. Hanford formation (H2 unit) $104.3 \mathrm{ft}-106.3 \mathrm{ft}$ 


\section{Distribution}

No. of

Copies

OFFSITE

Dr. Harry Babad

2540 Cordoba Court

Richland, WA 99352-1609

Dirk A. Dunning

Oregon Office of Energy

625 Marion Street NE

Salem, OR 97301-3742

Dr. Daniel I. Kaplan

Westinghouse Savannah River Company

Building 774-43A, Room 215

Aiken, SC 29808

Phil Reed

U.S. Nuclear Regulatory Commission

Office of Nuclear Regulatory Research

Division of Systems Analysis and

Regulatory Effectiveness

Radiation Protection, Environmental

Risk, and Waste Management Branch

Mail Stop: T9-F31

Washington, DC 20555-0001

Tom Stoops, LPG

Oregon Office of Energy

Nuclear Safety Division

625 Marion Street NE

Salem, OR 97303

Mr. Ronald G. Wilhelm

Office of Radiation and Indoor Air

401 M Street, S.W.

Mail Code 6603J

Washington, DC 20460
No. of

Copies

W. Alexander Williams

U.S. Department of Energy

Office of Environmental Restoration

EM-33

19901 Germantown Road

Germantown, MD 20874-1290

\section{ONSITE}

\section{DOE Richland Operations Office}

B. L. Foley

A6-38

J. P. Hanson

R. D. Hildebrand

A5-13

K. A. Kapsi

A6-38

J. G. Morse

A5-13

A6-38

K. M. Thompson

A6-38

DOE Public Reading Room (2)

$\mathrm{H} 2-53$

\section{DOE Office of River Protection}
P. E. LaMont
H6-60
R. W. Lober
H6-60
S. A. Wiegman
H6-60

14 CH2M HILL Hanford Group, Inc.
F. J. Anderson
H6-03
R. Calmus
H6-05
M. P. Connelly
H6-03
J. G. Kristofzski
H6-03
F. M. Mann (5)
H6-03
W. J. McMahon
H6-03
D. A. Myers (3)
H6-03
G. Parsons
S7-67

Fluor Federal Services

R. Khaleel

E6-17 
No. of

Copies

7 Fluor Hanford, Inc.

M. W. Benecke

E6-35

T. W. Fogwell

E6-35

B. H. Ford

J. G. Hogan

L. C. Swanson

M. I. Wood

C. Wright

\section{S.M. Stoller}

R. G. McCain

B2-62

2 U.S. Environmental Protection Agency
N. Ceto
B5-01
D. A. Faulk
B5-01

\section{Washington State Department of Ecology}

S. Dahl-Crumpler

HO-57

J. A. Caggiano

HO-57

J.A. Hedges

HO-57

B. Rochette

HO-57

J. Yokel

HO-57

D. Goswami
No. of

Copies

38 Pacific Northwest National Laboratory

B. N. Bjornstad K6-81

T. M. Brouns K9-69

C. F. Brown (15) P7-22

K. J. Cantrell K6-81

W. J. Deutsch K6-81

P. E. Dresel K6-96

K. M. Geisler P7-22

M. J. Fayer K9-33

M. D. Freshley K9-33

J. S. Fruchter K6-96

D. G. Horton K6-81

K. M. Krupka K6-81

G. V. Last K6-81

M. J. Lindberg P7-22

W. J. Martin K6-81

C. J. Murray K6-81

S. M. Narbutovskih K6-96

S. P. Reidel K6-81

R. J. Serne P7-22

H. T. Schaef K6-81

W. Um P7-22

B. A. Williams K6-81

Hanford Technical Library (2) P8-55 